\title{
Climate Change in the Southern Ocean during the Middle Eocene to Early Oligocene: A palynological perspective.
}

By

\section{CLAIRE ANDREA STORKEY}

\author{
A thesis \\ submitted to the Victoria University of Wellington \\ in fulfilment of the requirements for the degree of \\ Doctor of Philosophy
}

Victoria University of Wellington

MARCH 2013 


\begin{abstract}
The Antarctic and Southern Ocean is an area that was greatly affected by climatic changes during the Middle Eocene to Early Oligocene (E/O). This study aims to document climate-induced changes of the marine palynomorphs (mostly dinoflagellate cysts) by developing a Circum-Antarctic biozonation, and establishing the distribution and effects of cooling on the palynomorph assemblages and the palaeoenvironment.
\end{abstract}

Samples were obtained from four sites by the Ocean Drilling Program (ODP) and Deep Sea Drilling Project (DSDP) and the palynological content was analyzed. These sites were selected as they may record effects of circulation changes and cooling trends, reflecting climate changes. ODP site 696B, was inner neritic and located in the South Orkney microcontinent, Weddell Sea. The other three sites were pelagic with ODP 699A located on the Northeast Georgia Rise, Falklands, ODP 748B located in the Western part of the Raggart Basin, Kerguelen Plateau and DSDP 277 located in Cathedral Depression on the Southern Campbell Plateau. From this analysis a comprehensive record of the local climatic transitions was ascertained, utilising assemblages of fossil organic-walled dinoflagellate cysts (dinocysts), acritarchs, prasinophyte algae, microforaminiferal linings, scoledonts and terrestrial material.

The establishment of a standard nannofossil biostratigraphy provided a temporal framework of the marine palynomorphs in each site. Key dinocyst datums recognised as first or last occurrences that correlated reliably between sites, were compared with the nannofossil zones of each site. The purpose was to provide a Middle Eocene/Early Oligocene dinocyst biostratigraphy that temporally constrains the assemblages. Six primary datums and two secondary datums resulted, which lead to the recognition of four biozones and established a new biozonation in the Southern Ocean. The zones identified various dinocyst events, giving an indication of their probable palaeoenvironments.

The Circum-Antarctic distribution pattern of palynomorph assemblages was documented in each site as a total abundance of grains per gram. The ranges and 
composition of palynomorph assemblages of each site were displayed as a percentage of total abundance. To document any cooling effects the dinocysts were separated into Gonyaulacoid or Peridinioid assemblages to best illustrate their preferred palaeoenvironment.

Key findings showed that the pelagic and inner neritic sites differed greatly. Site 696B was the most climatically stable site and dominated by Peridinioid dinocysts which are predominantly heterotrophic. They are most common in an inner neritic palaeoenvironment, but are also present in nutrient upwellings and eutrophic surface waters with lower sea surface temperatures. Terrestrial material dominates all marine palynomorphs in this site which was shallow and warm with few changes up to the E/O boundary $33.7 \mathrm{Ma}$, but became more variable in the Early Oligocene. In comparison, the pelagic sites $(699,748 \mathrm{~B}, 277)$ were unstable, with missing or condensed sediments and no palynomorphs present at differing times. They were mostly dominated by Gonyaulacoid dinocysts, which are autotrophs and generally located in outer neritic to open ocean palaeoenvironments. The non dinocysts of Prasinophyte algae and Leiosphaeridia palynomorphs appeared in higher abundances in the pelagic sites than in the inner neritic sites.

Specific dinocyst markers identified temperature changes within the pelagic sites, subsequently highlighting the climatic changes that occurred during the Middle Eocene/Early Oligocene. From $\sim 46 \mathrm{Ma}$ the pelagic sites recorded conditions that were oceanic and cooler. Between $\sim 44-\sim 41.5 \mathrm{Ma}$, a warming in site 748B indicated enhanced stratification and elevated nutrient availability. This was not the case in site $696 \mathrm{~B}$ and may be due to warm temperatures already present. From $\sim 41.4 \mathrm{Ma}$ the pelagic sites showed that the palaeoenvironment continued to cool, indicated by the presence of Leiosphaeridia and Prasinophyte algae. The palaeoenvironment was oceanic with upwelling and offshore sea surface productivity, illustrated by the Gonyaulacoid and Peridinioid dinocysts present. During the Late Eocene from 37 Ma a transitional and changeable palaeoenvironment was shown by the high numbers of Operculodinium spp present in sites 696B and 277. From $33.7 \mathrm{Ma}$ (E/O boundary) in the pelagic sites, most Peridinioid dinocysts had disappeared and very few 
Gonyaulacoid dinocysts were present. In contrast the inner neritic site (696B)

Peridinioid dinocysts were still dominant, and a more gradual disappearance of all the marine palynomorphs was evident. 


\section{ACKNOWLEDGEMENTS}

I would like to thank my primary supervisor Mike Hannah for firstly suggesting the subject for this study. I have enjoyed every aspect of my research into the palaeoenvironment of the Southern Ocean. Thanks to his support and encouragement throughout, and patience during the writing of this thesis. Thanks to Erica Crouch who was my second supervisor during the first part of this study and who had many good ideas and suggestions and was always very helpful.

I appreciated the helpful advice I received on the course I attended in Urbino Italy, in particular from Sander Houben, Appy Sluijs and some guidance from Professor Brinkhuis was also appreciated.

I wish to thank my colleagues in particular the developmental students, thanks to those Maldivians Shukry and Faisal, and others I mixed with over the years of my studies at Victoria University. Thanks also to Bill McLea for some interesting chats we have had over the years on travel, a welcome break from writing a thesis.

I could not have completed this $\mathrm{PhD}$ without the support my family and close friends. Thanks for taking an interest in my progress. For my family, thanks to my wonderful husband Ian for his support and putting up with my long hours at the university. Thanks to Angela, Gavin and Corin for all their support and advice on writing my thesis. 
Abstract i

Acknowledgements iv

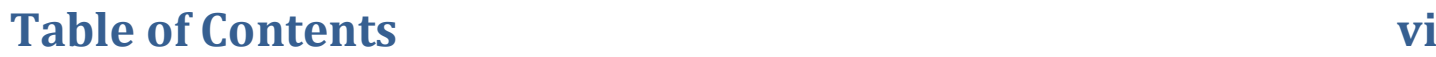

\section{Chapter One - Introduction}

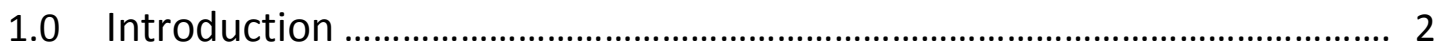

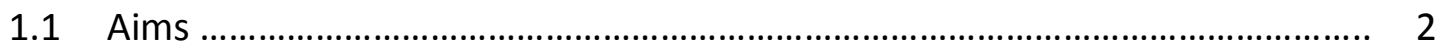

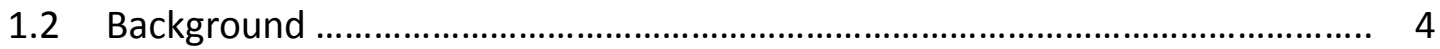

1.3 Paleogene Temperature Changes …………............................................................... 4

1.4 Causes of the Oi-1 …........................................................................................... 7

1.5 Previous Work in Antarctica and Southern Ocean ................................................... 10

1.6 Site Locations, Lithology and Palaeoenvironments .................................................. 15

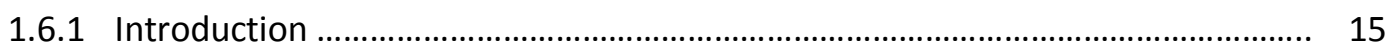

1.6.2 ODP Site 696B ………………............................................................... 16

1.6.2.1 Lithology and Palaeoenvironment .......................................................... 17

1.6.3 ODP Site 699A .................................................................................................. 18

1.6.3.1 Lithology and Palaeoenvironment .......................................................... 18

1.6.4 ODP Site 748B .................................................................................................. 19

1.6.4.1 Lithology and Palaeoenvironment ............................................................. 20

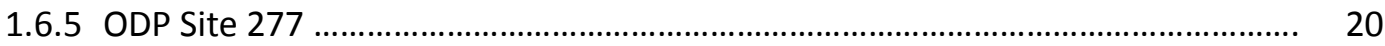

1.6.5.1 Lithology and Palaeoenvironment ............................................................ 21

1.7 Palaeopalynology ........................................................................................... 22

1.7.1 Why use Dinoflagellate Cysts? .............................................................................. 22

1.7.2 General Morphology ................................................................................................ 24

1.8 Method and Results ............................................................................................. 25

1.8.1 Palynological Processing ……………………............................................. 25

1.8.2 Fungal Contamination ........................................................................................ 26

1.8.3 Microscope and Camera Technique …………................................................. 30

1.8.4 Counting Method ........................................................................................ 30

1.9 General Results ........................................................................................... 31

\section{Chapter Two - Nannofossil Biostratigraphic Revision}

2.0 Nannofossil Biostratigraphic Revision 


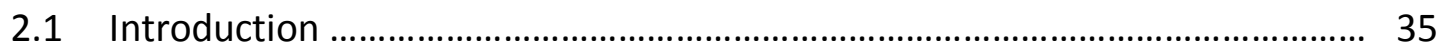

2.2 Nannofossil Biostratigraphic Zonation ....................................................... 35

2.2.1 Site 696B, South Orkney microcontinent, Weddell Sea .......................... 37

2.2.2 Site 699A, Northeast Georgia Rise ....................................................... 39

2.2.3 Site 748B, Raggatt Basin, Southern Kerguelen Plateau ........................... 42

2.2.4 Site 277, Southern Campbell Plateau ...................................................... 44

2.2.4.1 Reassessing Chiasmolithus solitus .................................................... 47

\section{Chapter Three - Dinocyst Biostratigraphy}

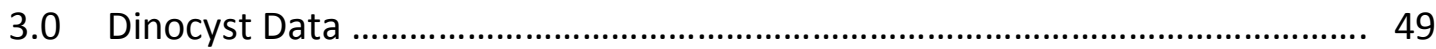

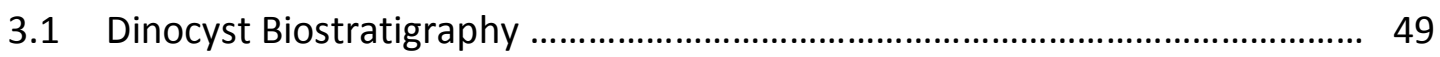

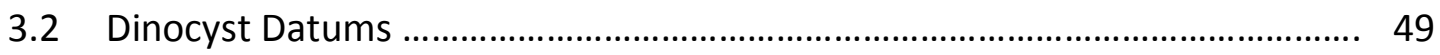

3.2.1 Phthanoperidinium echinatum Zone ....................................................... 51

3.2.2 Phthanoperidinium geminatum Zone ................................................... 53

3.2.3 Phthanoperidinium SpA Zone ........................................................... 54

3.2.4 Corrudinium regulare Zone ............................................................. 55

3.2.5 Discussion of Site 699A ........................................................................ 55

3.3 Dinocyst Datums and other Microfossils ...................................................... 56

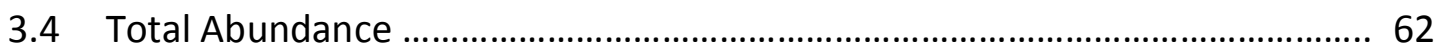

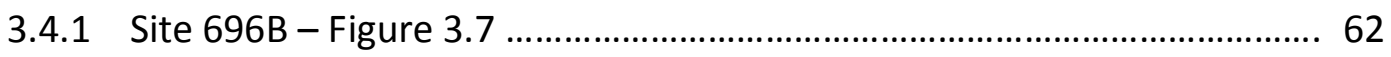

3.4.1.1 Dinocysts below the Oligocene ...................................................... 62

3.4.1.2 Dinocysts in the Early Oligocene ..................................................... 65

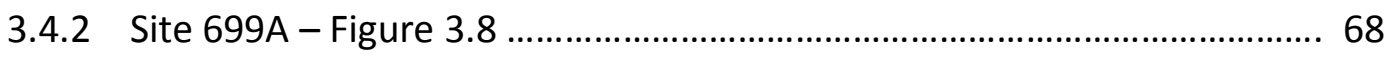

3.4.2.1 Dinocysts below the Oligocene .......................................................... 68

3.4.2.2 Dinocysts in the Early Oligocene ......................................................69 69

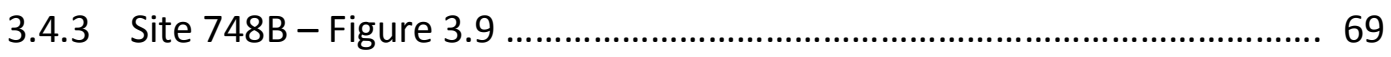

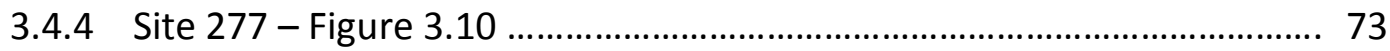

3.4.4.1 Dinocysts below the Oligocene .......................................................... 73

3.4.4.2 Dinocysts in the Early Oligocene ........................................................ 75

\section{Chapter Four - Assemblage Analysis}

4.0 Assemblage Analysis ................................................................................. 78 


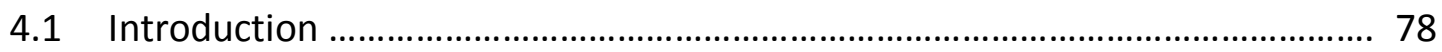

4.2 Gonyaulacoid and Peridinioid Dinocysts .................................................... 78

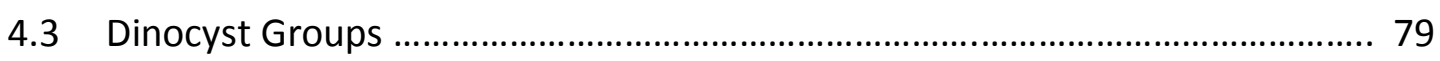

4.3.1 Site 696B Palynomorph assemblages (642.98-578.71 mbsf) .................. 80

4.3.1.1 Palynomorph assemblages in the Eocene (642.98-607 mbsf) ............83

4.3.1.2 Palynomorph assemblages in the Early Oligocene

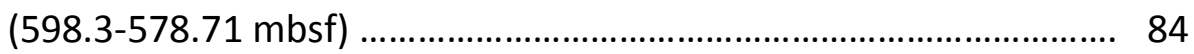

4.3.2 Site 699A Palynomorph assemblages (465.65-249.73 msf) ................... 85

4.3.2.1 Palynomorph assemblages in the Eocene (465.65-293.83 mbsf) .... 85

4.3.2.2 Palynomorphs assemblages in the Early Oligocene

(286.53-249.73 mbsf) .................................................................... 88

4.3.3 Site 748B Palynomorph assemblages 9200.47-76.83 mbsf) .................. 89

4.3.3.1 Palynomorph assemblages in the Eocene (200.47-126.36 mbsf) ... 89

4.3.4 Site 277 Palynomorph assemblages (435.01-122.17 mbsf) ..................... 95

4.3.4.1 Palynomorph assemblages in the Eocene (435.01-190.8 mbsf) ....... 95

4.3.4.2 Palynomorph assemblages in the Early Oligocene

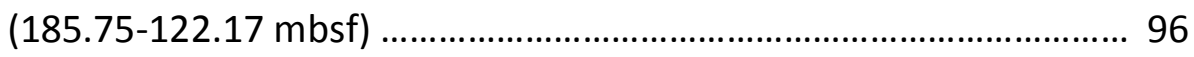

4.3.5 ODP Site 1172, Leg 189 (Sluijs et al., 2003) .............................................. 97

4.3.5.1 Dinocysts assemblages in the Eocene (364.24-364.06 mbsf) ......... 99

4.3.5.2 Dinocyst changes from the E/O transitions (360.31-356.14 mbsf).. 100

\section{Chapter Five - Discussion}

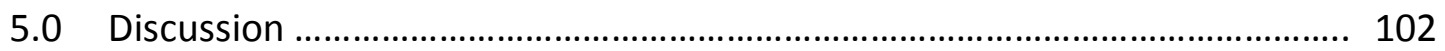

5.1 Introduction: The Palaeoenvironment: using marine and terrestrial

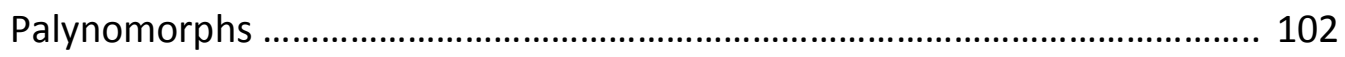

5.2 Interpreted Dinoflagellate Palaeoenvironments .......................................... 102

5.3 Palynomorph distribution and interpretation ............................................ 105

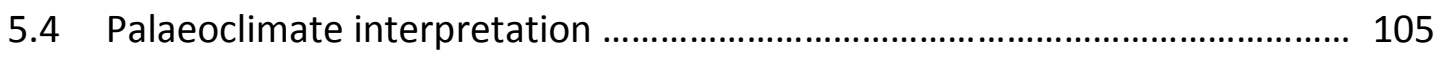

5.4.1 Pre Phthanoperidinium echinatum Zone ( 46- 44.8) ....................... 105

5.4.2 Phthanoperidinium echinatum Zone ( 44.8- 43 Ma) .......................... 111

5.4.3 Phthanoperidinium geminatum Zone ( 43- 40.3 Ma) ......................... 111 
5.4.4 Phthanoperidinium spA Zone ( 40.3- 37 Ma) ….............................. 112

5.4.5 Phthanoperidinium spA Zone ( 37- 35.4 Ma) ................................... 113

5.4.6 Corrudinium regulare Zone ( 35.4- 34.8 Ma) ...................................... 114

5.4.7 Post Corrudinium regulare Zone ( 34.8- 29 Ma) ............................... 114

5.5 Dinoflagellate Events in a Global Context .................................................. 117

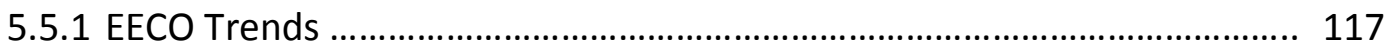

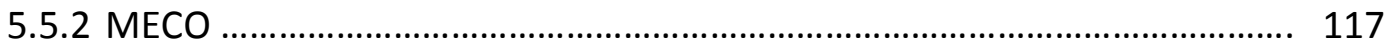

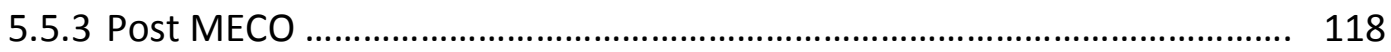

5.5.4 Late Eocene Warming …................................................................... 118

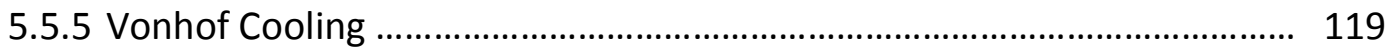

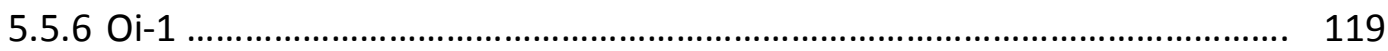

\section{Chapter Six - Conclusions}

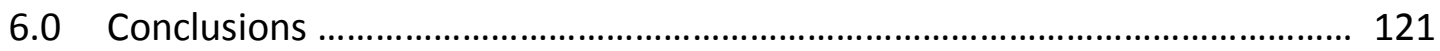

\section{List of figures}

\section{Chapter one}

Figure 1.1 Map positions of ODP and DSDP Sites ............................................. 3

Figure 1.2 Climate from $65 \mathrm{Ma}$ to recent ............................................................ 5

Figure 1.3 Compilation of Southern Ocean stable isotope data .......................... 6

Figure 1.4 Middle Eocene prediction of ocean circulation ................................... 8

Figure 1.5 Map of site 696B position in the Southern Ocean .............................. 17

Figure 1.6 Map of site 699A position in the Southern Ocean ............................. 18

Figure 1.7 Map of site 748B position in the Southern Ocean ............................ 19

Figure 1.8 Map of site 277 position in the Southern Ocean .............................. 21

Figure 1.9a Generalised section through a typical dinoflagellate ........................ 23

Figure 1.9b General morphology of a thecate motile cell ...................................... 23

Figure 1.9c Interpretation of a chorate cyst ........................................................ 23

Figure 1.9d Correlation between sea level and species diversity .......................... 23

Figure 1.9e Dinoflagellate generalised life-cycle .................................................. 23

Figure 1.10 Contamination by mycelium ......................................................... 27 


\section{TABLE OF CONTENTS}

Figure 1.11 Background material to remove ....................................................... 28

Figure 1.12 Graph of percentages of Marine Palynomorphs from each site ...... 32

\section{Chapter two}

Figure 2.1 Nannofossil biostratigraphic zonation ............................................. 36

Figure 2.2 ODP site 696B depth plot of key events ............................................ 38

Figure 2.3 ODP site 699A depth plot of key events ........................................... 40

Figure 2.4 ODP site 748B depth plot of key events .............................................. 43

Figure 2.5 DSDP site 277 depth plot of key events ............................................. 45

\section{Chapter three}

Figure 3.1 The dinocyst biostratigraphic zonation ............................................. 51

Figure 3.2 A3 displays timescale columns for all sites .......................................... 52

Figure 3.3 ODP 696B depth plot of dinocysts and nannofossils ........................... 58

Figure 3.4 ODP 699A depth plot of dinocysts, nannofossils, radiolarian and foraminifera 59

Figure 3.5 ODP 748B depth plots of dinocysts, nannofossils and foraminifera ... 60

Figure 3.6 DSDP 277 depth plot of dinocysts, nannofossils, radiolarian and foraminifera 61

Figure 3.7 Site 696B grains per gram total abundances ........................................ 63

Figure 3.8 Site 699A grains per gram total abundances ..................................... 67

Figure 3.9 Site 748B grains per gram total abundances ....................................... 70

Figure 3.10 Site 277 grains per gram total abundances ........................................ 74

\section{Chapter four}

Figure 4.1a Site 696B dinocyst GP Groups …...................................................... 81

Figure 4.1b Site 696B all palynomorphs ………................................................ 82

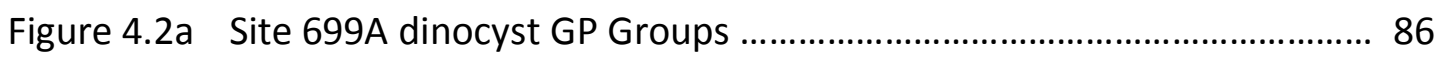

Figure 4.2b Site 699A all palynomorphs ……….................................................... 87

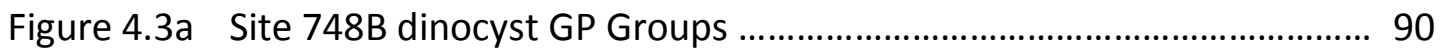

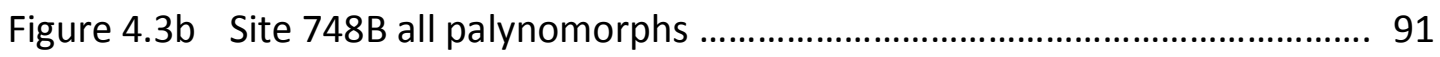

Figure 4.4a Site 277 dinocyst GP Groups .............................................................. 93

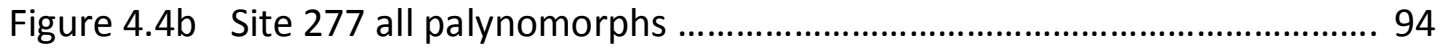

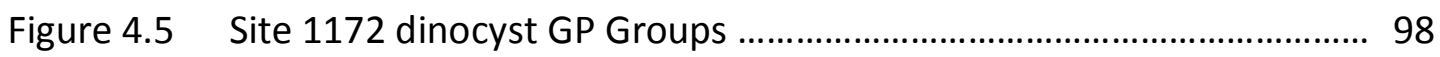




\section{Chapter five}

Figure 5.1 Average position of dinocysts preferred environmental setting ....... 106-7

Figure 5.2 Dinocyst palaeoenvironmental interpretation ................................... 108-9

Figure 5.3 Marine palynomorph comparisons to Southern Ocean Isotopes ...... 116

\section{List of Tables}

Table 1.1 Various estimates for Drake Passage opening …................................. 9

Table 1.2 Southern Ocean DSDP and ODP Sites core recovery ........................... 15

Table 1.3 Initial sites processed for investigation ............................................... 16

Table 1.4 Total counts from one slide of total palynomorph abundance ......... 31

Table 1.5 Displays all dinocysts genera occurring in the four sites ................... 33

Table 4.1 Dinocysts morphologically closely related groups .............................. 79

Table 5.1 Dinocysts Palaeoenvironmental Interpretation ................................... 103

Table 5.2 Non dinocysts Palaeoenvironmental Interpretation ............................. 104

References $\quad$.......................................................................... 126

\section{Appendices}

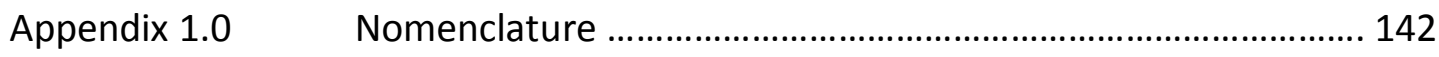

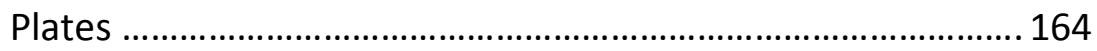

Appendix 2.1 Sites initially researched in Southern Ocean .......................... 193

Appendix 2.2 Report on DSDP and ODP legs in Southern Ocean ................. 196

Appendix 2.3a-d Sediments received and predominant lithology ..................... 205

Appendix 2.4 Dry weight processed ................................................................ 211

Appendix 2.5 Raw data total abundance counts ........................................ 220

Appendix 2.6 Totals of all Gonyaulacoid and Peridinioid dinocysts ............. 227

Appendix 2.7-2.10 Palynomorph total abundance counts (ODP 696B, 699A, 748B, DSDP 277)

Appendix 2.11-2.14 Genera total abundance counts (ODP 696B, 699A, 748B, DSDP 277) 


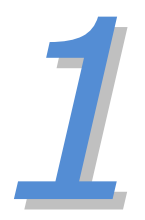

\section{Introduction}




\section{CHAPTER ONE}

\subsection{Introduction}

During the Cretaceous and early Cenozoic the Earth's climate was significantly warmer than the present day. Warmer conditions reached a peak in a transitory spike in temperature during the Late Palaeocene/Early Eocene (the PETM) (Kennett and Stott, 1991; Zachos et al., 2001) and was followed by a series of cooling events. At the Eocene/Oligocene $(\mathrm{E} / \mathrm{O})$ boundary $(\sim 33.7 \mathrm{Ma})$ an abrupt cooling is designated as the Oi-1 event (Coxall et al., 2005; Miller et al., 1987; Shackleton and Kennett, 1975; Zachos et al., 2001). This is characterized by a positive shift in oxygen isotopic $\left(\delta^{18} O\right)$ values of benthic foraminifera. The Oi-1 event resulted in a permanent drop in bottom water temperatures and the formation of the first continent wide Antarctic ice sheet and later, the first permanent ice-sheet developed (Barrett, 2003; DeConto and Pollard, 2003; Eldrett et al., 2004; Kump, 2009; Miller et al., 1987; Shackleton and Kennett, 1975; Zachos et al., 2001).

\subsection{Aims}

The broad aim of this project is to document the climate induced changes in marine palynomorph assemblages from the Middle Eocene through to the Early Oligocene i.e. over the Oi-1 event. In particular the study aims to document changes in the high latitude Eocene fossil dinocyst assemblages that have been recovered from southern high latitudes.

More specifically, this study aims to:

1. Develop a Circum-Antarctic biozonation for this climate transition in the Southern Ocean.

2. Establish the Circum-Antarctic distribution of palynomorph assemblages in the Eocene.

3. Document the effect of cooling on palynomorph distribution and palaeoecology. 


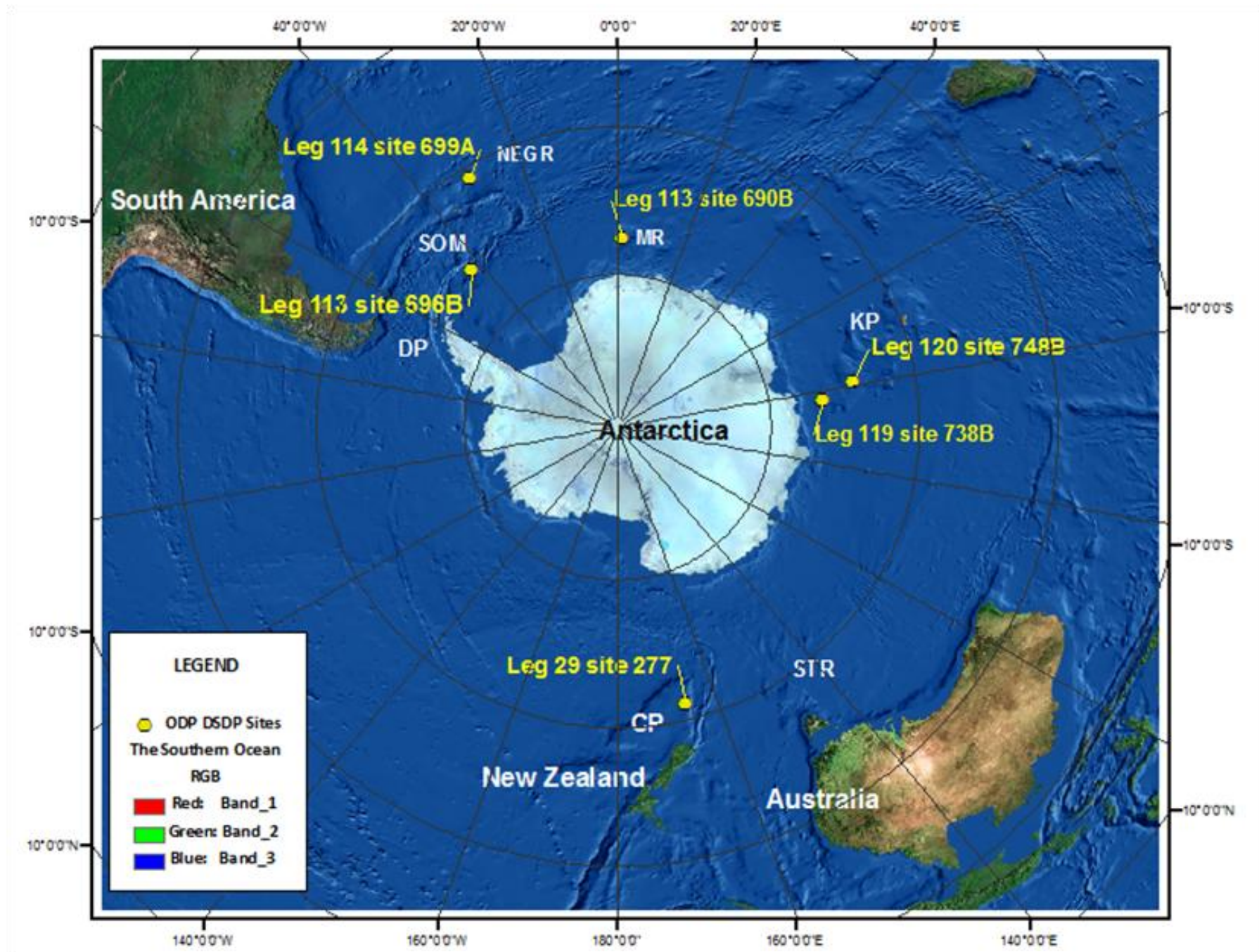

Figure 1.1: Antarctic and the Southern Ocean. Latitude and longitude positions for ODP sites 696B, 699A, 748B and DSDP site 277 that have been processed are marked by yellow circles. Sites 690B and 738B were processed but not included (see text). DP $=$ Drake Passage, SOM $=$ South Orkney Microcontinent, NEGR $=$ Northeast Georgia Rise. $M R=$ Maud Rise. $K P=$ Kerguelen Plateau. STR $=$ South Tasman Rise. $C P=$ Camnhell Plateau. 
Four sites were selected for this study (Figure 1.1):

- ODP site 696B, South Orkney microcontinent, Weddell Sea.

- ODP site 699A, Northeast Georgia Rise, Falklands area.

- ODP site 748B, Western part of the Raggart Basin, Kerguelen Plateau.

- DSDP site 277, Cathedral Depression on the southern Campbell Plateau.

The sites chosen are in areas that should record the effects of any cooling trends and circulation changes in the Paleogene that may reflect climate changes. The Antarctic circumpolar region covers a wide area and some sectors may have responded differently to Antarctic cooling and changes in oceanic circulation.

\subsection{Background}

Earth's geologic past has recorded many instances where global temperatures have risen dramatically then rapidly dropped e.g. the extreme warming event of the PETM was followed by a significant warming during the Middle Eocene (MECO) and both were followed by a rapid cooling (Figure 1.2, 1.3). Ocean temperatures can be estimated by using oxygen isotopes included in the calcareous tests of foraminifera (Figure 1.2; Zachos et al., 2001). Shifts in the ratio of ${ }^{16} \mathrm{O} /{ }^{18} \mathrm{O}$ are assumed to be a result of changes in both sea temperatures and ice volume. Variations in continental ice volume occur when freezing of the oceans is preferential for higher concentration of ${ }^{16} \mathrm{O}$ in ice sheets and more ${ }^{18} \mathrm{O}$ in the oceans during glacial periods. Higher ${ }^{16} \mathrm{O}$ ratios in the ocean reflect changes in ice volume and warmer temperatures (Lear et al., 2008; Liu et al., 2009; Boulton, 1993). The Cenozoic $\mathrm{O}_{2}$ isotope record of Zachos et al. (2001) is based on data from 40 DSDP and ODP sites combined to create a global deep-sea isotope record.

\subsection{Paleogene Temperature Changes}

The PETM has been recorded from a variety of areas including Clarence River Valley and Tawanui in the Southwestern Pacific, Wilson Lake and Bass River on The New Jersey Shelf and Lomonosov Ridge, Arctic Ocean (Crouch et al., 2003; Crouch and Brinkhuis, 2005; Hollis et al., 2005; Sluijs et al., 2008; Zachos et al., 2005, Zachos et 
al., 2008). The high global temperatures achieved during the PETM lasted for 170 kyr (Handley et al., 2011). The PETM is superimposed on a gradually rising temperature (Figure 1.2). Deep Ocean and high latitude surface temperatures rose by $6^{\circ}-8^{\circ} \mathrm{C}$ in less than 10,000 years and about that time more than $2,000 \mathrm{Gt}^{\mathrm{CO}_{2}}$ entered the atmosphere and oceans (Zachos et al., 2008). With the PETM intense warming and excess carbon, came changes in the marine and terrestrial biota. Included were changes in planktonic organisms, a benthic foraminiferal extinction event (Kennett and Stott, 1991) and a global occurrence of an acme for the dinocyst genus Apectodinium (Crouch et al., 2003).

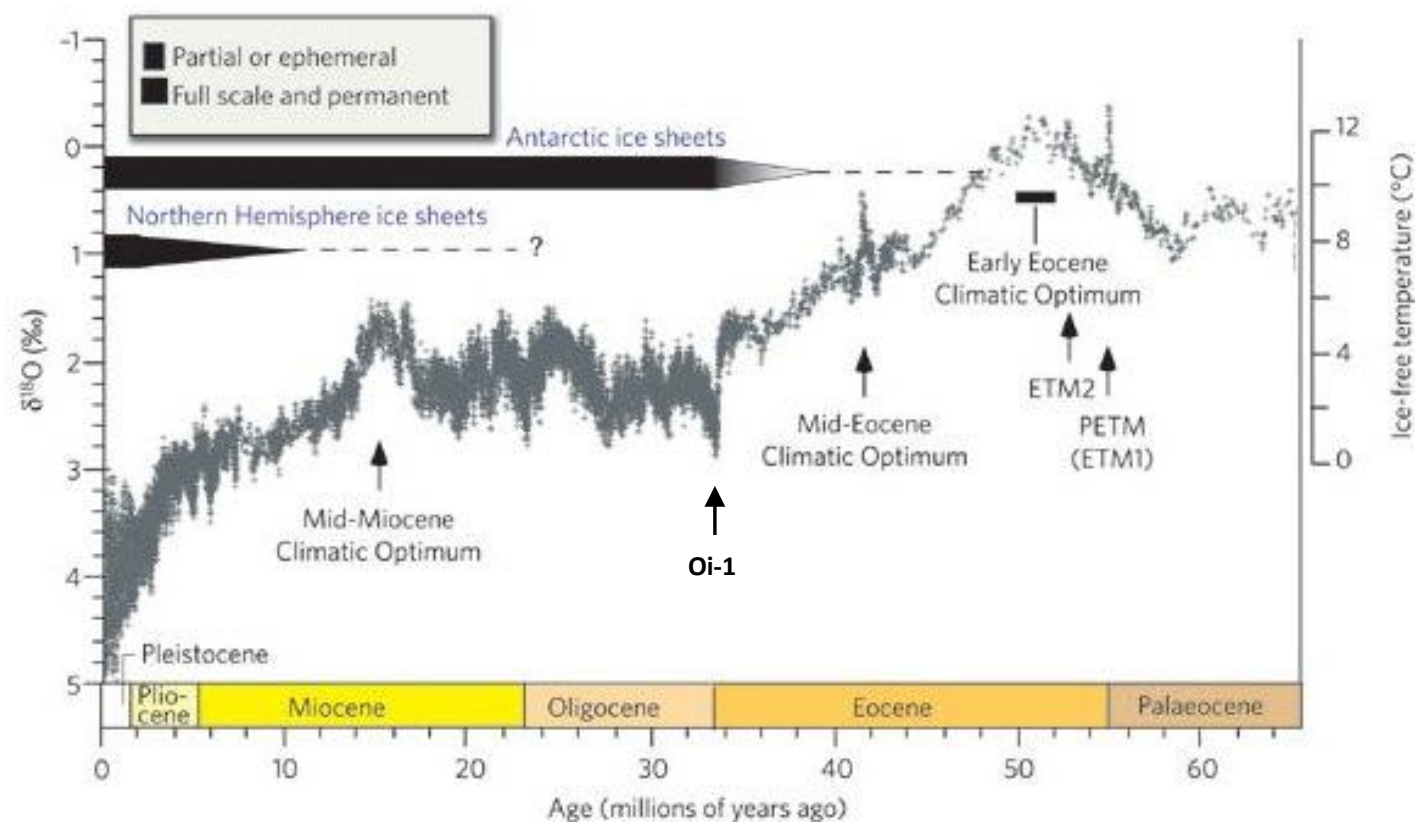

Figure 1.2: Climate from $65 \mathrm{Ma}$ up to Recent from deep-sea benthic foraminiferal oxygen-isotope curve from DSDP and ODP sites. The figure clearly shows the PETM (Eocene thermal max. 1) followed by a second ETM2 and the 2 Ma Early Eocene Climatic Optimum warming. The MECO event is also shown at $52 \mathrm{Ma}$ and the Oi-1 at the E/O boundary $\sim 33.7 \mathrm{Ma}$. The approximate positions of Antarctic ice sheets and Northern Hemisphere ice sheets are also displayed (Zachos et al., 2008).

A further brief peak in warm conditions is recorded as the Eocene Thermal Maximum 2 (ETM2), followed closely by a longer period of warming at the Early Eocene Climatic Optimum (EECO). The EECO temperature curve (Figure 1.2) is represented by a broader peak consistent with a longer period lasting $2 \mathrm{Ma}$ (51-53 $\mathrm{Ma})$ and is followed by a gradual decline in temperature. The MECO ( 42 Ma) is the next significant warming event with a steep rise in temperature followed by a rapid decrease (Figure 1.2, 1.3). Following the MECO a further Late Eocene warming ( 36 
Ma) was followed by a brief cooling ( $35 \mathrm{Ma}$; Vanhof et al., 2000), before the most significant cooling event of the Oi-1 ( 33.7 Ma; Figure 1.3).

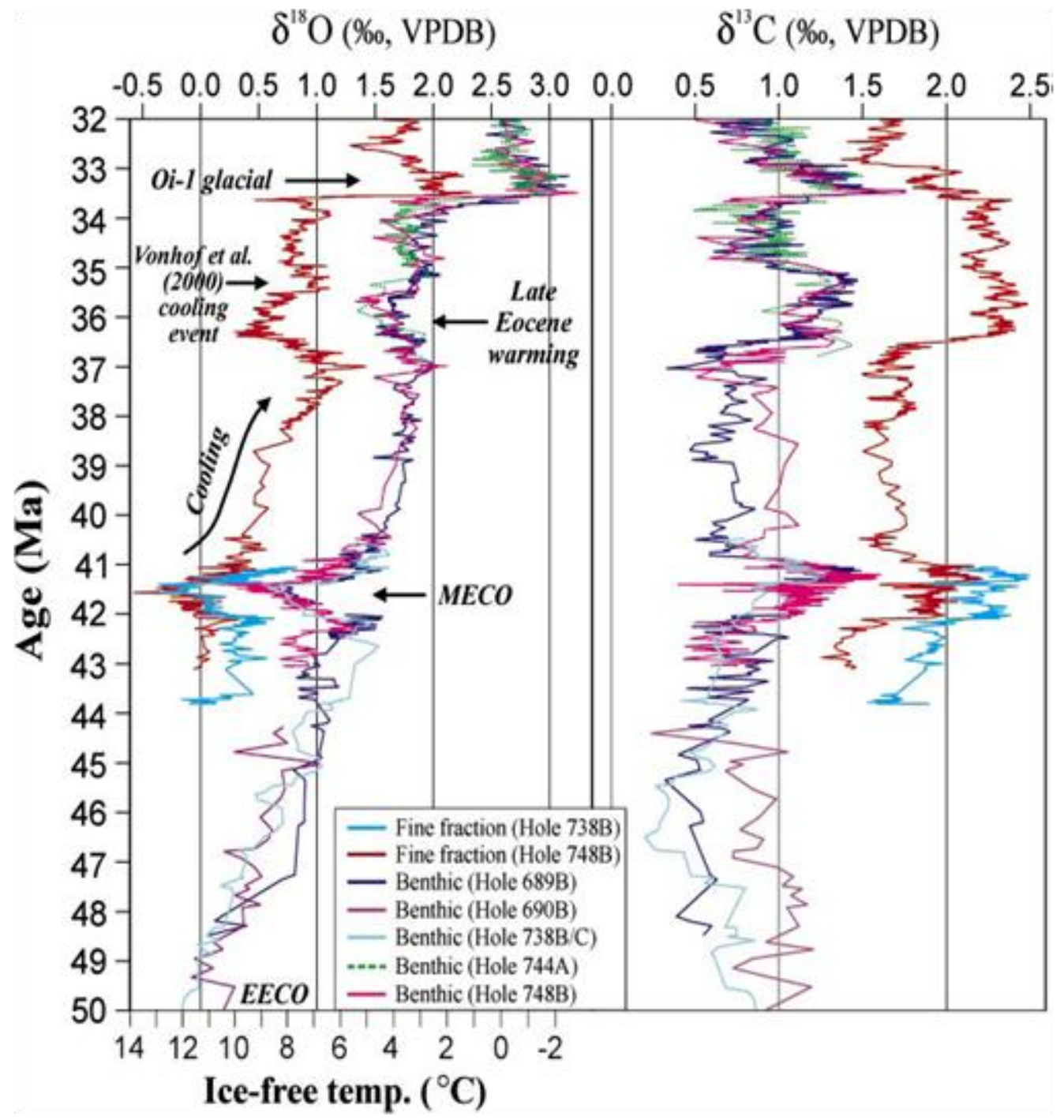

Figure 1.3: Compilation of Southern Ocean stable isotope data taken from ODP sites 689, 690, 738, 744 and 748. The early Eocene climatic optimum (EECO) is featured at the base of the chart. A prominent minimum event in the $\delta^{18} \mathrm{O}$ at $\sim 41.5 \mathrm{Ma}$, is interpreted as significant warming during $\mathrm{MECO}$. This was followed by gradual increase in $\delta^{18} \mathrm{O}$ events of cooling, a late Eocene warming with a further Vonhof et al. (2000) cooling. A most prominent event of glacial cooling at $33.5 \mathrm{Ma}$ is the Oi-1 event which represents significant cooling of both surface and deep waters (Palike et al., 2006). Figure adapted from Bohaty and Zachos (2003).

During most of the Eocene in the Northern Hemisphere winters were above freezing in the mid to high latitude continental interiors and both poles were free of significant permanent ice (Huber and Nof, 2005). After the MECO the climate cooled sufficiently to allow small ice sheets to form on the Antarctic continent. A decrease of partial pressure of atmospheric carbon dioxide $\left(p \mathrm{CO}_{2}\right)$, ensured the cooling continued (Figure 1.2, 1.3) from the middle to Late Eocene through to the 
Early Oligocene near the (E/O) boundary ( 33.7 Ma; DeConto and Pollard, 2003; Francis et al., 2009; Pagani et al., 2005). Surface water temperatures decreased rapidly over the $\mathrm{E} / \mathrm{O}$ boundary and this is reflected in a positive shift in $\delta^{18} \mathrm{O}$ excursion with the resulting cooling lasting $\sim 200,000$ years (Billups and Schrag, 2003; Bohaty and Zachos, 2003; Bohaty et al., 2009; Shackleton and Kennett, 1975; Zachos and Kump, 2005).

\subsection{Causes of the Oi-1}

The onset of the Antarctic Circumpolar Current (ACC) and the tectonic changes that deepened the Tasman Gateway between Australia and Antarctica and opened Drake Passage between South America and Antarctica, have been suggested as the triggers for Antarctic cryosphere initiation and growth (Kennett et al., 1975; Shackleton and Kennett, 1975; Zachos et al., 1996). However, DeConto and Pollard (2003) using a general circulation model (GCM), suggested that the opening of the Southern Ocean gateways and beginning of the ACC played only a secondary role in the sudden cooling and formation of the ice sheet. DeConto and Pollard (2003) proposed that a decline in atmospheric $\mathrm{CO}_{2}$ and a position in orbital cycles resulting in low insolation were the primary causes for the event. In support Huber et al. (2004) concludes there was no direct dynamic effect of a termination of warm currents resulting in Antarctic glaciation. Warm ocean currents did not penetrate to high latitudes during the climatic transition of the Eocene/Early Oligocene. Further to this Stickely et al. (2004) supported a deepening of the Tasman Gateway as preceding significant Antarctic glaciation by $2 \mathrm{Ma}$.

Figure 1.4 displays a proposed Middle Eocene ocean circulation inferred from the GCM results before full opening of gateways and commencement of the ACC (Francis et al., 2009). Previous work in the Southern Ocean and Antarctica has recognised the presence of dinocysts that were endemic to the southern high latitudes during the Eocene/Early Oligocene (Kemp, 1975; Haskell and Wilson, 1975; Goodman and Ford, 1983; Wrenn and Hart, 1988; Wilson, 1989; Hannah, 1997; Levy and Harwood, 2000). Endemics are species of flora and fauna that are restricted to and exclusively native to a region and not found elsewhere. 


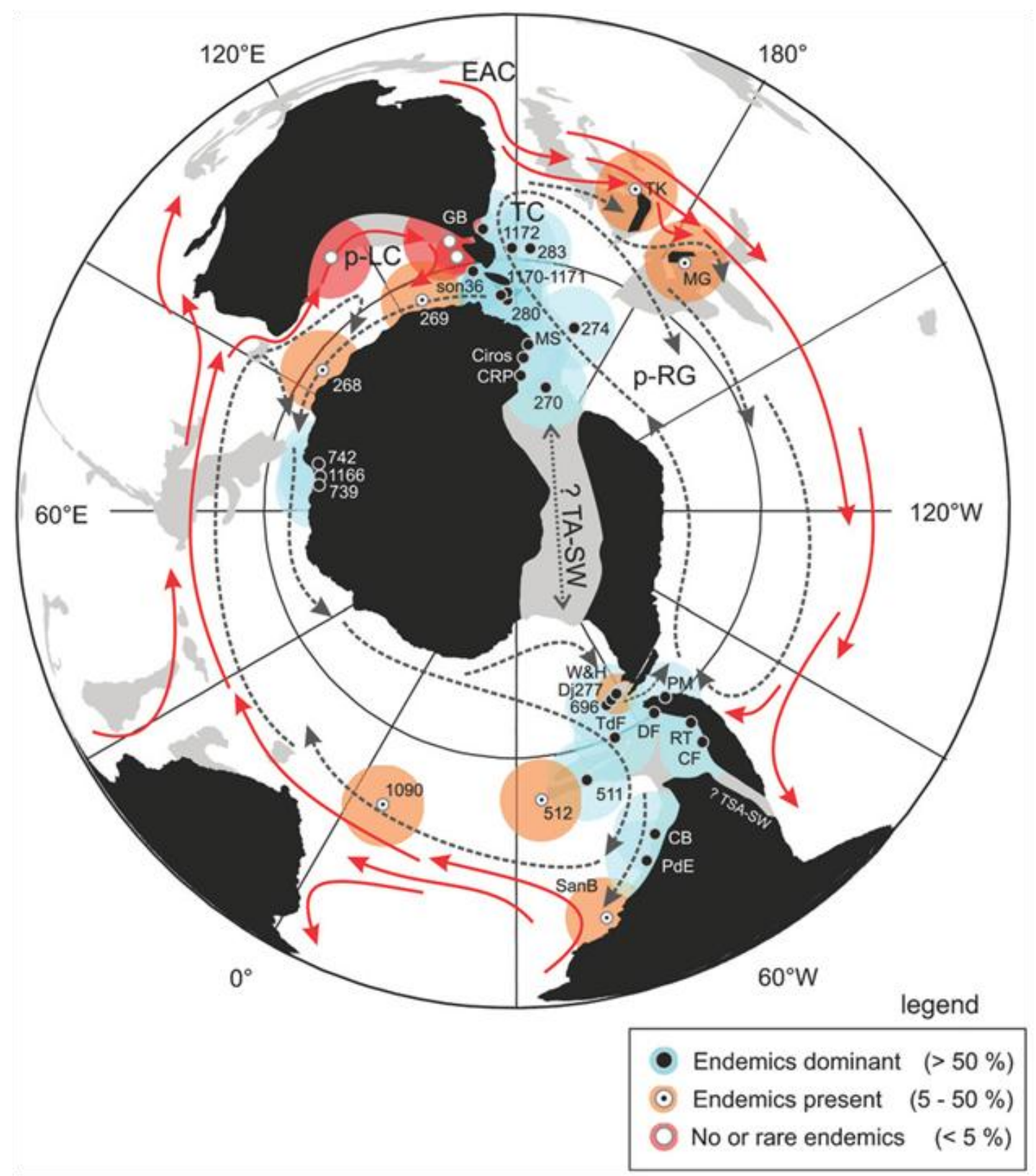

Figure 1.4: A Middle Eocene prediction for ocean circulation inferred from GCM results before full opening of gateways. Endemic dinocysts show as per legend. Lighter shading shows submerged continental blocks. Red arrows are warmer currents, black arrows are cooler currents which dominate the Southern Ocean round Antarctica as clockwise gyres. The map is derived from the Ocean Drilling Stratigraphic Network (ODSN). TASW, Trans-Antarctic Seaway (hypothetical; see Wrenn and Beckmann, 1982); TSA-SW, Trans-South American Seaway (hypothetical; see Kohn et al., 2004); EAC, East Australian Current; p-LC, proto-Leeuwin Current; p-RG, proto-Ross Gyre; TC, Tasman Current (Francis et al., 2009). 
Figure 1.4 utilizes the endemic southern high latitude fossil dinocysts to predict the Eocene palaeo-ocean circulation patterns before the opening of the ACC. Higher numbers of endemic dinocysts occupy the cooler equator ward flowing Tasman Current, the proto-Ross Gyre in the Pacific and the Counter Antarctic Current on the western side of the Antarctic. These currents were not warmed by sub tropical southward flowing currents. The warmer proto-Leeuwin Current circulating on the Western side of the Tasman Gateway between the Australian continent and Antarctica, contained cosmopolitan assemblages typical of low latitude taxa. Endemic high latitude southern dinocysts were rare in ODP sites in this region (Brinkhuis et al., 2003; Francis et al., 2009; Huber et al., 2004). The opening of the Tasman Gateway would have allowed the warmer proto-Leeuwin Current to flow into the Southern Pacific Ocean creating a mild warming for the region, rather than a predicted cooling effect. Changes to dinocyst assemblages would favour cosmopolitan species and fewer endemic dinocysts would exist (Huber et al., 2004; Stickely et al., 2004).

In addition, the timing of the opening of both the Tasman Gateway and Drake Passage are currently debated and Barker et al. (2007) point out that the timing of this event is not certain for Drake Passage (Table 1.1). Barker et al. (2007) have listed alternatives to the timing and onset of the ACC for the Drake Passage opening.

\begin{tabular}{|l|l|l|l|}
\hline \multicolumn{1}{|c|}{ Author/date } & \multicolumn{1}{|c|}{ Sites } & \multicolumn{1}{c|}{ Type of Research } & \multicolumn{1}{c|}{ Onset } \\
\hline $\begin{array}{l}\text { Diester-Haass and Zahn } \\
\text { (1996, 2001) }\end{array}$ & $689,763,592$ & Benthic biomass increase & $37 \mathrm{Ma}$ \\
\hline $\begin{array}{l}\text { Scher and Martin (2004, } \\
\text { 2006) }\end{array}$ & 689,1090 & Nd isotopes & $41 \mathrm{Ma}$ \\
\hline $\begin{array}{l}\text { Florindo and Roberts (2005) } \\
\text { Roberts } \text { et al. (2003) }\end{array}$ & $690,744,748$ & Magnetobiochronology & $31-30 \mathrm{Ma}$ \\
\hline Gamboa et al. (1983) & 515 & Increased sedimentation & Early Miocene \\
\hline Persico and Villa (2004) & $\begin{array}{l}689,690,744, \\
748\end{array}$ & Nannofossils & $33.5 \mathrm{Ma}$ \\
\hline Diekmann et al. (2004) & 1090 & $\begin{array}{l}\text { Opal pulse, reduced } \\
\text { sedimentation }\end{array}$ & $33-30 \mathrm{Ma}$ \\
\hline $\begin{array}{l}\text { Pfuhl and McCave (2003, } \\
\text { 2005) }\end{array}$ & 1170 & Grain size & $23.9 \mathrm{Ma}$ \\
\hline Wei and Wise (1992) & $\begin{array}{l}737,744,748, \\
751\end{array}$ & Planktonic biofacies & Latest Miocene \\
\hline
\end{tabular}


Livermore et al. (2005) suggest that a deep water connection at $34-30 \mathrm{Ma}$ developed due to seafloor extension of the West Scotia Ridge. Francis et al. (2009) suggests the Drake Passage from the Middle Eocene may have been open to upper bathyal water depths, as noted by Eagles et al. (2006).

ODP leg 189 was drilled to document the changes in the Australian sector of the Southern Ocean and the results from Stickley et al. (2004) for the Tasman Gateway suggest:

- $\quad$ 35.5 Ma, a minor deepening in the Tasman Gateway

- $\quad$ 35.5-33.5 Ma, the onset of glauconitic deposition, increased deepening of the Tasman Gateway and commencement of energetic bottom-water currents.

- 33.5-30.2 Ma further deepening to bathyal depths with episodic erosion and a further increase in energetic bottom water currents.

- $\quad$ 30.2 Ma oligotrophic warm temperate open ocean settings with siliceous carbonate ooze deposition (Stickley et al., 2004).

\subsection{Previous Work in Antarctica and Southern Ocean}

There has been a variety of studies on fossil dinocysts from Antarctica and the Southern Ocean and a particular focus has been on the Eocene/Oligocene boundary. Some of the earliest investigations of Antarctic and the Southern Ocean were completed during the 1960's. These include Cranwell et al. (1960) with one of the first records of Hystrichosphaerid species from Paleogene sediments in the McMurdo Erratics. Wilson (1967a) followed with an investigation into the palynomorph contact of the Erratics from Black Island and Minna Bluff. He named seven new species attributable to the dinocyst genera for Deflandrea and Spinidinium as well as Cordosphaeridium filosum. Further afield, Cookson (1965a,b) described the content of the Upper Eocene Browns Creek Clays, SW Victoria. The dinocysts described included Deflandrea phosphoritica, Impagidinium victorianum, 
Impagidinium elegans, Impagidinium dispertitum, Samlandia reticulifera, and Hystrichosphaeridium spp.

During the 1970's, Kemp (1975) examined sediments from beneath the Ross Sea reporting on results from DSDP sites drilled during leg 28 partly in the Ross Sea, and between Wilkes Land Antarctica and South of Australia in the Southern Indian Ocean. Sediments of possible Late Eocene age from site 274 yielded rich dinocyst assemblages that included Areosphaeridium diktyoplokus, Deflandrea spp, Selenopemphix nephroides, Spinidinium macmurdoense, Thalassaphora pelagica, and Turbiosphaera filosa. These assemblages can be considered to be typical of high latitude endemic Eocene environments. All other sites contained only sparse dinocyst assemblages

Haskell and Wilson (1975) reported on the dinocyst assemblages from DSDP sites 280-284 on leg 29, situated off the South Tasman Rise and to the west of New Zealand in the Tasman Sea. Most cores recovered Eocene/Oligocene sediments except site 284 which was restricted to the late Miocene to Pleistocene. Some typical Eocene dinocysts recorded included Areosphaeridium diktyoplokus, Deflandrea antarctica, Deflandrea cygniformis, Deflandrea phosphoritica, Thalassaphora pelagica and Impagidinium victorianum.

Analysis of gravity cores recovered from beneath the southern Ross Ice Shelf by Wrenn and Beckman (1982) recorded the presence of dinocysts, acritarchs and sporomorphs throughout the cored sequence. The dinocysts that were becoming accepted as Eocene endemics included Deflandrea antarctica, Spinidinium macmurdoense, and Vozzhennikovia apertura. Goodman and Ford (1983) examined DSDP sites 511, 512 and 513A from Leg 71 in the South Western Atlantic Ocean. Site 511 dinocysts were common to abundant and Goodman and Ford (1983) considered the flora recovered to be similar to those from the Browns Creek Clays (Cookson, 1965). Haskell and Wilson (1975) also concluded a similarity to the Browns Creek Clays and sites examined by them (DSDP sites 280, 283). Site 511 includes Phthanoperidinium SpA, Eurydinium sp, Deflandrea antarctica, Deflandrea 
phosphoritica, Samlandia reticulata, Spinidinium macmurdoense, and Vozzhennikovia apertura. Similar dinocysts were also recovered from site 512. Site 513A was restricted from the Lower Oligocene to Lower Miocene and contained few dinocyst assemblages including Corrudinium incompositum, Deflandrea antarctica, Phthanoperidinium SpA, and Impagidinium victorianum.

Wrenn and Hart (1988) documented the Paleogene dinocysts of Seymour Island, Antarctica from two lithologic formations, the Cross Valley and La Meseta. The Cross Valley Formation sediments are considered Late Paleocene in age and included cosmopolitan taxa with none of the endemic dinocysts. The La Meseta Formation did contain Eocene dinocysts including Arachnodinium antarcticum, Areosphaeridium diktyoplokus, Deflandrea antarctica, Deflandrea cygniformis, Impagidinium victorianum, Lejeunecysta fallax, Selenopemphix nephroides, Spinidinium essoi, Spinidinium macmurdoense, and Vozzhennikovia apertura.

CIROS-1 was drilled offshore of the Ferrar Glacier in McMurdo Sound and has been the focus for many marine palynomorph studies. Wilson (1989) originally described the flora and suggested that the late Eocene endemic flora found between 473-696 mbsf toward the base of the hole were a result of reworking. Based on diatoms an Early Oligocene age was suggested by Harwood (1989). The dinocyst assemblage included Deflandrea antarctica, Alterbidinium distinctum, Vozzhennikovia apertura, Spinidinium macmurdoense, Alterbidinium asymmetricum, Hystrichosphaeridium tubiferum and Turbiosphaera filosa. Following this Hannah (1997) re-sampled the base of CIROS-1 (455-696 mbsf), and suggested that the endemic dinocysts were in situ and of Eocene age with some last occurrences extending into the Early Oligocene. The dinocysts included Alterbidinium distinctum, Deflandrea antarctica, Enneadocysta partridgei, Hystrichosphaeridium tubiferum, Spinidinium macmurdoense, Turbiosphaera filosa, and Vozzhennikovia apertura.

ODP site 696B leg 113 from middle Eocene to Oligocene in the Weddell Sea yielded dinoflagellate cysts and sporomorphs with a stratigraphic range of late middle Eocene to late Eocene/earliest Oligocene (Mohr, 1990). Many of the species 
recovered were indicative of a shallow marine environment and contained endemic dinocysts including Areosphaeridium diktyoplokus, Deflandrea antarctica, Spinidinium essoi, Spinidinium luciae, Spinidinium macmurdoense, Turbiosphaera filosa, and Vozzhennikovia apertura. Site 696B was included in this study with results shown in the following chapters.

Crouch and Hollis (1996) revised the Paleogene palynomorph and radiolarian biostratigraphy from the Middle Eocene to Late Eocene for DSDP sites 280 and 281, leg 29 off the South Tasman Rise. The dinocyst distribution reflected the depositional differences between sites. Site 281, deposited in shallower marine conditions, yielded a restricted dinocyst assemblage, whereas site 280 contained an abundant and diverse dinocyst assemblage reflecting its deep water environmental deposition. Endemic dinocysts were present in both sites and many dinocysts were long ranging and extended through the Eocene into the Oligocene including Deflandrea antarctica, Spinidinium macmurdoense and Vozzhennikovia apertura. Other dinocysts recorded in the Middle and Late Eocene and part of the Early Oligocene are Eocene endemics. Hollis et al. (1997) described marine palynomorphs from the Paleocene to Middle Eocene in an integrated biostratigraphic study for site 277 leg 29 on the Campbell Plateau. Of the fifteen samples examined from this site, only five samples contained palynomorphs with no age significant taxa being reported.

Sites off Western Tasmania and the western edge of the South Tasman Rise were the focus of Truswells 1997 study. Samples from off Western Tasmania contained very low numbers of endemic dinocysts whereas South Tasman Rise sites contained higher frequencies for endemics including high numbers of Deflandrea antarctica. Levy and Harwood (2000) studied the McMurdo Erratics and most of the sediments examined appeared to be of Middle Eocene to Early Oligocene age based on taxon ranges. The most common dinocysts recovered were Vozzhennikovia apertura and Enneadocysta partridgei and other common dinocysts included Octodinium askinae, Alterbidinium asymmetricum, Deflandrea antarctica, Spinidinium colemanii, 
Spinidinium essoi, Spinidinium macmurdoense, Impagidinium victorianum and Thalassaphora pelagica.

ODP leg 189 drilled five sites in the Tasmanian Gateway $(1168,1169,1170,1171$, 1172). The purpose of the drilling was to assess whether the opening of the Gateway near the Eocene/Oligocene led to the formation of the ACC, causing climatic cooling and development of Antarctic glaciation.

Site 1168 (Brinkhuis et al., 2003a) off Western Tasmania contained sediments of Mid Eocene/Early Oligocene age and showed that the dinocysts present were largely cosmopolitan and virtually lacked typical endemic Antarctic dinocysts. Brinkhuis et al. (2003b) also looked at site 1172 off East Tasman Plateau from Late Cretaceous-Late Oligocene, samples investigated between the Middle Eocene to Early Oligocene contained endemic species which included Alterbidinium distinctum, Deflandrea antarctica, Octodinium askinae, Enneadocysta partridgei and Spinidinium macmurdoense.

Sluijs et al. (2003) examined sediments from Middle Eocene/Early Oligocene recovered from sites 1170-1172 off the South Tasman Rise. Sites 1170 and 1171 were sampled at a low resolution and showed similar results to site 1172 . Site 1172 was more thoroughly investigated with low resolution sampling up to the Late Eocene and a much higher resolution through to the Early Oligocene. The results showed changes occurred in the dinocyst assemblages from the Late Eocene. Site 1172 dinocyst analysis has been integrated with this study for comparison.

Guerstein et al. (2008) examined palynological data from northern Tierra del Fuego, Southern Argentina, in the Middle to Late Eocene La Despedida Formation and the Late Eocene/Early Oligocene Cabo Peña Formation. The most common dinocysts included Deflandrea spp, Spinidinium spp and Vozzhennikovia spp from the Middle Eocene with an increase of cosmopolitan dinocysts near the E/O boundary of Spiniferites spp, Operculodinium spp and Impagidinium spp. Bijl et al. (2011) examined Paleogene assemblages from a number of sites drilled from the DSDP and 
$\operatorname{ODP}(269,277,511,512,696.739,748,1090)$. They conclude that the spatial distribution of the endemic, bipolar, middle to low latitude and cosmopolitan groups match the GCM experiments of Huber et al. (2004) for ocean current patterns during the middle and late Eocene.

\subsection{Site Locations, Lithology and Palaeoenvironments}

\subsubsection{Introduction}

Sites used in this study were selected on the basis that they contained the thickest sections of Eocene/Oligocene sediments with the best core recovery over the interval. The need for wide geographical/circum-Antarctic coverage was required to improve understanding of Southern Ocean climatic development.

\begin{tabular}{|cl|cl|cl|}
\multicolumn{6}{|c|}{ Southern Ocean DSDP and ODP Sites Investigated } \\
\hline \multicolumn{1}{|c|}{ Legs } & \multicolumn{1}{c|}{ Sites } & Legs & \multicolumn{1}{c|}{ Sites } & Legs & \multicolumn{1}{c|}{ Sites } \\
\hline DSDP 28 & $264-274$ & DSDP 29 & $275-284$ & DSDP 35 & $322-325$ \\
DSDP 36 & $326-331$ & DSDP 71 & $511-514$ & DSDP 90 & $587-594$ \\
ODP 113 & $689-697$ & ODP 114 & $698-702$ & ODP 119 & $736-746$ \\
ODP 120 & $747-751$ & ODP 141 & $859-863$ & ODP 177 & $1088-1094$ \\
ODP 178 & $1095-1103$ & ODP 181 & $1119-1125$ & ODP 183 & $1135-1142$ \\
ODP 187 & $1152-1164$ & ODP 188 & $1165-1167$ & ODP 189 & $1168-1172$ \\
\hline
\end{tabular}

Table 1.2: Sites chosen for investigation into core recovery of sediments deposited during the Eocene through to early Oligocene.

Table 1.2 shows the DSDP and ODP sites that were initially investigated (Appendix

2.1). ODP cores having been drilled more recently than the DSDP cores are generally of better quality. Nevertheless DSDP site 277 was included because it completes the circum Antarctic coverage. Drilling was sparse in some areas of the oceans surrounding the Antarctic continent but sites 696B, 699A, 748B and 277 are reasonably spread and in positions that should reflect any paleoenvironmental changes that were occurring at that time (Table 1.2).

ODP Leg 113, site 690B and ODP leg 119, site 738B were investigated without success (Table 1.3). Site 690B proved to be barren of palynomorphs and was therefore replaced by site $696 \mathrm{~B}$, also within leg 113 , which proved to be rich in 
palynomorphs. Similarly site 738B from leg 119 was found to be sparsely populated with palynomorphs, making any count or comparison with other sites very problematic. However, due to the sites close proximity to site $748 \mathrm{~B}$ on the Kergulen Plateau, which did have a good count in palynomorphs, preference was given to site 748B and site 738B was eliminated from this study.

\begin{tabular}{|c|c|c|c|c|c|c|}
\hline Site & Leg & $\frac{\underline{E / O}}{\text { Depth }} \frac{\text { (mbsf) }}{\text { (mbs) }}$ & $\begin{array}{c}\text { Total } \\
\text { Samples }\end{array}$ & Lat-Long & $\begin{array}{l}\text { Predominant } \\
\text { Lithology }\end{array}$ & Southern Ocean \\
\hline $696 B$ & $\begin{array}{l}\text { ODP } \\
113 \\
\end{array}$ & $\begin{array}{l}578.71- \\
642.98\end{array}$ & 28 & $61^{\circ} \mathrm{S}-42^{\circ} \mathrm{W}$ & Sandy mudstone & $\begin{array}{l}\text { South Orkney } \\
\text { Microcontinent }\end{array}$ \\
\hline $699 A$ & $\begin{array}{l}\text { ODP } \\
114\end{array}$ & $\begin{array}{c}249.73- \\
465.65\end{array}$ & 30 & $51^{\circ} \mathrm{S}-30^{\circ} \mathrm{W}$ & $\begin{array}{l}\text { Siliceous } \\
\text { nannofossil ooze } \\
\text { Nannofossil ooze }\end{array}$ & $\begin{array}{l}\text { Northeast } \\
\text { Georgia Rise }\end{array}$ \\
\hline $690 B$ & $\begin{array}{l}\text { ODP } \\
113\end{array}$ & $\begin{array}{l}70.12- \\
134.36\end{array}$ & 17 & $65^{\circ} \mathrm{S}-1^{\circ} \mathrm{E}$ & $\begin{array}{l}\text { Nannofossil ooze } \\
\text { diatom rich, foram } \\
\text { nannofossil ooze }\end{array}$ & Maud Rise \\
\hline $748 B$ & $\begin{array}{l}\text { ODP } \\
120\end{array}$ & $\begin{array}{l}76.83- \\
200.47\end{array}$ & 22 & $58^{\circ} \mathrm{S}-78^{\circ} \mathrm{E}$ & $\begin{array}{l}\text { Nannofossil ooze, } \\
\text { nannofossil chalk, } \\
\text { chert, porcellanite }\end{array}$ & $\begin{array}{l}\text { Kerguelen Plateau: } \\
\text { (Western part } \\
\text { Raggatt Basin) }\end{array}$ \\
\hline $738 B$ & $\begin{array}{l}\text { ODP } \\
119 \\
\end{array}$ & $\begin{array}{l}20.09- \\
108.18 \\
\end{array}$ & 30 & $62^{\circ} \mathrm{S}-82^{\circ} \mathrm{E}$ & $\begin{array}{l}\text { Nannofossil ooze, } \\
\text { chalk some chert }\end{array}$ & $\begin{array}{l}\text { Southern Kerguelen } \\
\text { Plateau }\end{array}$ \\
\hline 277 & $\begin{array}{l}\text { DSDP } \\
29\end{array}$ & $\begin{array}{l}122.17- \\
435.01\end{array}$ & 28 & $52^{\circ} \mathrm{S}-166^{\circ} \mathrm{E}$ & $\begin{array}{l}\text { Nannofossil ooze, } \\
\text { chert nodules, } \\
\text { some clay. }\end{array}$ & $\begin{array}{l}\text { Southern Campbell } \\
\text { Plateau: (Cathedral } \\
\text { Depression) }\end{array}$ \\
\hline
\end{tabular}

Table 1.3: Eocene/Oligocene DSDP and ODP cores that were initially investigated for this study with leg, site and Southern Ocean position in a west/east transect. Latitude and longitude, depth in meters below the sea floor ( $\mathrm{mbsf}$ ), total number of samples and lithology of sediment received are also shown. Only sites 696B, $699 \mathrm{~A}, 748 \mathrm{~B}$ and 277 were chosen as suitable for this study.

The Shipboard Scientific Party $(1975,1988,1989)$ and except where noted is the source for the detailed information reported here.

\subsubsection{Site 696B}

Site 696B is located on the southeast margin of the South Orkney microcontinent (SOM), South Scotia Ridge at $61^{\circ} \mathrm{S}, 42^{\circ} \mathrm{W}$ (Figure 1.5). Drilling took place in March 1987 at a water depth of $650 \mathrm{~m}$. Site 696B was one of a series of nine sites, six in the Weddell Sea area (689-694) and three on the margin of the SOM (695-7). Site $696 \mathrm{~B}$ is the shallowest site and was drilled to recover continuously cored, shallow water sedimentary records from the middle Paleogene through to the Neogene. It was suggested (ref p16) that during the Eocene, sediments were deposited in less than $100 \mathrm{~m}$ water depth. The dominantly terrigenous deposition indicated that the SOM was still contiguous with the West Antarctic continental margin. 


\subsubsection{Lithology and Palaeoenvironment}

There are 28 samples from this study ranging from $642.9-578.7$ mbsf with samples spaced every 1-2 m except for the three youngest samples which were spaced every $10 \mathrm{~m}$. The sampled section is described as mainly terrigenous with minor pelagic content consisting of sandy mudstone from the base of the hole to $598.30 \mathrm{mbsf}$, where it changes to glauconite silty mudstone which continues up to $578.71 \mathrm{mbsf}$ (Appendix 2.3a). Barker et al. (1988) have suggested that between $645.6 \mathrm{mbsf}$ and 616.6 mbsf the presence of benthic foraminifera and the abnormally high chlorinity of interstitial waters, created hypoxic and slightly hyposaline conditions. The shallow hypersaline waters largely excluded planktonic assemblages in favour of abundant assemblages of invertebrates (Mollusca and Cnidaria).

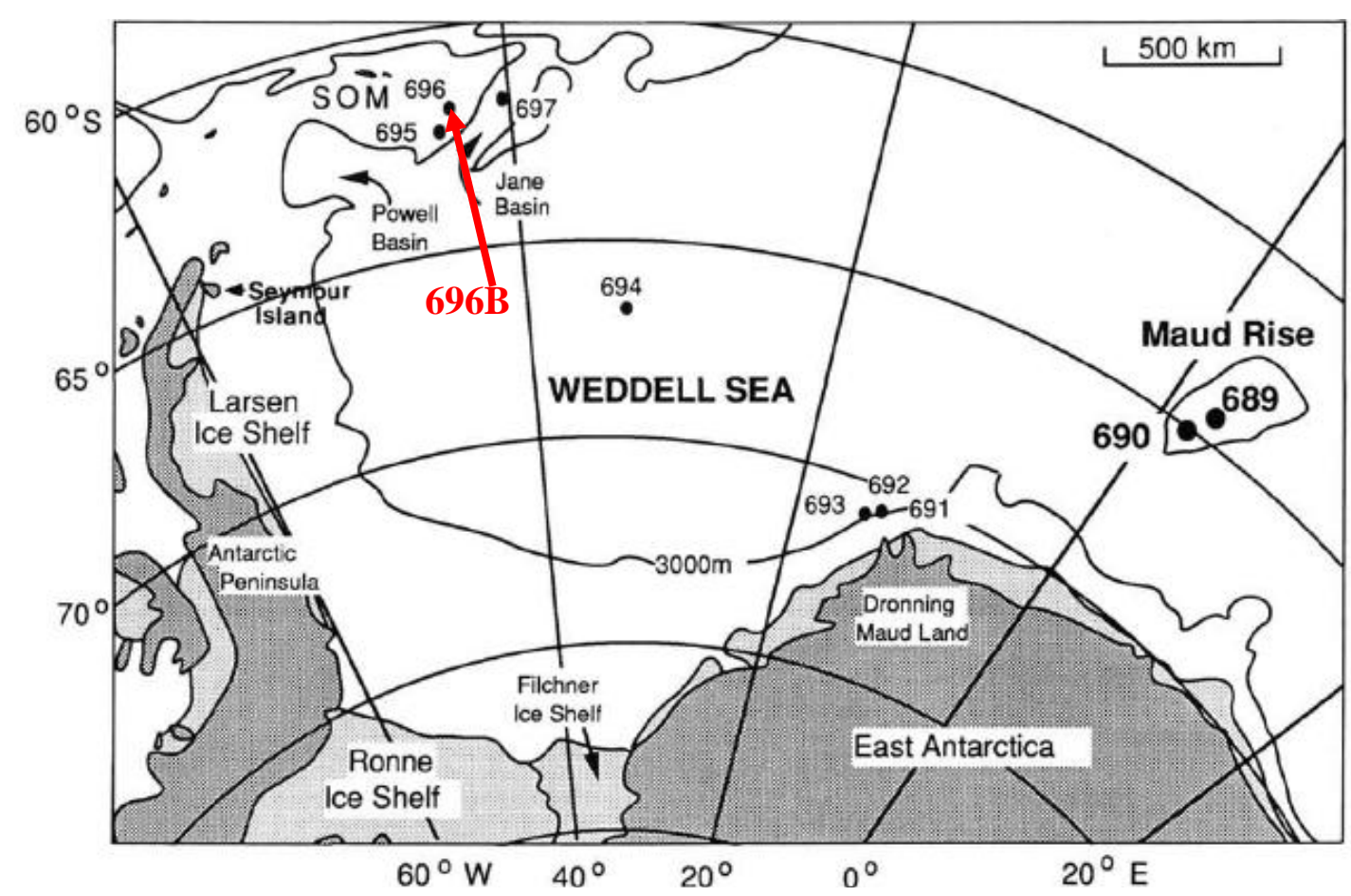

Figure 1.5: Red arrow depicts the position of site 696B in the SOM part of the Weddell Sea. Other sites within Leg 113 are also shown, six in the Weddell Sea area (689-694) and three in the SOM. Map was obtained from the initial results by the ODP Shipboard Scientific Party (1988).

Estimates of the Paleogene age for samples in this site are from a biostratigraphic age assessment provided by calcareous nannofossil and foraminifera between 607-631.6 mbsf. Isthmolithus recurvus, Reticulofenestra oamaruensis,

Chisamolithus altus and Reticulofenestra reticulata are common and well preserved age assigned nannofossils with a known range from the Middle Eocene to Early Oligocene. The foraminifera include Praeglobobulimina ovata, Gyroidinoides spp, 
and Cibicidoides spp contained in similar assemblages to Eocene/Oligocene deposits in England. The transition at the E/O boundary is not well established due to a 77 $\mathrm{m}$ condensed glauconitic terrigenous sequence of poorly dated sediments that are barren of stratigraphically useful microfossils. Glauconite contained in sediments usually implies a slow deposition rate and a non-oxidizing, shallow marine environment.

\subsubsection{Site 699A}

Site 699A was part of a series of seven sites drilled along a west-east transect in the South Atlantic Basin, and is located on the north eastern slope of the Northeast Georgia Rise on crust that is considered to be part of the rise itself at $51^{\circ} \mathrm{S}$ to $30^{\circ} \mathrm{W}$ (Figure 1.6). Five sites (698-702) were drilled in March 1987 in the east Georgia Basin on the west south side of the Mid Atlantic Ridge and two (703-704) on the east south side of the Mid Atlantic Ridge at Meteor Rise at a water depth of $3705.5 \mathrm{~m}$.

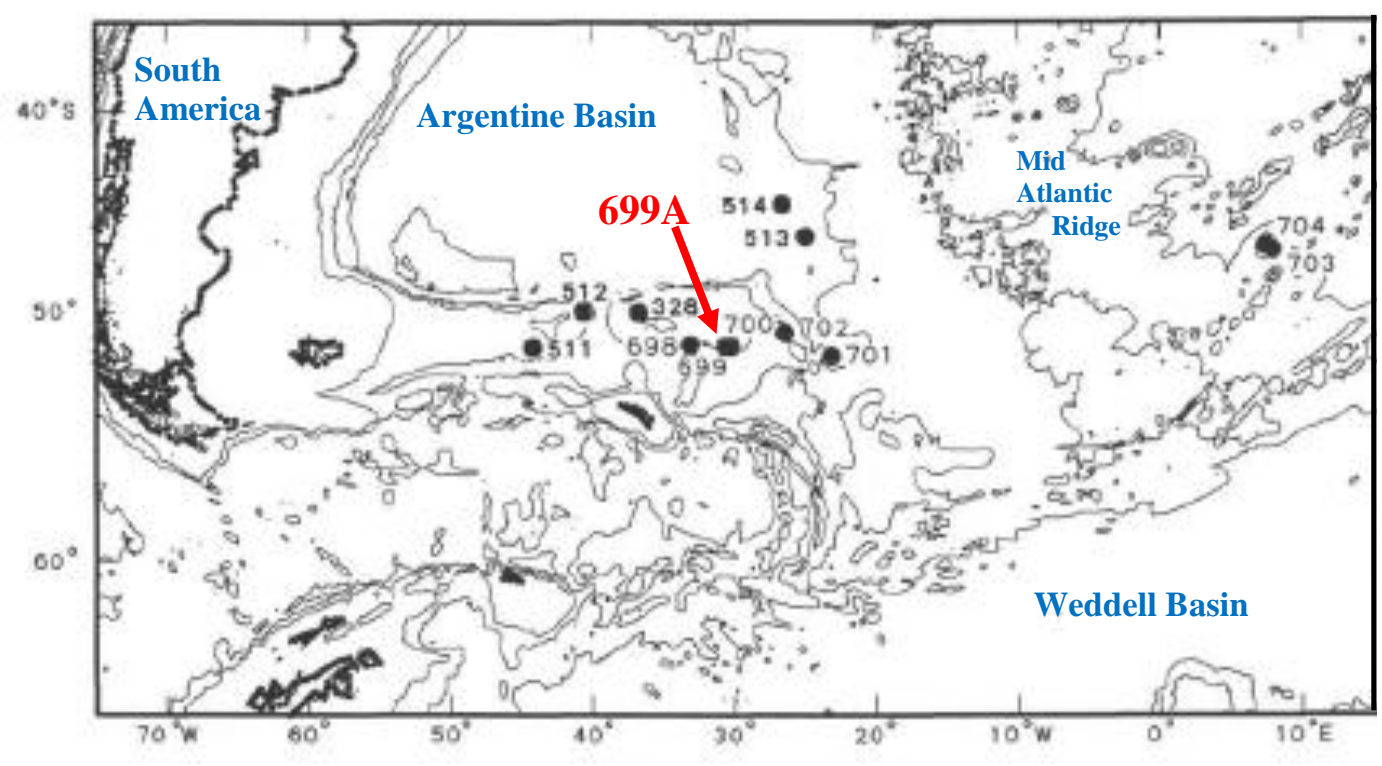

Figure 1.6: Red arrow depicts the position of site 699A. Five other sites are to the West of the Mid Atlantic Ridge (698-702) and two (703-704) are to the East of the Ridge. Site 328 is part of ODP Leg 36 and sites 511-514 are part of Leg 71. Map was obtained from the initial results by the ODP Shipboard Scientific Party, (1988).

\subsubsection{Lithology and Palaeoenvironment}

Site 699A sediments are described as predominantly pelagic in origin. There are 30 samples used in this study ranging from 249-465.6 mbsf with sample spacing varying between 4-14 m. A dominance of nannofossil chalk occurs between 465.6$335.4 \mathrm{mbsf}$ the lithology changes to nannofossil ooze up to $249.7 \mathrm{mbsf}$ (Appendix 
2.3b). An hiatus occurred at approximately the end of the middle Eocene which may have caused truncation of sediments down to the lower middle Eocene. This hiatus may also be seen at site 511, leg 71 (Figure 1.6) and sites 327 and 330, leg 36 where an unconformity occurred below the middle/late Eocene boundary and is believed to be a major erosional surface caused by bottom-current scouring (Ludwig et al. Leg 71 1983, Barker et al. Leg 36 1977; Robert and Maillot, 1983).

\subsubsection{Site 748B}

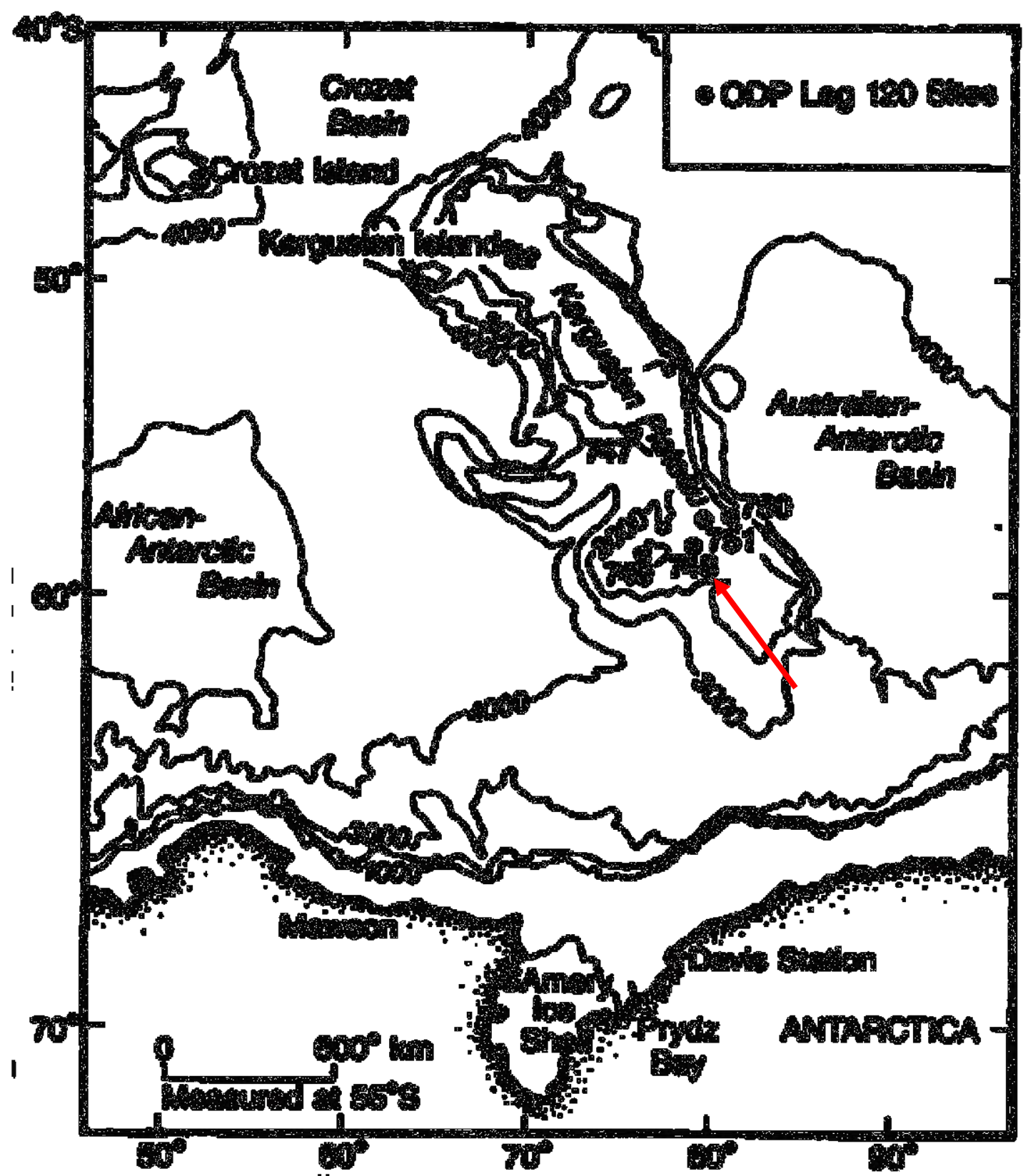

Figure 1.7: Red arrow depicts the position of site 748B. It is situated in the western part of the Raggatt Basin within the Kerguelen Plateau. The five sites above are part of Leg 120 (747-751). Map was obtained from the initial results by the ODP Shipboard Scientific Party (1989). 
Site 748B is located on the Southern Kerguelen Plateau in the western part of the Raggatt Basin, east of Banzare Bank at $58^{\circ} \mathrm{S}, 78^{\circ} \mathrm{E}$ (Figure 1.7). Site 748B was part of a series of five sites (747-751) drilled at a water depth of $1290 \mathrm{~m}$ on the Kerguelen Plateau in March 1988. The site was drilled for the purpose of recovering Cretaceous and Paleogene sediments to provide information on the geologic and tectonic history in the area. By the late Paleocene extensional tectonics caused rapid subsidence down to $\sim 1000 \mathrm{~m}$ in the Raggatt Basin, and pelagic sedimentation was nearly continuous during the rest of the Paleogene $(18 \mathrm{~m} / \mathrm{m} . \mathrm{y}$.$) .$

\subsubsection{Lithology and Palaeoenvironment}

Site 748B lithology is mainly pelagic in origin. There are 22 samples from this core ranging from 76.83-200.47 mbsf, with sample spacing varying between 4-9 m. Nannofossil ooze is dominant through all sediments in this site with four samples between 120.6-106.6 mbsf containing foraminiferal nannofossil ooze and siliceous foraminiferal nannofossil ooze (Appendix 2.3c). Ice rafted debris is present at intervals $115.45-115.77$ mbsf in the early Oligocene. The mineral assemblage in the IRD did not come from a volcanic source on the Kerguelen Plateau. Coeval glacial activity along the Antarctic margin (CIROS-1; ODP leg 113 and 119) supports the presence of ice bergs large enough to travel to the Kerguelen Plateau (Breza and Wise Jr., 1992).

\subsubsection{Site 277}

Site 277 was part of a series of 10 sites drilled during leg 29 from the western part of the south Tasman Rise through to the eastern part of the Campbell Plateau. Site 277 is located on the Southern Campbell Plateau at $52^{\circ} \mathrm{S}, 166^{\circ} \mathrm{E}$ and is situated in the Cathedral Depression, between Auckland and Campbell Islands (Figure 1.8). Drilling took place from site 277 at a water depth of $1214 \mathrm{~m}$ in 1973 with a total of

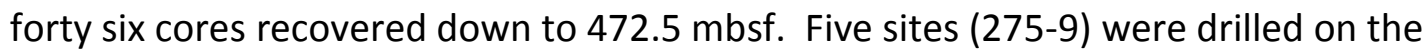
Campbell Plateau area, four sites (280-3) on the South Tasman Rise area and one site (284) on Lord Howe Rise. Drilling at site 277 was for the purpose of establishing a biostratigraphic sequence for the subantarctic Southern Ocean. 


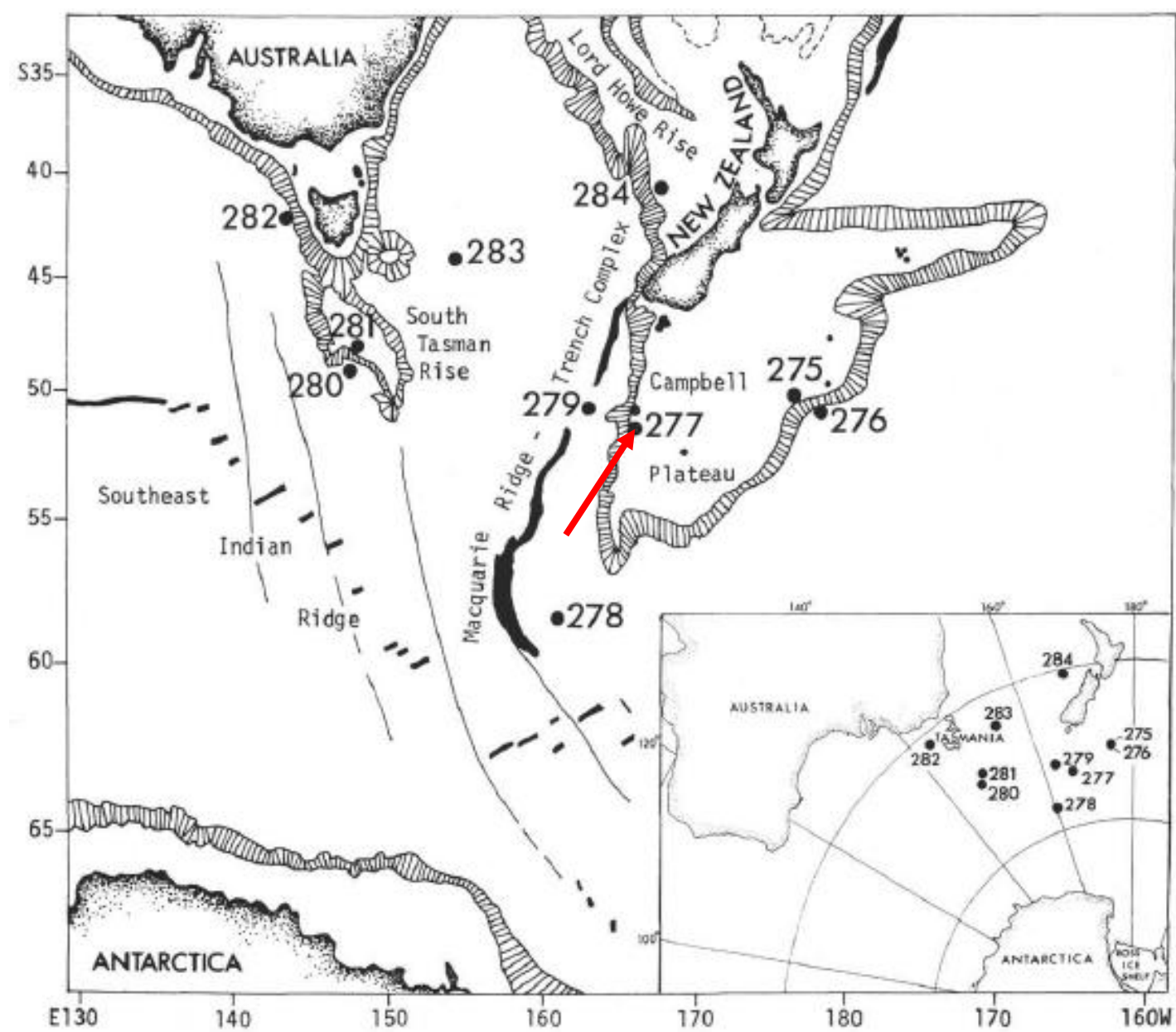

Figure 1.8: Red arrow depicts the position of site 277 on the Campbell Plateau. It is part of a series of 10 sites from DSDP Leg 29, five on the Campbell Plateau (275-9), four sites (280-3) on the South Tasman Rise area and on site (284) on Lord Howe Rise. Inset shows the proximity of site 277 to Antarctica today in the Southern Ocean. Map was obtained from the Initial results by the Shipboard Scientific Party, (1975).

\subsubsection{Lithology and Palaeoenvironment}

Site 277 contains 28 samples from 435-122.1 mbsf with sample spacing varying between 4-25 $\mathrm{m}$. Nannofossil ooze is present in all samples. The dominant lithology is nanno chalk for the lower seven samples (435.01 - $265.3 \mathrm{mbsf})$. Nannofossil ooze is the dominant lithology for the upper 21 samples (240.8-122.17 mbsf) which also contain foraminifera, diatoms, radiolarian, micarb and spicules (Appendix 2.3d). Within the Paleogene the sedimentation rates were typical for nannofossil oozes, with little influence from terrigenous sources and sediments were deposited under uniform, fully oceanic conditions over a period of $35 \mathrm{Ma}$. Depths of sediment deposition were much the same throughout and well above the lysocline. Palaeotemperature proxies indicate three major stages of cooling from 
the Late Eocene to earliest Oligocene. These indicators were positive shifts of $\delta^{18} 0$, an observed increase in abundance and diversity for radiolarians, a decline in the warm water Discoaster species abundance and an increase in the cold water Chiasmolithus species abundance (Hollis et al., 1997).

Of the five sites from 275-279 within the Campbell Plateau area, site 277 was the only site that produced a complete $462 \mathrm{~m}$ Paleogene sequence from the middle Paleocene to the late Oligocene (10-472.5 mbsf). The Paleogene sequence recovered at site 277 is thought to have extended over most of the Campbell Plateau; however, during the Neogene it was eroded off southern and eastern parts of the Plateau by strong bottom water currents (Andrews et al., 1975). The lack of active bottom currents affecting site 277 during the Paleogene can be seen by continued deposition of calcareous biogenic ooze which underlies a major hiatus that spans from late Oligocene to the Pleistocene. It is concluded that large areas of Paleogene sediment, as seen in seismic profile, are layered parallel to the sea floor exhibiting no obvious erosion (Kennett et al., 1975).

\subsection{Palaeopalynology}

\subsubsection{Why use Dinoflagellate Cysts?}

The term palynomorph refers to acid-resistant, organic-walled microfossils and includes spores, pollen, dinoflagellates, green algae and acritarchs (Batten, 1996). Dinoflagellates are a diverse group of unicellular algae that are included alongside diatoms as being the most prominent primary producers in the oceans today and are an important part of the global carbon cycle. Originally classified as protozoans by Zoologists and protophyta by Botanists they are now commonly referred to as protists (Pross et al., 2005; Sluijs et al., 2005; Williams et al., 2009). Today there are estimated to be $\sim 1,772$ marine and 230 freshwater species of living dinoflagellates, many of which have yet to be adequately described. 


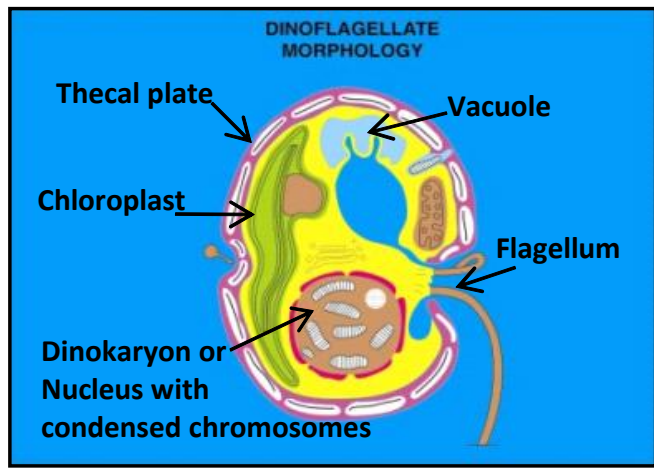

Figure 1.9a: Generalised section through a typical thecate motile dinoflagellate

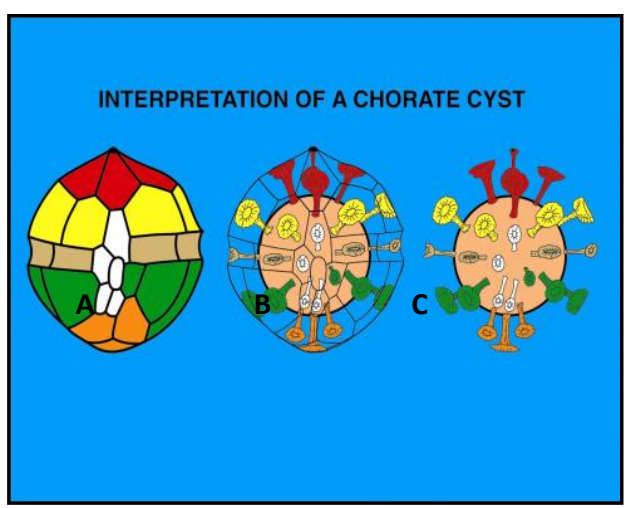

Figure 1.9c: An illustration depicting differences between $(A)$ thecate cell, (B) intermediate, and (C) chorate cyst.

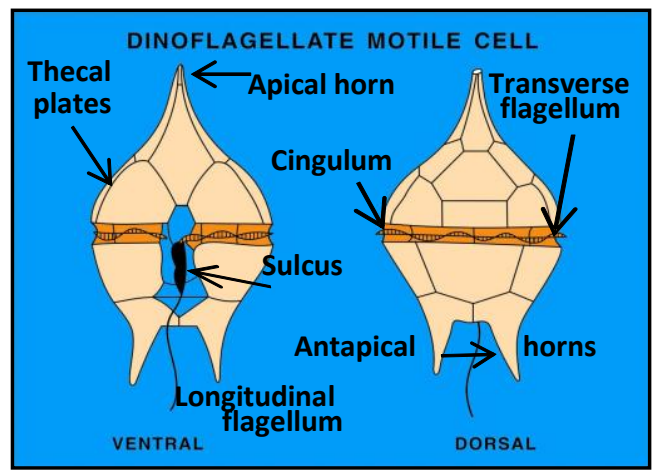

Figure 1.9b: General morphology of a thecate motile cell

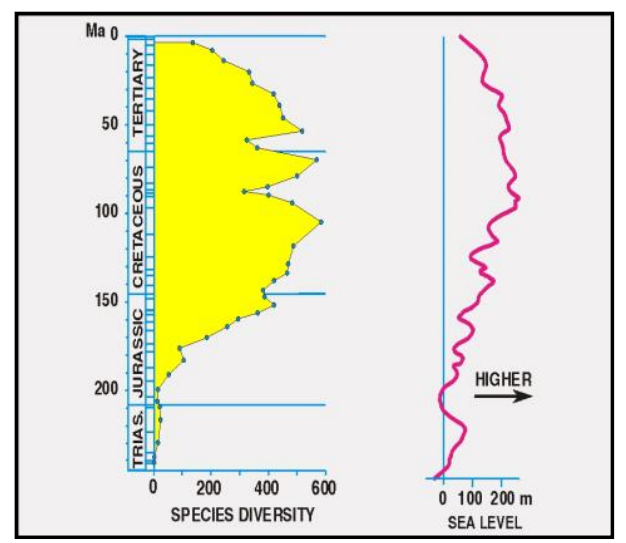

Figure 1.9d: A positive correlation between sea level and species diversity in shelfal environments. Dinocyst studies are a useful tool in sequence stratigraphv.

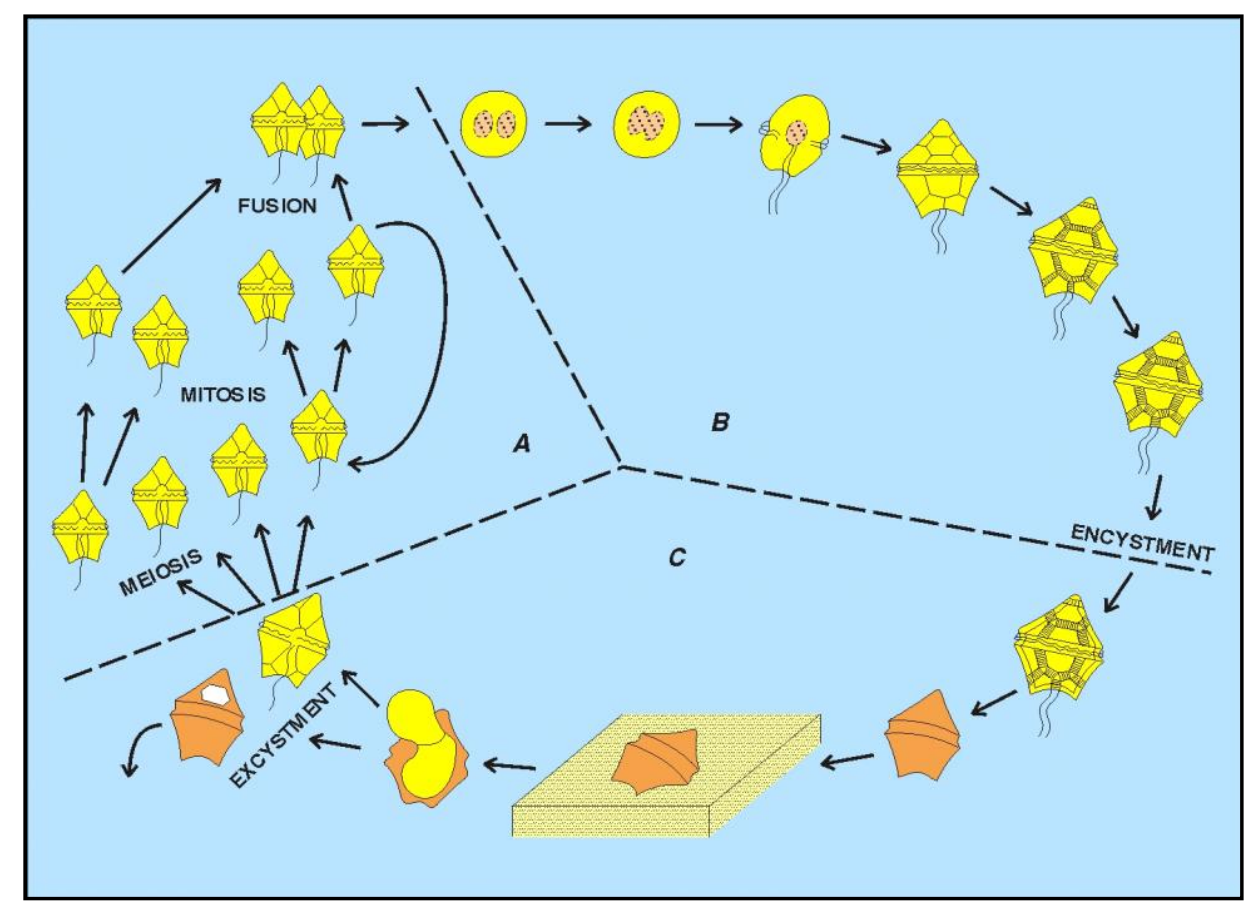

Figure 1.9e: Generalised life-cycle involving general reproduction and cyst formation. (A) Depicts motile and haploid cells. (B) Depicts motile and diploid cells. (C) Depicts non motile and diploid except for excysted cells on the left (Fensome et al., 1996; Urbino dinoflagellate cyst course, 2009) 
Dinoflagellates thrive in a variety of settings from relatively shallow marine environments along continental shelves, including fresh and brackish water, to continental rise settings from tropical to Polar Regions and some even inhabit ice, snow and the interstices of wet sand (Dale, 1996; Pross and Brinkhuis, 2005; Stover et al., 1996). Approximately 50\% of living dinoflagellates are autotrophic and utilise light and dissolved nutrients. The remaining dinoflagellates are either heterotrophic, capturing their prey (often diatoms), or mixotrophic, capable of using both living strategies (Dale, 1996). Some dinoflagellate species are photosynthetic endosymbionts of coral reefs or other protists, and play a major role in the marine ecosystem (Dale, 1996; Stover et al., 1996). Motile forms are sensitive to very slight changes in surface water masses and have an extreme sensitivity to changes in temperature and nutrient availability (Reichart et al., 2004; Sluijs et al., 2005). The distribution of living dinoflagellate motile cells can be used as a proxy for paleoenvironmental reconstructions with regard to sea-surface productivity, upwellings, temperature, salinity, and transport. There is a positive correlation between sea level rise and fall and the degree of ecological variance of dinocysts in shelfal environments (Figure 1.9d) and has led to dinocyst studies being a useful tool in sequence stratigraphy (Sluijs, et al., 2005; Williams et al., 2009).

\subsubsection{General Morphology}

Dinoflagellates are eukaryotic and most species include asexual and sexual reproduction as part of their life cycle (Evitt, 1985; Dale, 1996). At some stage of their life cycle (Figure 1.9e) all dinoflagellates have a motile cell with two flagella used to propel them through the water in a rotating or corkscrew fashion (Williams et al., 2009). One encircles the cell in a transverse furrow called the cingulum, and is ribbon like, and one trails posteriorly in a longitudinal furrow (the sulcus) (Figure 1.9b). They all possess dinokaryon (Figure 1.9a) which is an unusual type of cell nucleus lacking histones and containing chromosomes that remain condensed during cellular interphase (Fensome et al., 1996; Williams et al., 2009). Most motile dinoflagellates have a cellulistic test called a theca or an ephemeral membrane, neither of which are preservable as fossils. The complex outer membrane of the 
living cell (amphiesma) may include cellulosic thecal plates; others have no plates and are referred to as athecate (Fensome et al., 1996).

Some dinoflagellates produce a resting cyst (dinocyst), as part of their life cycle, i.e. a non motile cell possessing a cell wall and an opening (the archeopyle) for excystment (Dale, 1996; Fensome et al., 1996; Head, 1996; Wrenn et al., 1998). Cysts are formed inside the motile dinoflagellate theca and may mimic the motile cell, they have walls made of dinosporin, a complex organic compound that is very resistant to dissolution (Dale, 1996; Stover et al., 1996). Cysts may form processes that rise from ridges at plate edges or rise from central parts of the plate, which can vary in length as a percentage of the central body (Figure 1.9c) either: proximate <10\%; proximochorate 10-30\%; chorate >30\% (Evitt, 1985; Fensome et al., 1996). Cysts are often preservable and can be abundant in the fossil record. Ease of preservation ensures a more continuous fossil record and for this reason they have fewer restrictions than other micropaleontological groups as they are not as prone to dissolution (Stover et al., 1996).

\subsection{Method and Results}

\subsubsection{Palynological Processing}

A total of 155 sediment samples were requested from the ODP East Coast Repository at Lamont-Doherty Earth Observatory, Palisades, NY. On receipt of the sediments, tables were made up showing the core, section, top and bottom $(\mathrm{cm})$, depth (mbsf) and content of the sediment along with the approximate age as per shipboard scientific party (Appendix 2.3a-d).

Samples were placed in beakers and put in an oven overnight to dry. The dry weight was recorded (Appendix 2.4) and approximately half (usually up to 10 grams per sample if enough sediment was provided) was used in the palynological processing. To safely process the sediment, 2 beaker holders, each containing 8 
beakers were processed at one time. Sixteen samples representing differing depths and taken from different sites were chosen to process within each set of 16 beakers. Processing procedures followed standard palynological techniques with hydrochloric acid $(\mathrm{HCl})$ added to each beaker to dissolve carbonates and gas evolution was monitored. The process was repeated until all reaction had ceased. In samples consisting of nannofossil ooze this process took at least 5-7 days for complete dissolution. The slurry was diluted with filtered water, stirred thoroughly and left for an hour to settle, then decanted.

In order to dissolve silicates, hydrofluoric acid (HF) was added into each beaker. The samples were then stirred intermittently. A reaction time of $\sim 36$ hours proved insufficient to remove all the silicates and in most cases it took up to seven days.

Each sample was then diluted with filtered water, left to settle and then slowly decanted into a solution of sodium bicarbonate to neutralize the HF. Each beaker was filled with filtered water, stirred, and left to settle for about an hour then decanted again. Some of the samples contained very fine sediment that required as much as 24 hours to settle. The process was repeated until all reaction in the neutralising tank had ceased, in most cases this meant about 3 to 4 washes.

The samples were then transferred into test tubes, agitated and topped up with filtered water, then centrifuged at 2,600 rpm for 5 minutes. This process was repeated, and then a small amount of $\mathrm{HCl}$ was added to the samples to help with disaggregation and remove soluble fluorides. The samples were finally washed with filtered water a further 3 times.

\subsubsection{Fungal Contamination}

From analysis of preliminary slides, it became evident that in most samples fungal hyphae forming mycelia were present. The fungi are believed to have grown at the storage facilities but were not visible until after most of the processing was completed and preliminary slides made. The mycelia were present in all sites except 696B, and within each site the amount varied at different depths, with some 


\section{Introduction}
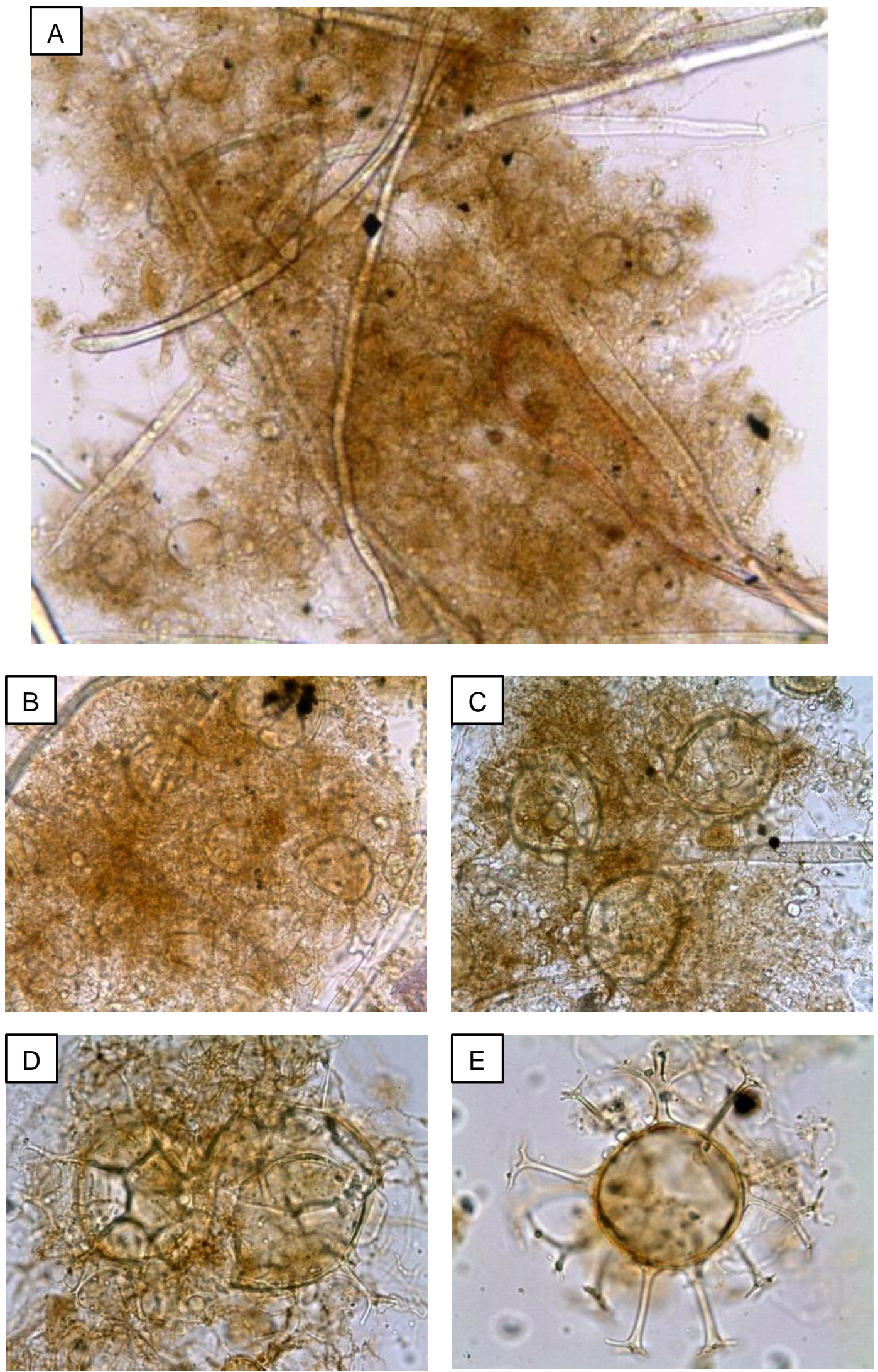

Figure 1.10: A-B an example of the fungal hyphae clumping and entangling the process of the dinocysts. C-D an example of a lesser contamination with dinocysts more easily seen and $E$ is an example of a dinocyst virtually free from fungal contamination. 

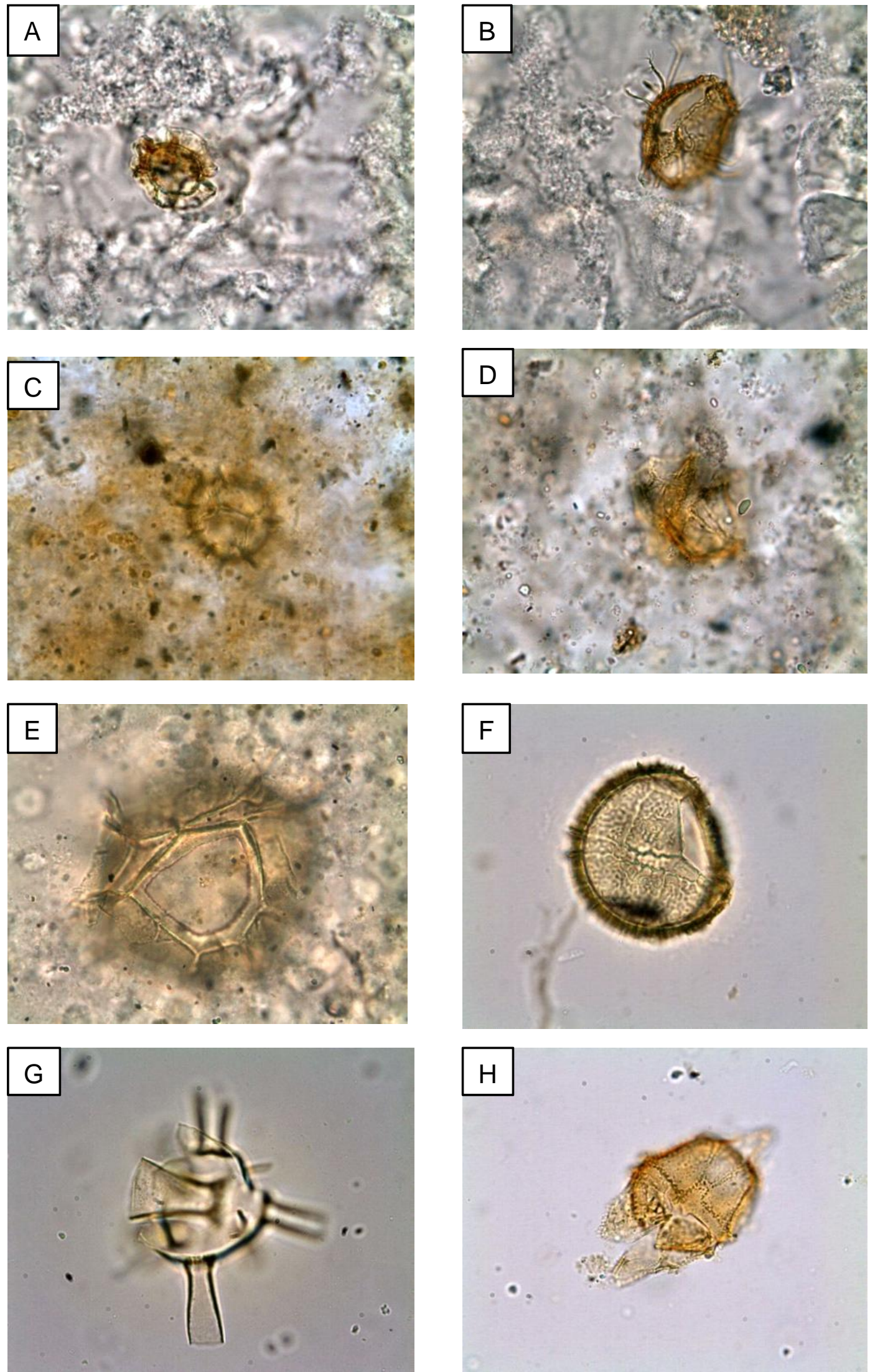

Figure 1.11: $A$ and $B$ are an example of background that required up to seven days of HF to remove $C-D$ are an example of the very fine background that required sieving with a 5 micron sieve unit to remove it. $F$. $\mathrm{H}$ are an example of the clarity of the slides after all the processing was completed. 
samples being either quite contaminated by it, only mildly affected or completely free of mycelium (Figure 1.10). Efforts were made to try and destroy the mycelium while still retaining the palynomorphs by slow centrifuging, swirling, oxidation and ultrasonic cleaning. The only process that was able to successfully remove the mycelia was chlorine which had the unwanted side effect of destroying most of the palynomorphs.

The processes on many of the chordate dinocysts became entangled in the thicker clumps of mycelium that occurred in some samples, creating difficulties with counting and identification. The normal procedure of floating with sodium polytungstate at specific gravity 2.0 used to separate any palynomorphs present from heavy material, was not viable as the mycelium prevented many of the palynomorphs from floating. As a result of the contamination the processing of all of site 277 samples, 8 from site 699A and 2 from site 748B had to be repeated, although the mycelium could not be eliminated.

Site $696 \mathrm{~B}$ was found to be free from mycelium and therefore could be floated in sodium polytungstate then sieved to remove finer background material (Figure 1.11). The samples were then centrifuged at $1,800 \mathrm{rpm}$ for 15 minutes, and left to settle for a few hours. A pipette was used to extract the floating residue (float $A$ ) which was put into a test tube with a little $\mathrm{HCl}$ to stop the organic matter from clumping. The sample was then diluted, agitated, and centrifuged at 3,000 rpm for 3 minutes. This washing process was repeated 6 times.

Preparation of slides involved preheating and adding a small drop of glycerine jelly, followed by a small drop of residue mixed in from each sample. A cover slip was placed on top of the slide, before being left overnight to dry. A second set of slides were made by reagitation and centrifuging the sodium polytungstate to produce a second float. 


\subsubsection{Microscope and Camera Technique}

Image acquisition was achieved using a light microscope Leica DML, mounted with a Leica DFC camera with still frames taken at several different focus levels for each palynomorph recorded. Slides were analysed at x20, x40, x63 and/or x100 magnification. Images were captured and slide references recorded with the name of the palynomorphs if possible and their size. The images were viewed in an image viewing programme (Picasa) where the use of the auto contrast and auto colour was used only to enhance each photo for clearer palynomorph detail. Picasa was also used to make up albums grouping the same species that were present in different sites within this study and for grouping of those species that could not immediately be identified. Over the course of this study $\sim 17,500$ photos were taken creating a comprehensive record of species encountered in all sites.

\subsubsection{Counting Method}

All slides were scanned for content before counting, although due to time constraints only one slide from each sample had a quantitative record of species made. All slides were scanned from left to right and any extra palynomorphs not noted in the initial slide were recorded and the image added to that sample. Individual palynomorphs were only counted if more than half of the cyst was present or it was positively recognisable even though not complete.

All data were entered on a separate excel worksheet for each sample with a record of the sample leg, site, core, section, sampling interval $(\mathrm{cm})$ top and bottom, depth (mbsf), lithology, era if known, dry weight processed and number of slides made up. Initially all dinocysts were recorded followed by separate totals each for acritarchs, prasinophytes, tasmanites, foraminiferal linings, insect casings and terrestrial material. Data from excel worksheets was transferred on to the master spreadsheet (Appendix 2.5) for each sample.

Charts have been compiled from the raw data to display the grains per gram $(\mathrm{g} / \mathrm{g})$ total abundance and charts to display the percentages total abundance for each 
site. The results of these charts will be discussed in detail in later chapters in this thesis.

\subsection{General Results}

The general results show that counts for dinocysts were higher than for other marine palynomorphs. The counts are taken from one slide in each site. In three sites in Table 1.4 (site 699A, 748B and 277) marine palynomorphs outnumbered terrestrial palynomorphs. Only site 696B contained more terrestrial than marine palynomorphs. Graphs of the percentages for marine palynomorphs are displayed in Figure 1.12.

\begin{tabular}{|lr|lr|lr|lr|}
\hline \multicolumn{2}{|c|}{ Site 696B } & \multicolumn{2}{c|}{ Site 699A } & \multicolumn{2}{c|}{ Site 748B } & \multicolumn{2}{c|}{ Site 277 } \\
\hline Dinocysts & 10733 & Dinocysts & 452 & Dinocysts & 1373 & Dinocysts & 3430 \\
Acritarchs & 145 & Acritarchs & 7 & Acritarchs & 554 & Acritarchs & 301 \\
Cymatiosphaera & 111 & Cymatiosphaera & 74 & Cymatiosphaera & 560 & Cymatiosphaera & 290 \\
Leiosphaerida & 1 & Leiosphaerida & 19 & Leiosphaerida & 3573 & Leiosphaerida & 192 \\
Tasmanites & 3 & Tasmanites & 0 & Tasmanites & 514 & Tasmanites & 142 \\
Foraminiferal & & Foraminiferal & & Foraminiferal & & Foraminiferal & \\
linings & 302 & linings & 0 & linings & 17 & linings & 101 \\
Insect parts & 82 & Insect parts & 70 & Insect parts & 5 & Insect parts & 11 \\
Terrestrial & 25106 & Terrestrial & 64 & Terrestrial & 61 & Terrestrial & 277 \\
\hline
\end{tabular}

Table 1.4: A total count from one slide on each site for dinocysts, acritarchs, prasinophytes, tasmanites, foraminiferal linings, insect parts and terrestrial palynomorphs. 


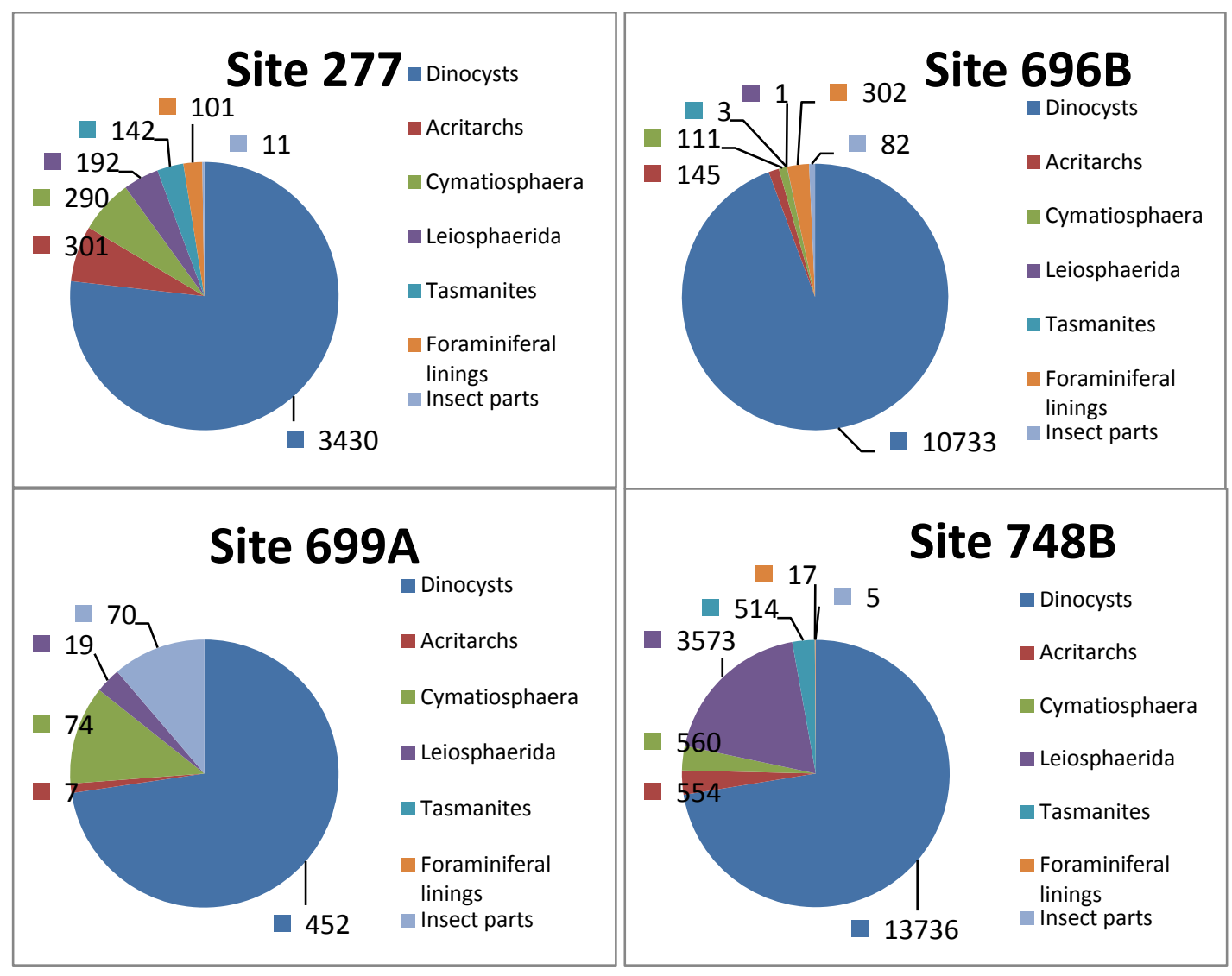

Fig 1.12: Percentage of all marine palynomorphs counted in each site. Terrestrial percentages were not included due to the dominance shown in site 696B which significantly distorted the marine percentages. Colours display the percentage total for each palynomorph.

Table 1.5 has been organised to show alphabetically a total of 54 genera that occurred in each site. This result varied considerably:

12 Genera were found in all 4 sites

10 Genera were found in 3 out of 4 sites

12 Genera were found in 2 out of 4 sites

20 Genera were found in 1 out of 4 sites

Photos showing most genera discussed in this thesis along with their nomenclature are placed in Appendix 1.0 


\section{Introduction}

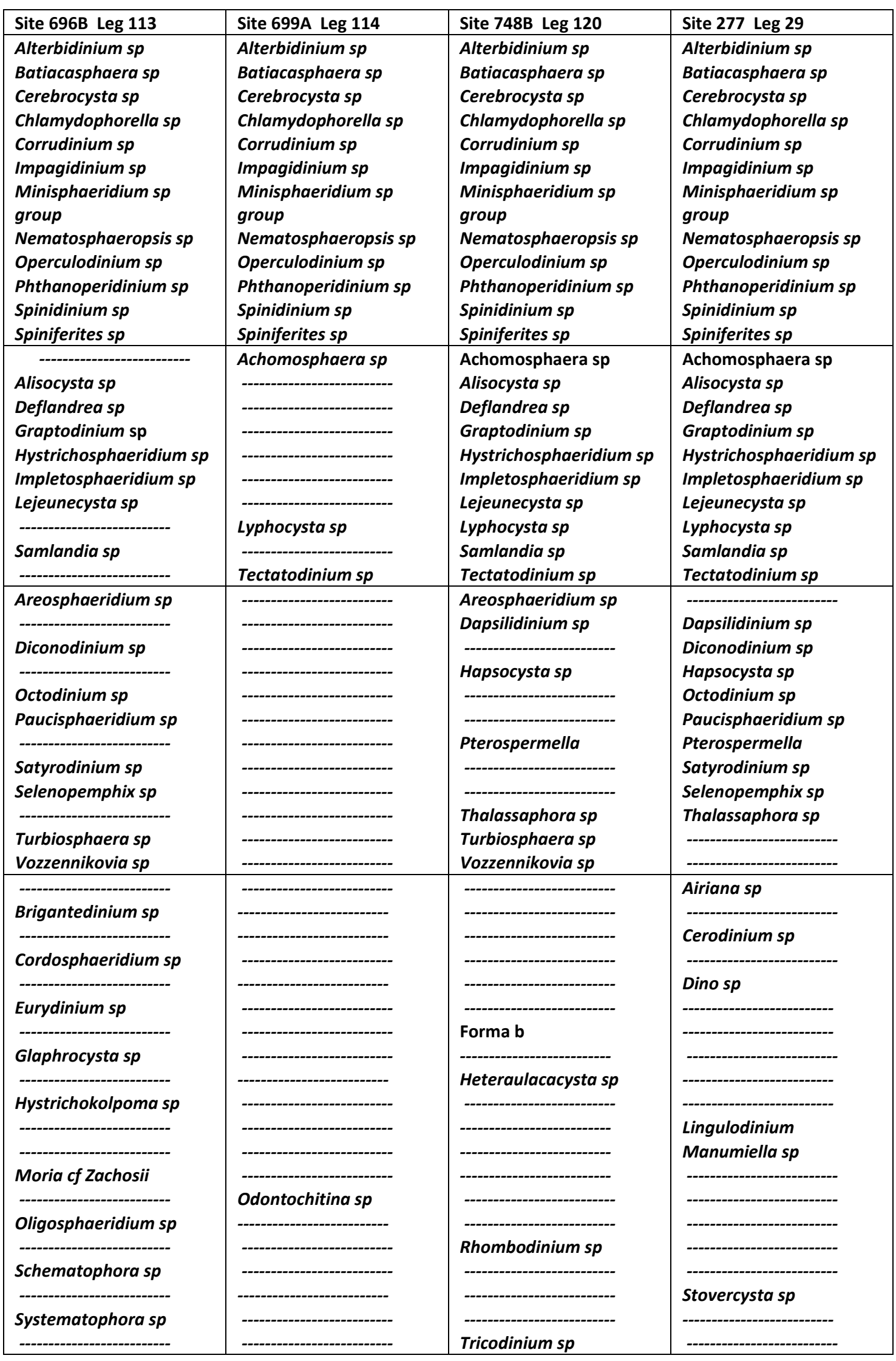

Table 1.5: 54 dinocyst genera occur within all 4 sites. 12 genera were found in all 4 sites 10 genera in 3 out of 4 sites 12 genera in 2 out of 4 sites and 20 were found in 1 out of 4 sites. 


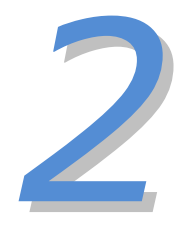

\section{Nannofossil Biostratigraphic Revision}




\section{CHAPTER TWO}

\subsection{Nannofossil Biostratigraphic Revision}

\subsection{Introduction}

The sites in this study were drilled over an extended period of time and have had various biostratigraphic schemes applied (Aubrey, 1992; Edwards and PerchNielsen, 1975; Hollis, 1997; Nocchi et al., 1991; Roberts et al., 2003; Strong, 1996; Villa et al., 2008; Waghorn, 1997; Wei and Wise, 1990, Wei et al., 1992). In order to provide a consistent biostratigraphy for this study a reassessment of the original nannofossil data from the holes has been undertaken. The zonations used are those of Okado and Bukry (1980) and Martini (1971), calibrated using Berggren et al. (1995). A new nannofossil biostratigraphic zonation for the Middle Eocene to Early Oligocene resulted and allows a detailed correlation between each site studied. This re-evaluation utilised nannofossil data taken from original studies carried out in each of the four sites.

\subsection{Nannofossil Biostratigraphic Zonation}

Figure 2.1 shows the nannofossil zonations of Okado and Bukry (1980) (CP denotes Palaeogene coccolith zone) and Martini (1971) (NP denotes Palaeogene nannoplankton zone) being the two most common nannofossil zonations used in Cenozoic sequences. Both zones are very similar apart from a slight shift at some zonal boundaries. Time (27-46 Ma), age, CP/NP numbers and first and last occurrences for nannofossils are shown. Boundaries in the age and nannofossil zones occurring from the Middle Eocene to Oligocene are marked by first and last occurrences and with other biostratigraphically useful nannofossils are as follows.

The last occurrence of Chiasmolithus gigas $\sim 44.5 \mathrm{Ma}$ is below the CP13c/NP15c boundary in the Middle Eocene. Above is the first occurrence of Reticulofenestra umbilicus at $\sim 43.7 \mathrm{Ma}$ towards the top of the CP13c/NP15c boundary. The first occurrence of Reticulofenestra reticulata at $\sim 42 \mathrm{Ma}$, is in CP14a/NP16. The boundary between CP14a/NP16 and CP14b/NP17 is placed at the last occurrence of Chiasmolithus solitus $\sim 40.4$ Ma. Berggren et al. (1995) established the last occurrence of Ericsonia formosa, at $39.7 \mathrm{Ma}, \mathrm{CP} 14 \mathrm{~b} / \mathrm{NP} 17$, in the High Southern 


\section{NANNOFOSSIL BIOSTRATIGRAPHIC ZONATION}

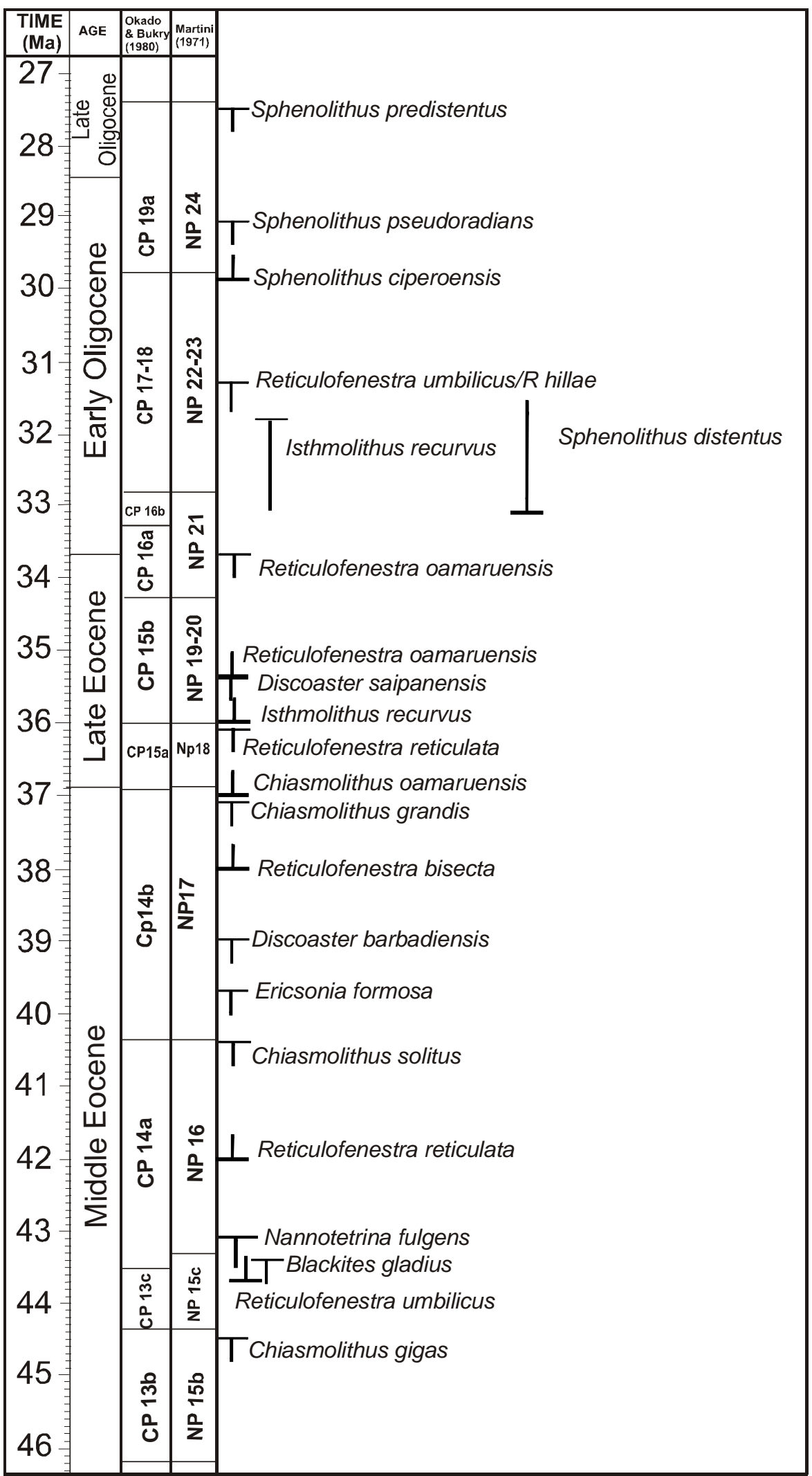

Figure 2.1: The nannofossil timescale adapted from the zonations of Okado and Bukry (1980) and Martini (1971) has been correlated into the revised magnetobiochronologic Cenozoic timescale of Berggren et al. (1995). The time scale 27 - $46 \mathrm{Ma}$ and age from Middle Eocene to Early Oligocene is from Berggren et al. (1995). 
latitudes and noted it is $\sim 7 \mathrm{Ma}$ earlier than recorded at low latitudes. Above is the first occurrence of Reticulofenestra bisecta at $38 \mathrm{Ma}, \mathrm{CP} 14 \mathrm{~b} / \mathrm{NP} 17$. The last occurrence of Chiasmolithus grandis at 37.1 Ma occurs close to the first occurrence of Chiasmolithus oamaruensis at $37 \mathrm{Ma}$, the latter marks the boundary at the top of CP14b/NP17 and the Middle/Late Eocene boundary.

The boundary at CP15a/NP18 and CP15b/NP19-20 is placed between the last occurrence of Reticulofenestra reticulata at 36.1 Ma and the first occurrence of Isthmolithus recurvus at $36 \mathrm{Ma}$. Close above is the first occurrence of Reticulofenestra oamaruensis, at $35.4 \mathrm{Ma}, \mathrm{CP} 15 \mathrm{~b} / \mathrm{NP} 19-20$ which Berggren et al. (1995) noted as restricted to the Southern High Latitudes. The last occurrence of Reticulofenestra oamaruensis at 33.7 Ma, is the only species in CP16a/NP21, and marks the Eocene/Oligocene boundary occurring approximately in the middle of that zone. The nearest species above the Eocene/Oligocene boundary are the first occurrence of Sphenolithus distentus and a last occurrence of Isthmolithus recurvus which are also very close to the E/O boundary. However, Berggren et al. (1995) allowed for some temporal uncertainty due to inconsistencies associated for both species which could be included in either CP15b/NP21 or CP17-18/NP22-23. The last occurrence of Reticulofenestra umbilicus CP17-18/NP22-23 is placed by Berggren et al. (1995) at $31.3 \mathrm{Ma}$ in the Southern High Latitudes which is younger than the low-mid latitude. The first occurrence of Sphenolithus ciperoensis at 29.9 Ma occurs at the top of CP17-18/NP22-23 in the Early Oligocene. The last occurrence of Sphenolithus predistentus at 27.5 Ma marks the top of the CP19a/NP24 zone which occurs in the Late Eocene (Berggren et al., 1995).

\subsubsection{Site 696B, South Orkney microcontinent, Weddell Sea}

The original nannofossil data from site 696B was from Wei and Wise (1990). Data was very poor and there are key nannofossil species missing. Last occurrences for some species are older than expected and many species are grouped the same depths with no nannofossils recorded between. Figure 2.2 is the completed reassessment and the nannofossil zones show one boundary between 


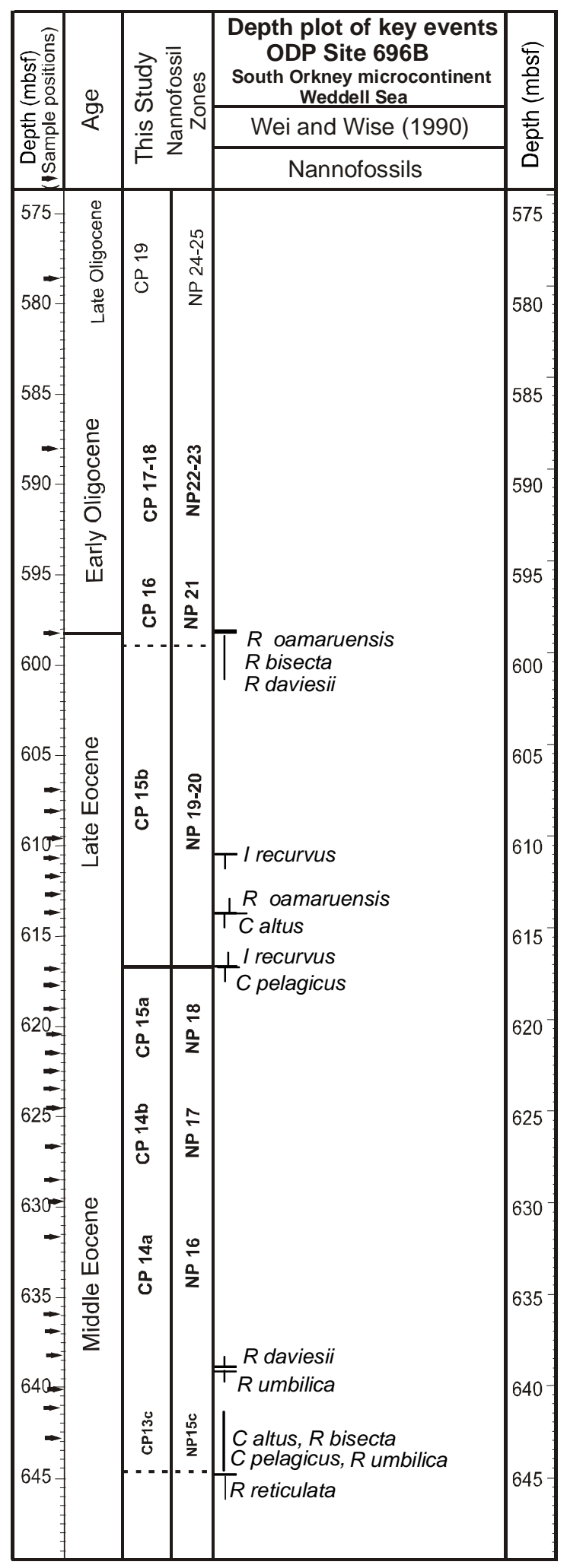

Figure 2.2: Depth plot of key events for nannofossils in site 696B, South Orkney microcontinent, Weddell Sea. Shown are the depth (mbsf), age, and nannofossil zones of Okado \& Bukry (1980) and Martini (1971). The nannofossil zones are taken from the data of Wei and Wise (1990).

Dashed lines indicate uncertain boundary positions. T Indicates a first appearance datum.

$\perp$ indicates a last appearance datum. 
CP15a/NP18 and CP15b/NP21 with all other possible boundaries not defined. The age boundary for the Eocene/Oligocene is defined.

Site 696B has some defining species in similar positions as the nannofossil biostratigraphic zonation (Figure 2.2) including the first occurrence of Reticulofenestra umbilica at 645 mbsf. The last occurrence of Reticulofenestra reticulata, $645 \mathrm{mbsf}$, the first occurrence of Reticulofenestra bisecta $\sim 645 \mathrm{mbsf}$ and the last occurrence of Reticulofenestra umbilica $\sim 637.7 \mathrm{mbsf}$, are earlier than expected from the standard nannofossil scheme. The boundary between CP15a/NP18 and CP15b/NP19-20 is placed at the first occurrence of Isthmolithus recurvus at $\sim 616$ mbsf. Above, the first occurrence of Reticulofenestra oamaruensis at 614 mbsf, CP15b/NP19-20 and the last occurrence of Isthmolithus recurvus at 612 mbsf, CP15b/NP19-20 are recorded younger in the nannofossil scheme (Figure

2.1). The last occurrence of Reticulofenestra oamaruensis $\sim 598 \mathrm{mbsf}$, marks the Eocene/Oligocene boundary. There are no nannofossils recorded in the Early Oligocene above $598.4 \mathrm{mbsf}$ and there are no foraminiferan or radiolarian results for this site.

\subsubsection{Site 699A, Northeast Georgia Rise}

The initial studies in site 699A of Ciesielski et al. (1988), Crux (1991) and Madile and Monechi, (1991) were followed by Wei, (1991) who utilized the first three results and obtained a better consistency for first and last occurrences (Figure 2.3). The foraminifera first and last occurrences are also calibrated to Berggren et al. (1995) in this site, though the radiolarian first and last occurrences of Takemura and Ling (1997) are not calibrated. The age boundaries are the Middle/Late Eocene and the Late Eocene/Early Oligocene and there are three nannofossil boundaries.

Biostratigraphically useful nannofossils, radiolarians and foraminiferan are as follows.

The first occurrence of the foraminiferan Morozovella crater at $\sim 460 \mathrm{mbsf}$ and the last occurrence of Morozovella crater $\sim 440$ mbsf (below P10) are towards the base 


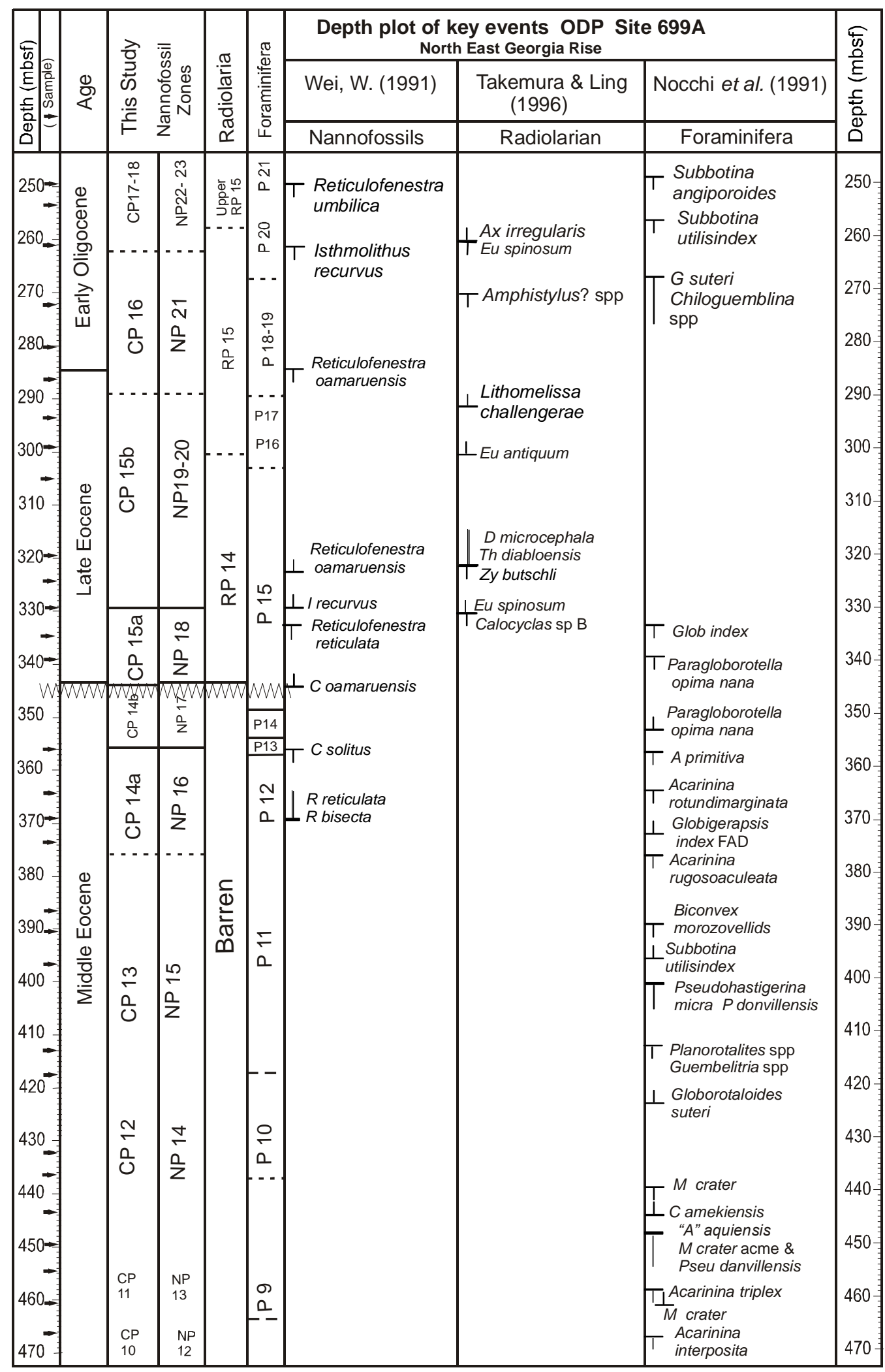

Figure 2.3: Depth plot of key events for nannofossils, radiolarian and foraminiferal linings, in site 699A, North East Georgia Rise. Shown are the depth (mbsf), age, and the nannofossil zones of Okado and Bukry (1980) and Martini (1971). The nannofossil zones are from Wei (1991), the radiolarian zones are from Takamura and Ling (1996) and the foraminifera zones are from Nocchi et al., (1991). Dashed lines indicate uncertain boundary positions. $\perp$ indicates a first appearance datum $T$ indicates a last appearance datum. The hiatus is indicated by 
of Figure 2.3 in the Middle Eocene, and also occur in site 277 near the base of Figure 2.5. Above is the first occurrence of the foraminifera Globigerapsis index 373 mbsf near P12 and CP14a/NP16. Occurring together are the first occurrences of the nannofossils Reticulofenestra bisecta and Reticulofenestra reticulata at 370.3 mbsf, CP14a/NP16 and no nannofossils were recovered below this depth. The boundary between CP14a/NP16 and CP14b/NP17 is placed at the last occurrence of the nannofossil Chiasmolithus solitus $\sim 356.30$ mbsf. Very close is the last occurrence of the foraminifera Acarinina primitiva 358 mbsf, P15, CP14a/NP16, though is placed slightly older in Berggren et al., (1995) at CP14b/NP17 (39.0 Ma, P14). The Middle/Late Eocene boundary and the boundary between CP14b/NP17 and CP15a/NP18 is marked by the first occurrence of the nannofossil Chiasmolithus oamaruensis at $~ 342$ mbsf.

The last occurrence of the nannofossils Reticulofenestra reticulata at $\sim 332.23 \mathrm{mbsf}$ CP15a/NP18 and the first occurrence of Isthmolithus recurvus $\sim 329$ mbsf CP15b/NP19-20 mark the boundary between them. The last occurrence of the foraminifera Globigerapsis index at $\sim 335$ mbsf, P15, CP15a/NP18 is also close to this boundary, though in Berggren et al., (1995) it is at the base of CP16a/NP21, 34.3 $\mathrm{Ma}, \mathrm{P} 16-17$. No foraminifera were recovered between depths of $335 \mathrm{mbsf}$ and $\sim 270$ mbsf. The last occurrence of the radiolarian Calocyclas spB and the first occurrence of Eucyrtidium spinosum occur together at 330.98 mbsf, RP14, CP15a/NP18 and no radiolarians were recovered below this depth.

The first occurrence of the nannofossil Reticulofenestra oamaruensis is at 322.84 mbsf, CP15b/NP19-20, where it is also placed in the nannofossil scheme (Figure 2.1). The last occurrence of the nannofossil Reticulofenestra oamaruensis 284.90 mbsf, CP16/NP21, marks the Eocene/Oligocene boundary. Nannofossils above the E/O boundary are the last occurrences of Isthmolithus recurvus $\sim 261.35 \mathrm{mbsf}$ and Reticulofenestra umbilica at 249.80 in the Early Oligocene where they also occur in the nannofossil biostratigraphic scheme. The radiolarians last occurrence of Axoprunum irregularis and the first occurrence of Eucyrtidium spinosum are both at $260.71 \mathrm{mbsf}$ and though their boundaries cannot be defined at this site they occur 
in the Early Oligocene. The last occurrence of the foraminifera Subbotina angiporoides $\sim 250 \mathrm{mbsf}$ is in the Early Oligocene in this site and placed there in Berggren et al., (1995) CP18/NP23 (30 Ma, P20).

\subsubsection{Site 748B, Raggatt Basin, South Kerguelen Plateau}

The original nannofossil data in site 748B were discussed by Aubrey (1992), Wei et al. (1992) and later Villa et al. (2008) revisited this site (Figure 2.4). There is one age boundary marked between the Eocene/Oligocene and two nannofossil boundaries. The foraminifera are calibrated to Berggren et al. (1995) first and last occurrences. The biostratigraphically useful nannofossils and foraminifera are as follows.

The first occurrence of the nannofossil Reticulofenestra reticulata, $171.8 \mathrm{mbsf}$ in the Middle Eocene cannot be defined in this site but is placed by Berggren et al., (1995) in CP14a/NP16. Below 171.8 mbsf there are no nannofossils recorded. The last occurrence of the nannofossil Ericsonia formosa $157.11 \mathrm{mbsf}, \mathrm{CP} 14 \mathrm{a} / \mathrm{NP} 16$ is placed younger at $\sim 39.7 \mathrm{Ma}, \mathrm{CP} 14 \mathrm{~b} / \mathrm{NP17}$ in the nannofossil scheme (Figure 2.1). The first occurrence of Chiasmolithus oamaruensis 155.01 mbsf is earlier than expected and below the last occurrence of Chiasmolithus solitus $150.2 \mathrm{mbsf}$ at the top of CP14a/NP16 which marks the nannofossil boundary (CP14b/NP17) above. The nannofossil biostratigraphic zonation (Figure 2.1) has the first occurrence of Chiasmolithus oamaruensis at $37 \mathrm{Ma}$, in CP14b/NP17 which marks the Middle/Late Eocene boundary and places it above Chiasmolithus solitus $40.4 \mathrm{Ma}, \mathrm{CP} 14 \mathrm{a} / \mathrm{NP} 16$. Subsequently the Middle/Late Eocene boundary and the boundary between these nannofossil zones cannot be defined in this site. The last occurrence of the foraminiferan Acarinina primitiva at $153.45 \mathrm{mbsf}$ (CP14a/NP16) in this site is placed earlier in CP14b/NP17 by Berggren et al., (1995) (39.0 Ma, P14). Below 153.45 mbsf no foraminifera are recorded.

The nannofossil first occurrence of Reticulofenestra bisecta, $143.90 \mathrm{mbsf}$ in CP14b/NP17 is also placed in that zone in the nannofossil scheme. The last occurrences of the foraminifera Subbotina linaperta $144.14 \mathrm{mbsf}, \mathrm{P} 15$, and 


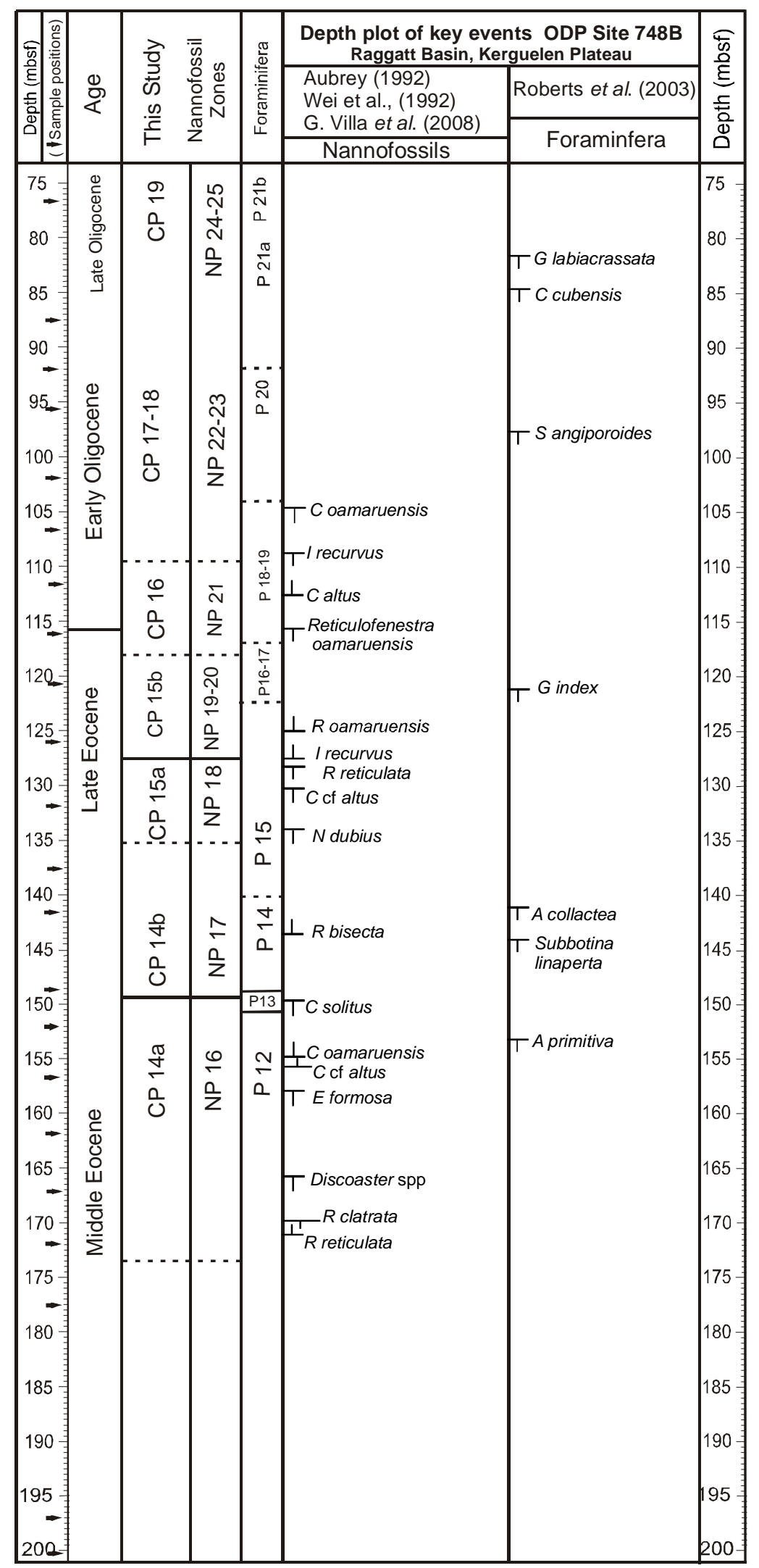

Figure 2.4: Depth plot of key events for nannofossils and foraminiferal linings, in site 748B, Raggatt Basin, Kerguelen Plateau. Shown are the depth (mbsf), age, and the nannofossil zones of Okado and Bukry (1980) and Martini (1971). The nannofossil zones are from Villa et al. (2008), and the foraminifera zones are from Roberts et al. (2003). Dashed lines indicate uncertain boundary positions. $T$ indicates a first appearance datum $\perp$ indicates a last appearance datum. 
Acarinina collactea $141.39 \mathrm{mbsf}, \mathrm{P} 15$, placed at different depths in this site, are both placed together by Berggren et al., (1995) at 37.7 Ma, P15, CP14b/NP17. The last occurrence of the nannofossils Reticulofenestra reticulata $128.35 \mathrm{mbsf}$, CP15a/NP18 and the first occurrence of Isthmolithus recurvus $127.48 \mathrm{mbsf}$ at the base of CP15b/NP19-20 mark the nannofossil boundary between them. However, in contrast to the findings of Aubrey (1992) and Wei et al., (1992) who placed the first occurrence of Isthmolithus recurvus at 127.48 mbsf where it is also placed in this study (Figure 2.4), Villa et al. (2008) placed this species at $148.25 \mathrm{mbsf}$ due to a rare occurrence at this depth.

The nannofossil above is the first occurrence of Reticulofenestra oamaruensis $125.20 \mathrm{mbsf}, \mathrm{CP} 15 \mathrm{~b} / \mathrm{NP} 19-20$ also recorded in the same nannofossil zone by Berggren et al., (1995). The last occurrence just above is the foraminiferan Globigerapsis index $121.45 \mathrm{mbsf}$, and although neither the nannofossil zone nor the foraminifera zone can be defined in this site, it does occur in Berggren et al., (1995) at 34.3 Ma, in CP16a/NP21. The last occurrence of the nannofossil Reticulofenestra oamaruensis 115.86 mbsf marks the Eocene/Oligocene boundary. Above that boundary the last occurrence of Isthmolithus recurvus 109.01 mbsf cannot be defined though is in the Early Oligocene. Above is the last occurrence of the nannofossil Chiasmolithus oamaruensis 104.84 mbsf and no nannofossils were recorded above this depth. The last occurrence of the foraminiferan Subbotina angiporoides $97.95 \mathrm{mbsf}$ is in the Early Oligocene and cannot be defined though Berggren et al., (1995) has placed it at 30Ma, in CP18/NP23.

\subsubsection{Site 277, Southern Campbell Plateau}

The original nannofossil data from site 277 (Edwards and Perch-Nielsen, 1975) was reassessed by Hollis et al. (1997). Age boundaries in this site occur at the Middle/Late Eocene and the Eocene/Oligocene (Figure 2.5) and there are two nannofossil boundaries defined, one radiolarian and one foraminiferal boundary. The biostratigraphically useful nannofossils and foraminifera are as follows. 


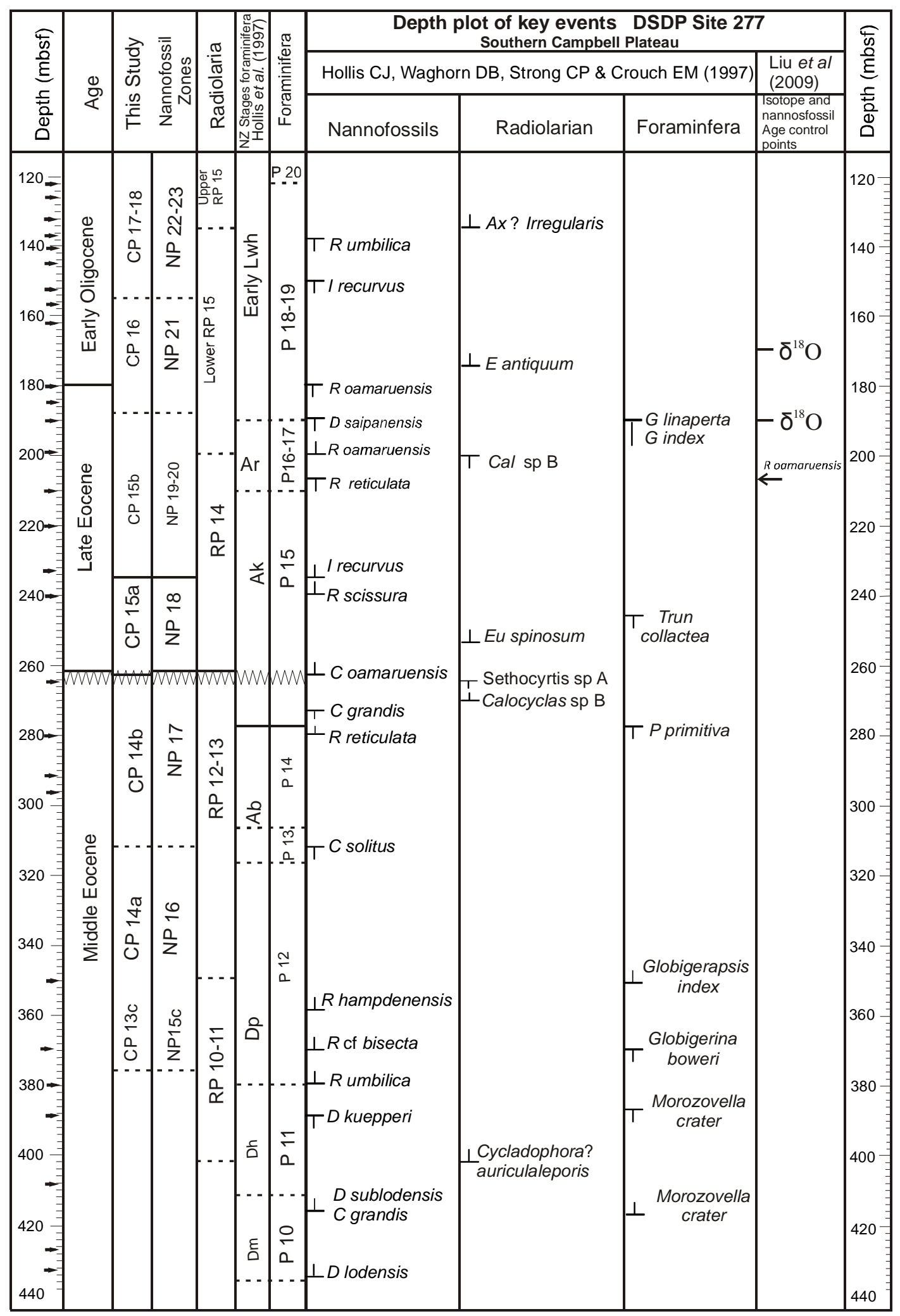

Figure 2.5: Depth plot of key events for nannofossils, radiolarian and foraminiferal linings, in site 277, Southern Campbell Plateau. Shown are the depth (mbsf), age, and the nannofossil zones of Okado and Bukry (1980) and Martini (1971). The nannofossil zones are from Waghorn, (1997), the radiolarian zones are from Hollis, (1997) and the foraminifera zones are from Strong, (1997). Dashed lines indicate uncertain boundary positions. The isotope and nannofossil age control points are adapted from Liu et al. (2009). $\perp$ indicates a first appearance datum $\top$ indicates a last appearance datum The hiatus is indicated by 
The first and last occurrence of the foraminifera Morozovella crater at $416 \mathrm{mbsf}$ and 386 mbsf is shown near the base of Figure 2.5, though the foraminiferal zone cannot be defined. The first and last occurrence for Morozovella crater also occurred near the base of Figure 2.3, site 699A. The first occurrence of the nannofossil Reticulofenestra umbilica at $\mathbf{3 8 0 . 2}$ mbsf cannot be defined in this site though it occurs at $43.7 \mathrm{Ma}, \mathrm{CP} 13 \mathrm{c} / \mathrm{NP} 15 \mathrm{c}$, in the nannofossil scheme. Above, is the last occurrence of Chiasmolithus solitus, $311 \mathrm{mbsf}$ however, a reassessment of this species was necessary (see below). The first occurrence of the nannofossil Reticulofenestra reticulata, 280 mbsf, CP14b/NP17, occurs younger in this site than the nannofossil scheme where it occurs in CP14a/NP16. The last occurrence of Chiasmolithus grandis, 273 mbsf occurs in CP14b/NP17 close to Chiasmolithus oamaruensis ( $260 \mathrm{mbsf}$ ) above. The boundary between CP14b/NP17 and CP15a/NP18 is placed by the first occurrence of Chiasmolithus oamaruensis, 260 mbsf and also marks the boundary between the Middle/Late Eocene. In the nannofossil scheme both Chiasmolithus grandis and Chiasmolithus oamaruensis also occur very close together towards the top of CP14b/NP17.

The first occurrence of the radiolarian Eucyrtidium spinosum 247 mbsf, RP14, CP15a/NP18 occurs younger at CP15b/NP19-20 in site 699A. The first occurrence of the nannofossil /sthmolithus recurvus $235.1 \mathrm{mbsf}$ at the base of CP15b/NP19-20 (Late Eocene) indicates the boundary with CP15a/NP18. Above, the last occurrence of Reticulofenestra reticulata, 210 mbsf, CP15b/NP19-20, occurs younger than the nannofossil scheme where this species is placed below Isthmolithus recurvus at the top of CP15a/NP18. The first occurrence of Reticulofenestra oamaruensis, 206 mbsf, CP15b/NP19-20, is in the same zone as the nannofossil scheme (Figure 2.1). The last occurrence of the radiolarian Calocyclas spB, 200 mbsf, CP15b/NP19-20, occurs younger than at site 699A where it is placed in CP15a/NP18.

The last occurrences of the foraminifera Globigerapsis linaperta, and Globigerapsis index both at 190 mbsf, cannot be defined in this site. In Berggren et al., (1995), the last occurrence of Globigerapsis index, 34.3 Ma, occurs at the top of CP15b/NP1920, while Globigerapsis linaperta is not recorded. The last occurrence of the 
nannofossil Reticulofenestra oamaruensis, $184 \mathrm{mbsf}, \mathrm{CP} 16 / \mathrm{NP} 21$ and marks the Eocene/Oligocene boundary. Notably the two $\delta^{18} \mathrm{O}$ of Liu et al. (2009) were very near the Eocene/Oligocene boundary with ages of 33.7 Ma (190.4 mbsf) and 33.5 Ma (171.4 mbsf) however, Reticulofenestra oamaruensis was lower than the last occurrence given above. Above, is the last occurrence of the nannofossil Isthmolithus recurvus, 150.2 mbsf and the last occurrence of Reticulofenestra umbilica, 137.6 mbsf though they cannot be defined both occur in the Early Oligocene. The nannofossil scheme places both species in CP17-18/NP22-23 in the Early Oligocene.

\subsubsection{Reassessing Chiasmolithus solitus}

Site 277 nannofossil zone NP17, has been reassessed in this study from the initial report by Edwards and Perch-Nielsen (1975). This reassessment also affects the results of NP17 in Figure 5, of Hollis et al., (1997). The NP17 nannofossil zone is defined by the first occurrence of Chiasmolithus oamaruensis at the top of the zone and the last occurrence of Chiasmolithus solitus at the top of NP16 below (Villa et al. 2008). In table 4C (p478, Edwards and Perch-Nielsen, 1975), Chiasmolithus solitus plus an undescribed Chiasmolithus spp were placed as a first occurrence together in the initial count at 434.5 mbsf with the last occurrence together at 311.0 mbsf. From 301.5 mbsf Chiasmolithus solitus is no longer recorded with Chiasmolithus spp (Table 4B, p477-478, Edwards and Perch-Nielsen, 1975). The undescribed Chiasmolithus spp eventually becomes less frequent with a last appearance at 149.5 mbsf. Accordingly including Chiasmolithus solitus and Chiasmolithus spp together makes it difficult to define the correct depth for the last appearance of Chiasmolithus solitus and subsequently to mark the boundary between NP16 and NP17. 


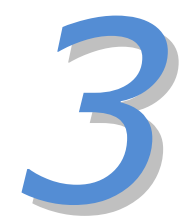

Dinocyst Data 


\section{CHAPTER THREE}

\subsection{Dinocyst Data}

\subsection{Dinocyst Biostratigraphy}

Chapter three is presented primarily to document the dinocyst biostratigraphy and compare it with the nannofossil zones in each site as developed in chapter two. Secondly, to review the palynomorph total abundance data for each site (mainly dinocysts).

The purpose of establishing a new zonation is to provide a biostratigraphy that temporally constrains the assemblages occurring during the Middle Eocene through to the Early Oligocene in the Southern High Latitudes. Brinkhuis and Biffi (1993) concluded that accurate long-range correlation of dinoflagellate cysts at the E/O boundary in central Italy was hampered by the effects of provincialism and environmental settings. They found it necessary to define a new zonation rather than relate to any existing zonation scheme where the E/O boundary may be poorly calibrated, missing or condensed. A new zonation is important to this project as it will assist with assessing the timing of dinocyst assemblage changes and any possible changes to the palaeoenvironment in the southern high latitude environmental settings.

\subsection{Dinocyst Datums}

The biostratigraphy was developed in this study using key datums recognised as first or last occurrence which reliably correlate between the sites. The two levels of datums recognised are:

A. Primary datums: of first or last occurrences from older to younger, always in the same temporal order and occur in at least two out of the four sites.

1. First occurrence of Corrudinium regulare

- Sites 696B, 699A, 748B, 277

2. First occurrence of Phthanoperidinium echinatum

- Sites 696B, 748B, 277 
3. First occurrence of Phthanoperidinium geminatum

- Sites 696B, 748B

4. Last Occurrence of Phthanoperidinium echinatum

- $\quad$ Site 696B, Site 748B, Site 277

5. Last occurrence of Phthanoperidinium spA

- $\quad$ Sites 696B, 699A 277

6. Last occurrence of Corrudinium regulare

- Sites 696B, 699A, 748B, 277

B. Secondary datums: first occur together in two of the four sites at the base or below the Phthanoperidinium echinatum zone.

1. First occurrence of Impagidinium victorianum

- $\quad$ Sites 748B, 277

2. First occurrence of Impagidinium aculeatum

- $\quad$ Sites 748B, 277

In addition acmes are documented in two of the cores and are an indication of dinocysts abundances that may have temporal or palaeoenvironmental significance.

Figure 3.1 displays the new dinocyst biostratigraphic zonation across the Middle and Late Eocene. From the left of the figure are time (Ma) from Berggren et al. (1995), age and the nannofossil zones of Okado and Bukry, (1980) and Martini (1971). The first and last occurrence of the five primary datums and first occurrence of secondary datums are depicted, along with the four newly named dinocyst zones on the right of the Figure.

Figure 3.2 displays from the left ODP sites 696B, 699A and 748B and DSDP site 277. The sample spacing for each site is shown by small arrows along with depth in mbsf, age, nannofossil zones from this study and if present foraminifera $(P)$ and radiolarian (RP) zones. Each site is aligned to the E/O boundary position. The primary and secondary datums with acmes are depicted for each site and the zones are coloured as Figure 3.1 below. 


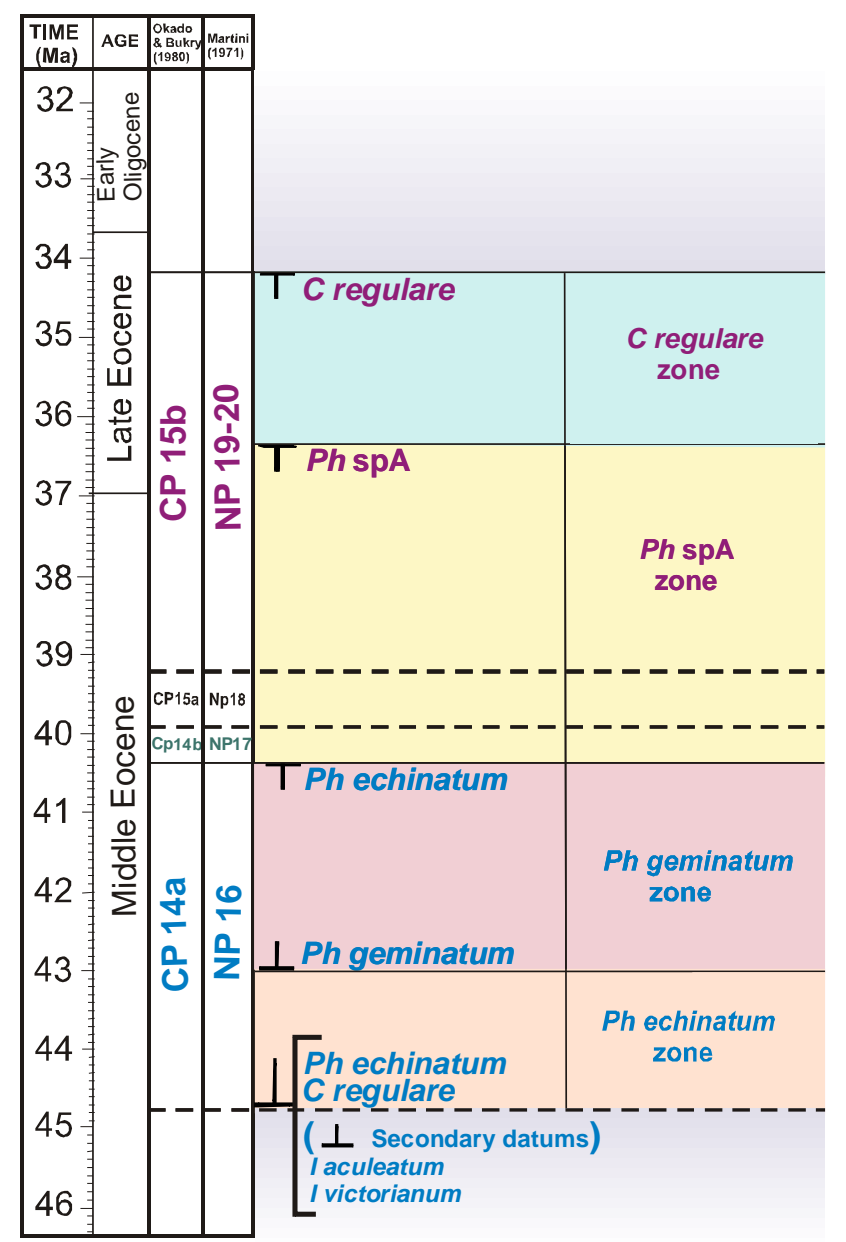

Figure 3.1: A new dinocyst biostratigraphic zonation across the Middle and Late Eocene. Time (Ma) from Berggren et al. (1995). Nannofossil Zones of Okado and Bukry, (1980) and Martini (1971), depicts first and last occurrence of primary datums and first occurrence of secondary datums, along with the newly named dinocyst zones.

Analysis of the species distribution in Figure 3.1 in Ma and their placement in each site in Figure 3.2 is outlined below.

\subsubsection{Phthanoperidinium echinatum Zone}

Base: In Figure 3.1 the first occurrence of Corrudinium regulare and Phthanoperidinium echinatum at approximately 45 Ma within the CP14a/NP16 nannofossil zone defines the base of the zone.

Top: The first occurrence of Phthanoperidinium geminatum at approximately 43 Ma in the CP14a/NP16 nannofossil zone defines the top of the zone. 


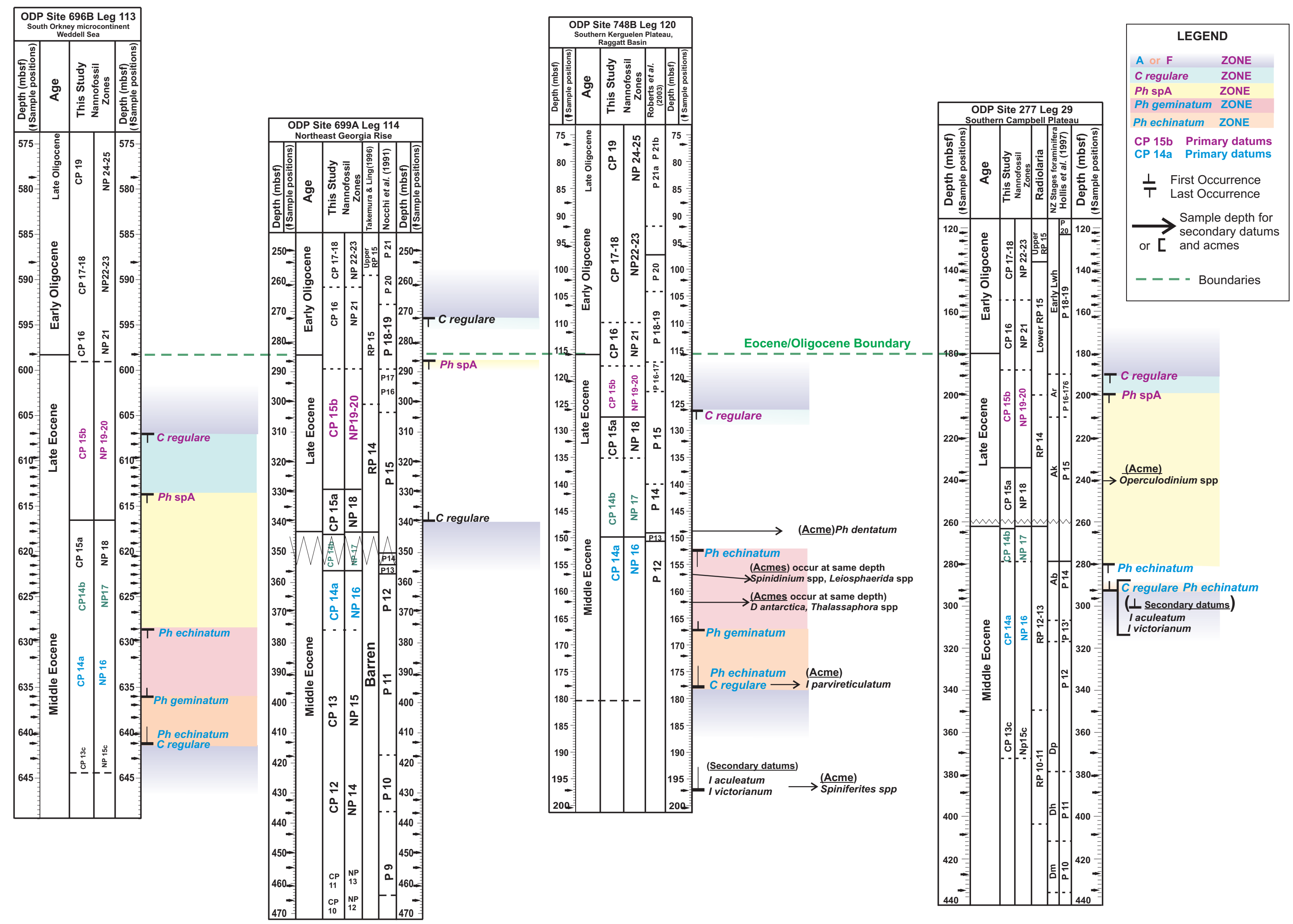

Figure 3.2: Dinocyst biostratigraphic zones correlating primary datums across all four sites. Primary datums are coloured coded to match their position within the nannofossil zones from this study CP Okado and Bukry,1980) NP (Martini,1971). $\perp=$ First occurrence $T=$ Last occurrence. Secondary datums and Acmes are labelled as such and their sample depth positons are shown by an arrow $\longrightarrow$ or $[$ The dashed green line $-\ldots$ shows the position of the E/O boundary. WW signifies an hiatus. 
Remarks (Figure 3.2): In site 696B, the base of this zone is identified by the first occurrence of Corrudinium regulare and Phthanoperidinium echinatum at $641.27 \mathrm{mbsf}$ in the Middle Eocene and the top of the zone is marked by the first occurrence of Phthanoperidinium geminatum (636 mbsf).

A full discussion of site 699A is given later due to differences occurring between this site and the other three sites.

Below the base of this zone in site 748B, the first occurrence of the secondary datums Impagidinium victorianum and Impagidinium aculeatum along with an acme of Spiniferites spp, occur at 197.38 mbsf. At the base of this zone the first occurrence of Corrudinium regulare, Phthanoperidinium echinatum and an acme of Impagidinium parvireticulatum occur at 177.76 mbsf. The top of the zone is identified by the first occurrence of Phthanoperidinium geminatum (167.39 mbsf)

The base of the zone at site 277 is placed at the first occurrence of Corrudinium regulare and Phthanoperidinium echinatum along with the secondary datums of Impagidinium victorianum and Impagidinium aculeatum at 292.53 mbsf. The top of the zone cannot be identified due to an inconsistency in the first occurrence of Phthanoperidinium geminatum. This species occurs at the same depth as the last occurrence of Phthanoperidinium echinatum (280.15 mbsf) which defines the base of the Phthanoperidinium spA zone as mentioned below. Further occurrences of Phthanoperidinium geminatum at 162.56 and 122.17 mbsf are sparse and considered to be reworked.

\subsubsection{Phthanoperidinium geminatum Zone}

Base: In Figure 3.1 the first occurrence of Phthanoperidinium geminatum at approximately $43 \mathrm{Ma}$ in the CP14a/NP16 nannofossil zone defines the base of the zone. 
Top: The last occurrence of Phthanoperidinium echinatum at approximately 40.5 Ma in the CP14a/NP16 nannofossil zone defines the top of the zone.

Remarks (Figure 3.2): The base of this zone is identified in site 696B with the first occurrence of Phthanoperidinium geminatum (636 mbsf) and the top of the zone is at the last occurrence of Phthanoperidinium echinatum (628.55 mbsf).

Site $748 \mathrm{~B}$ shows the base of this zone is identified with the first occurrence of Phthanoperidinium geminatum (167.39 mbsf). Acmes of Deflandrea antarctica and Thalassaphora spp occur at $162.1 \mathrm{mbsf}$, and above acmes of Spinidinium spp and the prasinophycean algae Leiosphaerida occur at 156.9 mbsf. The top of this zone is identified by the last occurrence of Phthanoperidinium echinatum (152.11 mbsf).

In site 277 the base of this zone cannot be identified due to an inconsistency in the first occurrence of Phthanoperidinium geminatum as mentioned above. The last occurrence of Phthanoperidinium echinatum (280.15 mbsf) which marks the top of this zone is identified.

\subsubsection{Phthanoperidinium SpA Zone}

Base: In Figure 3.1 the last occurrence of Phthanoperidinium echinatum at approximately $40.5 \mathrm{Ma}$ in the CP14a/NP16 nannofossil zone defines the base of zone.

Top: The last occurrence of Phthanoperidinium spA at approximately $36.4 \mathrm{Ma}$ in the CP15bNP19-20 nannofossil zone defines the top of the zone.

Remarks (Figure 3.2): This zone is identified in site 696B by the last occurrence of Phthanoperidinium echinatum (628.55 mbsf) at the base and at the top of the zone the last occurrence of Phthanoperidinium spA (613.65 mbsf). 
In site 748B the base of the zone is identified by the last occurrence of Phthanoperidinium echinatum (152.11 mbsf). Above, an acme is recorded for Phthanoperidinium dentatum (148.78 mbsf). The top of this zone cannot be identified due to the absence of Phthanoperidinium spA.

Site 277 shows the base of this zone is marked by the last occurrence of Phthanoperidinium echinatum (280.15 mbsf). Above, an acme is recorded for Operculodinium spp at $\mathbf{2 4 0 . 8 4}$ mbsf. The top of this zone is identified by the last occurrence of Phthanoperidinium spA (199.59 mbsf).

\subsubsection{Corrudinium regulare Zone}

Base: In Figure 3.1 the last occurrence of Phthanoperidinium spA at approximately 36.4 Ma in the CP15b/NP19-20 nannofossil zone defines the base of the zone.

Top: The last occurrence of Corrudinium regulare at approximately $34.2 \mathrm{Ma}$ in the CP15b/NP19-20 nannofossil zone marks the top of the zone.

Remarks (Figure 3.2): Site 696B shows the base of the Corrudinium regulare zone is identified by the last occurrence of Phthanoperidinium spA (613.65 mbsf) with the top of this zone marked by the last occurrence of Corrudinium regulare (607 mbsf.)

In site $748 \mathrm{~B}$ the base of this zone cannot be identified due to the absence of the last occurrence of Phthanoperidinium spA however, the last occurrence of Corrudinium regulare (126.36 mbsf) marks the top of this zone.

The base of this zone in site 277 is identified by the last occurrence of Phthanoperidinium spA (199.59 mbsf) and the top of this zone is marked by the last occurrence of Corrudinium regulare (190.8 mbsf).

\subsubsection{Discussion of Site 699A}

Remarks (Figure 3.2): The first occurrence of Corrudinium regulare (339.07 mbsf) in CP15a/NP18 is placed younger than the other three sites where it occurs in 
CP14a/NP16. This first occurrence marks the base of the Phthanoperidinium echinatum zone; however the other primary datums above are absent until the last occurrence of Phthanoperidinium spA (286.53 mbsf). The last occurrence of Phthanoperidinium spA is placed in the correct temporal position, although closer to the E/O boundary than the other three sites. Additionally, the last occurrence of Corrudinium regulare (272.24 mbsf) identifies the top of the Corrudinium regulare zone as occurring in the Early Oligocene which is much younger than at the other sites.

On reviewing the nannofossil occurrences in Figure 3.4 of this site, the position of the E/O boundary is placed at the last occurrence of Reticulofenestra oamaruensis (284.90 mbsf), consistent with the other sites. However, the dinocyst occurrences appear to be in the correct order although apparently in younger sediments as identified in Figures 3.2 and 3.4 .

\subsection{Dinocyst Datums and other Microfossils}

Figures 3.3-3.6 represent the incorporation of dinocyst primary and secondary datums with the nannofossil, radiolarian and foraminifera data from Chapter Two (Figs 2.2-2.5). The dinocyst datums were established through a compilation of first and last occurrences of each datum. They were documented as occurring in the same temporal order and in the same nannofossil zone within each site, and resulted in six primary and two secondary dinocyst datums being defined. In Figures 3.3-3.6 they are compared with the other microfossil data from chapter two.

It is evident that the dinocyst primary datums do not consistently correlate with the positions of other microfossils datums within each of the sites. For example, within the dinocyst primary datums, the first occurrence of Corrudinium regulare and Phthanoperidinium echinatum in sites 748B (177.76 mbsf) and 277 (292.53 mbsf; Figures 3.3-3.4) occur below, although close to, the first occurrence of 
Reticulofenestra reticulata (171 mbsf; CP14/NP16-17). However, in site 699A the first occurrence of Corrudinium regulare (339.07 mbsf; CP15a/NP18) occurs above the first occurrence of Reticulofenestra reticulata (370 mbsf; CP14/NP16-17) and in site 696B this species occurs in one sample only at $645 \mathrm{mbsf}$ placing it below the first occurrence of Corrudinium regulare.

In addition the last occurrence of Phthanoperidinium spA (CP15b/NP19-20) in sites 696B (613.65 mbsf) and 277 (199.59 mbsf) occurs very close to the first occurrence of Reticulofenestra oamaruensis in sites 696B (613.5 mbsf) and 277 (199.59 mbsf). In site 699A Phthanoperidinium spA (286.53 mbsf) occurs near the E/O boundary and much younger than the first occurrence of Reticulofenestra oamaruensis (321.5 mbsf) near the base of CP15b/NP19-20. In site 748B Phthanoperidinium spA occurs in only one sample at 172.12 mbsf well below the first occurrence of Reticulofenestra oamaruensis ( $\sim 125 \mathrm{mbsf}$ ).

The last occurrence of Corrudinium regulare (CP15b/NP19-20) in sites 696B (607mbsf) and 277 (190.8 mbsf) is placed above the first occurrence of Reticulofenestra oamaruensis in sites 696B (613.5 mbsf) and 277(261 mbsf). Site 748B shows the last occurrence of Corrudinium regulare (126 mbsf) is below the first occurrence of Reticulofenestra oamaruensis (125 mbsf) though still in CP15b/NP19-20. However, site 699A places the last occurrence of Corrudinium regulare (272.24 mbsf) as much younger occurring in the Early Oligocene and above the last occurrence of Reticulofenestra oamaruensis (286.5 mbsf).

Foraminifera show the last occurrence of Globigerina index (CP15b/NP19-20) in sites 748B (122 mbsf) and 277 (190.5 mbsf), occurs before the E/O boundary and after, although close to, the last occurrence of Corrudinium regulare within site 748B (126.36 mbsf), and is found in a similar location at site 277 (190.8 mbsf). In site 699A the last occurrence of Globigerina index (333 mbsf) occurs below in CP15a/NP18, while the last occurrence of Corrudinium regulare (272.24 mbsf) is Early Oligocene. Foraminifera are absent from site 696B. 


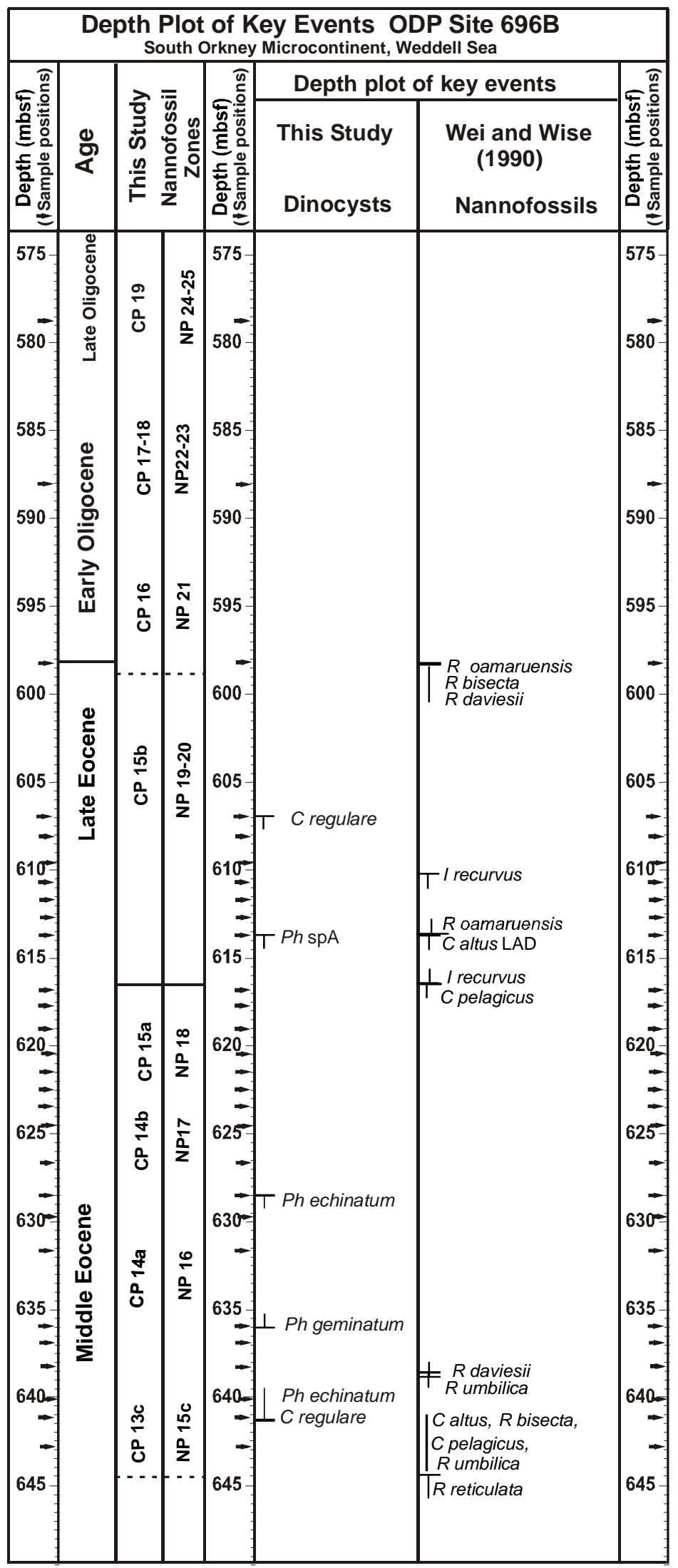

Figure 3.3: Dinocysts datums from this study are displayed against nannofossils from Wei and Wise (1990). The nannofossil zones are from Okado and Bukry (1980) CP and Martini (1971) NP. Also shown are age, depths (mbsf), arrows indicate sample positions. $\perp$ Indicates First Occurrence and $T$ Last Occurrence. 


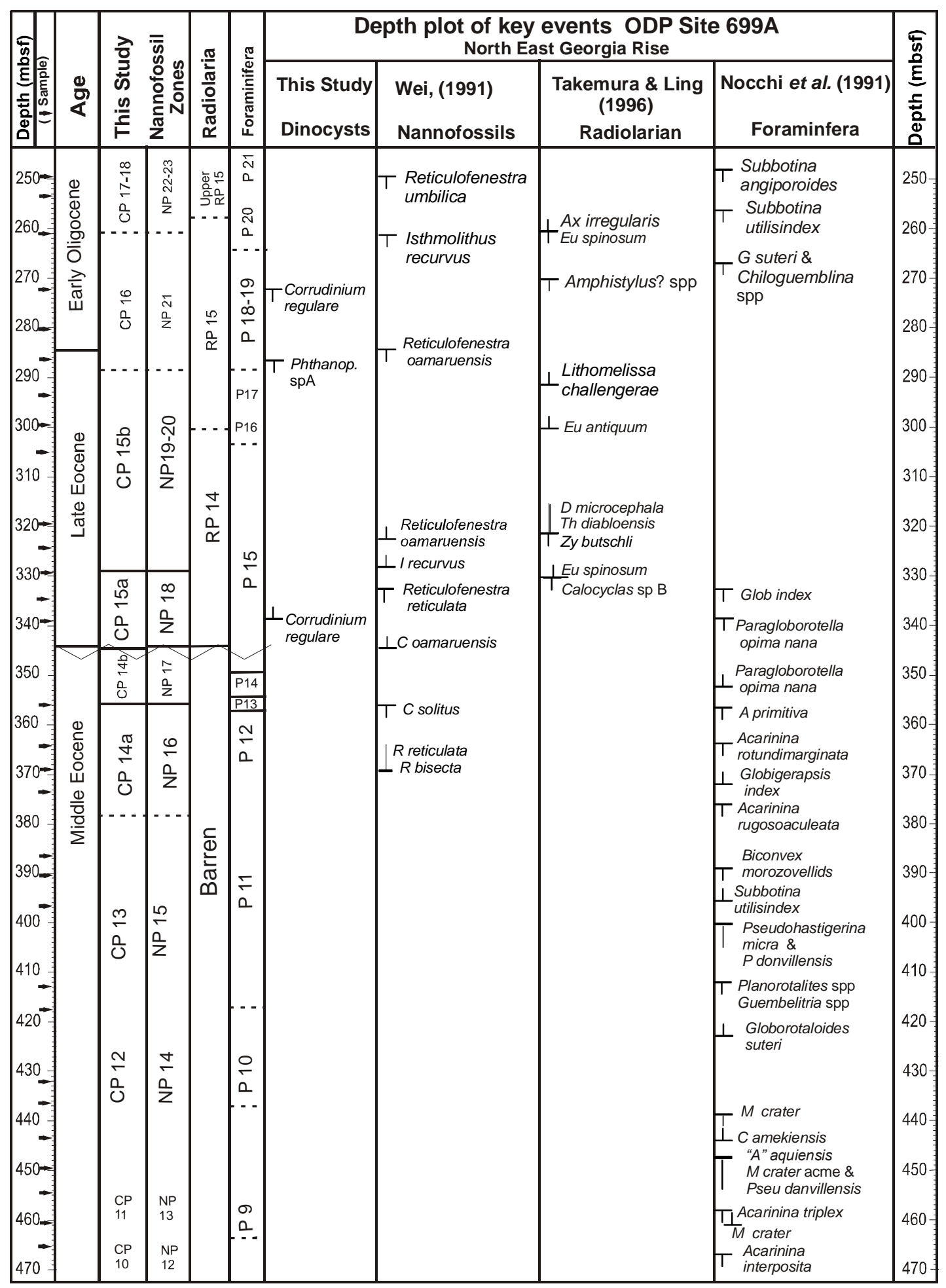

Figure 3.4: Dinocysts datums from this study are displayed against the nannofossils from Wei (1991), radiolarian from Takemura and Ling (1996), and the foraminiferal linings are from Nocchi et al. (1991). The nannofossil zones are from Okado and Bukry (1980) CP and Martini (1971). Also shown are age, depths (mbsf) Small arrows indicate sample positions in mbsf. $\perp$ Indicates First Occurrence and $T$ Last Occurrence. The hiatus is indicated by the rippled line $M$ 


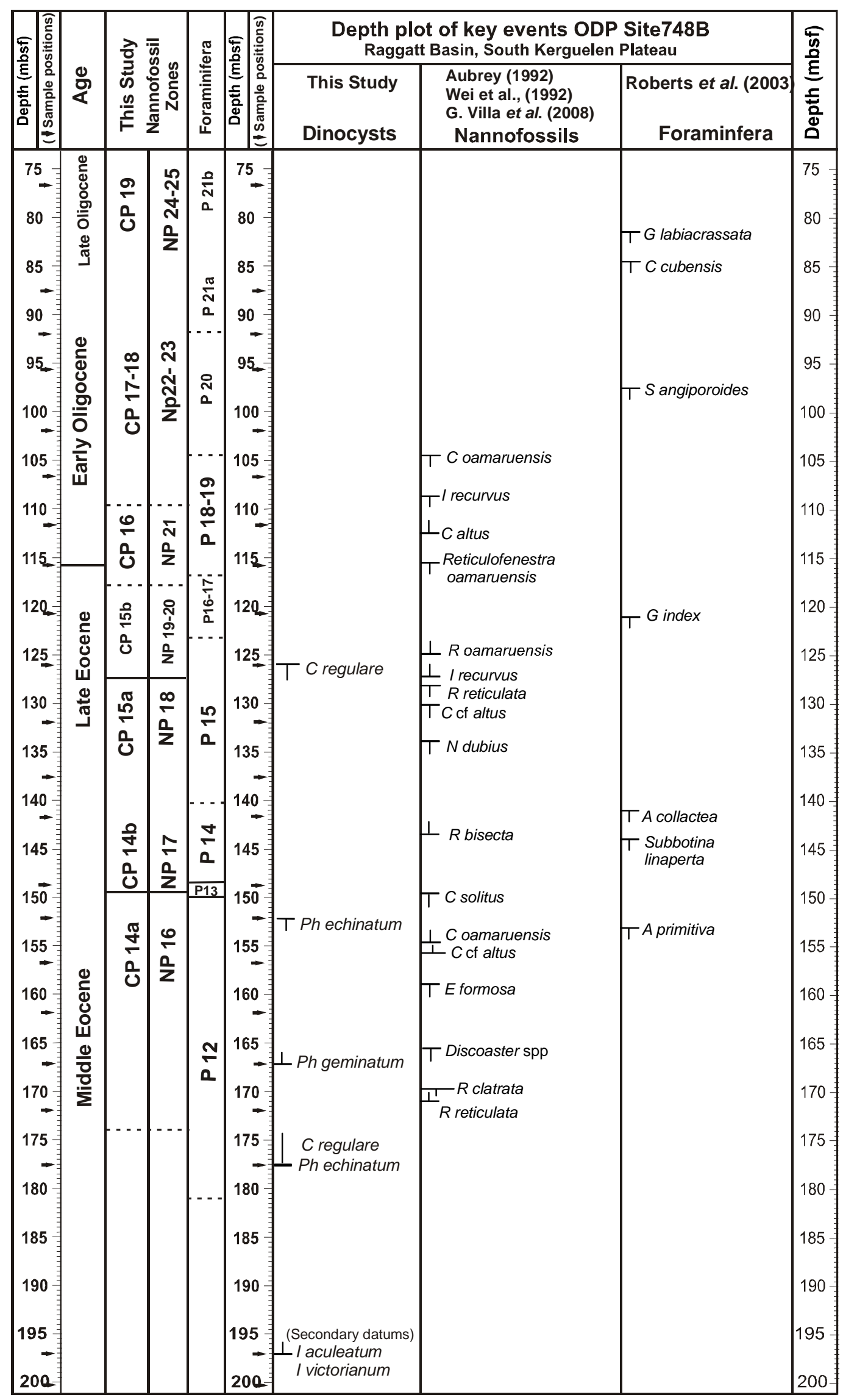

Figure 3.5: Dinocysts datums from this study are displayed against the nannofossils from Villa et al.(2008), foraminiferal linings from Roberts et al. (2003). The nannofossil zones are from Okado and Bukry (1980) and Martini (1971).Also shown are age, depths (mbsf). Small arrows indicate sample positions in mbsf. $\perp \quad$ Indicates First Occurrence and $T$ Last Occurrence. 


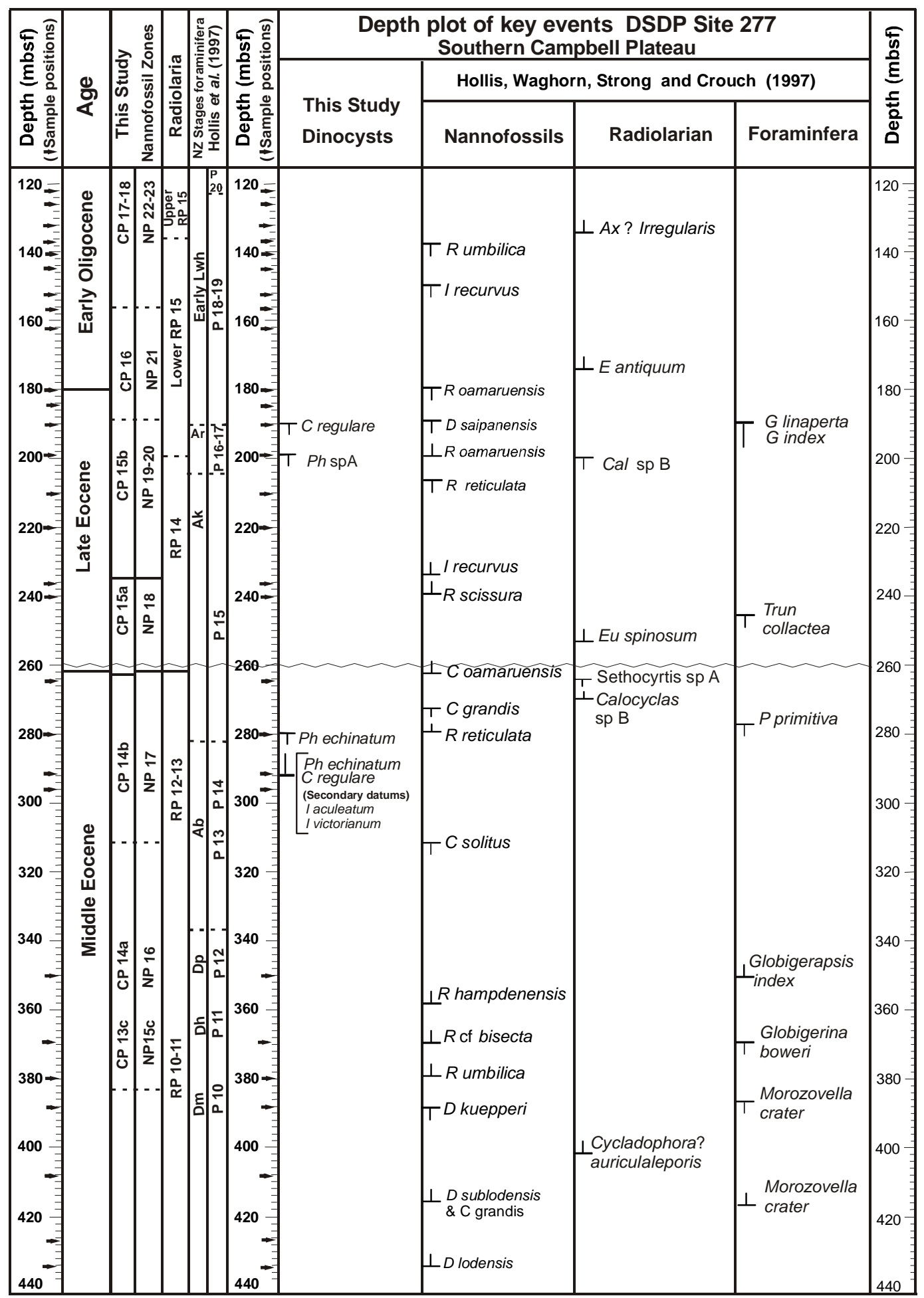

Figure 3.6: Dinocyst datums from this study are displayed against the nannofossils, radiolarian andforaminiferal linings from Hollis, Waghorn, Strong and Crouch (1997). The nannofossil zones are from Okado and Bukry (1980) and Martini (1971). Also shown are age, depths (mbsf), small arrows indicate sample positions. $\perp$ Indicates First Occurrence and T Last Occurrence. Secondary datums are shown as first occurrence beneath the first occurrences of Ph echinatum and $\mathrm{C}$ regulare. The hiatus is indicated by the rippled line 


\subsection{Total Abundance}

The palynomorph counts for each site (Appendix 3.5-3.8) are presented in terms of grains per gram (g/g) (Figure 3.7-3.10). To the left of each chart is the nannofossil biostratigraphic zonation as set out in chapter two, together with age, sample depths (mbsf) and if present foraminifera or radiolarian zones. Palynomorphs are numbered in alphabetical order at the top of each chart and listed in first occurrence order in the second row. Dinocysts marked as red are longer ranging and more consistent, occurring in nearly every sample while those marked as blue are more sporadic in occurrence. Primary dinocysts on the far right of each chart are marked by horizontal red lines showing their first or last occurrences. Dinocyst zones are shown in the same colours as Figure 3.1. Green intermittent lines mark age boundaries for the Middle/Late Eocene and Eocene/Oligocene. The positions of acmes are marked by blue arrows. Also listed on each chart are counts (purple) of acritarchs present with most species simply grouped as acritarchs while individual species if known are shown separately. The Prasinophycean algae of Cymatiosphaera spp and Tasmanites together with counts of microforaminiferal linings, insect parts and terrestrial material (spores and pollen coloured green) are shown on the far right.

\subsubsection{Site 696B - Figure 3.7}

Dinocysts abundances in this site range from $0.52 \mathrm{~g} / \mathrm{g}$ (Deflandrea cygniformis) to $238.7 \mathrm{~g} / \mathrm{g}$ (Vozzhennikovia apertura). All the dinocyst zones are present and acmes are absent in this site. Seventeen dinocyst species appear in the lowest sample depth and dinocysts occurring below the Oligocene include four that occur in every sample from $642.98 \mathrm{mbsf}$.

\subsubsection{Dinocysts below the Oligocene}

Those species consistently appearing below the Oligocene are Lejeunecysta fallax first occurring at $642.98 \mathrm{mbsf}(11 \mathrm{~g} / \mathrm{g})$, with a highest abundance of $29.6 \mathrm{~g} / \mathrm{g}$, at 607 mbsf, the top of the Corrudinium regulare Zone. Octodinium askinae has a first occurrence of $9 \mathrm{~g} / \mathrm{g}$ at $642.98 \mathrm{mbsf}$, and increases up section to peak at $47.7 \mathrm{~g} / \mathrm{g}$ 


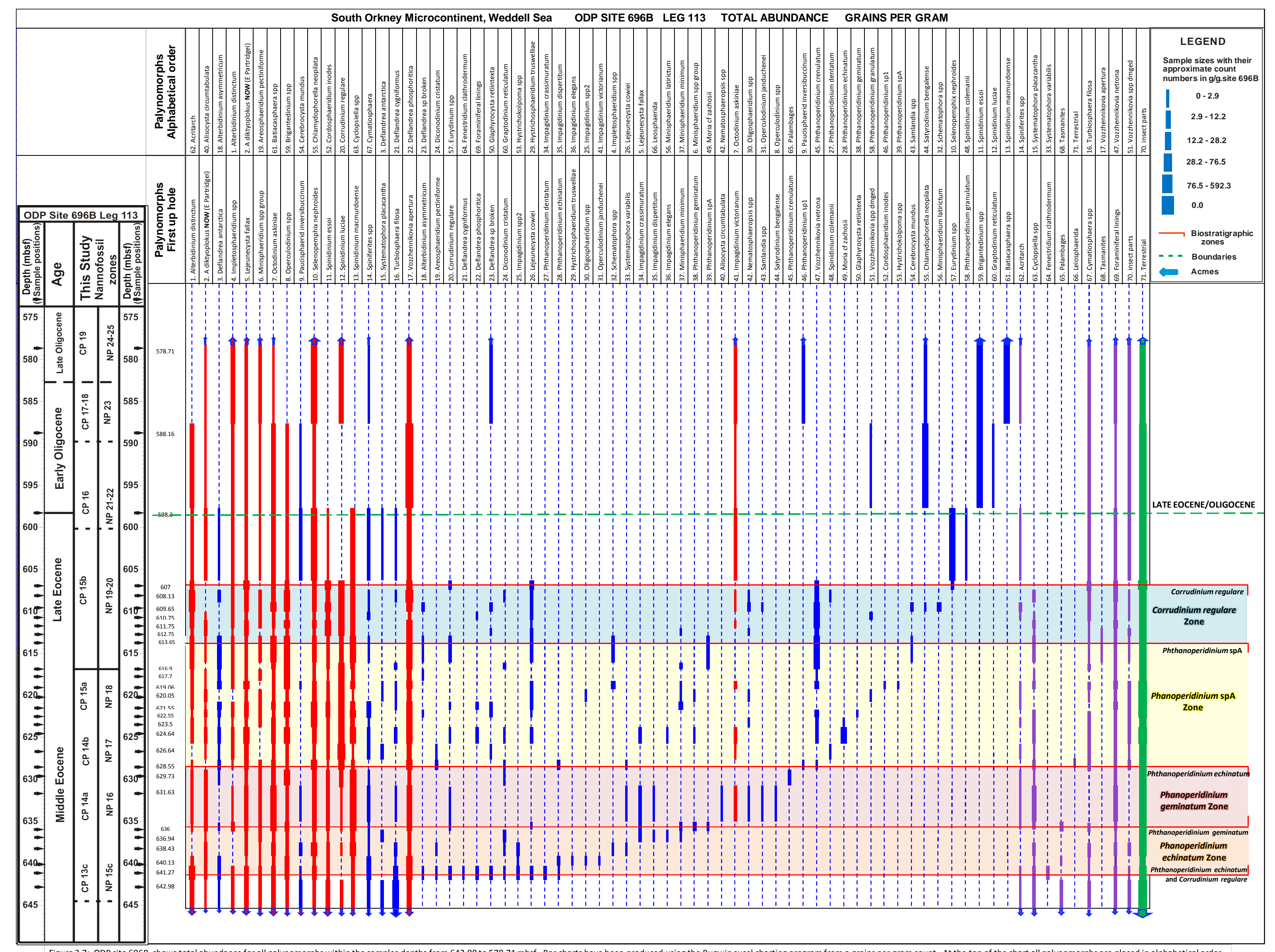

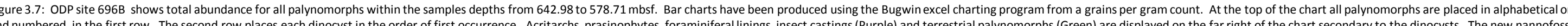

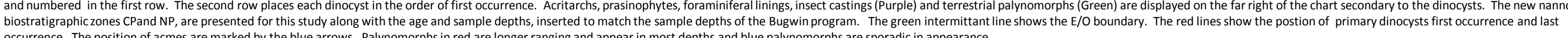


(613.65 mbsf) at the base of the Corrudinium regulare Zone. The first occurrence of Selenopemphix neophroides at $642.98 \mathrm{mbsf}$ yielded $7.7 \mathrm{~g} / \mathrm{g}$, increasing upsection to peak at $39.7 \mathrm{~g} / \mathrm{g}$, (628.55 mbsf). Vozzhennikovia apertura has a first occurrence at $642.98 \mathrm{mbsf}(17.2 \mathrm{~g} / \mathrm{g}$ ), with higher abundances occurring up section including 106 $\mathrm{g} / \mathrm{g}$, at $624.64 \mathrm{mbsf}$, and peaks at $239 \mathrm{~g} / \mathrm{g}$ (608.13 mbsf), in CP15b/NP19-20 the Corrudinium regulare Zone.

Other significant occurrences below the Oligocene are high abundances of Spinidinium luciae. Initially sparse, this species first occurs at $642.98 \mathrm{mbsf}(2.4 \mathrm{~g} / \mathrm{g})$, before increasing significantly up section, peaking at $209 \mathrm{~g} / \mathrm{g}$ (626.64 mbsf), within the Phthanoperidinium spA Zone, then decreasing at the top of the Corrudinium regulare Zone to $47.0 \mathrm{~g} / \mathrm{g}$ (607 mbsf). Alterbidinium distinctum makes its first appearance at $642.98 \mathrm{mbsf}(13.0 \mathrm{~g} / \mathrm{g})$, increases its numbers up section peaking at $71 \mathrm{~g} / \mathrm{g}, 641.27 \mathrm{mbsf}$ then is sporadic above before fading at $607 \mathrm{mbsf}$ to $9.8 \mathrm{~g} / \mathrm{g}$. Spinidinium macmurdoense first occurred at $642.98 \mathrm{mbsf},(3.6 \mathrm{~g} / \mathrm{g})$, peaking above at $60.5 \mathrm{~g} / \mathrm{g}$ (622.55 mbsf, CP15a/NP18), in the Phthanoperidinium spA Zone. The first occurrence of Operculodinium spp yielded low numbers of $7.7 \mathrm{~g} / \mathrm{g}(642.98$ mbsf). This species fluctuated up section with abundances peaking at $85.4 \mathrm{~g} / \mathrm{g}$, (621.5 mbsf, CP15a/NP18), in the Phthanoperidinium spA Zone and further upsection at $80 \mathrm{~g} / \mathrm{g}$ (608.13 mbsf, CP15b/NP19-20) near the top of the Corrudinium regulare Zone. Impagidinium victorianum first occurs at $638.63 \mathrm{mbsf}(1.1 \mathrm{~g} / \mathrm{g})$ and is sparse and sporadic upsection with an increase to $4 \mathrm{~g} / \mathrm{g}$ at $619.06 \mathrm{mbsf}$ then decreased higher in the section reaching $0.6 \mathrm{~g} / \mathrm{g}$ at $608.13 \mathrm{mbsf}$. Vozzhennikovia netrona at $0.6 \mathrm{~g} / \mathrm{g}(628.55 \mathrm{mbsf})$, is initially sparse then high abundances occur above at $148.65 \mathrm{~g} / \mathrm{g}$ (611.75 mbsf, CP15b/NP19-20), within the Corrudinium regulare zone (Late Eocene) before decreasing upsection. It last occurs at 607 mbsf $(14.8 \mathrm{~g} / \mathrm{g})$.

The remaining dinocyst occurrences are sparse in comparison. Abundances are significantly reduced with Phthanoperidinium echinatum at $1.0 \mathrm{~g} / \mathrm{g}$ (641.27 mbsf) before its last occurrence at the top of the Phthanoperidinium geminatum Zone (8.3 $\mathrm{g} / \mathrm{g}, 628.55 \mathrm{mbsf})$. Corrudinium regulare first occurs at $641.27 \mathrm{mbsf},(1.04 \mathrm{~g} / \mathrm{g})$ and 
is sparse up to its last occurrence of $3.7 \mathrm{~g} / \mathrm{g},(607 \mathrm{mbsf})$ at the top of the Corrudinium regulare zone. Impletosphaeridium spp first occurs at $642.98 \mathrm{mbsf}$ (6.5 $\mathrm{g} / \mathrm{g})$, is reduced in the Middle Eocene to $1.7 \mathrm{~g} / \mathrm{g}$, $(619.06 \mathrm{mbs})$. It then is present in every sample above. Deflandrea antarctica occurs at $642.98 \mathrm{mbsf}(0.6 \mathrm{~g} / \mathrm{g})$; this species reaches its highest occurrence peaking with $18.7 \mathrm{~g} / \mathrm{g}$ at $613.65 \mathrm{mbsf}$.

Among the other marine palynomorphs most acritarchs appear in the lowest sample ( $642.98 \mathrm{mbsf}$ ) but are sporadic above this level and few occur above the E/O boundary. Individuals assigned to the acritarch genus Cyclopsiella $(1.7 \mathrm{~g} / \mathrm{g}, 642.96$ mbsf) were the most abundant acritarch species peaking at $13.2 \mathrm{~g} / \mathrm{g}, 631.63 \mathrm{mbsf}$. The prasinophycean algae Cymatiosphaera spp occurs throughout the hole though they were not present in every sample. Their numbers were low at $1.8 \mathrm{~g} / \mathrm{g}(642.98$ mbsf), then peaked upsection with $8.6 \mathrm{~g} / \mathrm{g}$, at $607 \mathrm{mbsf}$ (CP15b/NP19-20). Tasmanites only occurred in two samples at $613.65 \mathrm{mbsf}(0.6 \mathrm{~g} / \mathrm{g})$ and $612.75 \mathrm{mbsf}$ at $1.2 \mathrm{~g} / \mathrm{g}$ (CP15b/NP19-20). Microforaminiferal linings were present in all samples in low abundances peaking with $17.7 \mathrm{~g} / \mathrm{g}$, at $608.13 \mathrm{mbsf}$ (CP15b/NP19-20).

\subsubsection{Dinocysts in the Early Oligocene}

Most of the dinocysts that occurred consistently also continued into the Early Oligocene. They are Alterbidinium distinctum (607 mbsf, $10 \mathrm{~g} / \mathrm{g}$ ), which continued up to $598.3 \mathrm{mbsf}(1.5 \mathrm{~g} / \mathrm{g})$, increasing upwards with a last occurrence at 588.16 mbsf of $13 \mathrm{~g} / \mathrm{g}$ in the Early Oligocene. Samples yielded high numbers of Vozzhennikovia apertura (607 mbsf, $87.7 \mathrm{~g} / \mathrm{g}$ ) increasing upwards into the Early Oligocene peaking at $172.5 \mathrm{~g} / \mathrm{g}(588.16 \mathrm{mbsf})$ then decreasing with a last occurrence at $578.71 \mathrm{mbsf}$ of $14.1 \mathrm{~g} / \mathrm{g}$. Spinidinium luciae $(607 \mathrm{mbsf}, 47 \mathrm{~g} / \mathrm{g}$ ), recurs at $578.71 \mathrm{mbsf}$, decreasing to $13.2 \mathrm{~g} / \mathrm{g}$ in the Early Oligocene. Octodinium askinae (607 mbsf, $11.1 \mathrm{~g} / \mathrm{g}$ ), continues into the Early Oligocene with $14 \mathrm{~g} / \mathrm{g}$ at $598.3 \mathrm{mbsf}$ before decreasing to $1.0 \mathrm{~g} / \mathrm{g}$ (578.71 mbsf). Impagidinium victorianum though sporadic and poor below ( $0.6 \mathrm{~g} / \mathrm{g}, 608.13 \mathrm{mbsf})$ increases with a last occurrence of $2.8 \mathrm{~g} / \mathrm{g}$, at $578.71 \mathrm{mbsf}$ and is the only species among the more sporadic dinocysts that extended into the Early Oligocene. Selenopemphix neophroides continues into the Early Oligocene ( $28 \mathrm{~g} / \mathrm{g}, 598.3 \mathrm{mbsf})$ increasing slightly with a last occurrence of 
$33 \mathrm{~g} / \mathrm{g}$, at $578.71 \mathrm{mbsf}$. Lejeunecysta fallax (8.5 g/g, $598.3 \mathrm{mbsf}$ ) decreases into the Early Oligocene before the last occurrence of $6.1 \mathrm{~g} / \mathrm{g}$ (578.71 mbsf). Spinidinium macmurdoense (607 mbsf, $20 \mathrm{~g} / \mathrm{g}$ ) decreased to $14.7 \mathrm{~g} / \mathrm{g}$ at $598.3 \mathrm{mbsf}$. Operculodinium spp (608.13 mbsf, $80 \mathrm{~g} / \mathrm{g}$ ) decreased significantly to $3 \mathrm{~g} / \mathrm{g}$ at 598.3 mbsf with the last occurrence of $4.7 \mathrm{~g} / \mathrm{g}$, at $588.16 \mathrm{mbsf}$ in the Early Oligocene. Impletosphaeridium spp ( $2.3 \mathrm{~g} / \mathrm{g}, 598.3 \mathrm{mbsf})$ increases in the Early Oligocene with a last occurrence of $14 \mathrm{~g} / \mathrm{g}$, at $578.71 \mathrm{mbsf}$ and Deflandrea antarctica $(6.6 \mathrm{~g} / \mathrm{g}$, $608.13 \mathrm{mbsf}$ ) decreases with a last occurrence of $0.8 \mathrm{~g} / \mathrm{g}$ at $598.3 \mathrm{mbsf}$.

Most of the less well represented dinocysts are not consistent in appearances and in most cases do not occur in the Early Oligocene. Dinocysts that do occur above the E/O boundary include Eurydinium spp which at the base of its range yields 4.9 $\mathrm{g} / \mathrm{g}$ (607 mbsf), but increases in numbers upsection reaching $91.8 \mathrm{~g} / \mathrm{g}$ at $598.3 \mathrm{mbsf}$. To a lesser extent the first occurrence of Chlamydophorella neopilata (609.65 mbsf, $1.2 \mathrm{~g} / \mathrm{g}$ ) was sparse in the Late Eocene, and is most abundant in the Oligocene with $33.4 \mathrm{~g} / \mathrm{g}$, at $588.16 \mathrm{mbsf}$, before the last occurrence of $4.7 \mathrm{~g} / \mathrm{g}(578.71 \mathrm{mbsf})$. The first occurrence of Brigantedinium spp at $588.16 \mathrm{mbsf}(25 \mathrm{~g} / \mathrm{g})$ is in the Early Oligocene, this species increases to $56.4 \mathrm{~g} / \mathrm{g}$ at $578.71 \mathrm{mbsf}$. Also recorded in the Early Oligocene in one sample only is Batiacasphaera spp (33.4 g/g, $578.71 \mathrm{mbsf}$ ). The prasinophycean algae Cymatiosphaera spp ( $8.6 \mathrm{~g} / \mathrm{g}, 607 \mathrm{mbsf}$ ) continues into the Early Oligocene decreasing to $2.8 \mathrm{~g} / \mathrm{g}$, at $578.71 \mathrm{mbsf}$. Microforaminiferal linings ( $7.7 \mathrm{~g} / \mathrm{g}, 598.3 \mathrm{mbsf})$, also continue into the Early Oligocene at $2.8 \mathrm{~g} / \mathrm{g}$ (578.71 mbsf) along with insect parts.

Terrestrial material dominates all assemblages making up to $68.8 \%$ of the total palynomorph assemblage. Present in all samples the highest counts were recorded near the top of the CP15a/NP18 (1048.8 g/g, $620.05 \mathrm{mbsf})$ before increasing up to $1517.2 \mathrm{~g} / \mathrm{g}$ at $607 \mathrm{mbsf}$ in the Late Eocene (CP15b/NP19-20) before decreasing in the Early Oligocene from $442.2 \mathrm{~g} / \mathrm{g}$ at $598.3 \mathrm{mbsf}$ down to $116.5 \mathrm{~g} / \mathrm{g}$ at $578.71 \mathrm{mbsf}$. 


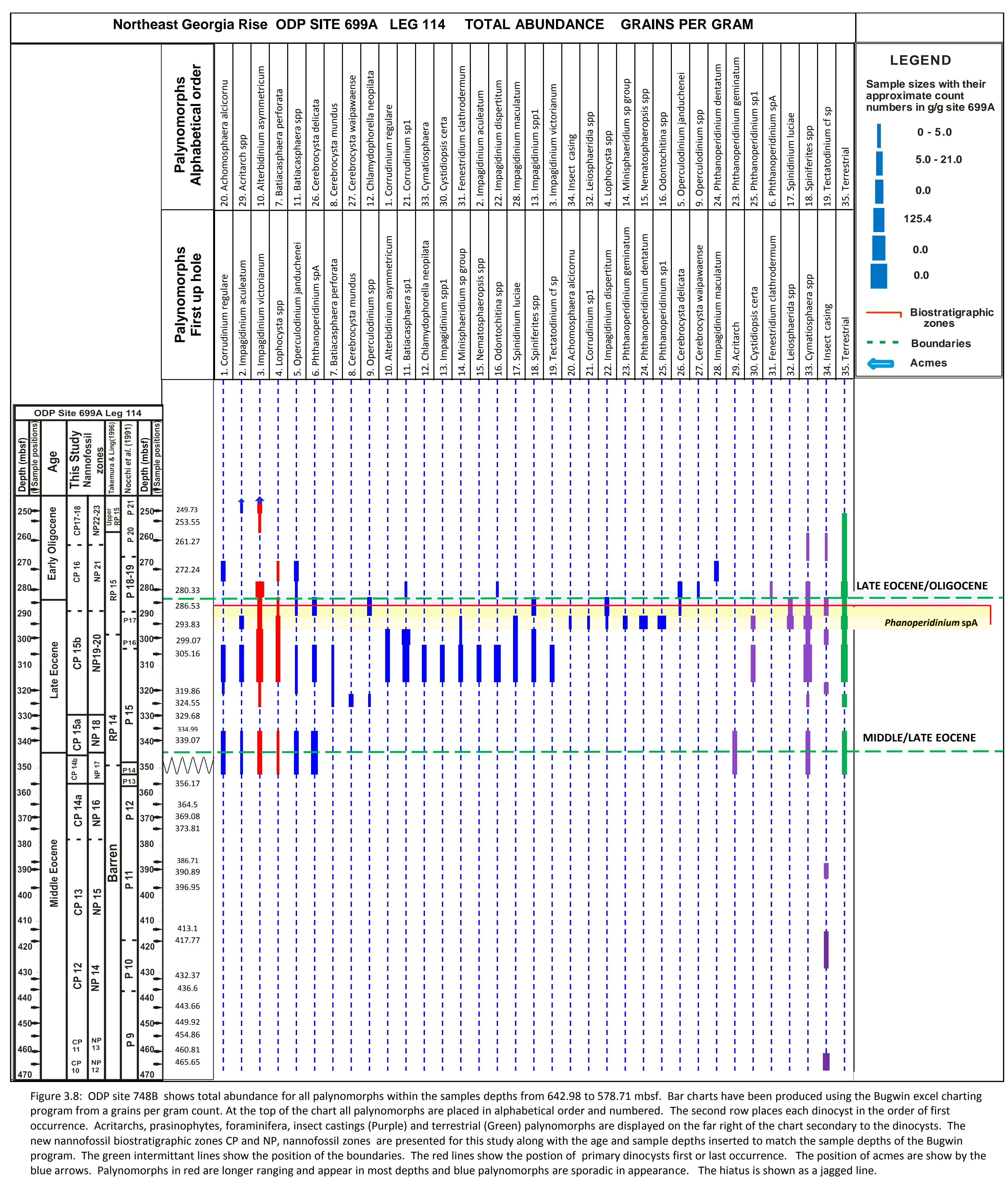




\subsubsection{Site 699A - Figure 3.8}

Samples from this site yielded only low diversity assemblages and dinocysts are not recorded between 465.65-356.17 mbsf. Dinocysts numbers range from $0.6 \mathrm{~g} / \mathrm{g}$ (Batiacasphaera spp) to $125.4 \mathrm{~g} / \mathrm{g}$ (Phthanoperidinium dentatum). The last occurrence of Phthanoperidinium spA is the only primary dinocyst in this site, and allows recognition of the top of the Phthanoperidinium spA zone and the base of the Corrudinium regulare zone. The presence of Corrudinium regulare first and last occurrences have been mentioned above in 3.2. No acmes have been recorded.

\subsubsection{Dinocysts below the Oligocene}

More consistent in appearances below the Oligocene is Impagidinium victorianum which first occurs at 339.07 mbsf with $8.4 \mathrm{~g} / \mathrm{g}$, (CP15a/NP18), and peaked upsection to $15.8 \mathrm{~g} / \mathrm{g}$ at $299.07 \mathrm{mbsf}$. Lyphocysta spp occurs at $339.07 \mathrm{mbsf}(1.05 \mathrm{~g} / \mathrm{g})$, and increased upsection to $7.2 \mathrm{~g} / \mathrm{g}$, at $293.83 \mathrm{mbsf}$ in the Late Eocene.

Other dinocysts occurring in the Late Eocene were Impagidinium aculeatum, (1.0 $\mathrm{g} / \mathrm{g}, 339.07 \mathrm{mbsf})$, with highest abundance upsection of $8.3 \mathrm{~g} / \mathrm{g}$ (305.16 mbsf). The first common occurrence of a number of dinocyst species is recorded at 305.16 mbsf (mid-Late Eocene). The most abundant is Batiacasphaera spp (14.7 g/g) which increased upsection to $21.0 \mathrm{~g} / \mathrm{g}$, at $299.07 \mathrm{mbsf}$. Corrudinium regulare first occurs at $3.2 \mathrm{~g} / \mathrm{g}$ (339.07 mbsf), with a slight increase above at $3.7 \mathrm{~g} / \mathrm{g}$ (305.16 mbsf). Operculodinium janducheni $(2.1 \mathrm{~g} / \mathrm{g}, 339.07 \mathrm{mbsf})$, is sparse and sporadic in occurrence upsection near the Early Oligocene (1.1 g/g, 286.53). Dinocysts occurring in one sample only that have recorded high abundances, include Phthanoperidinium dentatum at $125.4 \mathrm{~g} / \mathrm{g}, 293.83 \mathrm{mbsf}$ and Phthanoperidinium sp1 at $84.6 \mathrm{~g} / \mathrm{g}, 293.83 \mathrm{mbsf}$ in the Late Eocene.

Of the other marine palynomorphs, Acritarch species were sparse throughout, although numbers of Leiosphaerida with $18.0 \mathrm{~g} / \mathrm{g}$, at $293.83 \mathrm{mbsf}$ decreases to 3.4 g/g at 286.53 mbsf. Cymatiosphaera spp first occurs at $7.4 \mathrm{~g} / \mathrm{g}$ (339.07 mbsf), and peaks above at $28 \mathrm{~g} / \mathrm{g}, 305.16 \mathrm{mbsf}$, (CP15a/NP18) in the Late Eocene and again 
upsection at $27.5 \mathrm{~g} / \mathrm{g}$ (293.83 mbsf), toward the end of the Late Eocene. Insect casings were recorded in three samples (465.65, 417.77 and $390.89 \mathrm{mbsf}$ ) well below the barren interval for palynomorphs. They reoccur in the Late Eocene in three samples with one further occurrence in the Early Oligocene. Terrestrial material is present in most samples in the Late Eocene, fluctuating in numbers with a peak of $15.5 \mathrm{~g} / \mathrm{g}$, at $305.16 \mathrm{mbsf}$,

\subsubsection{Dinocysts in the Early Oligocene}

Dinocysts that occur above the E/O boundary are Impagidinium victorianum occurring with a high abundance of $25.6 \mathrm{~g} / \mathrm{g}$ at $280.33 \mathrm{mbsf}$ in the Early Oligocene then to a lesser extent last occurred at $2.0 \mathrm{~g} / \mathrm{g}$ at $249.73 \mathrm{mbsf}$. Lyphocysta spp ( $286.53 \mathrm{mbsf}, 1.1 \mathrm{~g} / \mathrm{g}$ ) last occurrence decreased to $0.8 \mathrm{~g} / \mathrm{g}(272.24 \mathrm{mbsf})$, in the Early Oligocene. Impagidinium aculeatum (293.83 mbsf, $2.4 \mathrm{~g} / \mathrm{g}$ ) last occurs in the Early Oligocene at 249.73 mbsf with $1.3 \mathrm{~g} / \mathrm{g}$ and Batiacasphaera spp (299.07 mbsf, $21 \mathrm{~g} / \mathrm{g}$ ) was sparse above in the Early Oligocene with a last occurrence of $1.0 \mathrm{~g} / \mathrm{g}$ at 280.33 mbsf. Corrudinium regulare (305.16 mbsf, $3.7 \mathrm{~g} / \mathrm{g}$ ), was sporadic below the boundary and reoccurs in the Oligocene with a last occurrence of $1.6 \mathrm{~g} / \mathrm{g}$ at 272.24 mbsf. Operculodinium janducheni (1.1 g/g, $286.53 \mathrm{mbsf})$ has a last occurrence of $1.6 \mathrm{~g} / \mathrm{g}$, at $272.24 \mathrm{mbsf}$ in the Early Oligocene. The Acritarch Cymatiosphaera spp $(5.6 \mathrm{~g} / \mathrm{g}, 286.53 \mathrm{mbsf})$ decreases with a last occurrence of $0.9 \mathrm{~g} / \mathrm{g}$, at $261.27 \mathrm{mbsf}$, in the Early Oligocene.

Terrestrial material ( $286.53 \mathrm{mbsf}, 3.4 \mathrm{~g} / \mathrm{g}$ ) occurs in the Early Oligocene with a peak at $13.8 \mathrm{~g} / \mathrm{g}$ at $280.33 \mathrm{mbsf}$, before decreasing with a last occurrence of $2 \mathrm{~g} / \mathrm{g}$ at 253.55 mbsf.

\subsubsection{Site 748B - Figure 3.9}

In site 748B palynomorphs were absent above the $\mathrm{E} / \mathrm{O}$ boundary, their last record is 126.36 mbsf towards the base of CP15b/NP19-20 in the Late Eocene. Dinocysts abundances in this site range from $0.26 \mathrm{~g} / \mathrm{g}$ (Spinidinium macmurdoense) to 1712.8 g/g (Thalassaphora spp). The Phthanoperidinium echinatum and geminatum zones are present and the last occurrence of Corrudinium regulare at 126.36 mbsf marks 


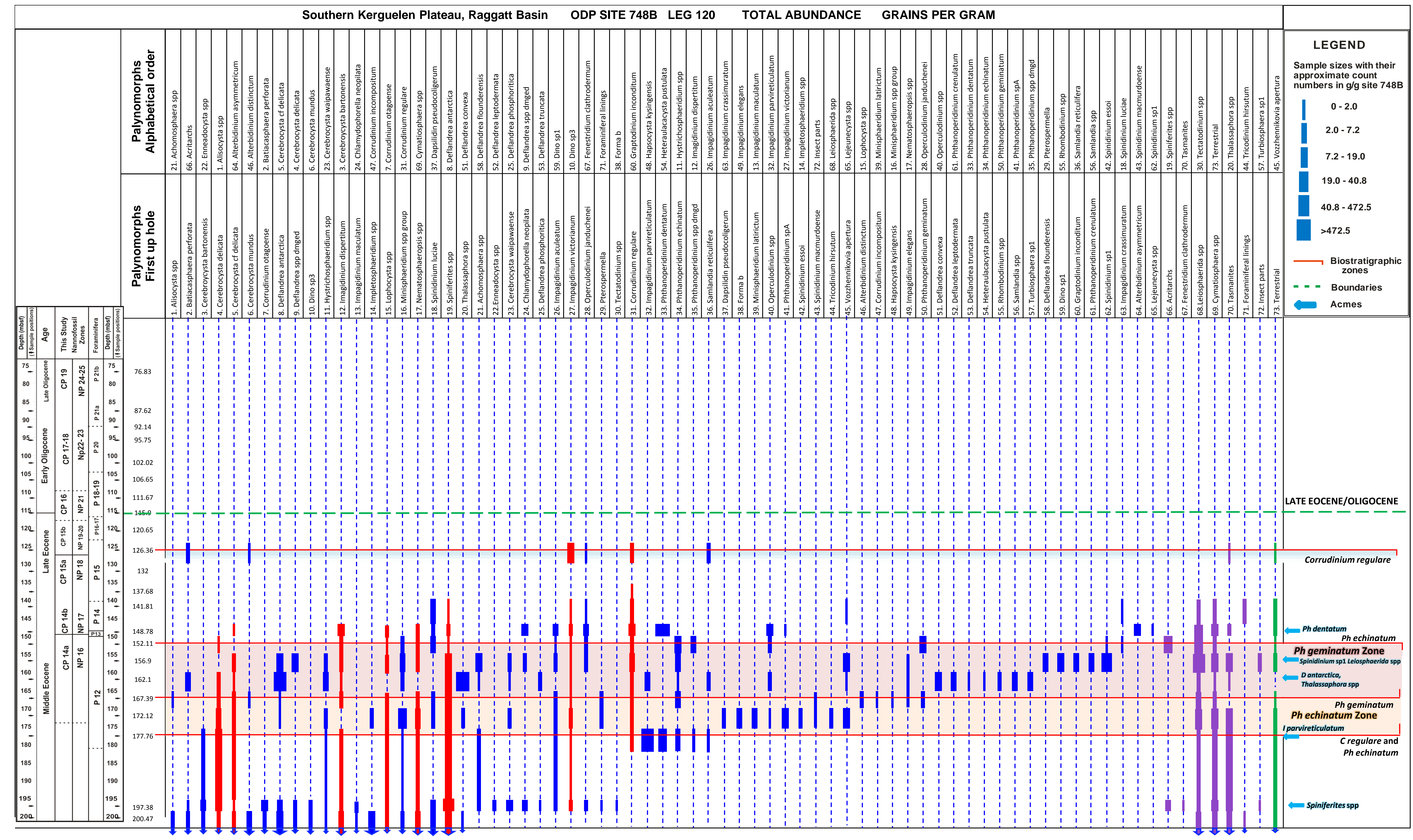

作

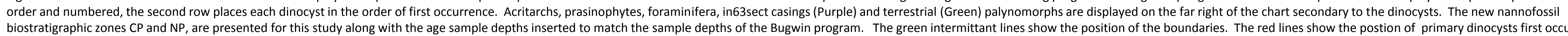
last occurrence. The position of acmes are show by the blue arrows. Palynomorphs in red are longer ranging and appear in most depths and blue palynomorrohs are sporadic in appearance. 
the top of the Corrudinium regulare zone. No primary datums have been recognised between the top of the Phthanoperidinium geminatum zone and the top of the Corrudinium regulare zone.

Twenty dinocysts species which first appear at the base of the section (200.47 mbsf), of which six are more consistent in appearance upsection. These are Cerebrocysta delicata $(7.7 \mathrm{~g} / \mathrm{g}, 200.47)$, reaching $31.7 \mathrm{~g} / \mathrm{g}$ at $177.76 \mathrm{mbsf}$, before decreasing to $0.4 \mathrm{~g} / \mathrm{g}$ at $148.78 \mathrm{mbsf}$. Cerebrocysta cf delicata $(2.6 \mathrm{~g} / \mathrm{g}, 200.47$ $\mathrm{mbsf}$ ), increases to $6.3 \mathrm{~g} / \mathrm{g}(167.39 \mathrm{mbsf})$, and decreases above to $0.2 \mathrm{~g} / \mathrm{g}$ at 141.81 mbsf. Impagidinium dispertitum (16.3 g/g, $200.47 \mathrm{mbsf}$ ) is found only sporadically above with the highest abundance at end of its range of $24.2 \mathrm{~g} / \mathrm{g}$ at $148.78 \mathrm{mbsf}$. Lyphocysta spp with a first occurrence of $1.7 \mathrm{~g} / \mathrm{g}$, at $200.45 \mathrm{mbsf}$, is consistent above though sparse throughout with a last occurrence reduced to $0.3 \mathrm{~g} / \mathrm{g}$ at 141.81 mbsf. The highest abundance of Nematosphaeropsis spp occurs at $15.4 \mathrm{~g} / \mathrm{g}$, 200.47 mbsf. Numbers fluctuate upsection, fading at the last occurrence with 0.3 g/g, at 148.78 mbsf. Spiniferites spp (42.0 g/g, 200.47 mbsf), peaks at $282.719 \mathrm{~g} / \mathrm{g}$ (197.38 mbsf) and is abundant above occurring in every sample upsection to its last occurrence at $141.81 \mathrm{mbsf}$ where it has decreased to $0.6 \mathrm{~g} / \mathrm{g}$.

Other long ranging dinocysts in this site are the first occurrence of Impagidinium victorianum at $197.38 \mathrm{mbsf}(6.6 \mathrm{~g} / \mathrm{g})$. This species occurs only sparsely up to the end of its range where it increases to $27.0 \mathrm{~g} / \mathrm{g}$ at $126.36 \mathrm{mbsf}$. Corrudinium regulare first occurs at $177.76 \mathrm{mbsf}(6 \mathrm{~g} / \mathrm{g})$ and increases up section reaching its highest abundance of $36 \mathrm{~g} / \mathrm{g}$, (148.78 mbsf), the last occurrence is at $126.36 \mathrm{mbsf}$ where it records only $2.2 \mathrm{~g} / \mathrm{g}$.

Dinocysts not as long ranging and more sporadic in their presence include Deflandrea antarctica first occurring at $200.47 \mathrm{mbsf}(42.9 \mathrm{~g} / \mathrm{g})$. This species is sporadic above with the highest abundance of $459.5 \mathrm{~g} / \mathrm{g}$ (162.1 mbsf) and decreases to $45.1 \mathrm{~g} / \mathrm{g}$ at $156.9 \mathrm{mbsf}$ in its last occurrence. Thalassaphora spp (200.4 mbsf, 0.9 $\mathrm{g} / \mathrm{g}$ ) has its highest abundance and last occurrence of $1712.807 \mathrm{~g} / \mathrm{g}$ at $162.1 \mathrm{mbsf}$. Impagidinium aculeatum first occurs at $197.38 \mathrm{mbsf}(3.6 \mathrm{~g} / \mathrm{g})$ and is consistent up 
section with the highest abundance in its last occurrence at $13.4 \mathrm{~g} / \mathrm{g}(148.78 \mathrm{mbsf})$. Phthanoperidinium dentatum at $177.76 \mathrm{mbsf}(151.6 \mathrm{~g} / \mathrm{g})$ is sporadic above although its last occurrence of $552.3 \mathrm{~g} / \mathrm{g}$ at $148.78 \mathrm{mbsf}$ shows very high numbers. There are a number of dinocysts that occur in one sample only in the Phthanoperidinium echinatum or Phthanoperidinium geminatum Zones.

Among the other marine palynomorphs the longest ranging are of the Acritarch Leiosphaerida spp (17.2 g/g, $200.47 \mathrm{mbsf})$ with high abundances of $157.0 \mathrm{~g} / \mathrm{g}$, (152.11 mbsf) and $163.5 \mathrm{~g} / \mathrm{g}(148.78 \mathrm{mbsf})$, then fading at their last occurrence at $2.4 \mathrm{~g} / \mathrm{g}$ (141.81 mbsf). The Prasinophycean Algae has a first occurrence of Cymatiosphaera spp at $200.47 \mathrm{mbsf}(18.8 \mathrm{~g} / \mathrm{g})$, and are consistent up section with a highest abundance of $49.7 \mathrm{~g} / \mathrm{g}$, at $148.78 \mathrm{mbsf}$ and a last occurrence at $141.81 \mathrm{mbsf}$ of $7.0 \mathrm{~g} / \mathrm{g}$. Tasmanites first occur at $200.47 \mathrm{mbsf}(16.2 \mathrm{~g} / \mathrm{g})$ and appear sporadically above with the highest abundance of $72.4 \mathrm{~g} / \mathrm{g}$ at $177.76 \mathrm{mbsf}$ and the last occurrence reduced to $1.1 \mathrm{~g} / \mathrm{g}$, at $126.36 \mathrm{mbsf}$. Microforaminiferal linings are very sparse being recorded in only two samples. Terrestrial material occurs in most samples up to $126.36 \mathrm{mbsf}$ but has low grains per gram counts.

Acmes occurring throughout this site are:

\section{Below The Phthanoperidinium echinatum Zone}

- Spiniferites spp at $283 \mathrm{~g} / \mathrm{g}$ (197.38 mbsf).

The Phthanoperidinium echinatum Zone

- Imagidinium parvireticulatum at $211.1335 \mathrm{~g} / \mathrm{g}$ (177.76 mbsf). The Phthanoperidinium geminatum Zone

- Deflandrea antarctica at $460.0 \mathrm{~g} / \mathrm{g}$ (162.1 mbsf).

- Thalassaphora spp at $1712.8 \mathrm{~g} / \mathrm{g}$ (162.1 mbsf).

- Spinidinium sp1 at $192.0 \mathrm{~g} / \mathrm{g}(156.9 \mathrm{mbsf})$.

- Leiosphaerida spp at $957.1 \mathrm{~g} / \mathrm{g},(156.9 \mathrm{mbsf})$. Above the Phthanoperidinium geminatum Zone

- Phthanoperidinium dentatum at $552.3 \mathrm{~g} / \mathrm{g}$, (148.78 mbsf). 
In site 748B palynomorph assemblages are dominated by Gonyaulacoid dinocysts recording the highest percentage of $95 \%$ at 197.38 mbsf. Peridinioids highest percentage of $72 \%$ occurs at 148.78 mbsf. Dinocyst percentages range from $0.05 \%$ (Deflandrea spp) to $73 \%$ (Minisphaeridium group).

\subsubsection{Site 277 - Figure $\mathbf{3} .10$}

Dinocysts occurring in this site range from $0.35 \mathrm{~g} / \mathrm{g}$ (Achomosphaera spp) to 175.3 g/g (Operculodinium spp). The Phthanoperidinium spA and Corrudinium regulare zones are present and first occurrences of Phthanoperidinium echinatum and Corrudinium regulare at 292.53 mbsf, define the base of the Phthanoperidinium echinatum zone. Dinocysts first occur at $296.3 \mathrm{mbsf}$, although some rare acritarchs and terrestrial material are recorded below this level.

\subsubsection{Dinocysts below the Oligocene}

Dinocysts consistently appearing below the Oligocene show three species that stand out as being more consistent and longer ranging than the rest. Spiniferites spp first occurrence is at $296.3 \mathrm{mbsf}(3.3 \mathrm{~g} / \mathrm{g})$ and is most abundant up section at 28.3 $\mathrm{g} / \mathrm{g}$, in $265.335 \mathrm{mbsf}$, in the Phthanoperidinium spA Zone. Impagidinium victorianum at $292.53 \mathrm{mbsf} 0.5 \mathrm{~g} / \mathrm{g}$ has a low grains per gram count throughout its occurrence which is consistent up to $185.55 \mathrm{mbsf}(0.55 \mathrm{~g} / \mathrm{g})$. The first occurrence of Operculodinium spp is at $292.53 \mathrm{mbsf}(4.7 \mathrm{~g} / \mathrm{g})$, this species numbers fluctuate above to $175.3245 \mathrm{~g} / \mathrm{g}$ (240.84 mbsf) before fading just before the Early Oligocene to $0.8 \mathrm{~g} / \mathrm{g}$, at $190.8 \mathrm{mbsf}$.

Dinocyst that are sporadic in appearance below the Oligocene are Corrudinium regulare (292.53 mbsf, $2.1 \mathrm{~g} / \mathrm{g})$. This species is sporadic above with a highest abundance at $15.2 \mathrm{~g} / \mathrm{g}, 220.145 \mathrm{mbsf}$ (CP15b/NP19-20) in the Phthanoperidinium spA Zone, and fading to a last occurrence of $0.4 \mathrm{~g} / \mathrm{g}$, at $190.8 \mathrm{mbsf}$. Impagidinium aculeatum from $292.53 \mathrm{mbsf}(2.1 \mathrm{~g} / \mathrm{g})$ is sparse and peaks at $3.5 \mathrm{~g} / \mathrm{g}(265.335 \mathrm{mbsf})$. Nematosphaeropsis spp at $292.53 \mathrm{mbsf}(1.1 \mathrm{~g} / \mathrm{g}$, $)$ is also sporadic above peaking at $8.3 \mathrm{~g} / \mathrm{g}(220.145 \mathrm{mbsf})$. 


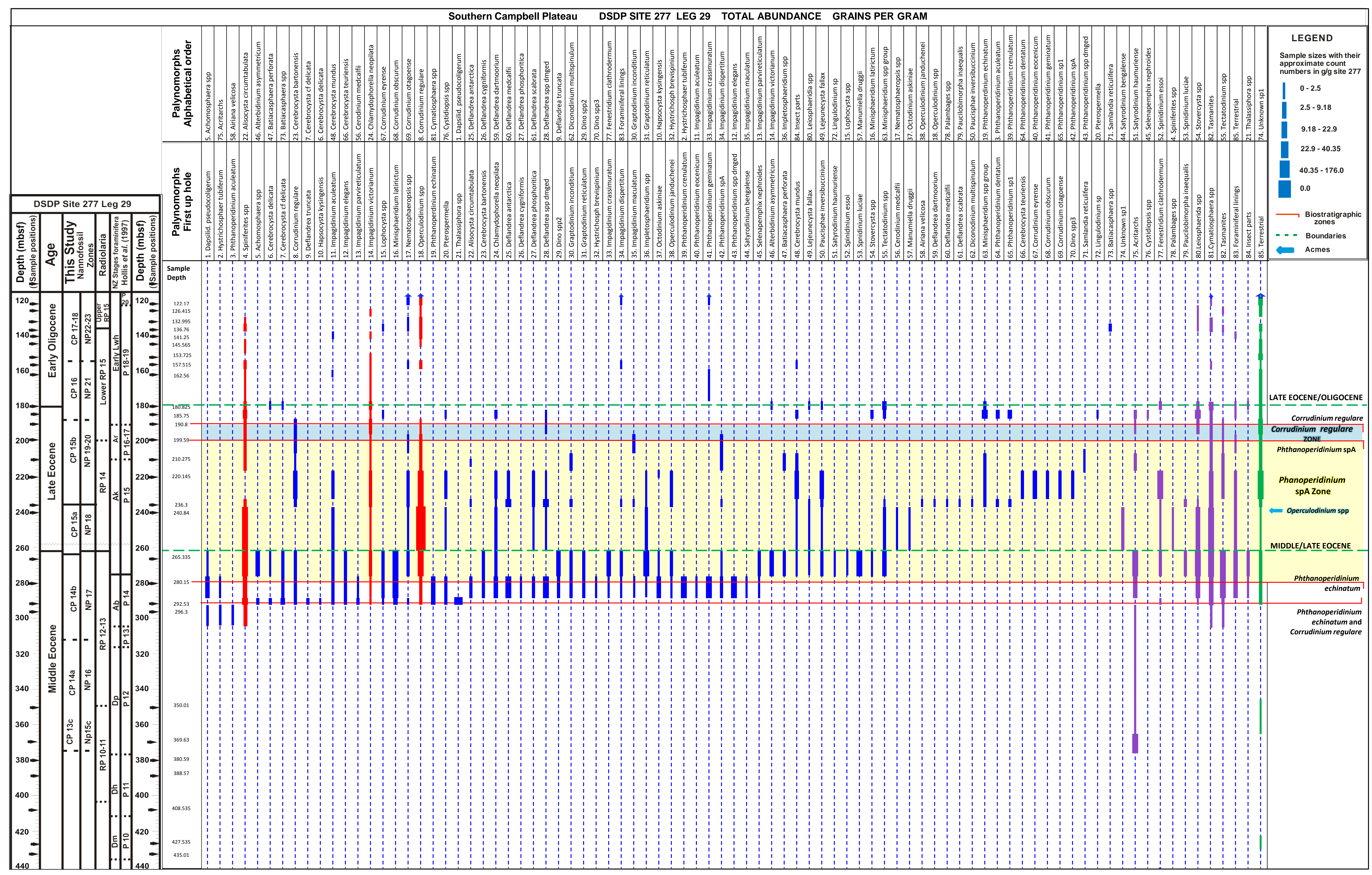

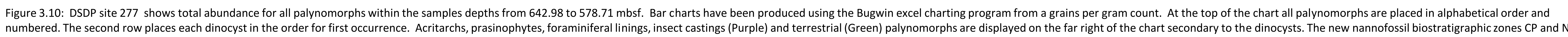
are presented for his sthis 
One acme is recorded for Operculodinium spp of $175.3 \mathrm{~g} / \mathrm{g}$, at $240.84 \mathrm{mbsf}$ (CP15a/NP18), in the Phthanoperidinium spA Zone.

The first occurrence of Acritarchs appears well below the dinocyst first appearances with $21.3 \mathrm{~g} / \mathrm{g}$, being at $369.63 \mathrm{mbsf}$ and a maximum abundance of $47.3 \mathrm{~g} / \mathrm{g}$ at 265.335 mbsf. Leiosphaerida spp first occurs at $292.53 \mathrm{mbsf}(0.5 \mathrm{~g} / \mathrm{g})$, appearances above this level are sporadic to $185.75 \mathrm{mbsf}$, at $24.6 \mathrm{~g} / \mathrm{g}$. The longest ranging of the Prasinophycean Algae is Cymatiosphaera spp which first occurs at 296.3 mbsf (0.7 $\mathrm{g} / \mathrm{g}$ ), with the highest abundance above of $32.8 \mathrm{~g} / \mathrm{g}$, at $240.84 \mathrm{mbsf}$. Tasmanites first occurrence at $296.3 \mathrm{mbsf}$ of $0.6 \mathrm{~g} / \mathrm{g}$, and has a highest abundance up section at $23.1 \mathrm{~g} / \mathrm{g}(280.15 \mathrm{mbsf})$. The first occurrence of microforaminiferal linings are at $16.0 \mathrm{~g} / \mathrm{g}, 280.15 \mathrm{mbsf}$ though they are sporadic above this level and fade near the Oligocene ( $0.5 \mathrm{~g} / \mathrm{g}, 185.75 \mathrm{mbsf})$. Insect casings are very sparse occurring between 280.15 mbsf to 180.825 mbsf.

The first occurrence of Terrestrial material had a small presence in samples below 296.3 mbsf. Above from 292.53 mbsf they occurred in nearly every sample peaking at $22.2 \mathrm{~g} / \mathrm{g}$, at $220.15 \mathrm{mbsf}$.

\subsubsection{Dinocysts in the Early Oligocene}

Dinocysts that continue into the Early Oligocene are Spiniferites spp at 180.825 $\mathrm{mbsf}(5.8 \mathrm{~g} / \mathrm{g})$, and decreases with the last occurrence of $0.4 \mathrm{~g} / \mathrm{g}$, at $132.995 \mathrm{mbsf}$. Impagidinium victorianum ( $180.825 \mathrm{mbsf}, 4.4 \mathrm{~g} / \mathrm{g}$ ) is sporadic above, fading with a last occurrence of $0.4 \mathrm{~g} / \mathrm{g}$, at $126.415 \mathrm{mbsf}$. Operculodinium spp (190.08 mbsf, 0.8 $\mathrm{g} / \mathrm{g}$ ) reoccurs at $157.515 \mathrm{mbsf}(1.6 \mathrm{~g} / \mathrm{g})$ and is sporadic above, decreasing to $3.8 \mathrm{~g} / \mathrm{g}$, at 122.17 mbsf in the Early Oligocene. Impagidinium aculeatum is sparse and sporadic in the Early Oligocene occurring in only two samples at 162.56 mbsf (0.4 $\mathrm{g} / \mathrm{g}$ ) and $141.25 \mathrm{mbsf}$ (0.9 g/g). Nematosphaeropsis spp (199.59 mbsf, $0.7 \mathrm{~g} / \mathrm{g}$ ) reoccurs in the Early Oligocene at $157.515 \mathrm{mbsf}(0.53 \mathrm{~g} / \mathrm{g})$ is sparse and sporadic above with the last occurrence at $122.17 \mathrm{mbsf}(1.6 \mathrm{~g} / \mathrm{g})$. 
The other marine palynomorphs have low grains per gram and are sporadic in the Early Oligocene. The acritarchs have a last occurrence of $0.5 \mathrm{~g} / \mathrm{g}$ is at $141.25 \mathrm{mbsf}$. Leiosphaerida spp last occurs at $1.3 \mathrm{~g} / \mathrm{g}$ at $126.415 \mathrm{mbsf}$ and Cymatiosphaera spp is sporadic up to the last occurrence fading at $0.5 \mathrm{~g} / \mathrm{g}$, at $122.17 \mathrm{mbsf}$. Tasmanites at $180.825(2.2 \mathrm{~g} / \mathrm{g})$ decreases and last occurs at $126.415 \mathrm{mbsf}(0.4 \mathrm{~g} / \mathrm{g})$ and microforaminiferal linings last occur at $141.25 \mathrm{mbsf}(1.5 \mathrm{~g} / \mathrm{g})$. Terrestrial material (180.825 mbsf, $6.5 \mathrm{~g} / \mathrm{g}$ ) last occur with a small reduction to $10.9 \mathrm{~g} / \mathrm{g}$, at 122.17 mbsf. 


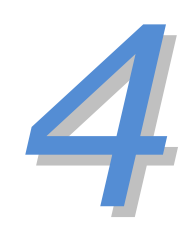

Assemblage Analysis 


\section{CHAPTER FOUR}

\subsection{Assemblage Analysis}

\subsection{Introduction}

Chapter four introduces the data from this study using percentages to document the proportion of various palynomorphs in the assemblages. Percentages from the initial data count were calculated separately for the dinocyst assemblages, the marine palynomorphs assemblages and the total palynomorphs count, including Terrestrial material. To avoid spurious abundance peaks samples containing less than twenty palynomorphs were omitted from calculations. The percentage results of the dinocyst assemblages are separated into two groups representing autotrophs and heterotrophs (Gonyaulacoid/Peridinioid) which are thought to reflect differing environments. Raw data (Appendices 2.5) contains the full counts of all samples, with total abundances in Appendices 2.7-2.14.

\subsection{Gonyaulacoid and Peridinioid Dinocysts}

Evitt (1985) recognized that on the basis of morphology most dinocyst genera could be assigned to either the Order Gonyaulacales or Order Peridiniales, here they will be referred to as Gonyaulacoid or Peridinioid dinocysts. The main differences between their morphology are the tabulation patterns. In Gonyaulacoid dinocysts six precingular and six postcingular plates are a typical number with one antapical plate, whereas the Peridinioid characteristically have seven precingular and five postcingular with two antapical plates. Gonyaulacalean tabulation is also missing the left sulcal plate and the cingulum is offset at the flagella pore. In the Peridinialean tabulation the cingulum is only slightly offset and both the left and right sulcal are present (Evitt, 1985; Fensome et al., 1996; Williams et al., 2000).

Gonyaulacoids are thought to largely represent autotrophs, reliant on sunlight for photosynthesis and dissolved nutrients as a food source and considered warmer water species. Peridinioids are mostly heterotrophs and capture their prey; they are common in high latitude sites where sea-ice can occur (Williams et al., 2009). 
High Gonyaulacoid percentages principally represent oligotrophic conditions of outer neritic to open ocean, low Gonyaulacoid percentages represent eutrophic conditions of shallow inner neritic waters, or may represent upwellings or sea-ice cover (Pross and Brinkhuis, 2005; Sluijs et al., 2005). Based on this assumption the differences in dinocyst feeding strategies are often used by researchers to indicate productivity variations during the Paleogene (Crouch and Brinkhuis, 2005; Dale, 1996; Pross and Brinkhuis., 2005; Röhl et al., 2004; Sluijs et al., 2005).

\subsection{Dinocyst Groups}

Brinkhuis and Biffi (1993) defined dinocysts groupings of morphologically related taxa and with a known similarity of environmental affinity. These groups are often dominated by one taxon after which the group is named. These are shown in Table 4.1.

\begin{tabular}{|c|c|}
\hline Dinocyst genera & Dinocyst Groups \\
\hline $\begin{array}{c}\text { Spiniferites spp (dominant) } \\
\text { Achomosphaera spp }\end{array}$ & Spiniferites group \\
\hline $\begin{array}{c}\text { Impagidinium spp (dominant) } \\
\text { Nematosphaeropsis spp }\end{array}$ & Impagidinium group \\
\hline $\begin{array}{c}\text { Operculodinium spp (dominant) } \\
\text { Impletosphaeridium spp }\end{array}$ & Operculodinium group \\
\hline Various genera & Minisphaeridium group \\
\hline
\end{tabular}

Table 4.1: Dinocysts that are morphologically related in this study have been placed in groups and named under their dominant genera. The Minisphaeridium group is considered to contain all very small spheroidal cysts and dominance of one genera cannot be ascertained (Brinkhuis and Biffi, 1993; Fensome et al., 2009).

The percentage figures were calculated using the groupings as defined by Brinkhuis and Biffi (1993) and Fensome et al. (2009). Throughout each site (ODP 696B, 699A, 748B, DSDP 277) the dominant genus for each dinocyst group was recorded as shown in Table 4.1 and combined with other dinocyst genera for interpreting the palaeoenvironment. The grouping of morphologically related dinocysts has been used by researchers to assist with interpretation of the palaeoenvironment in other 
studies (Brinkhuis and Biffi, 1993; Brinkhuis, 1994; Crouch and Brinkhuis, 2005; Eldrett and Harding, 2009; Firth, 1996; Pross and Schmiedl, 2002).

Among the Minisphaeridium group dominance of one genus cannot be ascertained. The group encompasses all very small spheroidal cysts (central body 20-25 $\mu \mathrm{m}$ across), proximochorate to chorate as discussed by Fensome et al. (2009). The dinocysts are placed into the Minisphaeridium group due to the high yields found in assemblages and a lack of a generic name to assign them. In this study the groups are found in each site.

Each site is represented by two figures ( $4.1 a, b$ to $4.4 a, b)$. All the "a" figures show the dinocyst data as discussed above. The " $b$ " figures show both the entire marine and non marine breakdown and the breakdown of the complete palynomorph assemblage. Appendix 2.6 displays Gonyaulacoid and Peridinioid dinocysts totals from each site. The dinocyst zones developed in chapter 3 are shown in all Figures. Charts of the total abundance and marine genera can be found in Appendices 2.72.14 respectively. A Gonyaulacoid and Peridinioid analysis of ODP site 1172 of Sluijs et al. (2003) has been included as Figure 4.5 for comparison to sites from this study.

\subsubsection{Site 696B, South Orkney microcontinent, Weddell Sea Palynomorph assemblages (642.98-578.71 mbsf)}

Figures 4.1a, b, illustrate the dominance of Peridinioid dinocysts assemblages among the marine palynomorphs, recording their highest percentage of $92 \%$ (612.75 mbsf) in the Corrudinium regulare zone. Gonyaulacoid dinocysts recorded their highest percentage of $37 \%$ (617.7 mbsf) in the Phthanoperidinium spA Zone. The dinocyst groups and species percentages range from the highest percentage of $76 \%$ recorded by Spinidinium spp to a low of $0.12 \%$ recorded by the Spiniferites group. The non dinocyst marine palynomorphs are sparse in this site and consist of Acritarchs, Prasinophyta algae, microforaminiferal linings and some insect parts. Terrestrial material are the most dominant palynomorphs present making up $68.8 \%$ of all the assemblages. 


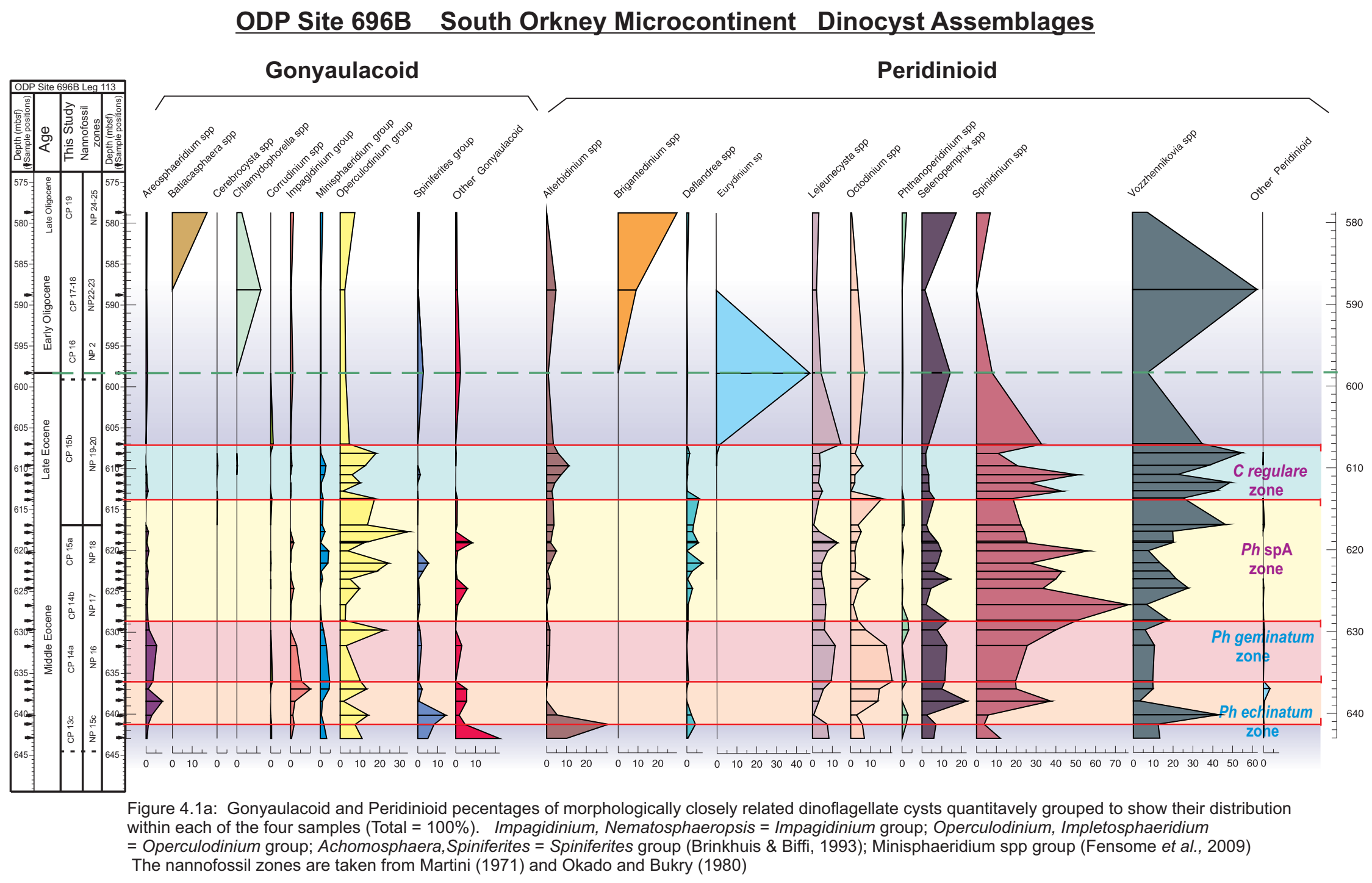




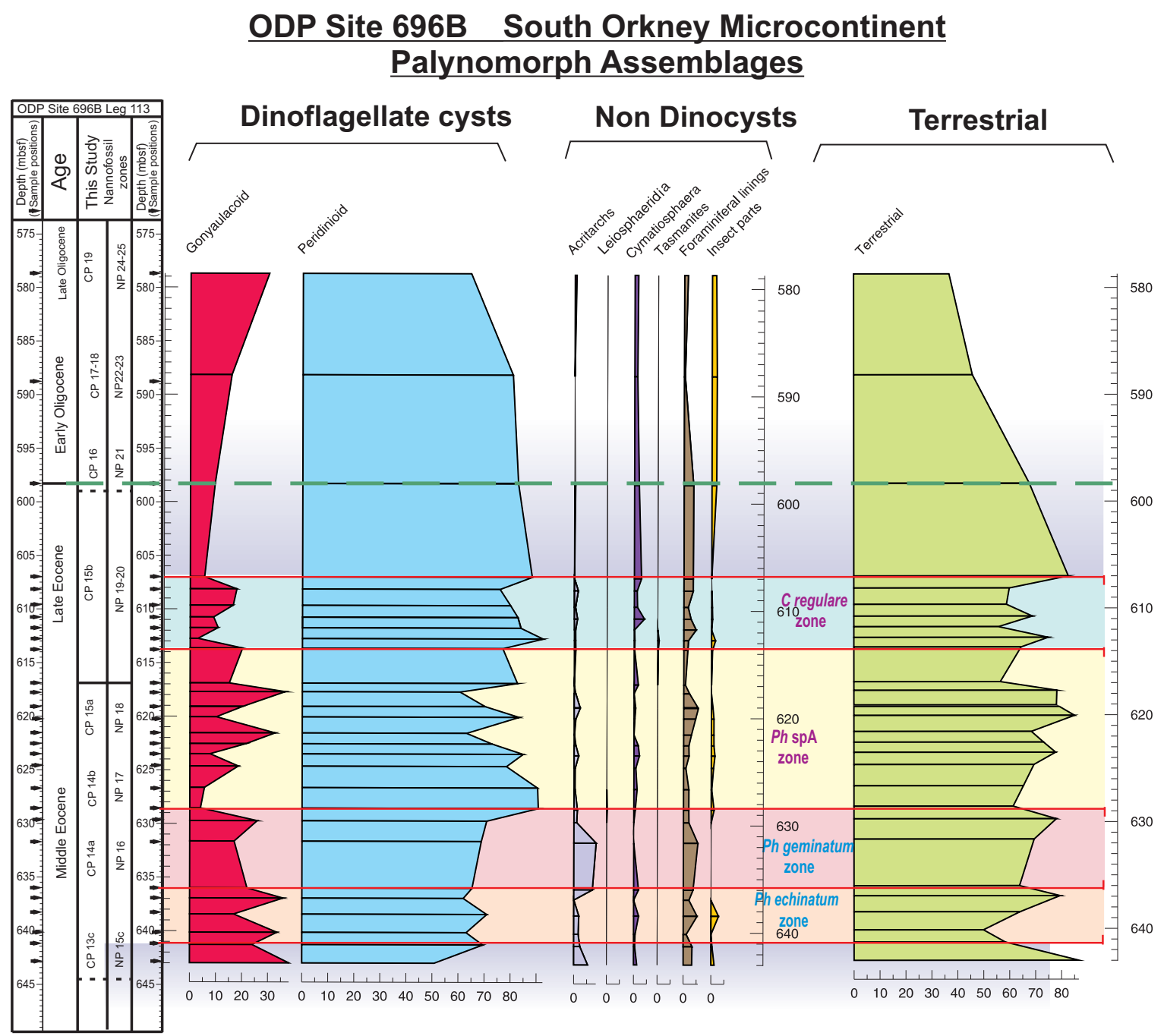

Figure 4.1b: Gonyaulacoid and Peridinioid dinocysts are compared with other marine palynomorphs (Acritarchs, Cymatiosphaera, Leiosphaerida,Tasmanites, Foraminifera and Insect parts). All marine palynomorphs $=100 \%$. Terrestrial palynomorphs percentage was taken from a total abundance and presented here for comparison. The green dashed lines represent the E/O and Middle/Late boundaries. The nannofossil zones are taken from Martini (1971) and Okado and Bukry (1980) 


\subsubsection{Palynomorph assemblages in the Eocene (642.98-607 mbsf)}

\section{Figure 4.1a}

Peridinioid dinocysts assigned to the genera Spinidinium spp and Vozzhennikovia spp display a reciprocal relationship between 642.98 and 607 mbsf. Yields were highest in the Middle Eocene with Spinidinium spp recording 76 \% (626.64 mbsf) in the Phthanoperidinium spA Zone. Vozzhennikovia spp yielded higher percentages in the Late Eocene peaking at 55 \% (608.13 mbsf) in the Corrudinium regulare zone. In addition other well represented dinocysts include peaks of Selenopemphix spp (22 \%, $638.43 \mathrm{mbsf}$ ) recorded in the Phthanoperidinium echinatum Zone, Octodinium spp (18 \%, $631.63 \mathrm{mbsf})$ recorded in the Phthanoperidinium geminatum Zone and, up section, Lejeunecysta spp peaks at the top of the Corrudinium regulare Zone (14 $\%, 607 \mathrm{mbsf})$.

Gonyaulacoids are sparse in comparison to Peridinioid dinocysts and are dominated by the Operculodinium group with the highest abundance of $34 \%$ at $617.7 \mathrm{mbsf}$ in the Phthanoperidinium spA Zone. Lower percentages of Areosphaeridium spp (638.43 mbsf), Spiniferites group (640.13 mbsf) and Impagidinium group (636.94 mbsf), peak in the Phthanoperidinium echinatum Zone at $8 \%, 14 \%$ and $10 \%$ respectively, while all other Gonyaulacoids dinocysts are sparse in the Eocene.

\section{Figure 4.1b}

This figure again demonstrates that Peridinioid dinocysts dominate all the marine palynomorphs over this interval. The Acritarchs are sparse although present in almost every sample with the highest percentage in the Phthanoperidinium echinatum Zone of 8 \%, (631.63 mbsf). The Prasinophyta algae Cymatiosphaera are sparse with $4 \%$ at 610.75 mbsf. Tasmanites percentages were low and specimens were recorded in only a few samples. Microforaminiferal linings occurred in every sample with the highest percentage of $6 \%$ occurring at $619.06 \mathrm{mbsf}$ in the Phthanoperidinium spA Zone. Insect parts were sporadic in appearance. Terrestrial material dominate this interval with peaks of $86 \%$ (642.98 mbsf), $85 \%$ (620.05 mbsf) and $83 \%$ (607 mbsf). 


\subsubsection{Palynomorph assemblages in the Early Oligocene (598.3-578.71 mbsf)}

\section{Figure 4.1a}

Above the Corrudinium regulare Zone the sampling is at a lower resolution $(\sim 10 \mathrm{~m}$ in comparison to the $\sim 2 \mathrm{~m}$ sampling below). Peridinioid dinocysts dominate the Early Oligocene assemblages. Changes occurring at the E/O transition include an increase in the percentage of Eurydinium spp from $2 \%$ at $607 \mathrm{mbsf}$ to a high yield of $47 \%$ at $598.3 \mathrm{mbsf}$, dominating the assemblages from this depth. Selenopemphix spp makes up $14 \%$ of the assemblage at $598.3 \mathrm{mbsf}$ while the percentage of all other dinocysts species has decreased.

At 588.16 mbsf Vozzhennikovia spp dominate the assemblage (63\%). Species attributable to the genus Brigantedinium make their first appearance at 588.16 mbsf where they represent $10 \%$ of the assemblage and increase to $30 \%$ at 578.71 mbsf. In the youngest sample at 578.71 mbsf Selenopemphix spp yields $17 \%$ and Vozzhennikovia spp has decreased to $7 \%$. Spinidinium spp (7\%), Octodinium spp (4 \%) and Lejeunecysta spp (7 \%) were sparse from 598.3 mbsf although they maintain a presence up to the youngest sample.

The yield of the Gonyaulacoid genus Chlamydophorella spp (12 \%, 588.16 mbsf) decreases to $2 \%$ at $578.71 \mathrm{mbsf}$ and the Operculodinium group (3 \%, $598.3 \mathrm{mbsf}$ ) increased slightly to $7 \%$ (578.71 mbsf). Batiacasphaera spp first occurs in the youngest sample at 578.71 mbsf where it makes up $18 \%$ of the assemblage.

\section{Figure 4.1b}

This figure illustrates the continuing dominance of Peridinioid dinocysts above the E/O transition yielding $83 \%$ at 598.3 mbsf decreasing to $64 \%$ in the youngest sample (578.71 mbsf). In contrast Gonyaulacoid dinocysts were $9 \%$ at $598.3 \mathrm{mbsf}$ and increase to $30 \%$ in the youngest sample ( $578.71 \mathrm{mbsf}$ ). At $578.71 \mathrm{mbsf}$ only low yields of Cymatiosphaera (1\%) and microforaminiferal linings (1\%) are present. Terrestrial material still dominate all marine palynomorphs at 598.3 mbsf yielding $68 \%$. However in the last two samples shows a decrease with $46 \%$ at 588.16, near 
equal with Peridinioid dinocysts, and is no longer dominant at $578.71 \mathrm{mbsf}$ with 37 $\%$.

\subsubsection{Site 699A, Northeast Georgia rise, Palynomorph assemblages (465.65-249.73 mbsf)}

Gonyaulacoid dinocysts assemblages are dominant throughout most of this site with the highest percentage at $72 \%$ (299.07 mbsf). Peridinioid percentages peak at 293.83 mbsf where they make up $77 \%$ of the dinocyst assemblage. Dinocyst genera are fewer in numbers compared with other sites in this study.

Phthanoperidinium spp has the highest percentage of $92 \%$ among the dinocyst groups and species with a low percentage of $0.5 \%$ from Corrudinium spp. Among the non-dinocysts, Acritarchs, Prasinophyta algae and Insect parts have been recorded. Terrestrial material is present in nearly every sample. Palynomorphs are present from the Late Eocene through to the Early Oligocene and are not present in the Middle Eocene.

\subsubsection{Palynomorph assemblages in the Eocene (465.65-293.83 mbsf)}

\section{Figure 4.2a}

In the early Late Eocene CP15a/NP18 at 339.07 mbsf dinocysts are sparse and the only Peridinioid dinocyst present at this depth is Phthanoperidinium spp which makes up $42 \%$ of the dinocyst assemblage. It is the most dominant dinocyst present. The Gonyaulacoid Impagidinium group is also present making up about 35 $\%$ of the assemblage while Corrudinium spp (10 \%) and Operculodinium group (7\%) are minor occurrences. Dinocysts are not present between 334.99-319.86 mbsf and at $319.86 \mathrm{mbsf}$.

Peridinioid dinocysts are absent at 324.55 mbsf and Cerebrocysta spp makes up 75 $\%$ of the assemblage. At 305.16 mbsf Peridinioid occurrences are sparse while Gonyaulacoids yield the highest percentages of Impagidinium group (29\%) and Batiacasphaera spp (17\%). At 299.07 mbsf Impagidinium group remain at $29 \%$ while Batiacasphaera spp has increased to $39 \%$. Spinidinium spp at $14 \%$ is the highest percentage for the Peridinioids at this depth. Close to and below the 
ODP Site 699A Northeast Georgia Rise Dinocyst Assemblages

\section{Gonyaulacoid}

Peridinioid

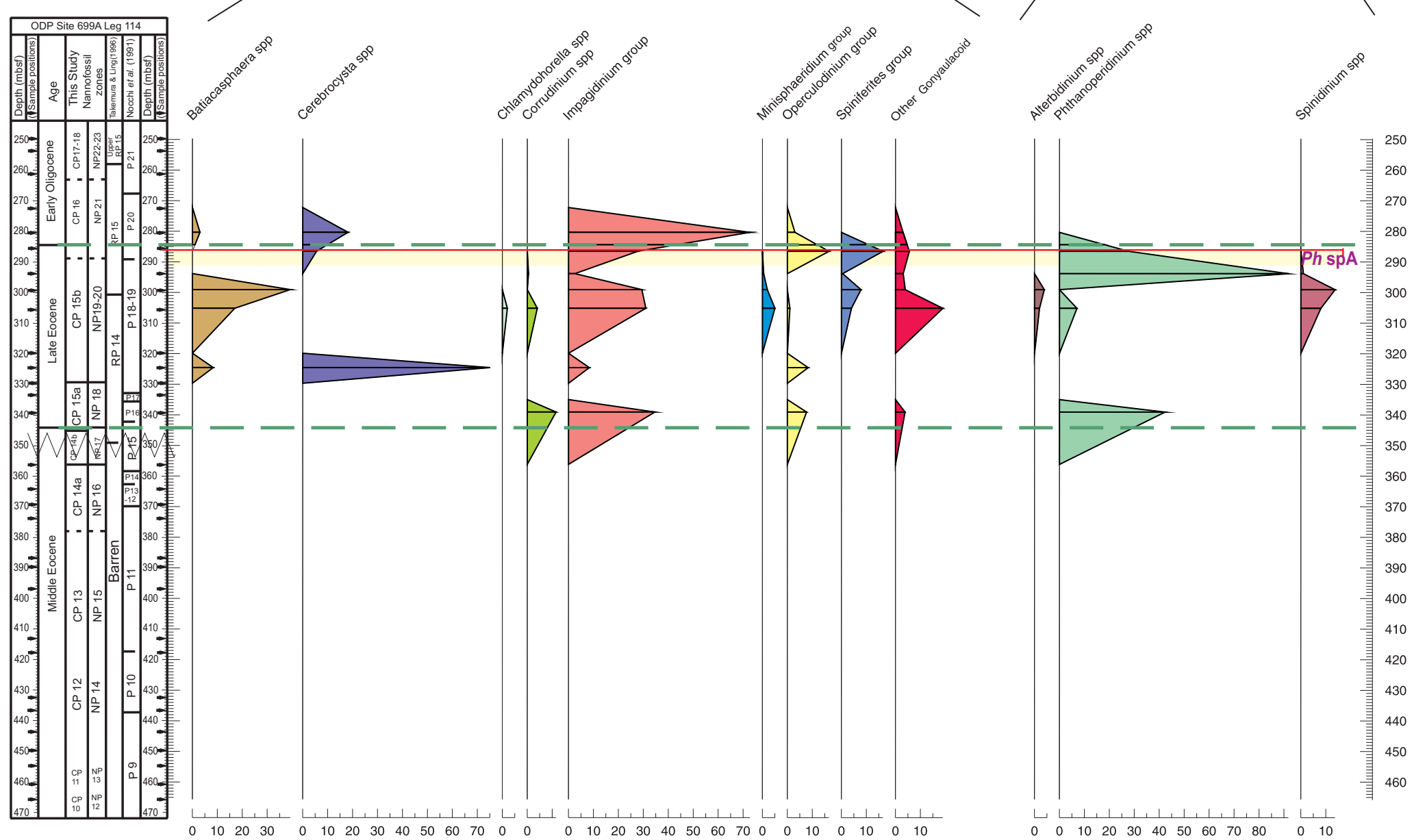
each of the four samples (Total = 100\%). Impagidinium, Nematosphaeropsis = Impagidinium group, Operculodinium, Impletosphaenidium = Operculodinium group: Achomosphaera, Spiniferites = Spiniferites group (Brinkhuis \& Biffi, 1993), Minisphaeridium spp group (Fensome et al., 2009). The nannofossil zones are taken from Martini (1971) and Okado and Bukry (1980). The hiatus is represented by $\mathrm{Wm}$ 


\section{ODP Site 699A Northeast Georgia Rise Palynomorph Assemblages}

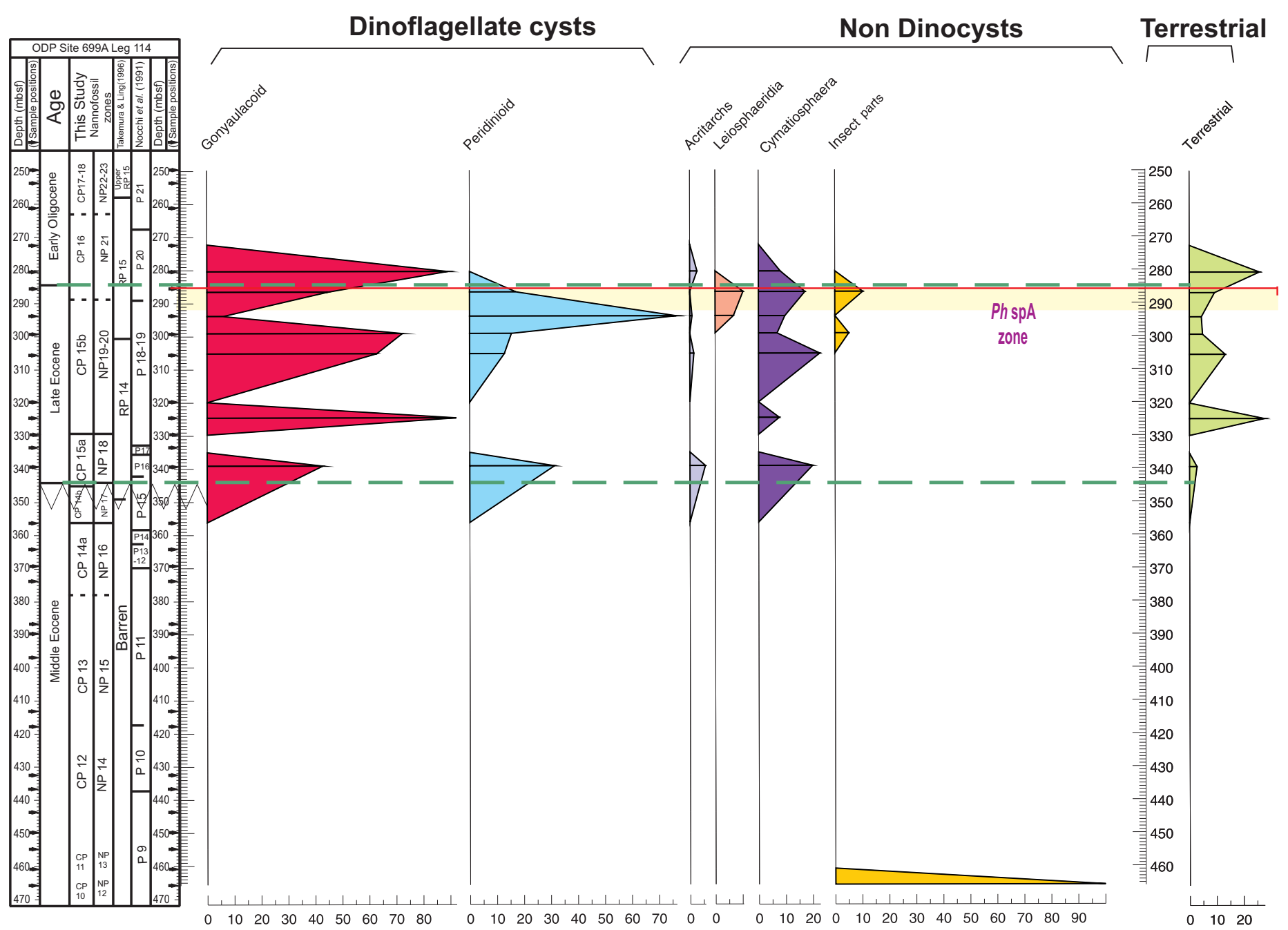

Figure 4.2b: Gonyaulacoid and Peridinioid dinocysts are compared with other marine palynomorphs (Acritarchs, Cymatiosphaera,Leiosphaerida,

Tasmanites, Foraminifera and Insect parts). All marine palynomorphs $=100 \%$. Terrestrial palynomorphs percentage was taken from a total abundance and presented here for comparison. The green dashed lines represent the $\mathrm{E} / \mathrm{O}$ and Middle/Late boundaries. The nannofossil zones are taken from Martini (1971) and Okado and Bukry (1980). The hiatus is represented by
a count of 43 whole and part specimens in one slide. They are a possible contamination 
Eocene/Oligocene transition at 293.83 mbsf, the Peridinioid Phthanoperidinium spp at $92 \%$ dominate the assemblages while all other dinocysts are sparse.

\section{Figure 4.2b}

At 339.07 mbsf Gonyaulacoids make up $43 \%$ and Peridinioids $31 \%$ of the marine palynomorph assemblage. The Prasinophyta algae Cymatiosphaera makes up 20\% while Acritarchs are sparse at $5 \%$. From the middle Late Eocene at $324.55 \mathrm{mbsf}$ only Gonyaulacoids (92\%) and the Prasinophyta algae Cymatiosphaera (8 \%) are present. Cymatiosphaera increase to $22 \%$ up section at $305.16 \mathrm{mbsf}$ and Gonyaulacoids decreased to $63 \%, 305.16$ mbsf although still remain dominant (72 \%) up to 299.07 mbsf. At 293.83 mbsf Gonyaulacoids faded significantly (6 \%) as the Peridinioids ( $77 \%$ ) dominate the assemblages. The Prasinophyta algae Cymatiosphaera is present at $10 \%$ and the Acritarch Leiosphaeridia spp occurs in only two samples, $7 \%$ at $293.83 \mathrm{mbsf}$ and $10 \%$ at $286.53 \mathrm{mbsf}$.

Insect casings occurred in a single sample well below the Middle/Late Eocene boundary at 465.65 mbsf which yielded no other palynomorphs. Despite a raw data count of 43 it is still likely that they are present as a downhole contamination, as insect casings are also present in two samples near the Eocene/Oligocene transition at $5 \%$ (299.07 mbsf) and $10 \%$ (286.53 mbsf).

\subsubsection{Palynomorph assemblages in the Early Oligocene (286.53-249.73 mbsf)}

\section{Figure 4.2a}

At the E/O transition (286.53 mbsf) assemblages of Impagidinium group at $28 \%$ and Phthanoperidinium spp $27 \%$ were nearly equal in dominance, while the Operculodinium and Spiniferites groups both yielded 17\%. In the Early Oligocene at 280.33 mbsf, the Impagidinium group dominate the assemblages at $72 \%$.

Cerebrocysta spp yielded $18 \%$ while Batiacasphaera spp, the Operculodinium group and the Other Gonyaulacoids all recorded $3 \%$. Palynomorphs are absent in samples above 280.33 mbsf. 


\section{Figure 4.2b}

Samples from the Early Oligocene yield assemblages dominated by Gonyaulacoid dinocysts (89 \% at $280.33 \mathrm{mbsf}$ ). Among the non dinocysts only the Prasinophyte Cymatiosphaera (8\%) and Acritarchs (3\%) were present. Terrestrial material is present in most samples with a highest percentage of $27 \%$ at $324.55 \mathrm{mbsf}$ and $26 \%$ at $280.33 \mathrm{mbsf}$ and to a lesser extent follows a similar distribution pattern to the Gonyaulacoid dinocysts.

\subsubsection{Site 748B, Southern Kerguelen Plateau, Raggatt Basin Palynomorph assemblages (200.47-76.83 mbsf)}

Figures 4.3a-b shows that Gonyaulacoid dinocysts dominate assemblages from the base of the site recording their highest percentage of $81 \%$ at $197.38 \mathrm{mbsf}$. Peridinioid assemblages become dominant from the middle of the Phthanoperidinium geminatum Zone. They dominated the assemblages with $57 \%$ at $148.78 \mathrm{mbsf}$ above that zone. Dinocyst groups and species percentages range from a high of $73 \%$ by the Minisphaeridium group with the lowest percentage of $0.05 \%$ by Deflandrea spp. The non dinocyst marine palynomorphs consist of Acritarchs, Prasinophyta algae, microforaminiferal linings and insect casings, although the latter are too sparse to be included. Terrestrial material is sparse at this site and all palynomorphs are absent across the E/O transition and into the Early Oligocene.

\subsubsection{Palynomorph assemblages in the Eocene (200.47- $126.36 \mathrm{mbsf}$ )}

\section{Figure 4.3a}

Gonyaulacoid dinocyst assemblages dominate between 197.38-162.1 mbsf with their dominance changing in each sample from the base of the section into the Phthanoperidinium echinatum and geminatum Zones above. From the lower sample of $197.38 \mathrm{mbsf}$, Spiniferites group is most dominant at $56 \%$. At the base of the Phthanoperidinium echinatum Zone at 177.76 mbsf Impagidinium group is most dominant at $46 \%$ while in the middle of that zone Minisphaeridium group at $73 \%$ (172.12 mbsf) is dominant. At the top of the zone the Spiniferites group with $59 \%$ 


\section{ODP Site 748B Southern Kerguelen Plateau, Raggatt Basin Dinocyst Assemblages}

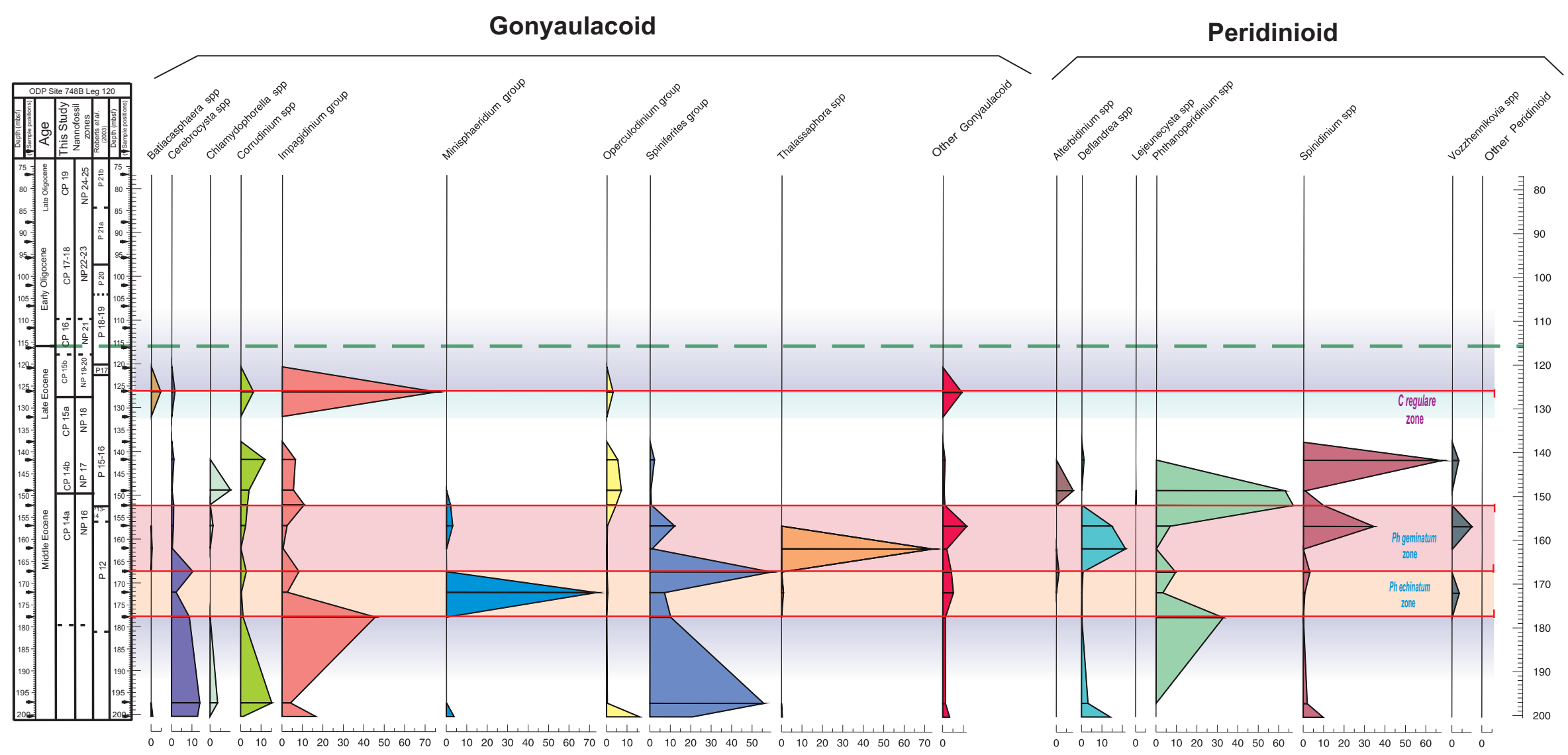

Figure 4.3a: Gonyaulacoid and Peridinioid pecentages of morphologically closely related dinoflagellate cysts quantitavely grouped to show their distribution within each of the four samples (Total $=100 \%$ ). Impagidinium, Nematosphaeropsis = Impagidinium group; Operculodinium, Impletosphaeridium = Operculodinium group; Achomosphaera, Spiniferites = Spiniferites group (Brinkhuis \& Biffi, 1993$) ;$ Minisph
The positions of the dinocyst zones are shown. 


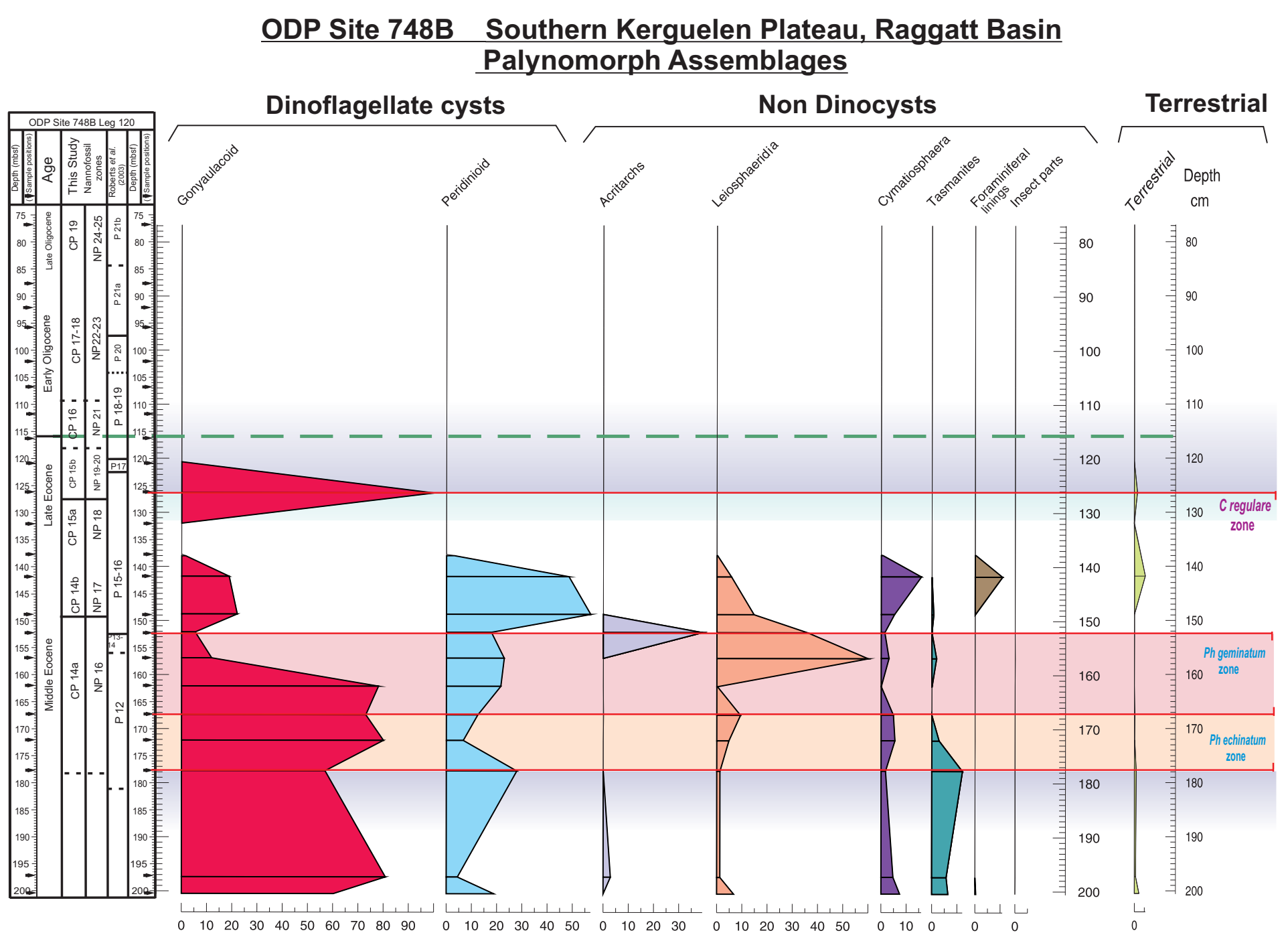

Figure 4.3b: Gonyaulacoid and Peridinioid dinocysts are compared with other marine palynomorphs (Acritarchs, Cymatiosphaera,Leiosphaerida,Tasmanites, Foraminifera and Insect parts). All marine palynomorphs $=100 \%$. Terrestrial palynomorphs percentage was taken from a total abundance and presented here for comparison. The green dashed lines represent the E/O and Middle/Late boundaries. The nannofossil zones are taken from Martini (1971) and Okado and
Bukry (1980). The positions of the dinocyst zones are shown. 
(167.39 mbsf) dominate the assemblages. In the Phthanoperidinium geminatum Zone, Thalassaphora spp with 74 \% (162.1 mbsf) dominate as an acme.

Peridinioid assemblages increase in the Phthanoperidinium geminatum Zone from $162.1 \mathrm{mbsf}$ as Deflandrea spp records $21 \%$. Gonyaulacoids become less abundant at 156.9 mbsf as Spinidinium spp yields $35 \%$ and Deflandrea spp $15 \%$ of the assemblages. At the top of the Zone and in the next sample above Phthanoperidinium spp now dominate the assemblages at $67 \%$ (152.11 mbsf) and $63 \%$ (148.78 mbsf) respectively, while further above at $141.81 \mathrm{mbsf}$, Spinidinium spp dominate at $68 \%$. Dinocysts are absent in samples 137.68 and 132 mbsf.

At the top of the Corrudinium regulare Zone 126.36 mbsf Peridinioid assemblages are absent and the Impagidinium group dominate, making up $75 \%$ of the dinocyst assemblages present.

\section{Figure 4.3b}

From the base of the section to the middle of the Phthanoperidinium geminatum Zone, Gonyaulacoids dominate all palynomorph assemblages yielding $60 \%$ at 200.47 mbsf with a highest yield of $80 \%$ at 197.38 and 172.12 mbsf. In this interval Peridinioid assemblages yielded $28 \%$ at 177.76 mbsf. At 156.9 mbsf the Acritarch Leiosphaeridia spp makes up $60 \%$ of all palynomorph assemblages, while Gonyaulacoids ( $11 \%$ ) have decreased as Peridinioids increased to $23 \%$. At the top of the Zone at 152.11 mbsf the Acritarchs (39\%) and Leiosphaeridia spp (36 \%) were most dominant. In samples 138.78 and 141.81 mbsf Peridinioids made up $57 \%$ and $49 \%$ of the marine assemblages respectively, dominating all other palynomorphs.

Minor occurrences of Tasmanites yielded $6 \%$ at $200.47 \mathrm{mbsf}$ and increased at the base of the Phthanoperidinium echinatum Zone yielding $12 \%$ at 177.76 mbsf before fading above. The only occurrence of microforaminiferal linings was recorded at 141.81 mbsf where they make up $11 \%$ of the marine palynomorph assemblage. Terrestrial material makes up less than $10 \%$ of the assemblages. 


\section{DSDP Site 277 Southern Campbell Plateau Dinocyst Assemblages}

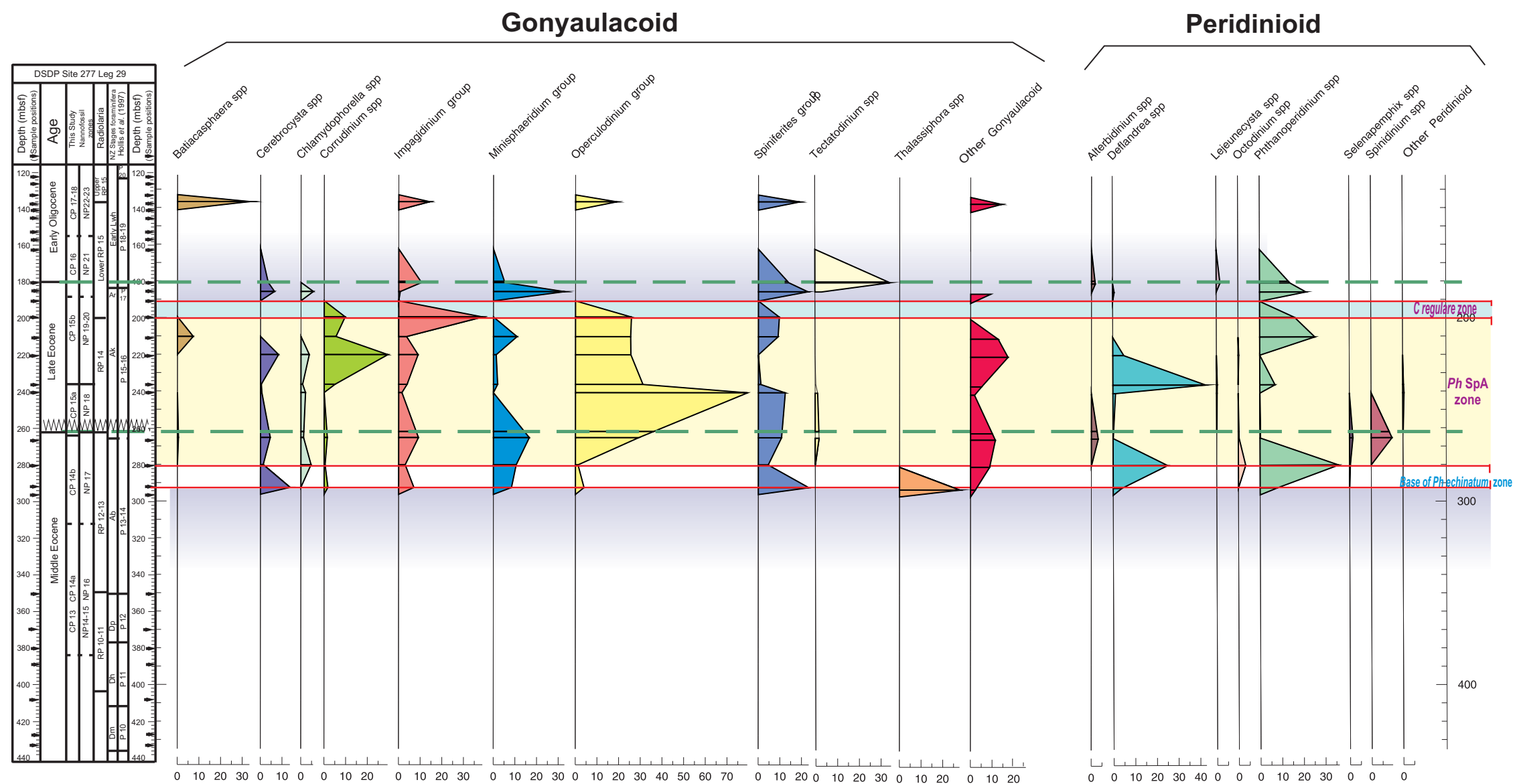

Figure 4.4a: Gonyaulacoid and Peridinioid pecentages of morphologically closely related dinoflagellate cysts quantitavely grouped to show their distribution within each of the four samples (Total $=100 \%$ ). Impagidinium, Nematosphaeropsis = Impagidinium group; Operculodinium, Impletosphaeridium = Operculodinium group; Achomosphaera, Spiniferites = Spiniferites group (Brinkhuis \& Biffi, 1993); Minisphaeridium spp group (Fensome et al., 2009) The nannofossil zones are taken from Martini (1971) and Okado and Bukry (1980). The hiatus = WWM 


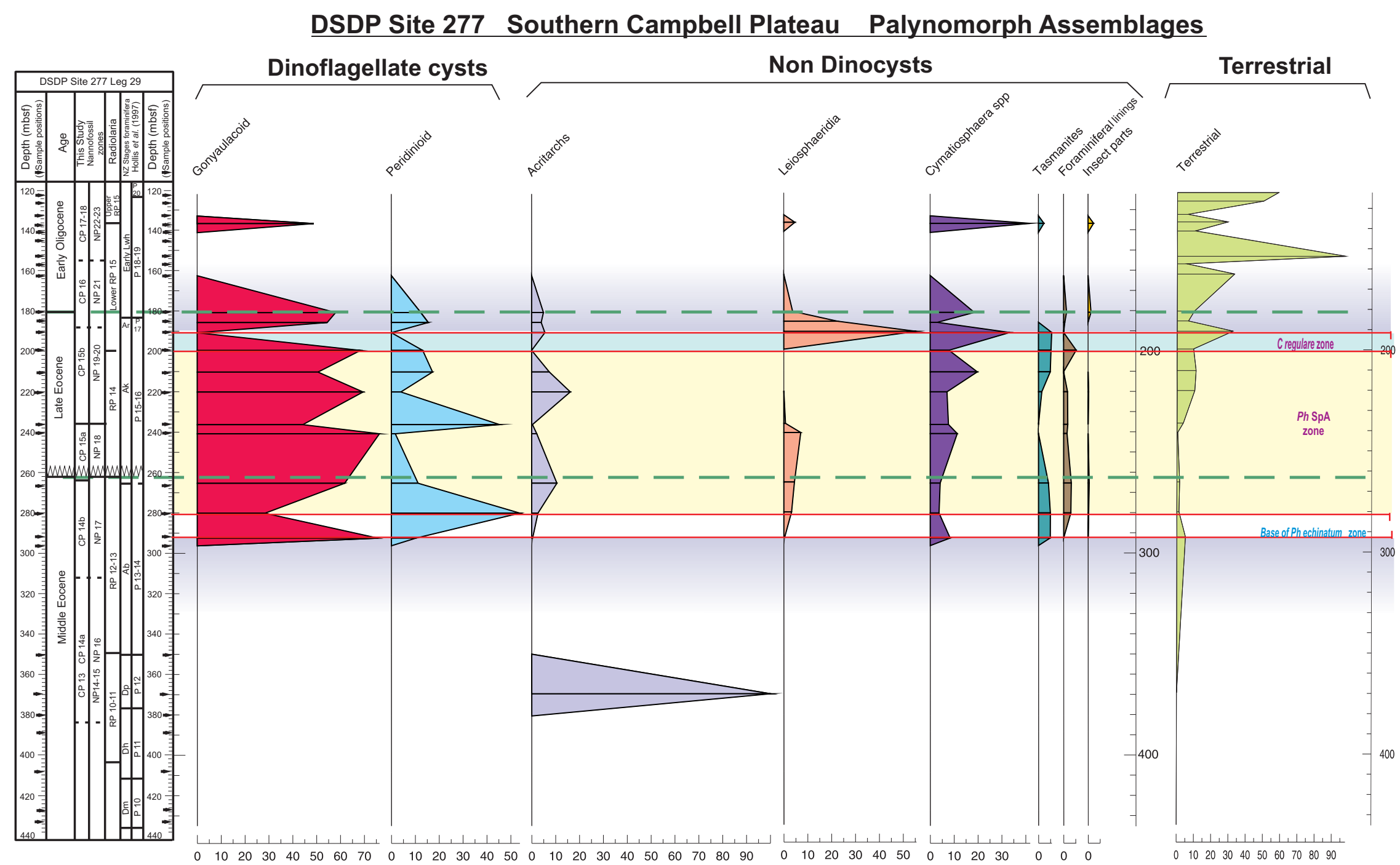

Figure 4.4b: Gonyaulacoid and Peridinioid dinocysts are compared with other marine palynomorphs (Acritarchs, Cymatiosphaera, Leiosphaeridia Tasmanites, Foraminifera and Insect parts). All marine palynomorphs $=100 \%$. Terrestrial palynomorphs percentage was taken from a total abundance and presented here for comparison. The green dashed lines represent the E/O and Middle/Late boundaries. The nannofossil zones are taken from Martini (1971) and Okado and Bukry (1980). The hiatus 


\subsubsection{Site 277, Southern Campbell Plateau Palynomorph assemblages (435.01-122.17 mbsf)}

Gonyaulacoid forms in Figures 4.4a-b dominate the dinocyst assemblages throughout most of this site, recording their highest percentage of $69 \%$ at 220.145 mbsf in the Phthanoperidinium spA Zone. Assemblages of Peridinioid dinocysts do make up $54 \%$ of the assemblages at $280.15 \%$, the base of the Phthanoperidinium spA Zone. Other dinocyst groups and species yield a high percentage of $79 \%$ by the Operculodinium group with the lowest percentage of $0.3 \%$ recorded by Octodinium spp. Non dinocysts that are present include Acritarchs, Prasinophyta algae, microforaminiferal linings and insect casings. Terrestrial material is present in every sample in this site.

\subsubsection{Palynomorph assemblages in the Eocene (435.01- $190.8 \mathrm{mbsf}$ )}

\section{Figure 4.4a}

At the base of the Phthanoperidinium echinatum Zone the Gonyaulacoid Thalassaphora spp and Spiniferites group together dominate the dinocysts. Assemblages peak at $28 \%$ and $23 \%$ respectively at 292.53 mbsf. At the base of the Phthanoperidinium spA Zone (280.15 mbsf), Peridinioid assemblages were most dominant yielding $36 \%$ of Phthanoperidinium spp and $25 \%$ of Deflandrea spp. Operculodinium group made up $79 \%$ of all dinocyst assemblages at 240.84 mbsf. However, the Peridinioid dinocyst Deflandrea spp at 43 \% (236.3 mbsf) yield a higher percentage than the Operculodinium group which decreases to $31 \%$ (236.3 mbsf).

Upsection, at 220.145, 210.275 and 199.59 mbsf the Operculodinium group consistently makes up about $26 \%$ of the dinocyst assemblages. Gonyaulacoids occurring with the Operculodinium group ( $26 \%$ ) dominated assemblages at 220.145 mbsf and 199.59 mbsf with Corrudinium spp yielding $29 \%$, and Impagidinium group $38 \%$ respectively. The Phthanoperidinium spp, near the top of the Phthanoperidinium spA Zone yielded $25 \%$ (210.275 mbsf) then decreased slightly to $16 \%$ at the top of that zone (199.59 mbsf). Dinocysts are absent at $190.8 \mathrm{mbsf}$ the top of the Corrudinium regulare Zone. 


\section{Figure 4.4b}

Figure $4.4 \mathrm{~b}$ clearly indicates that Gonyaulacoid dinocysts dominate the Peridinioid assemblage from most samples with a peak of $76 \%$ at $292.53 \mathrm{mbsf}$ then fluctuate up section; $77 \%$ at 240.84 mbsf and $70 \%$ at 220.145 mbsf. Notably, the Peridinioid dinocysts are dominant at 280.15 mbsf recording $54 \%$. Up section in the Phthanoperidinium spA Zone at 236.3 mbsf, Peridinioid dinocysts at $45 \%$ are slightly above the percentage recorded for Gonyaulacoids of $44 \%$ (236.3 mbsf).

Among the non dinocysts, Acritarchs are recorded at 369.63 mbsf (Middle Eocene) well below the first occurrences of all palynomorphs recorded above at 292.53 mbsf. From $292.53 \mathrm{mbsf}$ the Acritarch assemblages fluctuate through the Phthanoperidinium spA Zone yielding $11 \%$ at 265.335 mbsf and $16 \% 220.145$ mbsf. The Acritarch Leiosphaeridia spp were sparse, recording $7 \%$ (240.84 mbsf) then fading up section. The Prasinophyta algae Cymatiosphaera from $292.53 \mathrm{mbsf}$ at $8 \%$ was present in all samples through the Phthanoperidinium spA Zone and yielded 12 $\%$ at 240.84 mbsf, increasing to $20 \%$ at 210.275 mbsf. Species of the genus Tasmanites (5 \%) from 292.53 mbsf was sporadic and sparse through the Zone averaging $5 \%$ in most samples recorded. At 190.8 mbsf no dinocysts were present. The Acritarch Leiosphaeridia (56\%) dominate all palynomorph assemblages and Cymatiosphaera (33\%) is also an important component. Terrestrial material (5\%, $292.53 \mathrm{mbsf}$ ), is sparse initially and increases up section in the Phthanoperidinium spA Zone (10\%, $210.275 \mathrm{mbsf})$ and peaks (30 \%, $190.8 \mathrm{mbsf})$ at the top of the Corrudinium regulare Zone.

\subsubsection{Palynomorphs assemblages in the Early Oligocene (185.75-122.17 mbsf)} Figure 4.4a

The lowest sample from this interval ( $185.75 \mathrm{mbsf}$ ) yielded dinocyst assemblages dominated by the Minisphaeridium group (32 \%) and Spiniferites group (23\%). Species of the genus Phthanoperidinium were slightly less dominant yielding $21 \%$ of the assemblages. Across the E/O transition at 180.825 mbsf, Tectatodinium spp yielded the highest percentage at $49 \%$ while Spiniferites group (14\%), Phthanoperidinium spp (14\%) and Impagidinium group (10\%) were minor 
contributions. Marine palynomorphs were not present between samples 162.56141.25 mbsf although terrestrial material was present. Gonyaulacoid dinocysts were further recorded at 136.76 mbsf, with Batiacasphaera spp at $33 \%$ being the most significant among the dinocyst assemblages. Present to a lesser extent were Operculodinium group and Spiniferites group yielding $20 \%$ with Impagidinium group and the Other Gonyaulacoids yielding $14 \%$.

\section{Figure 4.4b}

The sample from 185.75 mbsf yielded assemblages dominated by Gonyaulacoids (55\%) increasing to $58 \%$ at 180.825 mbsf across the E/O transition. Peridinioid dinocysts (16\%, 185.75) decrease slightly (12\%, $180.825 \mathrm{mbsf})$ across the E/O transition. Also at this depth ( $185.75 \mathrm{mbsf}$ ) the Acritarch Leiosphaeridia yielding 23 $\%$ decreases across the E/O transition to $4 \%$ (180.825 mbsf). Cymatiosphaera (3\%, $185.75 \mathrm{mbsf}$ ) increases across the E/O transition yielding $19 \%$ (180.825).

Microforaminiferal linings occur in most samples averaging $3 \%$ up to the top of the Phthanoperidinium spA Zone.

Peridinioids were not present at 136.76 mbsf while Gonyaulacoids reoccur (49 \%) along with the Prasinophyta algae Cymatiosphaera (42\%). Also occurring recording very low percentages are Leiosphaeridia spp (5\%), Tasmanites (2\%) and insect parts (2\%). Terrestrial material continues into the Early Oligocene and occurs in every sample between (180.825-122.17 mbsf).

\subsubsection{ODP Site 1172, Leg 189 (Sluijs et al., 2003)}

Site 1172 (Figure 4.5) was part of a study from ODP leg 189 of the Tasmanian Gateway undertaken on dinocyst assemblages. The original dinocyst count from site 1172 (Sluijs et al., 2003, Table 3) have been converted to percentages of Gonyaulacoid and Peridinioid dinocysts for comparison with this study Figure 4.5. The dinocysts assemblages are placed in the same genera or grouped percentages of Gonyaulacoid and Peridinioid assemblages that are used in this study. The sample spacing for site 1172 was at a high resolution of $\sim 10 \mathrm{~cm}$ apart during the 


\section{Site 1172 Leg 189 East Tasman Plateau Dinocyst Assemblages}

Gonyaulacoid

Peridinioid

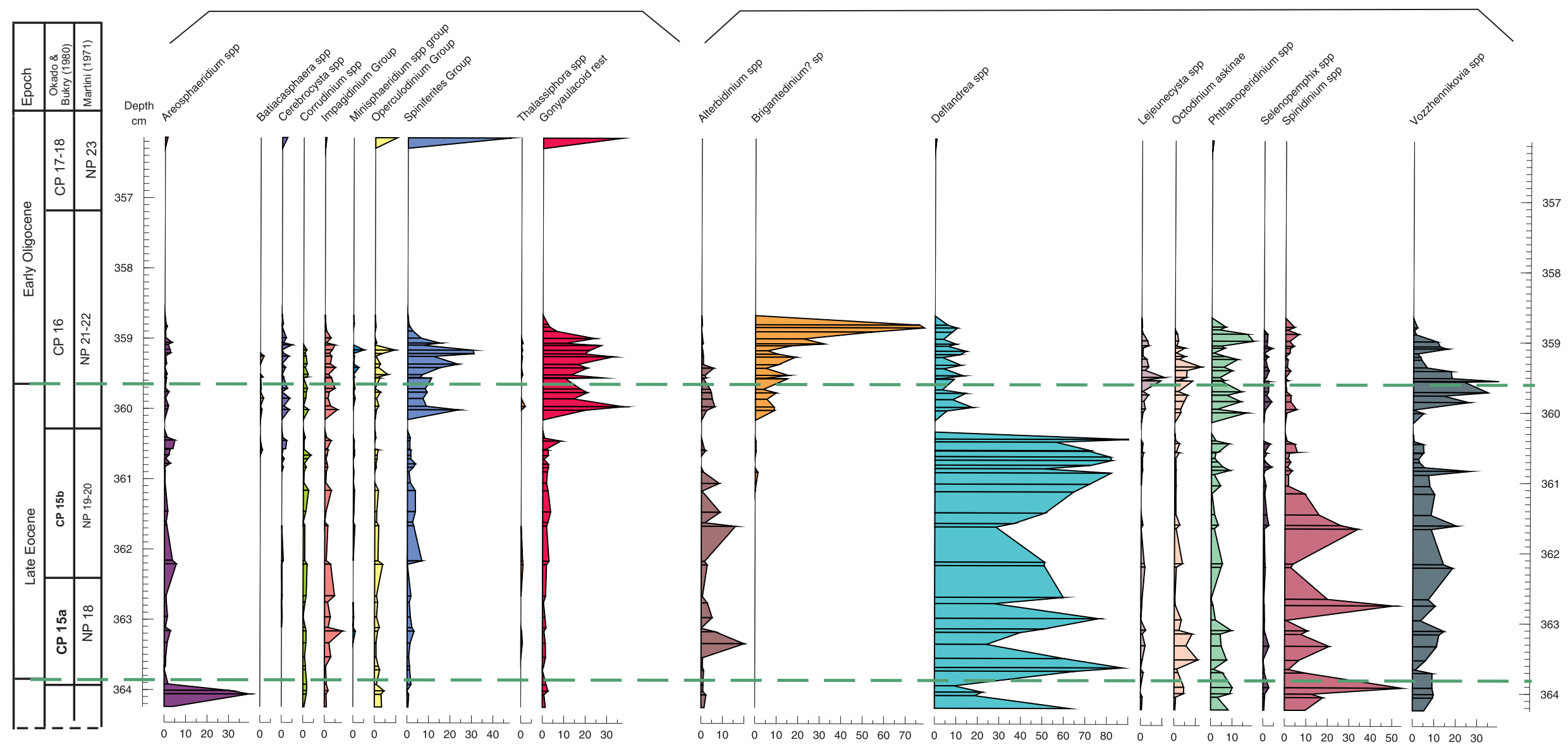

Figure 4.5. Gonyaulacoid and Peridinioid pecentages of morphologically closely related dinoflagellate cysts quantitavely grouped to show their distribution within each of the four samples $($ Total $=100 \%)$. Impagidinium, Nematosphaeropsis = Impagidinium group; Operculodinium, Impletosphaeridium = Operculodinium group; Achomosphaera, Spiniferites = Spiniferites group (Brinkhuis \& Biffi, 1993); Minisphaeridium spp group (Fensome et al., 2009). 
late Middle Eocene to Early Oligocene (364.24-356.14 mbsf) and below in the Middle Eocene (380.5-364.14 mbsf) sample spacing was at $\sim 1.5 \mathrm{~m}$ apart. This study utilizes the Sluijs et al. (2003) Late Eocene/Early Oligocene results sampled the highest resolution. Dinocysts occurring from the Middle Eocene to Early Oligocene are displayed in Appendix 2.15 which gives an indication of dinocyst assemblage percentages that were present during the Middle Eocene.

\subsubsection{Dinocysts assemblages in the Eocene (364.24-364.06 mbsf)}

Site 1172 has an overall dominance of Peridinioid assemblages with Deflandrea spp yielding 63 \% (364.24 mbsf) in CP14a,b/NP17, peaking up section at the Middle/Late Eocene boundary with a high yield of $87 \%$, (363.66 mbsf) in CP15a/NP18.

Spinidinium spp $55 \%$, (363.92), also occurs up to the boundary and to a lesser extent minor percentages are attributable to Vozzhennikovia $\operatorname{spp}(9 \%, 363.71 \mathrm{mbsf})$ and Phthanoperidinium spp (10\%, $363.71 \mathrm{mbsf})$. A significant occurrence was of the Gonyaulacoid Areosphaeridium spp yielding $40 \%$ at 364.06 mbsf.

From the Middle/Late Eocene boundary the dominant dinocyst assemblage is attributable to Deflandrea spp yielding $87 \%$ at 363.66 mbsf and $90 \%$ at 360.41 mbsf. Spinidinium spp (50\%, 362.75 mbsf and $34 \%, 361.66 \mathrm{mbsf}$ ) in the Late Eocene displays a reciprocal relationship with Deflandrea spp which yielded $28 \%$ at 362.75 and 361.66 mbsf. From 361.05 mbsf Spinidinium spp yield less than $10 \%$ while Deflandrea spp $80 \%$ at 360.89, 360.71 and 360.66 mbsf respectively, dominate.

Vozzhennikovia spp during the Late Eocene yields $20 \%$ of the dinocyst assemblages at 362.21 and $361.61 \mathrm{mbsf}$ and fluctuates up section, peaking at $26 \%$ at 360.83 mbsf then significantly reduces to $5 \%$ at 360.45 mbsf. To a lesser extent Phthanoperidinium spp and Octodinium spp occur at less than $10 \%$, between 363.66-360.41 mbsf. Alterbidinium spp is sparse below the Middle/Late Eocene boundary and sporadic above peaking at $20 \%$ at 363.33 and $361.66 \mathrm{mbsf}$. The Gonyaulacoid dinocyst Areosphaeridium spp is $40 \%$ at 364.06 mbsf in the late 
Middle Eocene although from there into the Late Eocene all Gonyaulacoid dinocysts assemblages are very sparse with very low percentages.

\subsubsection{Dinocyst Changes from the $E / O$ transition (360.31-356.14 mbsf)}

Dinocysts are not recorded in samples 360.31 and $360.15 \mathrm{mbsf}$ at the top of CP15b/NP19-20, very close to the E/O transition. The Peridinioid dinocyst Deflandrea spp decreases significantly yielding $5 \%$ at 360.01 mbsf. Brigantedinium spp increases from $8 \%$ at 360.01 mbsf to dominate all dinocyst assemblages in the Early Oligocene yielding $80 \%$ at 358.79 mbsf. Vozzhennikovia spp from $5 \%$ at 360.01 mbsf fluctuates through the E/O transition peaking at $40 \%$ at $359.55 \mathrm{mbsf}$ and $16 \%$ at 359.09 mbsf before fading at 358.59 mbsf. Phthanoperidinium spp (16 \%, $360.01 \mathrm{mbsf}$ ), increases to $19 \%$ at 358.99 mbsf. Slight increases occur to Octodinium askinae and Lejeunecysta spp both yielding $0.1 \%$, at $359.41 \mathrm{mbsf}$. Across the Eocene Oligocene transition the Gonyaulacoid Spiniferites group has increased (24\%, $360.01 \mathrm{mbsf})$, yielding the highest percentage of $31 \%$ at 359.21 mbsf. The Other Gonyaulacoid dinocysts spp yield 37 \% (359.96 mbsf) and decrease to $32 \%$ at 359.25 mbsf and $27 \%$ at 359.09 mbsf. From 358.66 to 356.29 mbsf there are no dinocysts present. At 356.14 mbsf Gonyaulacoid dinocysts of Spiniferites group (48\%), the Other Gonyaulacoids (36\%), and to a lesser extent Operculodinium group (10\%) also occur. Peridinioid dinocyst assemblages are not present from 358.66 mbsf. 


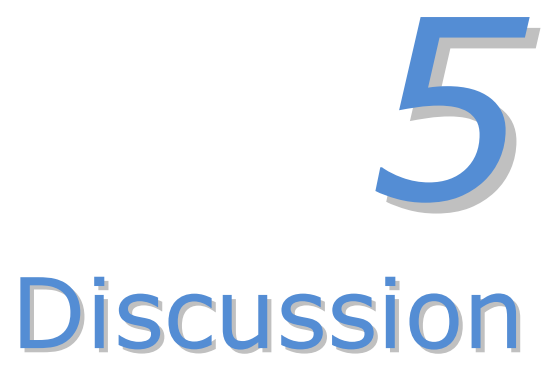




\section{CHAPTER FIVE}

\subsection{Discussion}

\subsection{Introduction}

The distribution of dinocysts during the Paleogene is influenced by many factors such as sunlight, water temperature, salinity, nutrient levels, surface winds, upwelling systems, currents and the level of ocean water mixing (Chapter 1.7; Batten, 1996; Pross and Brinkhuis, 2005; Sluijs et al., 2005). The dominant factors in the Late Eocene and Oligocene, surface water temperature and salinity, were arguably most important in the southern high latitudes, due to the development of the Antarctic ice sheets. $\delta^{18} \mathrm{O}$ curves (Figures $1.2,1.3$ ) show cooling temperatures since the EECO, but brief peaks of warmer temperatures were included during the Middle Eocene (MECO) and a further warming in the Late Eocene was followed by the Vonhof et al. (2000) cooling event (DeConto and Pollard, 2003; Francis et al., 2009; Pagani et al., 2005). Over the same time interval it was expected that marine palynomorphs would shift from older assemblages reflecting warm conditions to assemblages indicative of cooler conditions.

\subsection{Interpreted Dinoflagellate Palaeoenvironments}

The transition from neritic to fully marine oceanic conditions is reflected in a change from restricted marine (inner neritic), to coastal (outer neritic) and offshore (oceanic). High salinity inner neritic environments are generally dominated by Peridinioid dinocysts which are predominately heterotrophs and the outer neritic to oceanic environments are generally dominated by Gonyaulacoid dinocysts, predominately autotrophs. In addition, some Peridinioids may also be abundant in coastal or oceanic upwelling palaeoenvironments where nutrient rich or eutrophic waters containing food for heterotrophs are present.

Table 5.1 documents the inferred palaeoenvironment of various dinocyst groups and genera. Crouch and Brinkhuis (2005) refer to Gonyaulacoid dinocysts as oligotrophic, with a preferred environment ranging from outer neritic to open 
ocean conditions. They suggested that Peridinioid dinocysts prefer eutrophic

surface waters with lower sea surface temperatures and/or nutrient upwellings.

The dinocysts listed in Table 5.1 are mostly related to those conditions.

\begin{tabular}{|c|c|c|}
\hline \multicolumn{3}{|c|}{ Dinoflagellate Palaeoenvironment Interpretation } \\
\hline \multicolumn{3}{|c|}{ Gonyaulacoid Dinoflagellates } \\
\hline Genera & Possible Palaeoenvironment & References \\
\hline Gonyaulacoid & $\begin{array}{l}\text { Oligotrophic outer neritic to open ocean } \\
\text { conditions }\end{array}$ & $\begin{array}{l}\text { Crouch and Brinkhuis } \\
(2005)\end{array}$ \\
\hline $\begin{array}{l}\text { Cerebrocysta spp } \\
\text { Corrudinium spp }\end{array}$ & Oceanic, offshore taxa & Pross and Brinkuis (2005) \\
\hline Enneadocysta spp & Oligotrophic conditions, coastal taxa & Pross and Brinkuis (2005) \\
\hline $\begin{array}{l}\text { Impagidinium } \\
\text { group } \\
\text { Tectatodinium spp }\end{array}$ & $\begin{array}{l}\text { Outer most continental shelf, slope, rise and } \\
\text { abyssal sediments representing Oceanic and } \\
\text { transitional coastal - oceanic systems they } \\
\text { require stable salinities of about } 35 \%\end{array}$ & $\begin{array}{l}\text { Dale (1996) } \\
\text { Brinkhuis and Biffi (1993) } \\
\text { Sluijs et al. (2005) } \\
\text { Pross and Brinkhuis (2005) }\end{array}$ \\
\hline $\begin{array}{l}\text { Operculodinium } \\
\text { group }\end{array}$ & $\begin{array}{l}\text { Cool brackish stratified estuaries. Exploits } \\
\text { transitional or changing conditions can } \\
\text { tolerate the changes adapts to unstable } \\
\text { environments }\end{array}$ & $\begin{array}{l}\text { Wall et al. (1977) } \\
\text { Dale (1996) }\end{array}$ \\
\hline Spiniferites group & $\begin{array}{l}\text { Cosmopolitan and co occur with endemics to } \\
\text { a certain extent }\end{array}$ & Sluijs et al. (2003) \\
\hline $\begin{array}{c}\text { Thalassaphora spp } \\
\text { (Mainly } \\
\text { Thalassaphora } \\
\text { pelagica) }\end{array}$ & $\begin{array}{l}\text { Enhanced stratification, eutrophication and } \\
\text { productivity in upper water column, and } \\
\text { high salinity or } \\
\text { oxygen depletion in lower water column. }\end{array}$ & $\begin{array}{l}\text { Pross and Schmiedl, (2002) } \\
\text { Sluijs et al. (2005) } \\
\text { Vonhof et al. (2000) } \\
\text { Pross and Brinkuis (2005) }\end{array}$ \\
\hline \multicolumn{3}{|c|}{ Peridinioid Dinoflagellates } \\
\hline Peridinioid & $\begin{array}{l}\text { Eutrophic surface waters with lower sea } \\
\text { surface temperatures or nutrient upwellings }\end{array}$ & $\begin{array}{l}\text { Crouch and Brinkhuis } \\
\text { (2005) }\end{array}$ \\
\hline $\begin{array}{l}\text { Brigantedinium } \\
\text { spp }\end{array}$ & $\begin{array}{l}\text { Coastal and oceanic upwelling regions as } \\
\text { well as sea ice conditions. } \\
\text { Heterotrophs typically feeding on diatoms. }\end{array}$ & $\begin{array}{l}\text { Sluijs et al. (2003) } \\
\text { Wall et al. (1977) } \\
\text { Rochon et al. (1999) }\end{array}$ \\
\hline Deflandrea spp & $\begin{array}{l}\text { Marginal marine heterotrophic, closely tied } \\
\text { to ancient deltaic settings, organic rich } \\
\text { facies, inshore eutrophic conditions } \\
\text { associated with diatoms. } \\
\text { Elevated nutrient availability. Offshore sea } \\
\text { surface productivity }\end{array}$ & Sluijs et al. (2003; 2005) \\
\hline $\begin{array}{l}\text { Phthanoperidinium } \\
\text { spp } \\
\text { Spinidinium spp } \\
\text { Vozzhennikovia } \\
\text { spp }\end{array}$ & $\begin{array}{l}\text { Coastal and off shore sea surface } \\
\text { productivity. } \\
\text { Marginal marine, highly eutrophic, and high } \\
\text { latitude setting }\end{array}$ & $\begin{array}{l}\text { Pross and Brinkhuis (2005) } \\
\text { Sluijs et al. (2003) }\end{array}$ \\
\hline
\end{tabular}

Table 5.1: Peridinioid and Gonyaulacoid dinocysts including groups are shown separately, with suggested palaeoenvironmental preference from previous works as referenced.

Among the Gonyaulacoid genera are several genera considered to be truly oceanic e.g. Impagidinium, Corrudinium and Spiniferites. However, they can also be found 
with endemic species in more shallow conditions, although not usually in high numbers. The preferred marine conditions for the genus Thalassaphora are enhanced stratification and high salinity suggesting calm oceanic conditions. Wall et al. (1977) and Dale (1996) suggested that the Operculodinium group is capable of exploiting changeable conditions and can adapt to unstable and transitional environments, an exception to the general Gonyaulacoid inferred oceanic palaeoenvironment.

Peridinioid dinocysts in general can be linked to inner neritic eutrophic conditions (e.g. Deflandrea spp; Sluijs et al., 2003, 2005) or elevated nutrient availability and offshore sea surface productivity (e.g. Phthanoperidinium spp, Deflandrea spp; Pross \& Brinkhuis, 2005). Brigantedinium spp are referred to by Rochon et al. (1999), Sluijs et al. (2003) and Wall et al. (1977) as heterotrophs found in coastal and oceanic upwelling regions as well as conditions where sea ice is present.

\begin{tabular}{|c|c|c|}
\hline \multicolumn{3}{|c|}{ Non Dinocyst Palynomorph Palaeoenvironmental Interpretation } \\
\hline Taxon & Possible Palaeoenvironment & References \\
\hline $\begin{array}{c}\text { Acritarch spp } \\
\text { Leiosphaeridia spp }\end{array}$ & $\begin{array}{l}\text { Organic walled cysts that cannot be assigned } \\
\text { to known groups of organisms. } \\
\text { Abundant in nutrient rich cold waters, } \\
\text { adjacent to sea ice margins, normal to low } \\
\text { salinity. Ice age indicator of lower salinity. } \\
\text { Occur between margins of pack ice and sea } \\
\text { ice in the Arctic }\end{array}$ & $\begin{array}{l}\text { Strother (1996) } \\
\text { Batten (1996) } \\
\text { Wrenn et al. (1998) } \\
\text { Mudie (1992) }\end{array}$ \\
\hline $\begin{array}{c}\text { Prasinophyte algae } \\
\text { Cymatiosphaera spp } \\
\text { Tasmanites spp } \\
\end{array}$ & $\begin{array}{l}\text { Stratified water mass low salinity } \\
\text { In Arctic waters most abundant in upwelling } \\
\text { or nutrient rich waters in normal or low } \\
\text { salinity } \\
\text { Low temperature, reduced salinity }\end{array}$ & $\begin{array}{l}\text { Batten (1996) } \\
\text { Mudie and Harland (1996) } \\
\text { De Vernal and Mudie } \\
\text { (1992) } \\
\text { Guy-Ohlson (1996) } \\
\end{array}$ \\
\hline $\begin{array}{l}\text { Microforaminiferal } \\
\text { linings }\end{array}$ & $\begin{array}{l}\text { Nutrient rich upwelling, shallow water with } \\
\text { coarser sediment and high salinity. } \\
\text { Occurrences decreasing with increase in } \\
\text { water depth. }\end{array}$ & Stancliffe (1996) \\
\hline Scoledonts & $\begin{array}{l}\text { Most abundant in shallow water marine } \\
\text { sediments associated with spores and } \\
\text { acritarchs. Rare in deep water }\end{array}$ & Szaniawski (1996) \\
\hline Terrestrial & $\begin{array}{l}\text { High terriginous output, indicates eutrophic } \\
\text { conditions, possible warmer climate }\end{array}$ & $\begin{array}{l}\text { Crouch and Brinkhuis } \\
\text { (2005) }\end{array}$ \\
\hline
\end{tabular}

Table 5.2: Palaeoenvironments related to Quaternary and modern analogues and to other previous work for acritarchs, Leiosphaeridia, Cymatiosphaera, Tasmanites, microforaminifera and scoledonts.

Table 5.2 documents various non dinocyst palynomorphs and their suggested palaeoenvironments. The species assigned to the Acritarch genus Leiosphaeridia 
are abundant near sea ice margins or upwellings. Guy-Ohlson (1996) suggests that Prasinophyte algae such as Cymatiosphaera spp and Tasmanites may be ice indicators or found in low temperatures situations with reduced salinity. Microforaminiferal linings and scholedonts are most abundant in nutrient rich shallow water, with high salinity and rare in deeper water (Stancliffe, 1996; Szaniawski, 1996). Crouch and Brinkhuis (2005) suggest terrestrial material is an indication of eutrophic conditions, and a possible warmer climate.

\subsection{Palynomorph distribution and interpretation}

Figure 5.1 shows the distribution of the most dominant or environmentally significant palynomorphs occurring throughout each site. This data is plotted against age in millions of years. The biostratigraphic zones of Chapter 3 are shown with dashed lines for uncertain boundaries. The E/O boundary ( 33.7 Ma) and Middle/Late Eocene boundary ( $37 \mathrm{Ma}$ ) markers are also shown as dashed lines. The vertical arrows indicate palynomorph distribution, dotted arrows indicate palynomorphs are present but fading or sparse, and bars at the tips of the arrows indicate where distribution ends.

The interpreted palaeoenvironment for the four sites (696B, 699A, 748B, 277) shown in Figure 5.2, has been compiled by the translation of the palynomorph distribution laid out in Figure 5.1, to a possible palaeoenvironmental interpretation using Tables 5.1 and 5.2.

\subsection{Palaeoclimate Interpretation}

\subsubsection{Pre Phthanoperidinium echinatum Zone ( 46 - 44.8 Ma)}

The Peridinioid dinocysts present together with fluctuations in the numbers of Operculodinium spp suggest the Middle Eocene palaeoenvironment ( 46- 44.8 Ma) in site $696 \mathrm{~B}$ to be inner neritic, marginal marine and highly eutrophic with changeable conditions. Its close proximity to the shore would imply that inner neritic waters should be warmer than an open ocean environment. The non dinocysts of Leiosphaeridia and Prasinophyte algae are most abundant in cooler 
Figure 5.1: This figure is converted to time in Ma through the nannofossil zones of Berggren et al., (1995). Each site is separated into dinocysts, non dinocysts and terrestrial material. The biostratigraphic zones of Chapter 3 are shown with dashed lines for uncertain or missing positions of their boundaries. The E/O and Middle/Late boundary markers are shown as dashed lines. Verticle arrows show palynomorph distribution. Dotted arrows indicate palynomorphs are present but fading or sparse. Bars at the tips of arrows indicate where palynomorph distribution ends. Each site has been correlated to their positions at the E/O boundary and the nannofossils zones where possible. Condensed sediments and areas with no palynomorphs present are shown as grey. Distribution of palynomorphs that are dominant, significant or useful as palaeoenvironmental indicators are shown. 


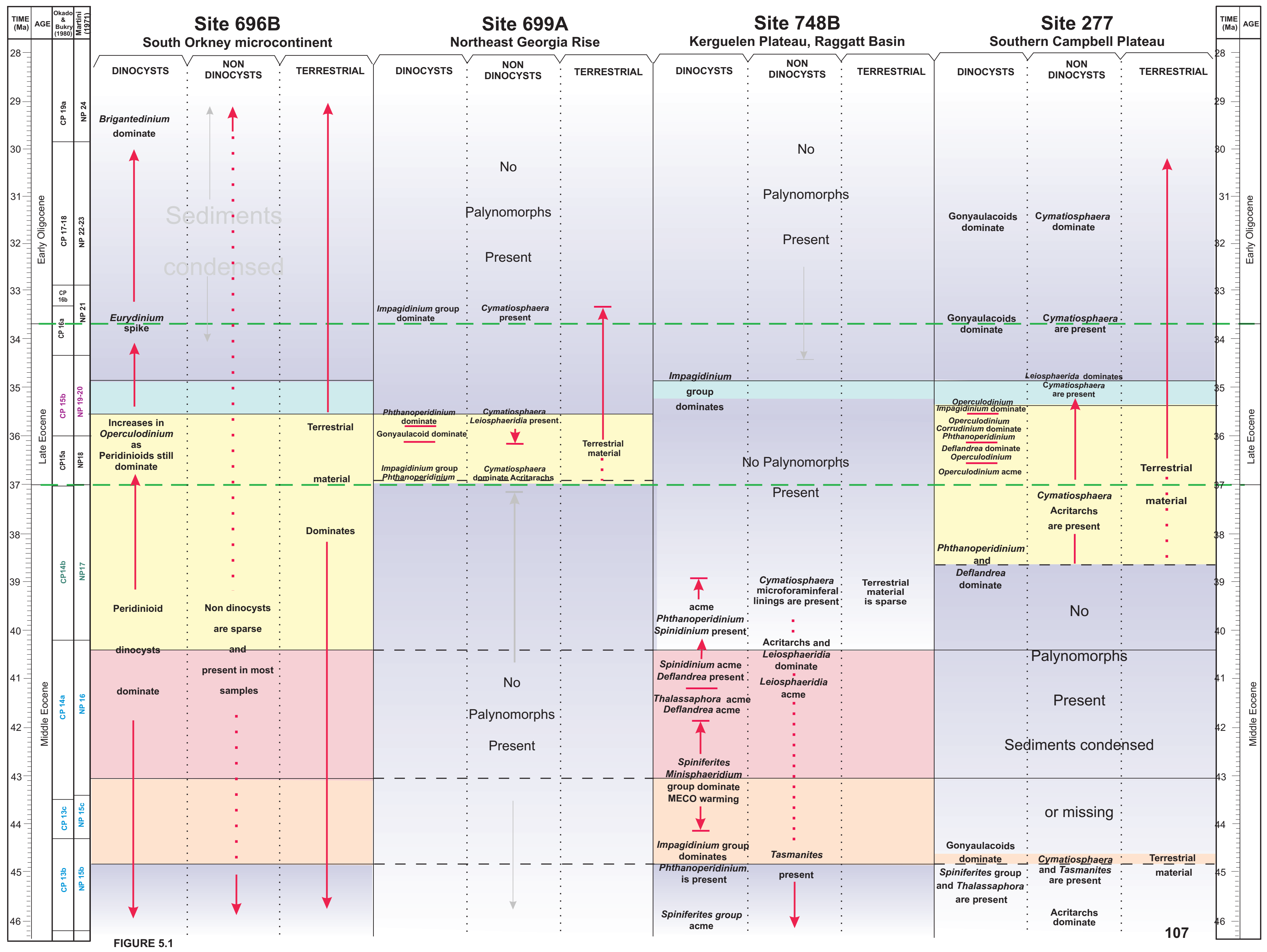




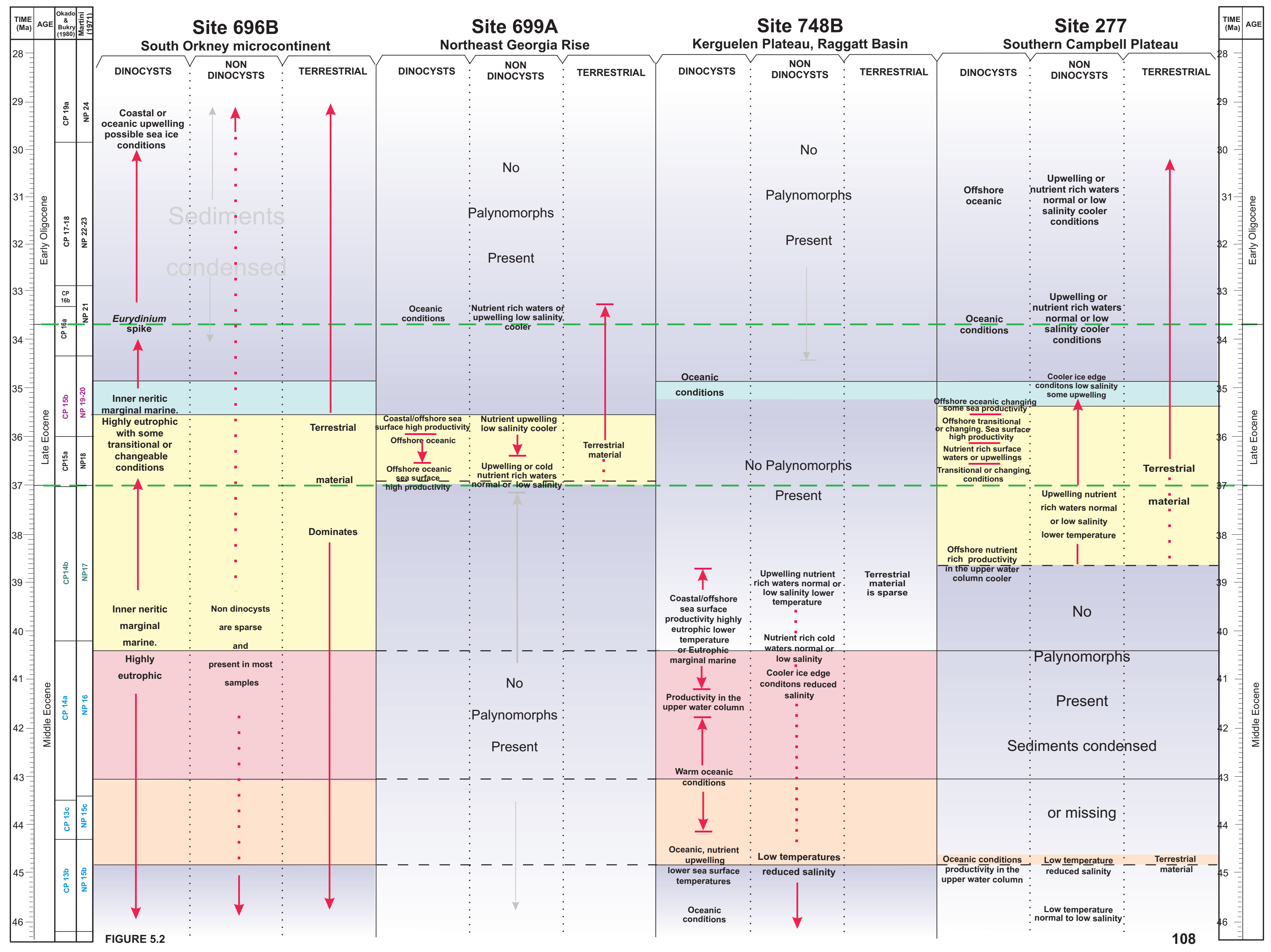


Figure 5.2: This figure is converted to time in Ma through the nannofossil zones of Berggren et al., (1995). Each site is separated into dinocysts, non dinocysts and terrestrial material. The biostratigraphic zones of Chapter 3 are shown with dashed lines for uncertain or missing positions of their boundaries. The E/O and Middle/Late boundary markers are shown as dashed lines. Verticle arrows indicate palynomorph distribution. Dotted arrows indicate palynomorphs are present but fading or sparse. Bars at the tips of arrows indicate where palynomorph distribution ends. Each site has been correlated to their positions at the E/O boundary and the nannofossils zones where possible. Condensed sediments and areas with no palynomorphs present are shown as grey. Palynomorph interpretation for the palaeoenvironment have been compiled by replacing their distribution laid out in Figure 5.1 with the translation of the possible palaeoenvironment of Tables 5.1 and 5.2. 
conditions but are sparse in site 696B and combined with the dominance of terrestrial material the site is indicative of prevailing warmer conditions.

Peridinioid dinocyst are useful in determining cooler conditions, therefore their domination of marine palynomorph assemblages in this site may indicate conditions were cooler than predicted (Crouch and Brinkhuis, 2005). Alternatively their dominance in this site may serve to indicate that they are also tolerant of warmer inner neritic conditions if food is plentiful. Peridinioid dinocysts are also found in cooler oceanic conditions with elevated nutrients, upwellings (i.e. a vertical mixing from the ocean depths of nutrient rich cold waters with surface waters) and sea surface productivity which suggests that the hunt for food was their main objective rather than a specific cool environment in the Southern Ocean.

During this interval site 699A has no palynomorphs present; however, Wei (1991), Takemura and Ling (1996) and Nocchi et al. (1991) indicate that nannofossils, radiolarian and foraminifera were present, although microforaminiferal linings were not found in this study at this site. In addition, the absence of dinocysts at this site may be a result of oxidation due to a slow rate of sedimentation $(3 \mathrm{~m} / \mathrm{m}$.y. averaging $14 \mathrm{~m} / \mathrm{m}$.y.). From $\sim 37 \mathrm{Ma}$ the sedimentation rate increased to $25 \mathrm{~m} / \mathrm{m}$.y. coinciding with the presence of dinocysts (Shipboard Scientific Party, 1988). However the sedimentation rate may not have been fast enough for some genera to be preserved, as not all the species that were common in the other sites were present in this site (e.g. Thalassaphora and Deflandrea spp), and many of the palynomorphs that were present were sparse. Therefore the sedimentation rate may still have been too slow to prevent oxidation of the dinocysts.

Site $748 \mathrm{~B}$ at $\sim 46 \mathrm{Ma}$ is dominated by an acme of the cosmopolitan Spiniferites group indicating prevailing oceanic conditions. The non dinocysts (Cymatiosphaera, Leiosphaeridia, Tasmanites) present confirm that salinity was reduced and temperatures were low. In site 277 acritarchs are present; however, their exact environmental interpretation is undetermined. Notably there are no other palynomorphs present until $\sim 44.8 \mathrm{Ma}$ in this site (Figures 5.1, 5.2). 


\subsubsection{Phthanoperidinium echinatum Zone ( 44.8 - 43 Ma)}

During the Phthanoperidinium echinatum Zone in site 696B, very little change in palynomorph assemblages is evident and an inner neritic palaeoenvironment is still indicated with non dinocysts remaining sparse and a dominance of terrestrial material. Also, there is no change in site 699A as it continues to be barren of palynomorphs.

At $\sim 44.8 \mathrm{Ma}$ the dominance of Gonyaulacoidia species suggests oceanic conditions were present at both sites $748 \mathrm{~B}$ and 277 . However, other dinocysts present (e.g. Phthanoperidinium in site 748B and Thalassaphora in site 277) point to an environment with nutrient upwelling, which is usually accompanied by cooler oceanic conditions and increased productivity in the upper water column. The presence of the Prasinophyte alga Tasmanites in both sites suggests salinity was reduced and that sea ice or cool waters may have been present or deeper oceanic conditions prevailed (Figures 5.1, 5.2).

Above $\sim 44.8 \mathrm{Ma}$, site 277 does not contain palynomorphs. However, in site 748B up to $43 \mathrm{Ma}$, the top of the Phthanoperidinium echinatum Zone, the palaeoenvironment was oceanic and warm. This interpretation is suggested by the reduction in numbers of the cooler species of Peridinioids such as Deflandrea, Phthanoperidinium and Spinidinium and may indicate less or no upwelling with calmer oceanic conditions. These changes are considered to be a response to the beginning of a warmer ocean environment which is further supported by the cooler non dinocysts species Leiosphaeridia and Cymatiosphaera becoming sparse during this interval.

\subsubsection{Phthanoperidinium geminatum Zone ( 43 - 40.3 Ma)}

In this zone sites 696B and 748B contain Middle Eocene strata of the right age for the MECO to be recorded ( $41.5 \mathrm{Ma}$; Bohaty and Zachos, 2003). In site 696B strata, there are no significant changes from the strata below, and Peridinioid dinocysts still dominate during this warmer interval that is indicative of a MECO 
palaeoenvironment. This implies that the interval was warm and dinocysts present remained unchanged.

In site 748B the palaeoenvironment was oceanic and warm with less of the cooler species of Peridinioids present such as Deflandrea, Phthanoperidinium and Spinidinium or the non dinocysts Leiosphaeridia and Cymatiosphaera. At $\sim 41.5 \mathrm{Ma}$ acmes of Thalassaphora and Deflandrea spp indicated enhanced stratification, highly eutrophic, nutrient rich sea surface productivity in the upper water column and high salinity. At $\sim 41 \mathrm{Ma}$ in site $748 \mathrm{~B}$ an acme of Spinidinium alongside the presence of Deflandrea signified highly eutrophic sea surface conditions. Also present is an acme of Leiosphaeridia, which points to cooler ice edge conditions in nutrient rich cold waters replacing the warmer MECO (Figures 5.1, 5.2).

Site 699A conditions have not changed from $\sim 46 \mathrm{Ma}$ and palynomorphs are not present. Site 277 also has no palynomorphs present.

\subsubsection{Phthanoperidinium spA Zone ( 40.3 - 37 Ma)}

The Palaeoenvironment remained unchanged in site 696B up to the Middle/Late Eocene boundary ( $37 \mathrm{Ma})$. Site 699A still lacks any palynomorphs.

In site 748B the Phthanoperidinium spA Zone cannot be properly documented due to key indicator dinocysts not being present. An acme of Phthanoperidinium in this site, suggests the climate continued to be highly eutrophic with offshore sea surface productivity and lower temperatures. Non dinocysts (Leiosphaeridia,

Cymatiosphaera) indicate the presence of nutrient rich cold waters with normal to low salinity. At $\sim 38.7$ Ma marine palynomorph conditions remain constant, while terrestrial material, although sparse, is still present. Additionally the interval between $\sim 38.7$ - $\sim 37 \mathrm{Ma}$ is void of all palynomorphs.

In site 277 assemblages of equivalent age ( 38.7 Ma) are initially dominated by Peridinioid dinocysts (Phthanoperidinium, Deflandrea), equivalent to events in site 748B. The non dinocysts present (Cymatiosphaera) point to a possible upwelling of 
nutrient rich waters bringing lower temperatures (Figures 5.1, 5.2) and although sparse, terrestrial material is also present. These identified conditions continue up to the Middle/Late Eocene boundary ( $\sim 37 \mathrm{Ma})$.

\subsubsection{Phthanoperidinium spA Zone ( 37 - 35.4 Ma)}

At the Middle/Late Eocene boundary ( $37 \mathrm{Ma}$ ) in site 696B, Peridinioid dinocysts dominate assemblages, still suggesting an inner neritic palaeoenvironment. In addition, increases of the Operculodinium group imply a changing, unstable palaeoenvironment, despite the consistency exhibited by both non dinocysts and terrestrial material during this interval.

Despite not being the dominant palynomorph in site 696B, appearance of the Operculodinium group is synchronous with an acme of the Operculodinium group occurring in site 277 ( 36.8 Ma). Present in site 277, is an initial domination of Peridinioid dinocysts (Deflandrea) in combination with the Operculodinium group. Sequential intermittent occurrences of Gonyaulacoid (Corrudinium) and Peridinioid (Phthanoperidinium) dinocysts then continue to dominate until oceanic conditions, (Impagidinium) with some offshore sea surface productivity prevail by $\sim 35.4 \mathrm{Ma}$

(Figures 5.1, 5.2). These predictions of cooler conditions are reinforced by analysis of non dinocysts with Leiosphaeridia present, being dominant over the Cymatiosphaera. Terrestrial material increases through this interval.

The environment in sites 696B and 277 during the early Late Eocene ( 37 - 35.4 $\mathrm{Ma}$ ) is different to that documented in site 699A, where assemblages of the Impagidinium group combined with Phthanoperidinium suggest an offshore setting with high surface productivity ( $\sim 36.8 \mathrm{Ma})$. The appearance of Cerebrocysta at $\sim 36$ Ma suggests that the site was becoming oceanic. During this period at $36 \mathrm{Ma}$ the presence of the non dinocyst (Cymatiosphaera) suggests possible upwelling or cold nutrient rich waters also evident with sparse terrestrial material. From $\sim 36 \mathrm{Ma}$ Gonyaulacoids dominate, indicating an offshore oceanic environment and cooler conditions associated with the presence of non dinocyst (Cymatiosphaera, Leiosphaeridia). Changes in dinocyst assemblages at $\sim 35.3 \mathrm{Ma}$ to one of a 
domination of Peridinioid dinocysts, reflect additional coastal/offshore sea surface productivity. Cooler temperatures during this period are signified by the non dinocysts (Cymatiosphaera, Leiosphaeridia) and terrestrial material present (Figures $5.1,5.2)$.

\subsubsection{Corrudinium regulare Zone ( $35.4-34.8 \mathrm{Ma})$}

In the middle Late Eocene ( $34.8 \mathrm{Ma}$ ) site 696B marine palynomorph assemblages continued to be dominated by Peridinioid dinocysts, with the non dinocysts remaining sparse and terrestrial material the most dominant palynomorph present. In contrast the Corrudinium regulare Zone in site 699A is void of a key dinocyst indicator in the upper part of the Zone, with a notable lack of marine palynomorphs from 35.4 Ma. Palynological assemblages from this Zone still yield terrestrial material.

The top of this zone is also recognised in site 748B, with Gonyaulacoid (Impagidinium) assemblages indicating an oceanic palaeoenvironment, with a notable lack of Peridinioid dinocysts, non dinocysts and terrestrial material. In contrast, site 277 yielded no dinocysts but non dinocysts are present, with Leiosphaeridia dominating, indicating sea ice edge or cold water conditions while the presence of Cymatiosphaera suggests cool, nutrient-rich waters. Terrestrial material is still present in this interval.

\subsubsection{Post Corrudinium regulare Zone (34.8 - 29 Ma)}

From $\sim 34.8 \mathrm{Ma}$, site 696B assemblages continue unchanged up to $33.7 \mathrm{Ma}$ (E/O boundary), where the Peridinioid genus Eurydinium dominates the dinocysts. Its appearance at the E/O boundary in this site coincided with its appearance in the Late Eocene/Early Oligocene of site 511 (Goodman and Ford, 1983). This key finding suggests this species may be characteristic of the E/O transition in the Southern Ocean. During this period Peridinioid dinocysts continue to dominate the marine palynomorphs. At $29 \mathrm{Ma}$ Brigantedinium spp are most dominant which signifies coastal or oceanic upwelling and possible sea ice conditions. This change replaces the inner neritic palaeoenvironment that was present throughout the 
Eocene. In addition, the first occurrences of the Gonyaulacoid genera

Chlamydophorella and Batiacasphaera indicate conditions may have begun to change to a deeper coastal palaeoenvironment in the Early Oligocene. Non dinocysts are sparse remaining unchanged and terrestrial material is still the most dominant Palynomorph in this site.

In site 748B palynomorphs are no longer present however, in the earliest Oligocene at $\sim 33.7 \mathrm{Ma}$ (115 mbsf) ice rafted debris indicates a presence of sea ice with cold conditions (Shipboard Scientific Party, 1992).

At $\sim 33.7 \mathrm{Ma}$ in site $699 \mathrm{~A}$, oceanic conditions are indicated by the dominance of Gonyaulacoid dinocyst (Impagidinium) assemblages, as the non dinocysts (Cymatiosphaera, Leiosphaeridia) indicate nutrient rich waters with upwelling, low salinity and cooler conditions. Terrestrial material continues up to this time, however no palynomorphs are present above the E/O boundary. Those conditions are very similar in site 277 ( 33.7 Ma) with Gonyaulacoid dinocysts dominant inferring oceanic conditions and non dinocysts (Cymatiosphaera, Leiosphaeridia) indicating upwelling or nutrient rich waters with cooler conditions. Terrestrial material is also present. However, further occurrences are indicated in this site at 31 Ma with Gonyaulacoids still dominating and conditions being offshore/oceanic. The non dinocysts are dominated by Cymatiosphaera which implies upwelling, nutrient rich waters and cooler conditions. Terrestrial material is still present up to this time, with no palynomorphs present above this interval.

In the pelagic sites $(699 \mathrm{~A}, 748 \mathrm{~B}, 277)$ it is considered that many of the marine palynomorphs are no longer present due to the climatic changes at the E/O boundary. The inner neritic site 696B differed in that it contained more palynomorphs and conditions were warmer than the pelagic sites, however this changed during the transition indicating the presence of colder and deeper waters during the Early Oligocene. These occurrences demonstrate that all the sites in this study were affected by the climatic changes during the transition from the Late Eocene culminating at the Oi-1 event of the Early Oligocene 
Oi-1 glacial: Above the E/O boundary Gonyaulacoid and Peridinioid dinocysts are present in site 696B. Gonyaulacoid dinocysts and non dinocysts are present in sites 699A, and 277 . In site $748 \mathrm{~B}$ no marine palynomorphs occur above the $\mathrm{E} / \mathrm{O}$ boundary.

Vonhof et al. (2000) cooling event: At 35.4 Ma in site 699A Phthanoperidinium dominate and Leiosphaeridia and Cymatiosphaera are present. In site 277 at $34.9 \mathrm{Ma}$ Leiosphaeridia dominates Cymatiosphaera and dinocysts are absent.

Late Eocene warming: At $\sim 36$ Ma Gonyaulacoid dominate site 699A. In site 277 Operculodinium and Corrudinium spp dominate.. Operculodinium spp increase in site 696B.

Cooling: Peridinioid and non dinocysts dominate between $\sim 41.3-\sim 37$ Ma. Site $696 \mathrm{~B}$ at $\sim 41.3$ Ma increases in Operculodinium spp and site $748 \mathrm{~B}$ shows acmes for Spinidinium spp and Leiosphaeridia. At $\sim 40.2 \mathrm{Ma}$ an acme for Phthanoperidinium spp occurs and Leiosphaeridia and Acritarchs dominate. At $\sim 39.4$ Ma Spinidinium spp and Cymatiosphaera occur. At $\sim 38.6$ Ma site 277 palynomorphs are present with Phthanoperidinium and Deflandrea spp dominating and all non dinocysts are present.

MECO: Gonyaulacoid dinocysts from 44.5 to 41 Ma dominate site $748 \mathrm{~B}$, warming begins at $\sim 44$ Ma Minisphaeridium group dominate; at $\sim 43$ Ma Spiniferites group dominate. The MECO between $\sim 42-41$ Ma is dominated by an acme of Thalassaphora spp and a smaller acme of Deflandrea spp.

EECO: A steady decline in temperature occurs from the EECO. Acritarchs dominate at 46 Ma in site 277. The non dinocysts of Tasmanites and Cymatiosphaera are present in $\sim 46 \mathrm{Ma}$ in site 277.
sites $748 \mathrm{~B}$ and 277.

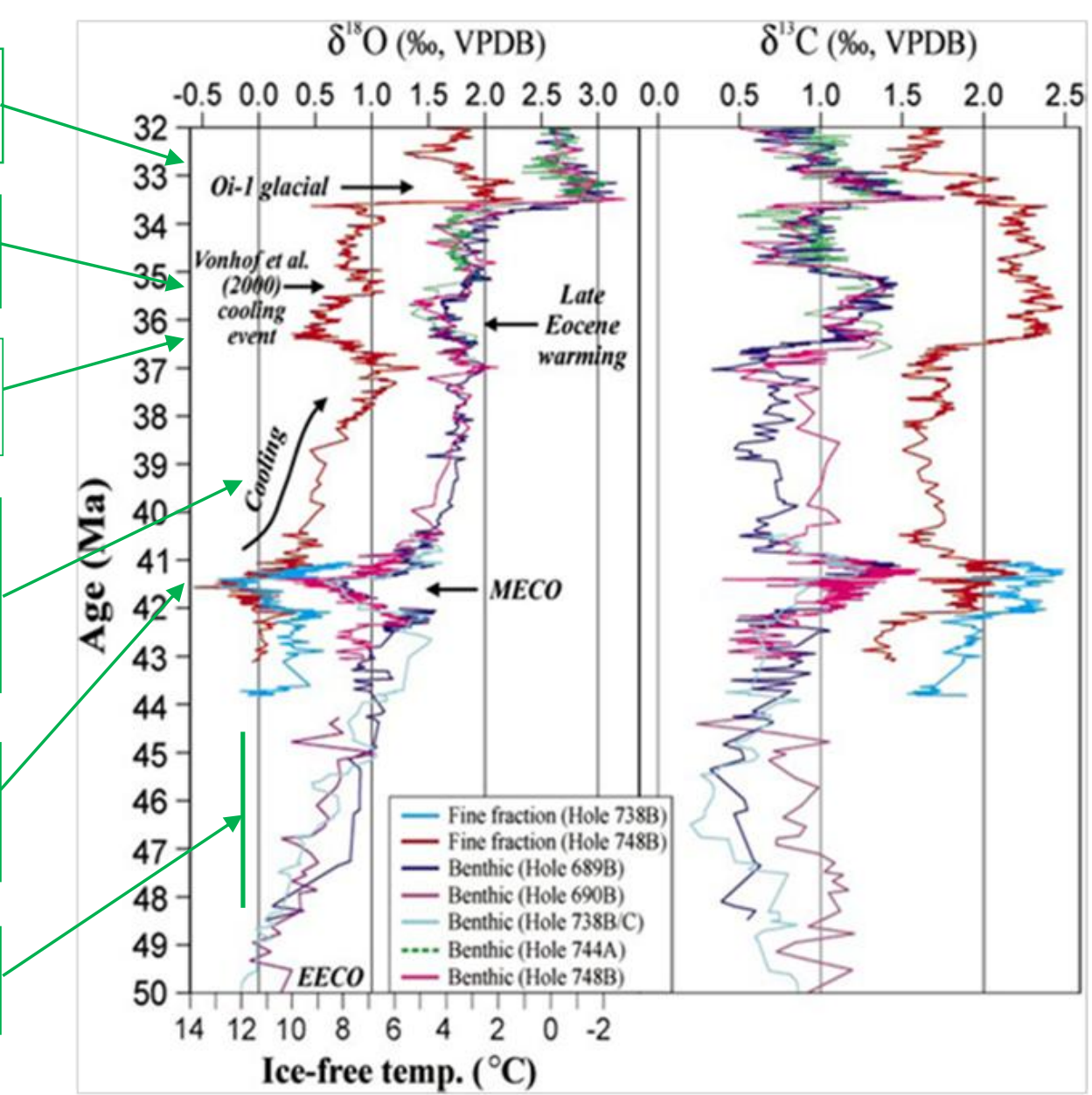

\section{Ice-free temp. $\left({ }^{\circ} \mathrm{C}\right)$}

Figure 5.3: A compilation of Southern Ocean stable isotope data taken from ODP sites 689, 690, 738, 744 and 748 adapted from Bohaty and Zachos (2003) as shown in Chapter one, page 6, Figure 1.3. The figure includes text boxes indicating the important events referred to on the isotope chart that can be related to the occurrences or dominance of Gonyaulacoid and Peridinioid dinocysts and non dinocysts. The sites from this study containing marine palynomorphs that are present for each event shown on the isotope chart include the approximate timing in Ma for their occurrences. Attached to each text box an arrow indicates the position of the event on the chart. 


\subsection{Dinoflagellate Events in a Global Context}

The isotope curve of Bohaty and Zachos (2003) (Chapter one, page 6) is repeated in Figure 5.3, along with key marine palynomorphs from Figures 5.1 and 5.2.

Significant changes in the presence or absence of marine palynomorphs in this study appear synchronous to the isotope events recorded in Figure 5.3. The figure is a compilation of Southern Ocean stable isotope data based on benthic foraminifera from ODP Sites 689, 690, 738, and 748 between 50 - 32 Ma (Bohaty and Zachos 2003), which complements the timeframe for this study ( $46-\sim 29 \mathrm{Ma}$ ). The EECO at the base of Figure 5.3 shows a steady decline in temperature from 50 $\mathrm{Ma}$ to $\sim 44 \mathrm{Ma}$. At $41.5 \mathrm{Ma}$, prominent minimum $\delta^{18} \mathrm{O}$ values were interpreted as a significant warming and designated as the MECO. A gradual cooling between $\sim 41-$ $37 \mathrm{Ma}$ is followed by a further Late Eocene warming at $\sim 36 \mathrm{Ma}$, and at $\sim 35 \mathrm{Ma}$ the Vonhof et al. (2000) cooling occurs. In addition to these events an Oi-1 glacial is recorded at $\sim 33.7 \mathrm{Ma}$.

\subsubsection{EECO Trends}

The palaeoclimate interpretations presented (5.4, page 105$)$ also can be related to the warming and cooling events listed in Figure 5.3. Although the EECO is not recorded in this study the cooling trend that followed the event can be seen in sites 748B and 277. An acme for the cosmopolitan Spiniferites group at $\sim 46$ Ma changed to Phthanoperidinium spp and Tasmanites at $\sim 44.8 \mathrm{Ma}$ in site $748 \mathrm{~B}$ indicative of colder waters. In site 277 at $\sim 46 \mathrm{Ma}$, Acritarchs dominate and at $\sim 44.8 \mathrm{Ma}$ the presence of the non dinocysts Cymatiosphaera spp and Tasmanites indicate conditions were cooler.

\subsubsection{MECO}

The MECO warming ( $42-41 \mathrm{Ma}$ ) begins in the Phthanoperidinium echinatum zone ( $\sim 4 \mathrm{Ma})$, with a dominance of Gonyaulacoid spp in site 748B culminating in an acme for Thalassaphora spp between $\sim 41-42 \mathrm{Ma}$, the middle of the Phthanoperidinium geminatum zone. Also present in site 748B, was an acme for Deflandrea spp, possibly indicating elevated nutrient availability, rather than cooler 
conditions (Sluijs et al., 2003; 2005). Warmer oceanic conditions occur during this period, with productivity in the upper water column. In contrast in site 696B the MECO was not recorded, although Operculodinium spp at the upper part of the Phthanoperidinium geminatum zone ( 41 Ma) increased significantly, indicating that changes or transitional events were being recorded in this neritic setting. A reduction in the Peridinioid numbers for Spinidinium and Vozzhennikovia spp were also recorded.

\subsubsection{Post MECO}

The cooling following the MECO ( 41 - 37 Ma) is reflected in the dinocyst record at the top of the Phthanoperidinium geminatum zone ( $\sim 1.3 \mathrm{Ma})$, and is seen in sites 699A, 748B and 277. In site 699A ( $37 \mathrm{Ma}$ ) Cymatiosphaera dominate Acritarchs. In site 748B ( 41 - 39 Ma) the Peridinioids of Deflandrea spp and an acme for Spinidinium spp were recorded. Above the Phthanoperidinium geminatum zone an acme for Phthanoperidinium spp is present while the non dinocysts have an acme for Leiosphaeridia and a presence of other Acritarchs and Cymatiosphaera. All are cooler temperature species. This cooling trend is also recorded in site 277 ( 36.8 - 36.5 Ma) with a dominance of Deflandrea spp. Cymatiosphaera and other non dinocysts are present. Conditions are interpreted in all three pelagic sites as offshore/oceanic, upwelling, cold nutrient rich waters, low salinity and lower sea surface temperatures. In addition, site 277 recorded transitional or changing conditions with an acme of Operculodinium spp.

\subsubsection{Late Eocene Warming}

Throughout the Late Eocene in site 696B Peridinioids still dominate, however Operculodinium spp increase significantly at $\sim 35.5$ Ma suggesting transitional changes were occurring during this period. The Late Eocene warming ( $\sim 36 \mathrm{Ma}$ ) is indicated by dominance of Gonyaulacoids in site 699A, and Corrudinium and Operculodinium spp in site 277 . Conditions were oceanic with high productivity recorded. 


\subsubsection{Vonhof Cooling}

The Vonhof et al. (2000) cooling event ( 35.4 Ma) in site 699A is reflected in the dominance of Phthanoperidinium spp and the presence of non dinocysts (Cymatiosphaera, Leiosphaeridia). In site 277 the cosmopolitan Impagidinium spp dominate however, Phthanoperidinium spp, Cymatiosphaera and Tasmanites are also present. Again these two sites appear to reflect as cooler ice edge conditions, with nutrient upwelling. In site 696B however, there is little change with Peridinioids still dominating.

\subsubsection{Oi-1}

The Oi-1 glacial shows no change in site 696B as Peridinioid dinocysts are still dominant. At $\sim 33.7 \mathrm{Ma}$ Eurydinium spp is dominant and in the Early Oligocene, Brigantedinium and Vozzhennikovia spp dominate up to 30 Ma. In site 699A Impagidinium group dominate and Cymatiosphaera spp are present at the E/O boundary. In site 277 Gonyaulacoids dominate and Cymatiosphaera spp are present between $\sim 37-31 \mathrm{Ma}$. The abundance of these species indicates that oceanic cooler conditions occurred in the Early Oligocene as seen in Figure 5.3. 


\section{6 \\ Conclusions}




\section{CHAPTER SIX}

\subsection{Conclusions}

This study has documented climate-induced changes in marine palynomorph assemblages in the Southern Ocean from the Middle Eocene across the E/O transition at the Oi-1 event and into the Early Oligocene. A total of 107 samples from four ODP and DSDP sites were processed for their palynological content. The locations of the investigated sites are the South Orkney microcontinent, in the Weddell Sea (ODP site 696B), the Northeast Georgia Rise, Falkland's area (ODP site 699A), the Western part of the Raggart Basin on the Kerguelen Plateau (ODP site 748B), and in the Cathedral Depression on the southern Campbell Plateau (DSDP site 277). The locations provided an interesting comparison and analysis of areas in the Southern Ocean.

An additional 47 samples from two sites (690B, 738B) were also processed but later discarded due to a lack of palynomorphs. In most cases the sediments proved difficult to process due to fungal contamination, requiring longer processing of the nannofossil ooze. Best results were achieved with additional sieving of the finer material in each sample to give an accurate count of the palynomorphic contents. Total abundance of assemblages included dinocysts, non dinocysts, microforaminiferal linings, insect casings and terrestrial material.

A standard nannofossil biostratigraphy was established in chapter two for all sites, using a timescale (Ma) by Berggren et al. (1995). The data were investigated to provide a temporal framework for this study.

The broad aim of this study was to document changes in marine palynomorph assemblages in the Middle Eocene/Early Oligocene. More specifically the first aim was to develop a Circum-Antarctic biozonation for the climate transition in the Southern Ocean. Using the nannofossil biostratigraphy as a framework, a new biozonation was achieved by identifying datum (first and last occurrences) correlations at each site that occurred in the same temporal order and the same nannofossil zone. The results show the assignment of six primary and two secondary datums, leading to the recognition of 
four new biozones. These were the Phthanoperidinium echinatum ( 45- 43 Ma), Phthanoperidinium geminatum ( 43- $\sim 40.5 \mathrm{Ma}$ ), Phthanoperidinium spA Zones ( 40.536.4 Ma) and the Corrudinium regulare Zone ( 36.4- 34.2 Ma). These zones were then used to identify various dinocyst events to indicate probable palaeoenvironments. This process was complicated by condensed or missing sediments in some sites affecting dinocyst occurrences (699A, 748B, 277). Site 696B proved to be the most stable palaeoenvironment, producing the best biostratigraphy for the Southern Ocean, and was complemented at differing timeframes, by the other three sites.

The second aim was to document the Circum-Antarctic distribution of palynomorph assemblages. This was accomplished by presenting the palynomorphs from each site as a total abundance of grains per gram. Analysis of the ranges and compositions of palynomorphs present was also displayed as a percentage of total abundance in each site, giving insight into palynomorphic distribution patterns.

To accomplish the third aim of documenting the effect of palaeoclimatic changes in the dinocysts assemblages, to the range of palaeoenvironmental signals, the dinocyst distribution was separated into Gonyaulacoid and Peridinioid assemblages. The Gonyaulacoid dinocysts are predominantly oceanic autotrophs while the Peridinioids are considered to be mostly heterotrophic and inner neritic, although they are also prevalent in oceanic palaeoenvironments that generate productivity and nutrient upwelling in the water column. A further grouping of the dinocysts was undertaken in order to place together morphologically related taxa associated to a known environmental affinity, to assist with interpretation of the palaeoenvironment in each site. Additionally, totals of Gonyaulacoid and Peridinioid dinocysts were combined with non dinocysts and terrestrial material for comparison and to provide further assistance with interpretation. Previous work in the Southern Ocean and Antarctica gave an indication of suggested palaeoenvironments for dinocysts and non dinocyst (including terrestrial) material, which additionally provided concise reference points for this study.

Comparison between each site showed that the Weddell Sea (site 696B) was the most climatically stable of the four sites. Here terrestrial material dominated all 
palynomorph assemblages, with Peridinioid dinocysts in turn dominating the identified marine palynomorphs. The indications were for a warmer inner neritic palaeoenvironment indicated by an approximate water depth of less than $100 \mathrm{~m}$, a high abundance of terrestrial material and few of the cooler species of Prasinophyte algae and Leiosphaeridia. Some possible transitional changes may have occurred due to Operculodinium present, although the site remained constant through to the middle of the Late Eocene ( $36 \mathrm{Ma})$. The pelagic sites where palynomorphs were present demonstrated a different palaeoenvironment. On the Kerguelen (site 748B) and Campbell (site 277) Plateaus at $\sim 46 \mathrm{Ma}$, oceanic conditions with low temperatures prevailed and by $45 \mathrm{Ma}$, additional nutrient upwelling and high productivity was recorded in the upper water column, while overall conditions remained cool. The only pelagic site that contained palynomorphs during most of the Middle Eocene was site 748B on the Kerguelen Plateau. This site illustrated an oceanic and warm period between $\sim 44-\sim 42 \mathrm{Ma}$, in addition, at $\sim 41.5 \mathrm{Ma}$ productivity was inferred in the upper water column. This period of warming and productivity was not, however, illustrated in the Weddell Sea (site 696) as the palaeoenvironment was already significantly warmer and did not register the changes that were shown in site 748B.

Between $\sim 41-\sim 38.7 \mathrm{Ma}$, site 748B underwent significant changes in palynomorph assemblages indicating that the palaeoenvironment was becoming cooler, with high productivity in the sea surface and highly eutrophic conditions prevailing. At $\sim 39 \mathrm{Ma}$ nutrient rich waters and upwelling is inferred, and the same conditions can be found on the Campbell Plateau (site 277 ) from $\sim 38.7 \mathrm{Ma}$ up to the Late Eocene ( 37 Ma). During the Late Eocene conditions changed both in the Weddell Sea (site 696B) and on the Campbell plateau (site 277), with both sites indicating changeable conditions through the presence of Operculodinium spp. The conditions were more pronounced in site 277 with Deflandrea dominating at $\sim 36.5 \mathrm{Ma}$, which changed to a domination of Impagidinium by $\sim 35.3 \mathrm{Ma}$ indicating deeper, oceanic and conditions were cooler, while site 696B remained as inner neritic with suggested warm conditions. In contrast the Falklands (site 699A) differed with cooler, oceanic (Impagidinium) sea surface high productivity suggested during this interval. By $35.3 \mathrm{Ma}$ Gonyaulacoid dinocysts were 
dominated by Peridinioid dinocysts and coastal/offshore conditions with high sea surface productivity prevailing.

At the E/O transition ( $\sim 33.7 \mathrm{Ma}$ ) the Weddell Sea (site 696B) is dominated by the Peridinioid dinocyst Eurydinium whose possible palaeoenvironment is unknown but may be considered as a transitional species. In the Falklands region (site 699A), the palaeoenvironment was oceanic and upwellings of nutrient rich cold waters continued, similar to the possible conditions on the Campbell Plateau (site 277). The Kerguelen Plateau (site 748B) was barren of palynomorphs; however, ice rafted debris was present suggesting cold sea surface conditions.

In the Early Oligocene indications of change in the Weddell Sea (site 696B) were identifiable with a slight increase in Gonyaulacoid dinocysts, indicating a possible outer neritic/coastal palaeoenvironment. These changes continued and by $\sim 29 \mathrm{Ma}$ coastal/oceanic upwelling (deepening) and possible sea ice conditions were present. The Falklands (site 699A) and Kerguelen Plateau (site 748B) were both barren of palynomorphs during this interval, while at the Campbell Plateau (site 277) 30 Ma cooler conditions, offshore/oceanic upwelling or nutrient rich waters were predominant.

Key findings between all sites in this study illustrate that the pelagic and inner neritic sites differed greatly in the Southern Ocean. In the inner neritic site Peridinioid dinocysts dominated, conditions were warmer and changes occurred more slowly. In comparison the pelagic sites were unstable and showed condensed sequences or missing sediments, with palynomorphs not present during those times. However, known palynomorph markers (e.g. Peridinioid dinocysts, Prasinophyte algae, Leiosphaeridia) for temperature change were present throughout the pelagic sites, highlighting the climatic changes occurring throughout the Middle Eocene/Early Oligocene.

In addition, Peridinioid (heterotrophic) dinocysts were present in both warm, inner neritic conditions and colder, oceanic upwelling palaeoenvironments. Perhaps this illustrates Peridinioid dinocysts were tolerant to changes in ocean temperatures, and 
the productivity in the Southern Oceans was the main reason for their presence. The preference of non dinocysts (Prasinophyte algae and Leiosphaeridia) for colder conditions, are more indicative of cooler temperature changes in the Southern Ocean. 


\section{References}




\section{REFERENCES}

Andrews, P.B., Gostin, V.A., Hampton, M.A., Margolis, S.V., Ovenshine, A.T. 1975 Synthesis - Sediments of the Southwest Pacific Ocean, Southeast Indian Ocean, and South Tasman Sea. Proceedings ODP Initial Reports. Leg 29 College Station, Texas. 29 (43) : 1147-1153

Aubry, M-P. 1992 Paleogene Calcareous Nannofossils from the Kerguelen Plateau, Leg 120. Proceedings ODP, Scientific results 120 (26) : 471-491.

Barker, P., Dalziel, I.W.D., et al., 1977 Site 327 Shipboard Scientific Party Proceedings DSDP, Initial Reports 36 (4) : 27-45

Barker, P., Dalziel, I.W.D., et al., 1977 Site 328 Shipboard Scientific Party Proceedings DSDP, Initial Reports 36 (4) : 87-140

Barker, P., Dalziel, I.W.D., et al., 1977 Site 330 Shipboard Scientific Party Proceedings DSDP, Initial Reports 36 (4) : 207-227

Barker P.F., Kennett, J.P., et al., 1988 Site report Site 696, Shipboard Scientific Party Proceedings ODP Initial Reports. 113 College Station, Texas. ODP Leg 113 (11) : 607-704

Barker, P.F.; Thomas, E. 2004 Origin, signature and palaeoclimatic influence of the Antarctic Circumpolar Current. Earth-Science Reviews 66 : 143-162

Barker, P.F.; Filippelli, G.M.; Florindo, F.; Martin, E.E.; Scher, H.D. 2007 Onset and role of the Antarctic Circumpolar Current. Deep-Sea Research Part II. 54 : 2388-2398.

Barrett, P. J. 2003 Cooling a continent Nature 421: 221-223

Batten, D.J. 1996 Palynofacies and Palaeoenvironmental Interpretation (eds) Jansonius, J., McGregor, D. C. In Palynology: Principles and applications AASP Foundation. 3 (26A) : 1011-1064

Berggren, W.A.; Kent, D.V.; Swisher III, C.C.; Aubry, M-P. 1995 : A Revised Cenozoic Geochronology and Chronostratigraphy. In (eds) Geochronology Time Scales and Global Stratigraphic Correlation; SEPM Special Publication No. 54 129-212.

Bijl, P.K., Pross, J., Warnaar, J., Stickley, C.E. Huber, M., Guerstein, R., Houben, A.J.P., Sluijs, A., Visscher, H., Brinkhuis, H. 2011 Environmental forcings of 
Paleogene Southern Ocean dinoflagellate biogeography Paleoceanography $26: 1-12$.

Billups, K.; Schrag, D.P. 2003 Application of benthic foraminiferal Mg/Ca ratios to questions of Cenozoic climate change. Earth and Planetary Science Letters. $209: 181-195$

Bohaty, S.M., Zachos, J.C. Florindo, F., Delaney, M.L. 2009 Coupled greenhouse warming and deep-sea acidification in the middle Eocene Paleoceanography $24: 1-16$

Bohaty, S.M.; Zachos, J.C. 2003 Significant Southern Ocean warming event in the late middle Eocene. Geology. 31 : 1017-1020

Boulton G.S. 1993 Ice ages and climatic change In (ed) Duff D, Holmes' Principles of Physical Geology, fourth ed, chpt 21 : 439-469

Breza, J.R., Wise, Jr. S. 1992 Lower Oligocene Ice-Rafted Debris on the Kerguelen Plateau: Evidence for East Antarctic Continental Glaciation Proceedings of the Ocean Drilling Program, Scientific Results 12012 : 161-178

Brinkkuis, H. 1994 Late Eocene to Early Oligocene dinoflagellate cysts from the Priabonian type-area (Northeast Italy); biostratigraphy and paleoenvironmental interpretation. Palaeogeography, Palaeoclimatology, Palaeoecology. 107 : 121-163

Brinkhuis, H., Biffi, U. 1993 Dinoflagellate cyst stratigraphy of the Eocene/Oligocene transition in central Italy Marine Micropaleontology 22: 131-183.

Brinkhuis, H., Munsterman, D. K., Sengers, S., Sluijs, A., Warnaar, J., Williams, G. L. 2003a Late Eocene-Quaternary Dinoflagellate Cysts from ODP Site 1168, off Western Tasmania Eds Exon, N. F., Kennett, J. P., Malone, M. J. Proceedings of the Ocean Drilling Program, Scientific Results Leg 189.

Brinkhuis, H., Munsterman, D.K., Sengers, S., Sluijs, A., Warnaar, J., Williams, G.L. 2003A Late Eocene-Quaternary Dinoflagellate Cysts from ODP Site 1168, off Western Tasmania Eds Exon, N. F., Kennett, J. P., Malone, M. J. Proceedings of the Ocean Drilling Program, Scientific Results Leg 189.

Brinkhuis, H., Sengers, S., Sluijs, A., Warnaar, J., Williams, G. L. 2003 b Latest Cretaceous-Earliest Oligocene and Quaternary Dinoflagellate Cysts, ODP Site 
1172, East Tasman Plateau, Eds Exon, N. F., Kennett, J. P., Malone, M. J. Proceedings of the Ocean Drilling Program, Scientific Results Leg 189.

Brinkhuis, H., Head, M.J., Pross, J., Riding, J.B., Schioler, P., Sluijs, A. 2009 Jurassic Cretaceous - Cenozoic Organic - Walled Dinoflagellate Cysts Morphology, Stratigraphy and Palaeoecology. Urbino Dinflagellate Course 1970- 2009 Ciesielski, P.F., Dristofferen, Y., et al., 1988 Site 699 Ship Board Scientific Party Proceedings ODP, Initial Reports 114 College Station, Texas (ODP) 114 (6) : $151-254$

Clowes, C.D.; Wilson, G.J. 2006 Some new species of Corrudinium Stover \& Evitt 1978 (Dinophyceae) from the Eocene of New Zealand. New Zealand Journal of Geology \& Geophysics. 49 : 399-408

Cookson, I. C., 1965a Cretaceous and Tertiary Microplankton from South-Eastern Australia. Proceedings of the Royal Society of Victoria 781 : 85-96

Cookson, I. C., 1965b Microplankton from the Paleocene Pebble Point Formation, South-Western Victoria. Proceedings of the Royal Society of Victoria 782 : $137-143$

Coxall, H.K., Wilson, P.A., Pälike, H., Lear, C.H., Backman, J. 2005 Rapid stepwise onset of Antarctic glaciations and deeper calcite compensation in the Pacific Ocean. Nature 433 : 53-57

Cranwell, L M., Harrington, H. J., Speden, I. G. 1960 Lower Tertiary microfossils from McMurdo Sound, Antarctica. Nature 186 : 700-702

Crouch E.M and Hollis C.J. 1996 Palaeogene palynomorph and radiolarian biostratigraphy of DSDP Leg 29, Sites 280 and 281 South Tasman Rise. Institute of Geological and Nuclear Sciences Science Report 96/19, 46pp.

Crouch, E.M.; Brinkhuis, H. 2005 Environmental change across the PaleoceneEocene transition from eastern New Zealand: A marine palynological approach. Marine Micropaleontology. 56 : 138-160

Crouch, E.M.; Dickens, G.R.; Brinkhuis, H.; Aubry, M-P.; Hollis, C.J.; Rogers, K.M.; Visscher, H. 2003 The Apectodinium acme and terrestrial discharge during the Paleocene-Eocene thermal maximum: new palynological, geochemical and calcareous nannoplankton observations at Tawanui, New Zealand. Palaeogeography, Palaeoclimatology, Palaeoecology. 194 : 387-403 
Crux, J.A. 1991 Calcareous Nannofossils Recovered by Leg 114 in the Subantarctic South Atlantic Ocean. Proceedings of the Ocean Drilling Program, Scientific Results, Leg 114 (7) : 155-176.

Dale, B. 1996 Dinoflagellate Cyst Ecology: Modeling and Geological Applications (eds) Jansonius, J., McGregor, D. C. In Palynology: Principles and applications AASP Foundation. 3 : 1249-1275

DeConto, R.M., \& Pollard, D. 2003 Rapid Cenozoic glaciation of Antarctica induced by declining atmospheric $\mathrm{CO}_{2}$. Nature $421: 245-249$

DeConto, R.M., \& Pollard, D. 2003 A coupled climate-ice sheet modelling approach to the Early Cenozoic history of the Antarctic ice sheet. Palaeogeography, Palaeoclimatology, Palaeoecology $198: 39-52$

De Vernal, A., Mudie, P. J. 1992 Pliocene and Quaternary Dinoflagellate Cyst Stratigraphy in the Labrador Sea: Paleoenvironmental Implications eds. Head, M. J. Wrenn, J. H. Neogene and Quaternary Dinoflagellate Cysts and Acritarchs American Association of Strigraphic Palynologists Foundation $329-346$

Diekmann, B., Huhn, G., Gersonde, R., Mackensen, A. 2004 Middle Eocene to early Miocene environmental changes in the sub-Antarctic Southern Ocean: evidence from biogenic and terrigenous depositional patterns at ODP Site 1090. Global and Planetary Change $40: 295-313$

Diester-Haass, L., Zahn, R. 1996 Eocene-Oligocene transition in the Southern Ocean: History of water mass circulation and biological productivity Geology 242 : 163-166.

Diester-Haass, L., Zahn, R. 2001 Paleoproductivity increase at the EoceneOligocene climatic transition: ODP/DSDP sites 763 and 592 Palaeogeography, Palaeoclimatology, Palaeoecology 172 : 153-170.

Eagles, G., Livermore, R., Morris, P., 2006 Small basins in the Scotia Sea: The Eocene Drake Passage gateway Earth and Planetary Science Letters 242 : 343-353.

Edwards, A.R.; Perch-Nielsen, K. 1975 Calcareous Nanofossils from the Southern Southwest Pacific, Deep Sea Drilling Project, Leg 29. In (eds) James P. Kennett, 
Robert E. Houtz, et al. Proceedings of the Ocean Drilling Program, Initial results Leg 29: College Station, Texas. Leg 29 : 469-495

Edwards, L.E., Andrle, V.A.S. 1992 Distribution of Selected Dinoflagellate Cystsin Modern Marine Sediments. In (Eds Head, M.J. and Wrenn, J.H.) Neogene and Quaternary Dinoflagellate Cysts and Acritarchs. American Association of Stratigraphic Palynologists Foundation. 259-288.

Eldrett, J.S., Harding, I.C. 2009 Palynological analyses of Eocene to Oligocene sediments from DSDP Site 338, Outer Vøring Plateau. Marine Micropaleontology 73 : 226-240

Eldrett, J.S., Harding, I.C., Firth, J.V., Roberts, A.P. 2004 Magnetostratigraphic calibration of Eocene-Oligocene dinoflagellate cyst biostratigraphy from the Norwegian-Greenland Sea. Marine Geology 204 : 91-27.

Evitt, W.R. 1985 Sporopollenin Dinoflagellate Cysts: Their Morphology and Interpretation. American Association of Straigraphic Palynologists Foundation, pp 333.

Fensome, R. A.; Riding, J. B.; Taylor, F. J. R. 1996 Dinoflagellates (eds) Jansonius, J., McGregor, D. C. In Palynology: Principles and applications AASP Foundation. $1: 107-169$

Fensome, R.A.; Williams, G.L. 2004. The Lentin and Williams Index of fossil dinoflagellates 2004 Edition. American Association of Stratigraphic Palynologists, Contribution Series, No. 42, 909p.

Fensome, R.A., MacRae, R.A. and Williams, G.L., 2008. DINOFLAJ2, Version 1. American Association of Stratigraphic Palynologists, Data Series no. 1 Fensome, R.A., Williams, G.L., MacRae, A.R. 2009 Late Cretaceous and Cenozoic Fossil Dinoflagellates and Other Palynomorphs from the Scotian Margin, Offshore Eastern Canada. Journal of Systematic Palaeontology 7 (1) : 1-79.

Firth, J.V. 1996 Upper Middle Eocene to Oligocene Dinoflagellate Biostratigraphy and Assemblage Variations in Hole 913B, Greenland Sea. Proceedings of the Ocean Drilling Program, Scientific Results Leg 151 (12) : 203-242.

Florindo, F.; Roberts, A. P. 2005 Eocene-Oligocene Magnetobiochronology of ODP Sites 689 and 690, Maud Rise, Weddell Sea, Antarctica Geological Society of America $117(1 / 2)$ : 46-66 
Francis, J.E.; Marenssi, S.; Levy, R.; Hambrey, M.; Thorn, V.C.; Mohr, B.; Brinkhuis, H.; Warnaar, J.; Zachos, J.; Bohaty, S.; DeConto, R. 2009 From Greenhouse to Icehouse - The Eocene/Oligocene in Antarctica. Developments in Earth \& Environmental Sciences $8: 310-367$

Gamboa, L.A., Buffler, R.T. 1983 Seismic Stratigraphy and Geologic History of the Rio Grande Gap ajnd Southern Brazil Basin Initial Reports of the Deep Sea Drilling Project, Leg 72 : 481-496

Goodman, D K., Ford, Jr. L. N. 1983 Preliminary dinoflagellate biostratigraphy for the middle Eocene to lower Oligocene from the southwest Atlantic Ocean. In Ludwig, W. J.; Krasheninnikov, V. A. Initial Reports of the Deep Sea Drilling Project, Leg 71 : 859-877

Guerstein, G.R., Guler, M.V., Williams, G.L., Fensome, R.A., Chiesa, J.O. 2008 Middle Palaeogene dinoflagellate cysts from Tierra del Fuego, Argentina: biostratigraphy and palaeoenvironments. Journal of Micropalaeontology. $27: 75-94$.

Guy-Ohlson, D. 1996 Green and Blue-Green Algae. 7B - Prasinophycean Algae. (eds) Jansonius, J., McGregor, D. C. In Palynology: Principles and applications AASP Foundation. 1 (7B) : 181-189.

Handley, L., Crouch, E.M., Pancost, R.D. 2011 A New Zealand record of sea level rise and environmental change during the Paleocene-Eocene Thermal Maximum. Palaeogeography, Palaeoclimatology, Palaeoecology 305 : 185200

Hannah, M. J. 1994 Eocene dinoflagellates from CIROS-1 Drillhole, McMurdo Sound, Antarctica. Terra Antartica 1 (2) : 3

Hannah, M. J. 1997 Climate Controlled Dinoflagellate Distribution in Late EoceneEarliest Oligocene Strata from CIROS-1 Drillhole, McMurdo Sound, Antarctica. Terra Antartica 4 (2) : 73-78

Hannah, M. J., Cita, M. B., Coccioni, R., Monechi, S. 1997 The Eocene/Oligocene Boundary at $70^{\circ}$ South, McMurdo Sound, Antarctica Terra Antartica 4 (2) : $79-87$

Hannah, M.J., Wilson, G.J., Wrenn, J.H., 2000 Oligocene and Miocene Marine Palynomorphs from CRP-2/2A. Terra Antartica 7 (4) : 503-511 
Harwood, D.M. 1989 Siliceous Microfossils. In Barrett, P.J. (ed), Antarctic Cenozoic history from the CIROS-1 drillhole, McMurdo Sound. New Zealand Department of Scientific and Industrial Research Bulletin 245 : 23-48

Haskell, T. R., Wilson, J. J. 1975 Palynology of sites 280-284, DSDP Leg 29, off Southeastern Australia and Western New Zealand eds. Kennett, J. P., Houtz, R. E. et al. Initial Reports of the Deep Sea Drilling Project, Vol. 29 : 723-741 Head, M.J. 1996 Modern Dinoflagellate Cysts and their Biological Affinities. (eds) Jansonius, J., McGregor, D. C. In Palynology: Principles and applications AASP Foundation. 3 : 1197-1248

Head, M.J., Norris, G., Mudie P.J. 1989a Palynology and dinocyst stratigraphy of the Miocene in Ocean Drilling Program Leg 105, Hote 645E, Baffin Bay. In: Srivastava, S.P., Arthur, M., Clement, B. Proceedings of the Ocean Drilling Program, Scientific Results Leg 105 : 467-514.

Head, M.J., Norris, G. 1989 Palynology and Dinocyst stratigraphy of the Eocene and Oligocene in ODP Leg 105, Hole 647A, Labrador Sea. In: Srivastava, S.P., Arthur, M., Clement, B. Proceedings of the Ocean Drilling Program, Scientific Results Leg 10528 : 515-550.

Herngreen, G.F.W., Kedves, M., Rovnina, L.V., Smirnova, S.B. 1996 Vegetational History. 29C - Cretaceous Palynofloral Privinces: A Review. (eds) Jansonius, J., McGregor, D. C. In Palynology: Principles and applications AASP Foundation. 3 : 1157-1188

Hollis C.J., Waghorn, D.B. Strong, C.P. Crouch E.M. 1997. Integrated Palaeogene biostratigraphy of DSDP site 277 (Leg 29): foraminifera, calcareous nannofossils, radiolaria and palynomorphs. Institute of Geological and Nuclear Sciences Science Report 97/07,

Hollis, C.J., Dickens, G.R., Field, B.D., Jones, C.M., Percy Strong, C. 2005 The Paleocene-Eocene transition at Mead Stream, New Zealand: A southern Pacific record of early Cenozoic global change. Palaeogeography, Palaeoclimatology, Palaeoecology 215 : 313-343.

Huber, M., Brinkhuis, H., Stickley, C. E., Doos, K., Sluiijs, A., Warnaar, J., Schellenberg, S. A., Williams, G. L. 2004 Eocene circulation of the Southern Ocean: Was Antarctica kept warm by subtropical waters? Paleoceanography $19: 1-12$ 
Huber, M., Nof, D., 2005 The ocean circulation in the Southern Hemisphere and its climatic impacts in the Eocene. Palaeogeography, Palaeoclimatology, Palaeoecology 231 : 9-28

Kemp, E. M. 1975 Palynology of Leg 28 drill Sites, Deep Sea Drilling project eds. Hayes, D. E., Frakes, L. A. Initial Reports of the Deep Sea Drilling project Leg 28 599-628

Kennett, J.P., Houtz, R.E., Andrews, P. B., Edwards, A. R., Gostin, V.A., Hajos, M., Hampton, M., Jenkins, D.G., Margolis, S.V., Ovenshine, A.T., Perch-Nielsen, K. 1975 Site 277 The Shipboard Scientific Party Proceedings ODP Initial Report Leg 29 (4) : 45-120

Kennett, J.P., Houtz, R.E., Andrews, P. B., Edwards, A. R., Gostin, V.A., Hajos, M., Hampton, M., Jenkins, D.G., Margolis, S.V., Ovenshine, A.T., Perch-Nielsen, K. 1975 Cenozoic Paleoceanography in the Southwest Pacific Ocean, Antarctic Glaciation, and the Development of the Circum-Antarctic Current Proceedings of the Ocean Drilling Program Leg 29 : 1155 - 1169

Kennett, J.P., Stott, L.D. 1991 Abrupt deep-sea warming, palaeoceanographic changes and benthic extinctions at the end of the Palaeocene. Nature 353 : 225-229.

Kump, L.R. 2009 Tipping Pointedly Colder. Science 323: 1175-1176

Lawver, L. A., Gahagan, L. M. 2003 Evolution of Cenozoic seaways in the circumAntarctic region Palaeogeography, Palaeoclimatology, Palaeoecology 198 : $11-37$

Lear, C.H., Bailey, T.R., Pearson, P.N., Coxall, H.K., Rosenthal, Y. 2008 Cooling and ice growth across the Eocene-Oligocene transition. The Geological Society of America. 36 (3) : 251-254.

Levy R.H. \& Harwood D.M. 2000. Tertiary marine Palynomorphs from the McMurdo Sound Erratics, Antarctica. In (Eds Stilwell J.D. Feldmann R.M.) Paleobiology and Palaeoenvironment of Eocene Rocks. Antarctic Research Series Vol 76

Liu, Z. Pagani, M., Zinniker, D., DeConto, R., Huber, M., Brinkhuis, H., Shah, S.R., Leckie, R.M., Pearson, A. 2009 Global Cooling during the Eocene-Oligocene Climate Transition. Science 323 : 1187-1190 
Livermore, R., Nankivell, A., Eagles, G., Morris, P. 2005 Paleogene opening of Drake Passage. Earth and Planetary Science Letters 236 : 459-470.

Ludwig, W.J., Krasheninnikov, V.A., et al., 1983 Site 511 Shipboard Scientific Party Proceedings DSDP, Initial Reports 71 (2) : 21-108

Madile, M., Monechi, S. 1991 Late Eocene to Early Oligocene Calcareous Nannofossil Assemblages from Sites 699 and 703, Subantarctic South Atlantic Ocean. Proceedings of the Ocean Drilling Program, Scientific Results Leg 114 (8) : 179-190

Mao, S., Mohr, B. A. R. 1995 Middle Eocene dinocysts from Bruce Bank (Scotia Sea, Antarctica) and their paleoenvironmental and paleogeographic implications Review of Palaeobotany and Palynology 86 : 235-263

Martini, E. 1971. Standard Palaeogene Calcareous Nannoplankton Zonation. Nature 226 : 560-561

Miller, K.G., Fairbanks, R.G., Mountain, G.S. 1987 Tertiary Oxygen Isotope Synthesis, Sea Level History and Continental Margin Erosion. Paleoceanography. 2 (1) : 1-19

Mohr, B. A. R. 1990 Eocene and Oligocene sporomorphs and dinoflagellate cysts from Leg 113 drill sites, Weddell Sea, Antarctica eds. Barker, P. F., Kennett, J. P. Proceedings of the Ocean Drilling Program, Scientific Results, Vol. 113 $595-612$

Mudie, P.J. 1992 Circum-Arctic Quaternary and Neogene Marine Palynofloras: Paleoecology and Statistical Analysis. In (Eds Head, M.J. and Wrenn, J.H.) Neogene and Quaternary Dinoflagellate Cysts and Acritarchs. American Association of Stratigraphic Palynologists Foundation. 347-390.

Mudie, P.J., Harland, R. 1996 Aquatic Quaternary. (eds) Jansonius, J., McGregor, D. C. In Palynology: Principles and applications AASP Foundation. 2 (21) : 843-877.

Nocchi, M., Amici, E., Silva, I.P. 1991 Planktonic Foraminiferal Biostratigraphy and Paleoenvironmental Interpretation of Paleogene Faunas from the Sub Antantarctic Transect. Eds. Ciesielski, P.F., Kristoffersen, Y. et al. Proceedings of the Ocean Drilling Program, Scientific Results, Vol. 114 233273 
Okada, H., Bukry, D. 1980 Supplementary Modification and Introduction of Code Numbers to the Low-Latitude Coccolith Biostratigraphic Zonation (Bukry, 1973; 1975). Marine Micropaleontology 5 : 321-325

Pagani, M., Zachos, J. E., Freeman, K. H., Tipple, B., Bohaty, S. M. 2005 Marked Decline in atmospheric Carbon Dioxide Concentrations During the Paleogene Science $309: 600-603$

Pälike, H., Norris, R.D., Herrle, J.O., Wilson P.A., Coxall, H.K., Lear, C.H., Shackleton, N.J., Tripati, K.A., Wade, B.S. 2006 The Heartbeat of the Oligocene Climate System. Science $314: 1894-1898$

Persico, D., Villa G., 2004 Eocene-Oligocene calcareous nannofossils from Maud Rise and Kerguelen Plateau/Antarctica: paleoecological and paleoceanographic implications. Marine Micropaleontology 52 : 153-179

Pfuhl, H.A.; McCave, N.I. 2003 Integrated Age Models for the Early OligoceneEarly Miocene, Sites 1168 and 1170-1172 Proceedings of the Ocean Drilling Program, Scientific Results, Vol. 189 : 1-21

Pfuhl, H.A.; McCave, N.I. 2005 Evidence for late Oligocene establishment of the Antarctic Circumpolar Current. Earth and Planetary Science Letters 235 715728.

Pross, J., Brinkhuis, H. 2005 Organic-walled dinoflagellate cysts as paleoenvironmental indicators in the Paleogene; a synopsis of concepts. Paläontologische Zeitschrift 79 (1) : 53-59

Pross, J., Schmiedl, G. 2002 Early Oligocene dinoflagellate cysts from the Upper Rhine Graben (SW Germany): palaeoenvironmental and paleoclimatic implications. Marine Micropaleontology $45: 1-24$

Reichart, G.J., Brinkhuis, H., Huiskamp, F., Zachariasse, W.J. 2004 Hyperstratification following glacial overturning events in the northern Arabian Sea. Paleoceanography 19 : 1-8

Robert, C., Maillot, H., 1983 Paleoenvironmental Significance of Clay Mineralogical and Geochemical Data, Southwest Atlantic, deep Sea Drilling Project Legs 36 and 71 In Ludwig, W.J., Krasheninnikov, V.A., et al., Eds. Proceedings of the DSDP, Initial Reports, DSDP 71 (11) : 317-342 
Roberts, A.P.; Wilson, G.S.; Harwood, D.M.; Verosub, K.L. 2003 Glaciation across the Oligocene-Miocene boundary in southern McMurdo Sound, Antarctica; new chronology from the CIROS-1 drill hole. Palaeogeography, Palaeoclimatology, Palaeoecology. 198 : 113-130

Rochon, A.; De Vernal, A.; Turon, J-L.; Matthiessen, J.; Head, M.J. 1999 Distribution of Recent Dinoflagellate Cysts in Surface Sediments from the North Atlantic Ocean and Adjacent Seas in Relation to Sea-Surface Parameters. AASP Contributions Series Number 35 : 1-152.

Röhl, U.; Brinkhuis, H.; Stickley, C.E.; Fuller, M.; Schellenberg, S.A.; Wefer, G.; Williams, G.L. 2004 Sea Level and Astronomically Induced Environmental Changes in Middle and Late Eocene Sediments from the East Tasman Plateau. In (eds) Exon, N.; Kennett, J.P.; Malone, M. The Cenozoic Southern Ocean: Tectonics, Sedimentation, and Climate Change Between Australia and Antartica. Geophysical Monograph 151 : 127-151

Shackleton, N. J., Kennett, J. P. 1975. Paleotemperature history of the Cenozoic and the initiation of Antarctic glaciation: oxygen and carbon isotope analyses in DSDP Sites 277, 279 and 281. Initial Reports of the Deep Sea Drilling Project $29: 743-755$

Scher, H. D., Martin, E. E., 2004 Circulation in the Southern Ocean during the Paleogene inferred from neodymium isotopes Earth and Planetary Science Letters 228 : 391-405

Scher, H. D., Martin, E. E., 2006 Timing and climatic consequences of the opening of Drake Passage. Science 312 : 428-430

Sluijs, A., Brinkhuis, H., Stickley, C. E., Warnaar, J., Williams, G. L., Fuller, M. 2003 Dinoflagellate Cysts from the Eocene-Oligocene Transition in the Southern Ocean: Results from ODP Leg 189 eds. Exon, N. F., Kennett, J. P., Malone, M. J. Proceedings of the Ocean Drilling Program, Scientific Results Volume 189 : $1-41$

Sluijs, A.; Brinkhuis, H.; Williams, G.L.; Fensome, R.A. 2009 Taxonomic revision of some Cretaceous-Cenozoic spiny organic-walled peridiniacean dinoflagellate cysts. Review of Palaeobotoany and Palynology 154 : 34-53 
Sluijs, A., Pross, J., Brinkhuis, H. 2005 From greenhouse to icehouse; organicwalled dinoflagellate cysts as paleoenvironmental indicators in the Paleogene. Earth Science Reviews 68 : 281-315.

Sluijs, A., Röhl, U., Schouten, S., Brumsack, H.J., Sangiorgi, F., Sinninghe Damsté, J.S., Brinkhuis, H. 2008 Arctic late Paleocene-early Eocene palaeoenvironments with special emphasis o the Paleocene-Eocene thermal maximum (Lomonosov Ridge, Itegrated Ocean Drilling Program Expedition 302), Paleoceanography, 23 PA1S11.

Stancliffe, R.P.W. 1996 Miscellaneous, Microforaminiferal Linings. (eds) Jansonius, J., McGregor, D. C. In Palynology: Principles and applications AASP Foundation. 1 (13D) : 373-387.

Stickley, C. E., Brinkhuis, H. 2004 Late Cretaceous-Quaternary Biomagnetostratigraphy of ODP Sites 1168, 1170, 1171, and 1172, Tasmanian Gateway eds Exon, N. F., Kennett, J. P., Malone, M. J. Proceedings of the Ocean Drilling Program, Scientific Results Leg 189 1-57

Stover, L.E., Brinkhuis, H., Damassa, S.P., de Verteuil, L., Helby, R.J., Monteil, E., Partridge, A.D., Powell, A.J., Riding, J.B., Smelror, M., Williams, G.L. 1996 Mesozoic-Tertiary Dinoflagellates, Acritarchs and Prasinophytes. (eds) Jansonius, J., McGregor, D. C. In Palynology: Principles and applications AASP Foundation. 2 (19) : 641-750

Strong, C.P. 1997 Foraminifera In Integrated Paleogene biostratigraphy of DSDP site 277 (Leg 29): foraminifera, calcareous nannofossils, radiolaria and palynomorphs Institute of Geological and Nuclear Sciences Limited SCIENCE REPORT 97/07 : 2-12.

Strother, P.K. 1996 Acritarchs (eds) Jansonius, J., McGregor, D. C. In Palynology: Principles and applications AASP Foundation. $1:$ 81-106

Szaniawski, H. 1996 Scolecodonts (eds) Jansonius, J., McGregor, D. C. In Palynology: Principles and applications AASP Foundation. $1: 337-354$

Takemura, A., Ling, H.Y. 1997 Eocene and Oligocene radiolarian biostratigraphy from the Wouthern Ocean: correlation of ODP Legs 114 (Atlantic Ocean) and 120 (Indian Ocean). 
Truswell, E.M. nee Kemp 1997 Palynomorph assemblages from marine Eocene sediments on the west Tasmanian continental margin and the South Tasman Rise. Australian Journal of Earth Sciences 44 : 633-654

Villa, G., Fioroni, C., Pea, L., Bohaty, S., Persico, D. 2008 Middle Eocene-Late Oligocene climate variablility: Calcareous nannofossil response at Kerguelen Plateau, Site 748 Marine Micropaleontology 69 : 173-192.

Vonhof,H.B., Smit, J., Brinkhuis, H., Montanari, A., Nederbragt, A.J. 2000 Global cooling accelerated by early late Eocene impacts? Geology 288 : 687-690.

Waghorn, D.B. 1997 Calcareous nannofossils In Integrated Paleogene biostratigraphy of DSDP site 277 (Leg 29): foraminfera, calcareous nannofossils, radiolarian and palynomorphs Institute of Geological and Nuclear Sciences Limited SCIENCE REPORT 97/07 : 12-20.

Wall, D., Dale, B., Lohmann, G.P., Smith, W.K. 1977 The Environmental and Climatic Distribution of Dinoflagellate Cysts in Modern Marine Sediments from Regions in the North and South Atlantic Oceans and Adjacent Seas. Marine Micropaleontology, 2 : 121-200

Wei, W. 1991 Middle Eocene-lower Miocene calcareous nannofossil magnetobiochronology of ODP Holes 699A and 703A in the subantarctic South Atlantic. Marine Micropaleontology 18 : 143-165.

Wei, W., Villa, G., Wise, S.W. Jr. 1992 Paleoceanographic Implications of EoceneOligocene Calcareous Nannofossils from Sites 711 and 748 in the Indian Ocean. Proceedings of the Ocean Drilling Program, Scientific Results, Leg 120 (55) : 509-521.

Wei,W., Wise, Jr. S.W. 1990 Middle Eocene to Pleistocene Calcareous Nannofossils Recovered by Ocean Drilling Program Leg 113 in the Weddell Sea. Proceedings of the Ocean Drilling Program, Scientific Results, Leg 113 : $639-660$

Wei,W., Wise, Jr. S.W. 1992 Oligocene-Pleistocene Calcareous Nannofossils from Southern Ocean Sites 47, 748, and 751 Proceedings of the Ocean Drilling Program, Scientific Results, Leg 120 : 509-521

Williams, G.L., Fensome, R.A., Miller, M.A., Sarjeant, W.A.S. 2000 A Glossary of the Terminology Applied to Dinoflagellates, Acritarchs and Prasinophytes, with 
Emphasis on Fossils: Third Edition AASP Contributions Series Number 37 AASP Stratigraphic Palynologists Foundation 1-365

Williams, G.L., Fensome, R.A., Brinkhuis, H., Pross, J. 2009 The Paleobiology of Dinoflagellates. Presenters Brinkhuis, H., Head, M.J., Pross, J., Riding, J.B., Schioler, P., Advanced course in Jurassic - Cretaceous - Cenozoic OrganicWalled Dinoflagellate Cysts, Morphology, Paleoecology and Stratigrahy, Urbino Dinocourse, 2009.

Wilson, G. J. 1967a Some new species of Lower Tertiary Dinoflagellates from McMurdo Sound, Antarctica. New Zealand Journal of Botany 5 : 57-83 Wilson, G.J. 1982a Eocene and Oligocene dinoflagellate assemblages from the Oamaru area, North Otago, NZ New Zealand Geological Survey Report PAL $60: 20 p$

Wilson, G.J., 1985 Dinoflagellate Biostratigraphy of the Eocene Hampden Section North Otago, New Zealand. New Zealand Geological Survey record 8: 93101

Wilson, G. J. 1989 Marine Palynology eds. Barrett, J. J. Antarctic Cenozoic history from the CIROS-1 drillhole, McMurdo Sound 129-133

Wrenn, J. H., Beckman, S. W. 1982 Maceral, Total Organic Carbon, and Palynological Analyses of Ross Ice Shelf Project Site J9 Cores Science 216 (4542) : 187-189

Wrenn, J. H., Hannah, M. J., Raine, J. I. 1998 Diversity and Palaeoenvironmental Significance of Late Cainozoic Marine Palynomorphs from the CRP-1 Core, Ross Sea, Antarctica Terra Antartica 5 (3) : 553-570

Wrenn, J. H., Hart, G. F. 1988 Paleogene dinoflagellate cyst biostratigraphy of Seymour Island, Antarctica eds. Feldmann, R. M., Woodburne, M. O. Geology and Paleontonology of Seymour Island, Antarctic Peninsula The Geological Society of America, Inc. Memoir 169 Colorado 321-447. Zachos, J.C., Dickens, G.R., Zeebe, R.E. 2008 An early Cenozoic perspective on greenhouse warming and carbon-cycle dynamics. Nature 451 279-283. Zachos, J. C., Kump, L.R. 2005 Carbon cycle feedbacks and the initiation of Antarctic glaciation in the earliest Oligocene. Global and Planetary Change $47: 51-66$ 
Zachos, J. C., Pagani, M., Sloan, L., Thomas, E., Billups, K. 2001 Trends, Rhythms and Aberrations in Global Climate 65 MA to Present Science 292 : 686-695

Zachos, J.C., Quinn, T.M., Salamy, K.A. 1996 High-resolution (10 ${ }^{4}$ years) deep-sea foraminiferal stable isotope records of the Eocene-Oligocene climate transition Paleoceanography $113: 251-266$

Zachos, J.C., Röhl, U., Schellenberg, S.A., Sluijs, A., Hodell, D.A., Kelly, D.C., Thomas, E., Nicolo, M., Raffi, I., Lourens, L.J., McCarren, H., Kroon, D. 2005 Rapid Acidification of the Ocean During the Paleocene-Eocene Thermal Maximum. Science 308 : 1611-1615 


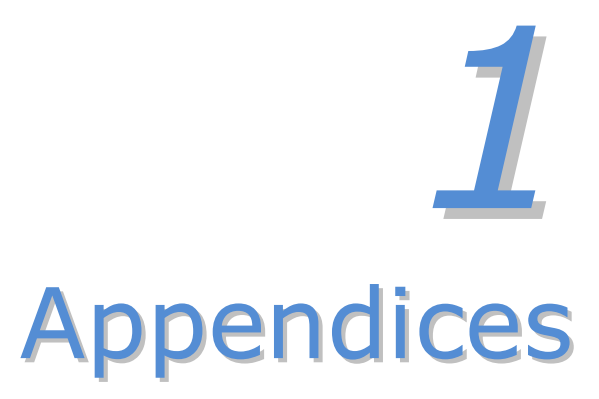




\section{NOMENCLATURE}

An alphabetical list of all marine palynomorphs is provided below with most illustrated on Plates 1-27. The synonymy lists are not intended to be complete. The taxonomic citations can be found in Lentin and Williams (2004), the electronic version also used is from DINOFLAJ2 (Fensome et al., 2008). Included is a reference to the journal used in identifying each genus or species.

Domain Eukarya Woese et al. 1990

Kindom Alveolata Cavalier-Smith 1991

Phylum Dinoflagellata Bütschli 1885

Class Dinophyceae (Bütschli 1885) Pascher 1914

Subclass Peridiniphycidae Fensome et al. 1993b

Order Gonyaulacales Taylor 1980

Suborder Gonyaulacineae Taylor 1980

Family Gonyaulacaceae Lindemann 1928

Genus: Achomosphaera Evitt, 1963; Lentin and Williams 1989.

Achomosphaera alcicornu Eisenack 1954b

Fensome et al. (2009)

Plate 1, Images 1-3

Occurrences: 699A Late Eocene present

748B Middle Eocene common

277 Middle Eocene present

Genus: Alisocysta Stover and Evitt 1978

Alisocysta circumtabulata (Drugg, 1967) Stover and Evitt, 1978

Brinkhuis et al., (2003b)

Plate 1, Images 4-6

Occurrences: 696B Middle Eocene present

748B Middle Eocene present

277 Middle-Late Eocene present

Genus: Batiacasphaera Drugg, 1970b

Goodman and Ford (1983) 
Plate 2, Images 1-4

Occurrences: 696B Early Oligocene common 699A Late Eocene common 748B Middle-Late Eocene present 277 Middle Eocene-Early Oligocene present

Genus: Cerebrocysta Bujak et al., 1980

Cerebrocysts bartonense Bujak et al., 1980

Brinkhuis et al., (2003b)

Plate 2, Images 5-6

Occurrences: 748B Middle Eocene common

277 Middle Eocene present

Cerebrocysta delicata Wilson, 1988

Wilson, (1988)

Plate 3, Images 3-6; Plate 4, Images 1-2

Comment: Cerebrocysta has been the preferred name for species of the mainly Cenozoic group. Pyxidiniopsis is preferred for Jurassic-Neocomian grouping by Fensome et al. (2009).

Occurrences: 699A Early Oligocene present 748B Middle Eocene abundant 277 Middle Eocene present

\section{Cerebrocysta cf delicata}

Comment: Cerebrocysta cf delicata differs in size ( $\sim 27 \mu \mathrm{m})$ from Cerebrocysta delicata $(\sim 40 \mu \mathrm{m})$.

Plate 4, Images 3-4

Occurrences: 748B Middle Eocene common

277 Middle Eocene common

Cerebrocysta mundus n sp Clowes, (2009)

Clowes, 2009, PI.74 figs 4-12

Occurrences: 696B Late Eocene present 699A Late Eocene present 748B Middle Eocene present 277 Middle Eocene-Early Oligocene present

Cerebrocysta teuriensis n sp Clowes, (2009) Clowes, 2009, PI.72 figs 7-12; PI.73, figs 1-6 
Occurrences: 277 Late Eocene present

\section{Cerebrocysta waipawaense Wilson, 1988}

Fensome et al. (2009)

Plate 3, Images 1-2

Occurrences: 699A Early Oligocene present

748B Middle Eocene common

Genus: Chlamydophorella Cookson and Eisenack, 1958

Fensome et al. (2009)

Plate 4, Images 5-6

Occurrences: 696B Late Eocene-Early Oligocene common

699A Late Eocene present

748B Middle Eocene abundant

277 Middle-Late Eocene common

Genus: Cordosphaeridium Eisenack, 1963b emend Morgenroth, 1968.

Cordosphaeridium inodes Eisenack, 1963b emend Morgenroth, 1968.

Cookson and Eisenack (1967a)

Occurrences: 696B Late Eocene present

Genus: Corrudinium Stover and Evitt, 1978

Corrudinium eyrense $\mathrm{n} . \mathrm{sp}$

Clowes and Wilson (2006)

Plate 5, Images 1-2

Occurrences: 277 Late Eocene present

Corrudinium incompositum (Drugg, 1970) Stover and Evitt, 1978.

Clowes and Wilson (2006)

Plate 5, Images 3-4

Occurrences: 748B Middle Eocene present

Corrudinium obscurum Wilson, 1988

Clowes and Wilson (2006)

Occurrences: 277 Late Eocene present

Corrudinium otagoense $\mathrm{nsp}$; (Wilson, 1982a) 
Clowes and Wilson (2006)

Plate 5, Images 5-6

Occurrences: 748B Middle Eocene abundant

277 Late Eocene present

Corrudinium regulare $\mathrm{n} \mathrm{sp}$.

Clowes and Wilson (2006)

Plate 6, Images 1-4

Occurrences: 696B Middle-Late Eocene present 699A Late Eocene-Early Oligocene present 748B Middle-Late Eocene abundant

277 Middle-Late Eocene common

Genus: Dapsilidinium Bujak et al., 1980

Dapsilidinium pseudocolligerum Stover, 1977

Fensome et al. (2009)

Plate 6, Images 5-6

Occurrences: 748B Middle Eocene present

277 Middle Eocene present

Genus: Enneadocysta Stover and Williams, 1995

Enneadocysta partridgei Stover and Williams, 1995

Levy and Harwood (2000)

Plate 7, Images 1-2

Occurrences: 696B Middle Eocene-Early Oligocene common-abundant 748B Middle Eocene present

Genus: Forma B, n sp Goodman and Ford, 1983

Goodman and Ford (1983)

Plate 7, Image 3

Occurrences: 748B Middle Eocene present

Genus: Glaphyrocysta Stover and Evitt, 1978

Glaphyrocysta retiintexta Cookson, 1965a

Fensome et al. (2009) 
Occurrences: 696B Late Eocene and Early Oligocene present

Genus: Graptodinium n gen Clowes 2009

Graptodinium inconditum Meiourogonyaulax sp cf. 1976

Plate 7, Image 4

Occurrences: 748B Middle Eocene present

277 Middle-Late Eocene present

Graptodinium reticulatum Clowes, n sp 2009

Clowes n sp (2009)

Plate 8, Image 1

Occurrences: 696B Early Oligocene present

277 Middle Eocene present

Genus: Hapsocysta Davey, 1979b

Hapsocysta kysingensis sp nov

Heilmann-Clausen and van Simaeys (2005)

Plate 7, Images 5-6

Occurrences: 748B Middle Eocene present

277 Middle Eocene present

Genus: Heteraulacacysta Drugg and Loeblich Jr., 1967.

Heteraulacacysta pustulata Jan du Chêne and Adediran, 1985

In Fensome et al. (2009)

Occurrences: 748B Middle Eocene present

Genus: Hystrichokolpoma Klumpp, 1953,

Brinkhuis et al. (2003b)

Occurrences: 696B Late Eocene present

Genus: Hystrichosphaeridium Deflandre, 1937b.

Occurrences: 748B Middle Eocene common

Hystrichosphaeridium brevispinum Davey and Williams 1966b

Wilson (1988)

Occurrences: 277 Middle Eocene present 
Hystrichosphaeridium truswelliae Wrenn and Hart, 1988

Brinkhuis et al. (2003b)

Occurrences: 696B Middle Eocene present

Hystrichosphaeridium tubiferum (Ehrenberg, 1838), Deflandre 1937b.

Brinkhuis et al. (2003b)

Occurrences: 277 Middle Eocene present

Genus: Impagidinium Stover and Evitt, 1978

Impagidinium aculeatum Wall, 1967

Schioler (2005) PI.9, fig 15.

Plate 8, Image 2

Occurrences: 699A Late Eocene-Early Oligocene present

748B Middle Eocene common

277 Middle-Late Eocene present

Impagidinium crassimuratum, Wilson, 1988

Wilson (1988)

Plate 8, Images 3-4

Occurrences: 696B Middle Eocene present

748B Middle Eocene present

277 Middle Eocene common

Impagidinium dispertitum (Cookson and Eisenack, 1965a) Stover and Evitt, 1978.

Wilson (1988)

Plate 8, Image 5

Occurrences: 696B Middle Eocene present

699A Late Eocene present

748B Middle Eocene abundant

277 Middle Eocene-Early Oligocene present

Impagidinium elegans (Cookson and Eisenack, 1965a) Stover and Evitt, 1978.

Plate 8, Image 6; Plate 9, Image1

In Wilson (1982b)

Occurrences: 696B Middle Eocene present

748B Middle Eocene present

277 Middle Eocene present 
Impagidinium maculatum (Cookson and Eisenack, 1961b) Stover and Evitt, 1978

Brinkhuis et al. (2003b)

Plate 9, Images 2-3

Occurrences: 699A Early Oligocene present

748B Middle Eocene present

277 Late Eocene present

Impagidinium parvireticulatum Wilson, 1988

Wilson (1988)

Plate 9, Image 4

Occurrences: 748B Middle Eocene acme

277 Middle Eocene present

Impagidinium victorianum (Cookson and Eisenack, 1965a) Stover and Evitt, 1978

Brinkhuis et al. (2003b)

Plate 9, Image 5-6

Occurrences: 696B Middle Eocene-Early Oligocene present

699A Late Eocene-Early Oligocene common

748B Middle-Late Eocene abundant

277 Middle Eocene-Early Oligocene present

Genus: Impletosphaeridium Morgenroth, 1966a

Levy and Harwood (2000)

Plate 10 , Image 1

Occurrences: 696B Middle Eocene-Early Oligocene abundant

748B Middle-Late Eocene common

277 Middle-Late Eocene abundant

Genus: Lophocysta Manum, 1979

Goodman and Ford (1983)

Plate 10, Image 2

Occurrences: 699A Late Eocene present

748B Middle Eocene common

277 Middle Eocene-Early Oligocene present

Genus: Minisphaeridium n gen Davey and Williams, 1969

Minisphaeridium group Fensome et al., 2009

Fensome et al (2009) 
Plate 10, Images 4-5

Occurrences: 696B Middle Eocene-Early Oligocene abundant 699A Late Eocene present 748B Middle Eocene acme 277 Late Eocene common

Minisphaeridium latirictum Davey and Williams 1966b.

Fensome et al (2009) Pl.6 figs r-t

Plate 10 , Image 3

Occurrences: 696B Middle-Late Eocene common 748B Middle Eocene present

277 Middle Eocene abundant

Genus: Moria gen nov. Sluijs et al., 2009

Moria zachosii sp nov Sluijs et al., 2009

Sluijs et al. (2009)

Plate 10, Image 6

Occurrences: 696B Middle-Late Eocene present

Genus: Nematosphaeropsis Deflandre and Cookson, 1955 emend. Wrenn, 1988.

Brinkhuis et al. (2003b)

Plate 11, Images 1-2

Occurrences: 696B Middle-Late Eocene present 699A Late Eocene present 748B Middle Eocene abundant 277 Middle Eocene-Early Oligocene common

Genus: Odontochitina Deflandre, 1937b emend Davey, 1970.

Fensome et al (2009)

Plate 11 , Image 3

Occurrences: 699A Late Eocene present

Genus: Oligosphaeridium Davey and Williams, 1966b. emend. Davey 1982b Fensome et al (2009)

Occurrences: 696B Middle Eocene-Early Oligocene present 
Genus: Operculodinium Wall, 1967, Emend. Matsuoka et al., 1997

Levy and Harwood (2000)

Plate 11, Images 4 and 6

Occurrences: 696B Middle Eocene-Early Oligocene high abundance

699A Late Eocene present

748B Middle Eocene abundant

277 Middle Eocene-Early Oligocene acme

Operculodinium janduchenei Head et al., 1989b

Brinkhuis et al. (2003a)

Plate 11, Image 5

Occurrences: 696B Middle Eocene present

699A Late Eocene present

748B Middle Eocene common

277 Late Eocene present

Genus: Paucisphaeridium Bujak et al., 1980

Paucishaeridium inversibuccinum (Davey and Williams, 1966b) Bujak et al., 1980

Levy and Harwood (2000)

Plate 12, Image 1

Occurrences: 696B Middle Eocene-Early Oligocene present

277 Late Eocene common

Genus: Samlandia Eisenack, 1954b

Samlandia reticulifera Cookson and Eisenack, 1965a

Goodman and Ford (1983)

Plate 12, Images 2-5

Occurrences: 748B Middle-Late Eocene present

277 Late Eocene present

Samlandia spp

Plate 12, Image 6; Plate 13, Images 1-6

Occurrences: 696B Middle-Late Eocene present

748B Middle Eocene present

Genus: Schematophora Deflandre and Cookson, 1955 
Brinkhuis et al. (2003b)

Occurrences: 696B Late Eocene present

Genus: Spiniferites Mantell, 1850

Brinkhuis et al. (2003b)

Plate 14, Images 1-5

Occurrences: 696B Middle Eocene-Early Oligocene abundant 699A Late Eocene present 748B Middle Eocene acme 277 Middle Eocene-Early Oligocene high abundance

Genus: Systematophora Klement, 1960; emend. Brenner, 1988

Systematophora placacantha (Deflandre and Cookson, 1955) Davey et al., 1969

Goodman and Ford (1983)

Occurrences: 696B Middle Eocene-Early Oligocene present

Systematophora ?variabilis (Cookson and Eisenack, 1967a) Stover and Evitt, 1978

Cookson and Eisenack, 1967a as Cyclonephelium PI 19 9-11

Occurrences: 696B Middle Eocene-Early Oligocene present

Genus: Tectatodinium Wall, 1967. Emend. Head, 1994a

Schiøler (2005)

Plate 15, Image 1

Occurrences: 699A Late Eocene present

748B Middle Eocene present

277 Late Eocene common

Genus: Thalassaphora Eisenack and Gocht, 1960. Emend. Gocht, 1968

Levy and Harwood (2000)

Plate 15, Image 2-4

Occurrences: 748B Middle Eocene acme

277 Late Eocene common 
Genus: Trichodinium Eisenack and Cookson, 1960, emend. Clarke and Verdier, 1967

Trichodinium hirsutum Cookson, 1965b

Williams et al. (2004)

Occurrences: 748B Middle Eocene present

Genus: Turbiosphaera Archangelsky, 1969a

Turbiosphaera filosa (Wilson, 1967a) Archangelsky, 1969a

Levy and Harwood (2000)

Plate 15, Image 5-6

Occurrences: 696B Middle-Late Eocene common

748B Middle Eocene present

Domain Eukarya Woese et al. 1990

Kindom Alveolata Cavalier-Smith 1991

Phylum Dinoflagellata Bütschli 1885

Class Dinophyceae (Bütschli 1885) Pascher 1914

Subclass Peridiniphycidae Fensome et al. 1993b

Order Peridiniales Haeckel 1894

Suborder Peridinlineae Haeckel 1894

Family Peridiniaceae Ehrenberg 1831

Genus: Alterbidinium Lentin and Williams, 1985; emend. Khowaja-Ateequzzaman and Jain, 1991

Alterbidinium ?distinctum (Wilson, 1967a) Lentin and Williams 1985

Levy and Harwood (2000)

Plate 16, Images 1-6; Plate 17, Images 1-2

Occurrences: 696B Middle Eocene-Early Oligocene high abundance

748B Middle Eocene present

Alterbidinium ?asymmetricum Wilson, 1967 
Wilson, (1989)

Occurrences: 696B Middle-Late Eocene present 699A Late Eocene present 748B Middle Eocene abundant 277 Middle Eocene present

Genus: Brigantedinium Reid, 1977, ex Lentin and Williams, 1993

Brinkhuis et al. (2003a)

Plate 17, Images 3-4

Occurrences: 696B Early Oligocene abundant

Genus: Cerodinium Vozzhennikovia, 1963 emend. Lentin and Williams, 1987.

Brinkhuis et al. (2003a)

Plate 17, Image 5

Occurrences: 277 Late Eocene present

Genus: Deflandrea Eisenack 1938b. emend Williams and Downie, 1966c; Stover, 1974.

Deflandrea antarctica Wilson, 1967a

Wilson (1988)

Plate 17, Image 6; Plate 18, Images 1-2

Occurrences: 696B Middle Eocene-Early Oligocene abundant 748B Middle Eocene acme

277 Middle-Late Eocene abundant

Deflandrea convexa Wilson 1988,

Wilson (1988)

Plate 18, Images 3-4

Occurrences: 748B Middle Eocene common

Deflandrea cygniformis Pöthe de Baldis, 1966

Wrenn and Hart (1988)

Plate 18, Images 5-6

Occurrences: 696B Middle Eocene present

277 Middle Eocene present 
Deflandrea dartmoorium Cookson and Eisenack, 1965b

Stover (1973)

Plate 19, Images 1-2

Occurrences: 277 Middle Eocene present

Deflandrea flounderensis Stover, 1974.

Stover (1973)

Plate 19, Images 3-4

Occurrences: 748B Middle Eocene present

\section{Deflandrea leptodermata}

Stover (1973)

Plate 19, Image 5

Occurrences: 748B Middle Eocene present

Deflandrea medcalfii Stover, 1974

Wilson (1988)

Occurrences: 277 Late Eocene present

Deflandrea phosphoritica Eisenack, 1938b

Stover (1973)

Plate 19, Image 6; Plate 20, Image 1

Occurrences: 696B Middle-Late Eocene present

748B Middle Eocene present

Deflandrea scabrata Wilson, 1988

Wilson (1988)

Occurrences: 277 Late Eocene present

Deflandrea truncata Stover, 1974

Wilson (1988)

Occurrences: 748B Middle Eocene present

277 Middle Eocene present

Genus: Diconodinium Eisenack and Cookson, 1960 emend. Morgan, 1977 
Diconodinium cristatum Cookson and Eisenack, 1974

Wrenn and Hart (1988)

Plate 20, Image 2

Occurrences: 696B Middle- Late Eocene present

Genus: Eurydinium Stover and Evitt, 1978

Goodman and Ford (1983)

Plate 20, Images 3-4

Occurrences: 696B Late Eocene abundant

Genus: Lejeunecysta Artzner and Dörhöfer, 1978

Lejeunecysta cowiei Hannah et al., 1998

Hannah et al. (1998)

Plate 20, Image 5

Occurrences: 696B Middle-Late Eocene common

Lejeunecysta fallax (Morgenroth, 1966b) Artzner and Dörhöfer, 1978 emend. Biffi and Grignani, 1983.

Wrenn and Hart (1988)

Plate 20, Image 6; Plate 21, Image 1

Occurrences: 696B Middle Eocene-Early Oligocene high abundance

748B Middle Eocene present

277 Late Eocene present

Genus: Manumiella Bujak and Davies, 1983

Manumiella druggii (Stover, 1974) Bujak and Davies, 1983

Brinkhuis et al. (2003a)

Occurrences: 277 Late Eocene present

Genus: Octodinium Wrenn and Hart, 1988

Octodinium askiniae Wrenn and Hart, 1988

Brinkhuis et al. (2003a)

Plate 21, Image 1 
Occurrences: 696B Middle Eocene-Early Oligocene high abundance 748B Middle Eocene common

Genus: Phthanoperidinium Drugg and Loeblich Jr., 1967 emend. Islam, 1982

Phthanoperidinium aculeatum (Benedek, ?1972) n sp Clowes

Clowes (PhD thesis) 2009

Occurrences: 277 Middle Eocene present

Phthanoperidinium crenulatum (de Coninck, 1975) Lentin and Williams, 1977b

Clowes (PhD thesis) 2009

Plate 21, Image 2

Occurrences: 696B Middle Eocene present

748B Middle Eocene common

277 Middle Eocene abundant

Phthanoperidinium dentatum Wilson 1982b

Clowes (PhD thesis) 2009

Plate 21, Images 3-4

Occurrences: 696B Middle Eocene present 699A Late Eocene abundant 748B Middle Eocene acme 277 Late Eocene present

Phthanoperidinium echinatum Eaton, 1976

Brinkhuis et al. (2003a)

Plate 21 , Image 5

Occurrences: 696B Middle Eocene present 748B Middle Eocene abundant 277 Middle Eocene common

Phthanoperidinium eocenicum (Cookson and Eisenack, 1965a) Lentin and Williams, 1973.

Cookson and Eisenack (1965) (as Peridinium eocenicum)

Occurrences: 277 Middle Eocene present

Phthanoperidinium geminatum Bujak et al., 1980

Schiøler (2005)

Plate 21, Image 6; Plate 22, Image 1 
Occurrences: 696B Middle Eocene present 699A Late Eocene present 748B Middle Eocene common

277 Middle Eocene common

Phthanoperidinium granulatum Clowes and Wilson, 2009 n sp.

Clowes (PhD thesis) 2009

Occurrences: 696B Early Oligocene present

Phthanoperidinium spA Goodman and Ford, 1983

Goodman and Ford (1983)

Plate 22, Images 2-3

Occurrences: 696B Late Eocene present 699A Late Eocene present 748B Middle Eocene common

277 Middle-Late Eocene common

Phthanoperidinium sp1 n sp

Plate 22, Images 4-6

Occurrences: 696B Early Oligocene present 699A Late Eocene common

277 Late Eocene present

Genus: Rhombodinium Gocht, 1955 emend. Bujak, 1979

Head and Norris (1989)

Plate 23, Images 1-3

Occurrences: 748B Middle Eocene present

Genus: Satyrodinium Lentin and Manum, 1986

Satyrodinium bengalense Lentin and Manum, 1986

Roncaglia (1999)

Occurrences: 696B Middle Eocene present

277 Middle Eocene present

Satyrodinium haumuriense (Wilson, 1984c) Lentin and Manum, 1986

Roncaglia (1999)

Occurrences: 277 Middle Eocene present 
Genus: Selenopemphix Benedek, 1972 emend. Head, 1993

Selenopemphix nephroides Benedek, 1972 emend. Head, 1993

Brinkhuis et al. (2003a)

Plate 23 Image 4

Occurrences: 696B Middle Eocene-Early Oligocene high abundance 277 Middle Eocene present

Genus: Spinidinium Cookson and Eisenack, 1962b emend. Lentin and Williams, 1976

Spinidinium colemanii Wrenn and Hart, 1988

Levy and Harwood (2000)

Plate 23, Image 5-6

Occurrences: 696B Middle Eocene present

Spinidinium essoi Cookson and Eisenack, 1967a

Levy and Harwood (2000)

Plate 24, Images 1-3

Occurrences: 696B Middle Eocene-Early Oligocene high abundance 748B Middle Eocene present

277 Middle Eocene present

Spinidinium luciae Wrenn and Hart, 1988

Brinkhuis et al. (2003a)

Plate 24 Image 4; Plate 25 Images 1-3

Occurrences: 696B Middle Eocene-Early Oligocene high abundance 699A Late Eocene present 748B Middle Eocene abundant

277 Middle Eocene common

Spinidinium macmurdoense (Wilson 1967a) Lentin and Williams, 1976

Brinkhuis et al. (2003a)

Plate 25 Images 4-6

Occurrences: 696B Middle Eocene-Early Oligocene high abundance 748B Middle Eocene present

Spinidinium sp1 n sp 
Plate 23, Images 5-6

Occurrences: 699A Late Eocene common

748B Middle Eocene acme

Genus: Vozzhennikovia Lentin and Williams, 1976

Vozzhennikovia apertura (Wilson, 1967a) Lentin and Williams, 1976

Levy and Harwood (2000)

Plate 26 Images 1-3

Occurrences: 696B Middle Eocene-Early Oligocene high abundance

748B Middle Eocene abundance

Vozzhennikovia netrona Mohr, 1990

Levy and Harwood (2000)

Plate 26 Image 4-6

Occurrences: 696B Middle Eocene-Early Oligocene high abundance

748B Middle-Late Eocene high abundance

Informal group Acritarcha, Evitt 1963a

Acritarchs

Plate 27, Images 1-2

Occurrences: 696B Middle Eocene-Early Oligocene present 699A Late Eocene present

748B Middle Eocene high abundance

277 Middle Eocene abundant

Genus: Cyclopsiella Drugg and Loebilch, 1967

Levy and Harwood (2000)

Plate 27, Image 3

Occurrences: 696B Middle-Late Eocene abundant

Genus: Cystidiopsis Nagy, 1965

Wrenn and Hart (1988) P394 24 4-5

Occurrences: 699A Late Eocene present 
277 Late Eocene present

Genus: Fenestridium clathrodermum (Clowes and Morgans, 1984) n sp Clowes

(PhD thesis) 2009

Clowes and Morgans (1984) as 'Valensiella' clathroderma p36

Plate 27, Image 4

Occurrences: 696B Middle Eocene present

699A Late Eocene present

748B Middle Eocene present

277 Late Eocene common

Genus: Paucilobimorpha De Coninck, 1986b

Paucilobimorpha inequalis De Coninck, 1986b, emend Prössl, 1994

Truswell (1997)

Occurrences: 277 Middle Eocene present

Genus: Leiosphaeridia Eisenack, 1958c

Hannah et al. (2000)

Plate 27 Image 5

Occurrences: 696B Middle Eocene present

699A Late Eocene present

748B Middle Eocene high abundance plus an acme

277 Middle Eocene-Early Oligocene abundant

Division Chlorophyta Pascher, 1914

Class Chlorophyceae Kützing, 1843

Order Chlorococcales Marchand, 1895 orth. Mut. Pascher, 1915

Family chlorococcaceae Blackman and Tansley, 1902

Genus: Palamages Wetzel, 1961

Levy and Harwood (2000)

Plate 27 Image 6

Occurrences: 696B Middle Eocene present

277 Middle Eocene present 
Division Prasinophyta, Round, 1971

Class Pterospermatales

Family Cymatiosphaeraceae

Genus: Cymatiosphaera Wetzel, 1961

Hannah et al. (2000)

Plate 28 Images 1-2

Occurrences: 696B Middle Eocene-Early Oligocene abundant 699A Late Eocene common

748B Middle Eocene high abundance

277 Middle Eocene-Early Oligocene abundant

\section{Family Pterospermellaceae}

Genus: Pterospermella

Hannah et al. (2000)

Occurrences: 748B Middle Eocene present

277 Middle- Late Eocene common

\section{Family Tasmanitaceae}

Genus: Tasmanites Newton, 1875

Prebble et al. (2005)

Plate 28, Image 3

Occurrences: 696B Late Eocene present

748B Middle Eocene high abundance

277 Middle Eocene-Early Oligocene abundant

\section{Kingdom Rhizaria,}

\section{Superphylum, retaria}

Microforaminifera Góczán, 1962

Microforaminiferal linings Stancliffe, 1996

Plate 28, Images 4-5 
Occurrences: 696B Middle Eocene-Early Oligocene abundant 748B Middle Eocene present

277 Middle Eocene-Early Oligocene abundant

\section{Insect Casing}

Plate 28, Image 6

Occurrences: 696B Middle Eocene-Early Oligocene common 699A Middle-Late Eocene common

748B Middle Eocene present

277 Late Eocene present

\section{Terrestrial Material}

Occurrences: 696B Middle Eocene-Early Oligocene very high abundances 699A Late Eocene-Early Oligocene common

748B Middle Eocene common

277 Middle Eocene-Early Oligocene abundant 

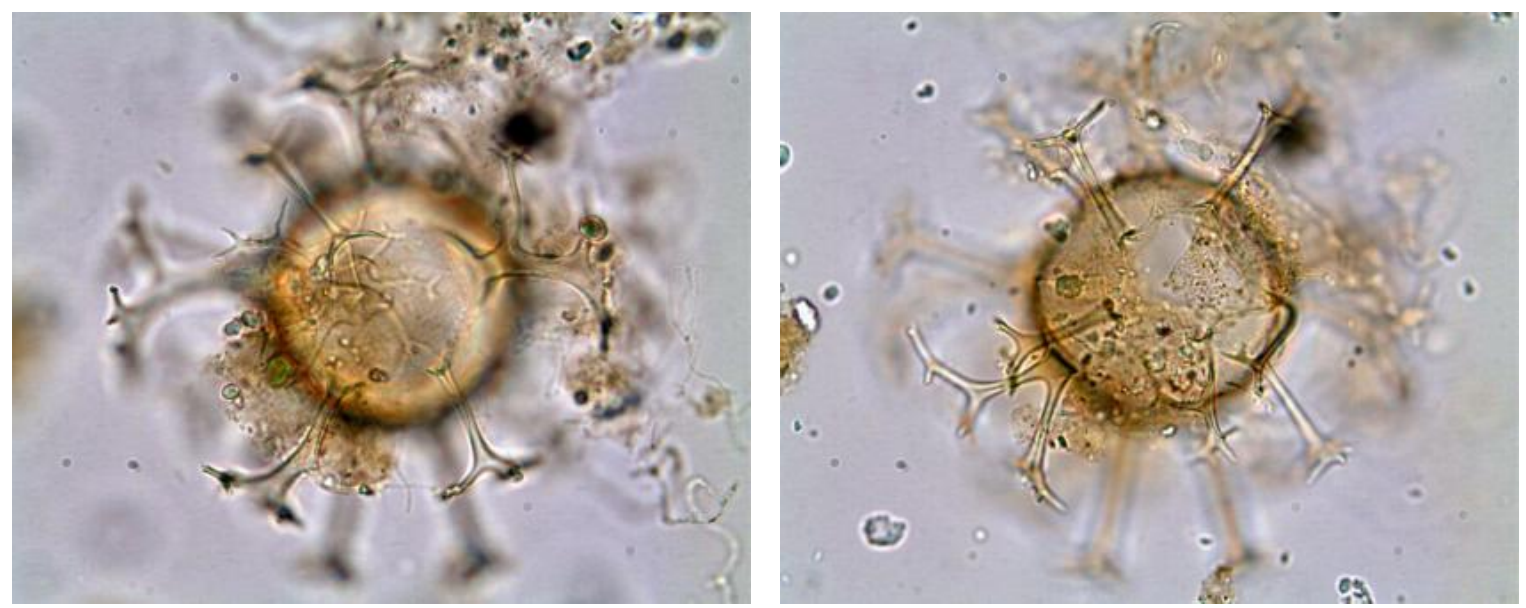

1

2
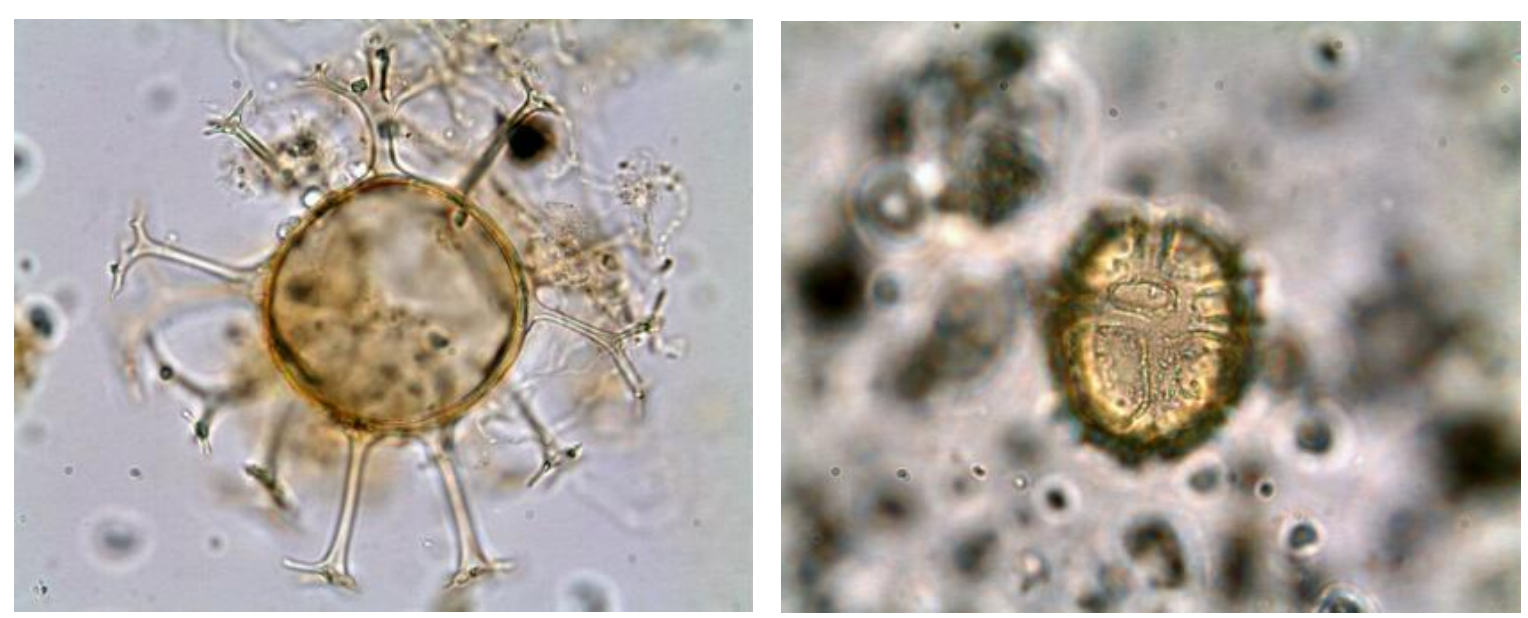

3

4

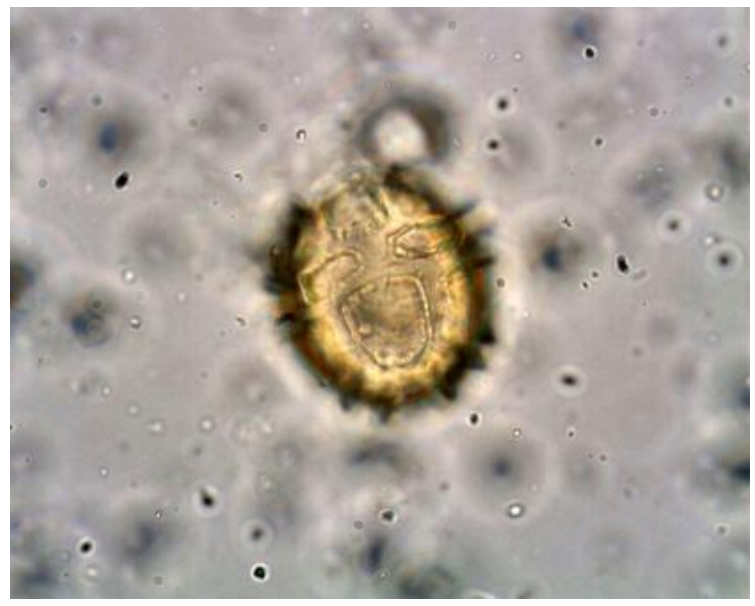

5

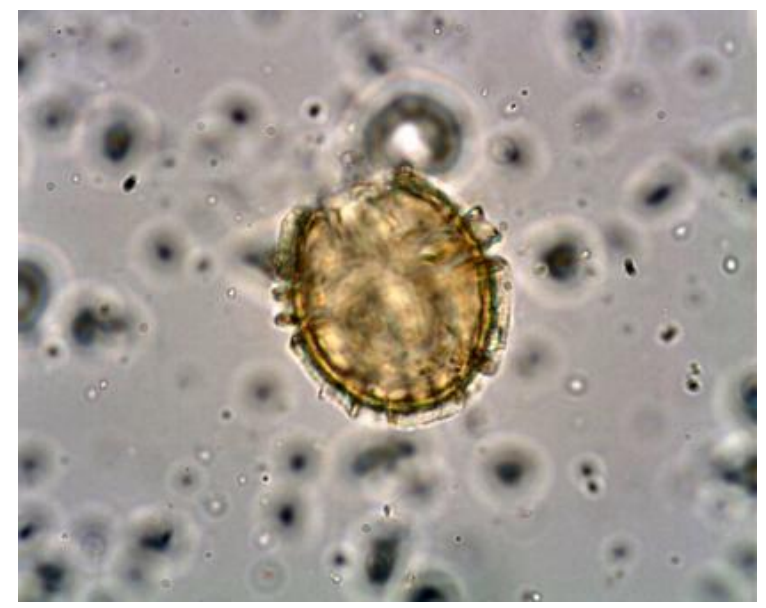

6

Illustrations of taxa, (cyst number, sample, slide coordinates and scale of length, includes processes unless otherwise stated). Scale taken from X100.

1-3. Achomosphaera spp (120-19H-1A, X53.5Y111, $100 \mu \mathrm{m})$.

4-6. Alisocysta spp (120-23X-3A, X46Y99.5, $45 \mu \mathrm{m}$; 120-23-3B, X53.5Y105, $45 \mu \mathrm{m})$. 


\section{Plate 2}

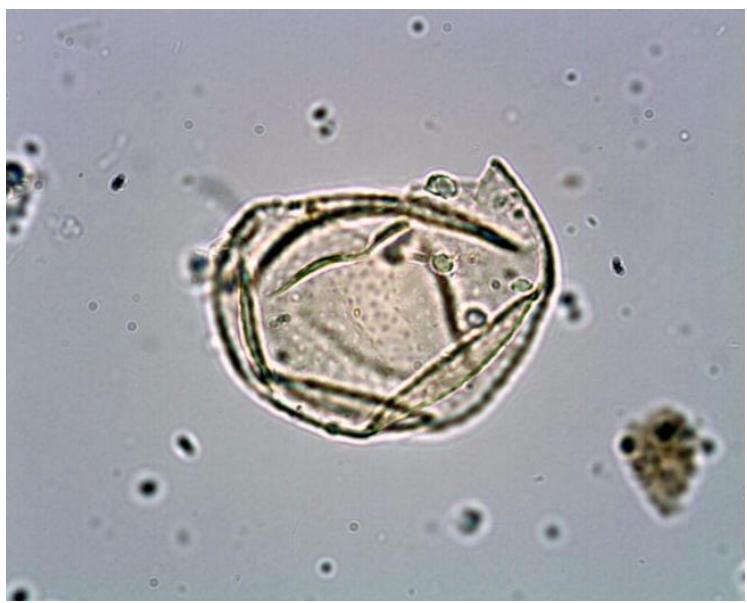

1

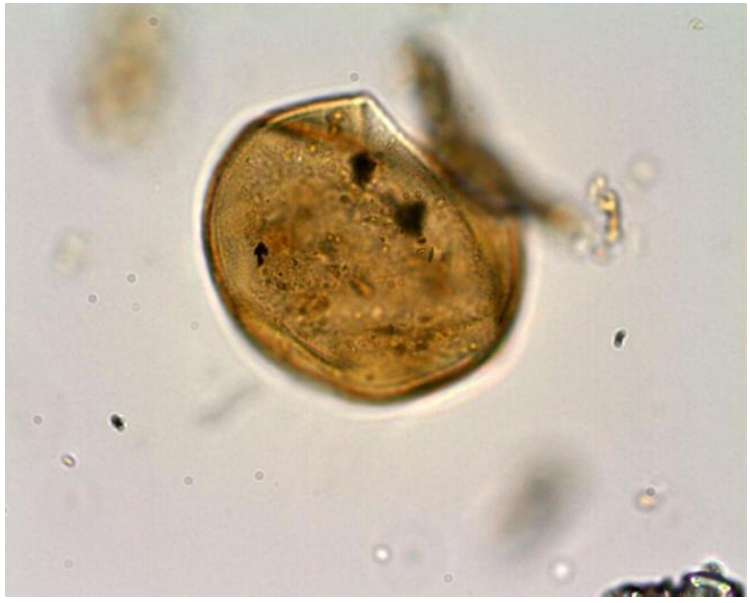

3

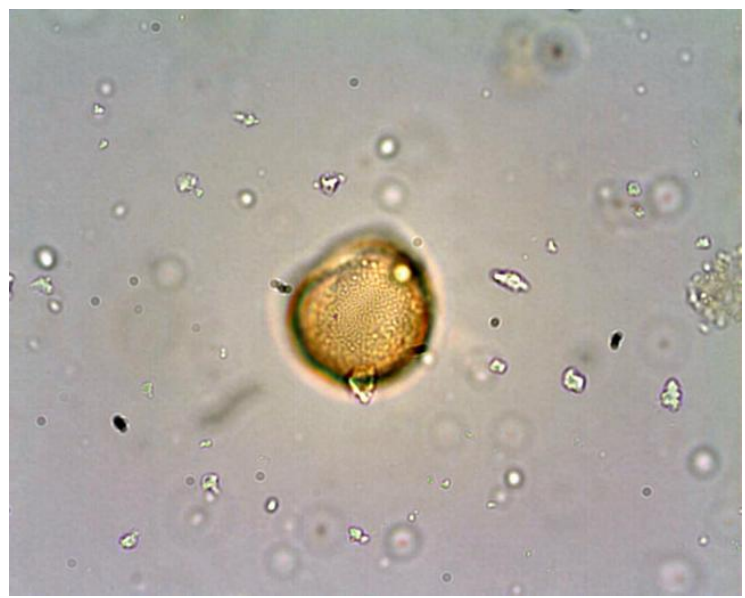

5

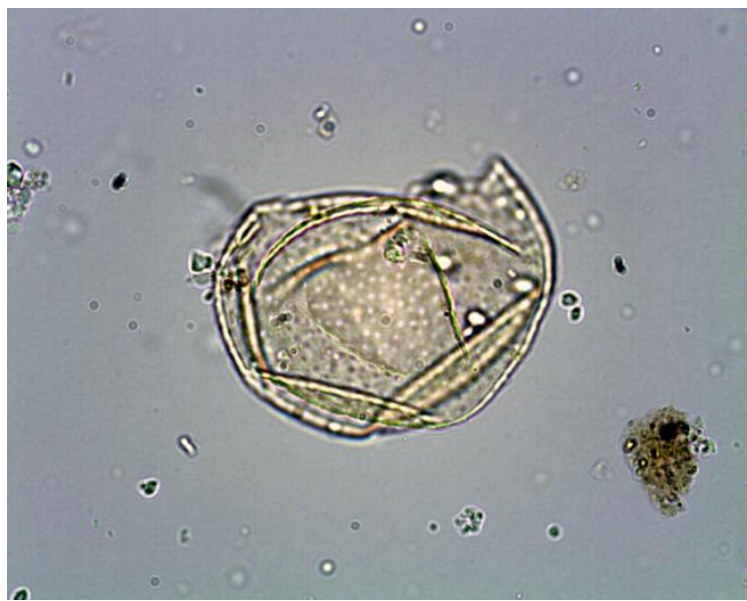

2

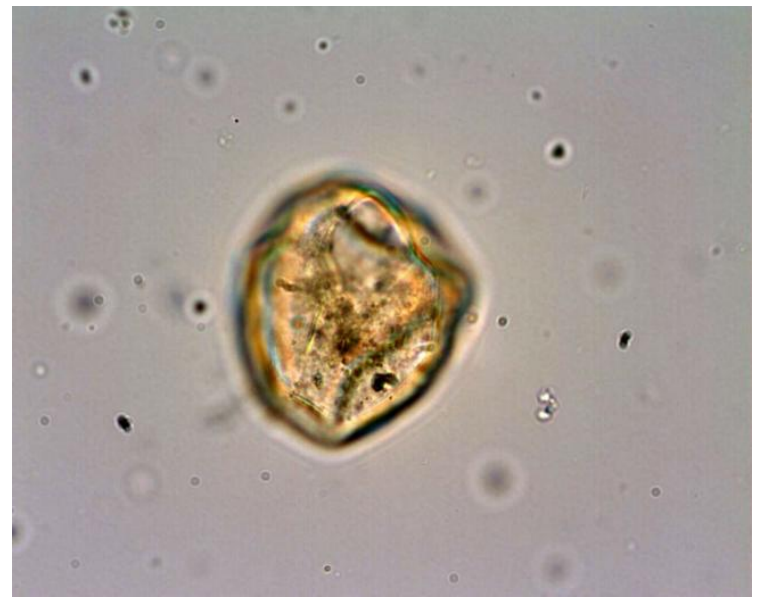

4

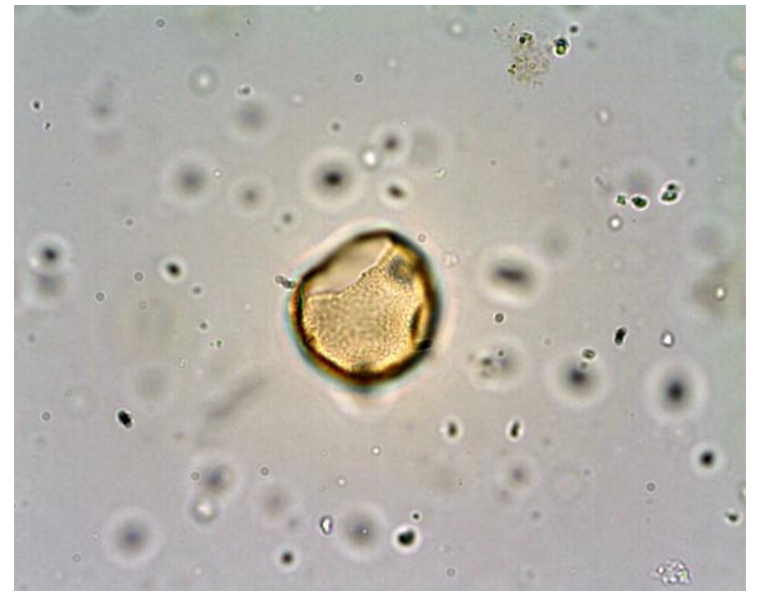

6

1-2. Batiacasphaera perforata (29-29-2Boa, X54.5Y111, $60 \mu \mathrm{m} ; 113-59 \mathrm{R}-2, \mathrm{X} 56 \mathrm{Y} 106,100 \mu \mathrm{m})$.

3-4. Batiacasphaera spp (3. 114-33X-2A, X49.8Y97, $45 \mu \mathrm{m}$; 4. 113-56R-1A, X36.5Y99, $55 \mu \mathrm{m}$ ).

5-6. Cerebrocysta bartonense (120-23X-1A, X32Y94, $25 \mu \mathrm{m})$. 


\section{Plate 3}
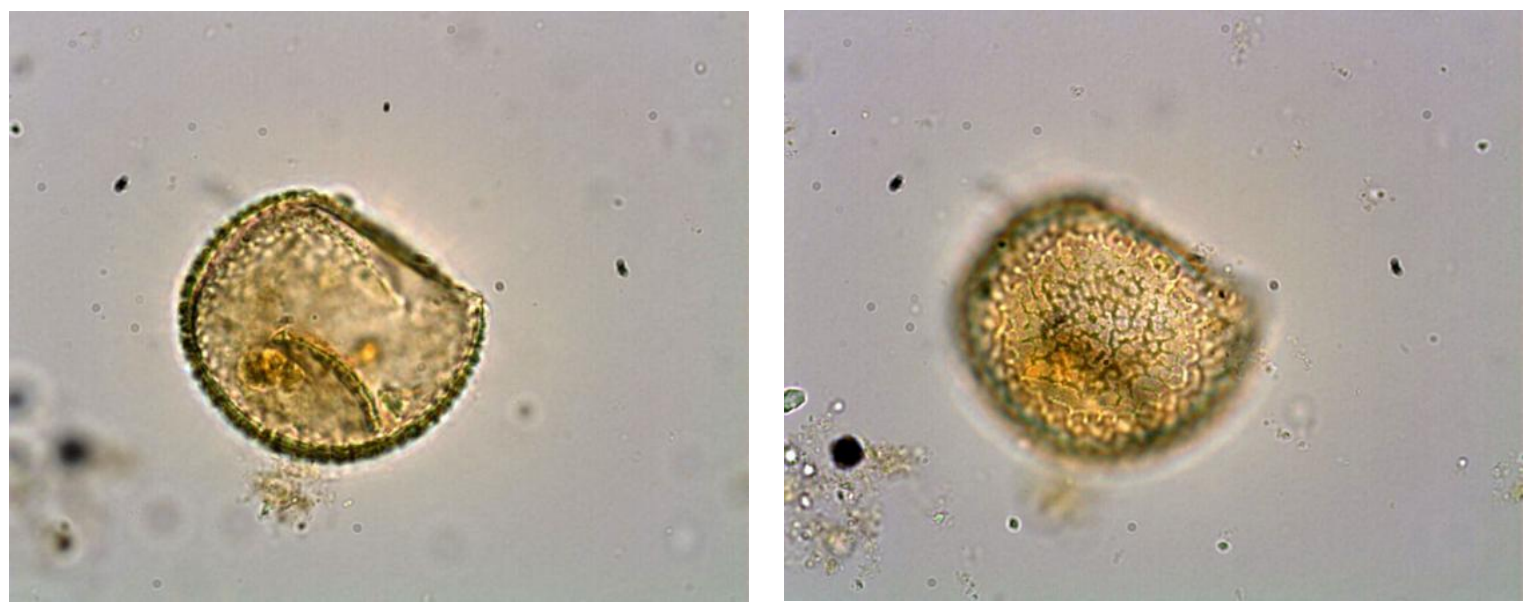

1

2
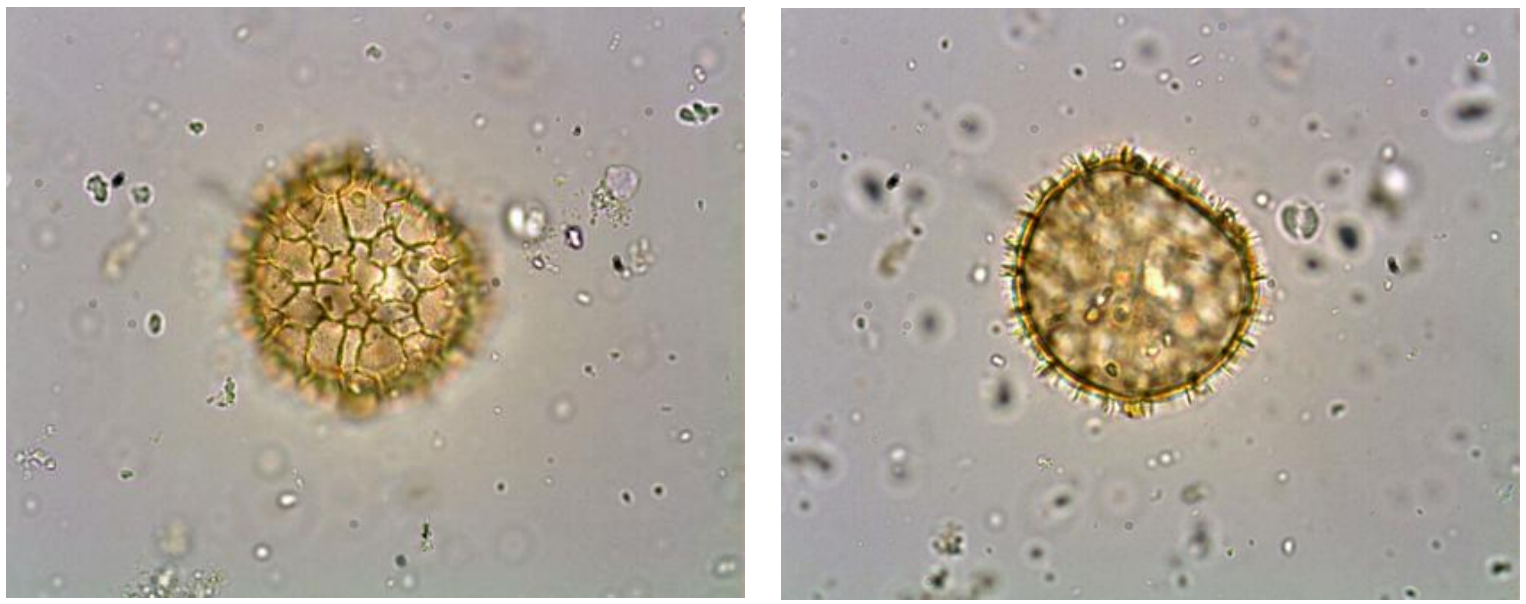

3

4
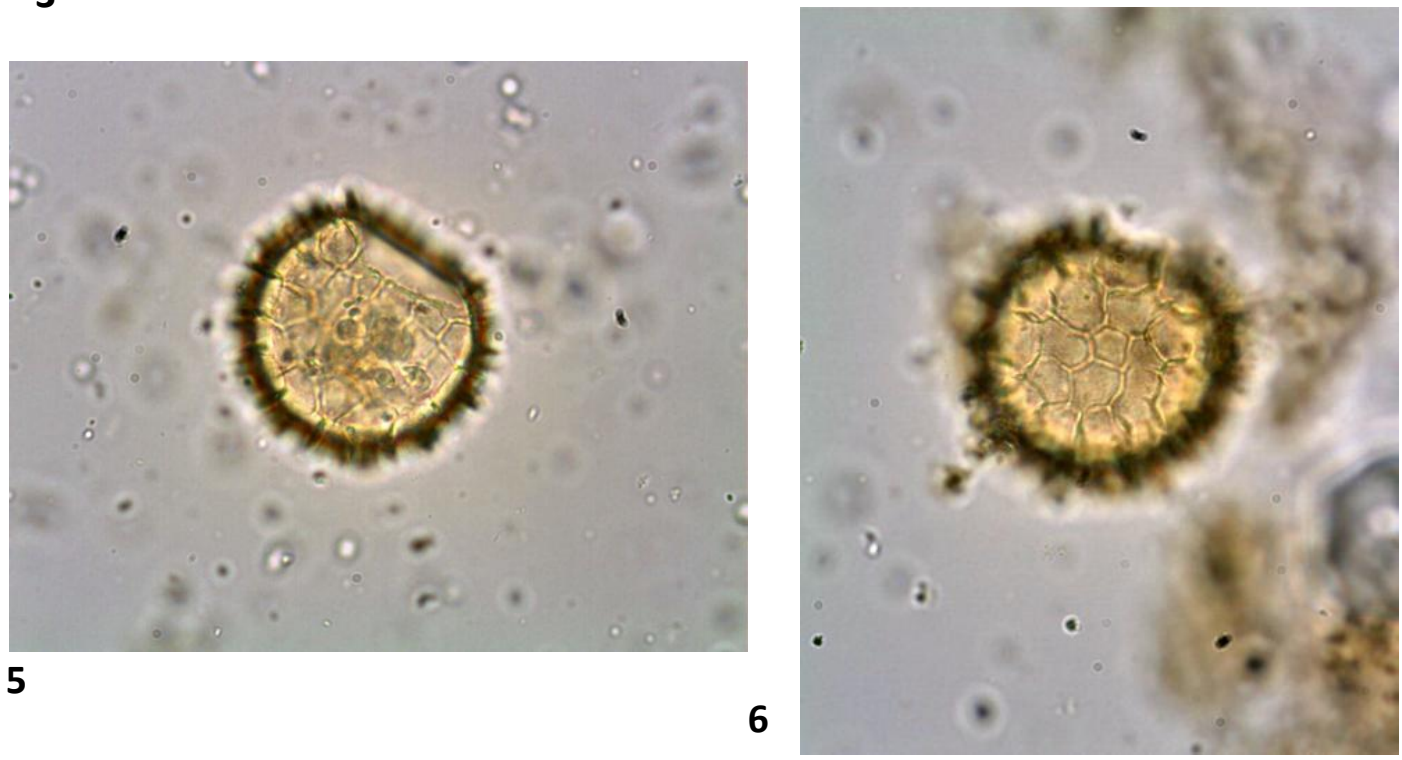

1-2. Cerebrocysta waipawaense (120-18H-4A, X50Y100, $50 \mu \mathrm{m})$.

3-6. Cerebrocysta delicata (120-20H-5A, X36.5Y108, $43 \mu \mathrm{m} ; 120-20 \mathrm{H}-1 \mathrm{~A}, \mathrm{X} 33 \mathrm{Y} 101,40 \mu \mathrm{m})$. 


\section{Plate 4}
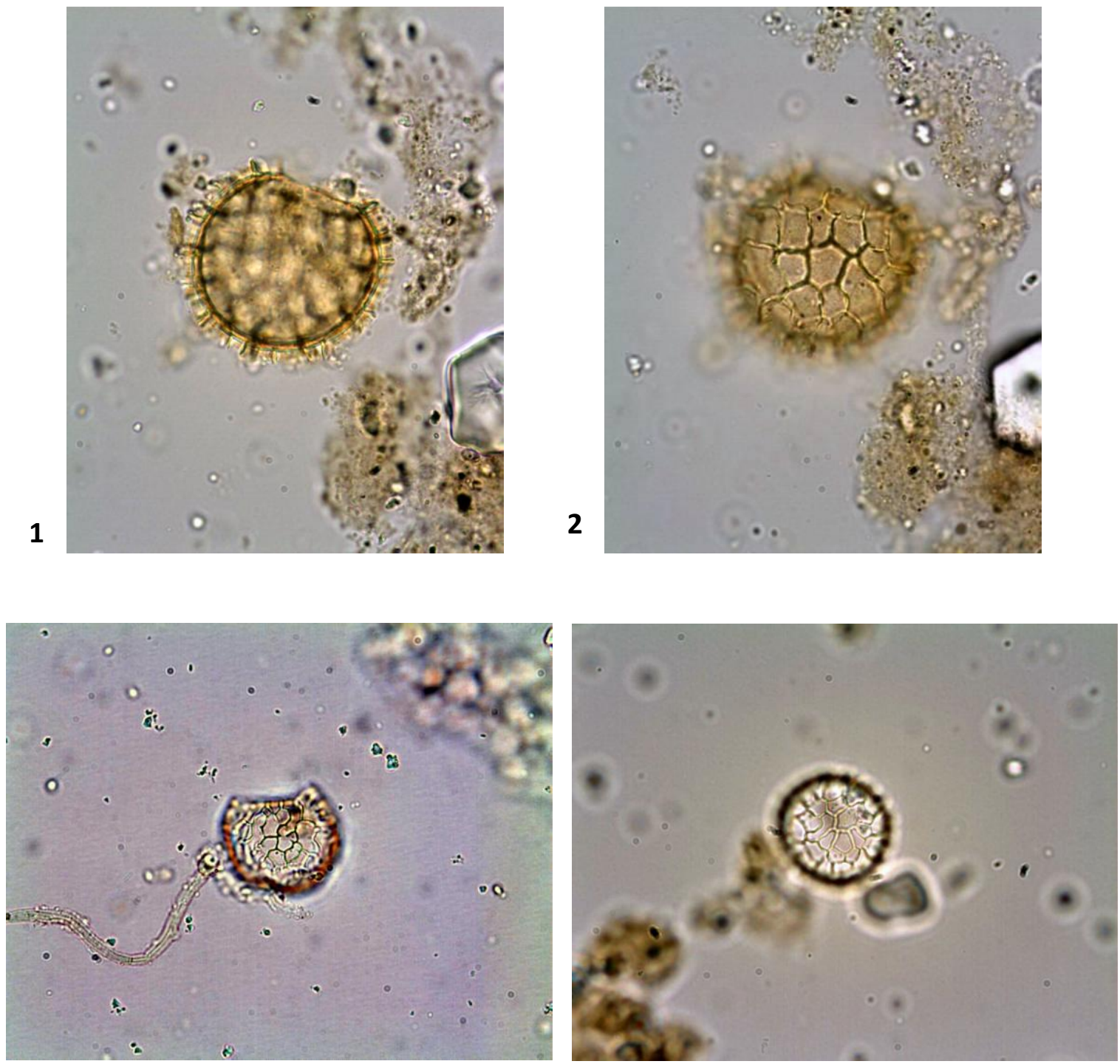

3

4

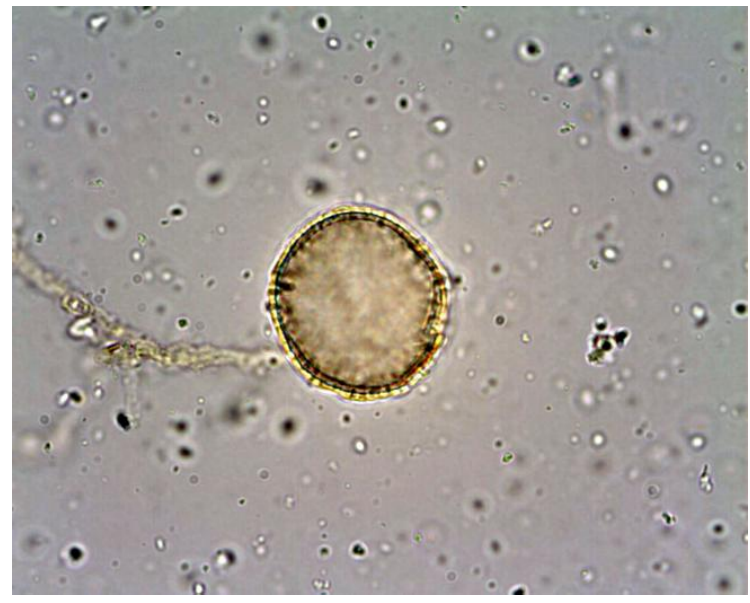

5

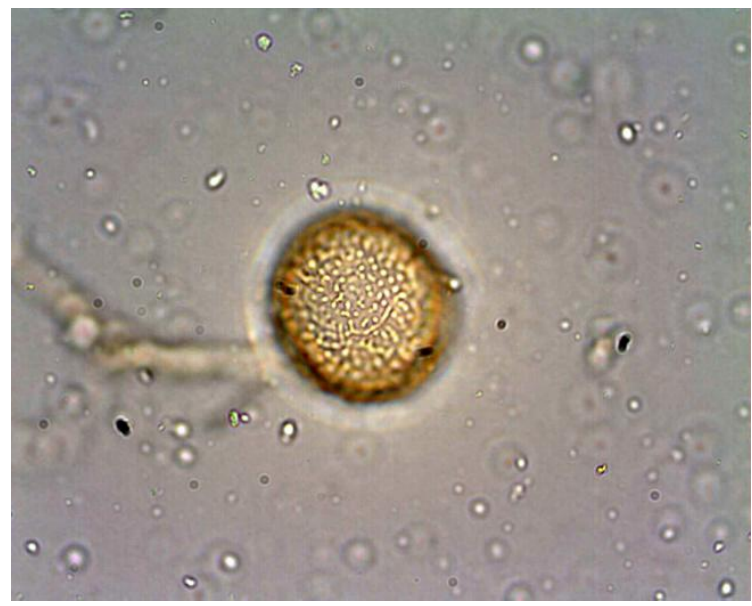

1-2. Cerebrocysta delicata (120-20H-1A, X33Y101, $40 \mu \mathrm{m})$.

3-4. Cerebrocysta cf delicata (120-19H-1A, X49.8Y94.5, $27 \mu \mathrm{m}$; 29-32-1A, X50Y101.5, $25 \mu \mathrm{m})$.

5-6. Chlamydophorella neopilata (120-17H-4B, X40Y94, $34 \mu \mathrm{m})$. 


\section{Plate 5}

1

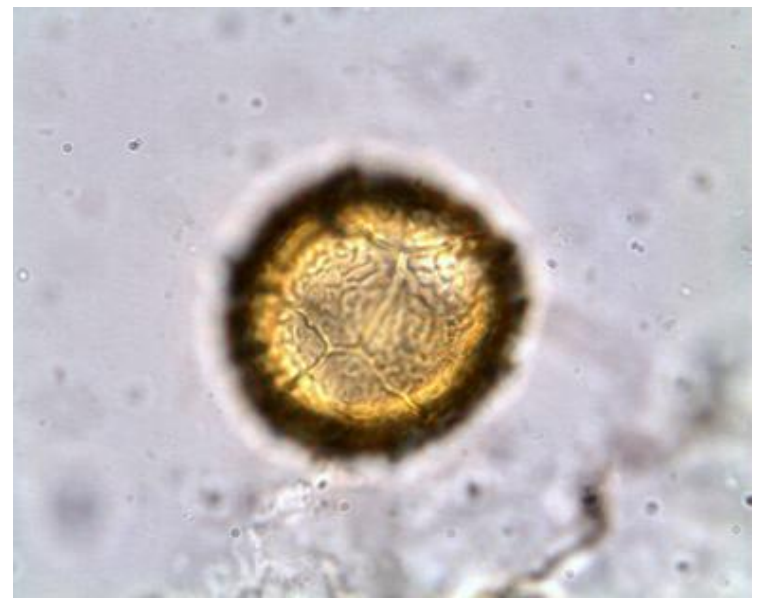

3

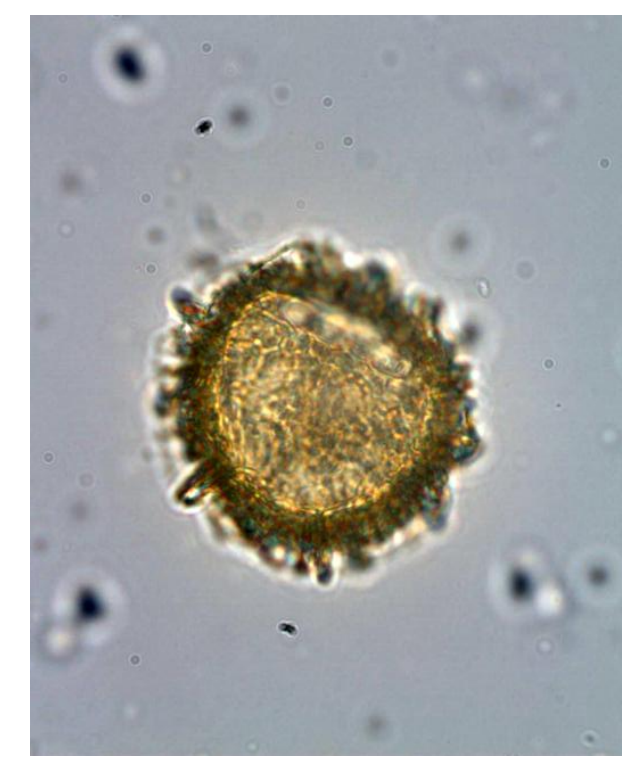

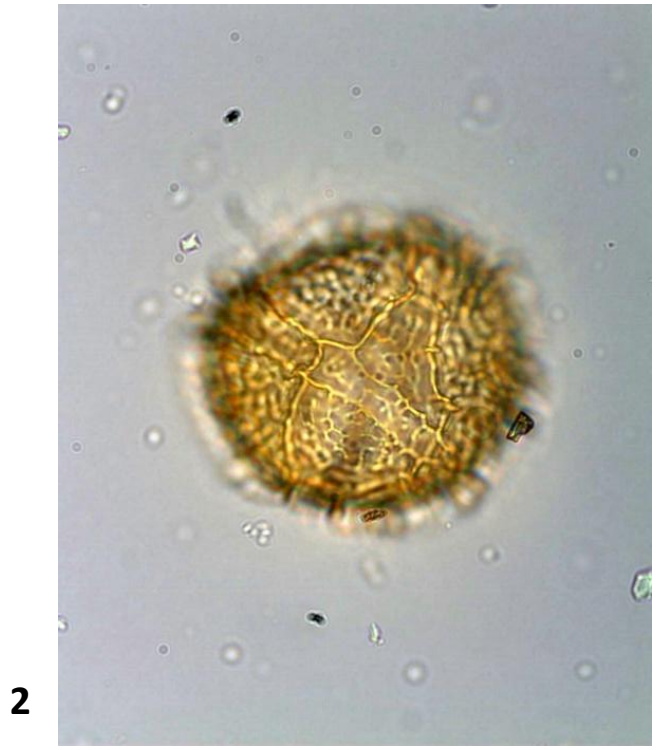

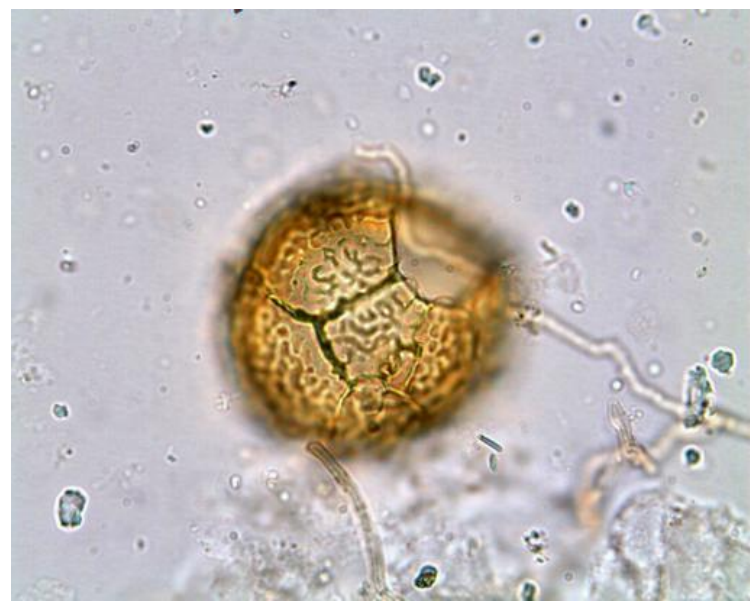

4

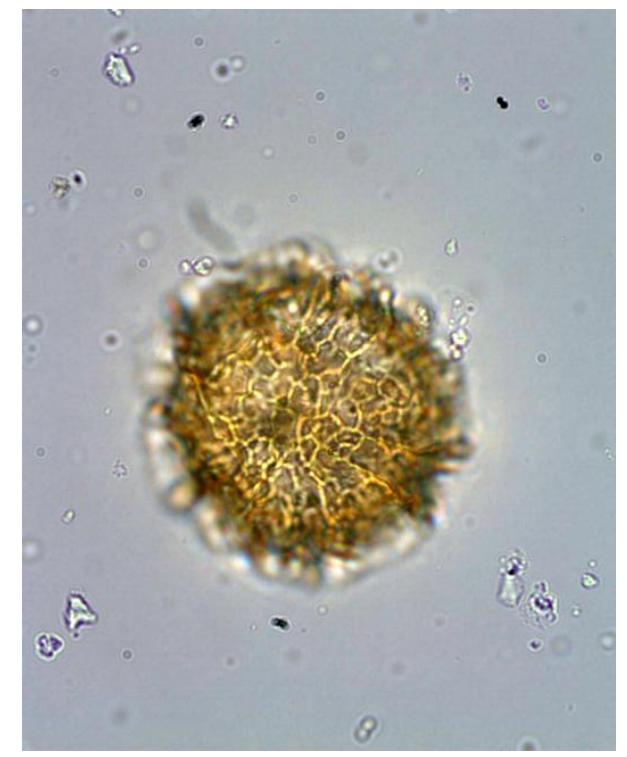

1-2. Corrudinium eyrense (29-22-2B, X59Y96, $55 \mu \mathrm{m})$.

3-4. Corrudinium incompositum (29-26-1A, X31Y98.5, $50 \mu \mathrm{m})$.

5-6. Corrudinium otagoense (29-24-3B, X30Y101.5, $55 \mu \mathrm{m}$ ). 


\section{Plate 6}
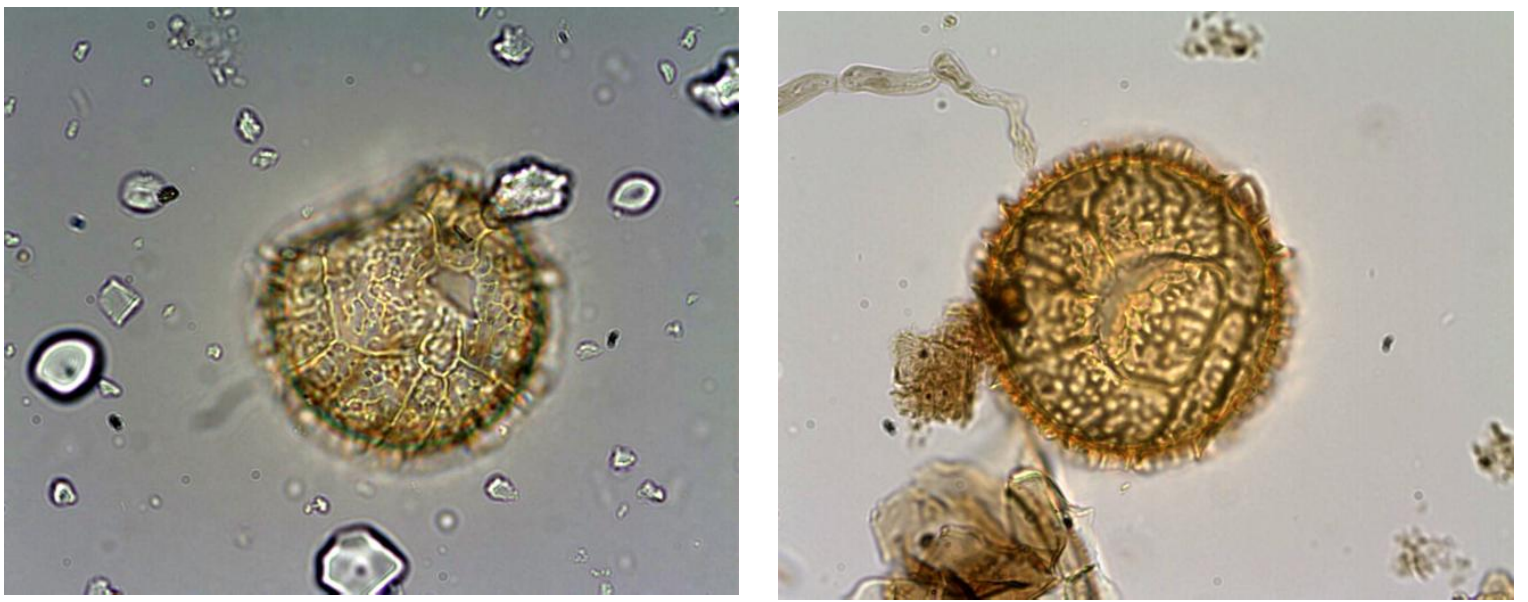

1

2
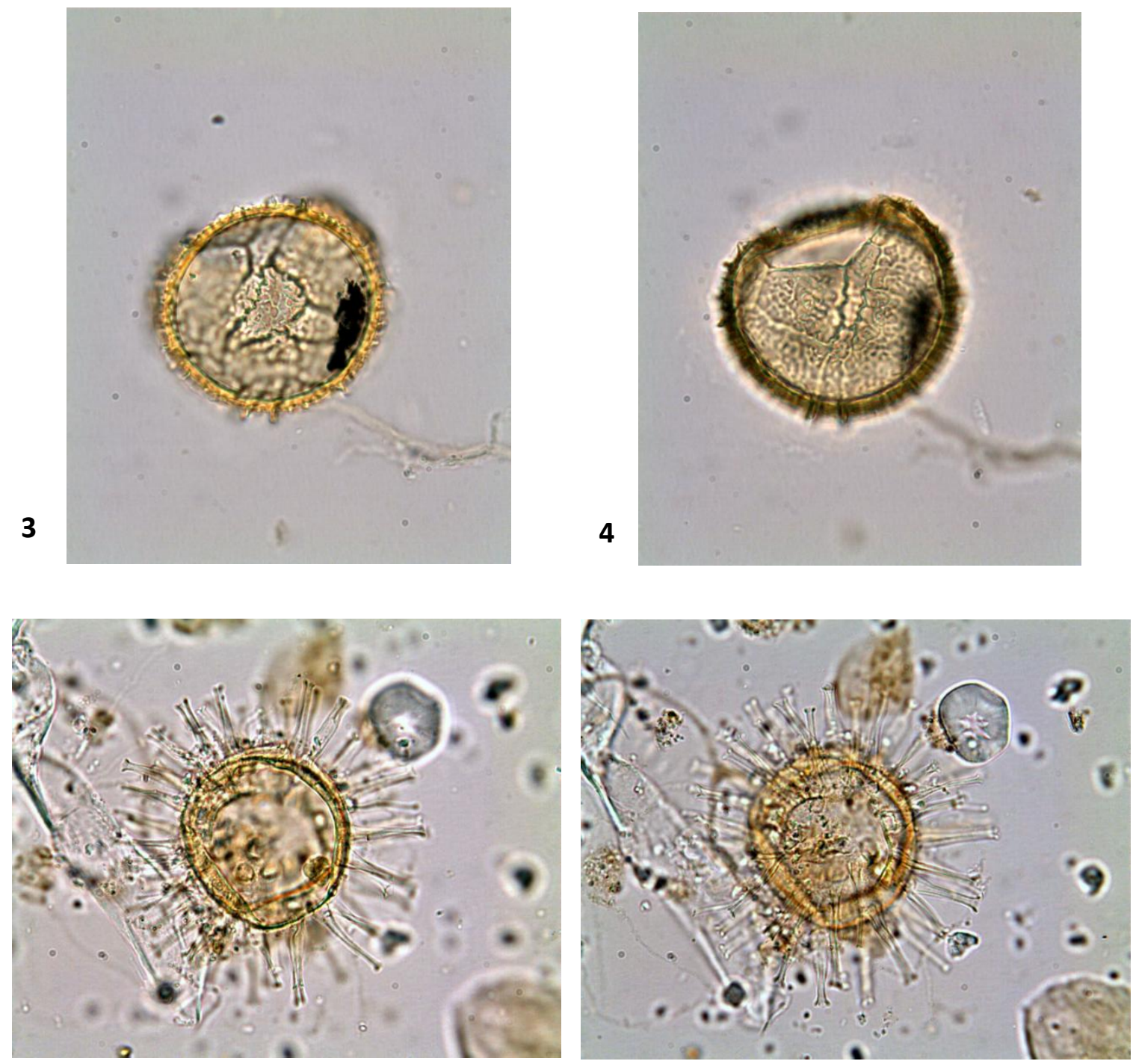

5

6

1-4. Corrudinium regulare (29-22-2B, X49.5Y1-2, $55 \mu \mathrm{m} ; 120-16 \mathrm{H} 7 \mathrm{~A}, \mathrm{X} 37.5 \mathrm{Y} 103,55 \mu \mathrm{m} ; 113-60 \mathrm{R}-6 \mathrm{~A} X 57 \mathrm{Y} 113.5,55 \mu \mathrm{m})$. 5-6. Dapsilidinium sp ( 29-30-5A, X34.3Y94, $40 \mu \mathrm{m}$ not including processes). 


\section{Plate 7}
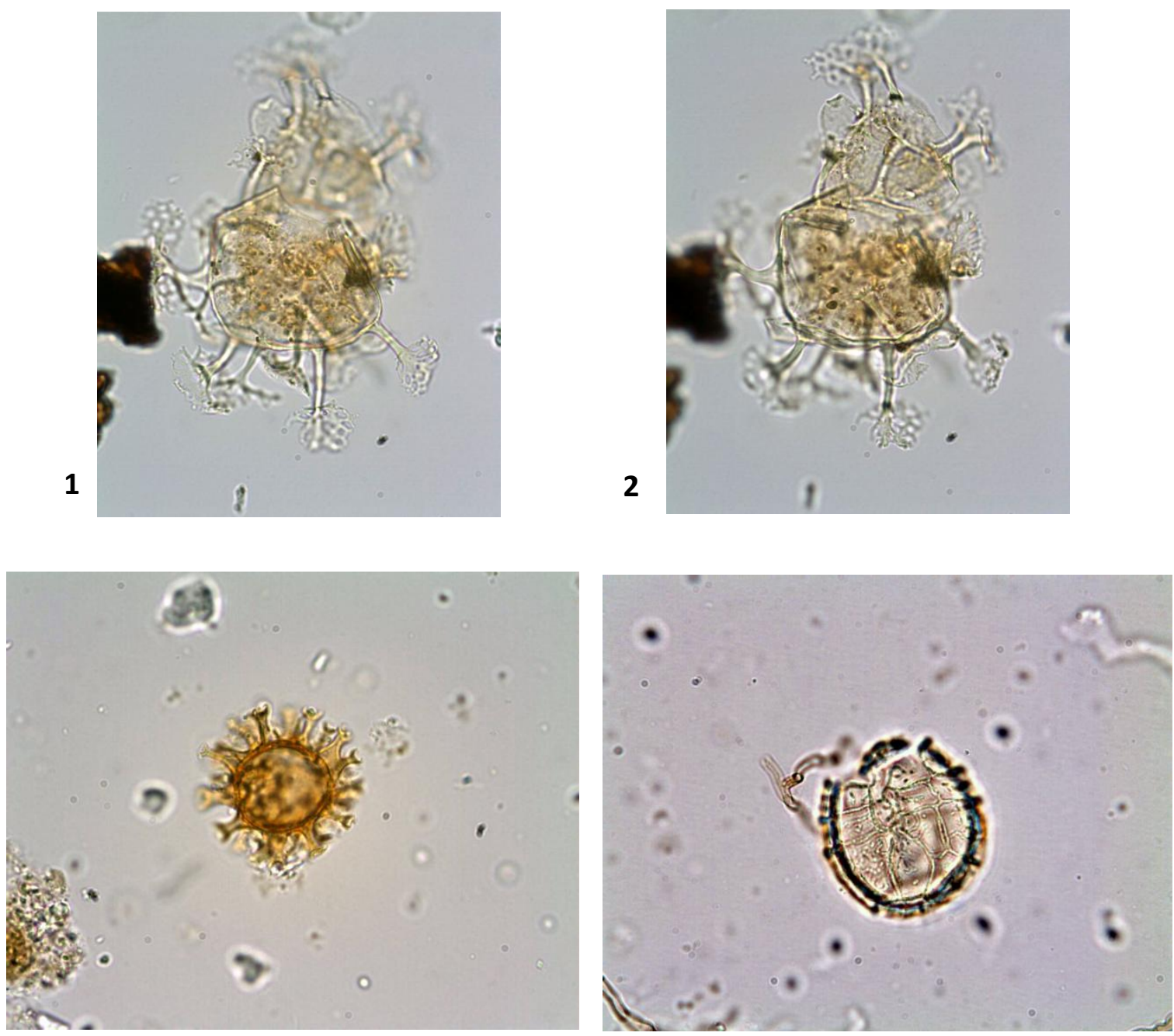

3

4

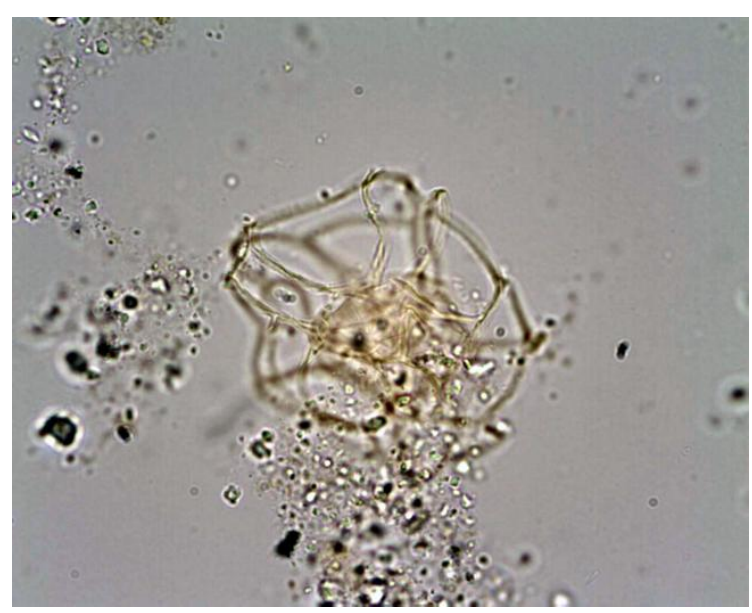

5

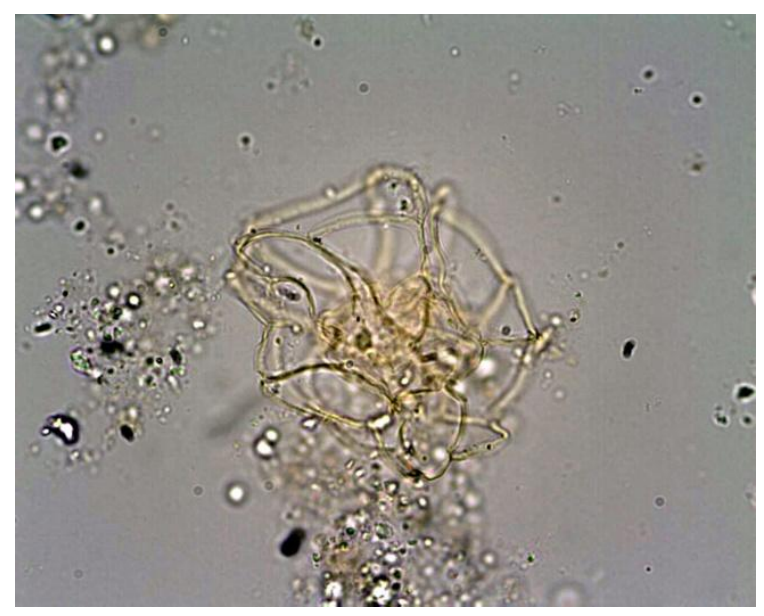

6

1-2. Enneadocysta partridgei (113-60R-1b, X51Y104.5, $40 \mu \mathrm{m}$ not including processes).

3. Forma $\mathrm{b}(120-20 \mathrm{H}-1 \mathrm{~A}, \mathrm{X} 38.5 \mathrm{Y} 98,20 \mu \mathrm{m}$ not including processes).

4. Graptodinium inconditum (29-26-1A X56Y97.5, $40 \mu \mathrm{m})$.

5-6. Hapsocysta kiysingensis (120-19H-4A X57.3Y109, $53 \mu \mathrm{m})$. 
Plate 8
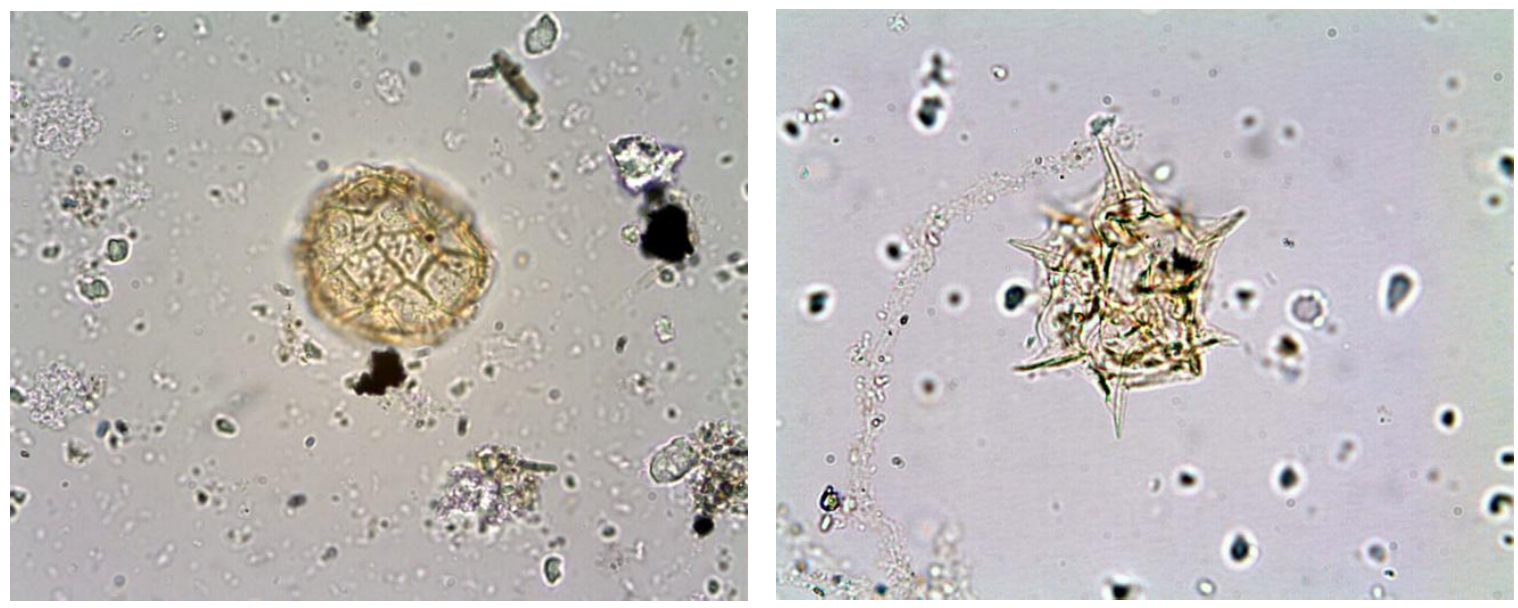

1

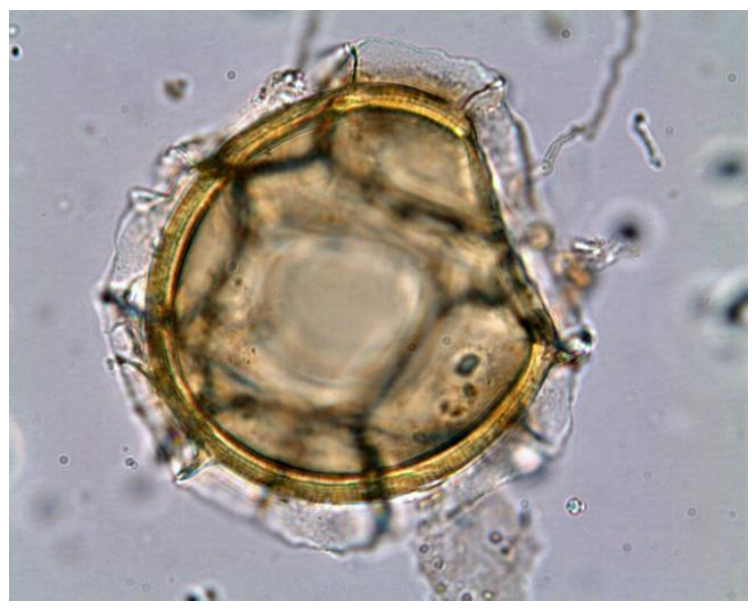

3

2

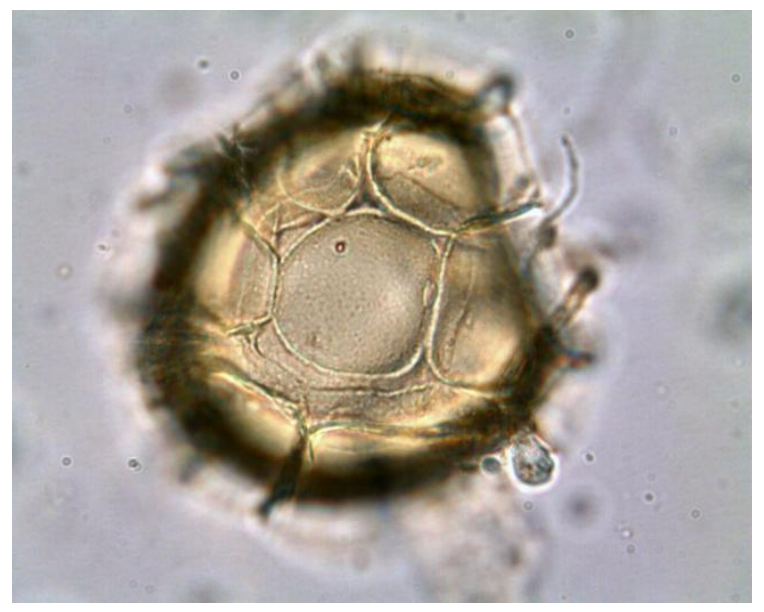

4

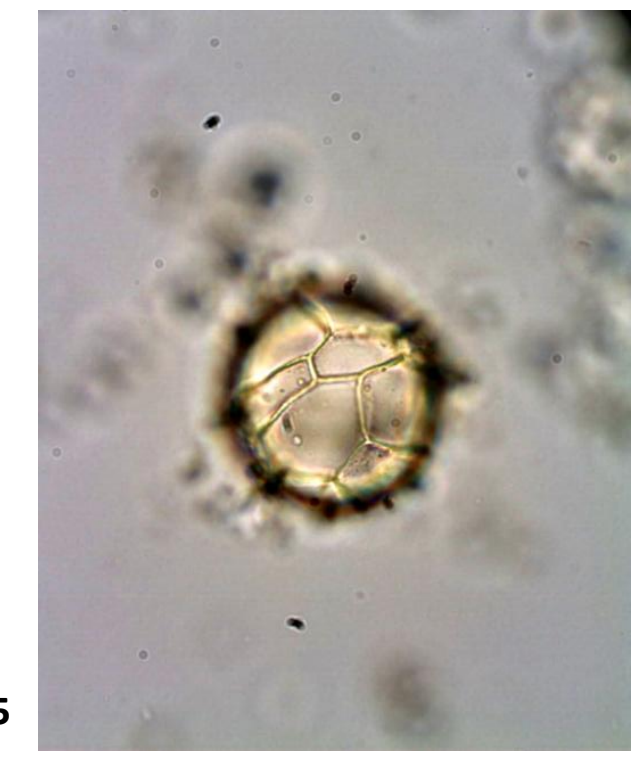

6

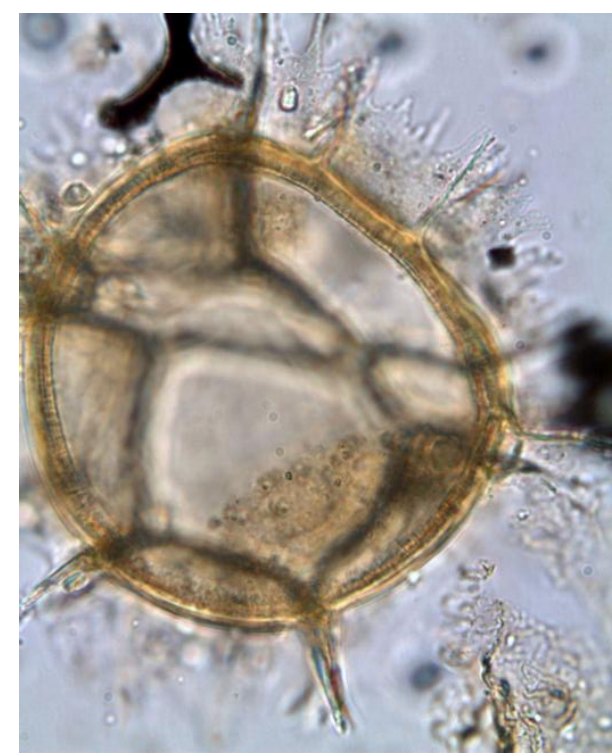

1. Graptodinium reticulatum (29.23.3B X53Y102, $30 \mu \mathrm{m})$.

2. Impagidinium aculatum (29-32-1A, $\mathrm{X} 30 \mathrm{Y} 106,53 \mu \mathrm{m})$.

3-4. Impagidinium crassimuratum (29-29-2, X41Y91, $85 \mu \mathrm{m})$.

5. Impagidinium dispertitum (114-32X-5A, X38.5Y104, $40 \mu \mathrm{m})$.

6. Impagidinium elegans (29-30-5A, X34.5Y99.5, $115 \mu \mathrm{m}$ ). 


\section{Plate 9}

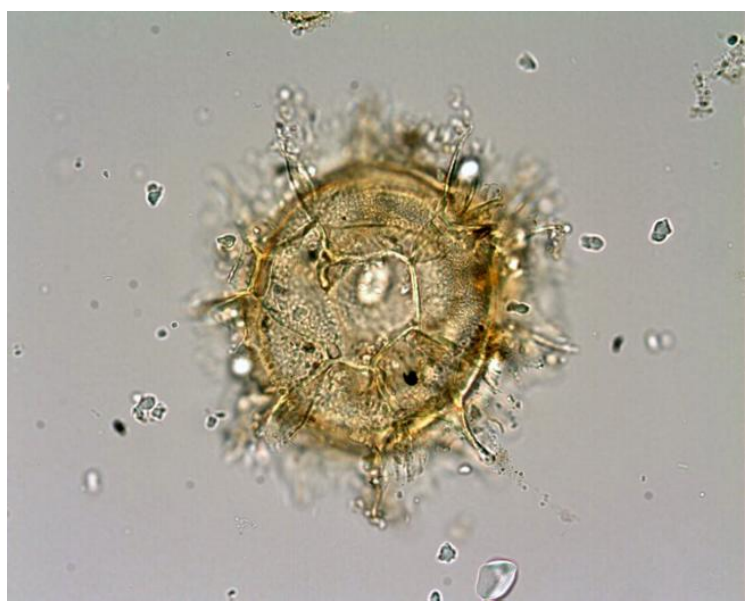

1

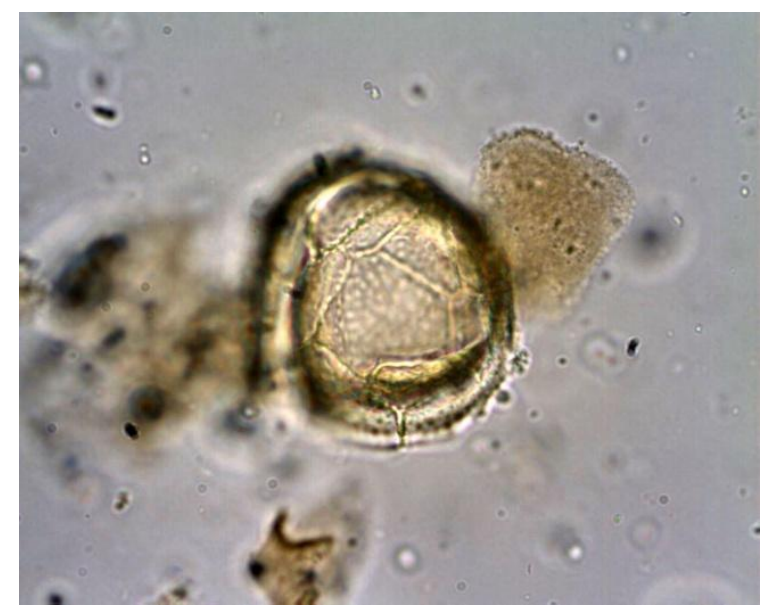

3

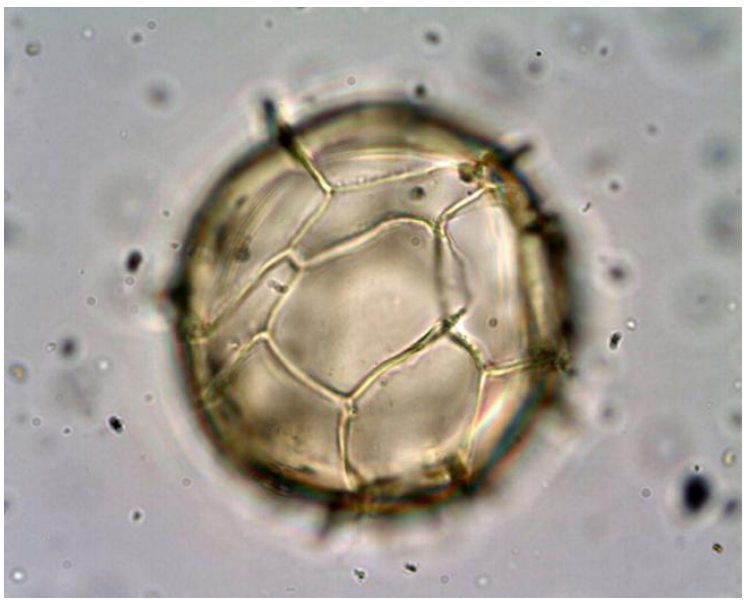

5

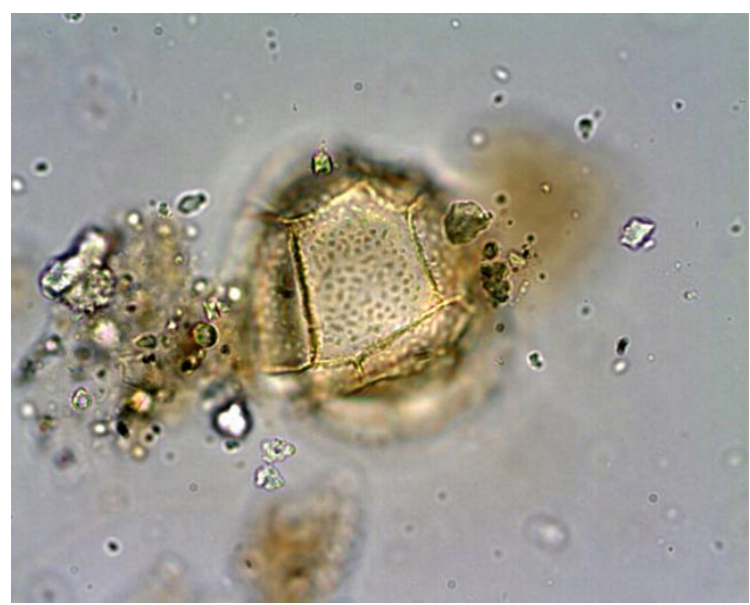

2

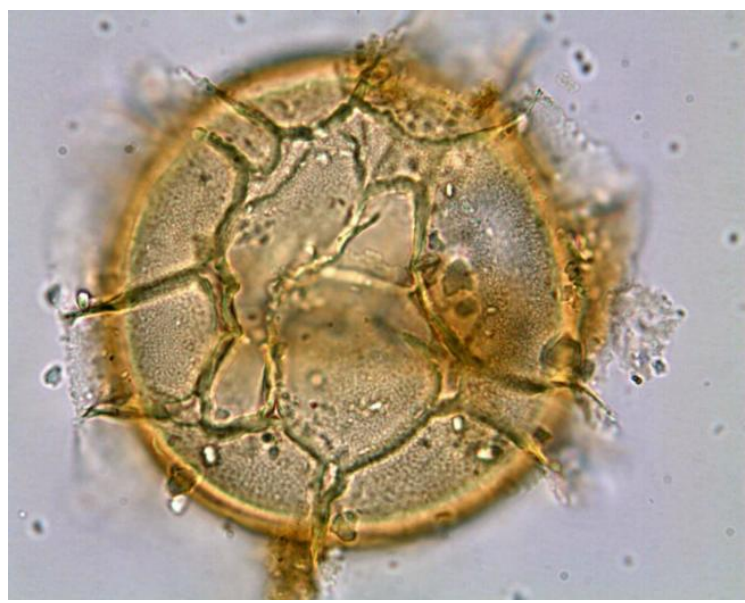

4

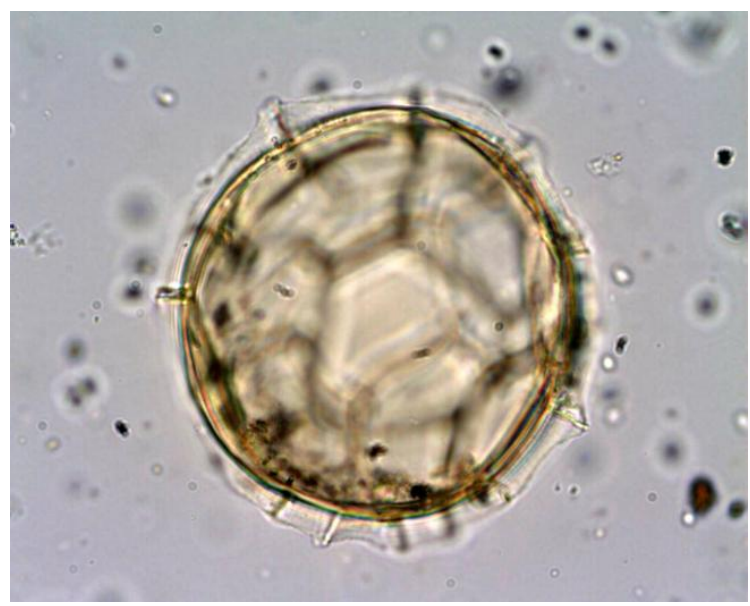

6

1. Impagidinium elegans ( 29-30-5B, X42Y94, $102 \mu \mathrm{m}$ ).

2-3. Impagidinium maculatum (120-23X-1A, X42Y93.5, $50 \mu \mathrm{m})$.

4. Impagidinium parvireticulatum (120-19-1A, X29Y111, $100 \mu \mathrm{m})$.

5-6. Impagidinium victorianum (114-37X-3B, X58Y93.8, $75 \mu \mathrm{m})$. 


\section{Plate 10}

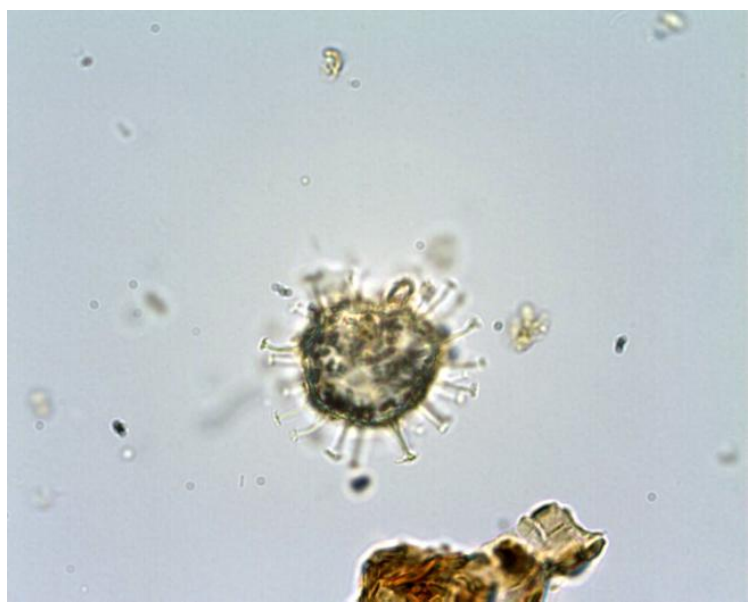

1

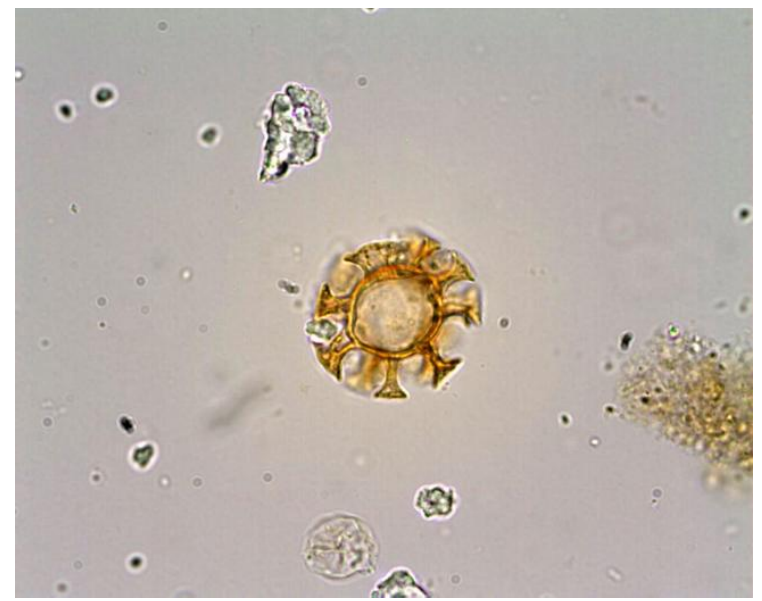

3

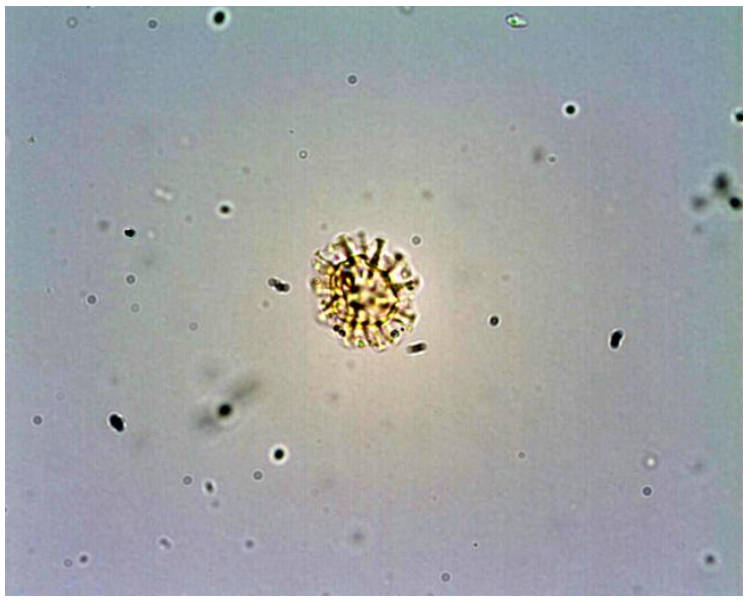

5

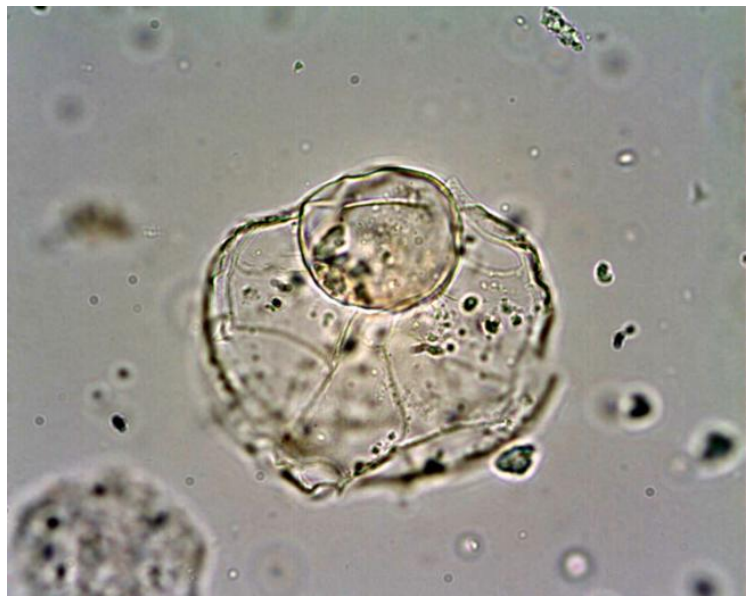

2

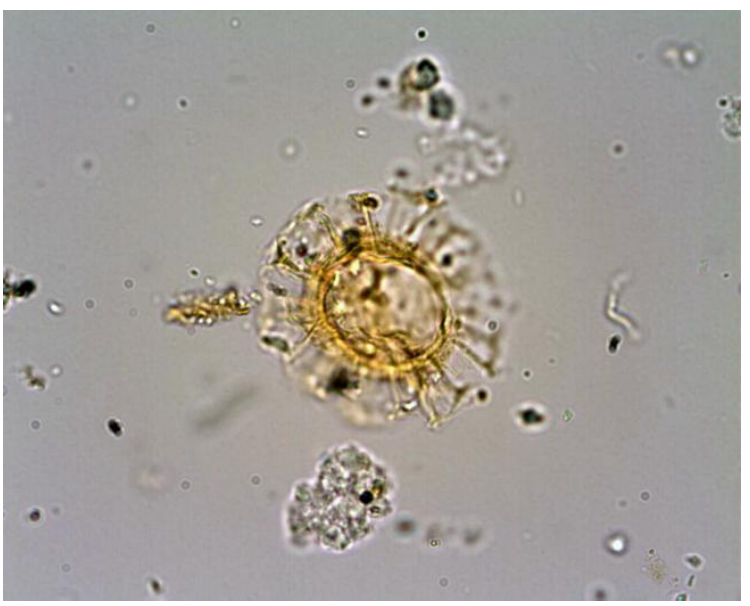

4

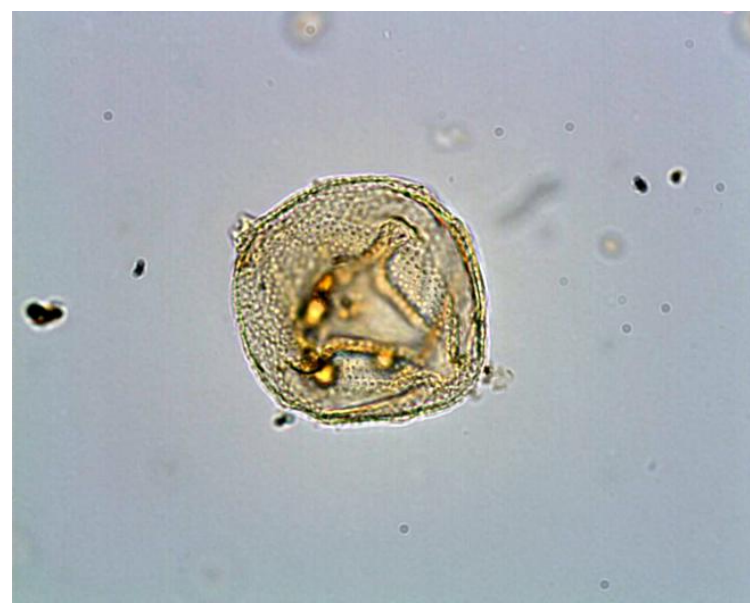

6

1. Impletosphaeridium spp (113-59R-4b, X43Y93, $35 \mu \mathrm{m})$.

2. Lophocysta spp (120-23X-1A X32.5Y108.2, $55 \mu \mathrm{m})$.

3. Minisphaeridium latirictum (120-20H-1A, $\mathrm{X} 44 \mathrm{Y} 100.6,15 \mu \mathrm{m}$ not including processes).

4-5. Minisphaeridium group (29-29-2B, X34Y100.5, $40 \mu \mathrm{m} ; 114-33 \mathrm{X}-6 \mathrm{~B}, \mathrm{X} 54 \mathrm{Y} 94.5,20 \mu \mathrm{m}$ ).

6. Moria zachosii (113-60R-5A X35Y100, $45 \mu \mathrm{m})$. 

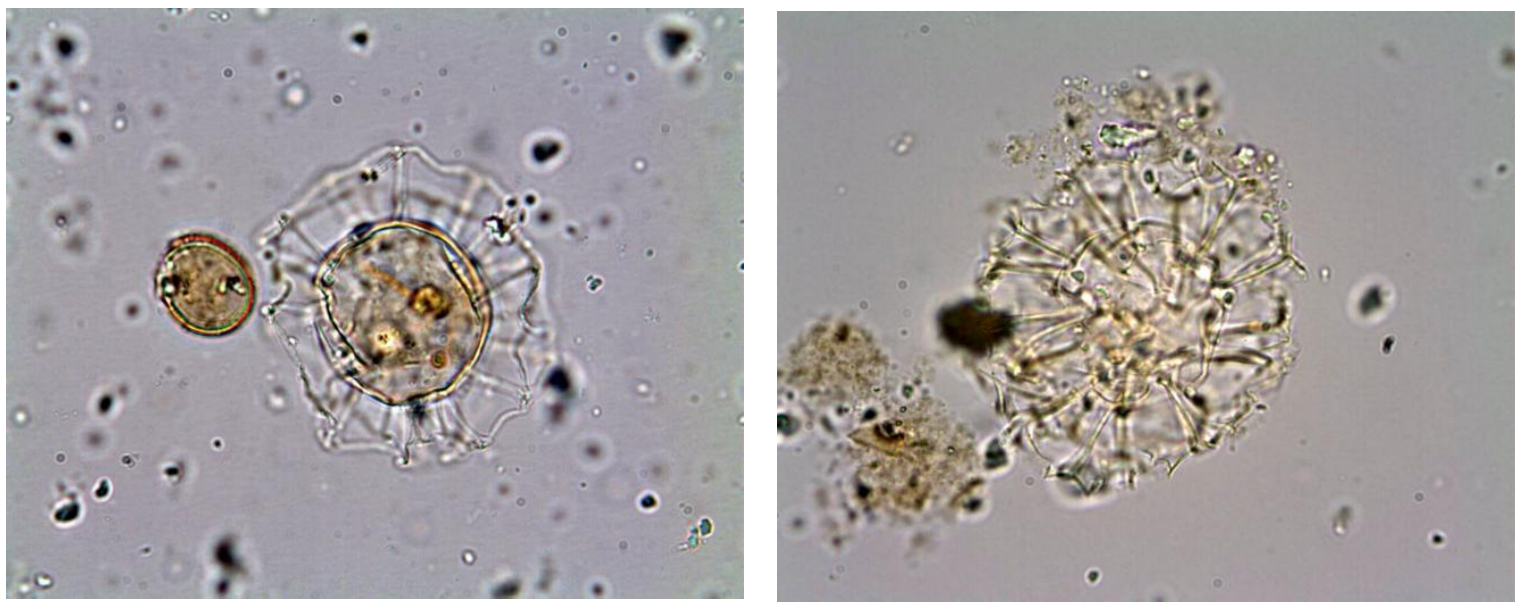

1

\section{2}

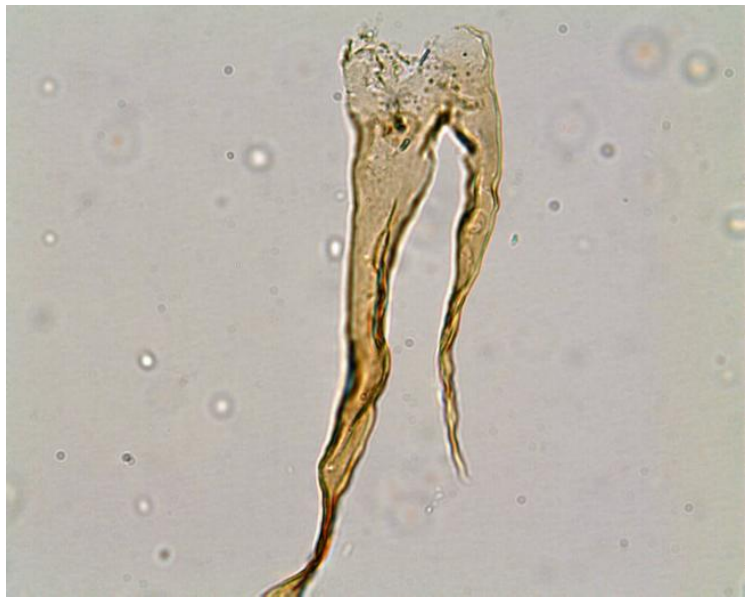

3

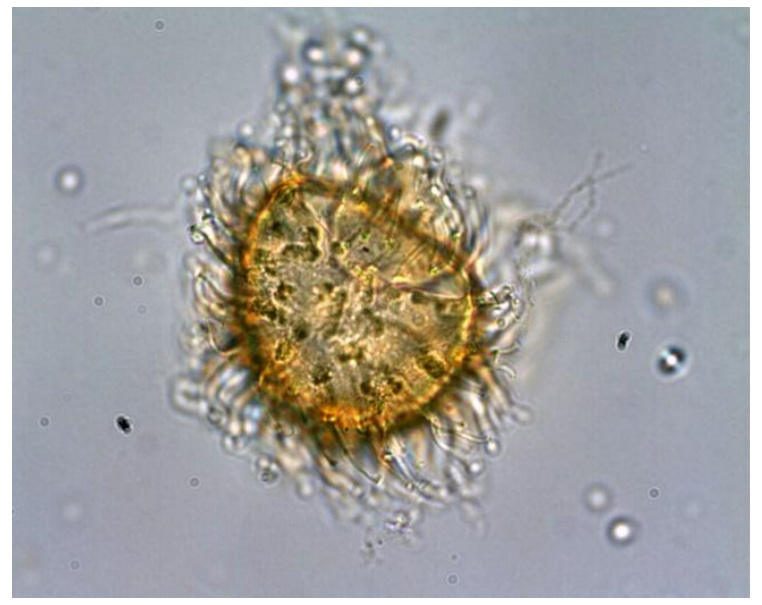

4
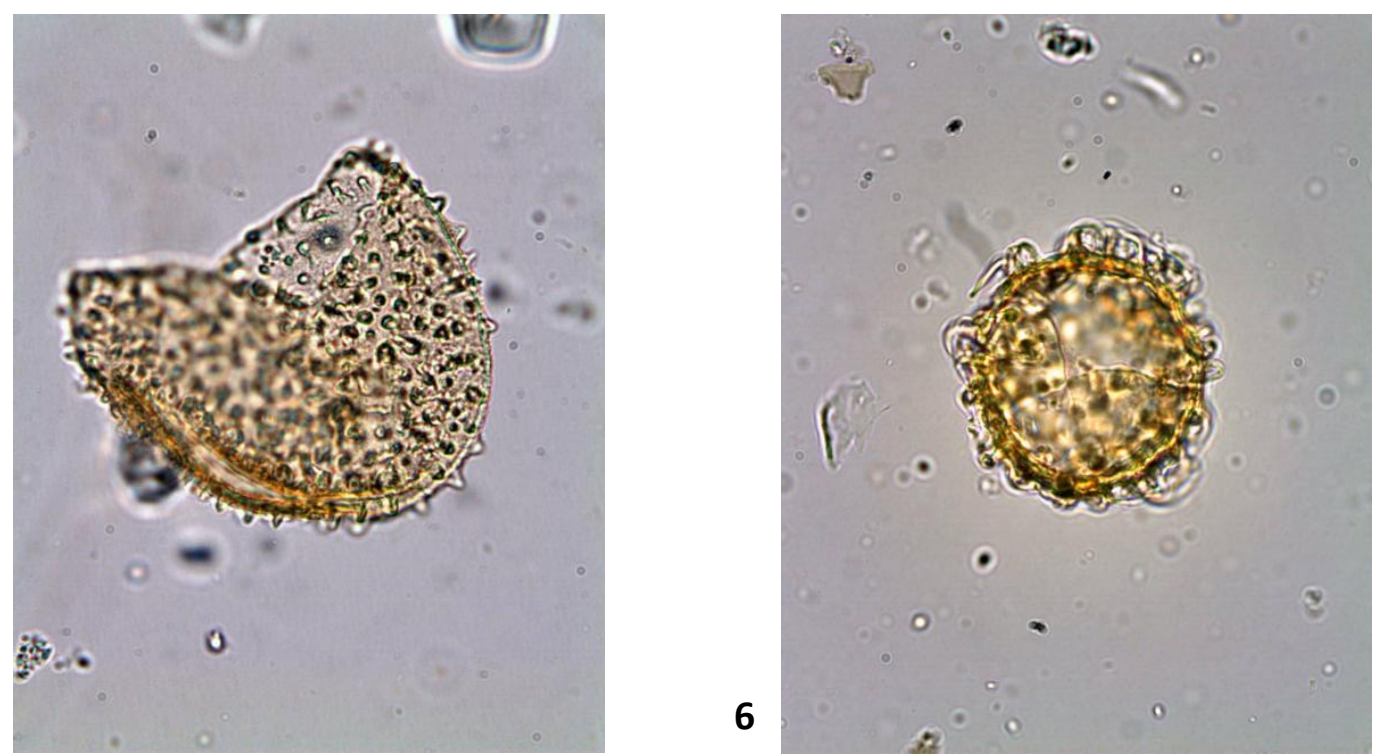

1-2. Nematosphaeropsis spp (120-23X-3A, X40.3Y91.5, $50 \mu \mathrm{m} ; 120-20 \mathrm{H}-1 \mathrm{~A}, \mathrm{X} 55 \mathrm{Y} 93,30 \mu \mathrm{m}$ not including processes). 3. Odontochitina spp (114-33X-6B, X38.5Y93, $130 \mu \mathrm{m}$ length).

5. Operculodinium janduchenei (29-22-2A, X54.5Y95, $73 \mu \mathrm{m})$.

4 \& 6. Operculodinium spp (29-29-2A, X45.9Y94, $45 \mu \mathrm{m} ; 29-29-2 \mathrm{~A}, \mathrm{X} 38.5 Y 95.5,55 \mu \mathrm{m})$. 

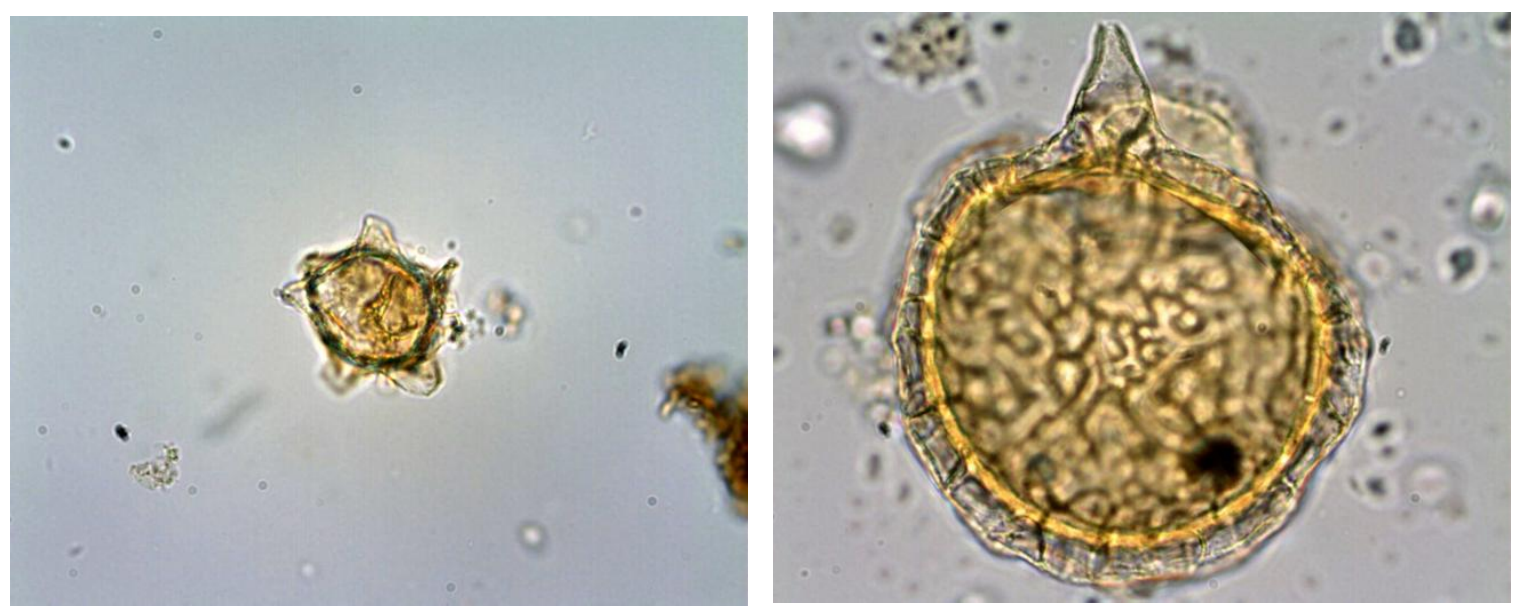

1

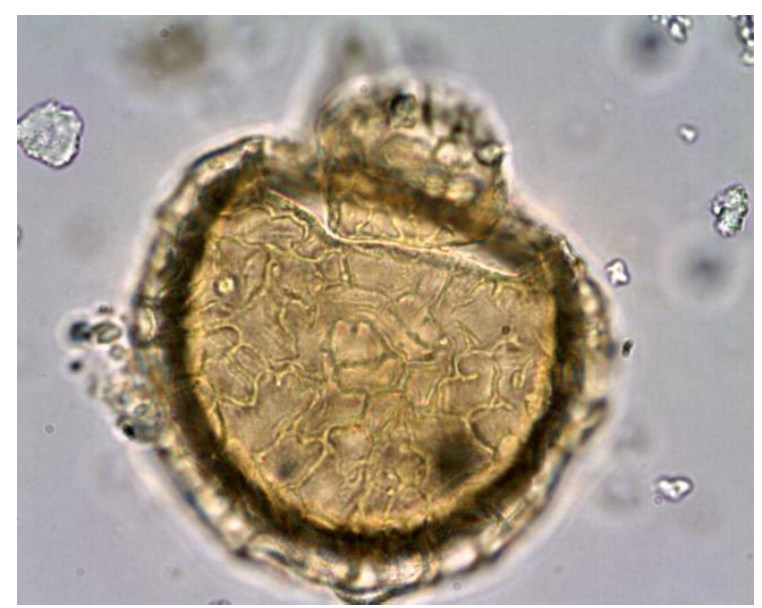

3

5

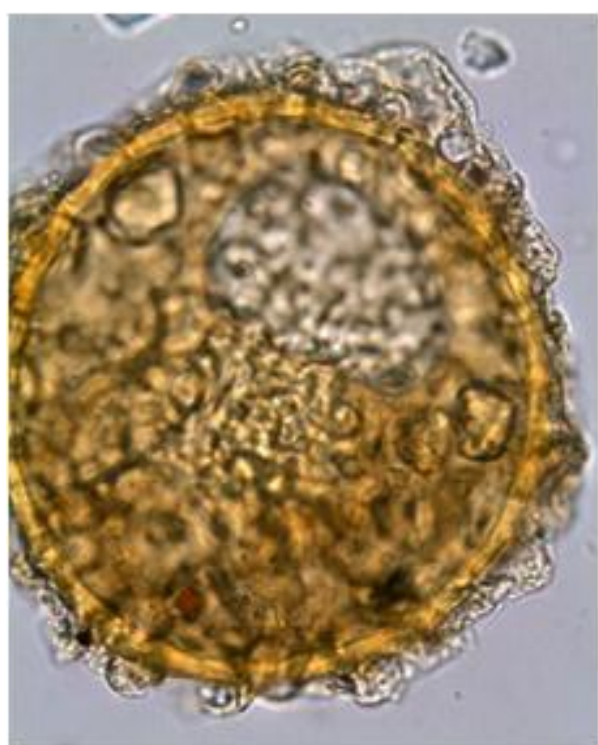

2
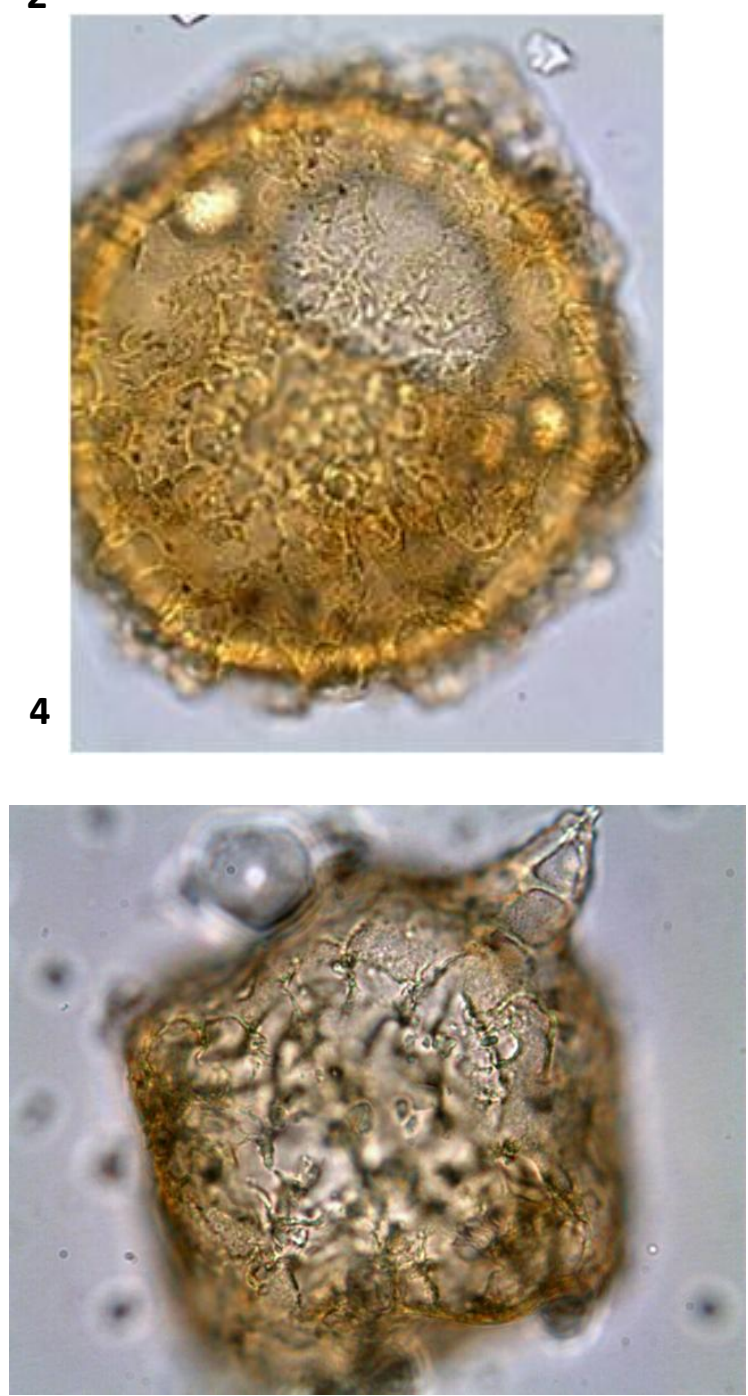

6

1. Paucisphaeridium inversibuccinium (113-58R-1A, $X 35.5 Y 100.8,30 \mu \mathrm{m})$.

2-3. Samlandia reticulifera (120-20H-5A, X48.5Y94, $95 \mu \mathrm{m})$.

4-5. Samlandia reticulifera (29-30-5A, X54Y101.5, $110 \mu \mathrm{m})$.

6. Samlandia spp (120-19H-1A, X40Y104, $130 \mu \mathrm{m})$. 


\section{Plate 13}
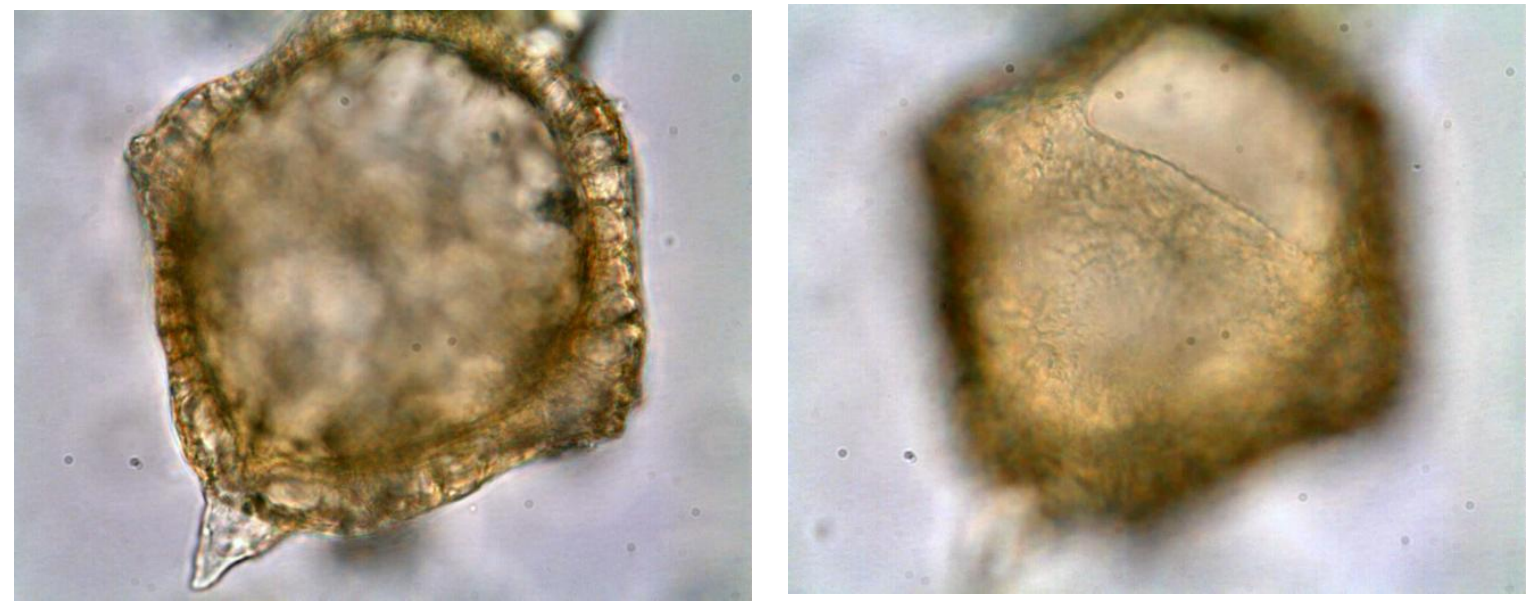

1

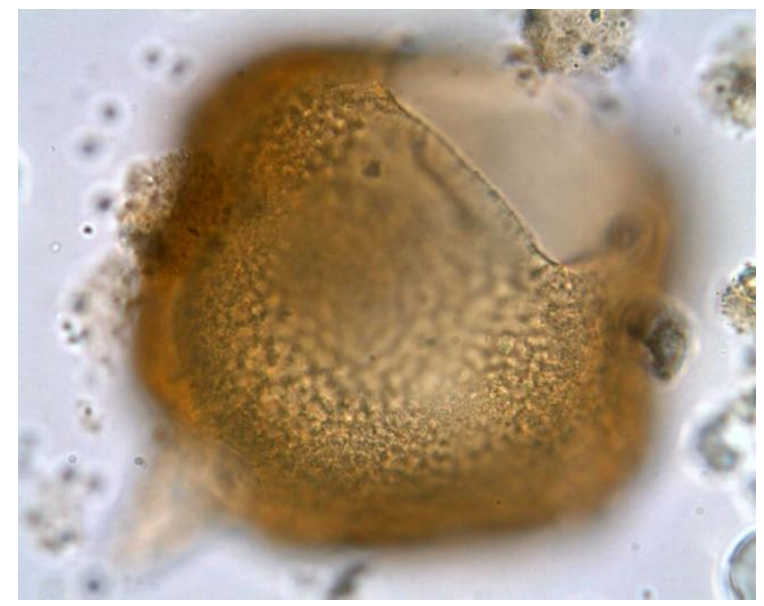

3

\section{2}

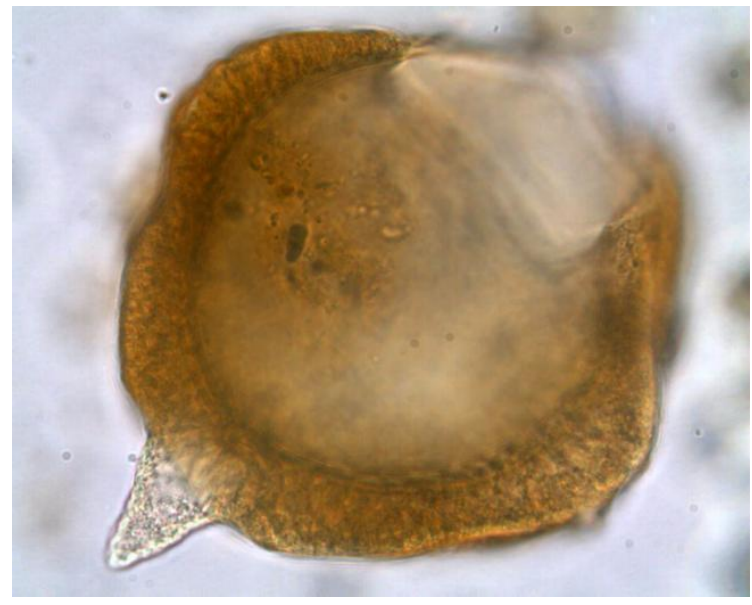

4

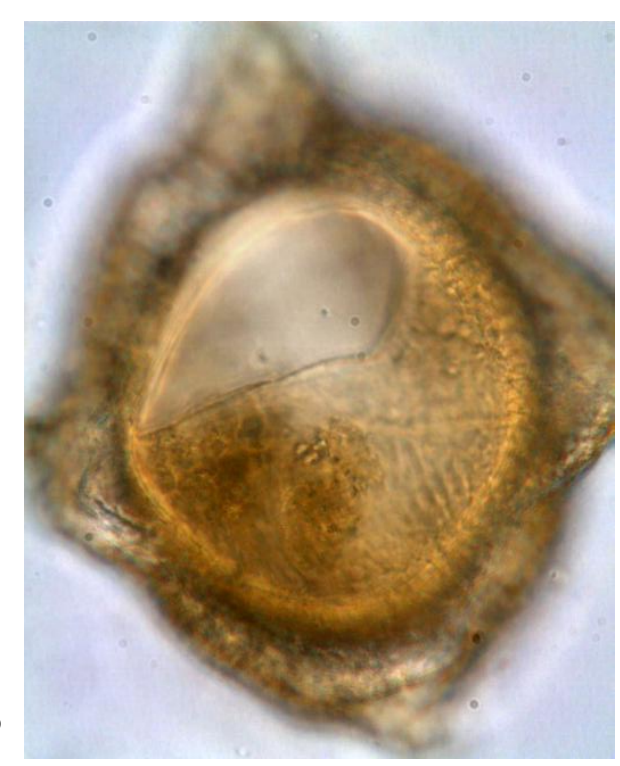

6

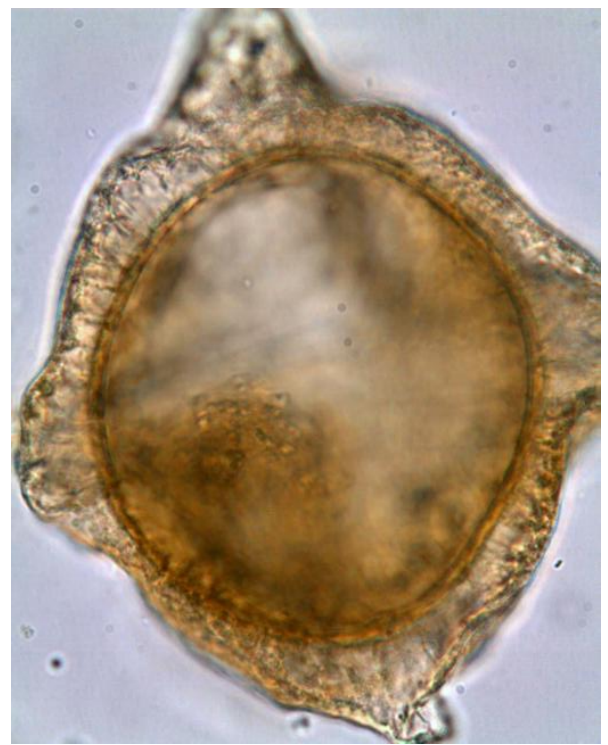

1-6. Samlandia spp (1-2. 120-19H-1A, X40Y104, $130 \mu \mathrm{m}$; 3-4. 120-19H-1A, X48,Y100, 115 $\mu \mathrm{m} ; 5-6.120-19 \mathrm{H}-1 \mathrm{~A}, \mathrm{X} 30.2 \mathrm{Y} 95,125 \mu \mathrm{m})$. 


\section{Plate 14}

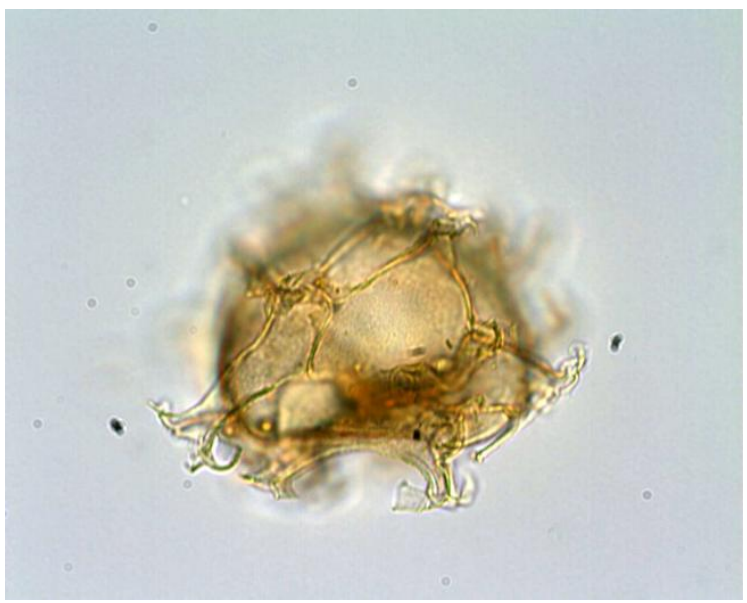

1
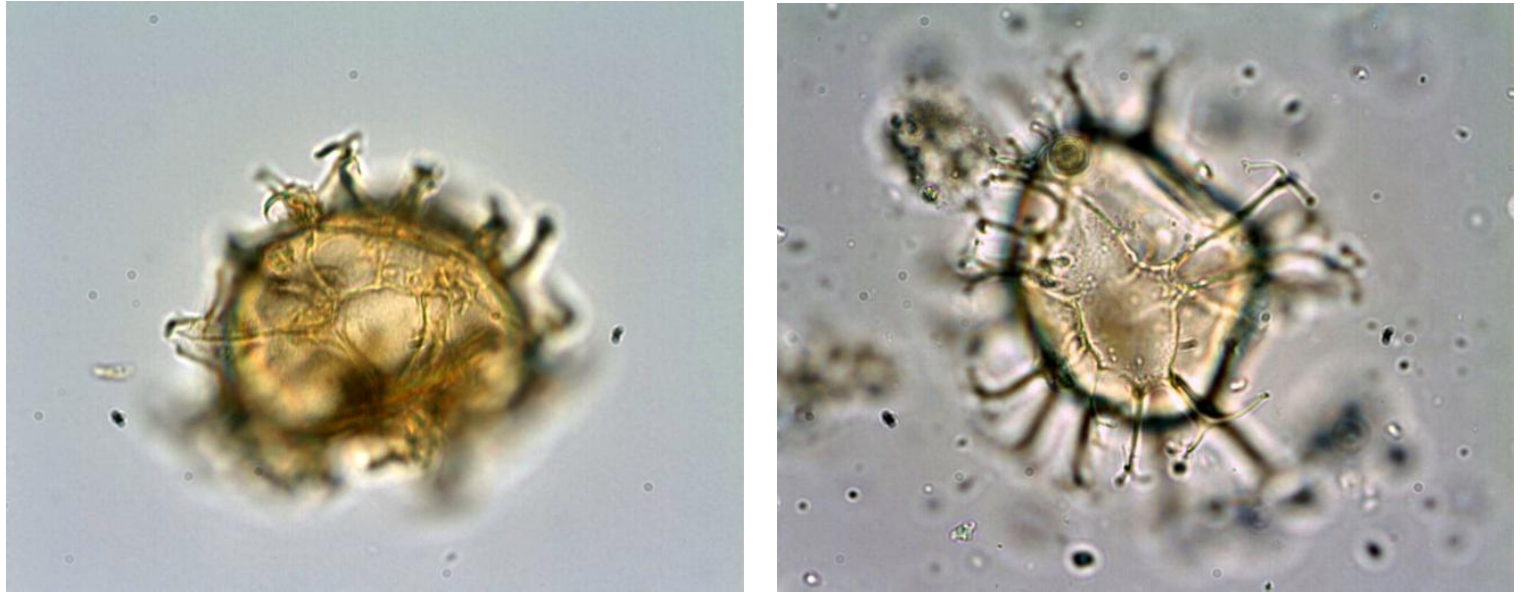

2

3
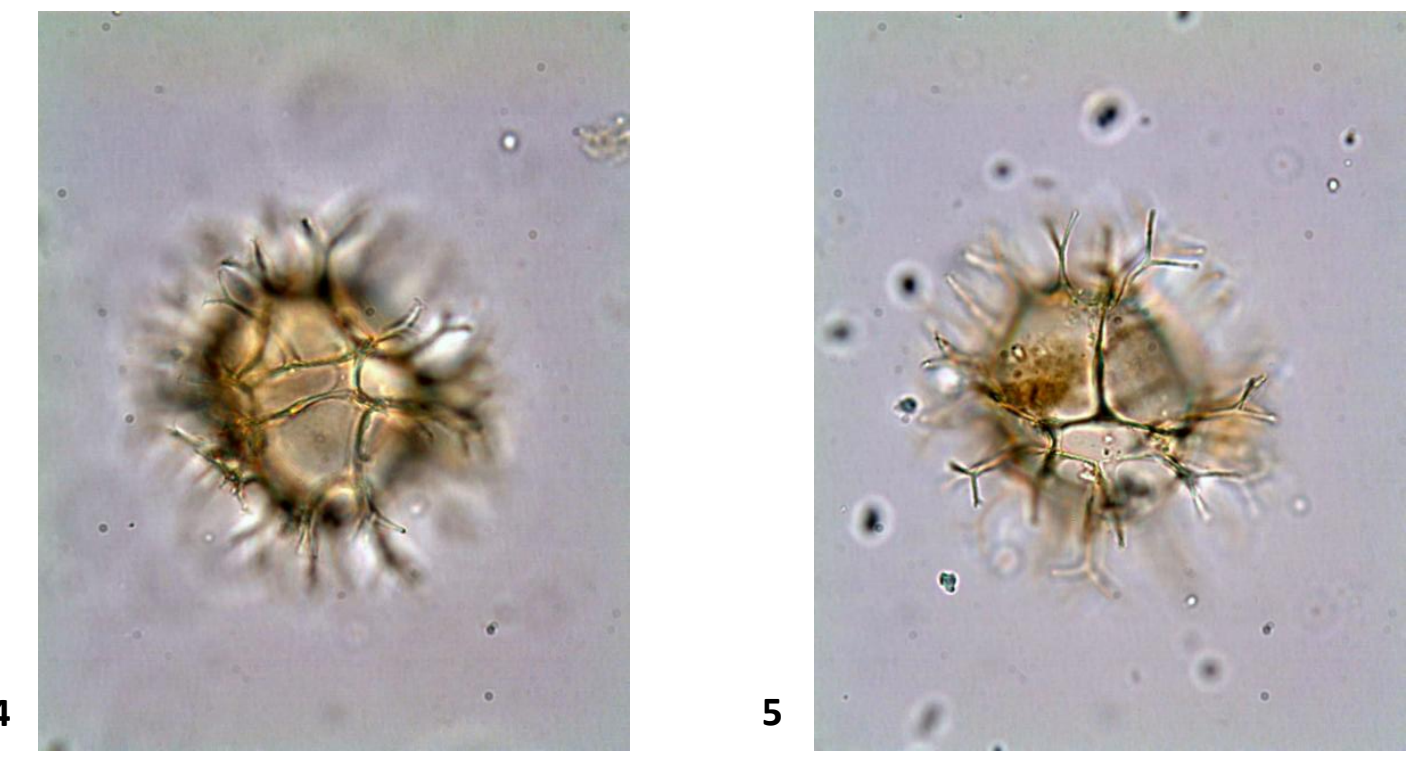

1-5. Spiniferites spp (2-3. 113-59R-3A, X36Y102, $70 \mu \mathrm{m}$; 4.120-23X-1A X48Y93.5. $50 \mu \mathrm{m}$; $120-19 \mathrm{H}-1 \mathrm{~A}, \mathrm{X} 58.5 \mathrm{Y} 95.8,60 \mu \mathrm{m}$ not including processes). 


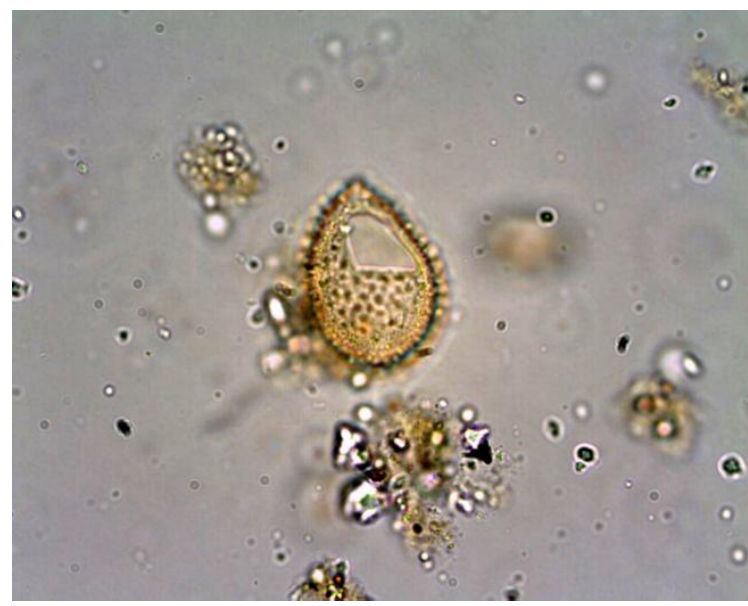

1
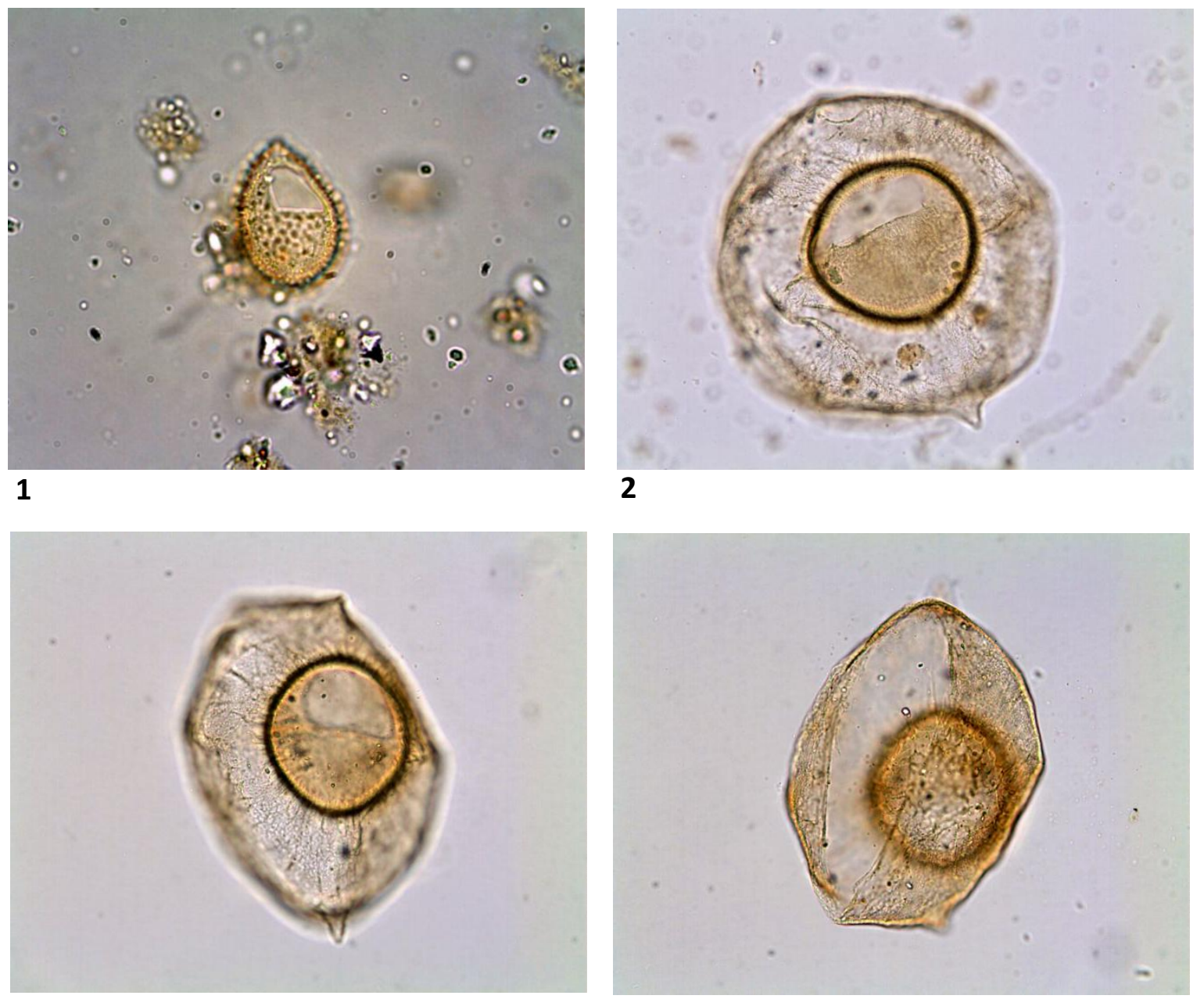

3

4

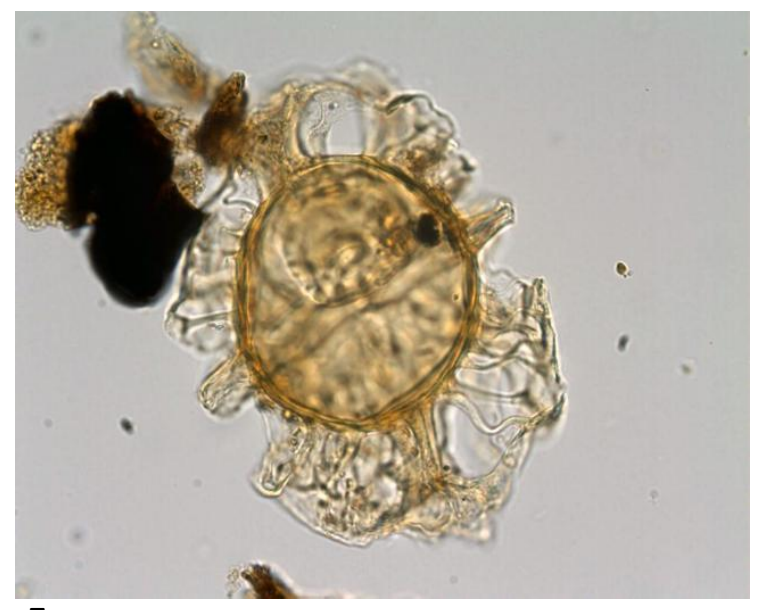

5

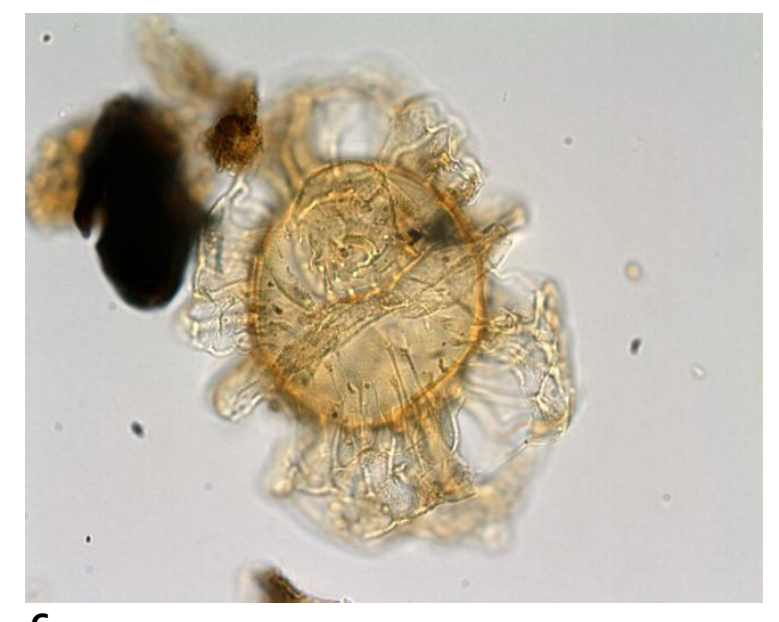

6

1. Tectatodinium spp (120-23X-1A, X44Y92, $34 \mu \mathrm{m})$.

2-4. Thalassaphora spp (2. 120-19H-1A, X31Y91.2, $200 \mu \mathrm{m} ; 3-4.120-19 \mathrm{H}-1)$.

5-6. Turbiosphaera filosa (113-62R-6A, X57Y93, $120 \mu \mathrm{m})$. 


\section{Plate 16}
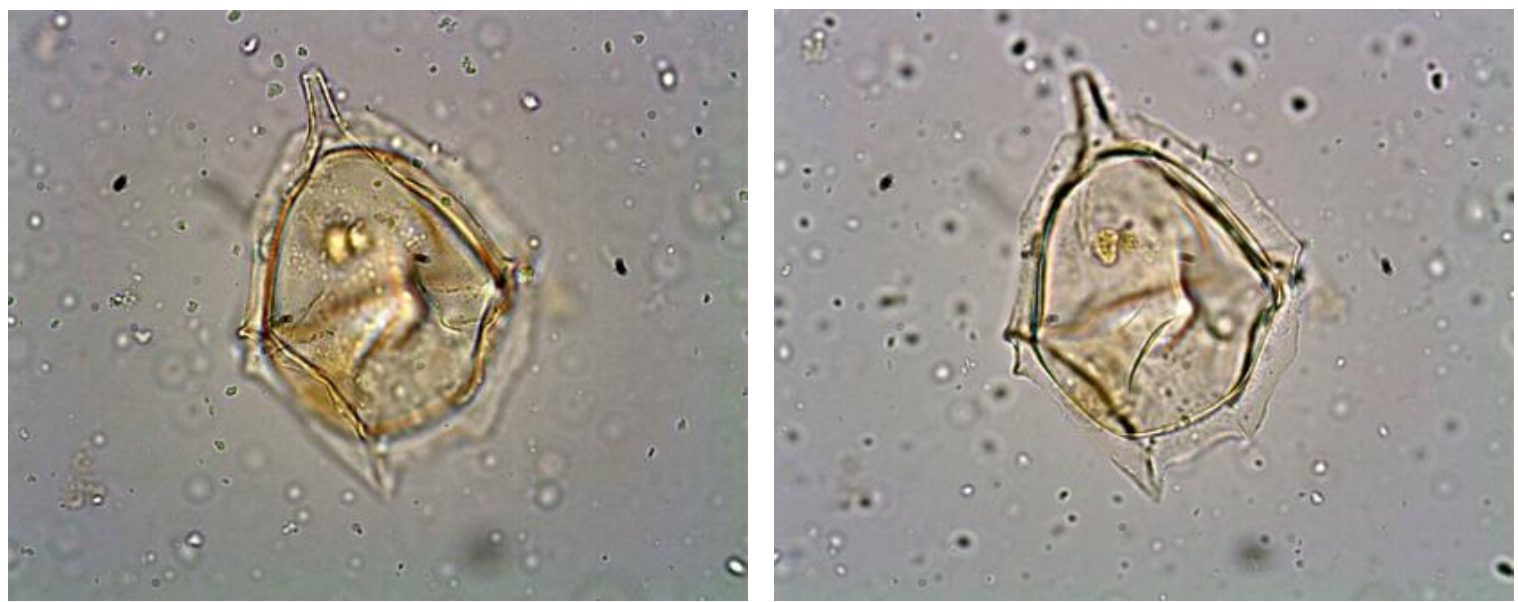

1

2

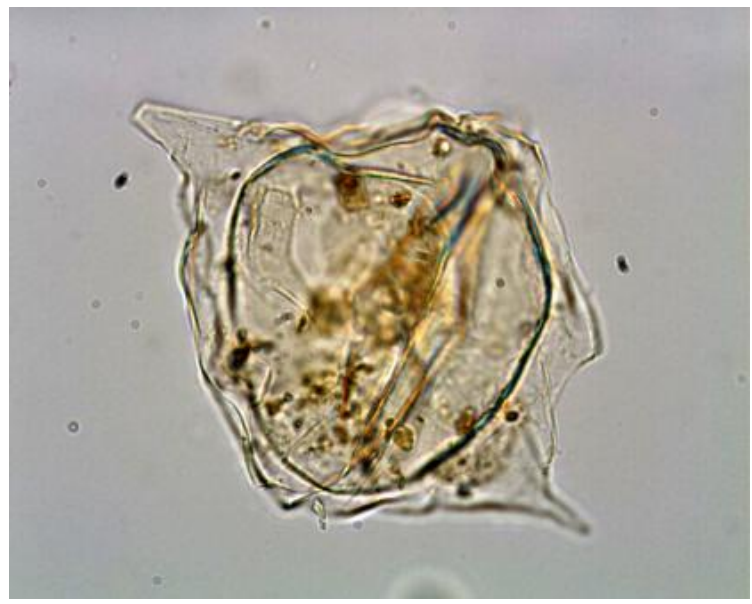

3

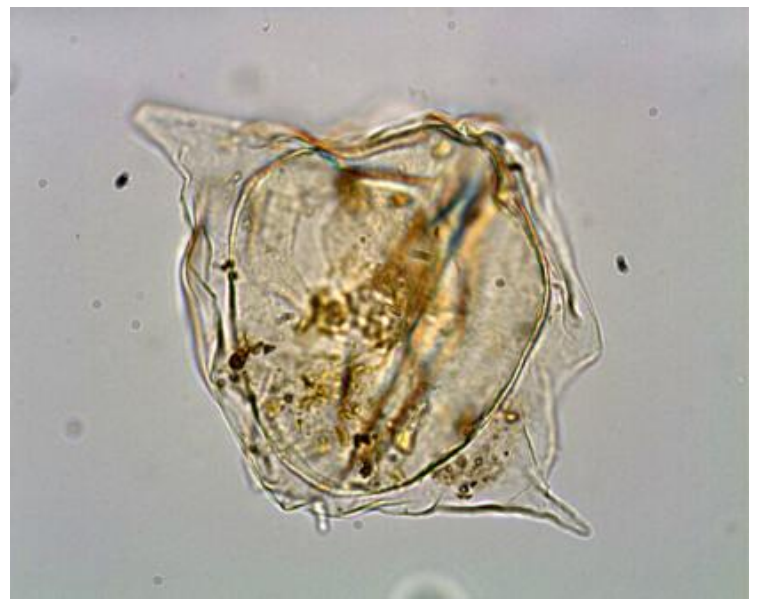

4
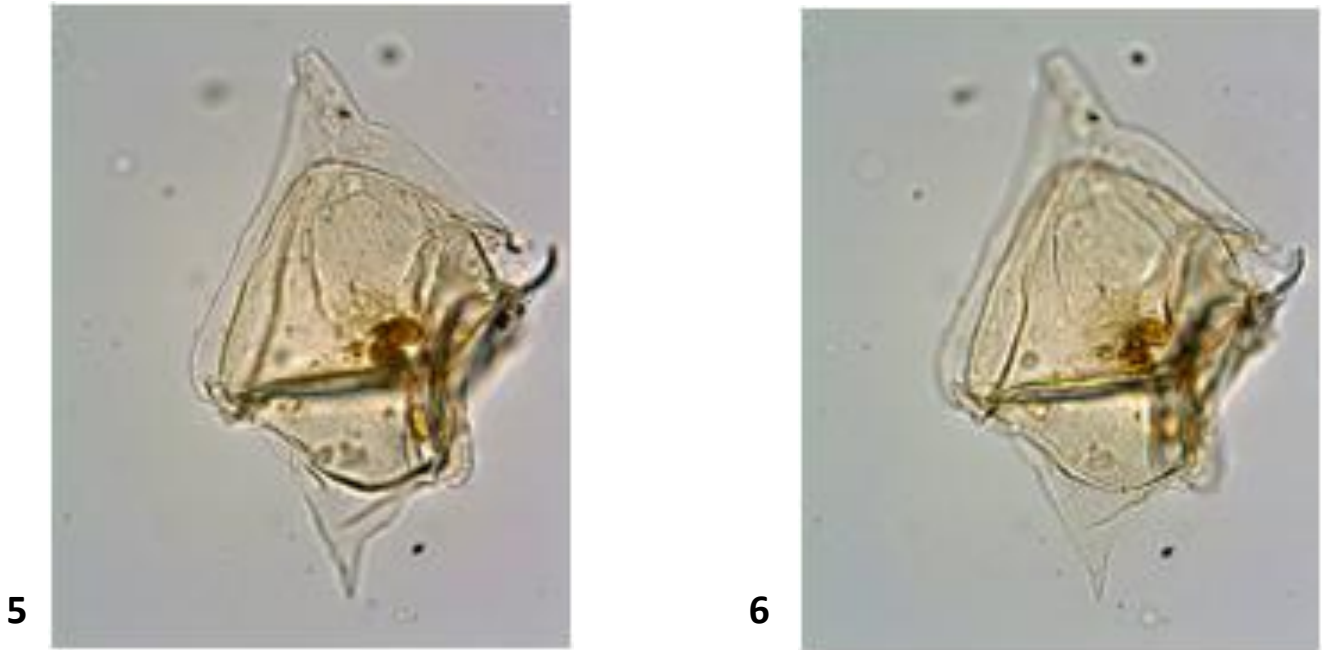

1-6. Alterbidinium distinctum (1-2. 120-17H-4B, X39.2Y95.2, $75 \mu \mathrm{m} ; 3-4.113-59 \mathrm{R}-1 \mathrm{~b}$, X52Y92.3, $110 \mu \mathrm{m}$; 5-6. 113-60R-2, X36Y97.3, $102 \mu \mathrm{m})$. 


\section{Plate 17}

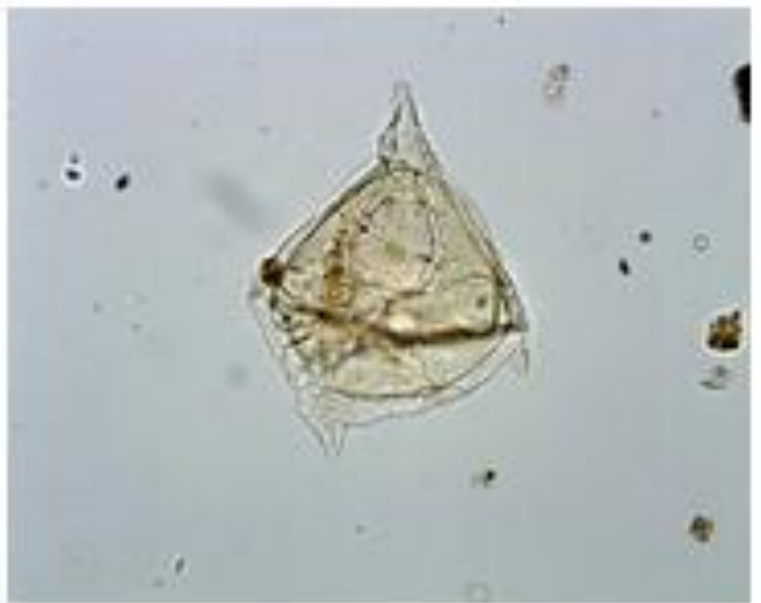

1

3
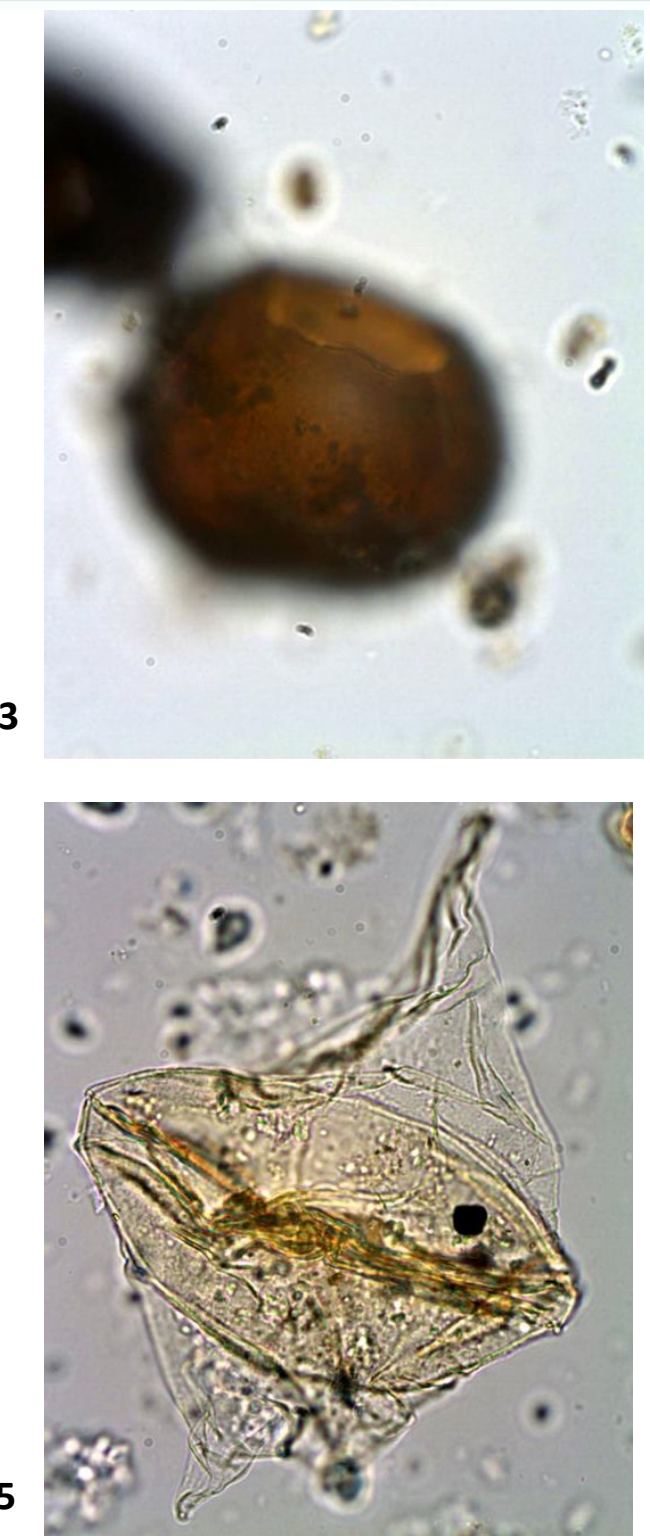

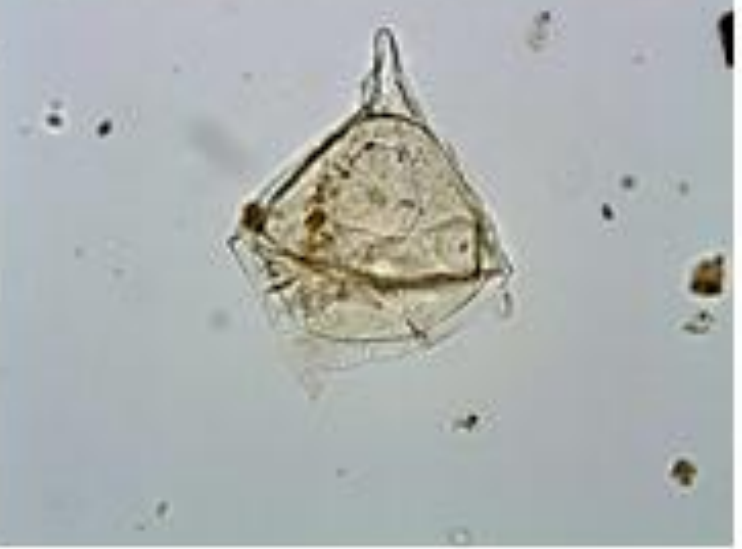

2

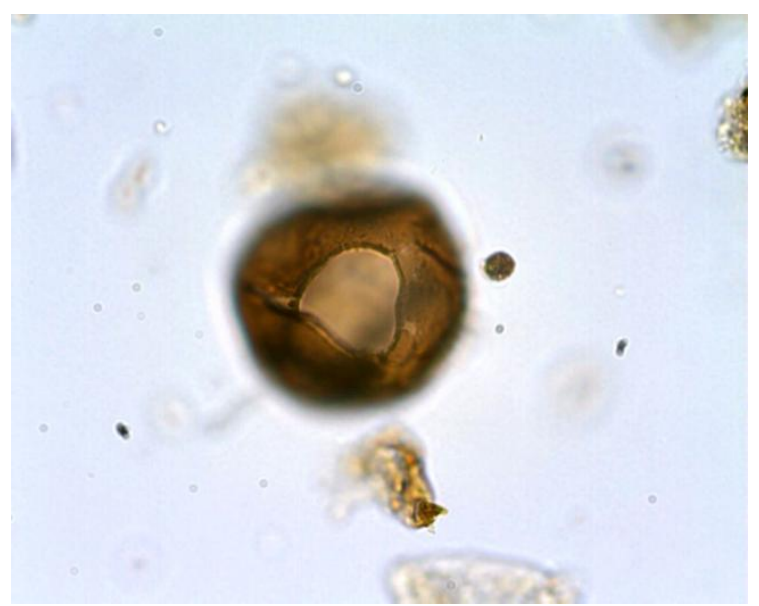

4

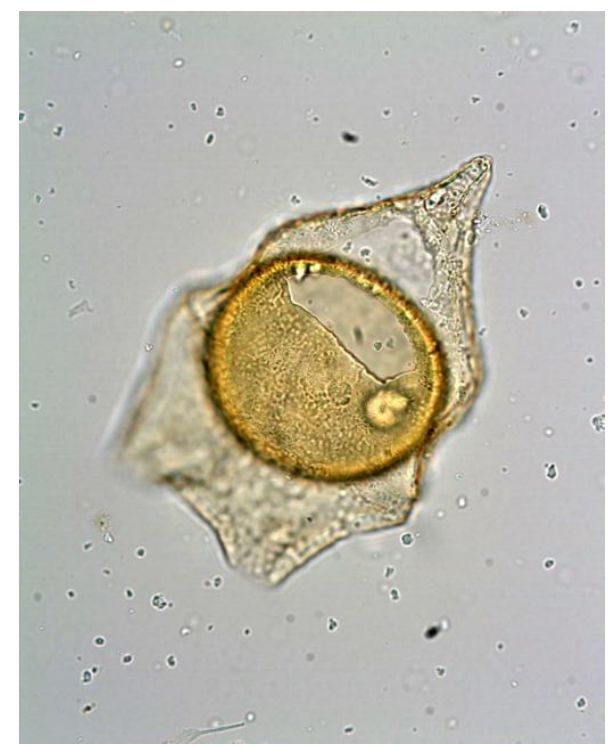

1-2. Alterbidinium distinctum (113-59R-2, X56Y106, $100 \mu \mathrm{m})$.

3-4. Brigantedinium spp (113-56R-1A, X34.3Y105, $60 \mu \mathrm{m} ; 113-56 \mathrm{R}-1 \mathrm{~A}, \mathrm{X} 34.3 \mathrm{Y} 105,65 \mu \mathrm{m})$.

5. Cerodinium medcalfii (29-26-4A X36Y104.5, $120 \mu \mathrm{m})$.

6. Deflandrea antarctica $(120-19 \mathrm{H}-1 \mathrm{~A}, \mathrm{X} 47 \mathrm{Y} 92.5,80 \mu \mathrm{m})$. 
1
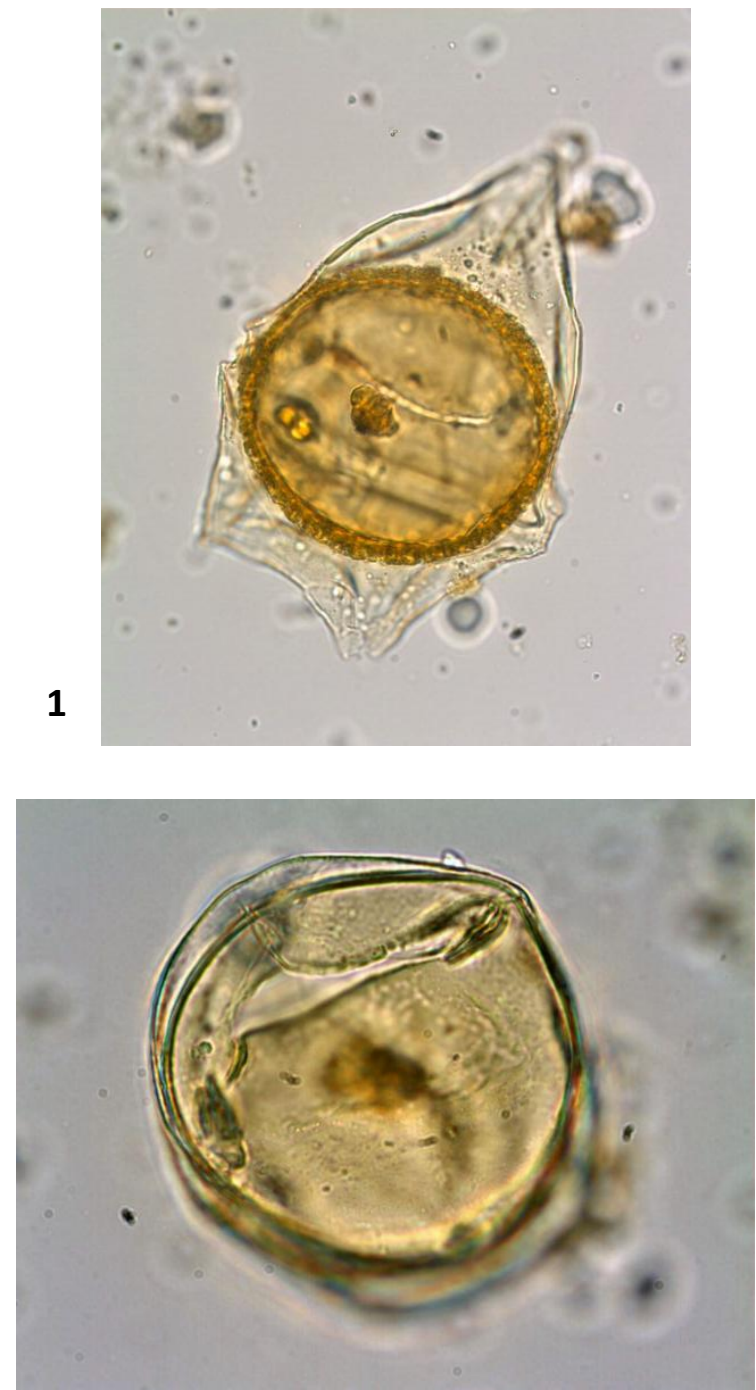

3

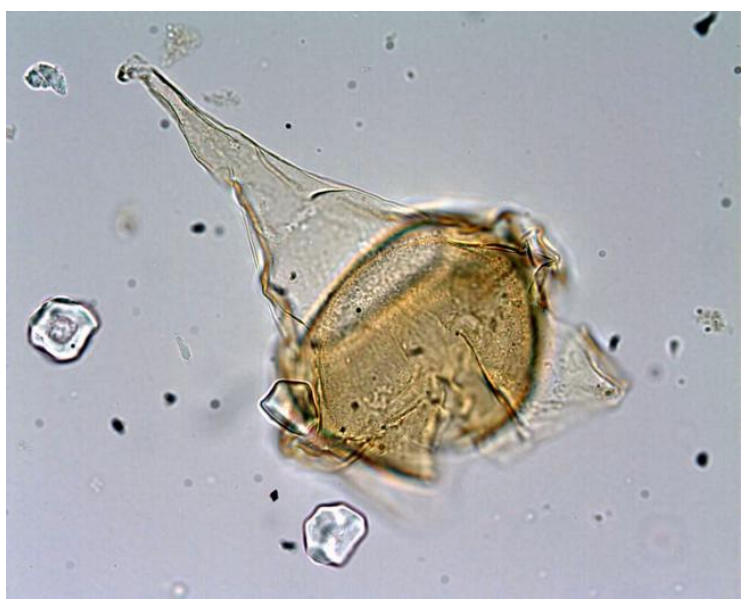

5

1-2. Deflandrea antarctica (29-30-5B X35Y101.5, $120 \mu \mathrm{m} ; 113-59 \mathrm{R}-5, \mathrm{X} 64 \mathrm{Y} 103,120 \mu \mathrm{m})$.

3-4. Deflandrea convexa (120-19H-1A X47Y97.5, $75 \mu \mathrm{m} ; 120-19 \mathrm{H}-1 \mathrm{~A}, \mathrm{X} 51 \mathrm{Y} 103,90 \mu \mathrm{m})$.

5-6. Deflandrea cygniformis (120-16H-7A, X54.5104, $65 \mu \mathrm{m})$.
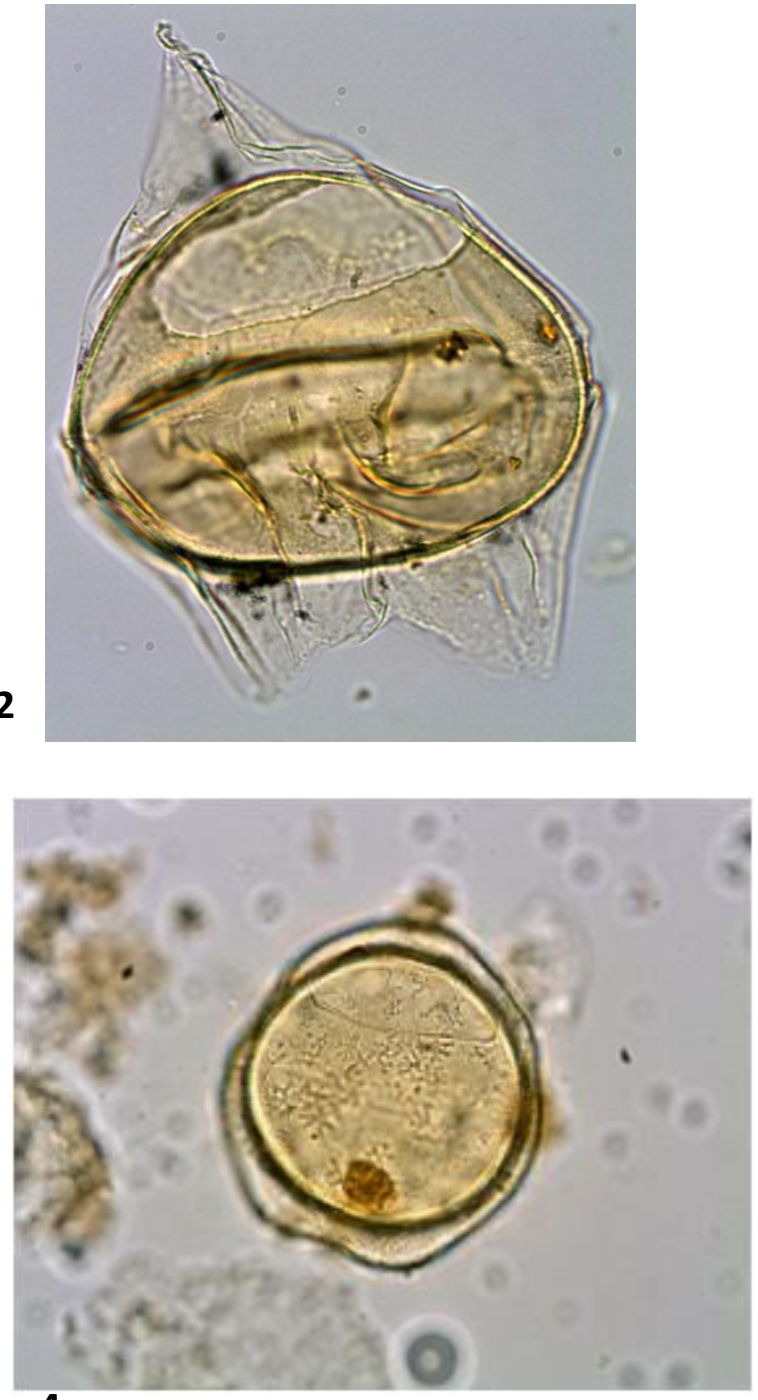

4

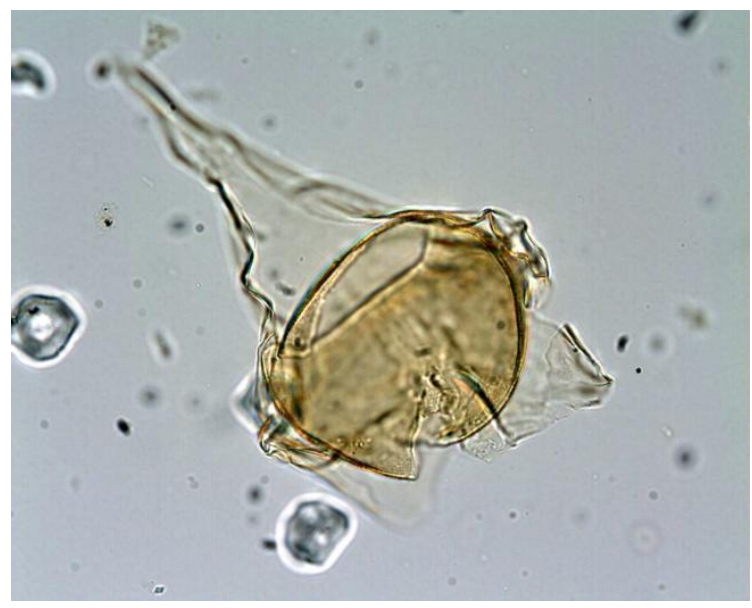

6 


\section{Plate 19}
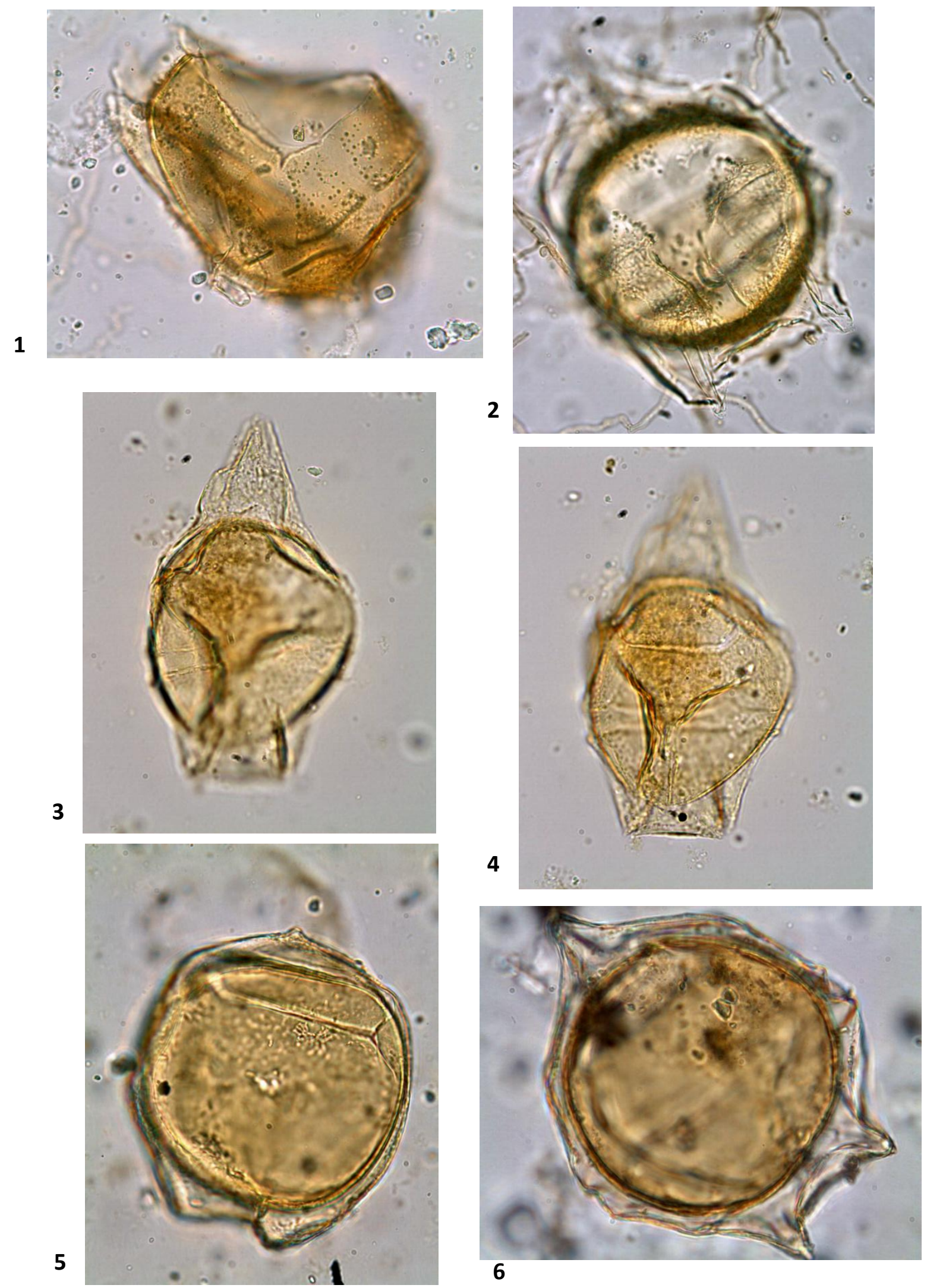

1-2. Deflandrea dartmooria (29-26-1A, X39.5Y93.4, $125 \mu \mathrm{m} ; 29-26-1 \mathrm{~A}, \mathrm{X} 35.5 Y 92,110 \mu \mathrm{m})$. 


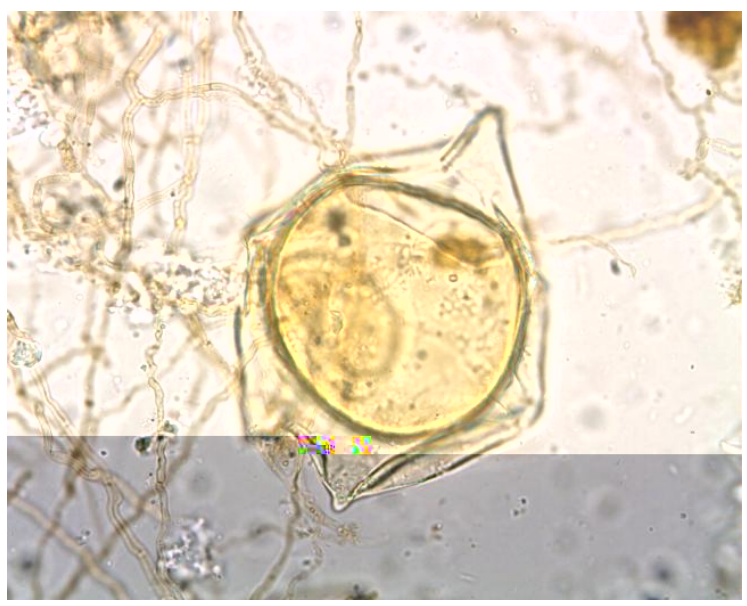

1

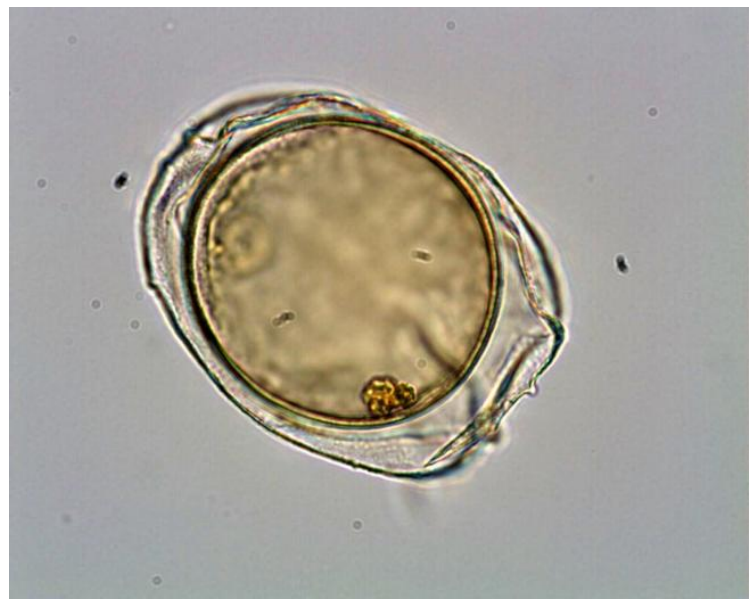

3

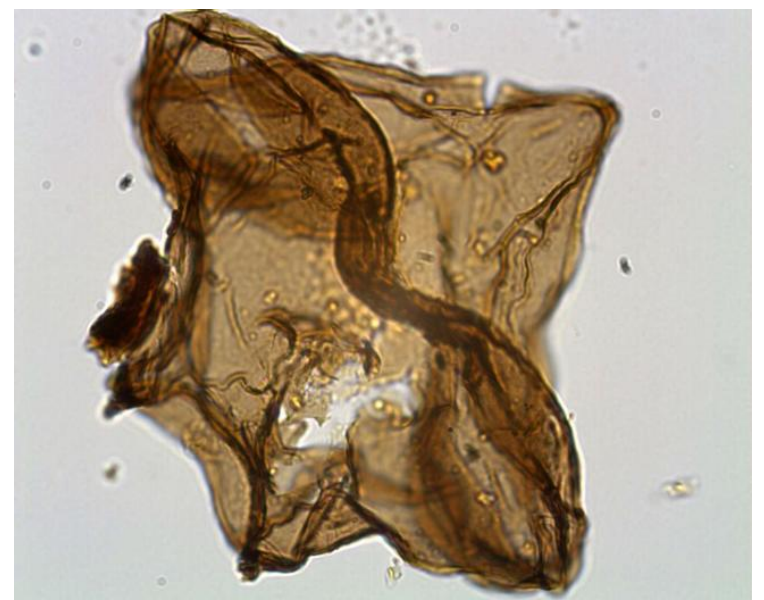

5

1. Deflandrea phosphoritica (29-26-1X31.5Y104, $115 \mu \mathrm{m})$.

2. Diconodinium cristatum (113-61R-2A, X37Y103.5, $95 \mu \mathrm{m})$.

3-4. Eurydinium sp (113-58R-1, X45Y110, $80 \mu \mathrm{m})$.

5. Lejeunecysta cowiei (113-59R-2A, X34Y93, $110 \mu \mathrm{m})$.

6. Lejeunecysta fallax (113-59R-3A, X51.5Y97, $95 \mu \mathrm{m})$.

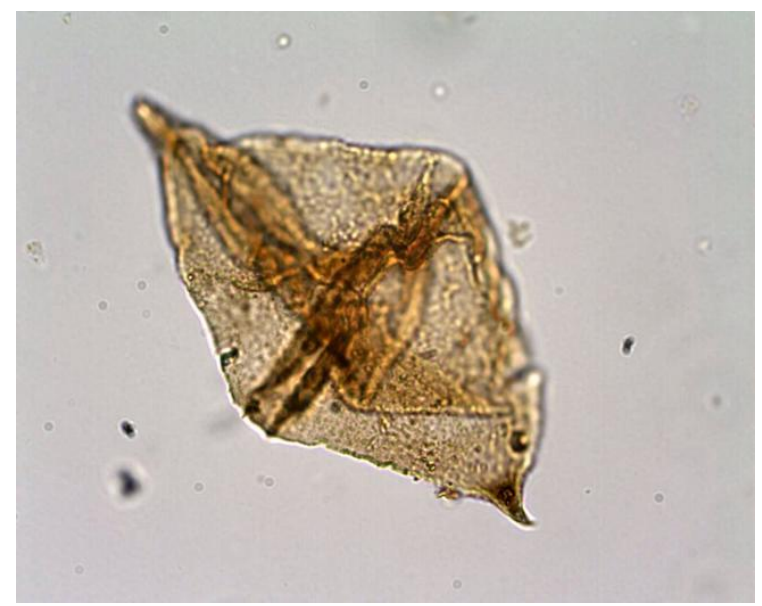

2

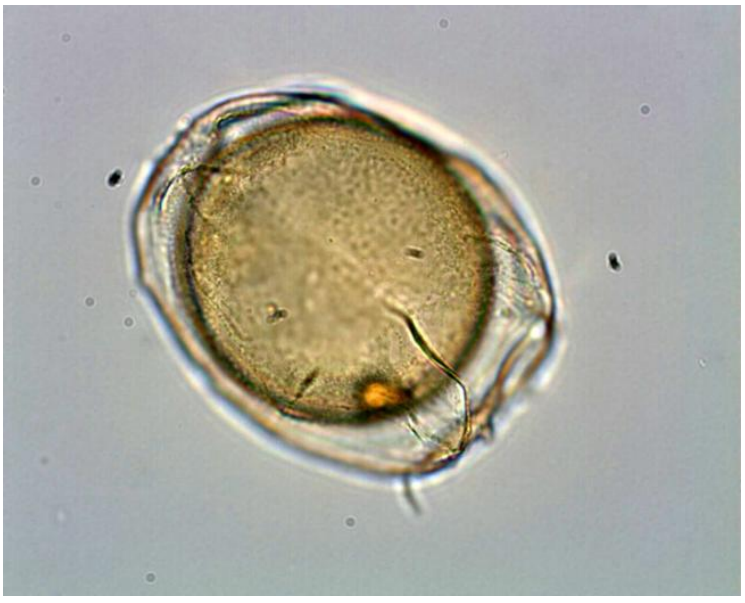

4

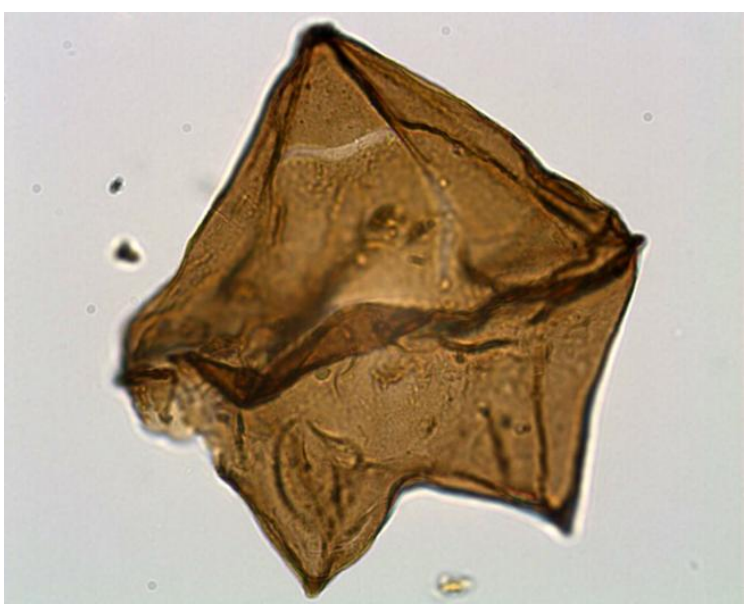

6 
Plate 21

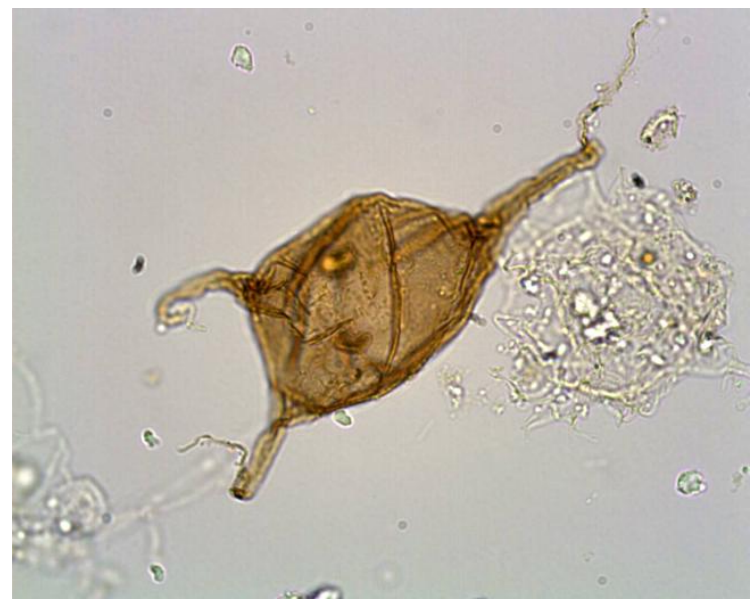

1
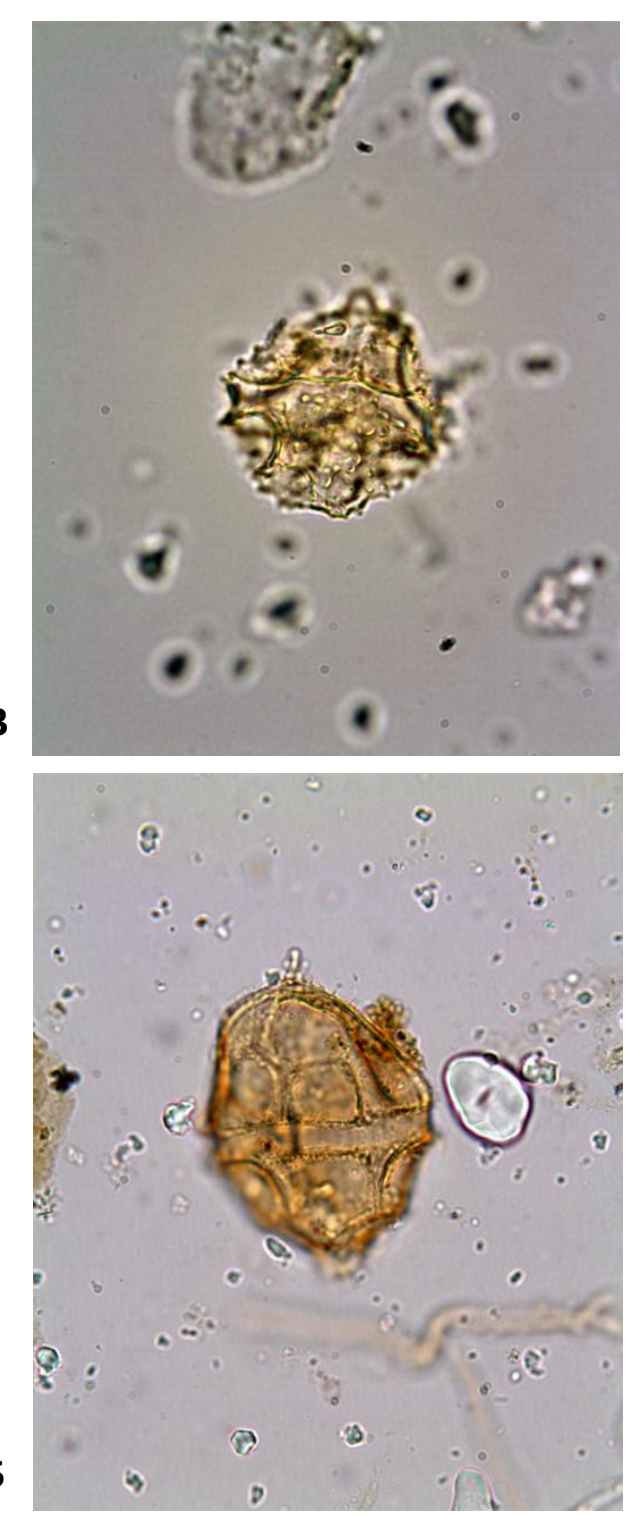
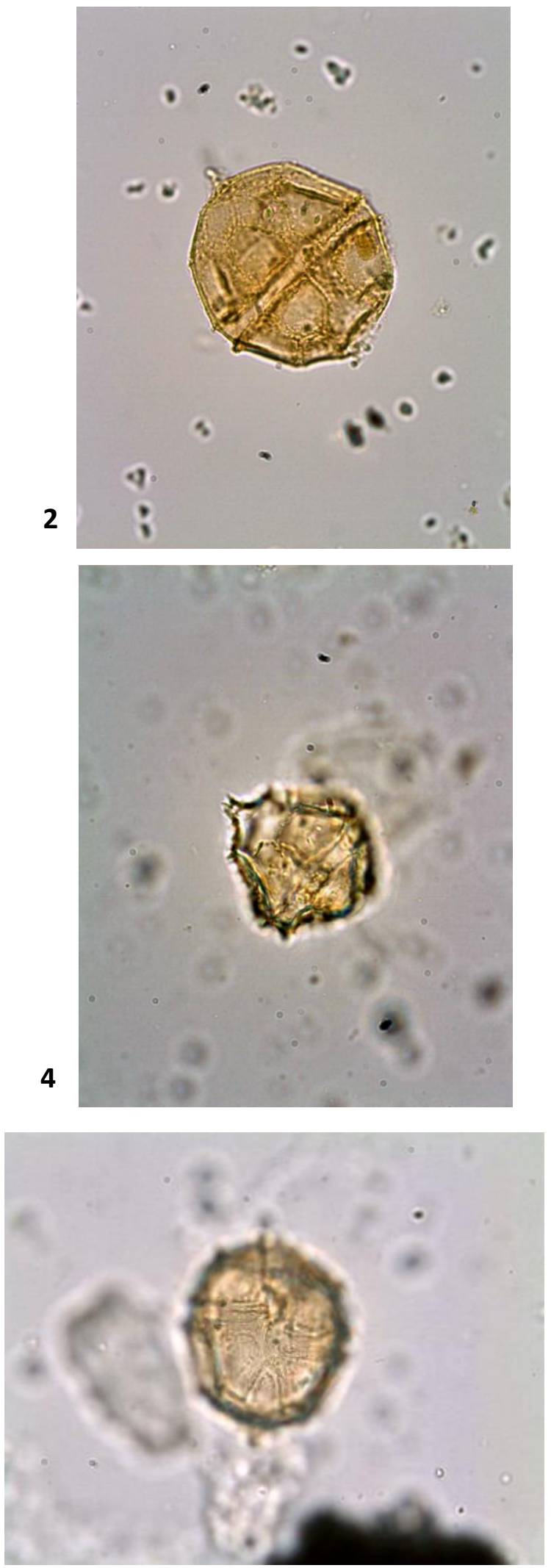

6

1. Octodinium askiniae (29-30-5B, X44Y95, $84 \mu \mathrm{m})$.

2. Phthanoperidinium ?crenulatum (29-30-5B, X51Y94.5, $50 \mu \mathrm{m})$.

3-4. Phthanoperidinium dentatum (114-32X-5, X46Y97, $40 \mu \mathrm{m} ; 120-20 \mathrm{H}-5 \mathrm{~A}, \mathrm{X} 50 \mathrm{Y} 92,40 \mu \mathrm{m})$.

5. Phthanoperidinium echinatum (29-30-5A, X33Y92, $60 \mu \mathrm{m})$.

6. Phthanoperidinium geminatum (29-24-3A, X50.2Y104, $45 \mu \mathrm{m})$. 


\section{Plate 22}
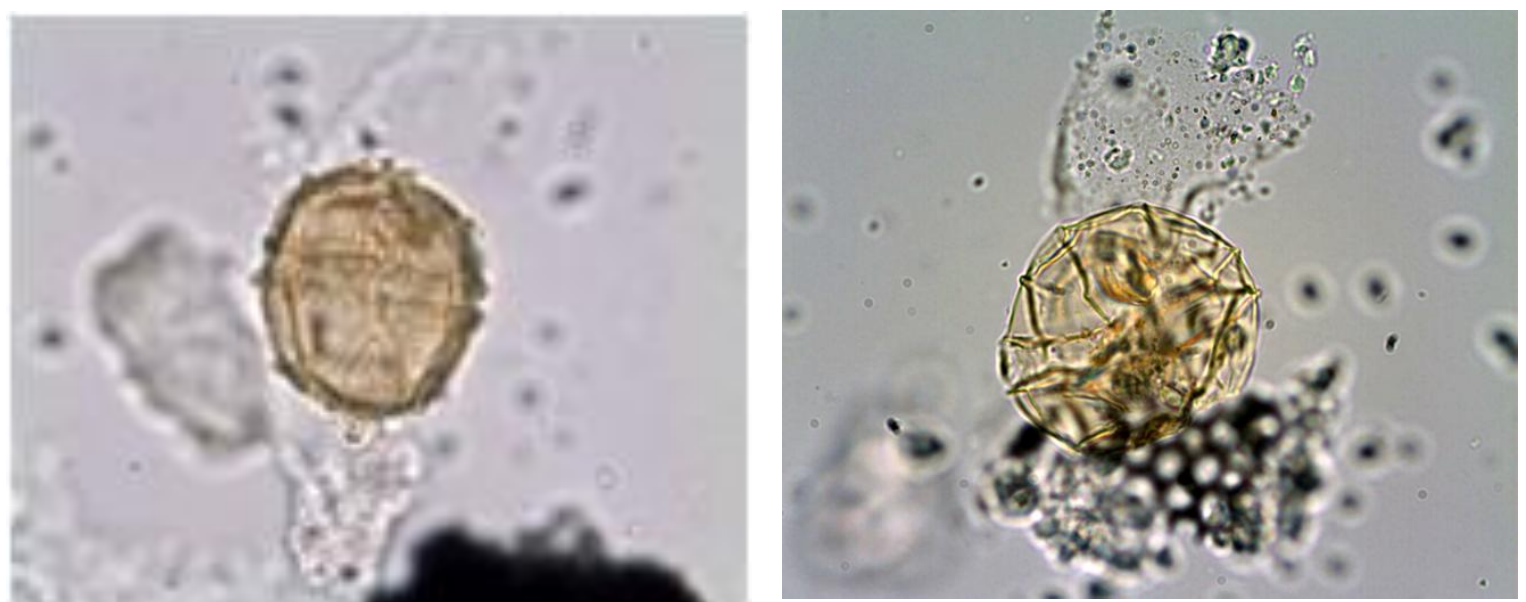

1

3
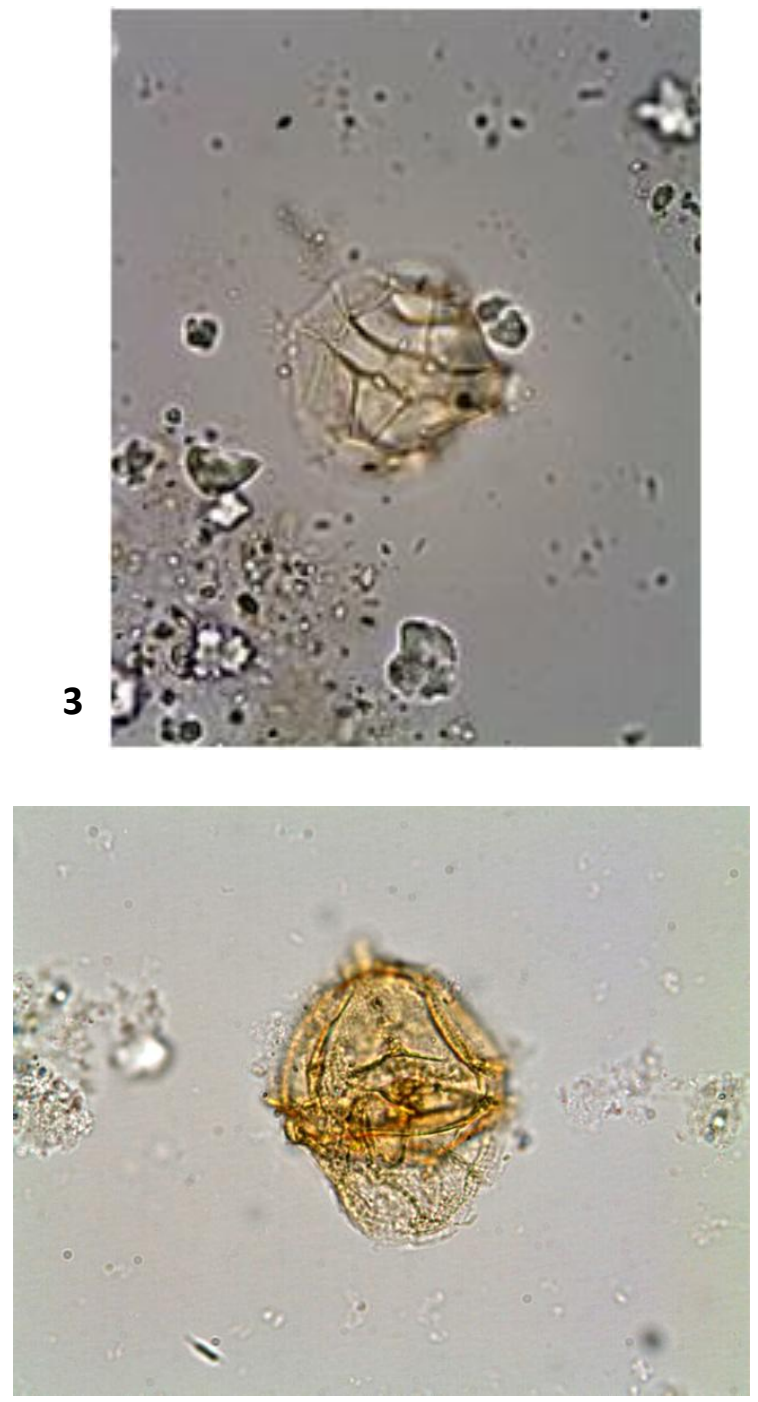

5
2
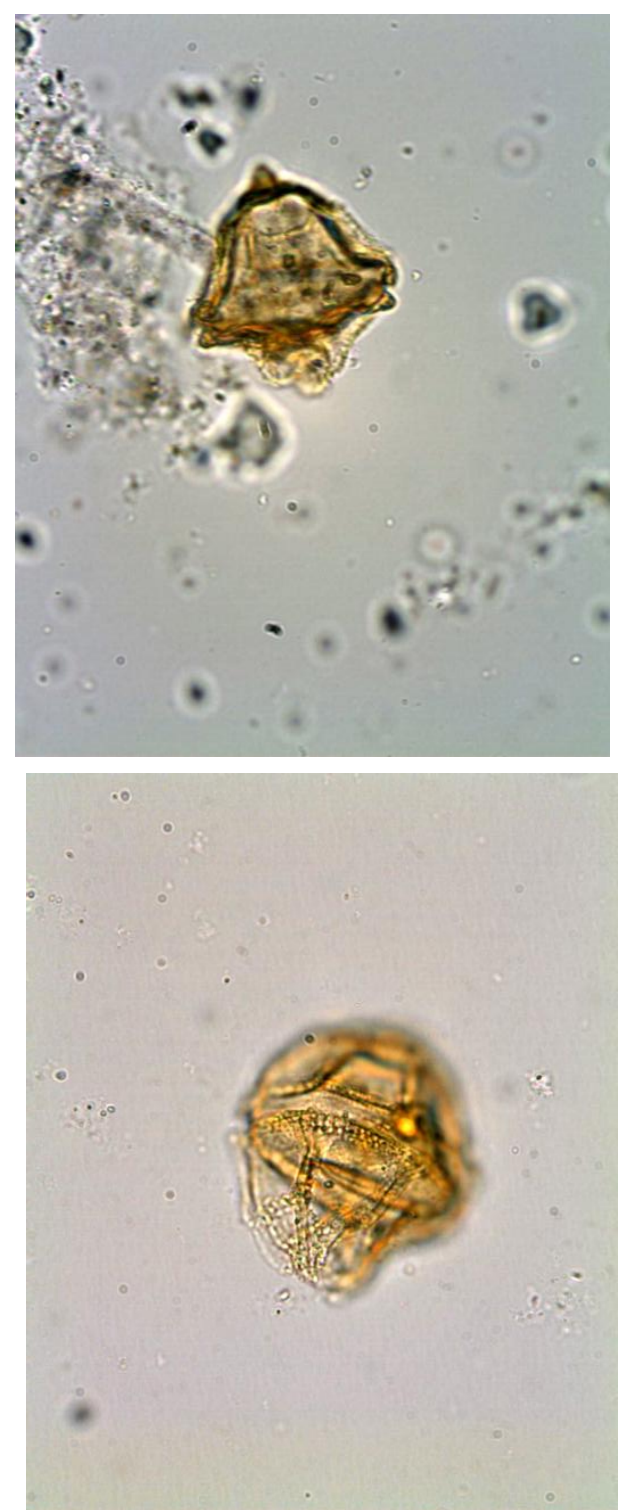

1. Phthanoperidinium geminatum (29-24-3A, $\mathrm{X} 50.2 \mathrm{Y} 104,45 \mu \mathrm{m})$. 

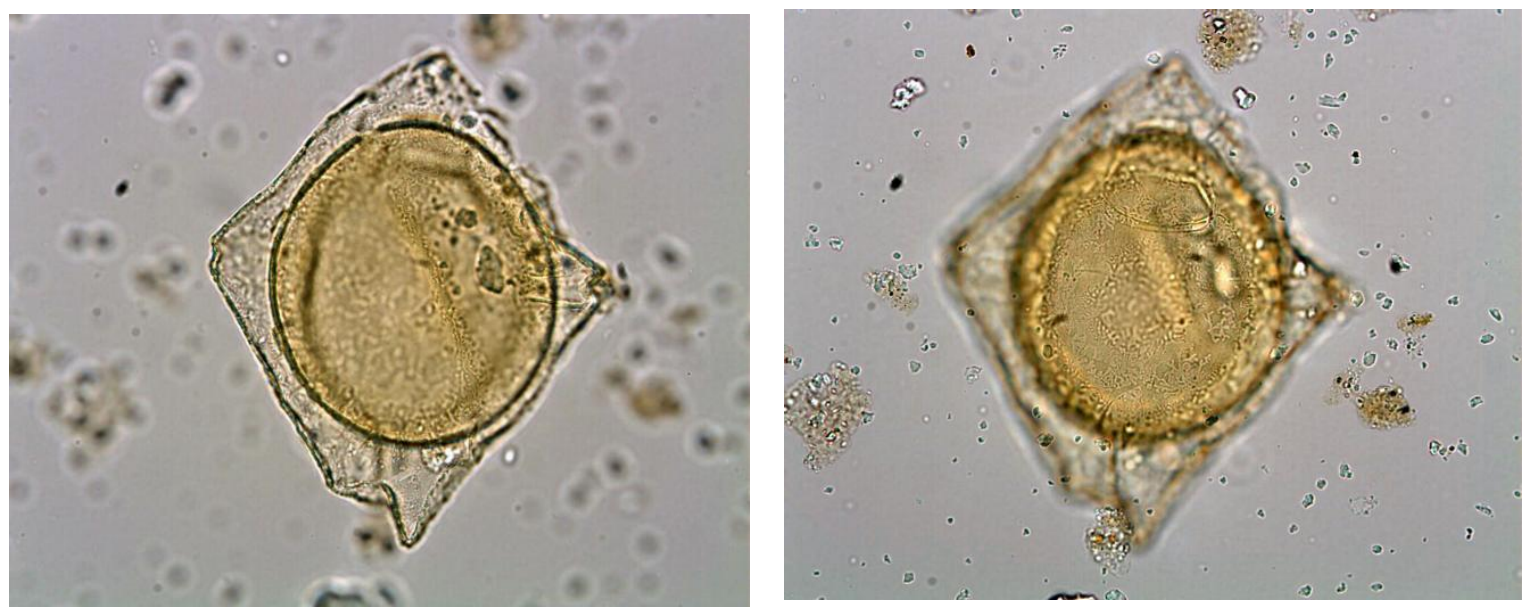

1

2
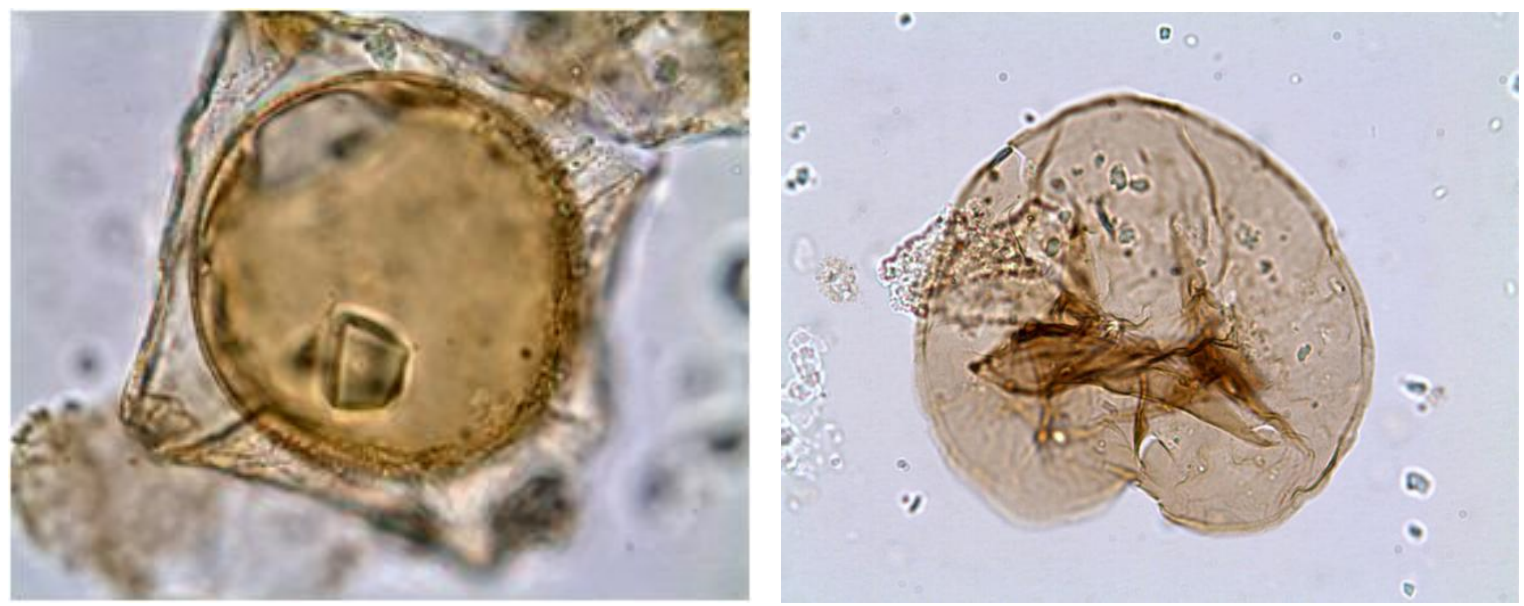

3

\section{4}

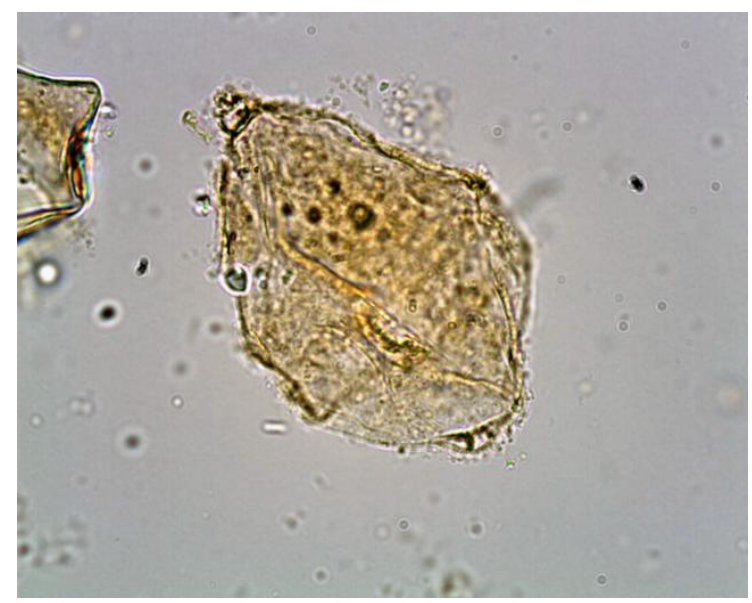

5

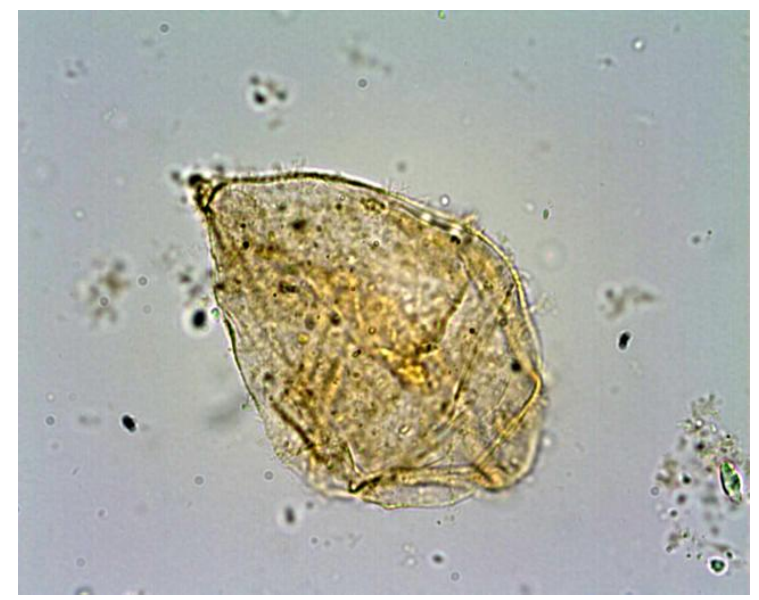

6

1-3. Rhombodinium spp (120-19H-1A, X48.3Y96, $125 \mu \mathrm{m} ; 129-19 \mathrm{H}-1 \mathrm{~A}, \mathrm{X} 39.5 Y 99.5,105 \mu \mathrm{m})$.

4. Selenopemphix nephroides (29-30-5A, X58.2Y97.5, $70 \mu \mathrm{m})$.

5-6. Spinidinium sp1 (120-18H-4A, X47Y101.5, $75 \mu \mathrm{m} ; 120-18 \mathrm{H}-4 \mathrm{~A}, \mathrm{X} 59 \mathrm{Y} 100.5,75 \mu \mathrm{m})$. 


\section{Plate 24}
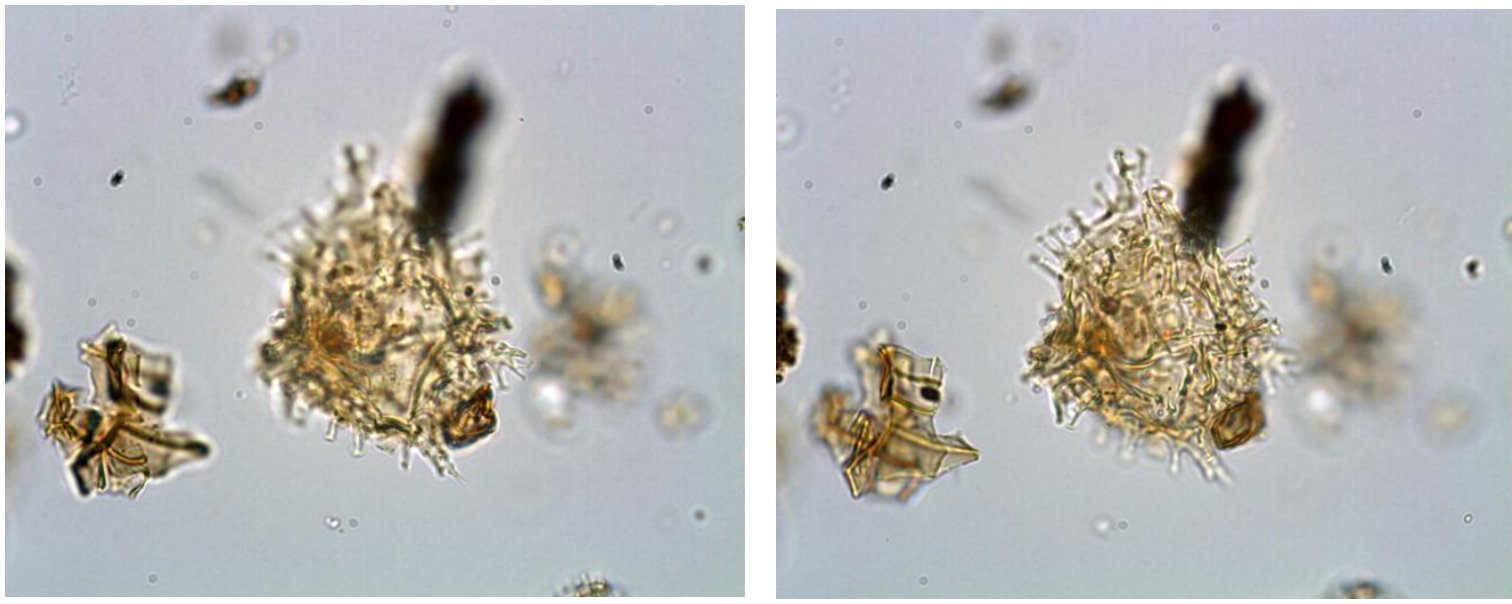

1

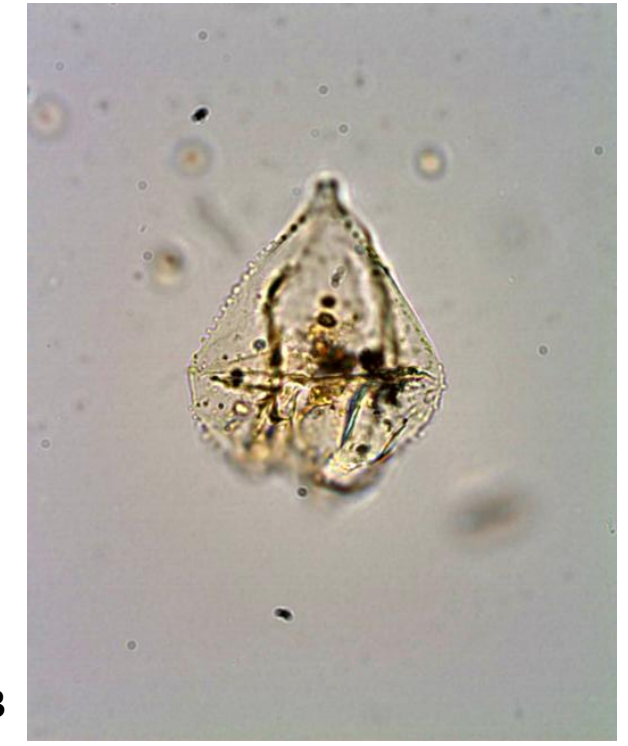

3

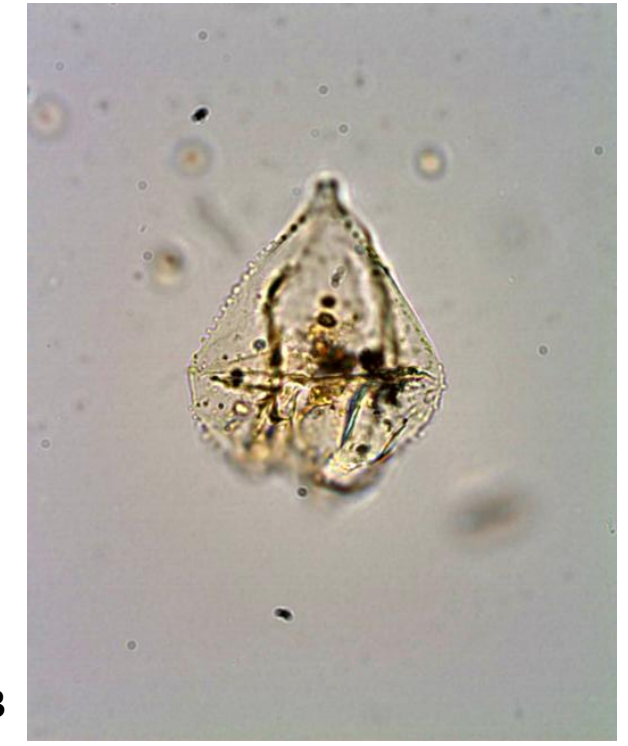

3

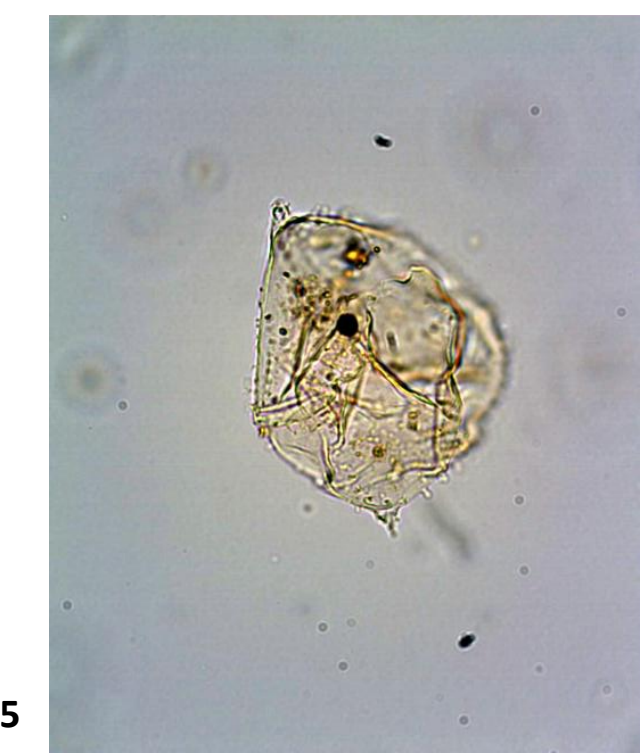

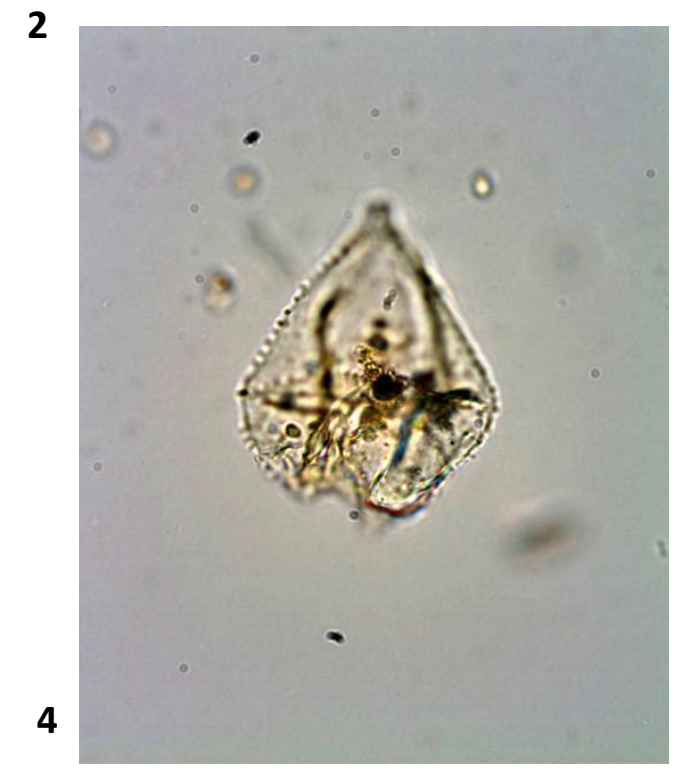

6

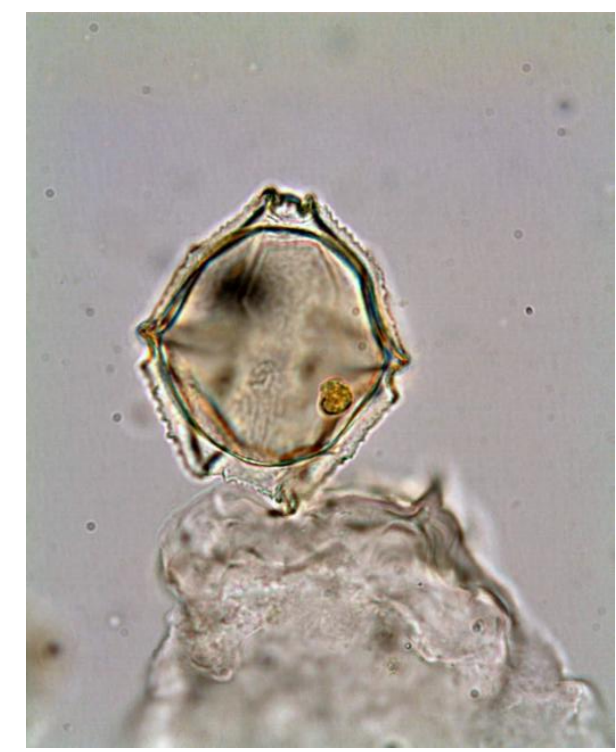

1-2. Spinidinium colemanii (113-59R-1b, X36.5Y95, $55 \mu \mathrm{m})$.

3-5. Spinidinium essoi (113-59R-2, X43.5Y94.5, $53 \mu \mathrm{m}$; 113-59-2, X39.5Y100, $60 \mu \mathrm{m})$.

6. Spinidinium luciae (120-16H-7A, X40Y92.5, $55 \mu \mathrm{m})$. 


\section{Plate 25}

1

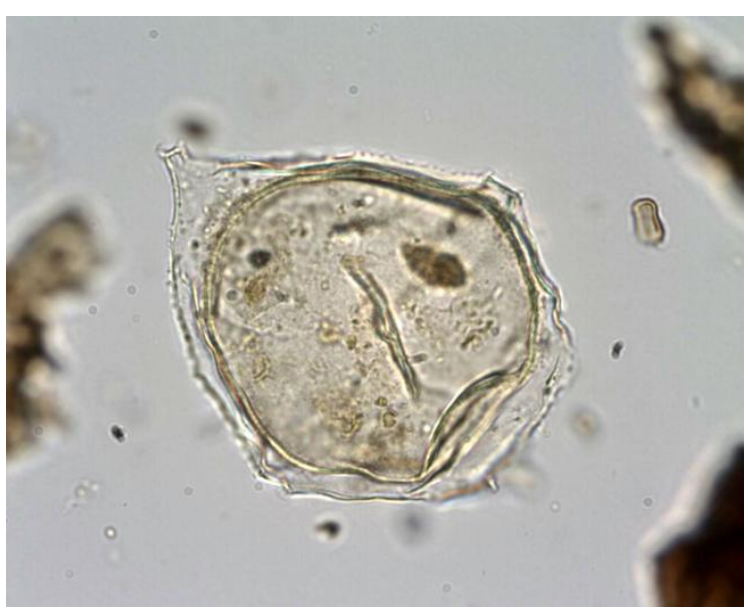

3

5
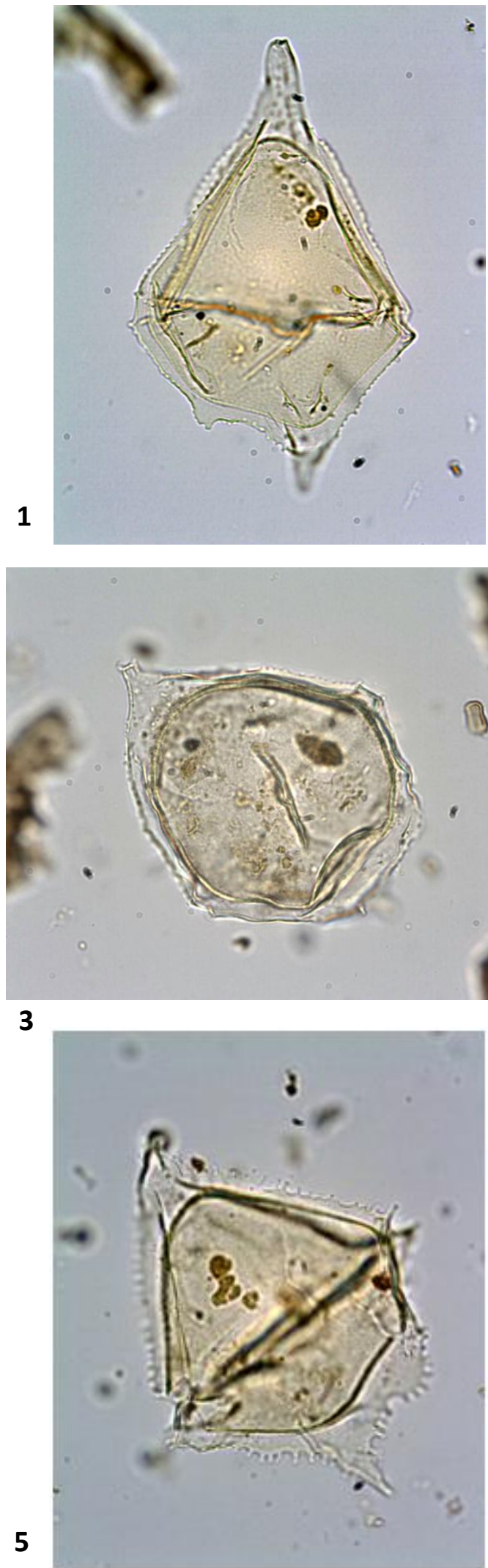

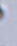

1
2
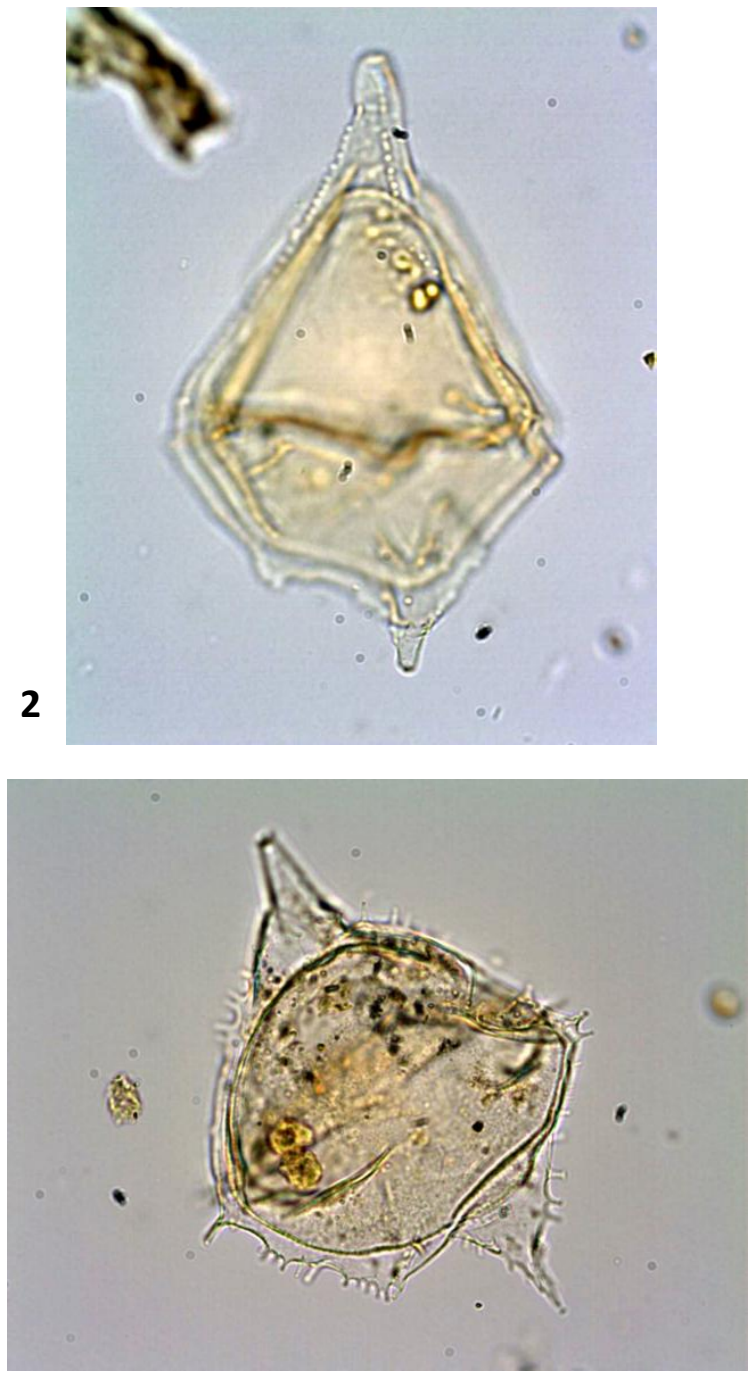

4

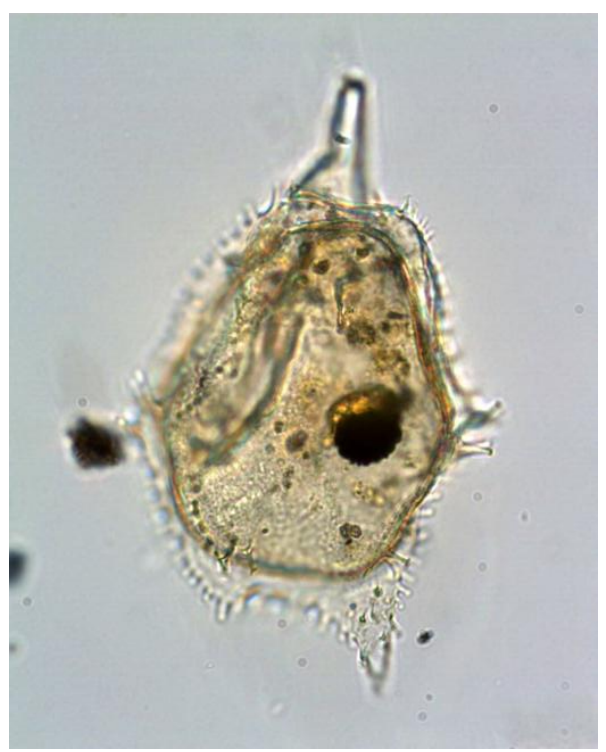

1-3. Spinidinium luciae (113-61R-3, X38Y102, $105 \mu \mathrm{m} ; 113-62 \mathrm{R}-1 \mathrm{~A}, \mathrm{X} 35.5 \mathrm{Y} 105,85 \mu \mathrm{m})$.

4-6. Spinidinium Macmurdoense (113-59R-4b, X62Y92.5, 90 m ; 113-59Ra-1, X44Y98.5, $100 \mu \mathrm{m}$; 113-60R4a$\mathrm{X} 61.8 \mathrm{Y} 105.2,98 \mu \mathrm{m})$. 


\section{Plate 26}
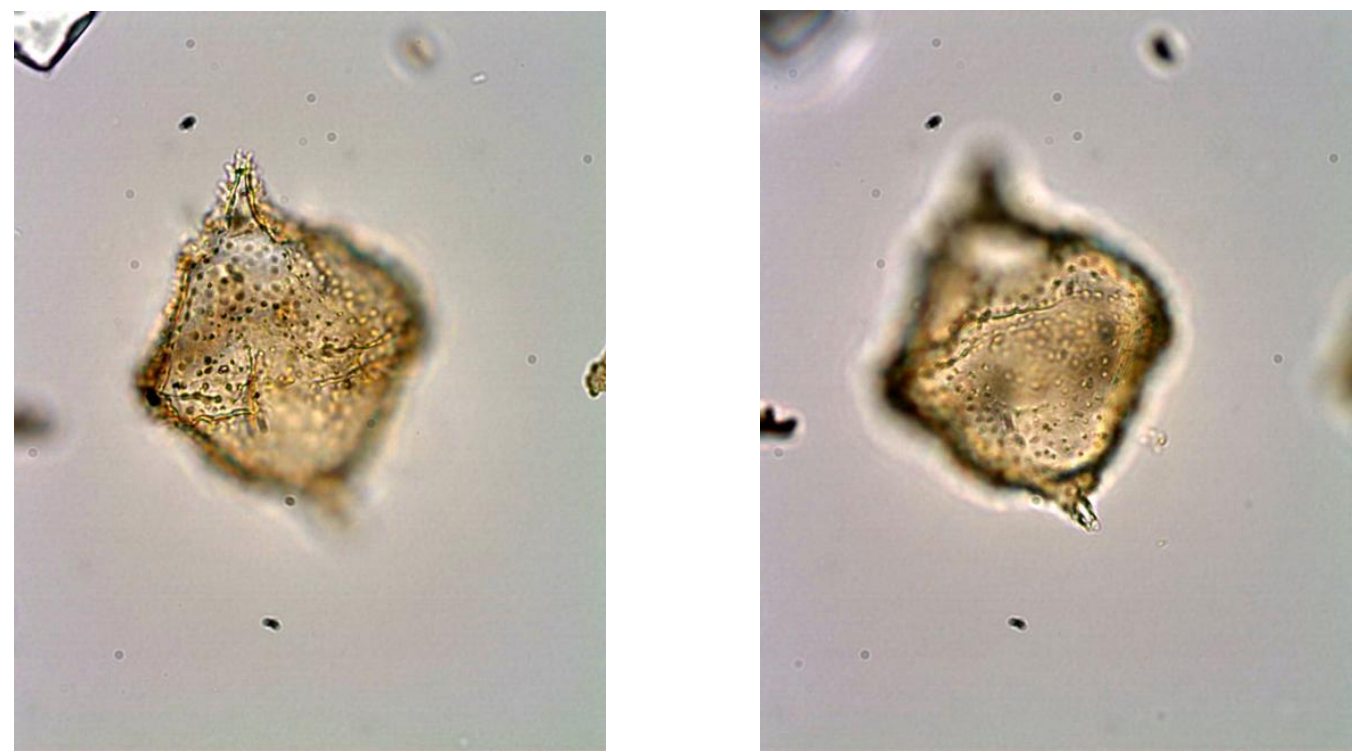

2
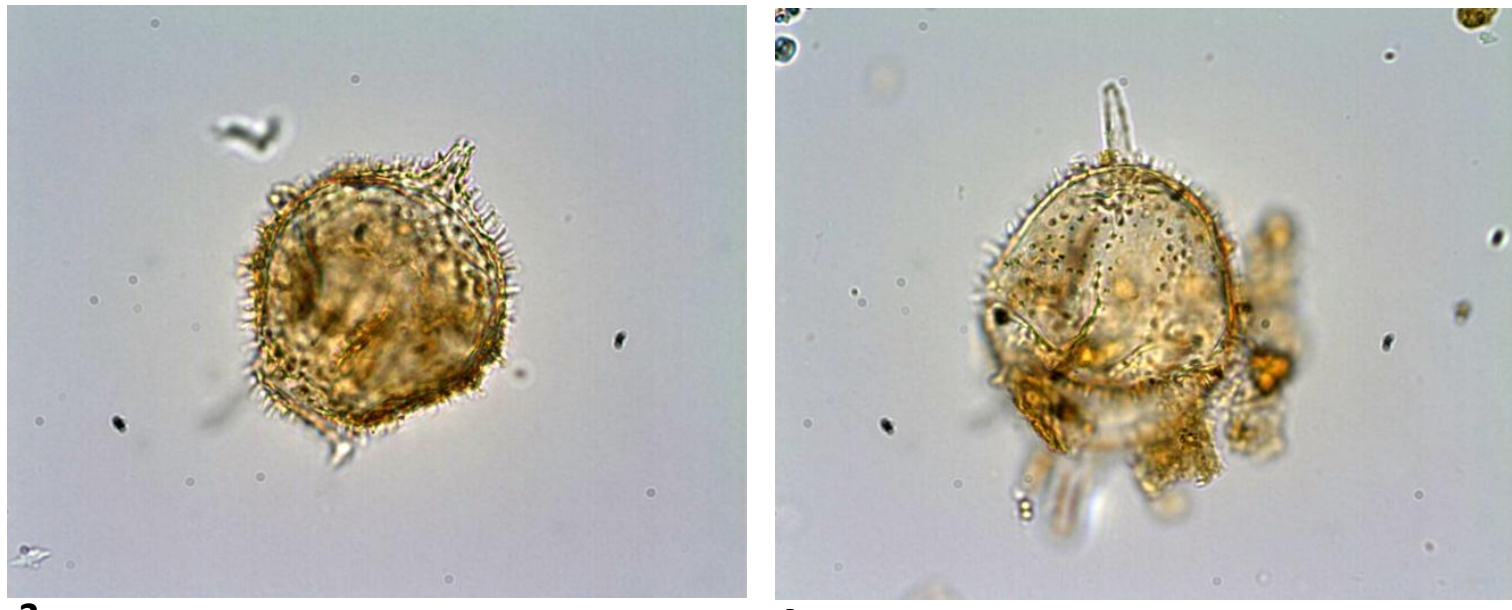

3

\section{4}

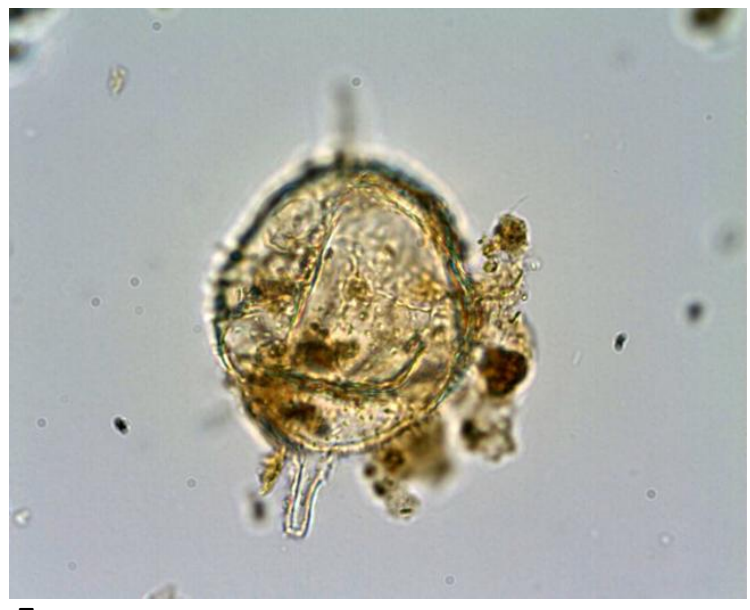

5

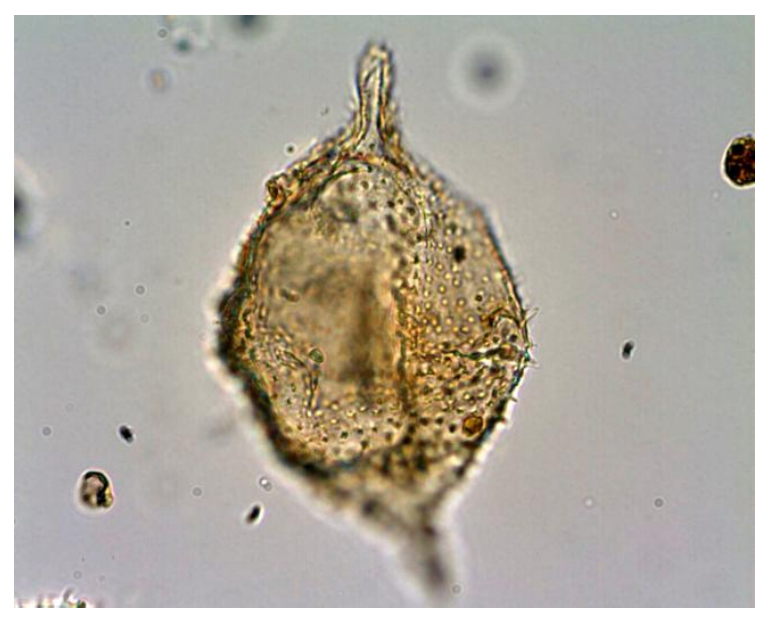

1-3. Vozzhennikovia apertura (113-59Ra-1, X42Y104, $65 \mu \mathrm{m}$; 113-59R1a-1, X33.5Y96, $60 \mu \mathrm{m})$.

4-6. Vozzhennikovia netrona (113-59R-1a, X32.5Y98, $75 \mu \mathrm{m}$; 113-59R-2, X43.5Y94, $90 \mu \mathrm{m}$ ). 


\section{Plate 27}
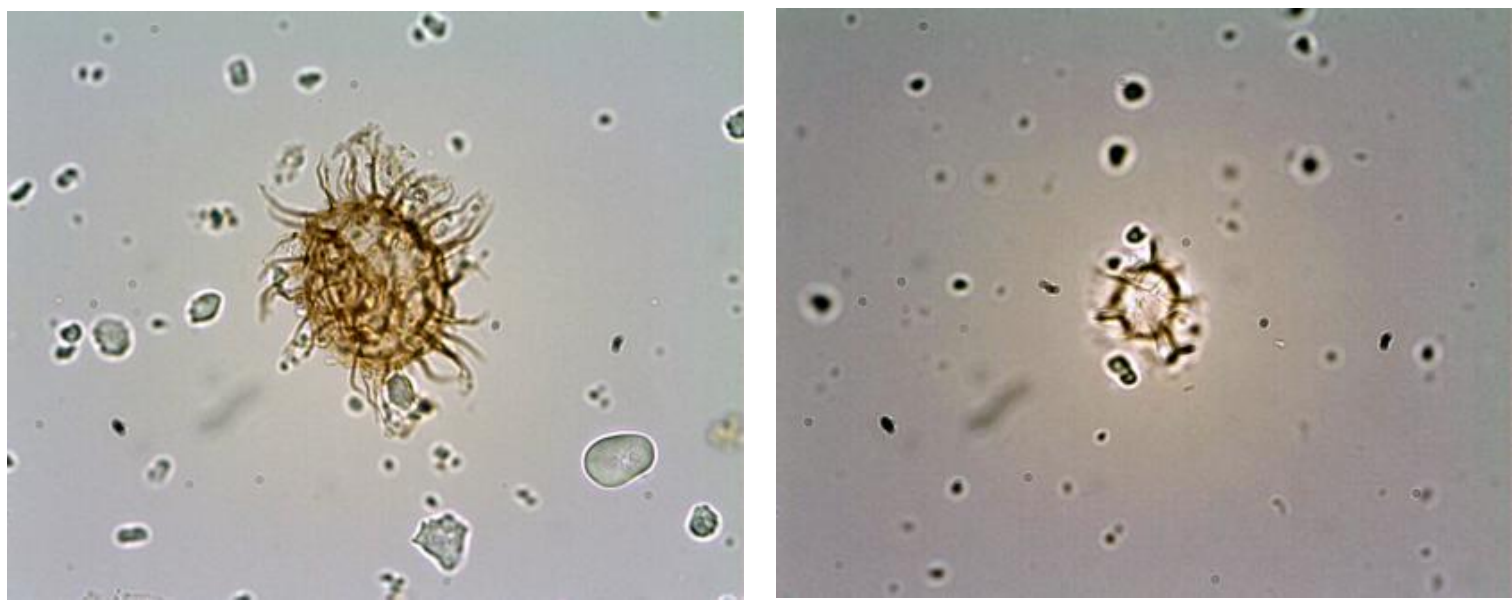

1

2

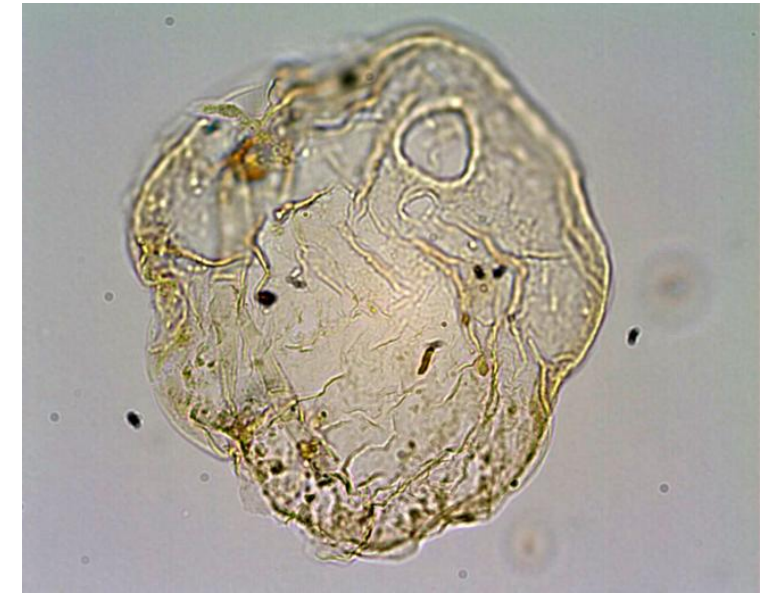

3
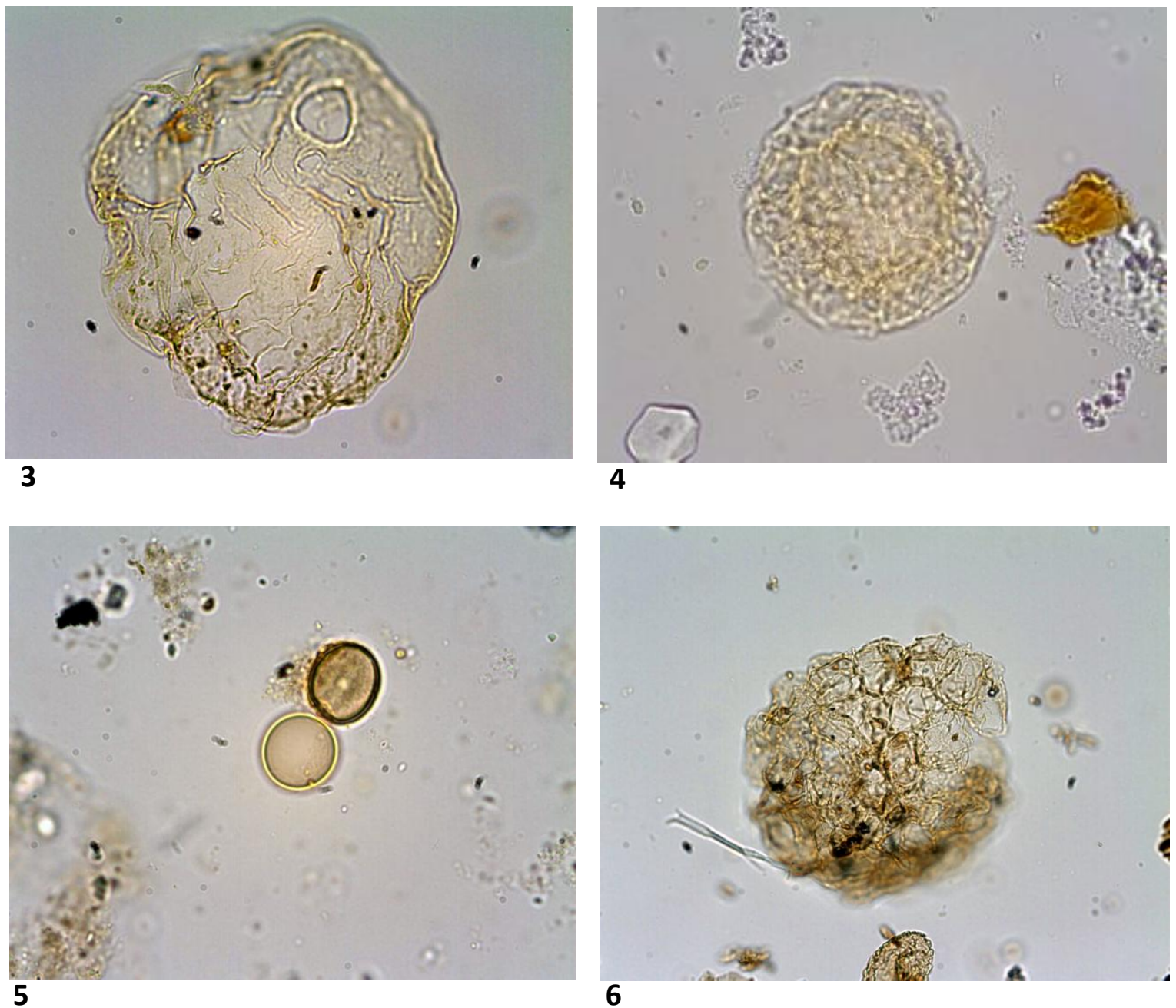

1-2. Acritarchs (29-30-5B X48.5Y94.5, $30 \mu \mathrm{m}$ processes not included; 29-36-2A, X45.5Y95, $20 \mu \mathrm{m})$.

3. Cyclopsiella (113-59R-3A, X34Y105, $95 \mu \mathrm{m})$.

4. Fenestridium clathrodermum (29-24-3B, X45.2Y108).

5. Leiosphaeridia $(120-18 \mathrm{H}-4 \mathrm{~A})$.

6. Palambages (113-62R-1A, X45Y96, $95 \mu \mathrm{m})$. 


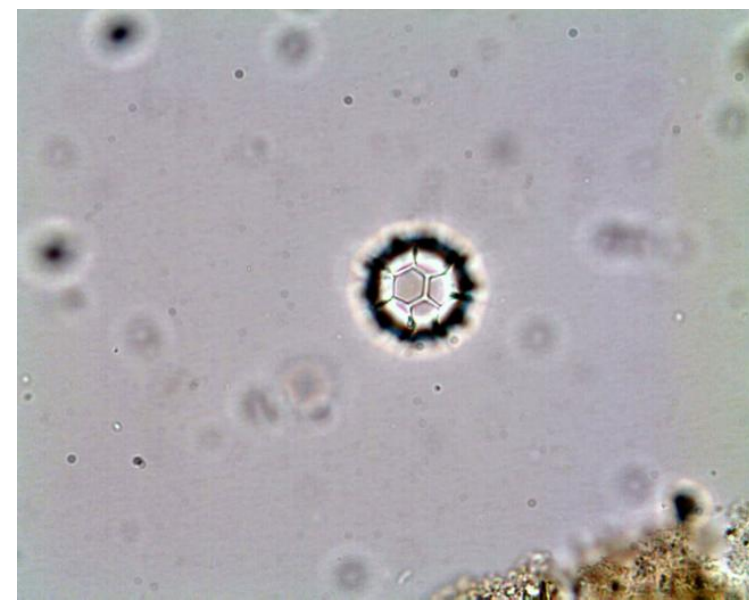

1
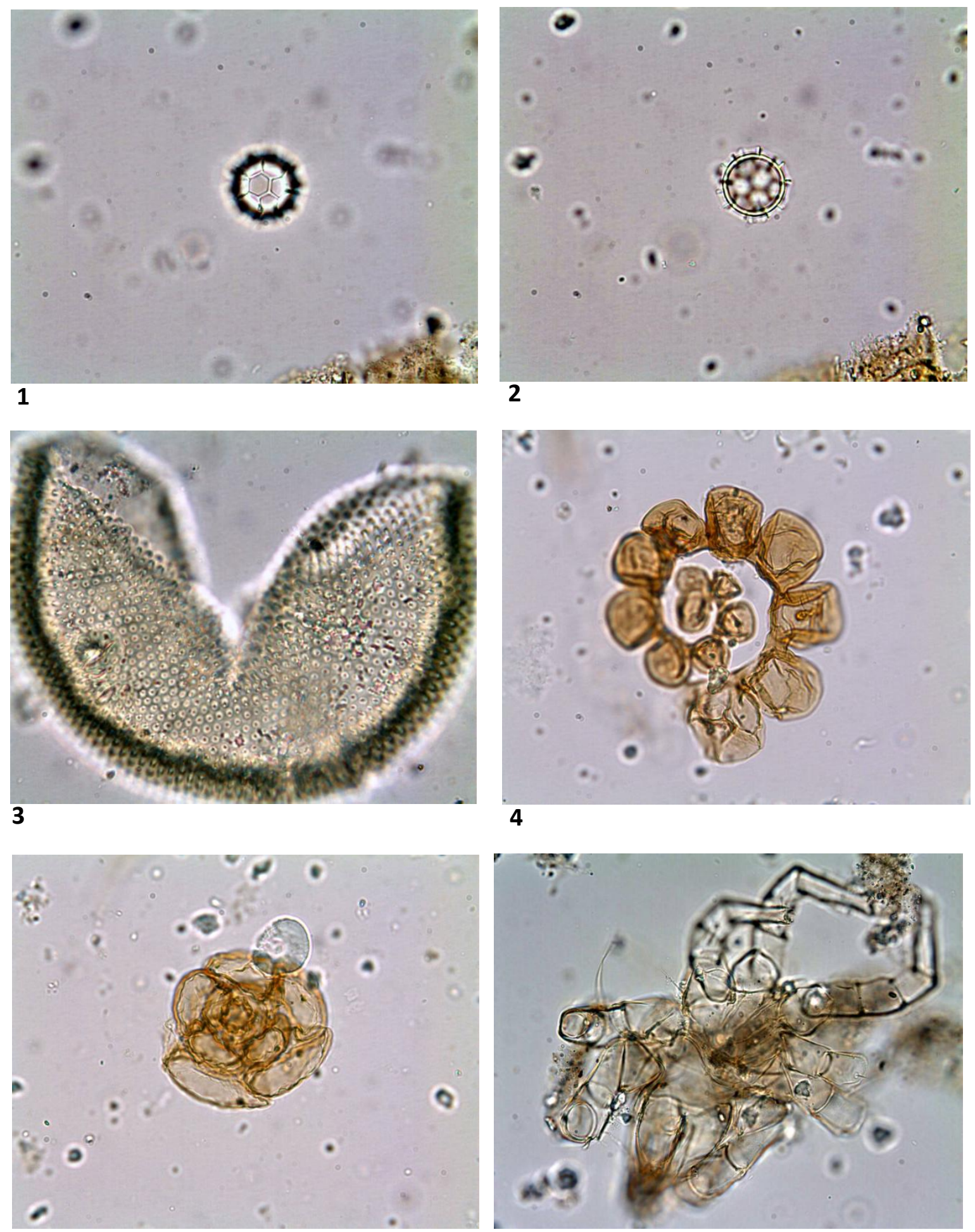

5

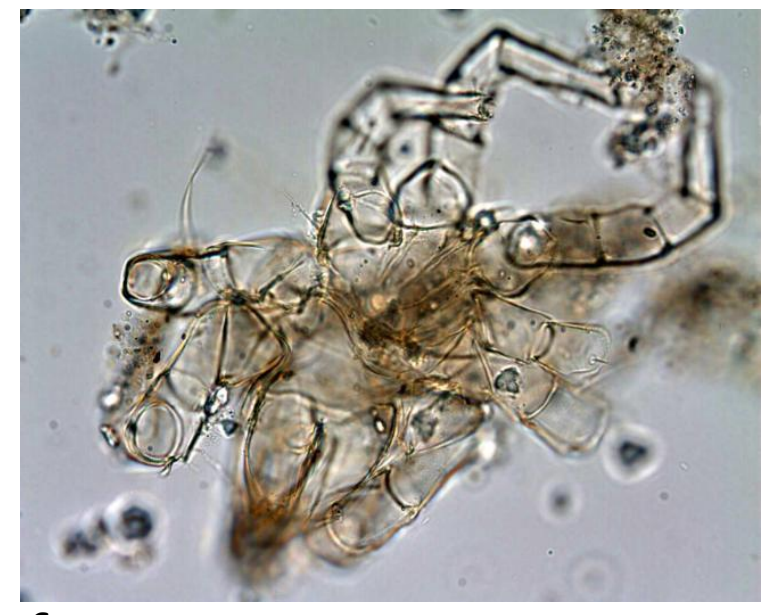

6

1-2. Cymatiosphaera (120.19H.1A, X34.5Y110, $20 \mu \mathrm{m})$.

3. Tasmanites (114-31X-2D, X45.2Y96.1, $125 \mu \mathrm{m})$.

4-5. Microforaminifera linings (29-29-2; 29-26-1A).

6. Insect casing (114-50X-5B). 


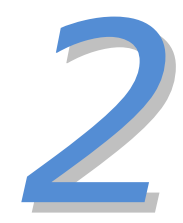

Appendices 


\section{Appendix 2.1 - Sites initially researched}

\begin{tabular}{|c|c|c|c|}
\hline Leg & Site & $\begin{array}{l}\text { Eocene - Oligocene } \\
\text { Transition present }\end{array}$ & $\begin{array}{c}\text { Comments } \\
\text { Sediments as Initial Reports showed }\end{array}$ \\
\hline \multirow[t]{2}{*}{28} & 267 & Early Oligocene/Late Eocene & $\begin{array}{l}\text { Core } 6 \mathrm{E} / \mathrm{O} \text { boundary photo shows } \\
\text { small rock pieces }\end{array}$ \\
\hline & 274 & Early Oligocene/Late Eocene & See Report \\
\hline \multirow[t]{4}{*}{29} & 277 & Early Oligocene/Late Eocene & Sediments good see report \\
\hline & $280 \mathrm{~A}$ & Early Oligocene/Late Eocene & Sediments good see report \\
\hline & 281 & Early Oligocene/Late Eocene?? & See Report \\
\hline & 282 & Early Oligocene/Late Eocene & Sediments good see report \\
\hline 35 & & Sites 322-325 not Oligocene/Eocene & \\
\hline \multirow[t]{3}{*}{36} & $328 \mathrm{~B}$ & Early Oligocene/Late Eocene & Sediments good \\
\hline & 329 & Oligocene/Early Eocene & Voids in Oligocene sediments not good \\
\hline & $330 \mathrm{~A}$ & Eocene to recent & Sediments not good \\
\hline 71 & 511 & Early Oligocene/Late Eocene & $\begin{array}{l}\text { Plenty Oligocene sediments not much } \\
\text { Eocene but sediments good }\end{array}$ \\
\hline \multirow[t]{3}{*}{90} & $588 \mathrm{C}$ & Late Oligocene to Middle Eocene & $\begin{array}{l}\text { situated at } 20^{\circ} \mathrm{S}-40^{\circ} \mathrm{S} \text { and there is a } \\
\text { gap also sediments not good }\end{array}$ \\
\hline & 592 & Early Oligocene to Late Eocene & $\begin{array}{l}\text { Situated at } 20^{\circ} \mathrm{S}-40^{\circ} \mathrm{S} \text { is a gap in the } \\
\text { Oligocene. good }\end{array}$ \\
\hline & 593 & Early Oligocene/Late Eocene & Sediments good \\
\hline \multirow[t]{4}{*}{113} & $689 \mathrm{~B}$ & Early Oligocene/Late Eocene & Sediments good \\
\hline & 689D & Early Oligocene/Late Eocene & Sediments good \\
\hline & 690B & Early Oligocene/Late Eocene & Sediments good \\
\hline & $696 B$ & Early Oligocene/Late Eocene & Sediments very dark hard to see \\
\hline \multirow[t]{3}{*}{114} & 699A & Early Oligocene/Late Eocene & Sediments good \\
\hline & $701 \mathrm{C}$ & Early Oligocene/Late Eocene & Sediments good \\
\hline & $703 \mathrm{~A}$ & Early Oligocene/Late Eocene & Sediments good \\
\hline \multirow[t]{3}{*}{119} & 737B & Early Oligocene/Late Eocene & Some sediments good \\
\hline & $738 \mathrm{~B}$ & Early Oligocene/Late Eocene & Sediments good \\
\hline & $744 \mathrm{~A}$ & Early Oligocene/Late Eocene & Sediments good \\
\hline \multirow[t]{4}{*}{120} & $747 \mathrm{~A}$ & Late $\&$ Early Oligocene/Late Eocene & Sediments good but not much there \\
\hline & $747 C$ & Early Oligocene/Upper and Lower Eocene & $\begin{array}{l}\text { Sediments good but not much there } \\
\text { especially for the Eocene }\end{array}$ \\
\hline & $748 B$ & Early Oligocene/Late Eocene & Sediments good \\
\hline & 749B & Early Oligocene/Late Eocene & Sediments good but not much there \\
\hline 177 & 1090B & Early Oligocene/Late Eocene & No photo \\
\hline 178 & & Sites $1095-1103$ not suitable & Miocene and earlier only \\
\hline \multirow[t]{2}{*}{181} & $1123 C$ & Early Oligocene/Late Eocene & $\begin{array}{l}\text { Voids present not much Oligocene no } \\
\text { photo }\end{array}$ \\
\hline & $1124 \mathrm{C}$ & Early Oligocene/Mid-Late Eocene & $\begin{array}{l}\text { Void present not much sediment no } \\
\text { photo }\end{array}$ \\
\hline 183 & $1138 \mathrm{~A}$ & Late Maastrichtian to Late Oligocene & $\begin{array}{l}\text { Does not show a boundary for } \\
\text { Eocene/Oligocene No photo }\end{array}$ \\
\hline 187 & & \multicolumn{2}{|c|}{$\begin{array}{l}\text { No litho or biostrat column this site focused on bacteria. The site was drilled in } \\
\text { deep ocean mantel }\end{array}$} \\
\hline 188 & $1166 \mathrm{~A}$ & Early Oligocene/Late Eocene & No photo \\
\hline
\end{tabular}




\begin{tabular}{|l|l|l|l|}
189 & $1168 \mathrm{~A}$ & \multicolumn{2}{|l|}{$\begin{array}{l}\text { Leg } \mathbf{1 8 9} \text { and these sites have been completed for dinoflagellates at the } \\
\text { Eocene/Oligocene boundary by Brinkhuis H. et al. }\end{array}$} \\
\cline { 2 - 4 } & $1170 \mathrm{~A}$ & Early Oligocene & \\
\hline $1170 \mathrm{D}$ & Mid Eocene (From Early Oligocene) & \\
\hline $1171 \mathrm{C}$ & Oligocene & \\
\hline $1171 \mathrm{D}$ & Early Eocene & \\
\hline $1172 \mathrm{~A}$ & Middle Eocene & \\
\hline $1172 \mathrm{D}$ & Late Cretaceous (from Mid Eocene) & \\
\hline
\end{tabular}

\begin{tabular}{|c|c|c|}
\hline Leg & Site & $\begin{array}{l}\text { Eocene - Oligocene } \\
\text { oldest sediment age }\end{array}$ \\
\hline 28 & 267 & Lower Tertiary \\
\hline \multirow[t]{7}{*}{29} & 275 & Upper Campanian Late Cretaceous \\
\hline & 277 & Middle Paleocene \\
\hline & 278 & Middle Oligocene \\
\hline & $280 \mathrm{~A}$ & Middle Eocene \\
\hline & 281 & Upper Eocene \\
\hline & 282 & Upper Eocene \\
\hline & 283 & Paleocene \\
\hline 35 & & Sites 322-325 not suitable \\
\hline \multirow[t]{3}{*}{36} & $328 \mathrm{~B}$ & Upper Cretaceous \\
\hline & 329 & Upper Paleocene \\
\hline & $330 \mathrm{~A}$ & Eocene \\
\hline \multirow[t]{4}{*}{71} & 511 & Jurrasic \\
\hline & 512 & Middle Eocene \\
\hline & $512 \mathrm{~A}$ & Middle Eocene \\
\hline & $513 \mathrm{~A}$ & Lower Oligocene \\
\hline \multirow[t]{3}{*}{90} & $588 \mathrm{C}$ & Middle Eocene to Late Oligocene \\
\hline & 592 & Late Eocene to Early Oligocene \\
\hline & 593 & Upper Eocene \\
\hline \multirow[t]{5}{*}{113} & 689B & Late Cretaceous (Campanian) \\
\hline & 689D & Late Eocene \\
\hline & 690B & Late Paleocene \\
\hline & $690 \mathrm{C}$ & Late Cretaceous (gap from Late Paleocene to Oligocene) \\
\hline & $696 \mathrm{~B}$ & Late Eocene to Oligocene \\
\hline \multirow[t]{3}{*}{114} & 699A & Paleocene \\
\hline & $700 \mathrm{~B}$ & Late Cretaceous (Coniacian) \\
\hline & $703 \mathrm{~A}$ & Early/Middle Eocene \\
\hline \multirow[t]{3}{*}{119} & 737B & Middle Eocene \\
\hline & $738 \mathrm{~B}$ & Middle Eocene \\
\hline & $744 \mathrm{~A}$ & Late Eocene \\
\hline \multirow[t]{2}{*}{120} & $747 \mathrm{~A}$ & Late Cretaceous (Campanian) \\
\hline & $747 \mathrm{C}$ & Late Cretaceous (early Santonian) \\
\hline \multirow[t]{2}{*}{120} & 748B & Middle Eocene \\
\hline & 749B & Middle Eocene \\
\hline \multirow[t]{3}{*}{177} & 1090B & Middle Eocene \\
\hline & $1090 \mathrm{D}$ & Oligocene \\
\hline & $1090 \mathrm{E}$ & Oligocene \\
\hline 178 & & Sites 1095-1103 not suitable \\
\hline 181 & $1123 \mathrm{C}$ & Late Eocene Late Eocene/Early Oligocene not very thick \\
\hline
\end{tabular}




\begin{tabular}{|l|l|l|}
\hline \multirow{3}{*}{$\mathbf{1 8 3}$} & $1124 \mathrm{C}$ & Eocene Mid late Eocene/ Early Oligocene not very thick \\
\cline { 2 - 3 } & $1135 \mathrm{~A}$ & Late Cretaceous fig. 4 Early Middle Eocene but gap to Late Pliocene \\
\cline { 2 - 3 } & $1136 \mathrm{~A}$ & Late Cretaceous Fig.6 Early Middle Eocene then gap \\
\hline $\mathbf{1 8 7}$ & & $\begin{array}{l}\text { Late Cretaceous Fig.2.\& 5. Late Maastrichtian to Late Oligocene but does not } \\
\text { show a boundary for Eocene/Oligocene }\end{array}$ \\
\hline $\mathbf{1 8 8}$ & $1166 \mathrm{~A}$ & $\begin{array}{l}\text { No litho or biostrat column this site focused on bacteria. The site was drilled in } \\
\text { deep ocean mantel }\end{array}$ \\
\hline $\mathbf{1 8 9}$ & $1168 \mathrm{~A}$ & $\begin{array}{l}\text { Late Cretaceous (Turonian) Upper Eocene to Lower Oligocene } \\
\text { the Eocene/Oligocene boundary }\end{array}$ \\
\cline { 2 - 3 } & $1170 \mathrm{~A}$ & Early Oligocene \\
\cline { 2 - 3 } & $1170 \mathrm{D}$ & Mid Eocene (From Early Oligocene) \\
\cline { 2 - 3 } & $1171 \mathrm{C}$ & Oligocene \\
\cline { 2 - 3 } & $1171 \mathrm{D}$ & Early Eocene \\
\cline { 2 - 3 } & $1172 \mathrm{~A}$ & Middle Eocene \\
\cline { 2 - 3 } & $1172 \mathrm{D}$ & Late Cretaceous (from Mid Eocene) \\
\hline
\end{tabular}




\section{Appendix 2.2 \\ Report on DSDP and ODP Legs in the Southern Ocean}

\section{DSDP Leg 28 sites 264-274}

Situated between $35^{\circ} \mathrm{S}$ and $70^{\circ} \mathrm{S}$ with 270-274 in the Ross Sea and 264-269 between Australia and the Antarctic.

Papers found in initial reports of DSDP that were related to palynomorphs were:

Kemp, E.M. 1975. Palynology of Leg 28 drill sites, Deep Sea Drilling Project (attached). In Barker and Dalziel initial reports DSDP 28. - Kemp reported that apart from sites 270 and 274 very little palynological material apart from abundant Leiospheres was recovered from sites 264,266, 268 and 269.

Site 264 unconformities' separate Miocene and younger strata from and Eocene sequence

Site 266 does not go beyond Early Miocene

Site 268 does not go beyond Oligocene

Site 269 no age given on this site.

Kemp comments that the lack of palynomorphs in some cores may be due to dilution factors.

Site 265 does not go beyond middle Miocene

Site 270 a nonconformity separates the Oligocene from earlier Palaeozoic

Site 272 does not go beyond Mid Miocene

Site 273 does not go beyond Lower Miocene

Site 274 Eocene Oligocene boundary in core 34 therefore core 35 to 45 must be Late Eocene

\section{Core data shows only two holes have results for dinoflagellates, pollen and spores 270 and 274.}

Other papers:

Fleming R.F., Barron J.A. 1996. Evidence of Pliocene Nothofagus in Antarctica from Pliocene marine sedimentary deposits (DSDP site 274). Marine

Micropaleontology 27 277-236. - Fleming comments on previous work on page 228, with some criticism of ODP Leg 113 shipboard work in evaluating the presence of palynomorphs. Fleming also comments on Leg 114 p 229 on their evaluation on presence of pollen in their initial reports.

\section{DSDP Leg 29 sites 275-284}

Situated between $40^{\circ} \mathrm{S}$ and $60^{\circ} \mathrm{S}$ with 270-274 in the Tasman Gateway and South Pacific area. Papers found in initial reports of DSDP that were related to palynomorphs were:

Haskell T.R. and Wilson, G.J. 1975. Palynology of sites 280-284, DSDP Leg 29, off south-eastern Australia and Western New Zealand

Site 281 core $13-3$ is Late Oligocene $(130 \mathrm{~cm})$ followed by a discontinuity which separates Upper greensand and Lower greensand CC13. Another discontinuity is followed by Core 14 which is the beginning of the Late Eocene. 
Site 280A cores 1-9 were either devoid of palynomorphs or yielded extremely sparse palynofloras and are Oligocene. Cores 10 to 22 were richer in species and Eocene.

Site 282 cores 6-18 from Oligocene to Eocene found plenty.

Have listed what was found but not gone into depth with this paper.

Wilson G. Palynology of Deep Sea Cores from DSDP site 275, Southeast Campbell Plateau.

Wilson looked at 5 cores from this site:

Core 1 barren

Core 2 upper had sparse assemblages, middle was barren and lower contained an excellent assemblage

Core 3 no material was available

Core 4 relatively rich assemblages of dinoflagellates and miospores

Core 5 “

\section{Short paper merely lists what is found}

\section{Other papers:}

Crouch E.M and Hollis C.J. 1996 Palaeogene palynomorph and radiolarian biostratigraphy of DSDP Leg 29, Sites 280 and 281 South Tasman Rise. Institute of Geological and Nuclear

Sciences Science Report 96/19, 46pp.

\section{This paper looks at Eocene sediments up to the Late Eocene}

Hollis C.J., Waghorn, D.B. Strong, C.P. Crouch E.M. 1997. Integrated Palaeogene biostratigraphy of DSDP site 277 (Leg 19): foraminifera, calcareous nannofossils, Radiolaria and palynomorphs. Institute of Geological and Nuclear Sciences Science Report 97/07,

This report focuses on Radiolaria and not much is done on palynomorphs

Levy R.H. \& Harwood D.M. 2000. Tertiary marine Palynomorphs from the McMurdo Sound Erratics, Antarctica. In (Eds Stilwell J.D. Feldmann R.M.) Paleobiology and Palaeoenvironment of Eocene Rocks. Antarctic Research Series Vol 76

\section{DSDP Leg 35 sites 322-325}

Situated between $60^{\circ} \mathrm{S}$ and $70^{\circ} \mathrm{S}$ near the Antarctic Peninsular. Papers found in initial reports of DSDP that were related to palynomorphs were:

\section{No papers on palynology in this volume}

Core data shows that only site 323 contained dinoflagellates with no mention of pollen or spores.

\section{DSDP Leg 36 sites 326-331}

Situated between $40^{\circ} \mathrm{S}$ and $60^{\circ} \mathrm{S}$ in the Subantarctic South Atlantic. Papers found in initial reports of DSDP that were related to palynomorphs were:

Harris W.K. 1977 Palynology of cores from DSDP sites 327, 328, 330, South Atlantic Ocean. In Barker P.F. and Dalziel et al Init. Repts. DSDP 36. 
Site 327 does not go from Eocene gap then to Pleistocene

Site 328 goes from Late Eocene gap then to Middle Miocene

Site 329 does go from Early Eocene to Oligocene but has two very large voids in

between

Site 330 is Cretaceous in age

Site 330A has only 0.50 meters of sediment between Eocene and Recent.

This is a brief paper stating the ages and naming of species found and supplies photos with plates showing many of the species.

Hedlund, R.W. and Beju, D. 1977 Stratigraphic palynology of selected Mesozoic samples DSDP Hole 327A and site 330.

Mesozoic only N/A. This paper discusses the results from 13 selected samples from the two cores and supplies photos with plates showing many of the species.

\section{DSDP Leg 71 sites 511-514}

Situated between $40^{\circ} \mathrm{S}$ and $60^{\circ} \mathrm{S}$ in the Subantarctic South Atlantic (Falkland Plateau). Papers found in initial reports of DSDP that were related to palynomorphs were:

Goodman, David K. and Ford L.N. Preliminary dinoflagellate biostratigraphy for the middle Eocene to lower Oligocene from the southwest Atlantic Ocean. (sites were $511,512,513 \mathrm{~A})$. They consider these results as preliminary only.

Bason I.A., Cresielski P.F., Krasheninnikov V.A., Weaver, F.M. and Wise Jr. S.W. Biostratigraphic and Paleontologic synthesis: DSDP Leg 71 Falkland Plateau and Argentine Basin. In Initial Reports.

This paper gives a run down on all groups from the Jurassic to Holocene but does not give specific information.

\section{DSDP Leg 90 587-594}

Situated between $40^{\circ} \mathrm{S}$ and $60^{\circ} \mathrm{S}$ west and east of New Zealand are sites 593 and 594 these were the only sites I have gathered information on in Leg 90. Papers found in initial reports of DSDP that were related to palynomorphs were:

Huesser L.E. Palynology of selected Neogene samples Holes 594 and 594A Is Neogene N/A

Other papers:

Marret F., De Vernal A., Benderra F, and Harland Rex. 2001 Late Quaternary seasurface conditions of DSDP Hole 594 in the southwest Pacific Ocean based on dinoflagellate cyst assemblages. Journal of Quaternary Science 16 (7) 739-751 PDF on laptop

\section{Late quaternary N/A}

\section{ODP Leg 113 sites 689-697}

Situated between $60^{\circ} \mathrm{S}$ and $70^{\circ} \mathrm{S}$ in the Weddell Sea. Papers found in Proceedings of the Ocean Drilling Program, Scientific Results volume 113 that were related to palynomorphs were: 
Futterer, Dieter Karl, The distribution of calcareous dinoflagellates at the

Cretaceous-Tertiary boundary of Queen Maud Rise, Eastern Weddell Sea, Antarctica. Holes 689B and 690C.

Specifically targets the K/T boundary N/A

Mohr, Barbara A.R. Early cretaceous palynomorphs from ODP sites 692 and 693, the Weddell Sea, Antarctica.

\section{Early Cretaceous palynomorphs N/A}

Mohr, B.A.R. Eocene and Oligocene sporomorphs and dinoflagellate cysts from Leg 113 drill sites, Weddell Sea, Antarctica.

Shipboard smear slides were used. Lists findings and gives some environmental interpretation. Provides some plates with photos

Fleming comments (see leg 28 DSDP paper) on previous work, with some criticism of ODP Leg 113 shipboard work in evaluating the presence of palynomorphs. Fleming also comments on Leg 114 p 229 on their evaluation on presence of pollen in their initial reports.

\section{Other papers:}

Hildebrand-Habel, Tania and Strent Michael. 2003. Calcareous dinoflagellate associations and Maastrichtian-Tertiary climatic change in a high-latitude core (ODP Hole 689B, Maud Rise, Weddell Sea). Palaeogeography, Palaeoclimatology, Palaeoecology 197 : 293-321

\section{Examines one ODP site only good paper, quite thorough}

Rex Harland, Meriel E.J. FitzPatrick and Carol J. Pudsey 1999: Latest Quaternary dinoflagellate cyst climatostratigraphy for three cores from the Falkland Trough, Scotia and Weddell seas, Southern Ocean

Review of Palaeobotany and Palynology, Volume 107, Issues 3-4, , Pages 265-281

Comment: the three cores are shallow from Holocene and Late Pleistocene not ODP

\section{Late Quaternary N/A}

\section{ODP Leg 114 sites 698-702}

Situated between $40^{\circ} \mathrm{S}$ and $60^{\circ} \mathrm{S}$ in the Subantarctic South Atlantic (Falkland Plateau). Papers found in Proceedings of the Ocean Drilling Program, Scientific Results volume 114 that were related to palynomorphs were:

Fenner, Julian. Rare and unknown nonclacareous microfossils recovered from Leg 114 sites.

\section{Not dinoflagellates, pollen or spores.}

Searches carried out on the internet or library journal finder have not been productive.

\section{ODP Leg 119 sites 736-746}

Situated between $40^{\circ} \mathrm{S}$ and $70^{\circ} \mathrm{S}$ with 5 sites drilled in Prydz Bay (738-743) and 6 sites were drilled on the Kerguelen Plateau (North KP 736, 737, and South KP 744- 
746). Papers found in Proceedings of the Ocean Drilling Program, Scientific Results volume 119 that were related to palynomorphs were:

Stockwell, Dean A. Distribution of Chaetoceros resting spores in the Quaternary sediments from Leg 119.

Quaternary N/A

Tocher, Bruce A. Late Cretaceous dinoflagellate cysts from the Southern Kerguelen Plateau, site 738 .

\section{Late Cretaceous N/A}

Data report: palynology of sediments from Leg 119 drill sites in Prydz Bay, East Antarctica 1991 Truswell E.M. Proc. scientific results, ODP, Leg 119, Kerguelen Plateau-Prydz Bay, pp. 941-945 (scopus results)

Truswell looked at sites 739-743 see paper attached

Gives brief descriptions of ages and some names of palynomorphs

\section{ODP Leg 120 sites 747-751}

Situated between $50^{\circ} \mathrm{S}$ and $60^{\circ} \mathrm{S}$ with 5 sites drilled in the central Kerguelen Plateau (747-751). Papers found in Proceedings of the Ocean Drilling Program, Scientific Results volume 120 that were related to palynomorphs were:

Mohr, Barbara A.R. and Gee C.T. An early Albian palynoflora from the Kerguelen Plateau Southern Indian Ocean (Leg 120, site 750B).

Mohr B.A.R. and Gee C.T. Late Cretaceous palynofloras (sporomorphs and dinocysts) from the Kerguelen Plateau, Southern Indian Ocean (sites 748 and 750)

Mao, Shozhi and Mohr, B.A.R. Late Cretaceous dinoflagellate cysts (?SantonianMaastrichtian) from the Southern Indian Ocean (Hole 748C).

Watkins, D.K. Quilty, P.G. Mohr, B.A.R. Mao,k S., Francis J.E. Gee, C.T., and Coffin M.F., 1992. Palaeontology of the Cretaceous of the Central Kerguelen Plateau. In Proceedings of Leg 120 951-960

\section{All 4 papers above are Cretaceous only}

\section{ODP Leg 141 sites 859-863}

Situated between $40^{\circ} \mathrm{S}$ and $60^{\circ} \mathrm{S}$ in the Chile triple junction. There were no papers found in Proceedings of the Ocean Drilling Program, Scientific Results volume 141 that were related to palynomorphs. In summary this is a spreading ridge subducting area in addition hot fluids cause hydrothermal alteration, anomalous diagenesis and mineralization.

\section{ODP Leg 177 sites 1088-1094}

Situated between $40^{\circ} \mathrm{S}$ and $60^{\circ} \mathrm{S}$ in the Subantarctic South Atlantic. The Scientific Results citations are attached but do not have any palynomorphs included in this write up. 
Shipboard scientific party report on the biostratigraphy for each site was based on calcareous nannofossils, planktic foraminifers, benthic foraminifers and Bolboforma, diatoms and radiolarians.

\section{ODP Leg 178 sites 1095-1103}

Situated between $60^{\circ} \mathrm{S}$ and $70^{\circ} \mathrm{S}$ at the Antarctic Peninsular. Papers found in Proceedings of the Ocean Drilling Program, Scientific Results volume 178 that were related to palynomorphs were:

Pudsey Carol, J. and Harland Rex. Data Report: Dinoflagellate cyst analysis of Neogene sediments from sites 1095 and 1096, Antarctic Peninsular Continental Rise.

Iwai, M. Kameo, K. and Miyake, N. Calcareous Nannofossils, Pollen and Spores from Leg 178 sites 1095, 1097, 1100 and 1103, Western Antarctic Peninsula: Age constraints and environmental implications.

\section{Both papers above are Miocene or earlier. N/A}

Shipboard scientific party report on biostratigraphy for each site was based on calcareous nannofossils, planktic foraminifers, benthic foraminifers, diatoms, radiolarians.

\section{Other papers:}

Harland Rex and Pudsey Carol J. 2002. Protoperidiniacean dinoflagellate cyst taxa from the Upper Miocene of ODP Leg 178, Antarctic Peninsula. Review of Palaeobotany and Palynology $120: 263-284$.

Sites 1095 and 1096 in the Bellingshausen Sea were looked at see attached paper. Upper Miocene only N/A

\section{ODP Leg 181 sites 1119-1125}

Situated between $40^{\circ} \mathrm{S}$ and $60^{\circ} \mathrm{S}$ in the Southwest Pacific (approx. North of Weddell Sea). Papers found in Proceedings of the Ocean Drilling Program, Scientific Results volume 181 that were related to palynomorphs were not present in the results.

Shipboard scientific party report on biostratigraphy for each site was based on calcareous nannofossils, planktic foraminifers, benthic foraminifers and Bolboforma, diatoms, radiolarians.

Other sources are

Mildenhall D.C. Hollis C.J and Naish T.R. 2004 Orbitally influenced vegetation record of the Mid-Pleistocene climate transition, offshore eastern New Zealand (ODP) Leg 181, site 1123). Marine Geology 205 87-111.

This paper is mainly on spores and pollen but does mention that dinoflagellate cysts are present in all samples as well as tasmanitids and fresh water Botryococcus and Pediastrum.

\section{ODP Leg 183 sites 1135-1142}

Situated between $40^{\circ} \mathrm{S}$ and $60^{\circ} \mathrm{S}$ in the Kerguelen Plateau-Broken Ridge with 11411142 within the $20^{\circ} \mathrm{S}$ and $40^{\circ} \mathrm{S}$. Papers found in Proceedings of the Ocean Drilling Program, Scientific Results volume 181 that were related to palynomorphs are: 
Mohr, B.A.R. Wahnert, V. and Lazarus D. 2002 Mid-Cretaceous Paleobotany and Palynology of the Central Kerguelen Plateau, Southern Indian Ocean (ODP Leg 183, Site 1138).

\section{Exert from vol 183 shipboard scientific party:}

"Plant fossils at site 1138: With proper specimen preparation onshore, the material should also be useful for palynomorphological biostratigraphy. The core-catcher material of Core 183-1138A-69R-CC seems to contain a rich flora of spores; we also observed some in the core catcher of Core 183-1138A-71R."

\section{These are all Cretaceous results. Smear slides used.}

\section{ODP Leg 187 sites 1152-1164}

Situated between $40^{\circ} \mathrm{S}$ and $60^{\circ} \mathrm{S}$ in the Australian Antarctic Discordance. Papers found in Proceedings of the Ocean Drilling Program, Scientific Results volume 181 that were related to palynomorphs were not recorded in this leg. Results were focused on microbial (i.e. Bacteria) found in basalt and their DNA sequences.

\section{Other papers:}

\section{ODP Leg 188 sites 1165-1167}

Situated between $60^{\circ} \mathrm{S}$ and $70^{\circ} \mathrm{S}$ at Prydz Bay, Cooperation Sea. Papers found in Proceedings of the Ocean Drilling Program, Scientific Results volume 188 that were related to palynomorphs were:

McPhail M.K. and Truswell E.M. Palynology of Neogene slope and rise deposits from ODP sites 1165 and 1167, East Antarctica

McPhail M.K. and Truswell E.M. Palynology of site 1166, Prydz Bay, East Antarctica

Thorn Vanessa C. Phytoliths in drill core sediments from sites 1165 and 1166, Leg 188, Prydz Bay, East Antarctica.

Shipboard scientific party report on biostratigraphy for each site was based on calcareous nannofossils, planktic foraminifers, benthic foraminifers, diatoms, radiolarians.

\section{Other papers:}

Hannah, M.J. 2006 The palynology of ODP site 1165, Prydz Bay, East Antarctica: A record of Miocene glacial advance and retreat Palaeogeography, Palaeoclimatology, Palaeoecology, 231, (1-2) : Pages 120-133

\section{ODP Leg 189 sites 1168-1172}

Situated between $40^{\circ} \mathrm{S}$ and $50^{\circ} \mathrm{S}$ at the Tasmanian Gateway. Papers found in Proceedings of the Ocean Drilling Program, Scientific Results volume 189 that were related to palynomorphs were: 
Brinkhuis, H., Munsterman, D.K., Sengers, S., Sluijs, A., Warnaar, J., and Williams, G.L., 2003. Late Eocene-Quaternary dinoflagellate cysts from ODP Site 1168, off western Tasmania. In Exon, N.F., Kennett, J.P., and Malone, M.J. (Eds.), Proc. ODP, Sci. Results, 189

Brinkhuis, H., Sengers, S., Sluijs, A., Warnaar, J., and Williams, G.L., 2003. Latest Cretaceous-earliest Oligocene and Quaternary dinoflagellate cysts, ODP Site 1172, East Tasman Plateau. In Exon, N.F., Kennett, J.P., and Malone, M.J. (Eds.), Proc. ODP, Sci. Results

Huber, M., Brinkhuis, H., Stickley, C.E., Doos, K. Sluijs, A., Warnaar, J., Schellenberg, S.A., Williams, G.L. 2004. Eocene circulation of the Southern Ocean: Was Antarctica kept warm by subtropical waters?

Sluijs, A., Brinkhuis, H., Stickley, C.E., Warnaar, J., Williams, G.L., and Fuller, M., 2003. Dinoflagellate cysts from the Eocene-Oligocene transition in the Southern Ocean: results from ODP Leg 189. In Exon, N.F., Kennett, J.P., and Malone, M.J. (Eds.), Proc. ODP, Sci. Results, 189

Stickley, C.E., Brinkhuis, H., McGonigal, K.L., Chaproniere, G.C.H., Fuller, M., Kelly, D.C., Nurnberg, D., Pfuhl, H.A., Schellenberg, S.A., Schoenfeld, J., Suzuki, N., Touchard, Y., Wei, W., Williams, G.L., Lara, J., and Stant, S.A., 2004. Late Cretaceous-Quaternary Biomagnetostratigraphy of ODP sites 1168, 1170, 1171, and 1172, Tasmanian Gateway.

Williams, G.L., Brinkhuis, H., Pearce, M.A., Fensome, R.A., and Weegink, J.W., 2004. Southern Ocean and global dinoflagellate cyst events compared: index events for the Late Cretaceous-Neogene. In Exon, N.F., Kennett, J.P., and Malone, M.J. (Eds.), Proc. ODP, Sci. Results, 189

Shipboard scientific party report on all sites includes calcareous nannofossils, planktic foraminifers, benthic foraminifers and Bolboforma, diatoms, radiolarians and pollen and spores and dinoflagellate cysts.

\section{SUMMARY OF POSSIBLE SITES TO WORK WITH}

\section{Kerguelen Plateau and Prydz Bay area:}

Leg 119 sites 736-746

Sites 737B, 738B, 744A

Leg 120 sites $747-751$

Sites 747A, 747C, 748B, 749B

Leg 183 sites 1135-1140

Sites 1138A

Leg 188 sites $1165-1167$

Sites 1166A

\section{Ross Sea Area}

Leg 28 sites 264-274

Sites 267, 274 


\section{Australian Antarctic Discordance}

Leg 187 sites 1152-1164

No papers for palynology results focused on bacteria.

\section{Tasmanian Gateway}

Leg 29 sites 275-284

Sites 277, 280A, 281, 282

Leg 189 sites $1168-1172$

Brinkhuis et al

\section{Southwest Pacific (New Zealand waters)}

Leg 90 sites 593-594

Sites 588C, 592, 593

Leg 181 sites1119-1125

Sites 1123C, 1124C,

\section{Antarctic Peninsular area}

Leg 35 sites 322-325

Not Eocene/Oligocene

Leg 178 sites 1095-1103

Miocene or earlier

\section{Chile Triple Junction}

Leg 141 sites 859-863

No papers on palynology for this site see leg summary.

\section{Sub Antarctic South Atlantic (Falkland Plateau)}

Leg 36 sites 326-331

Sites 328B, 329, 330A

Leg 71 sites 511-514

Sites 511

Leg 114 sites 698-702

Sites 699A, 701C, 703A

Leg 177 sites 1088-1094

Sites 1090B.

\section{Weddell Sea}

Leg 113 sites 689-697

Sites 689B, 689D, 690B, 696B 


\section{Appendix 2.3 - Sediments received - Predominant Lithology}

\section{LEG 113, Site 696B (Appendix 2.3a),}

Volume $(c c)=10.0$. Total number of samples: 27

Total volume of samples: 540 . Average volume of samples: $\mathbf{2 0 . 0 0}$

\begin{tabular}{|c|c|c|c|c|c|c|}
\hline & Core & Section & $\begin{array}{l}\text { Top } \\
\text { (cm) }\end{array}$ & $\begin{array}{c}\text { Bottom } \\
\text { (cm) }\end{array}$ & $\begin{array}{l}\text { Depth } \\
\text { (mbsf) }\end{array}$ & Predominant lithology \\
\hline 1 & $51 \mathrm{R}$ & 1 & 97 & 99 & 530.77 & Sandy mudstone not included \\
\hline 2 & $53 R$ & 1 & 108 & 112 & 549.98 & Mud/mudstone not included \\
\hline 3 & $53 R$ & 3 & 66 & 70 & 552.56 & Clay/claystone not included \\
\hline 4 & $54 \mathrm{R}$ & 1 & 122 & 126 & 559.72 & Mud/mudstone not included \\
\hline 5 & $54 R$ & 2 & 81 & 85 & 560.81 & Silty/mudstone not included \\
\hline 6 & $54 \mathrm{R}$ & 3 & 124 & 128 & 562.24 & Silty/mudstone not included \\
\hline 7 & $55 \mathrm{R}$ & 1 & 78 & 82 & 568.98 & Silty/mudstone not included \\
\hline 8 & $55 \mathrm{R}$ & 3 & 66 & 70 & 571.86 & Sandy/mudstone not included \\
\hline 9 & $55 \mathrm{R}$ & 5 & 140 & 144 & 575.64 & Silty/mudstone not included \\
\hline 10 & $56 \mathrm{R}$ & 1 & 81 & 85 & 578.71 & Silty/mudstone \\
\hline 11 & $57 \mathrm{R}$ & 1 & 56 & 60 & 588.16 & Silty/mudstone \\
\hline 1 & $58 \mathrm{R}$ & 1 & 110 & 112 & 598.30 & Sandy mudstone/silty mud Oligocene \\
\hline 2 & $59 R$ & $1 a$ & 10 & 12 & 607.00 & Sandy mudstone L Oligocene/U Eocene \\
\hline 3 & $59 R$ & $1 \mathrm{~b}$ & 123 & 125 & 608.13 & Sandy mudstone L Oligocene/U Eocene \\
\hline 4 & $59 R$ & 2 & 125 & 127 & 609.65 & Sandy mudstone L Oligocene/U Eocene \\
\hline 5 & $59 R$ & 3 & 85 & 87 & 610.75 & Sandy mudstone L Oligocene/U Eocene \\
\hline 6 & $59 R$ & $4 a$ & 35 & 37 & 611.75 & $\begin{array}{l}\text { Sandy mud mudstone L Oligocene/U } \\
\text { Eocene }\end{array}$ \\
\hline 7 & $59 R$ & $4 b$ & 135 & 137 & 612.75 & $\begin{array}{l}\text { Sandy mud mudstone L Oligocene/U } \\
\text { Eocene }\end{array}$ \\
\hline 8 & $59 R$ & 5 & 75 & 77 & 613.65 & $\begin{array}{l}\text { Sandy mud mudstone L Oligocene/U } \\
\text { Eocene }\end{array}$ \\
\hline 9 & $60 \mathrm{R}$ & $1 \mathrm{a}$ & 30 & 32 & 616.90 & Sandy mudstone L Oligocene/U Eocene \\
\hline 10 & $60 R$ & $1 \mathrm{~b}$ & 110 & 112 & 617.70 & Sandy mudstone L Oligocene/U Eocene \\
\hline 11 & $60 R$ & 2 & 96 & 98 & 619.06 & Sandy mudstone L Oligocene/U Eocene \\
\hline 12 & $60 R$ & 3 & 45 & 47 & 620.05 & Sandy mudstone L Oligocene/U Eocene \\
\hline 13 & $60 \mathrm{R}$ & $4 a$ & 45 & 47 & 621.55 & Sandy mudstone L Oligocene/U Eocene \\
\hline 14 & $60 R$ & $4 b$ & 145 & 147 & 622.55 & Sandy mudstone L Oligocene/U Eocene \\
\hline 15 & $60 \mathrm{R}$ & 5 & 90 & 92 & 623.50 & Sandy mudstone L Oligocene/U Eocene \\
\hline 16 & $60 R$ & 6 & 54 & 56 & 624.64 & Sandy mudstone L Oligocene/U Eocene \\
\hline 17 & $61 R$ & 1 & 44 & 46 & 626.64 & Sandy mudstone U Eocene \\
\hline 18 & $61 R$ & 2 & 85 & 87 & 628.55 & Sandy mudstone U Eocene \\
\hline 19 & $61 R$ & 3 & 53 & 55 & 629.73 & Sandy mudstone U Eocene \\
\hline 20 & $61 R$ & 4 & 93 & 95 & 631.63 & Sandy mudstone U Eocene \\
\hline 21 & $62 \mathrm{R}$ & 1 & 10 & 12 & 636.00 & Sandy mudstone M/U Eocene \\
\hline 22 & $62 \mathrm{R}$ & 2 & 63 & 65 & 636.94 & Sandy mudstone M/U Eocene \\
\hline 23 & $62 \mathrm{R}$ & 3 & 62 & 64 & 638.43 & Sandy mudstone M/U Eocene \\
\hline 24 & $62 \mathrm{R}$ & 4 & 82 & 84 & 640.13 & Sandy mudstone $\mathrm{M} / \mathrm{U}$ Eocene \\
\hline 25 & $62 \mathrm{R}$ & 5 & 46 & 48 & 641.27 & Sandy mudstone M/U Eocene \\
\hline 26 & $62 \mathrm{R}$ & 6 & 67 & 69 & 642.98 & Sandy mudstone M/U Eocene \\
\hline 27 & $62 \mathrm{R}$ & 7 & 88 & 90 & 644.69 & $\begin{array}{l}\text { Sandy mudstone } M / U \text { Eocene } \\
\text { This one not processed left out }\end{array}$ \\
\hline
\end{tabular}


LEG 114, Site 699A (Appendix 2.3b),

Volume $(c c)=10.0$. Total number of samples: $\mathbf{3 0}$

Total volume of samples: 690 . Average volume of samples: 10.00

\begin{tabular}{|c|c|c|c|c|c|c|}
\hline & Core & Section & $\begin{array}{l}\text { Top } \\
\text { (cm) }\end{array}$ & $\begin{array}{c}\text { Bottom } \\
\text { (cm) }\end{array}$ & $\begin{array}{l}\text { Depth } \\
\text { (mbsf) }\end{array}$ & Predominant lithology \\
\hline 1 & $27 X$ & 5 & 63.0 & 65.0 & 249.730 & Siliceous nanno and nannofossil ooze \\
\hline 2 & $28 \mathrm{X}$ & 1 & 95.0 & 97.0 & 253.550 & Nannofossil ooze \\
\hline 3 & $29 X$ & 2 & 67.0 & 69.0 & 261.270 & $\begin{array}{l}\text { Siliceous-bearing and siliceous nanno } \\
\text { ooze }\end{array}$ \\
\hline 4 & $30 \mathrm{X}$ & 3 & 64.0 & 66.0 & 272.240 & $\begin{array}{l}\text { Siliceous-bearing and siliceous nanno } \\
\text { ooze }\end{array}$ \\
\hline 5 & $31 \mathrm{X}$ & 2 & 73.0 & 75.0 & 280.330 & Siliceous-bearing nanno ooze \\
\hline 6 & $31 \mathrm{X}$ & 6 & 93.0 & 95.0 & 286.530 & Siliceous-bearing nanno ooze \\
\hline 7 & $32 X$ & 5 & 23.0 & 25.0 & 293.830 & $\begin{array}{l}\text { Siliceous-bearing and chalk and nanno } \\
\text { ooze }\end{array}$ \\
\hline 8 & $33 x$ & 2 & 47.0 & 49.0 & 299.070 & Nanno ooze \\
\hline 9 & $33 \mathrm{X}$ & 6 & 56.0 & 58.0 & 305.160 & Nanno ooze \\
\hline 10 & $35 X$ & 3 & 76.0 & 78.0 & 319.860 & $\begin{array}{l}\text { Nanno ooze and siliceous bearing nanno } \\
\text { ooze }\end{array}$ \\
\hline 11 & $35 X$ & 6 & 95.0 & 97.0 & 324.550 & $\begin{array}{l}\text { Nanno ooze and siliceous bearing nanno } \\
\text { ooze }\end{array}$ \\
\hline 12 & $36 \mathrm{X}$ & 3 & 108.0 & 110.0 & 329.680 & $\begin{array}{l}\text { Clayey nanno chalk ooze and clayey } \\
\text { nanno ooze }\end{array}$ \\
\hline 13 & $36 \mathrm{X}$ & 7 & 39.0 & 41.0 & 334.990 & $\begin{array}{l}\text { Clayey nanno chalk ooze and clayey } \\
\text { nanno ooze }\end{array}$ \\
\hline 14 & $37 X$ & 3 & 97.0 & 99.0 & 339.070 & Nanno chalk to clay-bearing nanno chalk \\
\hline 15 & $39 X$ & 2 & 57.0 & 59.0 & 356.170 & Nanno chalk to clay-bearing nanno chalk \\
\hline 16 & $40 \mathrm{X}$ & 1 & 90.0 & 92.0 & 364.500 & Nannofossil chalk \\
\hline 17 & $40 \mathrm{X}$ & 4 & 98.0 & 100.0 & 369.080 & Nannofossil chalk \\
\hline 18 & $41 \mathrm{X}$ & 1 & 71.0 & 73.0 & 373.810 & $\begin{array}{l}\text { Clay-bearing nanno chalk and clayey } \\
\text { nanno chalk }\end{array}$ \\
\hline 19 & $42 X$ & 3 & 111.0 & 113.0 & 386.710 & Nanno micritic chalk \\
\hline 20 & $42 X$ & 6 & 79.0 & 81.0 & 390.890 & Nanno micritic chalk \\
\hline 21 & $43 X$ & 4 & 35.0 & 38.0 & 396.950 & Nanno micritic chalk \\
\hline 22 & $45 X$ & 2 & 50.0 & 52.0 & 413.100 & Clay-bearing nanno micritic chalk \\
\hline 23 & $45 X$ & 5 & 67.0 & 69.0 & 417.770 & Clay-bearing nanno micritic chalk \\
\hline 24 & $47 X$ & 2 & 77.0 & 79.0 & 432.370 & Micrite-bearing nanno chalk \\
\hline 25 & $47 X$ & 5 & 50.0 & 52.0 & 436.600 & Micrite-bearing nanno chalk \\
\hline 26 & $48 \mathrm{X}$ & 3 & 106.0 & 108.0 & 443.660 & Nannofossil chalk \\
\hline 27 & $49 x$ & 1 & 82.0 & 85.0 & 449.920 & Nannofossil chalk \\
\hline 28 & $49 X$ & 4 & 126.0 & 129.0 & 454.860 & Nannofossil chalk \\
\hline 29 & $50 x$ & 2 & 71.0 & 73.0 & 460.810 & Micrite-bearing nanno chalk \\
\hline 30 & $50 \mathrm{X}$ & 5 & 105.0 & 107.0 & 465.650 & Micrite-bearing nanno chalk \\
\hline
\end{tabular}


LEG 120, Site 748B, (Appendix 2.3c),

Volume $(c c)=10.0$. Total number of samples: 22

Total volume of samples: 690 . Average volume of samples: 10.00

\begin{tabular}{|c|c|c|c|c|c|c|}
\hline & Core & Section & $\begin{array}{l}\text { Top } \\
\text { (cm) }\end{array}$ & $\begin{array}{c}\text { Bottom } \\
\text { (cm) }\end{array}$ & $\begin{array}{l}\text { Depth } \\
\text { (mbsf) }\end{array}$ & Predominant lithology \\
\hline 1 & $10 \mathrm{H}$ & 1 & 73.0 & 75.0 & 76.830 & Nannofossil ooze \\
\hline 2 & $11 \mathrm{H}$ & 2 & 52.0 & 54.0 & 87.620 & Nannofossil ooze \\
\hline 3 & $11 \mathrm{H}$ & 5 & 54.0 & 56.0 & 92.140 & Nannofossil ooze \\
\hline 4 & $12 \mathrm{H}$ & 1 & 65.0 & 67.0 & 95.750 & Nannofossil ooze \\
\hline 5 & $12 \mathrm{H}$ & 5 & 92.0 & 94.0 & 102.020 & Nannofossil ooze \\
\hline 6 & $13 \mathrm{H}$ & 2 & 55.0 & 57.0 & 106.650 & $\begin{array}{l}\text { Nannofossil ooze nanno ooze with } \\
\text { sil. debris }\end{array}$ \\
\hline 7 & $13 \mathrm{H}$ & 5 & 107.0 & 109.0 & 111.670 & $\begin{array}{l}\text { Nannofossil ooze nanno ooze with } \\
\text { sil. debris IRD present between } \\
115.45 \text { and } 115.77 \mathrm{mbsf}\end{array}$ \\
\hline 8 & $14 \mathrm{H}$ & 2 & 30.0 & 32.0 & 115.900 & $\begin{array}{l}\text { Nannofossil ooze with forams and } \\
\text { with sil.debris }\end{array}$ \\
\hline 9 & $14 \mathrm{H}$ & 5 & 55.0 & 57.0 & 120.650 & $\begin{array}{l}\text { Nannofossil ooze with forams and } \\
\text { with sil.debris }\end{array}$ \\
\hline 10 & $15 \mathrm{H}$ & 2 & 126.0 & 128.0 & 126.360 & Nannofossil ooze \\
\hline 11 & $15 \mathrm{H}$ & 6 & 90.0 & 92.0 & 132.000 & Nannofossil ooze \\
\hline 12 & $16 \mathrm{H}$ & 4 & 25.0 & 27.0 & 137.680 & Nannofossil ooze \\
\hline 13 & $16 \mathrm{H}$ & 7 & 66.0 & 68.0 & 141.810 & Nannofossil ooze \\
\hline 14 & $17 \mathrm{H}$ & 4 & 68.0 & 70.0 & 147.780 & Nannofossil ooze \\
\hline 15 & $17 \mathrm{H}$ & 7 & 51.0 & 53.0 & 152.110 & Nannofossil ooze \\
\hline 16 & $18 \mathrm{H}$ & 4 & 30.0 & 32.0 & 156.900 & Nannofossil ooze \\
\hline 17 & $19 \mathrm{H}$ & 1 & 50.0 & 52.0 & 162.100 & Nannofossil ooze \\
\hline 18 & $19 \mathrm{H}$ & 4 & 129.0 & 131.0 & 167.390 & Nannofossil ooze \\
\hline 19 & $20 \mathrm{H}$ & 1 & 102.0 & 104.0 & 172.120 & Nannofossil ooze \\
\hline 20 & $20 \mathrm{H}$ & 5 & 66.0 & 68.0 & 177.760 & Nannofossil ooze \\
\hline 21 & $23 X$ & 1 & 78.0 & 80.0 & 197.380 & Nannofossil ooze \\
\hline 22 & $23 X$ & 3 & 87.0 & 89.0 & 200.470 & Nannofossil ooze \\
\hline
\end{tabular}


LEG 29, Site 277 (Appendix 2.3d),

Volume (cc) $=20.0$ Total number of samples: 28

Total volume of samples: 560.00. Average volume of samples: 20.00

\begin{tabular}{|c|c|c|c|c|c|c|}
\hline & Core & Section & $\begin{array}{l}\text { Top } \\
\text { (cm) }\end{array}$ & $\begin{array}{c}\text { Bottom } \\
\text { (cm) }\end{array}$ & $\begin{array}{l}\text { Depth } \\
\text { (mbsf) }\end{array}$ & Predominant lithology \\
\hline 1 & 14 & 1 & 117.0 & 122.0 & 122.170 & Rad/spicule Foram bearing nanno ooze \\
\hline 2 & 14 & 4 & 91.5 & 96.5 & 126.415 & Rad/spicule Foram bearing nanno ooze \\
\hline 3 & 15 & 2 & 99.5 & 102.5 & 132.995 & Rad. Foram bearing nanno ooze \\
\hline 4 & 15 & 5 & 26.0 & 29.5 & 136.760 & Rad. Foram bearing nanno ooze \\
\hline 5 & 16 & 1 & 125.0 & 129.0 & 141.250 & Diatom/Glauconite Foram rich nanno ooze \\
\hline 6 & 16 & 4 & 106.5 & 110.0 & 145.565 & Foram rich nanno ooze \\
\hline 7 & 17 & 3 & 122.5 & 126.0 & 153.725 & Diatom/spicule Foram rich nanno ooze \\
\hline 8 & 17 & 6 & 51.5 & 56.0 & 157.515 & Diatom/spicule Foram rich nanno ooze \\
\hline 9 & 18 & 3 & 56.0 & 59.0 & 162.560 & Diatom/spicule Foram rich nanno ooze \\
\hline 10 & 20 & 2 & 132.5 & 134.5 & 180.825 & foram bearing micarb nanno ooze \\
\hline 11 & 20 & 6 & 25.0 & 28.0 & 185.750 & foram bearing micarb nanno ooze \\
\hline 12 & 21 & 3 & 30.0 & 33.0 & 190.800 & foram bearing nanno ooze \\
\hline 13 & 22 & 2 & 109.0 & 112.0 & 199.590 & foram rich nanno ooze \\
\hline 14 & 23 & 3 & 77.5 & 81.0 & 210.275 & spicule bearing foram rich nanno ooze \\
\hline 15 & 24 & 3 & 114.5 & 119.0 & 220.145 & spicule bearing foram rich nanno ooze \\
\hline 16 & 26 & 1 & 130.0 & 135.0 & 236.300 & foram bearing nanno ooze: chert nodules \\
\hline 17 & 26 & 4 & 134.0 & 137.0 & 240.840 & foram bearing nanno ooze: chert nodules \\
\hline 18 & 29 & 2 & 33.5 & 37.5 & 265.335 & nanno ooze: chert nodules \\
\hline 19 & 30 & 5 & 115.0 & 120.0 & 280.150 & nanno ooze chalk: chert nodules \\
\hline 20 & 32 & 1 & 53.0 & 57.5 & 292.530 & nanno ooze chalk \\
\hline 21 & 32 & 3 & 130.0 & 133.0 & 296.300 & nanno ooze chalks: chert nodules \\
\hline 22 & 35 & 1 & 101.0 & 104.0 & 350.010 & nanno chalk \\
\hline 23 & 36 & 2 & 13.0 & 16.0 & 369.630 & nanno chalk \\
\hline 24 & 37 & 3 & 9.0 & 11.0 & 380.590 & nanno chalk: chert nodules \\
\hline 25 & 38 & 2 & 7.0 & 9.5 & 388.570 & nanno chalk \\
\hline 26 & 40 & 2 & 103.5 & 106.5 & 408.535 & nanno chalk \\
\hline 27 & 42 & 2 & 103.5 & 106.5 & 427.535 & nanno chalk \\
\hline 28 & 43 & 1 & 51.0 & 53.0 & 435.010 & nanno chalk \\
\hline
\end{tabular}




\section{Sites below were initially processed and found to be either barren or} too sparse to work with

LEG 113, Site 690 B, Volume $(c c)=10.0$. Total number of samples: 17 Total volume of samples: 690 . Average volume of samples: $\mathbf{1 0 . 0 0}$

\begin{tabular}{|c|c|c|c|c|c|c|}
\hline & Core & Section & $\begin{array}{l}\text { Top } \\
\text { (cm) }\end{array}$ & $\begin{array}{l}\text { Bottom } \\
\text { (cm) }\end{array}$ & $\begin{array}{l}\text { Depth } \\
\text { (mbsf) }\end{array}$ & Predominant lithology \\
\hline 1 & $9 \mathrm{H}$ & 1 & 32.0 & 68.0 & 70.120 & nanno ooze Lower Oligocene \\
\hline 2 & $9 \mathrm{H}$ & 3 & 105.0 & 107.0 & 73.850 & nanno ooze Lower Oligocene \\
\hline 3 & $9 \mathrm{H}$ & 6 & 107.0 & 109.0 & 78.370 & nanno ooze Lower Oligocene \\
\hline 4 & $10 \mathrm{H}$ & 2 & 127.0 & 129.0 & 82.170 & nanno ooze Lower Oligocene \\
\hline 5 & $10 \mathrm{H}$ & 4 & 82.0 & 84.0 & 84.720 & $\begin{array}{l}\text { nanno siliceous ooze Lower } \\
\text { Oligocene }\end{array}$ \\
\hline 6 & $11 \mathrm{H}$ & 1 & 25.0 & 27.0 & 89.350 & $\begin{array}{l}\text { foram rad nanno ooze Lower } \\
\text { Oligocene }\end{array}$ \\
\hline 7 & $11 \mathrm{H}$ & 3 & 82.0 & 84.0 & 92.920 & nanno ooze Lower Oligocene \\
\hline 8 & $11 \mathrm{H}$ & 6 & 47.0 & 49.0 & 97.070 & nanno ooze Upper Eocene \\
\hline 9 & $12 \mathrm{H}$ & 2 & 46.0 & 48.0 & 100.760 & $\begin{array}{l}\text { foram bearing nanno ooze } \\
\text { Upper/Mid Eocene }\end{array}$ \\
\hline 10 & $12 \mathrm{H}$ & 5 & 14.0 & 16.0 & 104.940 & $\begin{array}{l}\text { foram bearing nanno ooze } \\
\text { Middle Eocene }\end{array}$ \\
\hline 11 & $13 \mathrm{H}$ & 1 & 105.0 & 107.0 & 109.550 & $\begin{array}{l}\text { foram bearing nanno ooze } \\
\text { Middle Eocene }\end{array}$ \\
\hline 12 & $13 \mathrm{H}$ & 4 & 52.0 & 54.0 & 113.520 & $\begin{array}{l}\text { foram bearing nanno ooze } \\
\text { Middle Eocene }\end{array}$ \\
\hline 13 & $13 \mathrm{H}$ & 6 & 128.0 & 130.0 & 117.280 & $\begin{array}{l}\text { foram bearing nanno ooze } \\
\text { Middle Eocene }\end{array}$ \\
\hline 14 & $14 \mathrm{H}$ & 3 & 52.0 & 54.0 & 122.020 & $\begin{array}{l}\text { nanno ooze Lower/Middle } \\
\text { Eocene }\end{array}$ \\
\hline 15 & $14 \mathrm{H}$ & 6 & 34.0 & 36.0 & 126.340 & $\begin{array}{l}\text { foram nanno ooze } \\
\text { Lower/Middle Eocene }\end{array}$ \\
\hline 16 & $15 \mathrm{H}$ & 2 & 44.0 & 46.0 & 130.040 & $\begin{array}{l}\text { foram nanno ooze Lower } \\
\text { Eocene }\end{array}$ \\
\hline 17 & $15 \mathrm{H}$ & 5 & 26.0 & 28.0 & 134.360 & nanno ooze Upper Paleocene \\
\hline
\end{tabular}


LEG 119, Site $738 \mathrm{~B}$, Volume $(\mathrm{cc})=10.0$. Total number of samples: 30 Total volume of samples: 300 . Average volume of samples: 10.00

\begin{tabular}{|l|l|l|l|l|l|l|}
\hline & Core & Section & $\begin{array}{l}\text { Top } \\
\text { (cm) }\end{array}$ & $\begin{array}{l}\text { Bottom } \\
\text { (cm) }\end{array}$ & $\begin{array}{l}\text { Depth } \\
\text { (mbsf) }\end{array}$ & Predominant lithology \\
\hline 1 & $3 \mathrm{H}$ & 5 & 59.5 & 62.0 & 20.095 & nanno ooze L Oligocene \\
\hline 2 & $4 \mathrm{H}$ & 2 & 63.5 & 66.0 & 25.135 & nanno ooze L Oligocene \\
\hline 3 & $4 \mathrm{H}$ & 5 & 65.5 & 67.5 & 29.655 & nanno ooze L Oligocene \\
\hline 4 & $5 \mathrm{H}$ & 1 & 124.0 & 126.0 & 33.740 & nanno ooze L Oligocene \\
\hline 5 & $5 \mathrm{H}$ & 5 & 124.5 & 127.0 & 39.745 & nanno ooze Upper Eocene \\
\hline 6 & $6 \mathrm{H}$ & 2 & 63.5 & 66.0 & 44.165 & nanno ooze U Eocene \\
\hline 7 & $6 \mathrm{H}$ & 6 & 93.0 & 96.0 & 49.980 & nanno ooze U Eocene \\
\hline 8 & $7 \mathrm{H}$ & 3 & 58.0 & 61.0 & 55.080 & nanno ooze U Eocene \\
\hline 9 & $7 \mathrm{H}$ & 6 & 123.5 & 125.5 & 60.235 & nanno ooze U Eocene \\
\hline 10 & $8 \mathrm{H}$ & 4 & 50.0 & 53.0 & 66.000 & nanno ooze U Eocene \\
\hline 11 & $8 \mathrm{H}$ & 7 & 41.0 & 44.0 & 70.410 & nanno ooze U Eocene \\
\hline 12 & $9 \mathrm{H}$ & 4 & 39.0 & 42.0 & 75.390 & nanno ooze M Eocene \\
\hline 13 & $10 \mathrm{H}$ & 3 & 81.0 & 84.0 & 83.810 & nanno ooze M Eocene \\
\hline 14 & $11 \mathrm{H}$ & 3 & 102.5 & 105.0 & 89.025 & nanno ooze M Eocene \\
\hline 15 & $11 \mathrm{H}$ & 6 & 129.0 & 132.0 & 93.790 & nanno ooze M Eocene \\
\hline 16 & $12 \mathrm{H}$ & 4 & 98.0 & 101.0 & 99.980 & nanno ooze M Eocene \\
\hline 17 & $13 \mathrm{H}$ & 1 & 106.0 & 109.0 & 105.060 & nanno ooze M Eocene \\
\hline 18 & $14 \mathrm{X}$ & 2 & 64.0 & 67.0 & 110.340 & nanno ooze M Eocene \\
\hline 19 & $15 \mathrm{X}$ & 2 & 110.0 & 113.0 & 120.400 & nanno ooze M Eocene \\
\hline 20 & $15 \mathrm{X}$ & 5 & 105.0 & 108.0 & 124.850 & foram nanno ooze M Eocene \\
\hline 21 & $17 \mathrm{X}$ & 2 & 103.0 & 106.0 & 139.730 & nanno ooze M Eocene \\
\hline 22 & $17 \mathrm{X}$ & 5 & 14.0 & 17.0 & 143.340 & nanno ooze M Eocene \\
\hline 23 & $18 \mathrm{X}$ & 4 & 26.0 & 29.0 & 151.560 & nanno ooze M Eocene \\
\hline 24 & $19 \mathrm{X}$ & 3 & 79.0 & 82.0 & 160.290 & nanno ooze M Eocene \\
\hline 25 & $19 \mathrm{X}$ & 6 & 84.0 & 87.0 & 164.840 & nanno ooze M Eocene \\
\hline 26 & $20 \mathrm{X}$ & 3 & 62.0 & 65.0 & 169.820 & nanno ooze M Eocene \\
\hline 27 & $21 \mathrm{X}$ & 3 & 32.0 & 35.0 & 178.580 & nanno ooze M Eocene \\
\hline 28 & $22 \mathrm{X}$ & 2 & 127.0 & 130.0 & 188.170 & nanno ooze M Eocene \\
\hline 29 & $24 \mathrm{X}$ & 1 & 55.0 & 57.0 & 205.150 & nanno ooze chalk M Eocene \\
\hline 30 & $24 \mathrm{X}$ & 3 & 58.0 & 61.0 & 208.180 & nanno ooze chalk M Eocene \\
\hline & & & & & & \\
\hline
\end{tabular}




\section{Appendix 2.4-Dry Weight Processed}

\begin{tabular}{|c|c|c|c|}
\hline $\begin{array}{l}\text { Samples, } \\
\text { Leg, Core, } \\
\text { section }\end{array}$ & $\begin{array}{l}\text { Weight of } \\
\text { cup without } \\
\text { sample }\end{array}$ & $\begin{array}{l}\text { Cup with dry } \\
\text { sample. } \\
\text { Dry weight }\end{array}$ & $\begin{array}{c}\text { Dry weight } \\
\text { processed } \\
\text { (gr. taken out) }\end{array}$ \\
\hline$\frac{\operatorname{Leg} 113}{\underline{696 B}}$ & $\frac{\operatorname{Leg} 113}{696 B}$ & $\frac{\operatorname{Leg} 113}{\underline{696 B}}$ & Leg 113 696B \\
\hline $\begin{array}{c}1 \\
51 R-1\end{array}$ & 26.08 & $\begin{array}{l}65.03 \\
38.95\end{array}$ & \\
\hline $\begin{array}{c}2 \\
53 R-1\end{array}$ & 26.08 & $\begin{array}{l}70.46 \\
44.38\end{array}$ & $\begin{array}{l}\text { NOT } \\
\text { DRY }\end{array}$ \\
\hline $\begin{array}{c}3 \\
53 R-3\end{array}$ & 28.28 & $\begin{array}{l}64.73 \\
16.45\end{array}$ & \\
\hline $\begin{array}{c}4 \\
54 R-1\end{array}$ & 28.28 & $\begin{array}{l}56.10 \\
27.82\end{array}$ & $\begin{array}{c}15.13 \\
(12.69)\end{array}$ \\
\hline $\begin{array}{c}5 \\
54 R-2\end{array}$ & 28.29 & $\begin{array}{l}63.40 \\
35.11\end{array}$ & $\begin{array}{c}22.54 \\
(12.57)\end{array}$ \\
\hline $\begin{array}{c}6 \\
54 R-3\end{array}$ & 28.29 & $\begin{array}{l}63.78 \\
35.49\end{array}$ & $\begin{array}{c}22.67 \\
(12.82)\end{array}$ \\
\hline $\begin{array}{c}7 \\
55 R-1 \\
\end{array}$ & 28.29 & $\begin{array}{l}59.05 \\
30.76 \\
\end{array}$ & $\begin{array}{c}18.09 \\
(12.67)\end{array}$ \\
\hline $\begin{array}{c}8 \\
55 R-3 \\
\end{array}$ & 28.6 & $\begin{array}{l}58.03 \\
29.77 \\
\end{array}$ & $\begin{array}{c}16.90 \\
(12.87)\end{array}$ \\
\hline $\begin{array}{c}9 \\
55 R-5\end{array}$ & 28.6 & $\begin{array}{l}62.00 \\
32.74 \\
\end{array}$ & $\begin{array}{c}20.43 \\
(12.31)\end{array}$ \\
\hline $\begin{array}{c}10 \\
56 \mathrm{R}-1\end{array}$ & 28.6 & $\begin{array}{l}61.16 \\
32.90 \\
\end{array}$ & $\begin{array}{c}20.13 \\
(12.77)\end{array}$ \\
\hline $\begin{array}{c}11 \\
57 R-1\end{array}$ & 28.6 & $\begin{array}{l}68.14 \\
40.88 \\
\end{array}$ & $\begin{array}{c}27.94 \\
(12.94)\end{array}$ \\
\hline $\begin{array}{c}1 \\
58 \mathrm{R}-1 \\
\text { 2nd } \\
\end{array}$ & $\begin{array}{l}26.05 \\
26.06\end{array}$ & $\begin{array}{l}46.96 \\
20.91 \\
37.93 \\
11.87 \\
\end{array}$ & $\begin{array}{c}9.03 \\
(11.87) \\
9.07 \\
(2.80) \\
\end{array}$ \\
\hline $\begin{array}{c}2 \\
59 R a-1 \\
\text { 2nd }\end{array}$ & 28.26 & $\begin{array}{c}42.21 \\
13.95 \\
32.31 \\
4.05\end{array}$ & $\begin{array}{c}9.90 \\
(4.07) \\
4.05 \\
(0.00)\end{array}$ \\
\hline $\begin{array}{c}3 \\
59 \mathrm{Rb}-1 \\
\text { 2nd }\end{array}$ & 28.27 & $\begin{array}{l}50.99 \\
22.74 \\
41.04 \\
12.77\end{array}$ & $\begin{array}{c}9.96 \\
(12.77) \\
9.05 \\
(3.72)\end{array}$ \\
\hline $\begin{array}{c}4 \\
59 R-2\end{array}$ & 26.06 & $\begin{array}{l}43.95 \\
17.89\end{array}$ & $\begin{array}{c}9.99 \\
(7.91)\end{array}$ \\
\hline $\begin{array}{c}5 \\
59 R-3\end{array}$ & 28.25 & $\begin{array}{l}51.78 \\
23.53\end{array}$ & $\begin{array}{c}9.58 \\
(15.42)\end{array}$ \\
\hline $\begin{array}{c}6 \\
59 R-4 a\end{array}$ & 26.06 & $\begin{array}{l}49.67 \\
23.61\end{array}$ & $\begin{array}{c}9.37 \\
(14.24)\end{array}$ \\
\hline $\begin{array}{c}7 \\
59 R-4 b\end{array}$ & 26.06 & $\begin{array}{l}50.42 \\
24.36\end{array}$ & $\begin{array}{c}10.08 \\
(14.30)\end{array}$ \\
\hline
\end{tabular}




\begin{tabular}{|c|c|c|c|}
\hline $\begin{array}{c}8 \\
59 R-5\end{array}$ & 28.24 & $\begin{array}{l}48.13 \\
19.89\end{array}$ & $\begin{array}{c}9.95 \\
(9.94)\end{array}$ \\
\hline 9 & 26.08 & 38.65 & 6.56 \\
\hline 60R-1a & & 12.57 & (6.01) \\
\hline \multirow{2}{*}{ 2nd } & 26.06 & 31.97 & 5.91 \\
\hline & & 5.91 & -- \\
\hline \multirow{2}{*}{$\begin{array}{c}10 \\
60 R-1 b\end{array}$} & 26.07 & 54.61 & 9.80 \\
\hline & & 28.54 & (18.74) \\
\hline \multirow{2}{*}{$\begin{array}{c}11 \\
60 R-2\end{array}$} & 26.06 & 47.18 & 9.73 \\
\hline & & 21.12 & (11.39) \\
\hline \multirow{2}{*}{ 2nd } & 26.05 & 37.41 & 8.68 \\
\hline & & 11.36 & (2.68 \\
\hline \multirow{2}{*}{$\begin{array}{c}12 \\
60 R-3\end{array}$} & 26.07 & 56.65 & 9.96 \\
\hline & & 30.58 & $(20.62)$ \\
\hline \multirow{2}{*}{$\begin{array}{c}13 \\
60 R-4 a\end{array}$} & 26.07 & 47.69 & 11.97 \\
\hline & & 21.62 & (9.65) \\
\hline \multirow[t]{2}{*}{$\underline{2 n d}$} & 28.24 & 37.80 & 9.56 \\
\hline & & 9.56 & -- \\
\hline \multirow{2}{*}{$\begin{array}{c}14 \\
60 R-4 b\end{array}$} & 28.28 & 62.03 & 18.67 \\
\hline & & 33.75 & (15.08) \\
\hline \multirow[t]{2}{*}{ 2nd } & 26.05 & 40.06 & 9.33 \\
\hline & & 14.01 & (6.12) \\
\hline \multirow{2}{*}{$\begin{array}{c}24 \\
62 R-4\end{array}$} & 26.08 & 50.10 & 12.89 \\
\hline & & 24.02 & (11.13) \\
\hline \multirow[t]{2}{*}{ 2nd } & 28.27 & 39.36 & 8.62 \\
\hline & & 11.09 & $(2.47)$ \\
\hline \multirow{2}{*}{$\begin{array}{c}25 \\
62 R-5\end{array}$} & 26.08 & 46.56 & 10.86 \\
\hline & & 20.48 & (9.62) \\
\hline \multirow[t]{2}{*}{ 2nd } & 26.08 & 35.66 & 9.58 \\
\hline & & 9.58 & $(0.00)$ \\
\hline \multirow{2}{*}{$\begin{array}{c}26 \\
62 R-6\end{array}$} & 26.09 & 50.09 & 12.75 \\
\hline & & 24.00 & (11.25) \\
\hline \multirow[t]{2}{*}{ 2nd } & 26.06 & 37.13 & 8.41 \\
\hline & & 11.07 & (2.66) \\
\hline \multirow{2}{*}{$\begin{array}{c}27 \\
62 R-7\end{array}$} & 26.08 & 46.15 & 10.37 \\
\hline & & 20.07 & (9.70) \\
\hline \multirow[t]{2}{*}{ 2nd } & 28.25 & 37.94 & 9.69 \\
\hline & & 9.69 & (0.00) \\
\hline
\end{tabular}




\begin{tabular}{|c|c|c|c|}
\hline $\begin{array}{l}\text { Samples, } \\
\text { Leg, Core, } \\
\text { section }\end{array}$ & $\begin{array}{l}\text { Weight of } \\
\text { cup } \\
\text { without } \\
\text { sample }\end{array}$ & $\begin{array}{l}\text { Cup with } \\
\text { dry } \\
\text { sample. } \\
\text { Dry } \\
\text { weight }\end{array}$ & $\begin{array}{l}\text { Dry weight } \\
\text { processed } \\
\text { (gr. taken } \\
\text { out) }\end{array}$ \\
\hline Leg 114 & Leg 114 & Leg 114 & Leg 114 \\
\hline $\begin{array}{c}1 \\
27 X-5\end{array}$ & 26.08 & $\begin{array}{l}42.45 \\
16.37\end{array}$ & $\begin{array}{c}9.07 \\
(7.30)\end{array}$ \\
\hline $\begin{array}{c}2 \\
28 X-1\end{array}$ & 28.24 & $\begin{array}{l}40.04 \\
11.80\end{array}$ & $\begin{array}{c}6.32 \\
(5.48)\end{array}$ \\
\hline $\begin{array}{c}3 \\
29 X-2 \\
\end{array}$ & 26.06 & $\begin{array}{c}35.93 \\
9.87 \\
\end{array}$ & $\begin{array}{c}5.54 \\
(4.33) \\
\end{array}$ \\
\hline $\begin{array}{c}4 \\
30 X-3 \\
\end{array}$ & 26.08 & $\begin{array}{l}39.25 \\
13.17 \\
\end{array}$ & $\begin{array}{c}7.44 \\
(5.73) \\
\end{array}$ \\
\hline $\begin{array}{c}5 \\
31 X-2 \\
\end{array}$ & 26.09 & $\begin{array}{l}43.75 \\
16.66\end{array}$ & $\begin{array}{l}10.09 \\
(6.57)\end{array}$ \\
\hline $2^{\text {nd }} 31 X-2$ & & & 6.57 \\
\hline $\begin{array}{c}6 \\
31 X-6\end{array}$ & 26.08 & $\begin{array}{l}36.36 \\
10.28\end{array}$ & $\begin{array}{c}5.33 \\
(4.95)\end{array}$ \\
\hline $\begin{array}{c}7 \\
32 X-5 \\
\end{array}$ & 28.25 & $\begin{array}{l}41.22 \\
12.97\end{array}$ & $\begin{array}{c}7.27 \\
(5.70)\end{array}$ \\
\hline $2^{\text {nd }} 32 X-5$ & 26.07 & 29.42 & 3.35?? \\
\hline $\begin{array}{c}8 \\
33 X-2 \\
\end{array}$ & 26.05 & $\begin{array}{l}37.13 \\
11.08 \\
\end{array}$ & $\begin{array}{c}5.71 \\
(5.37) \\
\end{array}$ \\
\hline $\begin{array}{c}9 \\
33 X-6\end{array}$ & 28.26 & $\begin{array}{l}42.95 \\
14.69\end{array}$ & $\begin{array}{c}8.15 \\
(6.54)\end{array}$ \\
\hline $2^{\text {nd }} 33 X-6$ & & & 6.54 \\
\hline $\begin{array}{c}10 \\
35 X-3\end{array}$ & 26.07 & $\begin{array}{l}39.59 \\
13.07\end{array}$ & $\begin{array}{c}8.34 \\
(5.18)\end{array}$ \\
\hline $\begin{array}{c}11 \\
35 X-6\end{array}$ & 26.08 & $\begin{array}{l}42.35 \\
16.27\end{array}$ & $\begin{array}{c}9.09 \\
(7.18)\end{array}$ \\
\hline $\begin{array}{c}12 \\
36 X-3\end{array}$ & 28.27 & $\begin{array}{l}44.22 \\
15.95\end{array}$ & $\begin{array}{c}9.71 \\
(6.24)\end{array}$ \\
\hline $\begin{array}{c}13 \\
36-7\end{array}$ & 26.08 & $\begin{array}{l}39.15 \\
13.07\end{array}$ & $\begin{array}{c}7.16 \\
(5.91)\end{array}$ \\
\hline $\begin{array}{c}14 \\
37 X-3\end{array}$ & 26.07 & $\begin{array}{l}45.69 \\
19.62 \\
\end{array}$ & $\begin{array}{l}12.04 \\
(7.58)\end{array}$ \\
\hline $2^{\text {nd }} 37 X-3$ & & & 7.58 \\
\hline $\begin{array}{c}15 \\
39 X-2 \\
\end{array}$ & 26.08 & $\begin{array}{l}76.89 \\
50.81 \\
\end{array}$ & $\begin{array}{c}22.43 \\
(28.38) \\
\end{array}$ \\
\hline $\begin{array}{c}16 \\
40 X-1\end{array}$ & 26.07 & $\begin{array}{l}42.83 \\
16.76\end{array}$ & $\begin{array}{l}10.76 \\
(6.00)\end{array}$ \\
\hline $\begin{array}{c}17 \\
40 X-4 \\
\text { 2nd } \\
\end{array}$ & $\begin{array}{l}28.26 \\
28.26\end{array}$ & $\begin{array}{c}45.73 \\
17.47 \\
35.13 \\
6.87\end{array}$ & $\begin{array}{c}9.39 \\
(8.08) \\
6.87 \\
(0.00)\end{array}$ \\
\hline $\begin{array}{c}18 \\
41 X-1\end{array}$ & 26.08 & $\begin{array}{l}41.32 \\
15.24\end{array}$ & $\begin{array}{c}9.10 \\
(6.14)\end{array}$ \\
\hline $\begin{array}{c}19 \\
42 X-3\end{array}$ & 26.06 & $\begin{array}{l}42.02 \\
15.96\end{array}$ & $\begin{array}{c}9.95 \\
(6.01)\end{array}$ \\
\hline 20 & 26.05 & 56.85 & 16.55 \\
\hline
\end{tabular}




\begin{tabular}{|c|c|c|c|}
\hline $42 X-6$ & & 30.80 & $(14.35)$ \\
\hline $2^{\text {nd }} 42 X-6$ & & & 14.35 \\
\hline 21 & 26.10 & 58.02 & 16.71 \\
$43 X-4$ & & 31.92 & $(15.21)$ \\
\hline 22 & 26.07 & 73.54 & 28.58 \\
$45 X-2$ & & 47.47 & $(18.89)$ \\
\hline $2^{\text {nd }} 45 X-2$ & & & 18.89 \\
\hline 23 & 26.07 & 40.08 & 7.83 \\
$45 X-5$ & & 14.01 & $(6.18)$ \\
\hline 24 & 26.08 & 66.68 & 20.96 \\
$47 X-2$ & & 40.60 & $(19.64)$ \\
\hline 25 & 26.08 & 54.99 & 15.95 \\
$47 X-5$ & & 28.91 & $(12.96)$ \\
\hline 26 & 26.08 & 71.61 & 23.77 \\
$48 X-3$ & & 45.53 & $(21.76)$ \\
\hline 27 & 26.08 & 70.94 & 24.04 \\
$49 X-1$ & & 44.68 & $(20.82)$ \\
\hline 28 & 26.09 & 53.72 & 15.80 \\
$49 X-4$ & & 27.63 & $(11.83)$ \\
\hline 29 & 28.26 & 62.02 & 19.71 \\
$50 X-2$ & & 33.76 & $(13.95)$ \\
\hline $2^{\text {nd }} 50 X-2$ & & & $2 n d$ \\
\hline 30 & 26.07 & 54.87 & 15.76 \\
\hline $50 X-5$ & & 28.80 & $(13.04)$ \\
\hline & & & \\
\hline
\end{tabular}

\begin{tabular}{|c|c|c|c|}
\hline $\begin{array}{l}\text { Samples, } \\
\text { Leg, Core, } \\
\text { section }\end{array}$ & $\begin{array}{l}\text { Weight of } \\
\text { cup } \\
\text { without } \\
\text { sample }\end{array}$ & $\begin{array}{l}\text { Cup with } \\
\text { dry } \\
\text { sample. } \\
\text { Dry } \\
\text { weight }\end{array}$ & $\begin{array}{l}\text { Dry weight } \\
\text { processed } \\
\text { (gr. taken } \\
\text { out) }\end{array}$ \\
\hline Leg 120 & Leg 120 & Leg 120 & Leg 120 \\
\hline 1 & 26.08 & 44.64 & 10.04 \\
$10 \mathrm{H}-1$ & & 18.56 & $(8.52)$ \\
\hline 2 & 28.26 & 58.78 & 14.66 \\
$11 \mathrm{H}-2$ & & 30.52 & $(15.86)$ \\
\hline 3 & 28.26 & 48.92 & 10.99 \\
$11 \mathrm{H}-5$ & & 20.66 & $(9.67)$ \\
\hline 4 & 28.26 & 46.09 & 10.26 \\
$12 \mathrm{H}-1$ & & 17.83 & $(7.57)$ \\
\hline 5 & 26.08 & 39.40 & 6.88 \\
$12 \mathrm{H}-5$ & & 13.32 & $(6.44)$ \\
\hline 6 & 26.09 & 40.18 & 7.87 \\
$13 \mathrm{H}-2$ & & 14.09 & $(6.22)$ \\
\hline 7 & 26.28 & 44.08 & 9.71 \\
$13 \mathrm{H}-5$ & & 17.80 & $(8.09)$ \\
\hline 8 & 26.07 & 47.46 & 12.13 \\
$14 \mathrm{H}-2$ & & 21.39 & $(9.26)$ \\
\hline 9 & 28.27 & 47.31 & 10.80 \\
$14 \mathrm{H}-5$ & & 19.04 & $(8.24)$ \\
\hline 10 & 28.26 & 46.37 & 10.91 \\
\hline & & & \\
\hline
\end{tabular}




\begin{tabular}{|c|c|c|c|}
\hline $15 \mathrm{H}-2$ & & 18.11 & $(7.20)$ \\
\hline 11 & 28.27 & 51.26 & 13.52 \\
$15 \mathrm{H}-6$ & & 22.99 & $(9.47)$ \\
\hline 12 & 26.08 & 50.05 & 13.91 \\
$16 \mathrm{H}-4$ & & 23.97 & $(10.06)$ \\
\hline 13 & 26.07 & 43.51 & 10.03 \\
$16 \mathrm{H}-7$ & & 17.44 & $(7.41)$ \\
\hline 14 & 26.08 & 41.69 & 8.93 \\
$17 \mathrm{H}-4$ & & 15.61 & $(6.68)$ \\
\hline 15 & 26.06 & 52.81 & 15.16 \\
$17 \mathrm{H}-7$ & & 26.75 & $(11.59)$ \\
\hline 16 & 26.09 & 72.56 & 26.12 \\
$18 \mathrm{H}-4$ & & 46.47 & $(20.35)$ \\
\hline 17 & 26.06 & 41.05 & 7.73 \\
$19 \mathrm{H}-1$ & & 14.99 & $(7.26)$ \\
\hline 18 & 26.07 & 53.24 & 15.17 \\
$19 \mathrm{H}-4$ & & 27.17 & $(12.00)$ \\
\hline 19 & 28.27 & 55.06 & 16.14 \\
$20 \mathrm{H}-1$ & & 26.79 & $(10.65)$ \\
\hline 20 & 26.09 & 52.20 & 14.91 \\
$20 \mathrm{H}-5$ & & 26.11 & $(11.20)$ \\
\hline 21 & 26.09 & 43.14 & 9.78 \\
$23 \mathrm{X}-1$ & & 17.05 & $(7.27)$ \\
\hline 22 & 26.08 & 45.56 & 11.32 \\
$23 \mathrm{X}-3$ & & 19.48 & $(8.16)$ \\
\hline $2^{\text {nd }} 23 \mathrm{X}-3$ & & & 8.16 \\
\hline & & & \\
\hline
\end{tabular}

\begin{tabular}{|c|c|c|c|}
\hline $\begin{array}{c}\text { Samples, } \\
\text { Leg, Core, } \\
\text { section }\end{array}$ & $\begin{array}{c}\text { Weight of } \\
\text { cup } \\
\text { without } \\
\text { sample }\end{array}$ & $\begin{array}{c}\text { Cup with } \\
\text { dry } \\
\text { sample. } \\
\text { Dry weight }\end{array}$ & $\begin{array}{c}\text { Dry weight } \\
\text { processed } \\
\text { (gr. taken } \\
\text { out) }\end{array}$ \\
\hline Leg 29 & Leg 29 & Leg 29 & Leg 29 \\
\hline 1 & 28.27 & $\begin{array}{c}47.75 \\
19.48\end{array}$ & $\begin{array}{c}10.23 \\
(9.25)\end{array}$ \\
\hline $14-1$ & & 35.28 & 9.20 \\
\hline $2^{\text {nd }} 14-1$ & 26.08 & 50.13 & 12.09 \\
\hline 2 & 26.09 & $(11.95)$ \\
\hline $14-4$ & & 24.04 & 11.22 \\
\hline $2^{\text {nd }} 14-4$ & 26.06 & 37.28 & $(12.95)$ \\
\hline 3 & 26.07 & 52.41 & 13.39 \\
\hline $15-2$ & & 26.34 & 12.59 \\
\hline $2^{\text {nd }} 15-2$ & 26.07 & 38.66 & $(9.60)$ \\
\hline 4 & 26.08 & 46.38 & 10.70 \\
\hline $15-5$ & & 20.30 & 9.56 \\
\hline $2^{\text {nd }} 15-5$ & 28.26 & 37.82 & 15.61 \\
\hline 5 & 28.27 & 54.10 & $(10.22)$ \\
\hline $16-1$ & & 25.83 & 10.16 \\
\hline $2^{\text {nd }} 16-1$ & 28.27 & 38.43 & $(11.77)$ \\
\hline 6 & 26.07 & 53.24 & \\
\hline
\end{tabular}




\begin{tabular}{|c|c|c|c|}
\hline $16-4$ & & 27.17 & 15.40 \\
\hline $2^{\text {nd }} 16-4$ & 26.08 & 38.99 & 12.91 \\
\hline 7 & 28.27 & 52.55 & $(11.36)$ \\
\hline $17-3$ & & 24.28 & 12.92 \\
\hline $2^{\text {nd }} 17-3$ & 28.27 & 39.02 & 10.75 \\
\hline 8 & 28.27 & 53.53 & 13.29 \\
\hline $17-6$ & & 25.26 & (10.22) \\
\hline $2^{\text {nd }} 17-6$ & 26.05 & 37.35 & 11.30 \\
\hline 9 & 28.27 & 47.58 & 10.09 \\
\hline $18-3$ & & 19.31 & (9.22) \\
\hline $2^{\text {nd }} 18-3$ & 26.06 & 35.25 & 9.19 \\
\hline 10 & 28.26 & 46.00 & $(8.27)$ \\
\hline 20-2 & & 17.74 & 9.47 \\
\hline $2^{\text {nd }} 20-2$ & 28.27 & 36.54 & 8.27 \\
\hline 11 & 28.27 & 53.85 & $(11.97)$ \\
\hline 20-6 & & 25.58 & 13.61 \\
\hline $2^{\text {nd }} 20-6$ & 26.09 & 37.07 & 10.98 \\
\hline 12 & 26.09 & 42.37 & 8.79 \\
\hline $21-3$ & & 16.28 & (7.49) \\
\hline $2^{\text {nd }} 21-3$ & 26.09 & 33.41 & 7.32 \\
\hline 13 & 28.27 & 45.24 & 8.64 \\
\hline $22-2$ & & 16.97 & (8.33) \\
\hline $2^{\text {nd }} 22-2$ & 26.07 & 34.36 & 8.29 \\
\hline 14 & 26.08 & 54.90 & $(13.34)$ \\
\hline $23-3$ & & 28.82 & 15.48 \\
\hline $2^{\text {nd }} 23-3$ & 26.07 & 38.41 & 12.34 \\
\hline 15 & 28.26 & 47.93 & 8.18 \\
\hline $24-3$ & & 19.67 & (11.49) \\
\hline $2^{\text {nd }} 24-3$ & 26.08 & 36.90 & 10.82 \\
\hline 16 & 28.26 & 59.17 & $(14.50)$ \\
\hline $26-1$ & & 30.91 & 16.41 \\
\hline $2^{\text {nd }} 26-1$ & 26.08 & 39.84 & 13.76 \\
\hline 17 & 28.27 & 43.43 & 7.83 \\
\hline $26-4$ & & 15.16 & (7.33) \\
\hline $2^{\text {nd }} 26-4$ & 26.09 & 33.39 & 7.30 \\
\hline 18 & 26.07 & 49.96 & 15.19 \\
\hline $29-2$ & & 23.89 & (8.70) \\
\hline $2^{\text {nd }} 29-2$ & 26.09 & 39.65 & 13.56 \\
\hline 19 & 28.26 & 51.73 & $(11.45)$ \\
\hline $30-5$ & & 23.47 & 12.02 \\
\hline $2^{\text {nd }} 30-5$ & 28.26 & 39.67 & 11.41 \\
\hline 20 & 28.32 & 48.43 & 10.05 \\
\hline $32-1$ & & 20.11 & $(10.06)$ \\
\hline $2^{\text {nd }} 21-1$ & 26.08 & 35.60 & 9.52 \\
\hline 21 & 28.26 & 47.70 & $(9.06)$ \\
\hline $32-3$ & & 19.44 & 10.38 \\
\hline $2^{\text {nd }} 32-3$ & 26.05 & 35.09 & 9.04 \\
\hline 22 & 28.26 & 51.71 & $(11.17)$ \\
\hline $35-1$ & & 23.45 & 12.28 \\
\hline $2^{\text {nd }} 35-1$ & 28.26 & 39.42 & 11.16 \\
\hline
\end{tabular}




\begin{tabular}{|c|c|c|c|}
\hline 23 & 28.26 & 44.55 & $(7.53)$ \\
$36-2$ & & 16.29 & 8.76 \\
\hline $2^{\text {nd }} 36-2$ & 28.26 & 35.76 & 7.50 \\
\hline 24 & 28.32 & 48.18 & 9.93 \\
$37-3$ & & 19.86 & $(9.93)$ \\
\hline $2^{\text {nd }} 37-3$ & 26.08 & 35.90 & 9.82 \\
\hline 25 & 28.26 & 47.51 & 10.86 \\
$38-2$ & & 19.25 & $(8.39)$ \\
\hline $2^{\text {nd }} 38-2$ & 28.27 & 39.10 & 10.83 \\
\hline 26 & 28.26 & 53.75 & $(11.90)$ \\
$40-2$ & & 25.49 & 13.59 \\
\hline $2^{\text {nd }} 40-2$ & 40.13 & 28.25 & 11.88 \\
\hline 27 & 28.27 & 54.69 & $(12.90)$ \\
$42-2$ & & 26.42 & 13.52 \\
\hline $2^{\text {nd }} 42-2$ & 28.27 & 41.14 & 12.87 \\
\hline 28 & 28.25 & 51.72 & 13.13 \\
$43-1$ & & 23.47 & $(10.34)$ \\
\hline $2^{\text {nd }} 43-1$ & 26.08 & 36.39 & 10.31 \\
\hline
\end{tabular}

Sites below were initially processed and found to be either barren or too sparse to work with

\begin{tabular}{|c|c|c|c|}
\hline $\begin{array}{l}\text { Samples, } \\
\text { Leg, Core, } \\
\text { section }\end{array}$ & $\begin{array}{l}\text { Weight of } \\
\text { cup } \\
\text { without } \\
\text { sample }\end{array}$ & $\begin{array}{l}\text { Cup with } \\
\text { dry } \\
\text { sample. } \\
\text { Dry } \\
\text { weight }\end{array}$ & $\begin{array}{c}\text { Dry weight } \\
\text { processed } \\
\text { (gr. taken } \\
\text { out) }\end{array}$ \\
\hline$\underline{\text { Leg 113 }}$ & $\underline{\text { Leg 113 }}$ & $\underline{\underline{\text { Leg 113 }}}$ & $\underline{\underline{\text { 6eg 113 }}}$ \\
\hline 1 & 26.08 & $\underline{\underline{690 B}}$ & $\underline{\mathbf{6 9 0 B}}$ \\
\hline $9 \mathrm{H}-1$ & & 14.85 & 8.56 \\
\hline 2 & 28.27 & 48.19 & $(6.29)$ \\
\hline $9 \mathrm{H}-3$ & & 19.92 & 11.04 \\
\hline 3 & 28.27 & 41.94 & $8.88)$ \\
\hline $9 \mathrm{H}-6$ & & 13.67 & $(5.56)$ \\
\hline 4 & 26.06 & 46.02 & 11.69 \\
$10 \mathrm{H}-2$ & & 19.96 & $(8.27)$ \\
\hline 5 & 28.27 & 45.03 & 9.92 \\
$10-4$ & & 16.76 & $(6.84)$ \\
\hline 6 & 28.26 & 40.22 & 6.97 \\
$11 \mathrm{H}-1$ & & 11.96 & $(4.99)$ \\
\hline 7 & 28.28 & 48.53 & 10.92 \\
$11 \mathrm{H}-3$ & & 20.25 & $(9.33)$ \\
\hline 8 & 28.26 & 42.14 & 8.03 \\
$11 \mathrm{H}-6$ & & 13.88 & $(5.85)$ \\
\hline 9 & 28.27 & 45.37 & 9.67 \\
$12 \mathrm{H}-2$ & & 17.10 & $(7.43)$ \\
\hline & & & \\
\hline
\end{tabular}




\begin{tabular}{|c|c|c|c|}
\hline 10 & 28.27 & 49.05 & 12.21 \\
$12 \mathrm{H}-5$ & & 21.78 & 9.57 \\
\hline 11 & 26.09 & 48.26 & 12.16 \\
$13 \mathrm{H}-1$ & & 22.17 & $(10.01)$ \\
\hline 12 & 26.08 & 44.76 & 11.10 \\
$13 \mathrm{H}-4$ & & 18.68 & $(7.58)$ \\
\hline 13 & 26.06 & 47.53 & 12.49 \\
$13 \mathrm{H}-6$ & & 21.45 & $(8.96)$ \\
\hline 14 & 26.12 & 44.32 & 9.82 \\
$14 \mathrm{H}-3$ & & 18.20 & $(8.38)$ \\
\hline 15 & 28.28 & 45.74 & 9.93 \\
$14 \mathrm{H}-6$ & & 17.46 & $(7.53)$ \\
\hline 16 & 26.08 & 52.64 & 14.75 \\
$15-2$ & & 26.56 & $(11.81)$ \\
\hline 17 & 26.09 & 42.40 & 9.34 \\
$15 \mathrm{H}-5$ & & 16.31 & $(6.97)$ \\
\hline
\end{tabular}

\begin{tabular}{|c|c|c|c|}
\hline $\begin{array}{l}\text { Samples, } \\
\text { Leg, Core, } \\
\text { section }\end{array}$ & $\begin{array}{l}\text { Weight of } \\
\text { cup } \\
\text { without } \\
\text { sample }\end{array}$ & $\begin{array}{l}\text { Cup with } \\
\text { dry } \\
\text { sample. } \\
\text { Dry } \\
\text { weight }\end{array}$ & $\begin{array}{l}\text { Dry weight } \\
\text { processed } \\
\text { ( gr. taken } \\
\text { out) }\end{array}$ \\
\hline Leg 119 & Leg 119 & Leg 119 & Leg 119 \\
\hline 1 & 28.27 & 39.08 & 6.18 \\
\hline $3 \mathrm{H}-5$ & & 10.81 & $(4.63)$ \\
\hline $2^{\text {nd }} 3 \mathrm{H}-5$ & & & 4.63 \\
\hline 5 & 28.27 & 40.43 & 7.04 \\
\hline $5 \mathrm{H}-5$ & & 12.16 & $(5.12)$ \\
\hline $2^{\text {nd }} 5 \mathrm{H}-5$ & & & 5.12 \\
\hline 9 & 28.27 & 39.38 & 6.11 \\
\hline $7 H-6$ & & 11.11 & $(5.00)$ \\
\hline $2^{\text {nd }} 7 \mathrm{H}-6$ & & & 5.00 \\
\hline 13 & 28.27 & 39.50 & 6.16 \\
\hline $10 \mathrm{H}-3$ & & 11.23 & (5.07) \\
\hline $2^{\text {nd }} 10 \mathrm{H}-3$ & & & 5.07 \\
\hline 17 & 28.27 & 40.79 & 7.29 \\
\hline $13 \mathrm{H}-1$ & & 12.52 & (5.23) \\
\hline $2^{\text {nd }} 13 \mathrm{H}-1$ & & & 5.23 \\
\hline 21 & 28.27 & 39.84 & 6.53 \\
\hline $17 X-2$ & & 11.57 & $(5.04)$ \\
\hline $2^{\text {nd }} 17 X-2$ & & & 5.04 \\
\hline 25 & 28.27 & 38.32 & 5.15 \\
\hline $19 x-6$ & & 10.05 & $(4.90)$ \\
\hline $2^{\text {nd }} 19 X-6$ & & & 4.90 \\
\hline 29 & 28.32 & 40.15 & 6.93 \\
\hline $24 X-1$ & & 11.83 & (4.90) \\
\hline 4 & 28.27 & 37.64 & $(4.12)$ \\
\hline $5 \mathrm{H}-1$ & & 9.37 & 5.25 \\
\hline 8 & 28.26 & 39.37 & (5.05) \\
\hline $7 \mathrm{H}-3$ & & 11.11 & 6.06 \\
\hline
\end{tabular}




\begin{tabular}{|c|c|c|c|}
\hline $\begin{array}{c}12 \\
9 \mathrm{H}-4\end{array}$ & 26.07 & $\begin{array}{l}40.20 \\
14.13\end{array}$ & $\begin{array}{c}(6.64) \\
7.49\end{array}$ \\
\hline $2^{\text {nd }} 9 \mathrm{H}-4$ & & & 7.49 \\
\hline $\begin{array}{c}14 \\
11 \mathrm{H}-3\end{array}$ & 28.27 & $\begin{array}{l}39.39 \\
11.12\end{array}$ & $\begin{array}{c}(4.94) \\
6.18\end{array}$ \\
\hline $\begin{array}{c}16 \\
12 \mathrm{H}-4\end{array}$ & 26.06 & $\begin{array}{l}37.52 \\
11.46\end{array}$ & $\begin{array}{c}(5.02) \\
6.44\end{array}$ \\
\hline $\begin{array}{c}20 \\
15 X-5\end{array}$ & 28.26 & $\begin{array}{l}41.91 \\
13.65\end{array}$ & $\begin{array}{c}(5.90) \\
7.75\end{array}$ \\
\hline $\begin{array}{c}24 \\
19 X-3\end{array}$ & 26.07 & $\begin{array}{l}37.66 \\
11.59\end{array}$ & $\begin{array}{c}(4.94) \\
6.65\end{array}$ \\
\hline $\begin{array}{c}30 \\
24 X-3\end{array}$ & 28.27 & $\begin{array}{l}41.59 \\
13.32\end{array}$ & $\begin{array}{c}(5.85) \\
7.47\end{array}$ \\
\hline $\begin{array}{c}2 \\
4 \mathrm{H}-2\end{array}$ & 26.09 & $\begin{array}{l}39.76 \\
13.67\end{array}$ & $\begin{array}{c}(6.09) \\
7.58\end{array}$ \\
\hline $\begin{array}{c}6 \\
6 \mathrm{H}-2\end{array}$ & 26.07 & $\begin{array}{l}39.37 \\
13.30\end{array}$ & $\begin{array}{c}(6.70) \\
6.60\end{array}$ \\
\hline $\begin{array}{c}7 \\
6 \mathrm{H}-6\end{array}$ & 26.08 & $\begin{array}{l}44.10 \\
18.02\end{array}$ & $\begin{array}{c}(8.51) \\
9.51\end{array}$ \\
\hline $\begin{array}{c}10 \\
8 \mathrm{H}-4\end{array}$ & 26.08 & $\begin{array}{l}37.98 \\
11.90\end{array}$ & $\begin{array}{c}(5.35) \\
6.55\end{array}$ \\
\hline $\begin{array}{c}15 \\
11 \mathrm{H}-6\end{array}$ & 26.07 & $\begin{array}{l}39.28 \\
13.21\end{array}$ & $\begin{array}{c}(5.97) \\
7.24\end{array}$ \\
\hline $\begin{array}{c}18 \\
14 X-2\end{array}$ & 26.08 & $\begin{array}{l}38.24 \\
12.16\end{array}$ & $\begin{array}{c}(5.91) \\
5.25\end{array}$ \\
\hline $\begin{array}{c}22 \\
17 X-5 \\
\end{array}$ & 26.06 & $\begin{array}{l}36.57 \\
10.51\end{array}$ & $\begin{array}{c}(4.98) \\
5.53\end{array}$ \\
\hline $\begin{array}{c}26 \\
20 X-3\end{array}$ & 26.07 & $\begin{array}{l}38.72 \\
12.65\end{array}$ & $\begin{array}{c}(5.96) \\
6.69\end{array}$ \\
\hline $\begin{array}{c}3 \\
4 \mathrm{H}-5\end{array}$ & 28.28 & $\begin{array}{c}37.56 \\
9.28\end{array}$ & $\begin{array}{c}(3.80) \\
5.48\end{array}$ \\
\hline $\begin{array}{c}11 \\
8 \mathrm{H}-7\end{array}$ & 26.08 & $\begin{array}{l}41.75 \\
15.67\end{array}$ & $\begin{array}{c}(6.28) \\
9.39\end{array}$ \\
\hline $\begin{array}{c}19 \\
15 X-2\end{array}$ & 26.08 & $\begin{array}{l}39.88 \\
13.80\end{array}$ & $\begin{array}{c}(6.13) \\
7.67\end{array}$ \\
\hline $\begin{array}{c}23 \\
18 X-4\end{array}$ & 26.08 & $\begin{array}{c}35.74 \\
9.66\end{array}$ & $\begin{array}{c}(4.08) \\
5.58\end{array}$ \\
\hline $\begin{array}{c}27 \\
21 X-3\end{array}$ & 28.26 & $\begin{array}{l}40.76 \\
12.50\end{array}$ & $\begin{array}{c}(5.92) \\
6.58\end{array}$ \\
\hline $\begin{array}{c}28 \\
22 X-2\end{array}$ & 26.11 & $\begin{array}{l}38.39 \\
12.28\end{array}$ & $\begin{array}{c}(5.70) \\
6.58\end{array}$ \\
\hline
\end{tabular}




\section{SITE 696B LEG 113 TOTAL ABUNDANCE}

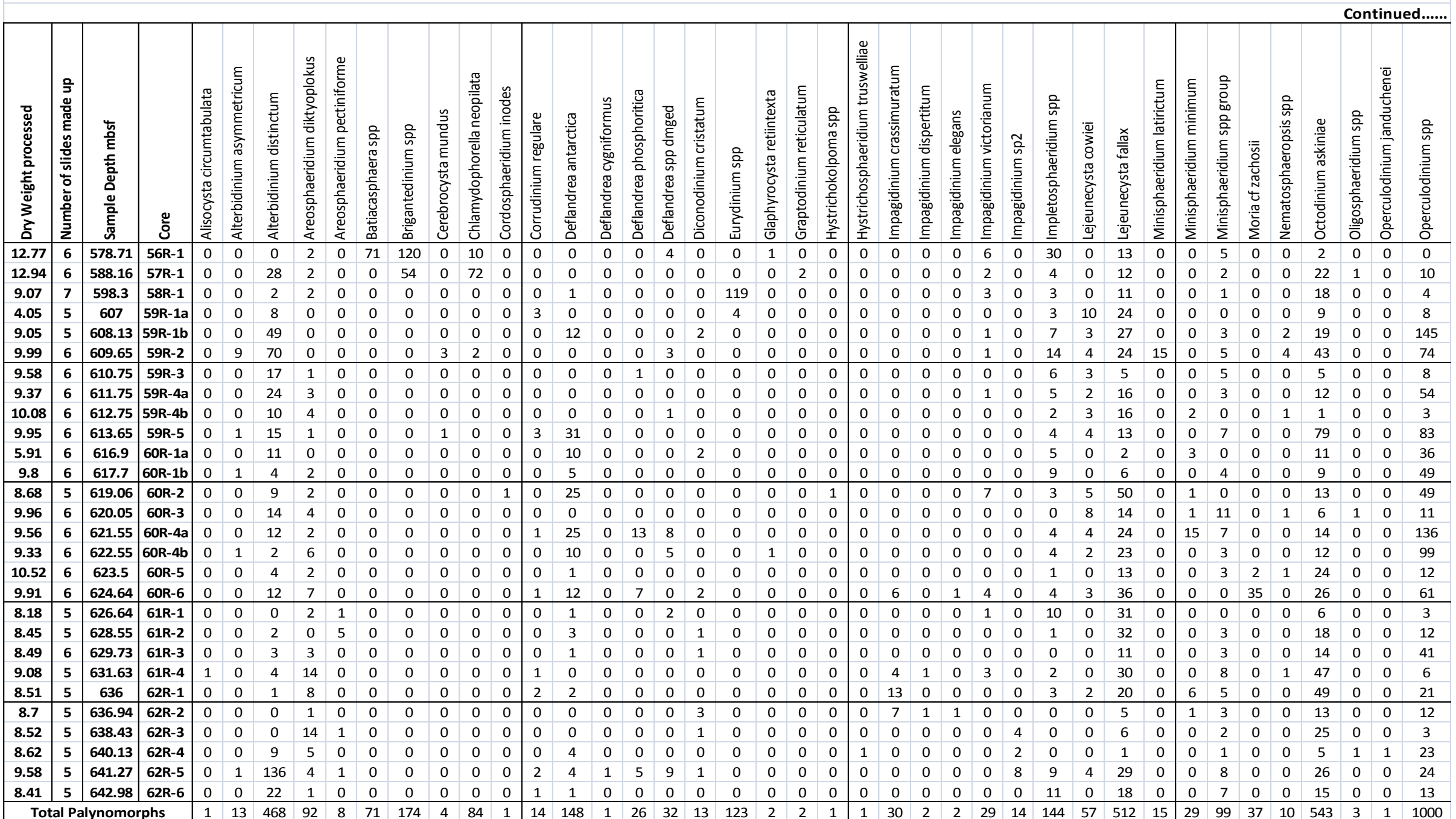




\section{SITE 696B LEG 113 TOTAL ABUNDANCE}

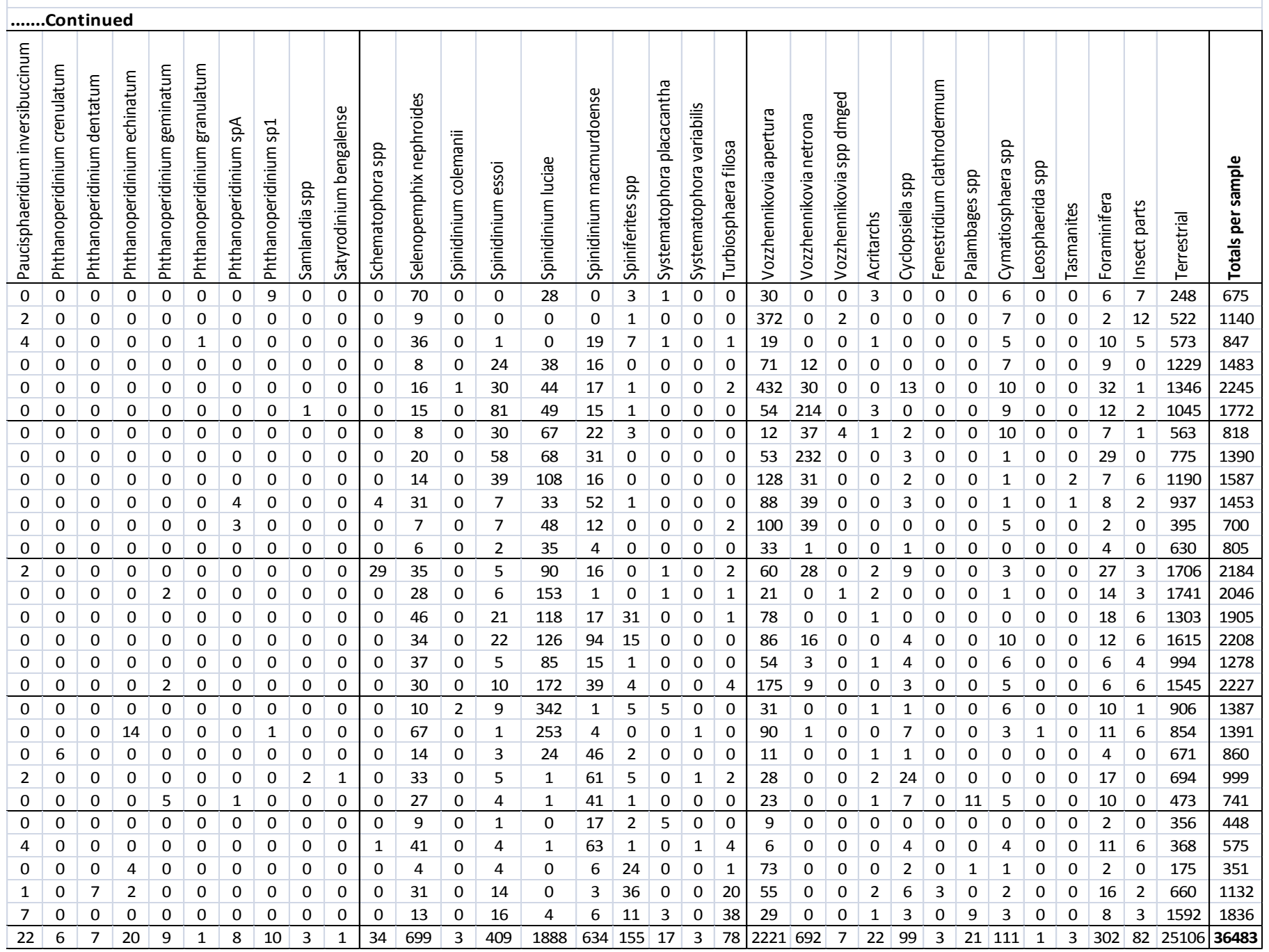




\section{SITE 699A LEG 114 TOTAL ABUNDANCE}

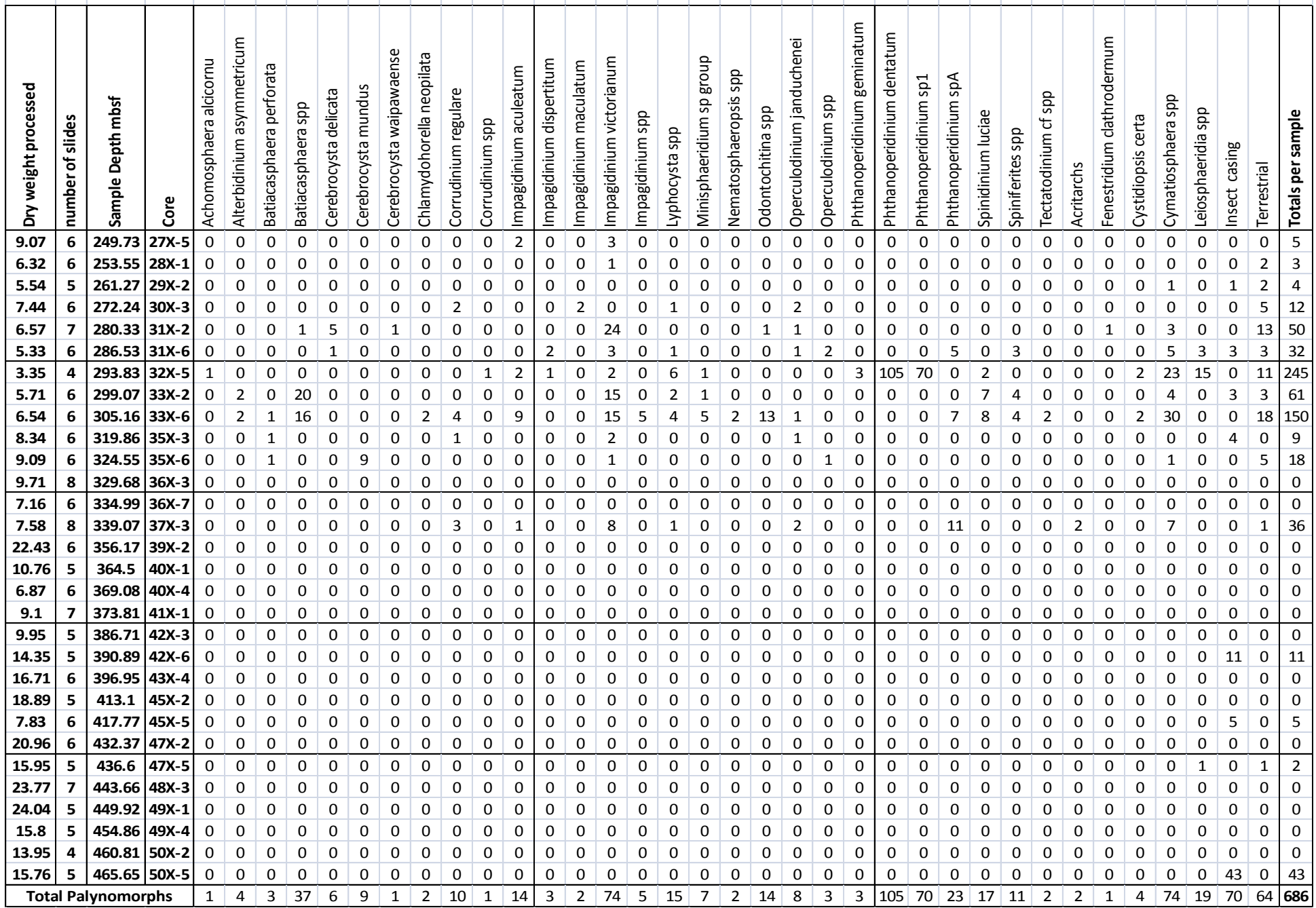




\section{SITE 748B LEG 120 TOTAL ABUNDANCE}

Continued.......

\begin{tabular}{|c|c|c|c|c|c|c|c|c|c|c|c|c|c|c|c|c|c|c|c|c|c|c|c|c|c|c|c|c|c|c|c|c|c|c|c|c|c|c|c|}
\hline 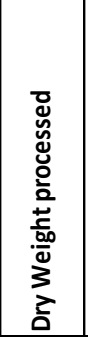 & 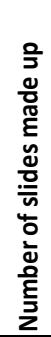 & 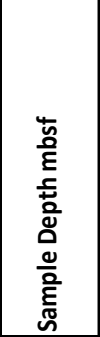 & ্ֻّ) & 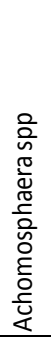 & 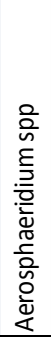 & 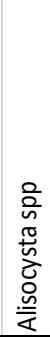 & 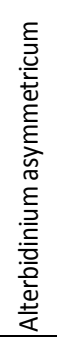 & 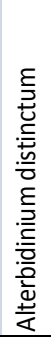 & 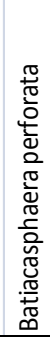 & 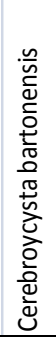 & 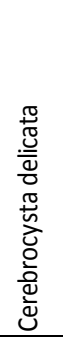 & 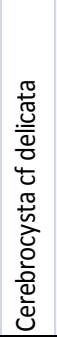 & 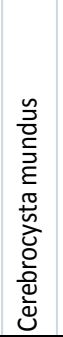 & 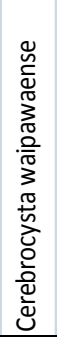 & 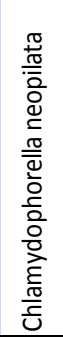 & 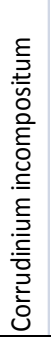 & 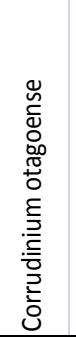 & 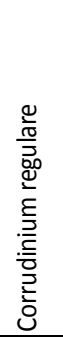 & 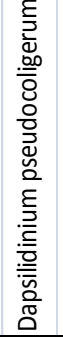 & 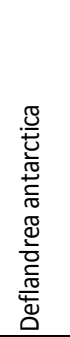 & 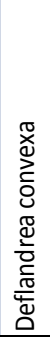 & 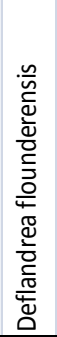 & 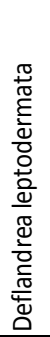 & 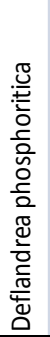 & 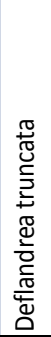 & 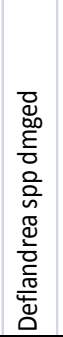 & $\begin{array}{l}\vec{a} \\
\bar{n} \\
\circ \\
\stackrel{0}{0}\end{array}$ & 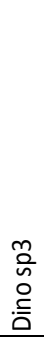 & 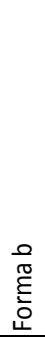 & 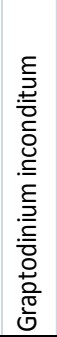 & 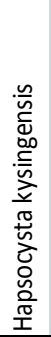 & 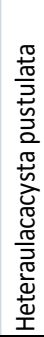 & 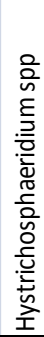 & 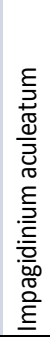 & 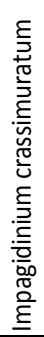 & 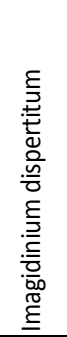 & 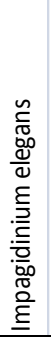 & 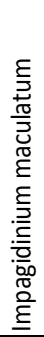 & 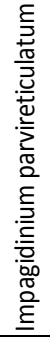 \\
\hline \begin{tabular}{|l|}
10.4 \\
\end{tabular} & 4 & \begin{tabular}{|l|}
76.83 \\
\end{tabular} & |10H-1 & 0 & 0 & 0 & 0 & 0 & 0 & 0 & 0 & 0 & 0 & 0 & 0 & 0 & 0 & 0 & 0 & 0 & 0 & 0 & 0 & 0 & 0 & 0 & 0 & 0 & 0 & 0 & 0 & 0 & 0 & 0 & 0 & 0 & 0 & 0 & 0 \\
\hline 14.66 & 4 & 87.62 & $11 \mathrm{H}-2$ & 0 & 0 & 0 & 0 & 0 & 0 & 0 & 0 & 0 & 0 & 0 & 0 & 0 & 0 & 0 & 0 & 0 & 0 & 0 & 0 & 0 & 0 & 0 & 0 & U & U & 0 & 0 & 0 & 0 & 0 & 0 & 0 & 0 & 0 & 0 \\
\hline 10.99 & 3 & 92.14 & $11 \mathrm{H}-5$ & 0 & 0 & 0 & 0 & 0 & 0 & 0 & 0 & 0 & 0 & 0 & 0 & 0 & 0 & 0 & 0 & 0 & 0 & 0 & 0 & 0 & 0 & 0 & 0 & U & U & 0 & 0 & 0 & 0 & 0 & 0 & 0 & 0 & 0 & 0 \\
\hline 10.26 & 3 & 95.75 & $12 \mathrm{H}-1$ & 0 & 0 & 0 & 0 & 0 & 0 & 0 & 0 & 0 & 0 & 0 & 0 & 0 & 0 & 0 & 0 & 0 & 0 & 0 & 0 & 0 & 0 & 0 & 0 & 0 & 0 & 0 & 0 & 0 & 0 & 0 & 0 & 0 & 0 & 0 & 0 \\
\hline 6.88 & 3 & 102.02 & $12 \mathrm{H}-5$ & 0 & 0 & 0 & 0 & 0 & 0 & 0 & 0 & 0 & 0 & 0 & 0 & 0 & 0 & 0 & 0 & 0 & 0 & 0 & 0 & 0 & 0 & 0 & 0 & 0 & 0 & 0 & 0 & 0 & 0 & 0 & 0 & 0 & 0 & 0 & 0 \\
\hline 7.87 & 3 & 106.65 & \begin{tabular}{|l|}
$13 \mathrm{H}-2$ \\
\end{tabular} & 0 & 0 & 0 & 0 & 0 & 0 & 0 & 0 & 0 & 0 & 0 & 0 & 0 & 0 & 0 & 0 & 0 & 0 & 0 & 0 & 0 & 0 & 0 & 0 & 0 & 0 & 0 & 0 & 0 & 0 & 0 & 0 & 0 & 0 & 0 & 0 \\
\hline 9.71 & 3 & 111.67 & $13 \mathrm{H}-5$ & 0 & 0 & 0 & 0 & 0 & 0 & 0 & 0 & 0 & 0 & 0 & 0 & 0 & 0 & 0 & 0 & c & 0 & 0 & 0 & 0 & 0 & 0 & 0 & $C$ & c & 0 & 0 & 0 & 0 & 0 & 0 & 0 & 0 & 0 & 0 \\
\hline 12.13 & 5 & 115.9 & $14 \mathrm{H}-2$ & 0 & 0 & 0 & 0 & 0 & 0 & 0 & 0 & 0 & 0 & 0 & 0 & 0 & 0 & 0 & 0 & 0 & 0 & 0 & 0 & 0 & 0 & 0 & 0 & 0 & 0 & 0 & 0 & 0 & 0 & 0 & 0 & 0 & 0 & 0 & 0 \\
\hline 10.8 & 6 & 120.65 & $14 \mathrm{H}-5$ & 0 & 0 & 0 & 0 & 0 & 0 & 0 & 0 & 0 & 0 & 0 & 0 & 0 & 0 & 0 & 0 & 0 & 0 & 0 & 0 & 0 & 0 & c & 0 & & 0 & 0 & 0 & 0 & 0 & 0 & 0 & 0 & 0 & 0 & 0 \\
\hline 10.91 & 6 & 126.36 & $15 \mathrm{H}-2$ & 0 & 0 & 0 & 0 & 0 & 3 & 0 & 0 & 0 & 1 & 0 & 0 & 0 & 0 & 4 & 0 & 0 & 0 & 0 & 0 & 0 & 0 & 0 & 0 & U & 0 & 0 & 0 & 0 & 0 & 0 & 0 & 0 & 0 & 0 & 0 \\
\hline 13.52 & 4 & 132 & $15 \mathrm{H}-6$ & 0 & 0 & 0 & 0 & 0 & 0 & 0 & 0 & 0 & 0 & 0 & 0 & 0 & 0 & 0 & 0 & 0 & 0 & 0 & 0 & 0 & 0 & 0 & 0 & 0 & 0 & 0 & 0 & 0 & 0 & 0 & 0 & 0 & 0 & 0 & 0 \\
\hline 13.91 & 2 & 137.68 & $16 \mathrm{H}-4$ & 0 & 0 & 0 & 0 & 0 & 0 & 0 & 0 & 0 & 0 & 0 & 0 & 0 & 0 & 4 & 0 & 0 & 0 & 0 & 0 & 0 & 0 & 0 & 0 & 0 & 0 & 0 & 0 & 0 & 0 & 0 & 0 & 0 & 0 & 0 & 0 \\
\hline 10.03 & 3 & 141.81 & $\mid 16 \mathrm{H}-7$ & 0 & 0 & 0 & 0 & 0 & 0 & 0 & 0 & 1 & 0 & 0 & 0 & 0 & 0 & 11 & 0 & 0 & 0 & 0 & 0 & 0 & 0 & 1 & 0 & 0 & 0 & 0 & 0 & 0 & 0 & 0 & 2 & 0 & 0 & 0 & 0 \\
\hline 8.93 & 4 & 148.78 & $17 \mathrm{H}-4$ & 0 & 0 & 0 & 160 & 1 & 0 & 0 & 1 & 2 & 0 & 0 & 195 & 0 & 0 & 80 & 0 & 0 & 0 & 0 & 0 & 0 & 0 & 0 & 0 & 0 & 0 & 0 & 0 & 0 & 0 & 30 & 0 & 54 & 0 & 0 & 0 \\
\hline 15.16 & 5 & 152.11 & $17 \mathrm{H}-7$ & 0 & 0 & 0 & 0 & 0 & 0 & 0 & 3 & 0 & 0 & 0 & 0 & 0 & 0 & 10 & 0 & 0 & 0 & 0 & 0 & 0 & 0 & 0 & 0 & 0 & 0 & 0 & 0 & 0 & 0 & 2 & 3 & 16 & 0 & 0 & 0 \\
\hline 26.12 & 10 & 156.9 & $18 \mathrm{H}-4$ & 64 & 0 & 0 & 0 & 1 & 0 & 0 & 0 & 9 & 0 & 4 & 20 & 0 & 0 & 35 & 0 & 118 & 0 & 25 & 0 & 0 & 0 & 71 & 129 & 0 & 0 & 30 & 0 & 0 & 6 & 6 & 0 & 5 & 1 & 1 & 0 \\
\hline 7.73 & 4 & 162.1 & $19 \mathrm{H}-1$ & 1 & 0 & 0 & 0 & 0 & 20 & 0 & 10 & 2 & 0 & 2 & 0 & 0 & 0 & 4 & 0 & 888 & 43 & 0 & 24 & 6 & 1 & 0 & 0 & 0 & 0 & 0 & 0 & 1 & 30 & 0 & 0 & 1 & 1 & 0 & 18 \\
\hline 15.17 & 4 & 167.39 & $19 \mathrm{H}-4$ & 0 & 0 & 2 & 0 & 6 & 0 & 0 & 22 & 24 & 2 & 1 & 0 & 5 & 0 & 8 & 0 & 3 & 0 & 0 & 0 & 0 & 0 & 0 & 0 & 0 & 0 & 0 & 4 & 0 & 0 & 13 & 0 & 10 & 1 & 0 & 0 \\
\hline 16.14 & 6 & 172.12 & $2 \mathrm{OH}-1$ & 0 & 1 & 0 & 0 & 0 & 0 & 0 & 23 & 10 & 0 & 6 & 0 & 0 & 0 & 6 & 10 & 3 & 0 & 0 & 0 & 0 & 0 & 0 & 0 & 0 & 36 & 0 & 0 & 0 & 13 & $y$ & 0 & 0 & 0 & 0 & 0 \\
\hline 14.91 & 4 & 177.76 & $2 \mathrm{OH}-5$ & 25 & 0 & 0 & 0 & 0 & 0 & 30 & 118 & 16 & 0 & 0 & 0 & 0 & 0 & 23 & 0 & 1 & 0 & 0 & 0 & 0 & 0 & 0 & 0 & 0 & 0 & 0 & 0 & 0 & 3 & 26 & 0 & 14 & 0 & 0 & 787 \\
\hline 9.78 & 5 & 197.38 & $\mathrm{x}-1$ & 6 & 3 & 0 & 0 & 0 & 1 & 40 & 46 & 2 & 0 & 51 & 37 & 0 & 153 & 0 & 0 & 1 & 0 & 0 & 0 & 1 & 0 & 13 & c & & 0 & 0 & 0 & 0 & 2 & 7 & 0 & 14 & 0 & 4 & 0 \\
\hline 8.16 & 7 & 200.47 & $23 X-3$ & 0 & 0 & 3 & 0 & 0 & 2 & 8 & 9 & 3 & 10 & 0 & 0 & 0 & 2 & 0 & 0 & 29 & 0 & 0 & 0 & 0 & 0 & 4 & 0 & 2 & 0 & 0 & 0 & 0 & 1 & 0 & 0 & 19 & 0 & 1 & 0 \\
\hline Pal & & & cars & 96 & 4 & 5 & 160 & 8 & 26 & 78 & 232 & 69 & 13 & 64 & 252 & 5 & 155 & 185 & 10 & 1060 & 43 & 25 & 24 & 7 & 1 & 89 & 129 & & 36 & 30 & & 1 & & 93 & & 133 & & & 805 \\
\hline
\end{tabular}




\section{SITE 748B LEG 120 TOTAL ABUNDANCE}

\begin{tabular}{|c|c|c|c|c|c|c|c|c|c|c|c|c|c|c|c|c|c|c|c|c|c|c|c|c|c|c|c|c|c|c|c|c|c|c|c|c|c|}
\hline \multicolumn{38}{|c|}{.......Continued } \\
\hline 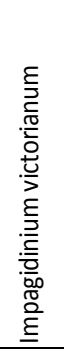 & 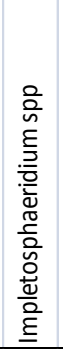 & 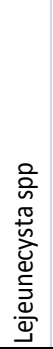 & 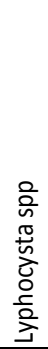 & 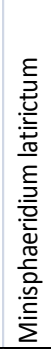 & 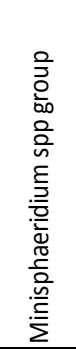 & 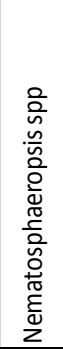 & 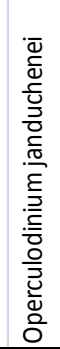 & 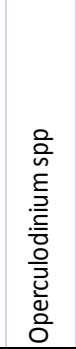 & 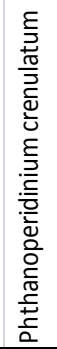 & 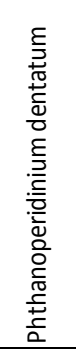 & 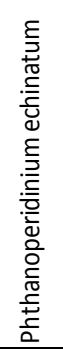 & 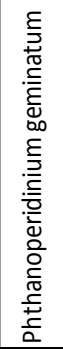 & 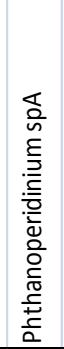 & 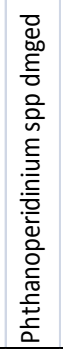 & 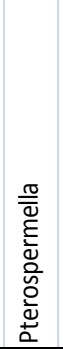 & 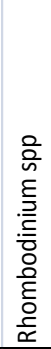 & 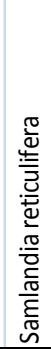 & 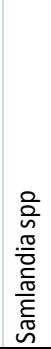 & 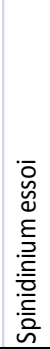 & 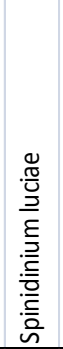 & 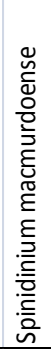 & 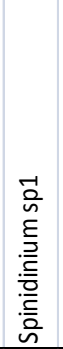 & 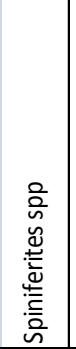 & 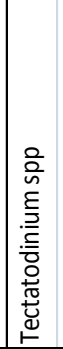 & 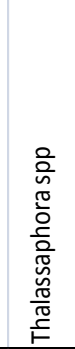 & 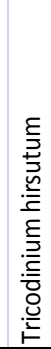 & 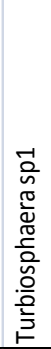 & 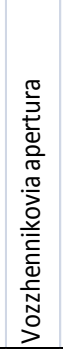 & 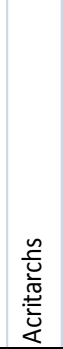 & 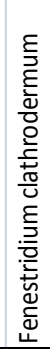 & 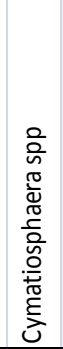 & 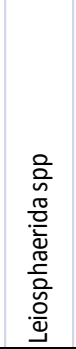 & 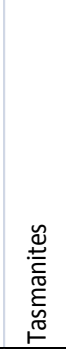 & 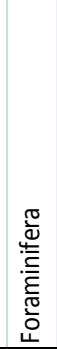 & 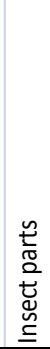 & 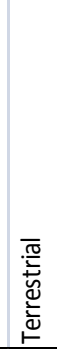 & 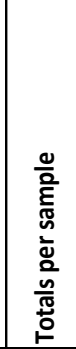 \\
\hline 0 & 0 & 0 & 0 & 0 & 0 & 0 & 0 & 0 & 0 & 0 & 0 & 0 & 0 & 0 & 0 & 0 & 0 & 0 & 0 & 0 & 0 & 0 & 0 & 0 & 0 & 0 & 0 & 0 & 0 & 0 & 0 & 0 & 0 & 0 & 0 & 0 & 0 \\
\hline 0 & 0 & 0 & 0 & 0 & 0 & 0 & 0 & 0 & 0 & 0 & 0 & 0 & 0 & 0 & 0 & 0 & 0 & 0 & 0 & 0 & 0 & 0 & 0 & 0 & 0 & 0 & 0 & 0 & 0 & 0 & 0 & 0 & & 0 & 0 & 0 & 0 \\
\hline 0 & 0 & 0 & 0 & 0 & 0 & 0 & 0 & 0 & 0 & 0 & 0 & 0 & 0 & 0 & 0 & 0 & 0 & 0 & 0 & 0 & 0 & 0 & 0 & 0 & 0 & 0 & 0 & 0 & 0 & 0 & 0 & 0 & 0 & 0 & 0 & 0 & 0 \\
\hline 0 & 0 & 0 & 0 & 0 & 0 & 0 & 0 & 0 & 0 & 0 & 0 & 0 & 0 & 0 & 0 & 0 & 0 & 0 & 0 & 0 & 0 & 0 & 0 & 0 & 0 & 0 & 0 & 0 & 0 & 0 & 0 & 0 & 0 & 0 & 0 & 0 & 0 \\
\hline 0 & 0 & 0 & 0 & 0 & 0 & 0 & 0 & 0 & 0 & 0 & 0 & 0 & 0 & 0 & 0 & 0 & 0 & 0 & 0 & 0 & 0 & 0 & 0 & 0 & 0 & 0 & 0 & 0 & 0 & 0 & 0 & 0 & 0 & 0 & 0 & 0 & 0 \\
\hline 0 & 0 & 0 & 0 & 0 & 0 & 0 & 0 & 0 & 0 & 0 & 0 & 0 & 0 & 0 & 0 & 0 & 0 & 0 & 0 & 0 & 0 & 0 & 0 & 0 & 0 & 0 & 0 & 0 & 0 & 0 & 0 & 0 & 0 & 0 & 0 & 0 & 0 \\
\hline 0 & 0 & 0 & 0 & 0 & 0 & 0 & 0 & 0 & 0 & 0 & 0 & 0 & 0 & 0 & 0 & 0 & 0 & 0 & 0 & 0 & 0 & 0 & 0 & 0 & 0 & 0 & 0 & 0 & 0 & 0 & 0 & 0 & 0 & 0 & 0 & 0 & 0 \\
\hline 0 & 0 & 0 & 0 & 0 & 0 & 0 & 0 & 0 & 0 & 0 & 0 & 0 & 0 & 0 & 0 & 0 & 0 & 0 & 0 & 0 & 0 & 0 & 0 & 0 & 0 & 0 & 0 & 0 & 0 & 0 & 0 & 0 & 0 & 0 & 0 & 0 & 0 \\
\hline 0 & 0 & 0 & 0 & 0 & 0 & 0 & 0 & 0 & 0 & 0 & 0 & 0 & 0 & 0 & c & 0 & 0 & 0 & 0 & 0 & 0 & 0 & 0 & 0 & 0 & 0 & 0 & 0 & 0 & 0 & 0 & 0 & 0 & 0 & 0 & 0 & 0 \\
\hline 49 & 0 & 0 & 0 & 0 & 0 & 0 & 1 & 1 & 0 & 0 & 0 & 0 & 0 & 0 & 0 & 0 & 6 & 0 & 0 & 0 & 0 & 0 & 0 & 0 & 0 & 0 & 0 & 0 & 0 & 0 & 0 & 0 & 2 & 0 & 0 & 1 & 68 \\
\hline 0 & 0 & 0 & 0 & 0 & 0 & 0 & 0 & 0 & 0 & 0 & 0 & 0 & 0 & 0 & 0 & 0 & 0 & 0 & 0 & 0 & 0 & 0 & 0 & 0 & 0 & 0 & 0 & 0 & 0 & 0 & 0 & 0 & 0 & 0 & 0 & 0 & 0 \\
\hline 2 & 0 & 0 & 0 & 0 & 0 & 0 & 1 & 0 & 0 & 0 & 0 & 0 & 0 & 0 & 0 & 0 & 0 & 0 & 0 & 0 & 0 & 0 & 0 & 0 & 0 & 0 & 0 & 0 & 0 & 0 & 0 & 0 & 0 & 0 & 0 & 1 & 8 \\
\hline 3 & 0 & 0 & 1 & 0 & 0 & 1 & 5 & 0 & 0 & 0 & 0 & 0 & 0 & 0 & 0 & 0 & 0 & 0 & 0 & 63 & 0 & 0 & 2 & 0 & 0 & 0 & 0 & 3 & 0 & 0 & 22 & 8 & 0 & 15 & 0 & 8 & 146 \\
\hline 16 & 0 & 3 & 12 & 0 & 0 & 8 & 32 & 108 & 0 & 1233 & 0 & 0 & 3 & 0 & 0 & 0 & 0 & 0 & 0 & 16 & 0 & 0 & $\varepsilon$ & 0 & 0 & 0 & 0 & 0 & 0 & 0 & 131 & 365 & 18 & 0 & 0 & 4 & 2480 \\
\hline 2 & 0 & 0 & 3 & 0 & 6 & 10 & 6 & 8 & 0 & 0 & 65 & 98 & 0 & 42 & 0 & 0 & 0 & 0 & 0 & 28 & 0 & 2 & 2 & 0 & 0 & 0 & 0 & 0 & 518 & 0 & 19 & 475 & 0 & 0 & 0 & 2 & 1320 \\
\hline 3 & 0 & 0 & 5 & 0 & 44 & 19 & 5 & 0 & 49 & 0 & 50 & 0 & 0 & 0 & 0 & 0 & 0 & 0 & 0 & 0 & 0 & 501 & 111 & 0 & 0 & 0 & 0 & 140 & 0 & 1 & 130 & 2500 & 77 & 0 & 4 & 4 & 4168 \\
\hline 1 & 0 & 0 & 0 & 0 & 4 & 0 & 0 & 5 & 0 & 0 & 2 & 0 & 0 & 0 & 0 & 5 & 4 & 25 & 0 & 0 & 0 & 0 & 46 & 0 & 3310 & 0 & 27 & 1 & 0 & 0 & 2 & 12 & 2 & 0 & 0 & 0 & 4498 \\
\hline 2 & 0 & 0 & 6 & 0 & 1 & 13 & 0 & 1 & 0 & 0 & 38 & 7 & 0 & 0 & 8 & 0 & 0 & 0 & 0 & 14 & 1 & 0 & 281 & 0 & 0 & 0 & 0 & 0 & 1 & 0 & 27 & 52 & 0 & 0 & 0 & 2 & 555 \\
\hline 8 & 6 & 0 & 15 & 28 & 1271 & 29 & 0 & 3 & 0 & 0 & 0 & 0 & 58 & 0 & 12 & 0 & 0 & 0 & 6 & 6 & 1 & 0 & 126 & 0 & 16 & 5 & 0 & 63 & 0 & 0 & 112 & 98 & 59 & 1 & 0 & 5 & 2045 \\
\hline 3 & 0 & 0 & 20 & 0 & 2 & 31 & 0 & 0 & 0 & 565 & 52 & 0 & 0 & 3 & 0 & 0 & 1 & 0 & 0 & 1 & 0 & 0 & 168 & 0 & 0 & 0 & 0 & 0 & 0 & 0 & 39 & 28 & 270 & 0 & 0 & 20 & 2246 \\
\hline 14 & 0 & 0 & 3 & 0 & 2 & 4 & 4 & 0 & 0 & 0 & 0 & 0 & 0 & 0 & 1 & 0 & 0 & 0 & 0 & 20 & 0 & 0 & 553 & 2 & 0 & 0 & 0 & 0 & 33 & 1 & 56 & 15 & 67 & 0 & 1 & 7 & 1184 \\
\hline 0 & 38 & 0 & 2 & 0 & 9 & 18 & 0 & 0 & 0 & 0 & 0 & 0 & 0 & 0 & c & 0 & 0 & 0 & 0 & 23 & 0 & 0 & 49 & 0 & 1 & 0 & 0 & 0 & 0 & 0 & 22 & 20 & 19 & 1 & 0 & 7 & 302 \\
\hline 103 & 44 & 3 & 67 & 28 & 1339 & 133 & 54 & 126 & 49 & 1798 & 207 & \begin{tabular}{|l|}
105 \\
\end{tabular} & 61 & 45 & 21 & 5 & 11 & 25 & 6 & 171 & 2 & 503 & 1346 & 2 & 3327 & 5 & 27 & 207 & 552 & 2 & 560 & 3573 & 514 & 17 & 5 & 61 & 19020 \\
\hline
\end{tabular}




\section{SITE 277 LEG 29 TOTAL ABUNDANCE}

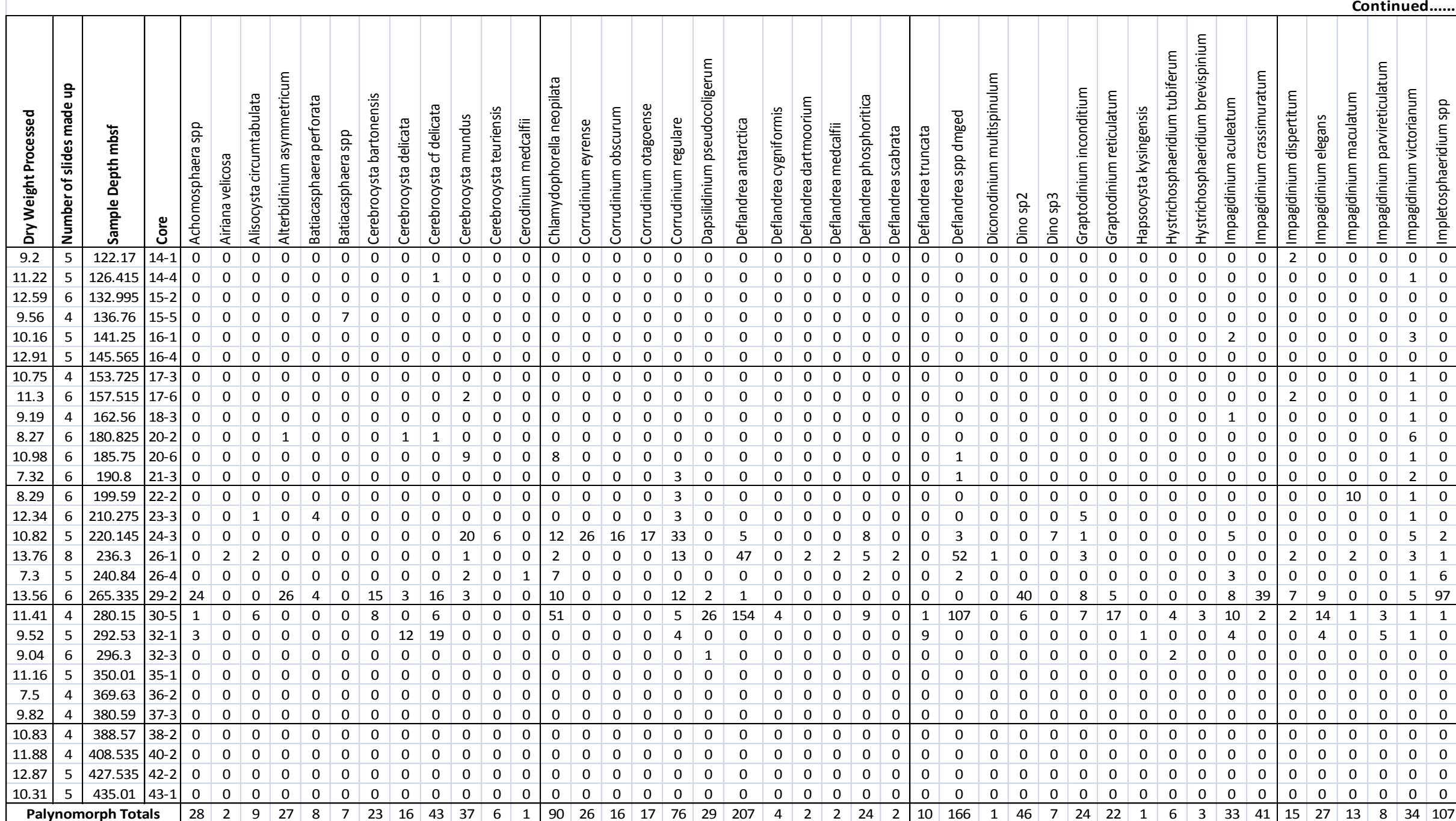




\section{SITE 277 LEG 29 TOTAL ABUNDANCE}

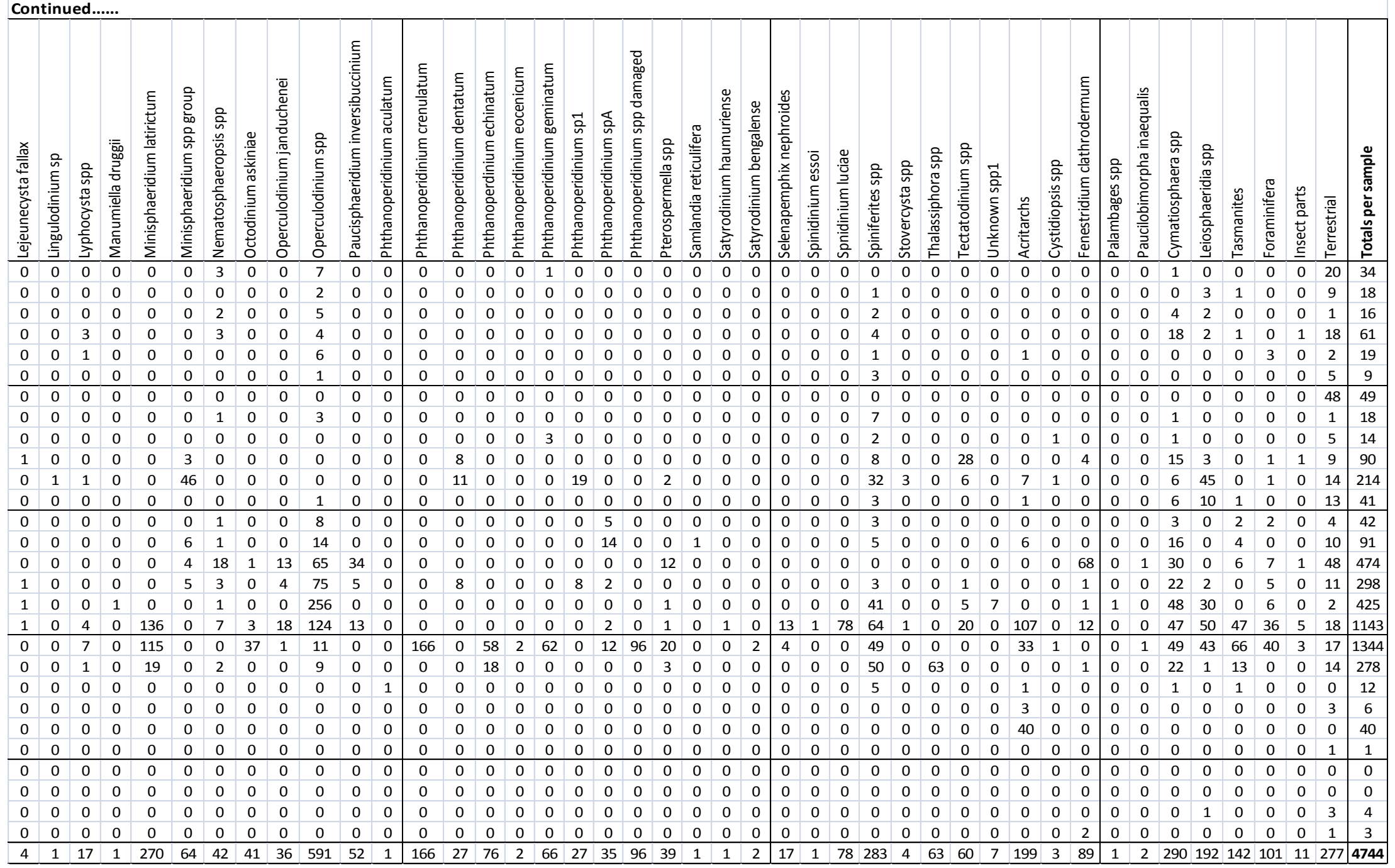




\section{Gonyaulacoid and Peridiniod Total Percentages}
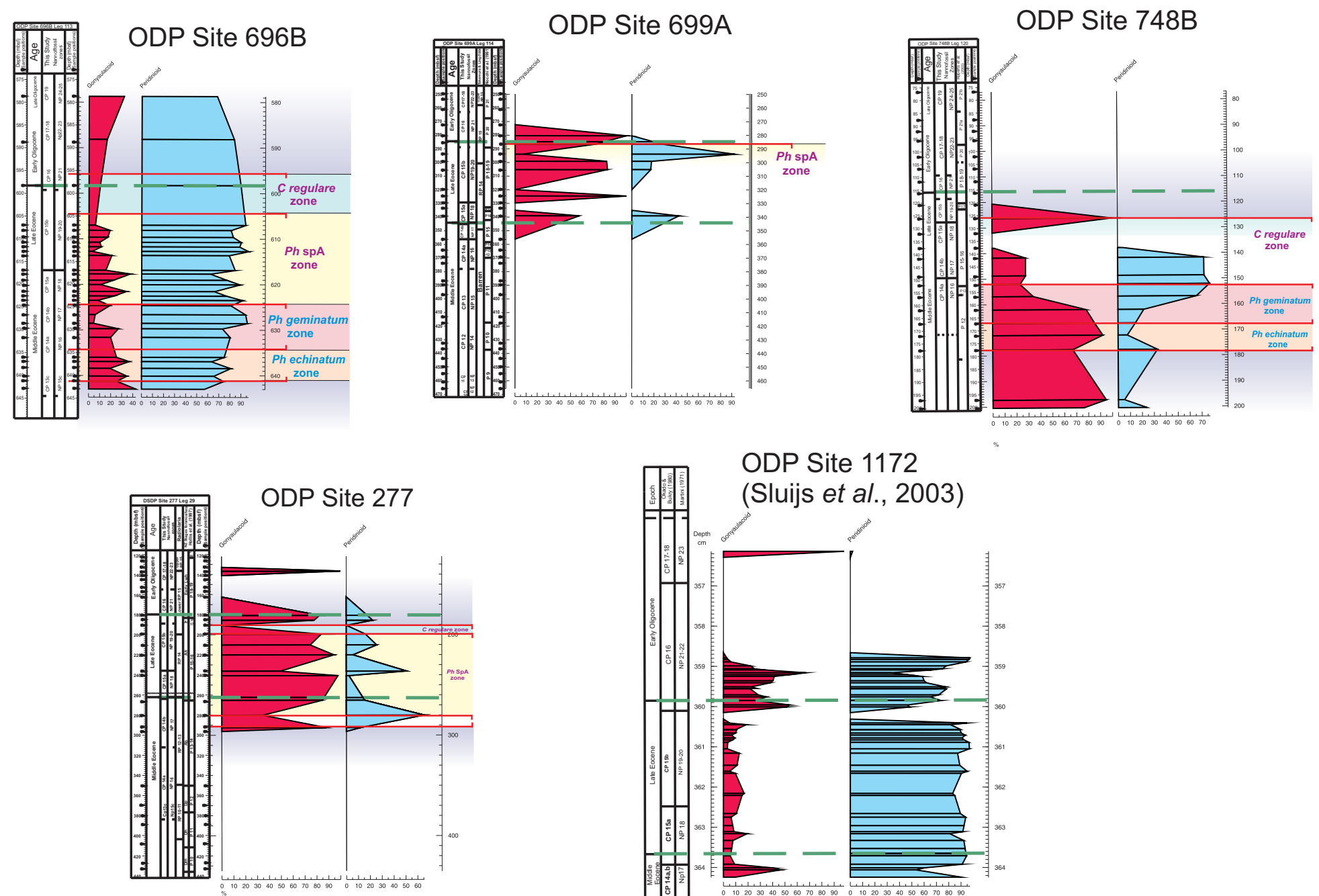

Appendix 2.6: Totals for Gonyaulacoid and Peridinioid dinocysts for the four sites in this study. Included are the Age, Depth for each site and Nannofossil zones (Martini, (1971) and Okado and Bukry, (1980). Also shown are Dinocyst Zones where present and the E/O boundary and Middle/Late Eocene boundary. Also included are the Gonlyaulacoid, Peridinioid results of ODP site 1172 of Sluijs et al., (2003). 
ODP Site 696B Total Abundance
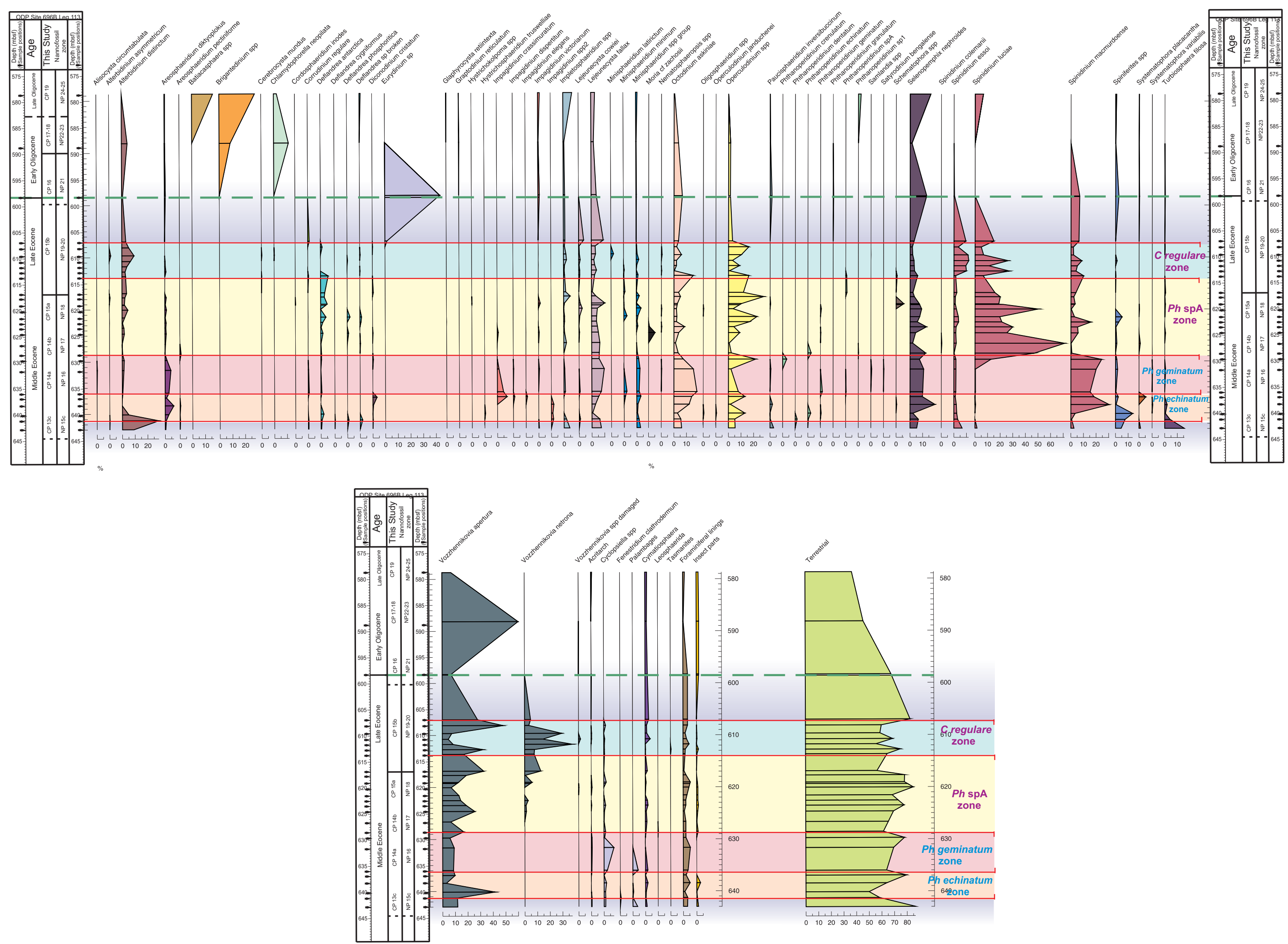

Appendix 2.7 Total abundance for site 696B for marine palynomorphs taken to one hundred percent. Terrestrial calculated from a total abundance of 100 percent and displayed above. The E/O and Middle/Late Eocene boundaries are marked with green dashed lines. Nannofossil zones are from Martini (1971) and Okado and Bukry (1980) 
ODP Site 699A Total Abundance

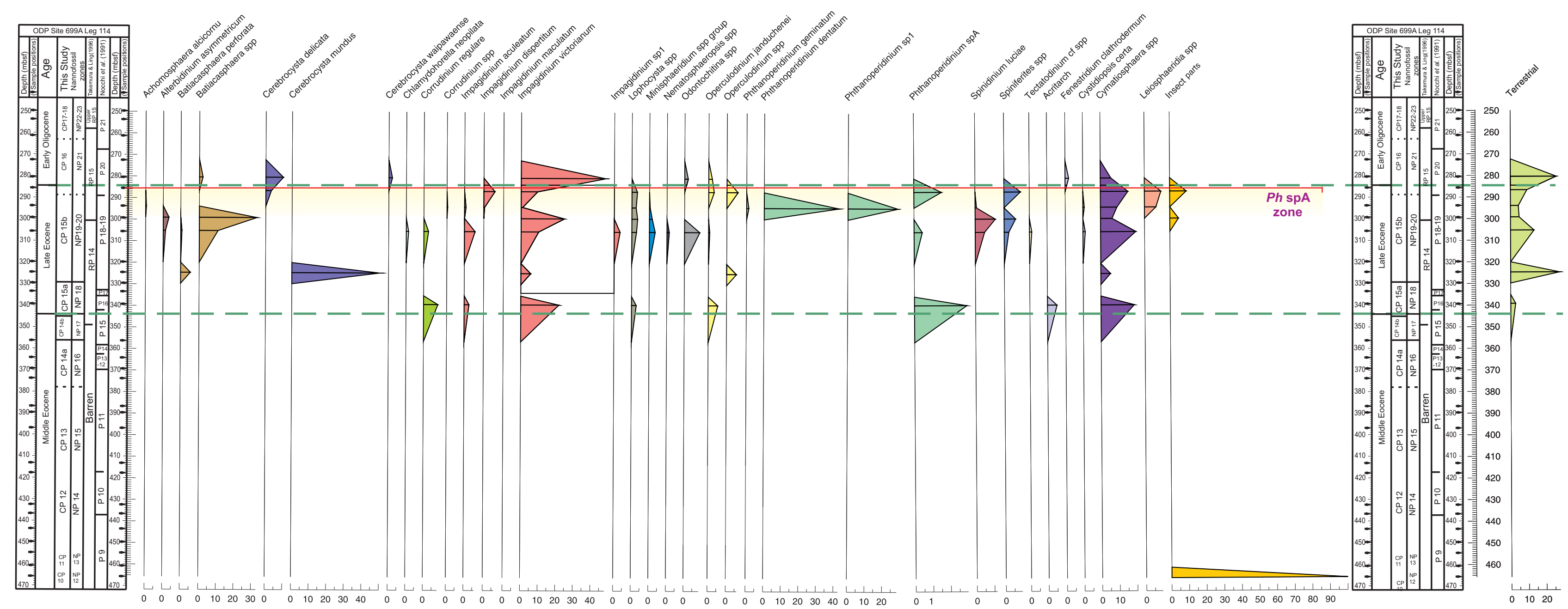

Appendix 2.8: Total abundance for site 699A for marine palynomorphs taken to one hundred percent. Terrestrial calculated for a total abundance 100 percent. The E/O and Middle/Late Eocene boundaries are marked with green dashed lines. Nannofossil zones are from Martini (1971) and Okado and Bukry (1980). 

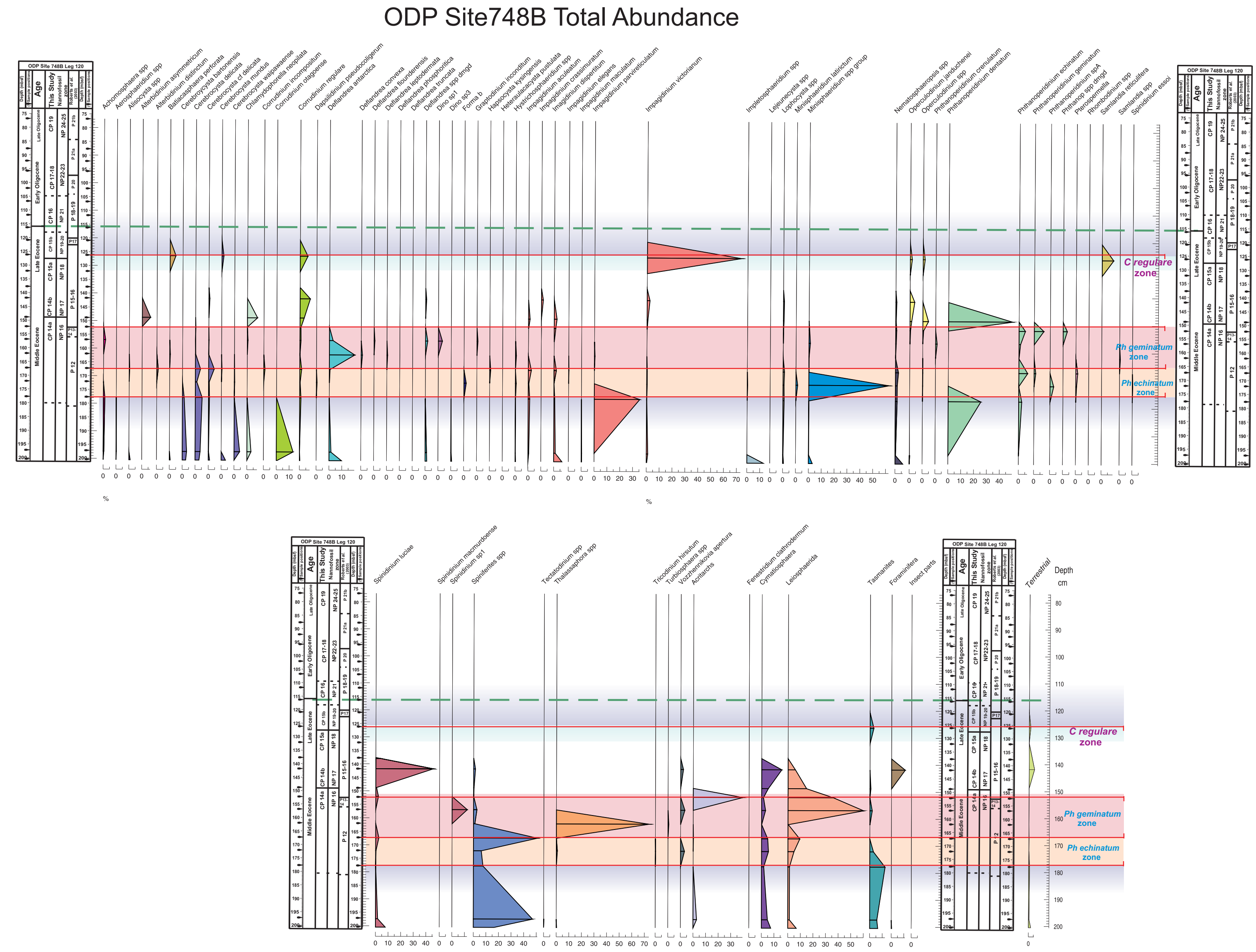

Appendix 2.9: Total abundance for site 748B for marine palynomorphs taken to one hundred percent. Terrestrial calculated from a total abundance of 100 percent and displayed above. The E/O and Middle/Late Eocene boundaries are marked with green dashed lines. Nannofossil zones are from Martini (1971) and Okado and Bukry (1980) 


\section{DSDP Site 277 Marine Total Abundance}
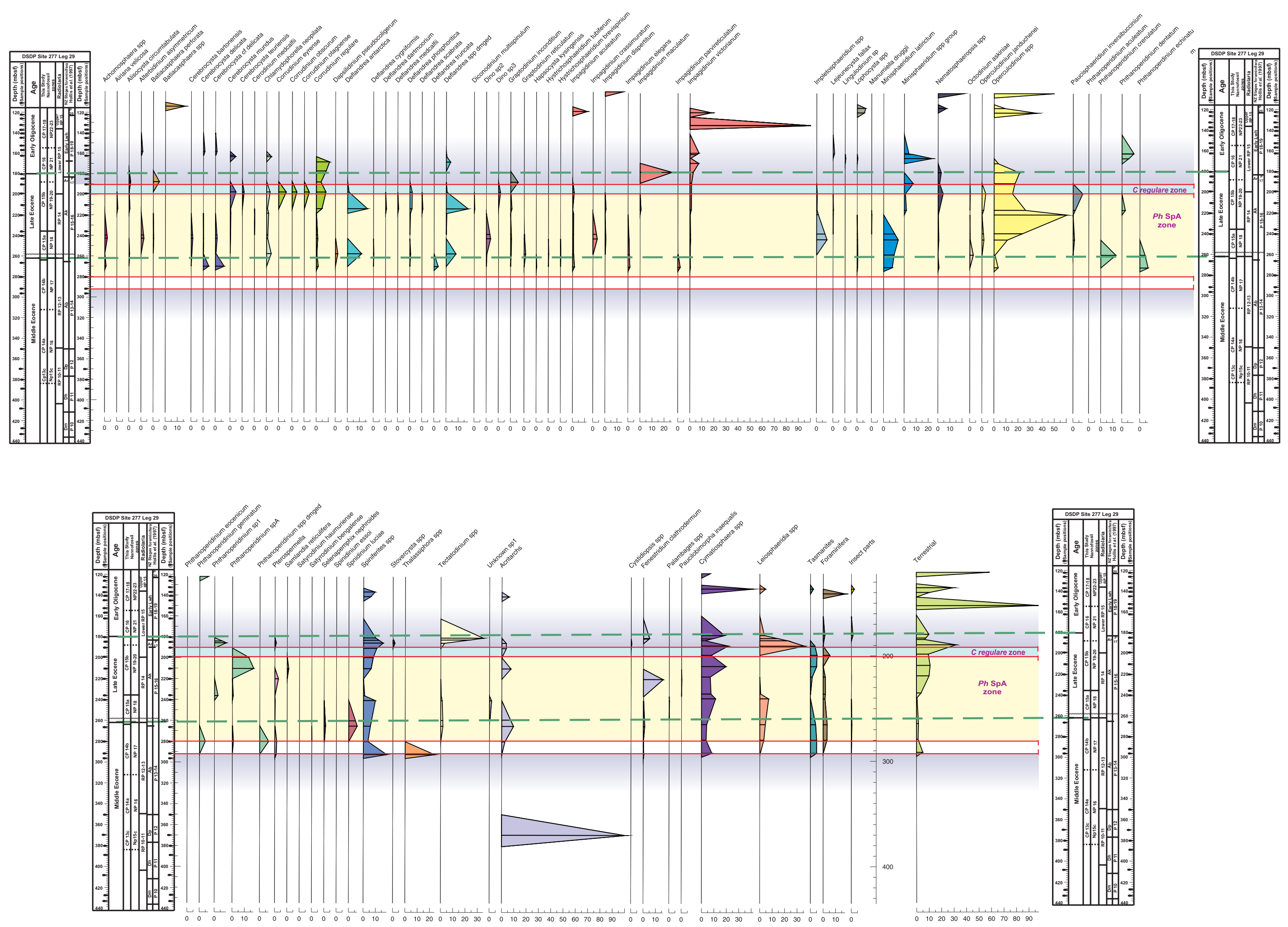

Appendix. 2.10: Total abundance site 277 for marine palynomorphs taken to one hundred percent. Terrestrial calculated from a total abundance of 100 percent and displayed above. The E/O and Middle/Late Eocene boundaries are marked with green dashed lines. Nannofossil zones are from Martini (1971) and Okado and Bukry (1980) 


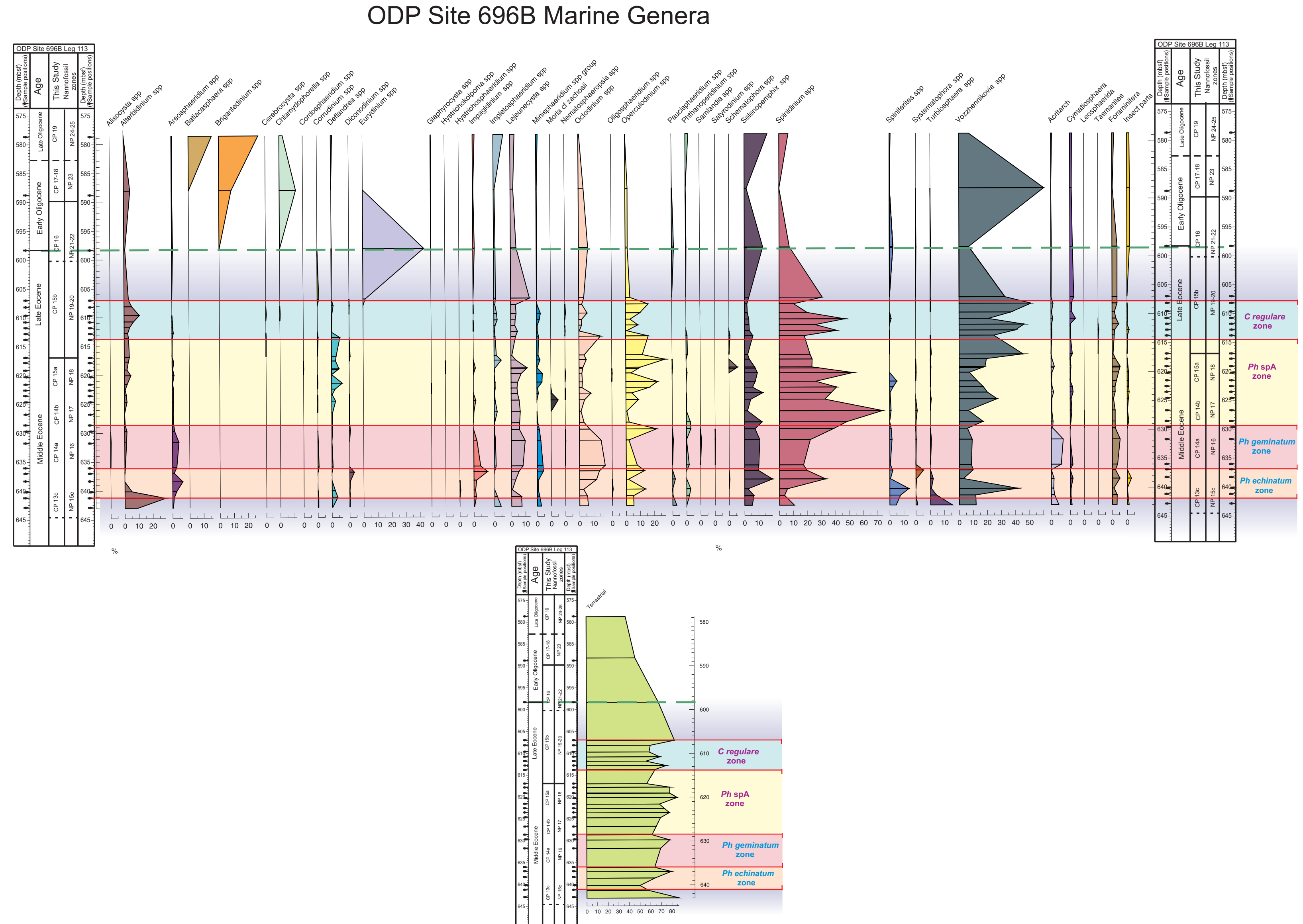

Appendix 2.11 Total abundance for site 696B for marine genera is taken to one hundred percent. Terrestrial is calculated from a total abundance of 100 percent and displayed above. The E/O and Middle/Late Eocene boundaries are marked with green dashed lines. Nannofossil zones are from Martini (1971) and Okado and Bukry (1980) 
ODP Site 699A Marine Genera

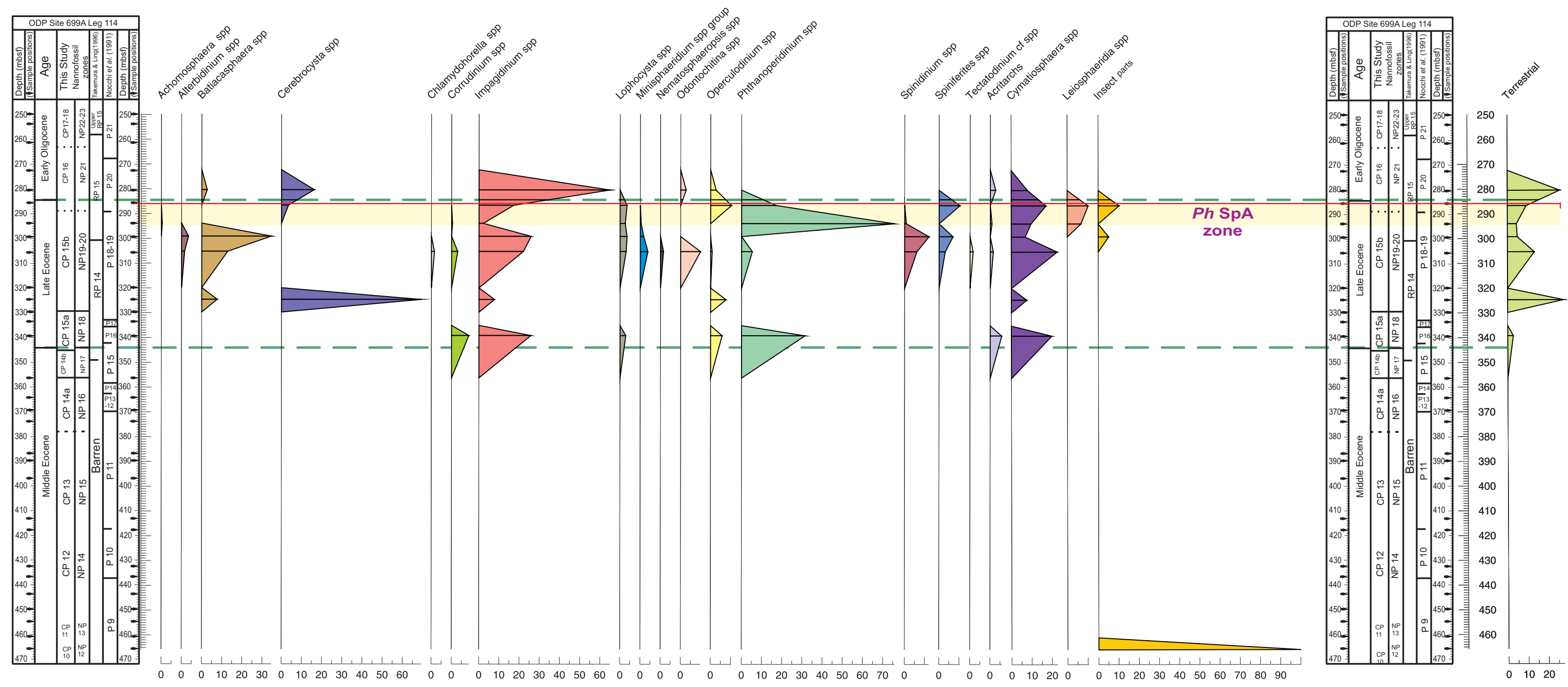

Appendix 2.12: Total abundance for site 699A for marine genera palynomorphs taken to one hundred percent. Terrestrial calculated for a total abundance 100 percent. The E/O and Middle/Late Eocene boundaries are marked with green dashed lines. Nannofossil zones are from Martini (1971) and Okado and Bukry (1980) 


\section{ODP Site748B Marine Genera}
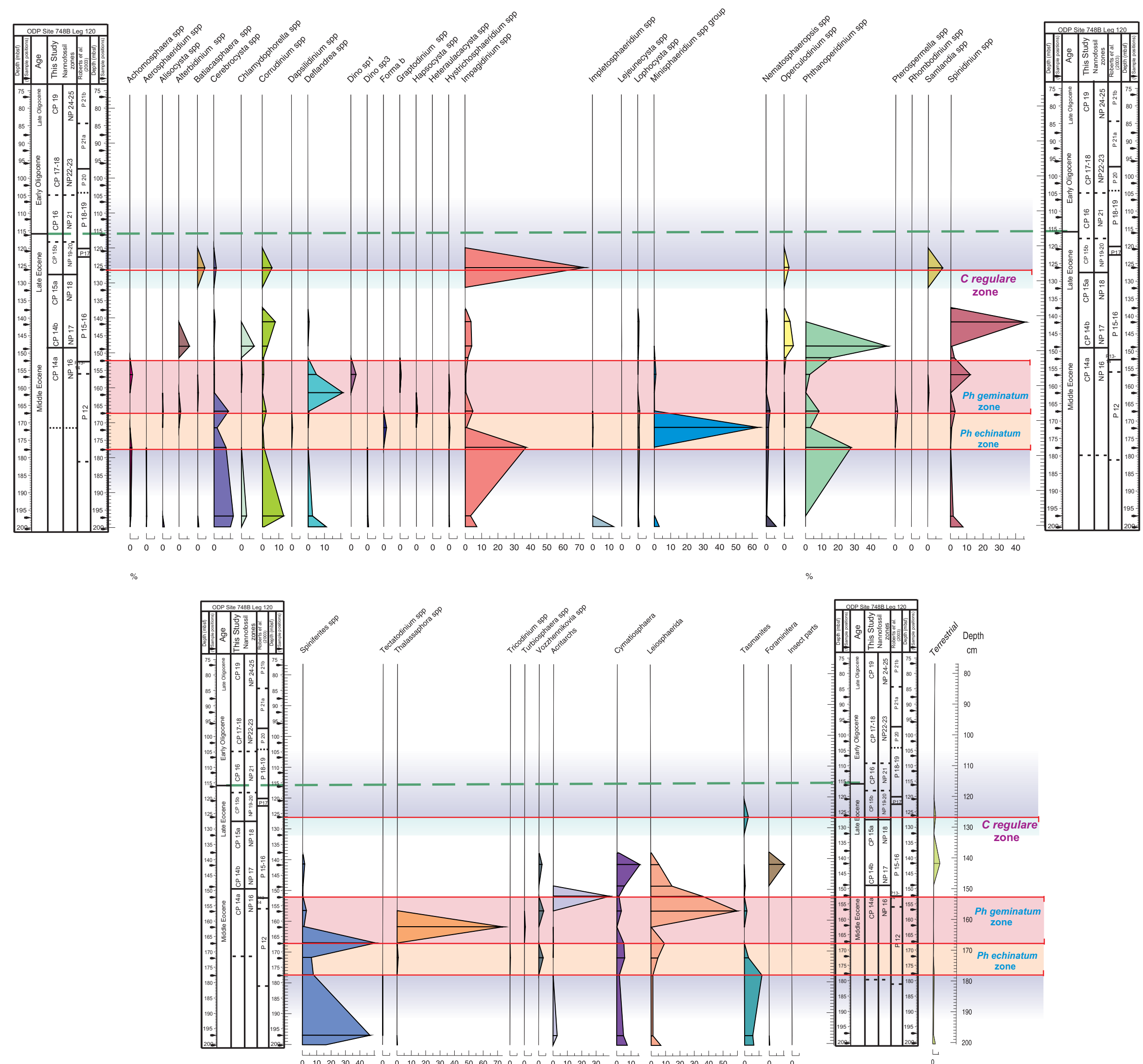

Appendix 2.13: Total abundance for site 748B for marine genera taken to one hundred percent. Terrestrial calculated from a total abundance of 100 percent and displayed above. The E/O and Middle/Late Eocene boundaries are marked with green dashed lines. Nannofossil zones are from Martini (1971) and Okado and Bukry (1980). 


\section{DSDP Site 277 Marine Genera}
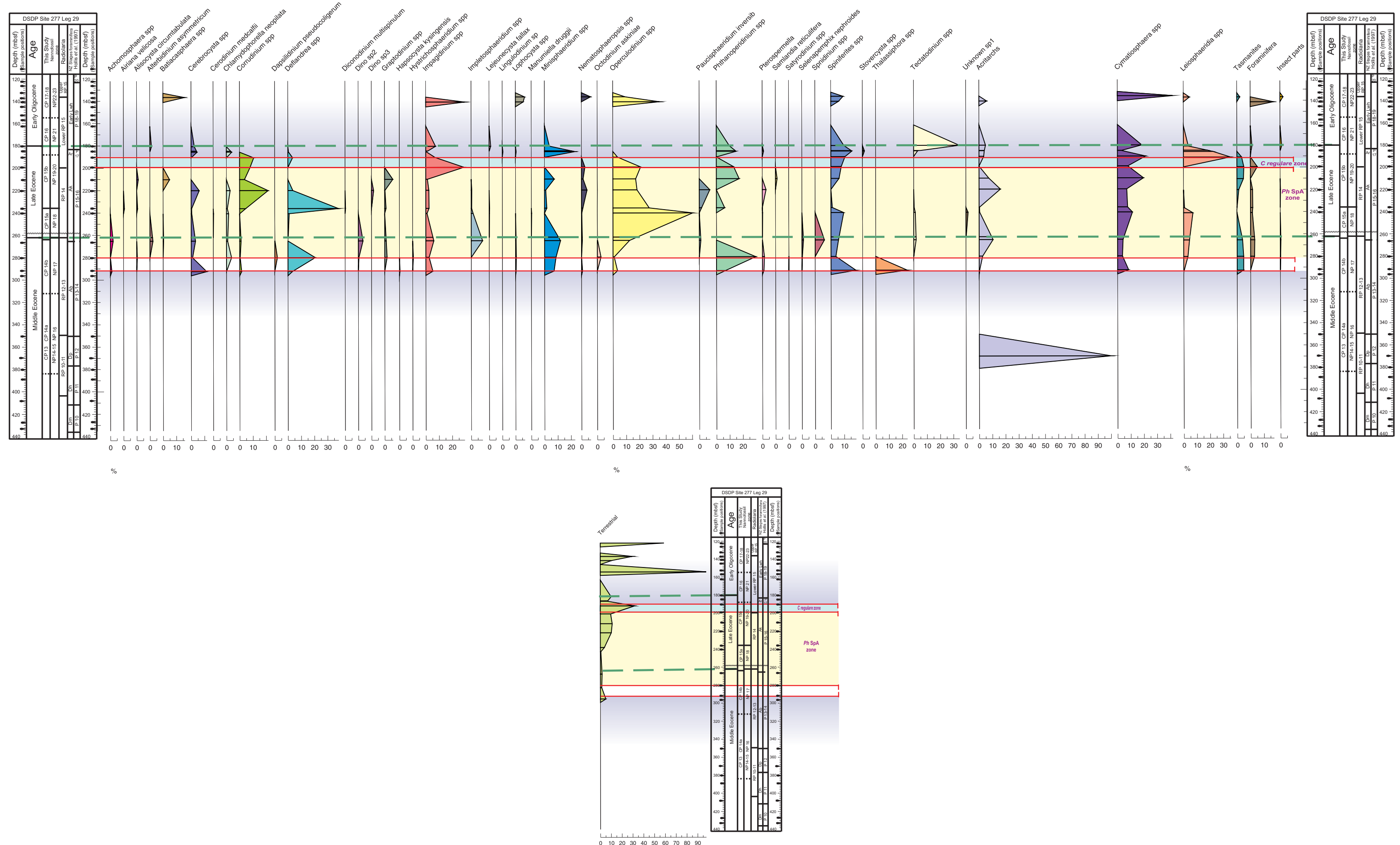

Appendix 2.14: Site 277 marine genera taken to one hundred percent. Terrestrial is calculated from a total abundance of 100 percent and displayed above. The E/O and Middle/Late Eocene boundaries are marked with green dashed lines. Nannofossil zones are from Martini (1971) and Okado and Bukry (1980) 


\section{Site 1172 Leg 189 East Tasman Plateau Dinocyst Assemblages}

\section{Gonyaulacoid}

\section{Peridinioid}
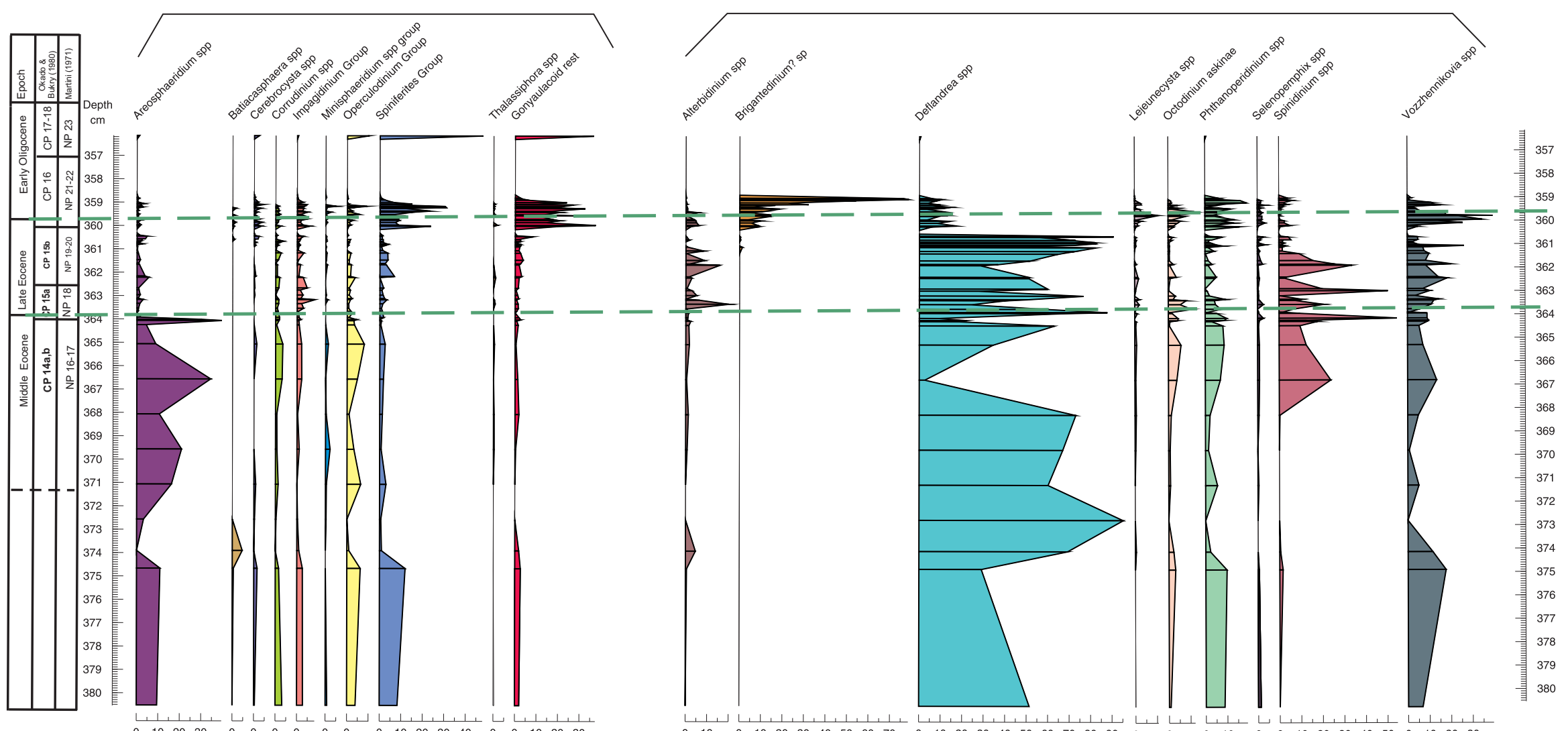

Appendix 2.15: Gonyaulacoid and Peridinioid pecentages of morphologically closely related dinoflagellate cysts quantitavely grouped to show their distribution within each of the four samples (Total $=100 \%)$. Impagidinium, Nematosphaeropsis = Impagidinium group; Operculodinium, Impletosphaeridium = Operculodinium group; Achomosphaera, Spiniferites =

Spiniferites group (Brinkhuis \& Biffi, 1993); Minisphaeridium spp group (Fensome et al, 2009). The nannofossil zones are taken from Martini (1971) and Okado and Bukry (1980) 